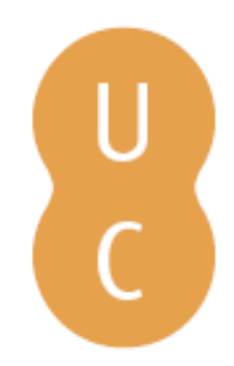

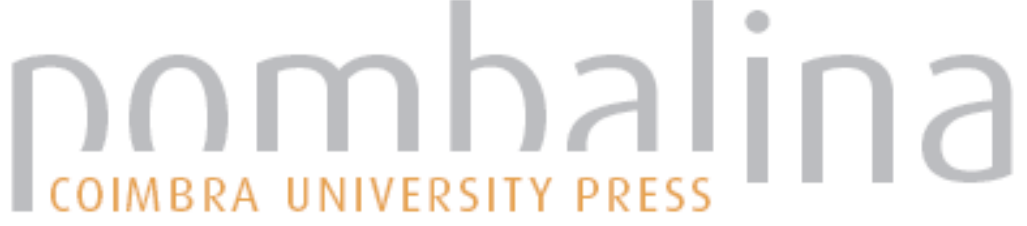

\section{As antiguidades da Lusitânia}
Autor(es):
Resende, André de
Publicado por: Imprensa da Universidade de Coimbra
URL
persistente:
URl:http://hdl.handle.net/10316.2/2697
DOI:
DOI:http://dx.doi.org/10.14195/978-989-26-0399-5

Accessed : $\quad$ 26-Apr-2023 08:10:31

A navegação consulta e descarregamento dos títulos inseridos nas Bibliotecas Digitais UC Digitalis, UC Pombalina e UC Impactum, pressupõem a aceitação plena e sem reservas dos Termos e Condições de Uso destas Bibliotecas Digitais, disponíveis em https://digitalis.uc.pt/pt-pt/termos.

Conforme exposto nos referidos Termos e Condições de Uso, o descarregamento de títulos de acesso restrito requer uma licença válida de autorização devendo o utilizador aceder ao(s) documento(s) a partir de um endereço de IP da instituição detentora da supramencionada licença.

Ao utilizador é apenas permitido o descarregamento para uso pessoal, pelo que o emprego do(s) título(s) descarregado(s) para outro fim, designadamente comercial, carece de autorização do respetivo autor ou editor da obra.

Na medida em que todas as obras da UC Digitalis se encontram protegidas pelo Código do Direito de Autor e Direitos Conexos e demais legislação aplicável, toda a cópia, parcial ou total, deste documento, nos casos em que é legalmente admitida, deverá conter ou fazer-se acompanhar por este aviso.

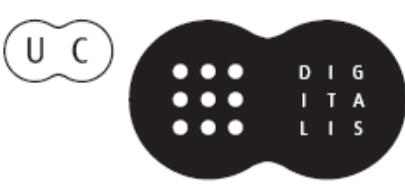




\title{
Portvgaliae
}

Monvmenta Neolatina

\author{
VoL. III
}

André de Resende

As Antiguidades

DA LUSITÂNIA

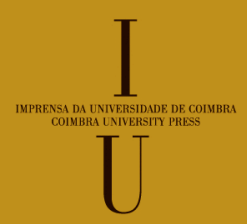


(Página deixada propositadamente em branco) 


\section{PORTVGALIAE \\ MONVMENTA NEOLATINA}

Coordenação Científica

$\begin{array}{llllll}\text { A } & P & \mathrm{E} & \mathrm{N} & \mathrm{E} & \mathrm{L}\end{array}$

Associação Portuguesa de Estudos Neolatinos

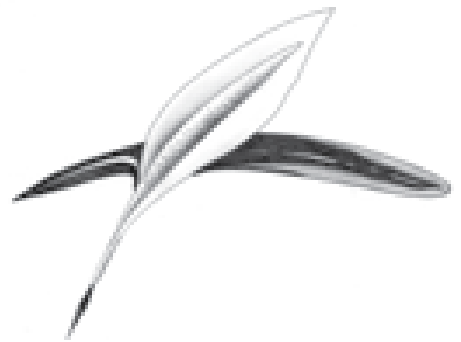

$\begin{array}{llllll}\text { A } & \text { P } & \text { E } & \text { N } & \text { E } & \text { L }\end{array}$ 


\section{COORDENAÇÃO CIENTÍFICA}

Associação Portuguesa de Estudos Neolatinos - APENEL

\section{DIRECÇÃO}

Sebastião Tavares de Pinho, Arnaldo do Espírito Santo, Virgínia Soares Pereira, António Manuel R. Rebelo, João Nunes Torrão, Carlos Ascenso André, Manuel José de Sousa Barbosa

COORDENAÇÃO EDITORIAL

Maria João Padez de Castro

\section{EDIÇÃO}

Imprensa da Universidade de Coimbra

Email: imprensauc@ci.uc.pt

URL: http://www.uc.pt/imprensa_uc

CONCEPÇÃO GRÁFICA

António Barros

PRÉ-IMPRESSÃO

SerSilito • Maia

IMPRESSÃO E ACABAMENTO

SerSilito • Maia

ISBN

978-989-8074-80-5

DEPÓSITO LEGAL

290367/09

OBRA PUBLICADA COM O APOIO DE:

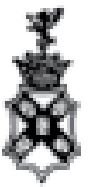

Fundação da Casa de Bragança

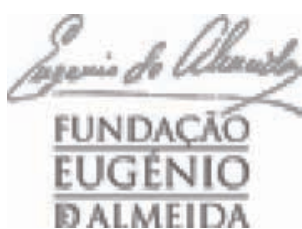


Portvgaliae Monvmenta Neolatina

VOL. III

ANDRÉ DE RESENDE

As ANTIGUIDADES DA LUSITÂNIA

Introdução, tradução e comentário

R. M. Rosado FERnandes

Estabelecimento do texto latino

Sebastião Tavares de Pinho

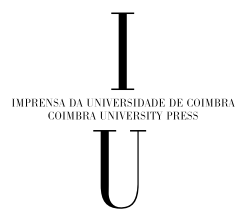


(Página deixada propositadamente em branco) 


\section{INTRODUÇÃO}

\section{I - Nota Biobibliográfica}

Não é realista encarar a figura e obra do quinhentista André de Resende como as de um arqueólogo empunhando uma enxada, recolhendo peças da antiguidade clássica, enfronhado nos problemas da sua Évora natal. A sua obra é mais rica, a sua vida bem mais movimentada e cosmopolita, mas seguindo os costume da época, numa sociedade, como a portuguesa, altamente controlada, sobretudo depois do concílio de Trento, em que o fundamentalismo católico, nessa época de Lutero e de lutas religiosas nos países para além dos Pirenéus, tinha sido assumido sem reservas pelo Portugal do seu tempo. Consequências: Resende que começou por ser erasmista e, portanto, defensor da tolerância, acabou a reduzir a sua visão mais liberal, e a refugiar-se numa zona neutra em que dominavam as inscrições, a história romana da Península, e a glorificação dos inícios lusitanos de Portugal.

No entanto, "quantum mutatus ab illo!" podemos exclamar com Virgílio, se pensarmos no que ele foi, onde ele esteve, como ele começou a escrever e como foi moldando a sua escrita e pensamento aos ambientes do seu país. Para um rapazinho eborense, que, nascido em 1500, entrou aos dez anos para o convento de S. Domingos em Évora; que, aos treze, desandou para a universidade de Alcalá, perto de Madrid, onde aprende com Nebrija; que, quatro anos depois, irá, passando por Toledo e Talavera, para Salamanca, onde é aluno de Aires Barbosa, o nosso helenista da época, podemos dizer que a vida lhe correu de feição. Até 1526, passará por Marselha e Aix-en-Provence, e acaba na Holanda, em Haia, para seguir para Paris, em 1527, onde, na Sorbonne, imperava o anti-erasmista António de Gouveia. Aí conhece como professor de Grego Nicolau Clenardo.

Com vinte e nove anos (1529) já se encontra em Lovaina, cujo louvor vai fazer num poema latino, e onde começa a fazer muitos amigos de longa duração, como Goclénio e João Vaseu, por exemplo, que juntará a Clenardo, nesse grupo, que era bem maior e variado, nele se contando Erasmo que troca com ele correspondência. Um ano depois entra no círculo do embaixador D. Pedro de Mascarenhas, que por sua vez acompanha Carlos V, e na comitiva portuguesa vai passar por Colónia, Bruxelas, 
Ratisbona, Passau, Linz, Viena, Mântua, Bolonha, Génova, Barcelona, até acabar em Portugal, em 1533, com 33 anos. Acabou nessa altura em Évora a sua peregrinação cosmopolita, para começar a interessar-se pela realidade lusitana.

Conhecido pela sua erudição e importância social, movimenta-se no meio da classe dirigente, e logo na sua terra com o cardeal-infante D. Henrique. É objecto das atenções dos seus amigos estrangeiros e portugueses, entre os quais Damião de Góis, cosmopolita como ele e latinista, ao qual dedica um poema, impresso na Flandres, em que descreve os prazeres e complicações da vida palaciana, sem que deixe de manter correspondência com altos dignitários, como D. João de Castro, nosso vice-rei na Índia, ou com eruditos que ensinam em Portugal, como João Vaseu, ao qual dedica uma longa carta-ensaio sobre a Era de Espanha, que será incluída na Crónica da Hispânia publicada por aquele em 1552. A pedido de D. João III escreve sobre Aquedutos, entre os quais faz especial menção do chamado Da Água de Prata que ainda hoje vemos em Évora. Já vai trabalhando desde 1545, sobre As Antiguidades da Lusitânia, com a finalidade de expor e estudar as inscrições latinas que vai encontrando e que ainda hoje têm inegável valor documental, ao mesmo tempo que glorifica o passado dos Lusíadas, os descendentes de Luso, filho de Baco, e fundador da Lusitânia, que começa a ser entendida e consagrada como equivalente do topónimo Portugal. Não terminará esta obra até morrer em 1573, no reinado de D. Sebastião, e deixa inacabado o livro V, que mal consegue começar. A obra será publicada postumamente em Évora em 1593, quando em Portugal já reinam os monarcas espanhóis.

Entretanto, vai pouco a pouco arredando a Espanha dos nossos santos, os que, segundo ele, deviam ser incluídos no nosso hagiológio, e de muitos outros pormenores históricos, e cria a lenda de Viriato que até hoje será uma espécie de Pai Fundador da nossa nacionalidade, mesmo que a investigação histórica o desminta parcialmente. Não quer sobretudo aceitar a definição de que Todos somos Hispanos, uma vez que liga Castela, com a qual o intercâmbio cultural e das famílias portuguesas não podia ser maior, à visão da Hispânia. Já pronunciara orações de sapiência em Coimbra e em Lisboa, e vai seguindo a tradição de cartas-ensaios dirigidas a seus colegas e amigos espanhóis, como Bartolomeu Quevedo, ou Ambrósio Morales, sobre assuntos piedosos e históricos, tentando discretamente valorizar o que era retintamente português.

A sua obra é grande e variada e ocupa, na bibliografia publicada no Arquivo Histórico Português, vol. IX (1914), pp. 310-322, as 154 rubricas que lhe são dedicadas, nessa altura, nada impedindo que se possam ainda encontrar outros escritos seus, na confusão secular que ainda reina, embora lentamente combatida, nos nossos arquivos.

Mesmo assim tem havido a paciência e a coragem para estudar e publicar o nosso Autor, em congressos e em publicações avulsas. O conhecimento da sua obra, ainda que não esteja totalmente estudada, traduzida e comentada, bem como da sua posição intelectual, religiosa e política, tem avançado com entusiasmo e com saber, 
no trabalho conjunto dos classicistas das nossas universidades e de universidades estrangeiras.

Há que pôr em evidência em primeiro lugar as publicações sobre o Humanismo português e o seu lugar na Europa do Renascimento:

L'Humanisme Portugais et l'Europe, Actes du XXI Colloque International d'Études Humanistes, Tours, 3-13 Juillet, 1978, Fundação Gulbenkian, Paris, 1984.

O Humanismo Português, 1500-1600, Primeiro Simpósio Nacional, 21-25 de Outubro de 1985, Academia das Ciências de Lisboa, Lisboa, 1988.

Cataldo e André de Resende - Congresso Internacional do Humanismo Português, Coimbra-Lisboa-Évora, 25 a 29 de Outubro de 2000, Lisboa, 2002.

Dentro das publicações individualizadas ou em conjunto das obras de Resende, as mais recentes são:

Oração de Sapiência (Oratio pro rostris), trad. Miguel Pinto de Meneses, intr. e notas de A. Moreira de Sá, Lisboa, 1956.

Obras Portuguesas, pref. e notas de José Pereira Tavares, Sá da Costa, Lisboa, 1963.

Vincentius leuita et martyr, trad. e com. em francês por J. V. de Pina Martins, Braga, 1981.

Oração de André de Resende Pronunciada no Colégio das Artes em 1551, reprodução fac-similada, leitura moderna, tradução e notas, de Gabriel de Paiva Domingues, Coimbra, 1982.

Carta a Bartolomeu de Quevedo, ed., trad. e notas de Virgínia Soares Pereira, Coimbra, 1988.

Aegidius Scallabitanus, Um Diálogo Sobre Frei Gil de Santarém, ed., trad. e notas de Virgínia Soares Pereira, Fundação Gulbenkian, Lisboa, 2000.

Algumas Obras de André de Resende, vol. I (1531-1551), edições com tradução e comentário de vários AA. contemporâneos, publicadas com um estudo de M. Cadafaz de Matos, Edições Távola Redonda, Lisboa, 2000.

Algumas Obras de André de Resende, vol. II (1529-1551), ed., introd. e estudo de M. Cadafaz de Matos, que reproduz as edições traduzidas e comentadas de vários AA. Contemporâneos, Edições Távola Redonda, Lisboa, s. d.

\section{II - O título do "De antiquitatibus Lusitaniae» e a sua estrutura e concepção}

Ao tratar das antiguidades da Lusitânia em pleno séc. XVI, André de Resende estava consciente de que a mesma noção geográfica, administrativa e até étnica, tinha estado sempre presente nas crónicas dos seus antecessores e que não constituía novidade recordar a história passada de uma zona pobre, montanhosa e situada no finis terrae, que contudo aparecia de modo pouco nítido, digamos até 
extremamente difuso, no panorama histórico da Península Ibérica a que pertencia o reino de Portugal que com a poderosa Espanha castelhana a compartilhava. A verdade é que a Lusitânia, que antes de Augusto até compreendia a Galécia e ia rumo a Sul até ao rio Tejo, depois da divisão administrativa de 26 a. C. passou a ser compreendida entre o Douro e o Guadiana, tornando-se a Galécia parte integrante da Província da Tarraconense ${ }^{1}$. A agravar a ambiguidade do espaço histórico ocupado na época quinhentista pelo reino português, acrescia o facto de que a Lusitânia do Império Romano tinha a sua capital em Mérida, o que em muito prejudicava a importância política que se pretendesse dar a Portugal. No entanto, apesar de toda essa ambiguidade, é de Portugal-Lusitânia que Resende se vai ocupar, o que já levou a que o título latino fosse trasladado para português como Das antiguidades de Portugal e não da Lusitânia. A nosso ver contraria esta tradução o espírito do que pretende Resende dizer-nos na epígrafe escolhida, e que muito simplesmente se resume na ideia de que Portugal mais não é do que a velha Lusitânia de tão grandes e nobres tradições de heroicidade e de genuína valentia na resistência contra o poderio da mais forte nação da antiga Europa, ou seja, da nação romana. Consciente dessa ambiguidade é Resende que nos diz que «se déssemos a Portugal só o nome de Lusitânia, por ser este o da maior parte da região, existiria hoje uma Lusitânia a Sul e a Norte bastante mais extensa e mais larga, é verdade, mas muito mais estreita do que a antiga, a Oriente junto dos Vetões...». Preferimos por isso traduzir o título latino como Antiguidades da Lusitânia e não de Portugal. De resto, o nome de Lusitânia, como já demos a entender, era conhecido na historiografia anterior a Resende já de antiga data, desde os anais que se ocupam do reinado de D. Afonso Henriques e da Vida de S. Teotónio do séc. XII que refere o fundador de Portugal como dux Portugalis que «depois foi elevado a rei de quase toda a Lusitânia e de parte da Galécia”, até à Primeira Crónica General de España do séc. XIII, que se refere a "La provincia de Luzenna, que es ell Algarve» ou que «es entre Guadiana e Tajo». O nome latino, contudo, pode encontrar-se igualmente na Crónica Geral de Espanha de 1344 e na Crónica dos Reis de Portugal de 1419, ao mesmo tempo que lhe aparece ligado o nome de Viriato e a sublevação por ele chefiada contra o poderio romano ${ }^{2}$.

Resende não faz mais do que confirmar uma velha tradição, da qual vai tirar o nome poético de Lusíadas, fundamentando-se para tal na etimologia do topónimo, bem como a vai enquadrar metodologicamente na história romana, visigótica, árabe e medieval, socorrendo-se para tanto dum sem-número de autoridades gregas e latinas, medievais e renascentistas, portuguesas e estrangeiras, e de um acervo, a todos os títulos admirável, de documentos da época, sejam eles epigráficos ou manuscritos. 


\section{II.2 - O Humanista Resende}

No seu método de trabalhar é André de Resende, formado nas escolas de Alcalá, de Aix-en-Provence e de Lovaina, um representante legítimo do Humanismo europeu, com o qual conviveu e aprendeu nas primeiras décadas da sua vida quando ainda não estava dilacerado pelas profundas divergências que virão a dividi-lo aquando da Reforma. Esta cisão entre o bloco protestante e o católico terá, como pensamos e defendemos, óbvias repercussões na obra resendiana, sobretudo no seu itinerário erasmista, que encontrará cada vez mais dificuldades em prosseguir, numa Península Ibérica que virá a afirmar-se como bastião da Contra-Reforma ${ }^{3}$. Interessado primeiramente numa abordagem europeia e internacional de cariz erasmista dos problemas culturais e filosóficos da vida sua contemporânea afastar-se-á Resende, como nos parece óbvio, desse caminho para regressar a uma certa ortodoxia que sempre caracterizara muitos sectores da vida intelectual portuguesa francamente contra qualquer abertura mais liberalizante, como se demonstrou no concílio de Valladolid de 1527, numa altura em que ainda era pacífico dissertar sobre o grande Humanista de Roterdão, como o fará, aliás, o próprio Resende no rasgado Elogio de Erasmo. O De antiquitatibus Lusitaniae, que no fundo será a obra que mais o notabilizará, e que do ponto de vista de metodologia histórica corresponderá fielmente aos caminhos seguidos pelos eruditos renascentistas, será a nosso ver como que um refúgio menos dialéctico e portanto menos perigoso em relação à discussão ideológica que prosseguia nas regiões europeias mais infectadas de luteranismo, e que permitia a Resende exercer a sua imponente erudição, recheada de autores de todas as épocas, credos e nacionalidades e dos mais variados documentos e monumentos, que analisava à luz dos diversos ramos da ciência exegética que despertavam com o Renascimento, como sejam a crítica textual, a epigrafia e a arqueologia, ciências que estavam na "moda" e constituíam o fundamento cultural da época.

No tratamento das antiguidades revela-se um grande à-vontade com os assuntos versados, que provém não só da sua erudição mas do convívio pessoal ou livresco com os humanistas, historiadores e antiquários da época como é o caso de Ambrósio de Morales, de Florião do Campo, de Vaseu, de Bartolomeu Quevedo seus contemporâneos na Península Ibérica, bem como com Ânio de Viterbo e as suas fraudes, como Onofre Panvínio, Guilherme Rondelet, Paulo Jóvio e tantos outros que facilmente se encontrarão registados nesta obra ${ }^{4}$.

Surgem, porém, estas Antiguidades no fim da vida de Resende e são por certo a súmula de um trabalho de anos, ainda que, pelo que sabemos, a sua redacção não tenha sido assim tão longa. A verdade é que em vernáculo já se tinha distinguido por outra obra sobre antiguidades, dada ao prelo em 1553, e que intitulou História da antiguidade da cidade de Évora, impressa em Évora neste ano e em 1576 e depois em Lisboa em 1783, e que foi traduzida para Latim por Andreas Schottus, e publicada na Hispania Illustrata, edições de Colónia, de 1600 e 1613, vol. II, 
Frankfurt, 1603, como continuação e livro V das Antiquitates Lusitaniae, bem como na edição de Coimbra, $1790{ }^{5}$.

Vinte anos antes da impressão da edição portuguesa acima referida já Resende, contudo, oferecia ao Cardeal Infante D. Afonso, filho de D. Manuel, uma recolha de documentos epigráficos romanos, a que Leitão Ferreira dá o nome de Antiqua epitaphia, cuja existência, contudo, ainda não foi verificada. O manuscrito com transcrições epigráficas de Resende a que Huebner se refere no C. I. L., II, n. ${ }^{\circ} 17$, p. XI, não tem valor científico bastante ${ }^{6}$. Devemos, pois, contentar-nos de momento com a notícia da carta, que tão-pouco é explícita no que se refere à publicação, uma vez que se limita a dizer, depois de expressar o desejo de "dar a conhecer ao mundo" as antigas colónias romanas da Lusitânia: "Damos a conhecer os dados que se nos deparam por ocasião das muitas peregrinações». Nada nos indica que se trate de uma publicação impressa, tal como deduz Leitão Ferreira, que, ao referir-se a 1533 como data de regresso de Resende a Évora, após a sua longa estada no estrangeiro, e à carta ao Cardeal D. Afonso, transcreve o passo final da vida de Resende de Diogo Mendes de Vasconcelos, seu editor, como prova bastante da existência de um livro: "Estes são os factos biográficos do nosso Resende, factos que pareceram dignos de ser contados e aos quais vou juntar uma carta sua ao Cardeal D. Afonso, na qual é evidente que, já há muito tempo, tinha nascido no seu espírito esta obra sobre as antiguidades" ${ }^{7}$. Não nos parece que daqui se possa deduzir a publicação de um livro, pese embora a hipótese de Leitão Ferreira de que Mendes de Vasconcelos teria tido somente notícia do livro, mas que só teria visto a carta. O próprio Braamcamp Freire, editor de Leitão Ferreira, é extremamente cuidadoso na apreciação destas informações e liga-as à notícia dada por D. Rodrigo da Cunha, bispo de Lisboa, que se refere a "hum livro escrito de mão e da letra de Mestre André de Resende, intitulado Monumenta Romanorum in Lusitanis Vrbibus, dedicado ao Cardeal D. Afonso, que se nos comunicou». Trata-se aqui, portanto, de uma publicação manuscrita, o que parece ser mais aceitável, face ao que nos diz o próprio Resende na carta em apreço. Seja como for ou venha no futuro a ser descoberto, pode desde já concluir-se que a obra tardia de Resende, que o consagrou como antiquário no mundo erudito do seu tempo, tem a sua génese na época em que frequentou os grandes centros culturais europeus, uma vez que ao chegar a Portugal em 1533 já oferece a um dos seus patronos eborenses os resultados, impressos ou não, do seu esforço de coleccionador de antiguidades, sobretudo de documentos epigráficos, que 60 anos depois, quando da publicação por Diogo Mendes de Vasconcelos do seu legado erudito, constituirão um monumento de consulta de primeira grandeza quanto às antiguidades romanas em território português, mal-grado alguns óbices quanto à probidade científica do humanista, como adiante veremos. O De antiquitatibus Lusitaniae, juntamente com a História da antiguidade da cidade de Évora e outras obras menores de Resende, entre as quais salientamos a Carta a Bartolomeu Quevedo, constituem ainda hoje obras de consulta necessária, apesar de toda a investigação posterior que em Portugal sobre as antiguidades romanas se publicou ${ }^{8}$. 


\section{II.3 - A. Resende e o seu editor Diogo Mendes de Vasconcelos}

É inegável a interdependência existente entre Resende e o seu editor Mendes de Vasconcelos, que se vai permitir publicar, apenso aos quatro livros deixados, um quinto livro de sua autoria sobre um assunto já versado em vernáculo pelo mesmo Resende: as antiguidades de Évora. Esta interdependência é até bem caracterizada pelos poetas da época, como Manuel Cabedo de Vasconcelos, sobrinho do editor, que de uma forma exaltada e barroca tenta demonstrar o modo sublime como Vasconcelos completa Resende, uma vez que aquele, ao contrário de exemplos célebres, consegue, sem desmerecer do valor do modelo, levar a cabo com igual qualidade a história por ele começada ${ }^{9}$. O próprio Vasconcelos na carta dirigida em 1580, a 15 de Janeiro, ao Cardeal D. Henrique, então rei de Portugal por mais dezasseis dias, pois vem a morrer em 31 de Janeiro desse ano, já se dava conta do melindre da sua situação de editor de um grande humanista que morrera sete anos antes, em 1573, deixando inacabada uma obra de grande importância para a compreensão do passado de Portugal. Nessa carta, depois corroborada no essencial pela carta final por alturas da impressão, dirigida em 1592 a Filipe II de Espanha 10 e primeiro de Portugal, analisa Vasconcelos o melindre da sua situação de grande humanista, o que realça abertamente, na contingência de ter de editar a obra de outro grande humanista, o que o colocava evidentemente numa posição de certa subsidiariedade.

Diz Vasconcelos: "que não faltarão os que me censurem por ser de alguma maneira acomodatício e com pouco apreço pela ideia que de mim se faça, visto que investido em altas funções oficiais e podendo por mim próprio realizar e fazer obra em qualquer género literário, venha eu aplicar o meu esforço a obra alheia e em tal qualidade ser activo, o que pelo comum dos mortais é considerado indigno de alguém que se dedicou aos estudos de jurisprudência e durante tanto tempo foi versado na governação do Estado" ${ }^{11}$. E pretexta a obediência que deve ao CardealRei, a qualidade da obra que vai editar, como atenuantes para uma aceitação que em nada o prestigia. Habilmente, contudo, como forma de dourar a finalidade da edição, entrega-se, depois de um preâmbulo apologético, ao elogio de Resende cuja posição de erudito e de introdutor de um novo método de fazer história encarece e especifica, numa época «em que já se começou a pôr de parte a inabilidade rude e gética", ou seja os métodos tradicionais da Idade Média, Idade das Trevas segundo a velha visão de Petrarca ${ }^{12}$. Na carta a Filipe de Espanha e de Portugal de 1592, não voltará a repetir as informações preciosas que nesta nos proporciona e limitar-se-á a confirmar que havia cumprido a tarefa que doze anos antes tinha encetado, apesar da sua avançada idade. No entanto, na carta ao Cardeal-Rei não deixará aqui e ali de valorizar o seu trabalho de editor apontando a desordem em que Mestre Resende deixara o seu espólio de informações sobre as antiguidades. É Vasconcelos, contudo, a única fonte que nos dá notícia pormenorizada sobre a forma como esta obra resendiana fora concebida, não só nesta carta, como também no poema que dedica 
à memória do Mestre eborense, e que só em parte publica na edição de $1593^{13}$. De resto, as notícias que Resende dá a conhecer na carta de 1533 ao Cardeal D. Afonso ${ }^{14}$, bem como na que envia ao jurisconsulto espanhol Bartolomeu Frias Albornoz ${ }^{15}$, e sobretudo na primeira, somente nos dão conta da sua visão das antiguidades e do precioso contributo da epigrafia, e não do andamento geral da sua obra de antiquário. Temos pois de nos socorrer das informações prestadas pelo seu editor, tanto na Vida que juntamente se traduz, como na referida carta ao Cardeal-Rei.

\section{II.4 - A elaboração do "De antiquitatibus Lusitaniae»}

Sabemos pelas diversas cartas de Resende a João Vaseu, a Ambrósio de Morales, a Bartolomeu Quevedo e mesmo pelas anotações ao seu Poema sobre S. Vicente, que a investigação das antiguidades no território de Portugal e da antiga Lusitânia ocuparam parte significativa da sua actividade de erudito e homem enciclopédico do Humanismo, capaz de comparar a qualidade dessas antiguidades, bem como o seu significado histórico, com as que simultaneamente eram estudadas no espaço europeu pelos humanistas seus concorrentes e colegas. Diz-nos Vasconcelos na carta ao Cardeal-Rei que foram "quase cinquenta anos» de investigação antiquária, o que nos parece aceitável considerando que já em 1533 Resende referia esse trabalho inovador como velho hábito ao Cardeal D. Afonso ${ }^{16}$. A cronologia da criação desta obra, pelo que nos informa Vasconcelos, é simples: cerca de cinquenta anos a recolher e a meditar, publicando, no decorrer da vida, as cartas eruditas e a História das Antiguidades de Évora, e só em 1569, quatro anos antes de morrer, é que passou a redigir sobre o material recolhido e ordenado. A partir de 1573, data da sua morte, repousa essa parte do seu espólio durante sete anos, até que o Cardeal D. Henrique, já nos últimos tempos de vida, encarrega Mendes de Vasconcelos de o editar (carta de 1580). Finalmente em 1592, depois de todos os acontecimentos históricos de mudança dinástica, o mesmo Vasconcelos escreve a Filipe II de Espanha, agora também rei de Portugal, e se declara pronto a entregar o material, coligido e redigido por Resende, à tipografia, aconselhando o Rei a proteger, amar e abraçar a Lusitânia, "cujos monumentos foram arrancados das trevas, melhor direi, das fauces do próprio tempo» ${ }^{17}$, por André de Resende. Já as mesmas palavras tinha ele proferido em 1580, quanto aos quatro livros de Resende que «revistos por mim poderão ser imediatamente editados e divulgados, contanto que ordenes [O Cardeal D. Henrique] ao tesouro real para que sejam atribuídas as verbas necessárias para tal empreendimento» ${ }^{18}$. Só que os acontecimentos históricos assim o não permitiram.

Sobre o estado em que o espólio de Resende lhe chegou às mãos também dá conta Vasconcelos ao Cardeal, pois apesar de ter redigido até ao fim e deixado um prefácio ao Quinto Livro sobre as antiguidades de Évora, todas as folhas estavam rasuradas, anotadas, com asteriscos e obeliscos, o que mostra, diz-nos o seu editor, 
que Resende só depois de muito pensar é que escrevia. Põe, no entanto, o leitor de sobreaviso quanto à desilusão que possa sentir quando pensa que vai ler uma história organizada, sistematizada, com inúmeras informações sobre as cidades, pois muito se reduz a insignificantes anotações. E o leitor moderno sente aqui, mesmo que bem-intencionado, a emulação do colega, a raiva bem contida do rival Vasconcelos, que não resistirá a publicar, seguidamente aos quatro livros de Resende, um quinto livro da sua autoria sobre as antiguidades de Évora, com o qual vai tentar disputar a primazia ao livro resendiano escrito em vernáculo sobre o mesmo assunto.

Há, contudo, que considerar que a descrição epistolográfica de Vasconcelos contém em si, ainda que discretamente, uma apreciação crítica do trabalho deixado por Resende, uma vez que, cuidadosamente, à medida que vai enumerando os vários itens de cada livro, não hesita em avaliar o que tantas fadigas lhe custou a melhorar e a editar. A verdade é que admite ter Resende confiado demasiadamente na sua memória e que "não se tivesse preocupado com o elaborar primeiramente esboços, planos e ensaios da matéria, mas tivesse escrito os quatro livros, conforme os factos lhe ocorriam ao espírito...» ${ }^{19}$, o que está em nítida contradição com a acribia acima aludida, quando diz que Resende "se habituara a escrever não ao correr da pena, nem de improviso, mas sim depois de ter pensado maduramente» ${ }^{20}$. Não conseguimos, ao ver as críticas que prudentemente vai semeando, furtar-nos à sensação de um certo despeito sentido pelo editor, que para agradar a um poderoso, ou talvez por não ter capacidade para ir muito mais além, tinha metido por obediência os ombros a uma obra que não era sua, mas que para cúmulo tinha uma qualidade erudita de desigual valor, de contornos desordenados, e que constituía novidade total no mundo intelectual português. Em que medida houve intervenção do editor no texto, porque na disposição das inscrições confessa ele que houve, não nos é possível determinar com segurança. Sentimos, todavia, que anota todas as ausências que as promessas de Resende não faziam prever, como no livro quarto, em que anuncia ir tratar das cidades e acaba por não saciar a curiosidade de quem esperava mais do que a descrição de "quinze ou, quando muito, dezasseis ópidos» ${ }^{21}$. Por outro lado, quando do livro primeiro, diz claramente Vasconcelos que Resende «de passagem toca nalguns problemas de menos importância e um pouco obscuros» ${ }^{22}$, e salienta que no terceiro livro a narração sobre os povos da Lusitânia é «difusa» 23 .

Mão é possível, portanto, ignorar a posição crítica do editor com o qual não raras vezes somos forçados a concordar, visto que o plano dos quatro livros deixados por Resende é bastante confuso, com múltiplas digressões, como é o caso da que faz sobre o esturjão, quando da descrição dos rios portugueses no livro segundo, e tantas outras que, embora nos afastem do assunto, nos dão a conhecer as preocupações de Resende no fervilhar dos seus múltiplos conhecimentos, das suas inúmeras leituras, nem sempre sistematizadas como gostaríamos que fossem.

Sobre o quinto livro só sabemos por Vasconcelos que foram escritas por Resende vinte e cinco linhas, que se ocupavam de Évora, donde se afirmava e era natural, livro que constitui o ensejo de Vasconcelos nos brindar com um Ersatz da sua lavra, 
não sem o fazer preceder de uma autobiografia que, quanto a modéstia, deixa muito a desejar ${ }^{24}$, o que naturalmente também não surpreende quem conheça o mundo erudito de sempre e os seus complicados académicos.

Seja como for, os quatro livros de Resende, trabalhados por Mendes de Vasconcelos, que afirma tê-los já encontrado acabados, «absolutos», diz-nos, são muito semelhantes em método e concepção às obras europeias suas contemporâneas.

\section{II.5 - Metodologia e concepção histórica}

Mesmo sabendo de antemão que o plano inicial de Resende era escrever dez livros, tal como nos assevera o seu biógrafo editor ${ }^{25}$, nem por isso deixa de ressaltar na leitura o sinuoso da descrição, ainda que pressintamos um plano mais ou menos definido como fundamento expositivo, invadido nos seus contornos bem demarcados por um sem-número, como já se disse, de digressões, que mais fazem lembrar os textos dos historiadores antigos (Plínio, Estrabão e tantos outros), que, quer queiramos quer não, lhe serviram certamente de modelo. A abordagem das origens lusitanas de Portugal já é feita, contudo, dentro de uma concepção que se aproxima da que vai ser hoje em dia adoptada pelos historiadores.

Seguindo, no entanto, a moda da época, inicia o primeiro livro com a discussão da etimologia do nome Lusitânia, o que arrasta Resende para o domínio do fabuloso e da mitologia, que corresponde na essência à metodologia "científica" da sua altura. Como se trata, neste caso, de um intelectual português de formação religiosa e teológica, afloram igualmente as bases da visão providencialista da história que perdurará nas próximas gerações, vindo a ser por isso a fonte dilecta da historiografia alcobacense da Monarquia Lusitana e de dissertações mais ou menos históricas como as de Frei Amador Arrais ${ }^{26}$. Constitui, contudo, novidade a sistematização que faz seguidamente quanto aos povos que habitaram a Lusitânia, tais como Túrdulos, Vetões, Célticos e muitos outros, dos quais vai salientar sobretudo os Lusitanos e o seu chefe Viriato: detém-se num capítulo à parte sobre o seu carácter, os seus costumes e naturalmente sobre a sua coragem. Não difere neste aspecto pois, grosso modo, do que hoje vemos nas obras sobre o Portugal romano, com excepção, é evidente, de uma metodologia mais actualizada. O gérmen, contudo, já está aqui. Ainda no primeiro livro consagra-se o humanista, o que constitui outra novidade, a uma descrição nitidamente de cariz geográfico, sobre os montes e serras portugueses, o que o toma, a nosso ver e de alguns estudiosos, um pioneiro da Geografia em Portugal, visto que procura a respeito de cada uma das zonas descritas salientar as características, o habitat, o clima e as produções. Esta linha geográfica será mantida no segundo livro.

De facto, vamos encontrar no Livro segundo uma tentativa geofísica de descrição dos rios portugueses, do Sul ao Norte do país, tal como dos montes, que não encontra correspondente quanto às antiguidades romanas que se centrarão sobretudo 
na zona alentejana e algarvia, descrição que logo de início vai ser cortada por um capítulo, que constitui uma digressão bem pensada e bastante à moda da época que se ocupará da discussão ictiológica do misterioso esturjão ${ }^{27}$, cuja classificação dentro dos peixes conhecidos de então levantava a maior dificuldade. Efectivamente o seu nome moderno não coincidia com o nome latino conhecido e divulgado pelos manuais mais seguidos de zoologia, que ainda eram os manuais da antiguidade clássica, com especial relevo para Plínio. Dez páginas da edição princeps são consumidas a discutir o esturjão e até a novidade que para um Português constituía o caviar e a botarga, depois de uma breve introdução aos rios portugueses, que mais adiante voltarão a ser estudados um a um ou em grupos (caso dos rios de Braga), com excepção do Guadiana que propositadamente é referido com menos pormenor, posto que aparecerá várias vezes com as suas peculiaridades em muitos outros passos da obra. No meio de citações clássicas, mas demonstrando um conhecimento factual dos rios, dá-nos Resende a conhecer as suas virtualidades, os seus peixes e, quando calha, a sua etimologia ou mesmo a sua mitologia (como é o caso do Tejo), quando não pormenores históricos, como seja o Cachão da Valeira em pleno rio Douro ${ }^{28}$. Ligada à água e consequentemente aos rios aparece-nos para o fim deste livro um pequeno capítulo destinado à descrição da fertilidade da Lusitânia, noção que é retirada muito especialmente dos Deipnosofistas de Ateneu e que certamente reflecte muito mais um lugar-comum, resultante do exotismo desta parte da ecúmena, do que propriamente uma análise mais ou menos sólida em que não aparecesse a amenidade do clima como ponto fundamental. A verdade é que já a Antiguidade tinha uma noção das limitações da fertilidade lusitana, provenientes da irregularidade do clima e da má qualidade de grande parte do solo, de tal forma que a história romana encontrava atenuantes para os "salteadores» Lusitanos, devido a viverem sob a constante pressão da sua pobreza ${ }^{29}$.

A história dos povos que, diz-se expressamente, "dominaram a Lusitânia", Cartagineses, Romanos ou Godos, é lançada por assim dizer no livro terceiro e em moldes que sem dúvida constituem novidade absoluta na historiografia portuguesa de então. A caracterização étnica e histórica dos povos invasores daquela zona desde a época pré-romana até ao domínio visigótico é abordada efectivamente pela primeira vez e ligada ao território de Portugal que virá a ser constituído em reino independente, o que revela um conhecimento minucioso e organizado, apesar das lacunas e das distorções e das interpretações abusivas que hoje é possível determinar. É interessante notar que os fundamentos em que se apoia a construção histórica de Resende em nada diferem no que respeita à concepção e finalidade, do que se escreve hoje, pois até mesmo a ligação do relato histórico dos historiadores e geógrafos gregos e romanos não deixa de ser relacionada com as provas palpáveis no terreno, uma vez que os documentos arqueológicos, muito em especial epigráficos, são largamente estudados e esquadrinhados, e, de quando em quando, forjados, tal como era conhecido hábito nos historiadores e antiquários renascentistas ${ }^{30}$. Claro que a influência da historiografia e geografia da antiguidade e da época medieval 
(cronistas de língua alemã) é seguida com enorme respeito, o que implica a admissão sem crítica de muitos factos fantasiosos e lendários, que hoje seriam interpretados certamente de outra forma, sobretudo no sentido de averiguar qual a finalidade da lenda e o significado dos símbolos à sua volta criados.

Ocupa-se Resende, sobretudo, do povo lusitano e das suas alianças com os povos seus vizinhos, bem como do significado das guerras que durante mais de um século moveram contra o invasor Romano e nas quais demonstraram ser um povo de enorme coragem, de que deram também provas já em guerras mais internacionais quando para Roma se dirigiram nas tropas recrutadas pelo cartaginês Aníbal. É pois um capítulo da história antiga da Península Ibérica, da sua parte ocidental, que aqui se traça, sem esquecer os primeiros reis da lenda e os primeiros povos de que se tem notícia, como Fenícios e Cartagineses, ainda que com o cuidado bastante para generalizar o reconhecimento factual da presença dos Gregos, que, à excepção de Ulisses em Lisboa e de um ou outro pormenor que aparenta os Iberos com usos gregos ou nomes gregos, pouco transparece ${ }^{31}$. Não podem deixar de ser considerados os grandes chefes dos Lusitanos, que são Viriato, que servirá a Resende para o introduzir na história portuguesa como herói nacional, e o romano Sertório, romano perseguido e paladino da nobre causa da resistência contra o invasor. Na História da Antiguidade de Évora, já Resende o tinha sobejamente ligado à cidade, e aí certamente de forma mais fantasiosa do que neste livro em que se limita a fazer como que um florilégio dos passos mais importantes da historiografia grega e romana atinente à Ibéria lusitana, prenúncio metodológico e historiográfico da história antiga contemporânea, uma vez que consagra importante parte dos passos ainda hoje considerados dentro do corpus referente a este momento histórico, o que revela um conhecimento aturado dos autores clássicos, que depois serão confrontados com os textos medievais e seus contemporâneos. Do tratamento dos testemunhos antigos depreende-se a intenção de elaborar uma obra de defesa dos interesses lusitanos face aos romanos, que por certo nos fazem reflectir no seu valor quase alegórico e actual de defesa dos interesses nacionais da época perante a ameaça estrangeira, uma vez que há autênticas interpelações aos historiadores romanos que na generalidade são acusados de parcialidade e de má fé. Algumas referências particulares aos factos da história antiga fazem de facto lembrar que o território português sempre esteve sujeito à possibilidade de invasões, o que não é de desligar da realidade histórica de então, em que as ligações a Castela tornavam sempre potencialmente frágil a continuação dinástica em mãos portuguesas, sobretudo numa altura em que o rei $\mathrm{D}$. Sebastião tinha morrido sem deixar descendência e o país estava a ser governado por um Cardeal-Rei de provecta idade e que por definição também não teria filhos. Conhecida como era a tendência da rainha mãe, castelhana de gema e com influência política, Resende dá a entender por todos os signos que pode inventar que a coragem lusitana é o sustentáculo possível para a independência, e que poderá servir ainda melhor se fizer parte integrante de uma consciência nacional ${ }^{32}$. Fica-se este livro pelos Godos, como povo que dominou a 
Lusitânia, sobre os quais vai dar as informações que colhe nos historiadores antigos que deles se ocuparam, Iordanes e Procópio, não sem que faça digressões sobre os usos e formas linguísticas por eles usados, demonstrando também que dominava os textos medievos escritos em latim pelos historiadores godos, como Widukind e outros, que muitos séculos depois virão a ser editados na edição monumental de Mommsen, Monumenta Germaniae Historica ${ }^{33}$. Mesmo fora da historiografia clássica vemos o nosso humanista tratar com à-vontade textos difíceis de conhecer, uma vez que ainda hoje não se encontram em todas as bibliotecas devido à sua obscuridade e a tratarem de uma época histórica que nunca foi beneficiada pela opinião da Idade Moderna, aliás como demonstram as próprias palavras de Resende ao falar dos tempos góticos, como a avalanche que fez aluir todo o magnífico edifício construído pelos Romanos e pela Antiguidade Clássica, apesar da sua boa vontade e respeito por $S$. Isidoro de Sevilha, que ele sempre cita e trata com a maior reverência ${ }^{34}$.

É com um capítulo, de certa maneira desfasado do teor geral do livro, que o termina falando sobre as Vias militares romanas, que discute apoiando-se sobre o Itinerário de Antonino-o-Pio, bem como sobre o seu conhecimento arqueológico do terreno ${ }^{35}$.

No livro quarto, a enumeração dos ópidos romanos em Portugal começa arbitrariamente por Moura e Mértola: a primeira fora do Coventus Pacensis e a segunda a caminho do Algarve, para depois começar pela parte mais meridional desta província e vir acabar em Elvas, Vila Viçosa e num templo de Júpiter situado entre Évora e Beja, exactamente no Torrão. Já Mendes de Vasconcelos apontava para esta limitada lista de 16 ópidos que vai frustrar o leitor que acreditou nas promessas de que se iriam tratar as principais povoações da Lusitânia. É possível que Resende pensasse ainda publicar mais sobre este esboço corográfico, que depois será aproveitado muito contra seu gosto por Gaspar Barreiros ${ }^{36}$ e por tantos outros que no século a seguir muito o imitaram, como Frei Bernardo de Brito e mais historiadores interessados em antigualhas. Seja como for, a verdade é que a propósito de cada povoação permite-se Resende elaborar um florilégio precioso de história local, como é o caso de D. Vataça e a sua história de Dona Bizantina e a cruzada contra os Infiéis ${ }^{37}$, ou a magnífica fraude da história da inscrição mandada gravar por D. Sebastião no arco da vitória que celebrava a derrota em Ourique do poder mouro face às armas e à fé de D. Afonso Henriques, e do aparecimento das cinco chagas e dos símbolos presentes no escudo da bandeira portuguesa 38 , bem como a preciosa recolha epigráfica das inscrições dedicadas a Endovélico, o Esculápio lusitano, em Terena, que efectivamente tanto significado tem na história dos cultos antigos ligados ao território português ${ }^{39}$. A análise histórica, ajudada pela recolha e exame das inscrições, pela abordagem etimológica de muitos dos topónimos, pelo enquadramento documental dos factos afirmados, constitui a prova mais evidente de que a literatura científica, ainda que misturada com a lenda e com o desejo de, pela fraude, se colmatarem lacunas e comprovarem teorias, começava a dar os seus primeiros passos, constituindo pelo material recolhido importante contributo 
para a historiografia posterior, mal-grado a relutância de Emil Huebner em admitir procedimentos pouco científicos e pseudo-epigráficos, que o levaram por vezes a não acreditar sequer no que apesar de tudo era verdadeiro e autêntico ${ }^{40}$. Por toda a matéria recolhida e sistematizada se verifica que Resende começou a praticar, como o faziam os grandes espíritos da sua época, uma história essencialmente dos princípios de Portugal mas que analisará factos até à época sua contemporânea socorrendo-se do enorme manancial dos seus conhecimentos enciclopédicos que convém conhecer com alguma minúcia.

\section{II.6 - As fontes}

Os conhecimentos da antiguidade e da história em geral que André de Resende compartilha com o leitor provêm, além da sua experiência pessoal em Portugal e no estrangeiro, da sua vasta leitura de autores clássicos, medievais e modernos, bem como da documentação mais diversa e da paixão que manifestamente sentia pelos restos antigos deixados no terreno pelos Antigos, entre os quais avultam as inscrições que procurava, desenterrava e pelos vistos até forjava.

\section{II.6.1 - Autores Gregos e Romanos}

Como é óbvio, o contingente mais poderoso de autores antigos do mundo clássico é constituído por aqueles que se ocuparam da história da Ibéria ou da sua geografia, o que não exclui a possibilidade de vermos outros citados a propósito dos aspectos mais controversos da história peninsular, mas que encontravam analogias na história romana em geral.

Dos historiadores gregos utiliza principalmente o nosso humanista as obras dos que mais directamente se ocuparam da Península, como Políbio, ligado ao círculo dos Cipiões, e sobretudo Apiano (séc. II d. C.), que escreveu especificamente sobre as guerras dos Romanos na Ibéria na sua história universal do império romano e dedica alguma atenção à acção de Viriato e de Sertório, o que não o impede de recorrer eventualmente a informações de Heródoto (séc. V a. C.), de Arriano (séc. I-II a. C.), historiador de Alexandre Magno, na tradução de Perotto, à história romana de Díon Cássio (séc. II-III a. C.), ou à Biblioteca de Diodoro da Sicília (séc. I a. C.), grande repositório da história da região mediterrânica até meados do séc. I a. C. A Descrição da Grécia de Pausânias (séc. II d. C.) é também consultada para um ou outro aspecto especial, como a história eclesiástica de Eusébio de Cesareia (séc. II-III d. C.), mas já as Guerras Góticas apresentadas por Procópio também de Cesareia (séc. VI d. C.) são abundantemente compulsadas quando do capítulo sobre os Godos, no livro terceiro ${ }^{41}$. 
Ainda dentro da cultura helénica, na qual parece movimentar-se Resende com à-vontade, utiliza exaustivamente as obras geográficas de Estrabão (séc. I a. C. - II d. C.) e de Ptolomeu (séc. II d. C.) que largamente o influenciam, bem como o epítome ao Ethnika de Estêvão de Bizâncio (séc. VI d. C.). Eventualmente, para aspectos ligados às ciências naturais ou a aspectos históricos mais específicos, vemo-lo referir os testemunhos de Arístóteles (séc. IV a. C.), Plutarco (séc. I - II d. C.) e Ateneu (séc. III d. C.) e até a própria obra de Galeno (séc. II d. C.), sobretudo quando da discussão levantada pelo esturjão.

Maior do que o dos autores gregos é o número de autores romanos compulsados por motivos óbvios, uma vez que a Península romana foi objecto da atenção da classe dirigente e culta de Roma, pois as ligações culturais eram estreitas, sobretudo com a parte mais rica da Ibéria, sem dúvida a actual Andaluzia. André de Resende conhece extremamente bem os historiadores latinos e ainda hoje nos dá uma antologia de passos que tratam a península que só encontra equivalente nos trabalhos de Schulten e das suas Fontes. César (séc. I a. C.) e o anónimo Bellum Hispaniense são utilizados, tal como Tito Lívio (séc. I a. C. - I d. C.) que é analisado e criticado pelo seu parcialismo romano e até interpelado pelo humanista, que defende o valor Lusitano e despreza a má fé romana. Embora Suetónio (séc. I d. C.) também seja uma fonte erudita para certos aspectos mais peculiares, são Valério Máximo (séc. I d. C.), Veleio Patérculo (séc. I d. C.), Floro (séc. II d. C.) e Justino (séc. III d. C.) que proporcionam a Resende o material histórico com que ele compõe a sua defesa da terra Lusitana, citando ditos célebres, factos paradigmáticos, mirabilia, ajudando-se para tanto de Solina (séc. III d. C.), Obsequente (séc. IV d. C.) e de autores mais tardios como Amiano Marcelino (séc. IV d. C.), Eutrópio (séc. IV d. C.) e sobretudo Orósio, também deste século, que hispano e providencialista como Resende lhe fornece um arsenal de argumentos contra o poderio romano.

Para a época visigótica é Iordanes (séc. VI d. C.) a sua fonte latina, ainda que utilize profusamente S. Isidoro de Sevilha para as questões mais variadas, sobretudo linguísticas e, digamos, pré-históricas, sendo nele que fundamenta parte da sua errada tese sobre a identificação do esturjão. É evidente que outros autores são utilizados, desde o velho Catão (séc. III-II a. C.) e Cícero (séc. I a. C.) ao seu comentador Ascónio Pediano (séc. I a. C. - séc. I d. C.), mas nos livros em que se trata mais das origens da Lusitânia, da sua geografia e dos seus costumes as fontes compulsadas são essencialmente Plínio-o-Velho (séc. II d. C.), de longe a mais importante, porque a mais minuciosa sobre a Península, na esteira de Varrão (séc. II-I a. C.), e mais secundariamente acompanhado por Columela (séc. I d. C.) e Aulo Gélio (séc. II d. C.), consultado para questões linguísticas, e já em proporção mais significativa e nalguns pontos de geografia essencial, a obra de Pompónio Mela (séc. I d. C.). Da época tardia e para esclarecer aspectos de pormenor, Resende utiliza Marciano Capela (séc. V) e Prisciano (séc. VI), bem como compulsará os autores cristãos, como por exemplo Tertuliano (séc. II-III d. C.), Prudêncio (séc. IV) e S. Ambrósio (séc. IV), ou Cassiodoro (séc. VI) e Gregório de Tours (séc. VI). Para alguns aspectos jurídicos 
peninsulares consulta Resende a Plínio, para outros, contudo, a Paulo (séc. II-III d. C.), bem como, para a rede viária romana, cita abundantemente o Itinerário de Antonino Pio (séc. III d. C.), no fim do livro terceiro.

\section{II.6.2 - Fontes medievais}

A noção de antiquitates na Lusitânia não se limita para Resende às que os romanos ou povos pré-romanos nos deixaram. Pretende, sim, dar uma continuidade até ao seu tempo e por isso lança mão de um importante acervo de textos medievais gregos, mas muito especialmente latinos, alguns dos quais visam o fim de constituir novidade.

Os Bizantinos têm um lugar modesto, ainda que interessante, no capítulo do livro quarto em que Resende se debruça sobre a história de D. Vataça, nobre de Bizâncio, que veio para Portugal com D. Isabel, a futura esposa de D. Dinis. Embora assente a sua exposição também em autores seus contemporâneos, cita contudo três historiadores de Bizâncio, todos eles ligados à Igreja do Oriente como Zonaras (séc. XI-XII), Nicetas Coniates (séc. XII-XIII) e Nicéforo Calisto Xantópulo (séc. XIII-XIV), com citações correctas ainda que breves. Não é fácil especular sobre o conhecimento que tinha destes autores, por isso limitamo-nos a registar o facto.

Já quanto a autores medievais que escrevem em Latim é o seu número bem mais elevado, sobretudo se entre eles contarmos alguns dos autores já mencionados como Isidoro de Sevilha. Ligou, contudo, a datas um pouco mais tardias autores como Einhard ou Eginhard (séc. VIII-IX), o biógrafo de Carlos Magno, e Widukind von Corvey (séc. IX), que dão informações preciosas sobre os Visigodos e a sua civilização e língua. Do lado português vemo-lo utilizar a obra de Apríngio (séc. XI) e referir-se ao problemático Isidoro de Beja (séc. VIII). Outros textos têm um maior interesse pela sua novidade, como o texto do mouro Rasis trasladado para português por Eanes, escrivão de D. Dinis, e que ainda hoje é um dos elementos fundamentais para o conhecimento do texto perdido da crónica árabe, bem como a Vida de S. Martinho de Soure (provavelmente do séc. XI) ou a estranha vida do taumaturgo S. Frei Gil de Santarém (séc. XIII), História de Santa Iria e a Vida de S. Rosendo (séc. XII), bem como documentos notariais, constituídos pelos testamentos no Livro Negro e o livro de testamentos e vendas de Santa Cruz de Coimbra, o que a nosso ver já marca um progresso no tipo de investigação histórica em Portugal. Este limitado acervo de textos medievais consultados por Resende dá, contudo, a noção exacta da preparação do humanista, que para ilustrar ou documentar a exposição que vai traçando do seu país não hesita em recorrer a tudo o que se escrevera depois da "enxurrada gótica", tal como ele denomina a invasão dos povos godos, dominado como está da visão humanista petrarquiana da «idade das trevas» definidora desse longo período da história europeia. Textos hagiológicos, documentos notariais, crónica árabe, bem como fontes estrangeiras e tratados teológicos, tudo lhe 
serve para investigar o passado português que ele quer distinguir bem do passado espanhol, ou, melhor, castelhano.

\section{II.6.3 - Fontes renascentistas}

Com igual entusiasmo, porém, lança mão de toda a produção erudita e intelectual sua contemporânea, e quando não contemporânea, dos tempos do humanismo europeu, dos séculos XV e XVI. Autores e personalidades de Portugal, de Espanha, de França, da Itália e da Europa civilizada são citados, utilizados e criticados ou seguidos, conforme as teses que vai defendendo e alicerçando para a construção, que ficará por certo incompleta devido à morte do humanista, do edifício das antiguidades lusitanas e portuguesas que queria erigir. É evidente o seu conhecimento de figuras como as de D. Miguel da Silva, Bispo de Viseu, fidalgo elegante e latinista, inimigo de D. João III, ou de Martim de Figueiredo, tradutor de Plínio e engenheiro frustrado, e Francisco Nunes de Beja, difícil de identificar, Portugueses célebres na sua época, bem como de Espanhóis eruditos como Fernán Nuñez de Guzmán, filólogo de Salamanca, Bartolomeu Quevedo de Toledo, Honorato João Valenciano, Florião do Campo, continuado por Ambrósio de Morales, cronista de Espanha, aliás como Jerónimo Zurita, historiador aragonês, nomes importantes da erudição e das letras espanholas. Mas de além-Pirenéus conhece outras fontes da maior importância, quer como estudiosos de antiqualhas, como João Ânio de Viterbo, bem conhecido pelas suas falsificações e os seus estudos sobre o Pseudoberoso, ou o carmelita Onofre Panvínio de Verona, historiador dos fastos da Roma antiga, ou eruditos como o médico Paulo Jóvio, bom conhecedor de Portugal e dos seus Descobrimentos, de Baptista Egnácio, historiador dos Césares famosos da Europa e de Bizâncio, de André Alciato e os seus trabalhos sobre Tácito e o Direito Romano, do Patriarca de Veneza Hermolau Bárbaro, erudito e célebre, ou Paulo Cortese, assim como de poetas com nomes famosos em toda a Europa como Baptista Mantuano ou Sabélico, ou eruditos gregos como Teodoro de Gaza, que vem em meados do séc. XV de Constantinopla para Itália. Mostra conhecimento do trabalho do francês Rondelet, professor de medicina na Universidade de Montpellier. Da Flandres citará o seu colega humanista João Vaseu que virá ensinar para Portugal, como da Suíça consultará a obra de Joachim Watt (Vadianus), editor de Pompónio Mela, ou, da Alemanha, Gelénio editor de Plínio. Toda esta bibliografia permite-lhe dissertar sobre crítica textual, história bizantina, ictiologia (esturjão) e sobre a influência da velha Roma consubstanciada sobretudo nas inscrições que até nós chegaram, e cuja colecção e escolha devemos a Resende. 


\section{II.7 - Originalidade}

No entanto, parte significativa do que nos foi legado é proveniente das investigações pessoais do humanista, quer no domínio da arqueologia e história, quer no da língua portuguesa e suas origens. Muitas inscrições hoje conhecidas e estudadas foram recolhidas e analisadas por André de Resende, assim como certas fontes medievais como a crónica de Rasis ou a vida de S. Gil de Santarém, ou a de S. Martinho de Soure, cujos textos ainda se fundamentam nas informações deixadas por ele. Seguindo a moda da sua época, Resende é apesar disso inovador sobretudo no que respeita ao aproveitamento da epigrafia e da arqueologia em geral, uma vez que considera as inscrições romanas como a fonte mais fiável da antiguidade visto reproduzirem fielmente na pedra a forma como escreviam os Romanos e darem, como nos afirma na carta a D. Afonso, uma ideia mais directa da antiguidade ${ }^{42}$

\section{III - A atitude erudita e científica de Resende}

Não podemos dizer que Resende tenha alterado radicalmente a metodologia científica legada pelos Antigos, uma vez que já eles conheciam muitos dos domínios adaptados pelo humanista ao território português. Plínio, o mais enciclopédico de todos os autores consultados, reunira impressionante quantidade de informação e de dados objectivos que, discutíveis ou não, constituíam um imprescindível corpus para qualquer erudito do séc. XVI. Era respeitado, seguido e tratado com especial deferência; podemos juntar ao seu os nomes de tantos outros como Estrabão, ou Pausânias, na geografia e na arqueologia, ou dos historiadores gregos e romanos, fontes seguidas, como já foi indicado, por André de Resende. Resende procede, contudo, ao tratamento das suas informações com espírito crítico, e embora aceite muitos factos não correctos com excessiva tolerância, ou mesmo com desconhecimento, a verdade é que raramente deixa de actualizar os dados que recebe com as informações carreadas dos autores medievais e renascentistas e com os que encontra nos mais diversos documentos, sejam eles provenientes das chancelarias medievais, sejam originários de inscrições da mesma época. Muito do que nos vai relatar assenta na sua observação pessoal, pois nunca evitou calcorrear terreno munido das suas ferramentas arqueológicas que lhe permitiam escavar onde lhe parecesse necessário ${ }^{43}$. Há, pois, um conhecimento livresco adquirido nas fontes, que igualmente se fundamenta numa investigação documental (epigráfica, paleográfica), processos que frequentemente são comprovados, quando necessário, por uma presença física no terreno, de onde por sua vez vão surgindo com frequência informações completamente inéditas.

Mesmo tendo em conta a dependência que evidencia das fontes que the são anteriores, não parece ser de hesitar considerarmos Resende como profundamente inovador, não só pelas informações inéditas que nos proporciona como por desempenhar em Portugal, pela primeira vez, o papel de iniciador de muitas 
disciplinas científicas que já concebe sistematicamente e metodologicamente, como seja a geografia e mesmo alguns aspectos da linguística. Não queremos exagerar a sua originalidade, nem encarecer sem critério o valor do humanista, uma vez que só comparando com os seus concorrentes estrangeiros seria possível uma ideia mais concreta, e por isso limitaremos a nossa exposição à análise do que consideramos os principais domínios que versou e nos quais apresenta resultados novos, mesmo quando não inéditos, visto que pela primeira vez são apresentados ordenadamente e com algum espírito a que chamaremos científico.

\section{2 - A linguística}

Ainda que de forma rudimentar, as preocupações com a origem da língua e a sua análise fazem parte da abordagem científica de Resende quanto aos problemas históricos que se põem. A origem das palavras e a sua identificação com os ramos linguísticos conhecidos é uma das suas preocupações, seguindo neste ponto o método etimológico há muito instituído pelos Antigos. No entanto, avança com algumas hipóteses que ainda hoje têm a maior validade e que na sua época serviram para desfazer equívocos e para reivindicar a portugalidade de nomes ou coisas confundidas então na vaga noção do hispânico. Surgem, como é de esperar, etimologias que são completamente fantasiosas, mas que obedecem fundamentalmente a uma finalidade patriótica de reivindicar uma origem castiça ou lusitana, como sejam as da Lusitania, que faz remontar o nome ao seu fundador Luso, filho de Baco, nos tempos quase da génese do mundo, e mais não significa senão nobreza e antiguidade, do nome de Viriato, ligado indevidamente ao latim vis, e do nome do esturjão, que Resende patrioticamente intitula de *asturjão, por considerar o nome do peixe ligado ao rio Minho e por consequência às Astúrias, em cujas montanhas nasce. Para outros topónimos, contudo, encontra etimologias perfeitamente aceitáveis e ainda hoje respeitadas, como a de Beja, que faz derivar de Pax Julia, propondo a explicação de que o resultado fonético Beja teria sido condicionado pela sua entrada no vocabulário e pronúncia dos Árabes que então aí habitavam. Muitos outros topónimos são examinados por Resende, em abordagem linguística próxima da explicação actual, ou ainda pseudocientífica, tais como os nomes de Aramenha, Cacem (que diz derivar do nome do tirano árabe Cacim), Cetobriga, que Resende decompõe apresentando o elemento -briga como indicação de nome de povoação, o que corresponde à realidade, Coa, cujo nome deduz do nome do povo que aí habitava, os Transcudani, derivado portanto de Cuda e que aparece na inscrição da ponte de Alcântara, Monte Córdova, Covilhã, que faz derivar de Cavea Juliani, Douro, Estói, Elvas, Moura, Sor, Tâmega (deduzido igualmente da inscrição da ponte de Alcântara), Tejo e Zêzere, para o qual aceita o nome de Ozecarus, hoje admitido por J. Piel como a etimologia a considerar, podendo ainda acrescentar a esta lista a discussão de Resende a respeito do etnónimo Godos, para 
o qual vai buscar uma explicação proveniente do mítico Rei Guto que encontra nos cronistas saxónicos ${ }^{44}$.

A linguística, incipiente como é óbvio, servir-lhe-á sempre de instrumento auxiliar para encontrar a explicação da origem real do que pretende explicar do ponto de vista histórico e dentro de um conteúdo conceptual ou ideológico bem definido, sobretudo como forma de reivindicar, pela língua, mais antiguidade e nobreza para o povo português.

\section{III.3 - Crítica textual}

Numa época que se interessava ardentemente pelas notícias da antiguidade e em que se procurava com ardor toda a documentação que as autenticasse, que, portanto, preconizava o retorno aos textos autênticos, passou a ser moda, além de necessidade, manusear com cuidado os códices manuscritos que já se conheciam ou que se iam encontrando pela Europa fora. Surgiam bem conhecidas edições das oficinas de livreiros e editores cultíssimos, e o contacto com os manuscritos e as suas lições textuais era constante, o que forçava qualquer humanista que se prezasse a escolher uma ou outra lição para que o texto que se propusesse editar ou comentar fosse quanto possível próximo do original antigo ${ }^{45}$. O aspecto mais saliente que poderá ilustrar o conhecimento textual de Resende encontra-se no passo em que a propósito da antiga geografia da Hispânia procura o humanista contradizer uma versão de Plínio propondo outra que encontrara em dois manuscritos de Salamanca e de Toledo que consultara na companhia do célebre Pinciano, seu amigo, ou seja o humanista e filólogo Fernando Nuñez de Guzmán. Trata-se da forma atribuída à costa Noroeste da Península Ibérica pela versão de Plínio, conhecida de Resende, e que não corresponde à sua forma real, uma vez que no actual cabo da Roca ou Olissiponense, situado por alturas de Lisboa, começaria a costa ocidental portuguesa, o que significaria que toda a costa a norte deste cabo se confrontaria com o actual golfo da Biscaia. O cabo da Roca teria, portanto, a mesma situação geográfica que é desempenhada na realidade pelo cabo Finisterra. Neste caso Resende não resiste a intervir violentamente no texto manuscrito, que efectivamente reflecte um erro de Plínio, e apresenta-nos uma versão sua, que reporia a verdade geográfica, o que demonstra a sua atitude voluntarista de tentar repor a "sua" verdade, sobretudo quando a verdade dos outros não corresponde aos seus desejos, corrigindo para tanto a realidade dos factos ${ }^{46}$. Esta tendência leva-lo-á a extremos bem mais complicados, sobretudo quando se trata de encontrar vestígios que comprovem teses ou contrariem adversários eruditos ou internacionais. No caso em apreço acaba, contudo, por admitir o erro pliniano, após ter feito a sua própria correcção do texto e de aceder que é possível mesmo a um grande homem como Plínio enganar-se, porque um pequeno engano deste género não chegará para afectar a sua credibilidade. Não se ficará por aqui o seu zelo de intervir no texto, pois proporá amiúde correcções 
que facilitem o que tenta provar, na maior parte das vezes sem razão, ainda que se detenha com rara perspicácia em determinadas tradições textuais que corrige com grande conhecimento ${ }^{47}$.

\section{III.4 - A História}

Mas se todos estes aspectos já focados contribuem para que Resende dê uma visão cientificamente correcta, do seu ponto de vista, dos factos que pretende expor, a verdade é que essencialmente a sua finalidade é descrever com conhecimento de causa os nobres antecedentes da história portuguesa, considerada lato sensu, pois incluirá não só os factos que normalmente se classificam como históricos como englobará lendas e pormenores que mais ligados estão ao folclore ou à literatura bem como às ciências naturais, mas que contribuem para criar uma ideia de originalidade em relação ao país que deseja prestigiar e que evidentemente ama com enorme zelo patriótico. Por isso não estranhamos que as "antiguidades", antes de tudo o mais, dêem conhecimento de tudo o que se passou na antiguidade mais remota em território português, e o que se lhe seguiu nas épocas mais próximas. Isto o leva a tratar com enorme pormenor da história antiga da Lusitânia, sobretudo na época romana, para o que se serve dos textos gregos e romanos e da arqueologia em geral, mas a sua tarefa não se fica por aí, pois muitos dos factos relatados necessitam de um fundamento mais recente e autorizado, o que o força a utilizar não raro elementos da história medieval, inclusive da longínqua história bizantina, e da história contemporânea, neste caso, talvez, com mais intuitos políticos. Para tal utilizará como sempre as fontes documentais mais adequadas e que revelam a sua vasta cultura.

\section{III.4. 1 - História antiga}

Não dispunha Resende de outras fontes que não fossem os historiadores antigos que trataram da Península e que na maior parte dos casos nem pela Ibéria tinham passado. De Homero a Iordanes utilizará, como já vimos, o nosso humanista todos os que à Lusitânia se referiram com maior ou menor conhecimento da realidade e há que salientar neste número Estrabão, Políbio, Tito Lívio, Plínio, Ptolomeu, Apiano, Pompónio Mela e outros, cujas lacunas, de que se dá conta, procura colmatar com as inscrições e restos arqueológicos que já eram conhecidos no séc. XVI ou que entretanto ia escavando. Seguindo as suas pisadas, tentava ligar os acontecimentos históricos aos locais em que se tinham processado, o que força naturalmente o humanista a dedicar muito do seu labor científico à descrição geográfica e à identificação dos topónimos da sua época com os velhos topónimos transmitidos pela tradição clássica, recorrendo quando necessário aos conhecimentos linguísticos 
de que dispunha, o que o levou a identificações ainda hoje correctas, por se ter dado conta dos diversos estratos por que passara a língua latina, de que não era de retirar o árabe, que muito alterou os antigos nomes.

E evidente que qualquer historiador gosta de chegar aos inícios da história e Resende, não fugindo à regra, também o procura quanto à Lusitânia, o que o faz tratar das figuras lendárias dos primeiros reis ligados ao nosso território entre as quais inclui a Túbal que estaria na origem do nome de Setúbal.

Habis, Gérion e tantos outros aparecem-nos nomeados, até se chegar pouco a pouco a tempos mais conhecidos dos historiadores greco-latinos, de que consegue coligir impressionante somatório de passos que ainda hoje servem de fundamento a qualquer investigação sobre os primeiros povos da Lusitânia e sobre a conquista e dominação romana da mesma.

Os inúmeros povos que habitavam antes e durante a ocupação romana o território português serão tidos em conta minuciosamente por André de Resende. No primeiro livro sucedem-se capítulos sobre povos que ainda hoje constituem um problema para a história antiga peninsular, pois só podem ser estudados pelas notícias dos Antigos que, parte das vezes, nunca tinham tomado contacto com eles e muitas vezes nem com a Península, como é o caso de Estrabão e até de Plínio. Os Turdetanos, os Célticos, os Túrdulos, os Vetões, os Barbários (povo fantasioso), os Pesures, os velhos Túrdulos e finalmente os Lusitanos e a sua índole vão ocupar uma quinzena de páginas da primeira edição, nalguns casos discutidos com falsas questões como Vetões ou Vectões ou os referidos Barbários, mas que nos dão uma visão bastante alargada dos que, com os Cartagineses, teriam habitado a Península e muito particularmente a Lusitânia-Portugal. Há que realçar a novidade sentida por Resende e simultaneamente pelos seus colegas humanistas espanhóis, como é o caso de Florião do Campo e de Ambrósio Morales, em pôr em evidência esses aspectos etnológicos fundamentais para a compreensão da génese de um povo. Só que Resende liga-os à Lusitânia-Portugal, e os seus vizinhos à Hispânia no sentido mais lato, partindo da velha ideia tão do desagrado de Resende de que Hispani omnes sumus.

Essencialmente, o intuito de Resende é dar a conhecer a forma como as instituições romanas e as divisões administrativas dos conuentus, bem como o próprio direito romano, foram adaptados às estruturas sociais e políticas dos povos da Ibéria, muito especialmente às dos Lusitanos. Há uma preocupação constante em esclarecer a posição da Lusitânia perante o poder central de Roma, posição essa que Resende pretende livrar de todo o labéu colonial para lhe dar plenos direitos concedidos às populações mais romanizadas e, portanto, mais civilizadas e menos bárbaras, pelo direito do Lácio. Não raro atreve-se Resende a encontrar origens mais nobres pela comparação com os costumes dos Gregos, o que se denota no retrato traçado dos Lusitanos, cujos costumes chega a comparar com os de Esparta, não se importando para tal de forçar um pouco o texto de Estrabão ${ }^{48}$. 
No que respeita à História peninsular durante o processo da conquista romana, é evidente que a abordagem feita por Resende e que já faz lembrar a que constituirá alguns séculos depois a de A. Schulten, L. Pericot e R. Grosse, nas Fontes Hispaniae Antiquae, não obedecerá, contudo, ao mesmo intento. Ao passo que os modernos procuram essencialmente encontrar uma sequência histórica que marque a progressão do poderio e domínio romanos na Península e eventualmente na Lusitânia, Resende procura, sim, reunir material retirado dos historiadores gregos e romanos que ateste a ferocidade do invasor face às heróicas populações lusitanas que o humanista acabará por caracterizar, para tal forjando, inclusive, inscrições com a imagem do "bom Lusitano", generoso até para com os seus inimigos ${ }^{49}$. Como veremos, será uma forma de valorizar o passado português e de nobilitar a sua história e de criar como que uma consciência nacional. A apologia dos valores lusitanos face à ganância e à tradição dos adversários romanos constituirá o pano de fundo para a apresentação dos dois heróis que chefiarão a resistência contra Roma: Viriato e Sertório. Também a apresentação seleccionada das batalhas, vitórias e derrotas dos Lusitanos servirá para organizar o aparelho dialéctico de defesa dos invadidos e de expor não só a má fé dos invasores como a parcialidade dos historiadores romanos que deles se ocuparam. Haverá até interpelações directas a Lívio e Justino ${ }^{50}$, por exemplo, pedindo-lhes contas da sua parcialidade e acusando-os de tentarem elevar os valores negativos da suposta coragem do Romano, em vez de relatarem o saudável e valoroso comportamento do Lusitano, pois até em muitos casos exageram o número de baixas por parte dos Lusitanos e não relatam com fidelidade os estragos causados por estes nas tropas romanas.

Apesar do seu carácter apologético e quase parenético, a história resendiana nem por isso deixa de constituir um primeiro documento de recolha minuciosa dos passos históricos ainda hoje fundamentais para a compreensão da época que medeia desde o início da vinda dos Romanos para a Península no séc. III a. C. até à época de Augusto e intermitentemente até às invasões visigóticas do séc. IV da nossa era, o que continuará, quando necessário, até à Idade Média e Renascimento.

Entretanto, Resende não deixará de focar historicamente, na parte respeitante aos Lusitanos, as relações da Península com a ocupação Cartaginesa, e tomar certo partido discreto pelo contingente lusitano que vai ser incorporado nas tropas de Aníbal na sua marcha sobre Roma ${ }^{51}$. Afinal o inimigo do Romano era o natural amigo do Lusitano. Independentemente dos inúmeros episódios que Resende tenta tratar à maneira do seu adversário Tito Lívio, isto é, de forma épica e valorizadora dos feitos dos que pensa serem seus antepassados, o essencial da descrição e compilação históricas vai convergir no sentido de fazer ressaltar os heróis pré-nacionais, Viriato e Sertório, sendo este último um herói adoptado, uma vez que, embora cidadão romano, tinha combatido contra os seus compatriotas à frente das forças lusitanas. Sertório tinha, além disso, o aliciante de ser considerado como quase munícipe de Évora, terra de Resende, e por isso um conterrâneo seu, também, por adopção, uma espécie de cidadão honorário. Daí as inscrições forjadas por Resende para provar a 
tese da presença de Sertório em Évora, que são sobretudo de encontrar na história em vernáculo sobre as antiguidades da cidade alentejana 52.

Mas é Viriato quem vai ocupar o lugar de protagonista nesta epopeia ibérica que Resende imaginará para dar a conhecer mais nitidamente à comunidade internacional o verdadeiro herói ancestral português, tal como acontecia em França com Vercingetorix e na Alemanha com o invencível Arminius, o Hermann das gerações teutónicas futuras. Para tal não hesita em lançar-se nos textos gregos e latinos seus conhecidos, em traçar primeiro um esboço antropológico do que constituía as principais características do povo Lusitano, esquecendo um pouco que as tribos que o compunham se estendiam muito para lá de Mérida e que tanto podem ser consideradas antecessoras dos Portugueses como dos Castelhanos. Não deixa de lado os pormenores relatados sobre os costumes dos Lusitanos, tais como a alimentação, o vestuário, o armamento, a habitação e muitos pormenores que ainda hoje são essenciais para definir esse povo deficientemente conhecido devido à falta de tradição escrita, muito embora a sua origem céltica dificilmente possa ser posta em dúvida 53 .

O teatro das operações guerreiras dos Lusitanos comandados por Viriato e que certamente foi muito mais largo do que pretende Resende, ultrapassando na maior parte das acções militares o território português, também é analisado de um ponto de vista patriótico pelo humanista, que examina com atenção muitos dos seus movimentos guerreiros que o levam desde o monte Hermínio, a actual Serra da Estrela, como todos os Portugueses aprenderão na escola do séc. XX, até Peniche.

Esta visão a que podemos chamar pré-nacionalista da história de Portugal do séc. XVI já tinha, contudo, algumas raízes até na própria antiguidade, sobretudo no providencialismo histórico do historiador hispânico Paulo Orósio, que mistura na sua visão e análise dos acontecimentos que relata a sua formação cristã e a sua nacionalidade hispânica, o que até já possibilitou sem grandes excessos de ridículo que alguns eruditos o quisessem conquistar para os paladinos da história patriótica portuguesa ${ }^{54}$. A parcialidade dos historiadores romanos era já bem conhecida até por eles próprios que se entreacusavam de abusos com os números de cativos ou de mortos depois das vitórias romanas. Resende, porém, ainda vai mais longe nas suas ambições, pois não só quer reivindicar para os Lusitanos a dignidade que os antigos romanos lhes não concediam completamente mas também desmentir as acusações feitas por historiadores romanos a Viriato de ser um bandoleiro, que nos tempos modernos granjearia o título de combatente da liberdade, de guerrilheiro, porque o queria fazer o primeiro herói português, como quer, com essa visão, dar uma ideia de nobre continuidade dos feitos históricos portugueses até à sua época. Aproveita habilmente as fontes antigas que utiliza e cria uma teoria histórica que enriquece o valor lusitano e a generosidade dos seus guerreiros, ao mesmo tempo que reivindica para Portugal uma importante quota-parte dos feitos antigos, distinguindo-o claramente, tal como o fará noutros sectores da vida hispânica, do 
resto da Hispânia, o que em termos práticos significava uma certa em relação ao Reino de Castela.

A caracterização do território ocupado pelos Portugueses relativamente ao seu passado histórico e pré-histórico, com a enumeração dos povos que o tinham habitado, cria um todo coerente em que vai assentar um reino que tinha uma individualidade própria, o que na época importava afirmar, uma vez que as ligações políticas e culturais com Castela eram inúmeras e que os próprios colegas seus vizinhos tentavam demonstrar a originalidade da sua pátria na qual englobavam toda a Hispânia, sem se darem sequer ao trabalho de excluir o território português. De facto, a preocupação de Resende e a sua intenção independentista é perfeitamente justificada para quem, como os fundadores da nacionalidade portuguesa, queria manter Portugal coeso, independente e, mais do que isso, original. Daí a insistência de Resende que, no livro primeiro, descreve os povos da pré-história e depois volta, no livro terceiro, a descrever os povos que dominaram a Lusitânia até chegar aos Godos, não sem passar episodicamente no livro quarto pelo domínio árabe, como vai ser o caso de Santiago do Cacém. De resto, o árabe fará sempre parte da sua análise, visto que para a explicação do resultado histórico do Portugal seu contemporâneo dificilmente o poderia fazer sem recorrer à fonte árabe ou mesmo à língua árabe (caso da etimologia de Beja).

Não se limita, contudo, Resende ao estudo da história ligada aos primeiros séculos da dominação romana. Segue com algum cuidado, tanto quanto nos é possível ver nos livros que até nós chegaram - só quatro, quando deveriam ser dez, conforme nos diz Mendes de Vasconcelos - até à época medieval e visigótica, portanto, apontando para as alterações administrativas do território correspondente a Portugal que se foram operando, bem como para as características dos Godos que ocuparam Portugal, de cujas tribos traça uma breve história, apoiado sempre em fontes dignas de credibilidade, desde a Vida de Carlos Magno, a Procópio, Gregório de Tours, e Vitichindo.

\section{III.4.2 - História medieval}

Entramos, assim, nos primórdios da Idade Média que já se anunciavam com o estudo de alguns aspectos da presença cristã na Lusitânia, com a apresentação de uma discutida inscrição cristã do Torrão, com os nomes dos mártires Justo e Pastor, o que nos revela o posicionamento de Resende face ao passado cristão pré-português que ele aprofundará na sua obra com vários estudos e edições de textos medievais de S. Teotónio e mesmo de S. Rosendo, textos que ele manuseia e comenta, como vai fazer uso do Livro Negro de Santa Cruz, quando nos dá a conhecer, a propósito do nome dos montes Hermínios identificados com a Serra da Estrela e possível zona de habitação dos Lusitanos, os documentos notariais dos primeiros reis de Portugal em que efectivamente a identificação é feita e cuja transcrição comparada 
agora com a leitura mais recente dos mesmos documentos apresenta uma fidelidade que é de registar ${ }^{55}$. A hagiologia nesta obra servirá, sobretudo, para comprovar a independência de Portugal em relação a Castela, pois Resende procura portugalizar os santos que teriam estado no espaço nacional como S. Manços, e outros, e que muitas vezes eram reivindicados pelos historiadores castelhanos 56 .

Uma das peças fundamentais da história medieval que encontramos dispersa por esta obra sobre as antiguidades romanas é o milagre de Ourique, objecto já de tanta polémica histórica, e que Resende procura consubstanciar não só numa descrição pormenorizada da vitória milagrosa de Afonso Henriques sobre os Mouros, mas, mais do que isso, modernizar, fazendo-a objecto de um arco de triunfo construído pelo seu rei contemporâneo D. Sebastião, inscrição e arco que na realidade nunca existiram. Teria sido uma forma de dar a conhecer à comunidade erudita internacional um facto de tão transcendente significado histórico, pois para uso interno, o mesmo, tomando em conta a dificuldade de informação e de locomoção num país como o Portugal quinhentista, não deveria ter grande repercussão.

Ao suposto arco erguido por D. Sebastião dedica Resende um capítulo do livro quarto, e aproveita para juntamente com o capítulo anterior consagrado a Campo de Ourique traçar, em breve síntese, a história do reinado portucalense e do confronto entre o primeiro rei de Portugal e os Mouros no seu esforço de reconquista. A lenda de Ourique e das cinco quinas será lançada e ficará até hoje como um símbolo do patriotismo nacional, apesar da refutação histórica contra ela movida e que a todos os títulos merece o maior crédito 57 .

Os seus conhecimentos medievais serão demonstrados ocasionalmente quando da discussão de vários problemas históricos, como os relacionados com a cidade de Ossónoba (Estói) em que o humanista se socorre da Crónica do Mouro Rasis, traduzida em tempos de D. Dinis por um clérigo ao serviço de D. Periannes de Portel, tal como se servirá das Vidas de S. Martinho de Soure e de S. Rosendo para determinar locais que vai estudando na sua peregrinação irregular pelas povoações e cidades portuguesas, com seus mosteiros, rios, castelos e restos da antiguidade clássica e cristã. Será o caso da heroína D. Vataça, dona bizantina, que Resende liga à conquista de Santiago do Cacém e de quem traça uma breve história biográfica, utilizando para tanto fontes medievais bizantinas, que possivelmente existiriam na livraria do Convento de Alcobaça e cujo conhecimento, ainda que auxiliado por via indirecta pelos trabalhos do espanhol Zurita, demonstra um domínio razoável das fontes referentes ao império romano do Oriente e às suas ramificações fortuitas para Espanha por intermédio do Rei Aragão, que dará abrigo a refugiados da família real de Bizâncio. A história de D. Vataça, embora não coincida totalmente com o que hoje se conhece sobre essa nobre bizantina, refere contudo dados essenciais para a sua inserção na história portuguesa e na história patriótica, ainda que nem sempre fiel à verdade, devido ao épico estro de Resende. Personagens lendárias como Aginaldo de Nabância, quando trata do rio Nabão que atravessa Tomar, ou Santa Iria, ou tantas outras figuras da lenda secular e da lenda sagrada portuguesas, 
são evocadas com a maior seriedade e apresentadas com fundamento em fontes nem sempre dignas de crédito, mas que interessa utilizar para criar o ambiente histórico que Resende pretendia para o Portugal de então, para o Portugal que apresentava a todos os que em Latim o poderiam seguir na Europa, um Portugal de Santos, de heróis antigos e modernos (os das Descobertas), de sábios (S. Isidoro de Beja), de nobres e antiquíssimas tradições que remontam à época imemorial do Dilúvio (Túbal) e aos lendários reis da Península Ibérica, que deixaram vestígios na onomástica e na lenda.

\section{III.4.3 - Os tempos modernos contemporâneos de Resende}

Querendo embora afirmar-se como grande conhecedor das antigualhas lusitanas, na esteira dos antiquários que então se celebrizavam na Itália e na Europa mais civilizada, procurando, por outro lado, pelo menos em palavras, distanciar-se de forjadores bem conhecidos como Ânio de Viterbo, nem por isso Resende desiste de mostrar a sua boa informação quanto ao que se passava naquela época dentro do seu país e fora dele. É fácil ver nesta obra a familiaridade com que trata os autores estrangeiros em moda, como vemos no caso paradigmático da discussão sobre o esturjão, em que surgem citados os nomes mais importantes dos naturalistas e eruditos antigos, bem como os de naturalistas contemporâneos, num esforço baldado de reduzir o peixe a uma proveniência asturiana e minhota.

Até em ciência não conseguia Resende escapar ao seu fanatismo patriótico. Mas a bibliografia que cita em relação a inscrições, a direito romano, a epigrafia e a história antiga, é actualizada e abundante: Onofre de Verona, Vaseu, Morales, no seguimento de Florião do Campo, Bartolomeu Quevedo, a quem dedicará uma importante carta em publicação separada, o velho Pinciano e tantos outros a que já nos referimos, mostram-no a par da ciência mais recente, que liga conscientemente a eventos e figuras históricas do seu tempo, como a D. Luís da Cunha, quando trata de Peniche e da Atouguia da Baleia, a D. Sebastião, com o arco comemorativo da vitória de Ourique, ou a Martim de Figueiredo, o primeiro, ainda que incompleto, comentador de Plínio, que tentara, em obra de engenharia, acabar com o Cachão da Valeira em pleno rio Douro. São referências avulsas a propósito sobretudo de sítios descritos historicamente e arqueologicamente, mas que constituem informação importante para o conhecimento da época e também para a averiguação do método ziguezagueante do humanista, ainda muito influenciado pelos seus mentores clássicos e pelo enciclopedismo de um Plínio ou de um Ateneu. Embora com um pano de fundo clássico e sobretudo romano, a verdade é que temos várias acções em vestes modernas e actualizadas do séc. XVI. 


\section{III.5 - Arqueologia e Epigrafia}

Apesar de todo o material que coligimos e sintetizámos anteriormente, a realidade mais palpável da obra de Resende consubstancia-se na recolha de textos antigos sobre os quais escreve as suas reflexões históricas, mas mais do que isso na colectânea, autêntica sylloge de inscrições romanas que nos oferece. Reside aí ainda hoje o maior contributo desta sua obra, que juntamente com a que publicou sobre as antiguidades de Évora constituíram, pese isso embora ao erudito Emil Huebner e à sua teutónica seriedade, fundamento importante para o estudo da epigrafia romana em Portugal.

A verdade é que apesar das reticências de Huebner, que um pouco infantilmente manifesta desde a bibliografia inicial do volume II do Corpus Inscriptionum Latinarum (Hispania) ${ }^{58}$ uma antipatia feroz a respeito de Resende, são as inscrições a comprovação mais imediata, mais directa, das afirmações dos historiadores antigos sobre a Lusitânia, ao mesmo tempo que um complemento indispensável dos conhecimentos por eles adquiridos muitas vezes longe do terreno. O último artigo de José d 'Encarnação sobre o assunto denota uma nova atitude perante as recolhas esforçadas de Resende ${ }^{59}$, que, além do complemento que são, são também completa novidade quanto a cultos que se praticavam em território lusitano, como o de Endovélico, deus curandeiro, com um santuário perto de Terena do Alentejo. Que algumas das inscrições, em número não desprezível, são forjadas, não há a menor dúvida, mas mais adiante veremos o que julgamos ter motivado o lado falsário de Resende, em que era exímio, diz Huebner ${ }^{60}$, numa prática que tinha bastantes adeptos na sua época e que era vista como prova de erudição imaginativa e portanto tolerada indulgentemente pelo pensamento elegante dessa altura ${ }^{61}$. As inscrições recolhidas ou transmitidas por Resende cobrem uma vasta gama de factos históricos, e muito embora a sua grande parte respeite ao Alentejo e Algarve romanizados, um pouco o que se entende pelo conventus pacensis, nem por isso o conhecimento de inscrições fora de território português deixa de ser visível, quando a Resende se torna necessário comparar nomes, instituições romanas e até descobrir os étimos de alguns etnónimos, como será o caso da inscrição na Ponte de Alcântara ${ }^{62}$ ou na de Chaves.

A preponderância dos documentos epigráficos é, pois, uma constante nesta obra e constitui novidade na historiografia portuguesa, que seguidamente a Resende os utilizará profusamente desde Gaspar Barreiros a Bernardo de Brito e à historiografia alcobacense ou a Contador de Argote, para não citar senão alguns nomes bem conhecidos ${ }^{63}$. Convém, no entanto, ter em mente que esse processo científico e erudito já não era original na Europa, como podemos ver nas obras dos grandes antiquários italianos, para só escolhermos um exemplo frisante, que há muito se ocupavam das inscrições regionais e das que tinham interesse nacional, uma vez que Roma tinha sido durante tantos séculos a capital de tão vasto Império. Resende limitou-se a utilizar material original por ele mesmo descoberto, outro que já era 
conhecido, utilizando o processo científico com que entrara em contacto nos tempos em que estudara na Europa e na época em que acompanhara D. Luís de Mascarenhas, nosso embaixador junto de Carlos V. Seja como for, é ele, repetimos, um pioneiro, que embora nem sempre seguindo pelo atalho certo, nos leva aos lugares necessários de que se desfruta uma visão assaz completa do que foi a antiguidade romana em território português, consciente que estava de que as provas epigráficas eram o testemunho mais directo que se encontra à nossa disposição, quanto a um passado já longínquo. Por isso também nunca se limitou só às inscrições romanas, mas também às da época cristã, às medievais, e até às do seu tempo, só que a principal, nesse caso, a da comemoração de Ourique, é certamente forjada. Juntamente com as inscrições encontramos algumas referências aos edifícios em que elas se encontravam, ou originalmente ou deslocadas (a de Torrão), abusando também Resende de uma certa uniformização errónea dos objectos, em que predomina a classificação de cipo ${ }^{64}$, o que nem sempre correspondia à verdade. Por outro lado, as peças da estatuária antiga a que faz referência neste livro, como o baixo-relevo de Beja, não são localizáveis actualmente ${ }^{65}$.

\section{6 - Geografia}

Se olharmos para o plano dos livros que constituem esta obra de Resende e verificarmos o seu conteúdo, dificilmente poderemos ignorar o cariz geográfico das suas descrições, que nalguns casos prevalece até em relação ao seu aspecto histórico ou arqueológico. Basta olharmos para o livro II ou para o livro IV, em que se trataram respectivamente os rios de Portugal e as suas cidades (este último muito incompleto), para ficarmos com uma noção muito clara, se conhecermos sobretudo a literatura do mesmo género que lhe é anterior, de que a obra de Resende é inovadora como obra de Geografia. Já anteriormente teria havido uma obra a que o seu editor moderno Aires do Nascimento deu o título de Roteiro de Arautos ${ }^{66}$, em que, com metodologia diferente da seguida por Resende, se fazia uma resenha geográfica do território português, em pleno séc. XV. Não julgamos que haja qualquer relação entre esta primeira obra e o trabalho de Resende, que dá em Latim e com o fim de comunicar com o grande público erudito e internacional, sobretudo no capítulo dos rios portugueses (o Sado, por exemplo), uma descrição breve da sua existência e da sua morfologia. Esta tendência geográfica será concretizada posteriormente por um Gaspar Barreiros, cujo «latrocínio» acusará, por ter usado e abusado das informações prestadas, sem fazer menção da sua origem ${ }^{67}$, mas sobretudo pela influência que vai exercer na geografia de Duarte Nunes de Leão ${ }^{68}$. Resende já se refere a um opúsculo sobre o Entre Douro e Minho que julgamos poder identificar com a obra de mestre António de 1511 mas publicado só em $1959^{\text {69 }}$, de preferência à de um tal Dr. João de Barros, com o mesmo título, e que só foi publicada em 1919. De qualquer forma, grande parte do manancial informativo posto à disposição 
do leitor por Resende será repetido por Barreiros, por Nunes de Leão e por toda a historiografia alcobacense, sem falar depois dos historiadores que se dedicaram à descrição histórica e geográfica mais regionalizada, como D. Rodrigo da Cunha, Frei Amador Arrais, Contador de Argote. É sem dúvida um esforço inovador no capítulo da geografia da Lusitânia e que permite a quem ler situar no espaço os eventos históricos do passado de Portugal.

Para que o leitor português e o europeu pudessem situar no espaço os inúmeros factos históricos relatados, preocupa-se Resende em traçar com algum cuidado o quadro em que ocorreram, o quadro geográfico, bem entendido. O processo não era novo, pois já os seus modelos clássicos o tinham seguido com acribia e não só geógrafos como Estrabão ou Pompónio Mela, ou antiquários cientistas como Plínio-oVelho, mas até amadores de antiqualhas, como o grego Pausânias, conhecido e citado pelo humanista ainda que brevemente no seu livro de peregrinação (periégesis) na Hélade. Mesmo os Antigos preferiam relacionar o relato histórico dos eventos com o espaço terráqueo onde se passara, muito embora nem sempre conseguissem fugir à Utopia e ao reino da imaginação, como Platão e a sua Atlântida. No que respeitava à Península as informações da antiguidade não eram escassas, mas muito especialmente no que dizia respeito à Lusitânia "Extremum mundi» aí já elas escasseavam devido à distância e a certa pobreza que naturalmente repelia exploradores mais sofisticados ${ }^{70}$. As operações de Viriato deram-se a maior parte das vezes em território depois castelhano, porque aí se encontravam mais riquezas, como ainda hoje em dia é fácil constatar. Havia, pois, para um bom conhecedor da antiguidade como Resende, múltiplos exemplos de conhecimento do espaço da oikouméne, da terra habitada, que, embora eivado de erros e fantasias, ainda hoje são a fonte que permite aos modernos situarem o antigo face ao moderno. Resende aproveita desse conhecimento para o modernizar no tocante à toponímia portuguesa, apesar da sua tendência humanista de tudo latinizar. Basta lermos os títulos dos diversos capítulos, sobretudo do primeiro, segundo e quarto livros, para nos darmos conta do cuidado que põe na descrição, muitas vezes pormenorizada, dos montes, rios e cidades portuguesas, vistas na perspectiva da antiguidade. Há sem dúvida uma preponderância da geografia do Sul de Portugal, sobretudo quanto às cidades e ópidos do país, certamente por ser a que mais bem conhecia, mas consegue dar uma visão mais global quanto aos montes e aos rios. Publicada em forma de livro, porque o livro dos arautos que lhe é anterior só foi publicado neste século, podemos dizer que é, sem assim se intitular, a obra de Resende o primeiro ensaio impresso de geografia como ciência aplicada ao terreno que surge em Portugal, com realce para as descrições do Sado e seus afluentes ou dos terraços do Guadiana, do Cachão da Valeira no Douro, perto do qual, no séc. XIX, morreu o Barão de Forrester e se salvou D. Antónia Ferreirinha, e por se encontrar já muito perto dos objectivos alcançados pela cartografia que se ocupa do território português, como é o caso da carta de Fernão Vaz Seco de 1570. Gaspar Barreiros, na sua Corographia, aproveitar-se-á de Resende sem nomear quem lhe tinha dado os ensinamentos, deslealdade de que se ressente por escrito 
Resende na carta a Bartolomeu Quevedo, mas, tal como demonstra Susanne Daveau, os mesmos ensinamentos de Resende serão aproveitados por Duarte Nunes de Leão no século seguinte e de forma bastante ancilar, sem esquecermos a enorme influência que vai ter Resende em todos os escritores portugueses da Lusitanidade, como sejam Frei Bernardo de Brito ou Frei Amador Arrais. Romero de Magalhães, Orlando Ribeiro e Susanne Daveau ${ }^{71}$, o primeiro relativamente à História das Antiguidades de Évora, mas o segundo já em relação ao Roteiro dos Arautos e ao De antiquitatibus, cujo contributo geográfico é nitidamente superior ao prestado pela obra resendiana em vernáculo, enquadraram as obras de Resende dentro do acervo publicado na Península e fora dela quanto ao conhecimento geográfico da Lusitânia-Portugal. Há que reconhecer que apesar de submetido à descrição antiquária dos vestígios deixados pelos Antigos em território português, o De antiquitatibus apresenta novidades indesmentíveis, relativamente aos seus predecessores. Pena é que a Geografia em latim que João de Barros começara a escrever ${ }^{72}$ não tivesse chegado até nós. De qualquer forma, o contributo resendiano pôde ser apreciado pelos especialistas em relação ao passado e aos seus seguidores, sobretudo na breve análise feita nos trabalhos de Susanne Daveau e de Orlando Ribeiro, devendo ainda salientar-se a geografia dos mirabilia que Resende procura assinalar.

\section{III.7 - Ciências Naturais}

Em coordenação com a geografia, Resende localiza em Portugal alguns fenómenos naturais como o das águas de Fervenças ${ }^{73}$, águas sulfúricas e em ebulição, e coloca em Lisboa e em Benavente o caso celebrado na antiguidade das éguas que pariam do vento. Vai ser esta uma forma de concretizar a lenda narrada por Varrão das éguas de Lisboa que eram cobertas pelo Zéfiro e dele concebiam crias, velozes como vento, mas que duravam pouco. Este fenómeno, que corresponde à ideia antiga de que o vento era fecundador e não simples veículo da fecundação, do pólen, por exemplo, conheceu grande sucesso na antiguidade e vai ser repetida à saciedade até à descoberta, por Kammerherr (Camerarius) no séc. XVII, da verdadeira função do vento na fecundação das plantas. Resende vai mais longe, pois afirma ter conhecido um lavrador de Benavente que tinha uma manada num mouchão do Tejo e sem nela ter introduzido qualquer padreador uma das éguas teria parido uma cria muito branca e muito rápida, que em pouco tempo morreu. Se a égua ficou prenha numa pastagem onde não havia macho, a cria só podia ser do vento. Este caso ilustra mais uma vez a imaginação de Resende e a sua tendência para acreditar no maravilhoso, a fim de valorizar o assunto que descreve e dar crédito a histórias lendárias que lhe interessava realçar, para tornar o seu país mais importante e interessante ${ }^{74}$.

Mas é no segundo livro e ao tratar dos rios portugueses que Resende se entrega à discussão apaixonada do mais elegante peixe que povoava a imaginação dos naturalistas: o esturjão. Surpreendidos por este nome de origem germânica que 
destoava com o clássico acipenser dos Romanos, os humanistas enciclopédicos, alguns deles médicos como Jóvio ou Rondelet, tentavam identificar o sturio. Resende, levado pelo seu patriotismo um pouco infantil, apressa-se a propor que o sturio seja denominado asturio, uma vez que sendo o esturjão habitante do rio Minho e nascendo este nas Astúrias, nada mais normal do que encontrar um étimo ligado ao nome da região e chamar ao peixe asturjão das Astúrias. Vai mais longe e identifica-o com a toninha, o golfinho, utilizando para isso uma falsa etimologia para o nome português do esturjão, solho, que Resende faz derivar do vocábulo suillum, "porquinho" que encontra em S. Isidoro. Uma discussão naturalista em que o espírito científico do humanista português será, como sempre, obnubilado pelo seu zelo nacionalista ${ }^{75}$. Mas Resende vai ainda mais longe e tenta encontrar esturjão no rio Senegal e no Zaire, identificando-o com o porco das águas, ou seja o mamífero conhecido por peixe-porco ou por peixe-mulher, o manato ou manatim, e que os Portugueses conheceram primeiro que os outros povos da Europa, tanto na África como no Brasil. Infelizmente serão os Holandeses que darão a conhecer este sirenídeo à Europa culta ${ }^{76}$.

Não se fica, porém, André de Resende pelos mirabilia ou aspectos naturalistas mais notáveis. E evidente o seu esforço para nos dar a conhecer a fauna sobretudo piscícola dos rios que nos vai descrevendo, fazendo como Mestre António, o geógrafo do Entre Douro e Minho, que descreve as suas «avondanças». Isso não o impede, contudo, de apresentar, quer acredite ou não, histórias como a do Tritão de Lisboa a tocar numa concha que os membros da embaixada lisbonense a Tibério deram a conhecer em todo o maravilhoso que evocavam ${ }^{77}$, nem de nos transmitir o que constava sobre o Zêzere de águas azuis devido às fábricas de tecelagem de linho instaladas nas suas margens. Mais factos se poderão encontrar coleccionados nesta obra, que segue geograficamente e com atenção as curiosidades que se poderiam deparar no Portugal de então e no de outrora a quem o visitasse fisicamente ou sobre ele lesse o que os Antigos tinham legado às gerações futuras.

\section{IV - Finalidade do "De antiquitatibus Lusitaniae»}

A leitura exaustiva de uma obra deste género, situada dentro das contingências e modas do seu tempo, provoca inevitavelmente o leitor moderno e até o pode irritar pelos excursos errantes a propósito de tudo e de todos, bem como pelo método ziguezagueante que denota. Sente-se, contudo, que o humanista procura essencialmente traçar para a Europa culta do seu tempo o quadro histórico e cultural em que o Portugal da sua época nascera e crescera. Preocupa-o a origem dos Portugueses, composta de inúmeros povos só conhecidos pelos relatos dos Antigos, como o interessa dominar a origem da língua que fala e dos nomes que caracterizam as suas gentes e as suas povoações. É pois o fundamento de uma nacionalidade que Resende procura, utilizando para tal os seus conhecimentos 
linguísticos, históricos e até biológicos, que muito conscientemente alarga para sectores até então pouco explorados no seu país, como seja o conhecimento geográfico e a caracterização do terreno em que se passaram os acontecimentos históricos que descreve. Caracterizar um povo, que para mais é o seu, não é, porém, para Resende uma operação de puro racionalismo e erudição. Sente-se por toda a parte que é ao mesmo tempo uma demonstração de amor à pátria que o criou, amor esse que o leva a demonstrações de grande fidelidade à tradição portuguesa e por vezes de paixão e parcialidade em relação ao assunto que descreve. Só assim se compreende a dialéctica reivindicativa continuamente utilizada para portugalizar os santos, os nomes (Beja, etc.), os povos e até as situações da própria Natureza, como o Cachão da Valeira, no Douro, que considera como obstáculo posto por Deus, para impedir que rio abaixo viessem os inimigos do povo português: os Vaceus, metonimicamente neste passo, por Castelhanos ${ }^{78}$.

Eis aqui o ponto de tensão que leva aos argumentos profusamente utilizados durante esta obra para valorizar o passado e o presente do reino de Portugal. Não podemos deixar de concordar que todo este esforço se aplica a tentar criar uma consciência nacional que até então existira mais difusa, uma vez que Portugal e Espanha, contrariamente ao que muitos pensam, não estavam tão divididos quanto o desejariam acendrados nacionalistas, pois o castelhano e o português viviam paredes meias como línguas na produção literária portuguesa, e as relações políticas entre as cortes de Espanha e de Portugal não podiam ser mais íntimas ${ }^{79}$. Resende procura, neste ambiente que sem exagero poderíamos intitular de certa promiscuidade de nacionalidades, dar o seu a seu dono, tanto mais que do lado de lá da fronteira os seus rivais e colegas humanistas e eruditos reivindicavam sem dó nem piedade tudo o que era português, como se castelhano fosse, partindo do velho princípio de que Hispani omnes sumus, verdade incontestável, se se partir da tradição legada pelos escritores da antiguidade clássica. Não há por isso pormenor mais íntimo de características portuguesas que Resende não tente reivindicar para Portugal, ao mesmo tempo que pretende, com certa desenvoltura, portugalizar o que a ambas as nações pertencia, não sem primeiro valorizar historicamente o assunto. É o caso de Viriato e dos Lusitanos e da sua luta indómita contra o invasor Romano.

Assume Resende o papel de defensor histórico dos Lusitanos e dos seus esforços de resistência contra Roma. Viriato e Sertório são apresentados como heróis nacionais: o primeiro como filho da nação lusitana, o segundo como seu filho adoptivo. Os Romanos são interpelados no tribunal da história e de forma patética pelo humanista português como sendo agressores brutais e sem lei, ao passo que os Lusitanos, cujo território Resende faz coincidir, contra a realidade histórica, com o território português, são apresentados como um povo corajoso e generoso, não faltando para isso inscrições que o atestem. Não teve aqui Resende o menor rebuço em forjar inscrições, de resto facilmente detectáveis, em que a generosidade lusitana face aos Romanos é largamente atestada. Desta forma será lançada a lenda de Viriato herói nacional que perdurará até hoje e que permitirá aos mais patriotas ombrearem com 
os Franceses e Alemães e os seus Vercingetorix e Hermann. Só que esta acribia patriótica não fica por aqui e, imbuído de certo espírito renascentista revelado por predecessores seus, como Ânio de Viterbo e tantos outros, força Resende a verdade arqueológica colmatando lacunas com inscrições da sua invenção. Daí a antipatia do velho Huebner a que fizemos referência.

Seja como for, deixou-nos Resende um repositório de saber, juntamente com a primeira colecção de textos antigos referentes à história da Lusitânia Romana, bem como a acompanhá-los importante recolha de informações arqueológicas e epigráficas. Utilizando todos os meios científicos de que então podia dispor, criou para a posteridade uma imagem de Portugal antigo e moderno, tantas vezes afectada por certo anacronismo, mas que essencialmente obedece nos seus traços à vontade política de the conferir uma identidade que lhe faltava. Nesse aspecto conseguiu Resende levar a cabo a sua persistente intenção. A imagem criada será assumida e desenvolvida pelos seus sucessores, será até aumentada durante o reinado de Castela em Portugal ${ }^{80}$ e persistirá até ao século vinte nos livros escolares em que todos os Portugueses nascidos a meio deste século estudaram e aprenderam, acreditando ou não, os deveres do bom Português, que primeiro tinha sido o bom Lusitano.

Raul Miguel Rosado Fernandes 


\section{ESTABELECIMENTO DO TEXTO LATINO}

\section{I - Tradição textual}

A presente edição do De antiquitatibus Lusitaniae de André de Resende, no que respeita ao estabelecimento do texto latino, assenta no da $1^{\text {a }}$ edição, saída em Évora em 1593 segundo a informação colhida na folha de rosto, mas de cujos prévios pareceres e aprovações há dois com datas de 2 e 25 de Fevereiro de 1594, respectivamente.

Apesar de se tratar de uma edição póstuma (saída vinte anos após a morte de Resende), ela foi feita pelo jurisconsulto e humanista Diogo Mendes de Vasconcelos sobre o manuscrito do autor com os quatro livros fundamentais desta obra, e por isso representa a sua real e última vontade.

Além desses quatro livros sobre a Lusitânia, o editor Vasconcelos juntou alguns Scholia ou comentários de sua lavra aos mesmos quatro livros, bem como um quinto livro sobre a antiguidade do Município Eborense, que fazia parte do projecto do próprio Resende, mas para o qual deixara apenas uns parcos apontamentos que serviram de ponto de partida ao seu verdadeiro autor, que é manifesta e assumidamente Diogo Mendes de Vasconcelos. Por isso, o Liber Quintus da $1^{\text {a }}$ edição não entra na presente edição bilingue do De antiquitatibus Lusitaniae de André de Resende.

Quanto à posterior transmissão do texto, ela conta com outras edições, designadamente: a de Roma de 1597, organizada por Gonçalo Mendes de Vasconcelos e Cabedo, parente do primeiro editor; a de Colónia em 1600, da responsabilidade do tipógrafo alemão Arnoldo Mylius Birckmann, Filho, e provavelmente promovida pelo português Simão Rodrigues, cônsul em Antuérpia; a de Francoforte, saída em 1603 da tipografia do mesmo Arnoldo M. Birckmann e com a possível intervenção do mesmo Simão Rodrigues e de seu irmão Nicolau Rodrigues; a edição de Colónia de 1613 (em boa verdade, edição simulada que aproveita a parte remanescente do texto impresso em 1600 e não vendido, conforme a crítica moderna demonstrou); e, finalmente, a edição de Coimbra de 1790, incluída no Tomo I dos Opera Historica de A. de Resende publicados pela Tipografia Académico-Régia. 
A identificação descritiva completa de todas estas edições vem à cabeça da Bibliografia deste livro.

Ora, a colação e confronto das últimas cinco edições do De antiquitatibus Lusitaniae mostram que, apesar de saídas a público em locais e enquadramentos diversos e mediante promotores por vezes diferentes, elas apresentam uma fidelidade quase absoluta ao texto da edição príncipe, cujo exame permitiu encontrar apenas algumas variantes de pouco significado, que figuram no aparato crítico da presente edição.

Nesta, entram também as pequenas composições preliminares em latim (pareceres e aprovações, biografias, poesias, cartas dedicatórias, etc.), mas apenas aquelas que figuram na $1^{a}$ edição, porquanto as que acompanham as sucessivas reedições variam no todo ou em parte conforme o intuito circunstancial de cada respectivo editor.

Também não conta para efeitos de crítica textual a edição deste livro promovida pela Fundação Calouste Gulbenkian, Lisboa, 1996, com esta tradução, agora revista pelo mesmo tradutor, uma vez que o texto latino nela incluído é a reprodução facsimilar da $1^{\text {a }}$ edição do De antiquitatibus Lusitaniae, de 1593.

\section{II - A Ortografia}

Em matéria de ortografia, André de Resende apresenta algumas características muito próprias, que se manifestam no gosto por certas formas arcaicas ou arcaizantes, que ele usa de modo sistemático, consciente e motivado e que, por isso e sempre que elas não colidem frontalmente com o rigoroso sentido do texto, nós respeitámos. Foi uma tendência ortográfica resendiana que causou, mesmo na sua época, alguma estranheza, manifestada pelos especialistas da escrita, como se vê no exemplo do já referido tipografo alemão Arnoldo M. Birckmann, que na primeira edição de Colónia do De antiquitatibus Lusitaniae, em 1600, fazia o seguinte reparo: "No processo de escrita, o Antiquário saía do normal a ponto de sentir prazer em escrever "Adceptum" e "Quuius", imitando lápides e mármores".

De facto, sendo André de Resende um estudioso apaixonado da arqueologia, não admira que preferisse tais formas e que as tenha mesmo defendido e justificado à luz dos testemunhos antigos e arqueológicos, como acontece na Carta dirigida ao cardeal-infante D. Afonso que faz parte dos textos preliminares do De antiquitatibus Lusitaniae, e na parte final das "Adnotationes" ao seu poema Vincentius Leuita et Martyr, publicado em Lisboa em 1545.

Estão nesse caso a forma "quum", que aparece sistematicamente (com cerca de 130 occorrências) em vez de "cum", de pouquíssimo uso, quando tem valor conjuncional, bem como na expressão sufixal "-quumque" (em vez de "-cumque") que entra em composições do tipo "quantaquumque", "quiquumque", "ubiquumque"; a grafia "quuius" por "cuius", de que falava Birckmann e cuja opção Resende justifica na nota 106 das Anotações ao Livro II do seu Vincentius, evocando a autoridade de Terêncio Mauro e usando-a cerca de trinta e cinco vezes, em contraste com menos de meia dúzia sob a forma "cuius"; a forma do interrogativo "quur", que alterna com 
"cur", embora uma e outra apareçam poucas vezes; e ainda as formas arcaizantes "consequutio" e "insequutio", que o autor justifica na nota 105 do mesmo Livro II do Vincentius com formas analógicas, por exemplo "perquutio" e "inquutio".

Pertencem também ao domínio dos arcaísmos preferidos por André de Resende as formas de acusativo do plural terminadas em '-eis' em vez de '-es', por exemplo "treis", "monteis", "fonteis", “Aquiflauienseis", “confluenteis", "ignobileis", "urbeis", "palanteis", "genteis", "imbeleis", "redeunteis", "hosteis", "omneis", "qualeis", "pareis", etc.; e também o uso do ditongo 'ei' em vocábulos como "heic", "heinc" e "eidus", em vez de "hic", "hinc" e "idus".

Finalmente, são também arcaizantes alguns casos de assimilação ou não assimilação de consoantes em contacto, por exemplo em "solennis" ou "conlibuisset" e "conloquutionem", respectivamente, matéria que Resende justifica mais uma vez no seu Vincentius, nota 100 do Livro II.

Ponto de parte os arcaísmos de uso resendiano, que mantivemos, o sistema ortográfico geral desta obra apresenta-se relativamente equilibrado e coerente quando comparado com outros escritores latinos da sua época. Mesmo assim, e em obediência às regras preconizadas pela Associação Portuguesa de Estudos Neolatinos (APENEL) no seu plano editorial dos Portugaliae Monumenta Neolatina, interviemos em algumas grafias consideradas erradas pela filologia moderna, ou na harmonização pelas formas mais correctas em caso de oscilação por parte do autor. Tal intervenção visou os seguintes casos:

1. Em matéria de vocalismo: a) normalização na oscilação entre os ditongos 'ae' e 'oe' e a vogal longa 'e', uniformizando pela forma mais correcta, por exemplo em "caelum" e "coelum" (passim) em contraste com "caelesti" (fol. 236), "pene"(fol. 105)/"paene" (passim), "aeconomiae" (fol. 75) / "oeconomiae" (fol. 76), "haereditate" (fol. 45) e "haeredes" (fol. 137" / "hereditate" (fol. 44) e "heredes" (fol. 137); b) correcção de, por exemplo, "faemina" para "femina", "caeterus" (passim) para "ceterus", "faelix" e "foelicitas" para "felix" e "felicitas", "praelium" (passim) para proelium" e derivados, incluindo a forma verbal "praeliandum" (fol. 217), "faecunditate" (passim) para "fecunditate", "cetra" para "caetra", "coena" para "cena" e, ao contrario, "secula" para "saecula"; b) correcção do uso do 'y' em vocábulos como "hyemem", "hybernis" e "satyra", por "hiemem", "hibernis" e "satira".

2. No âmbito das consoantes: a) correcção das formas "author" e "autor" (passim) para "auctor", que também aparece e em maioria (29 vezes); b) substituição da consoante 't' por 'c' e vice-versa, frequentemente confundidas, em vocábulos por vezes etimologicamente diferentes, como "conditio", "ditio" e mesmo "dictio" por "condicio" e "dicio", em "internitio" por "internicio", e em "supposititius", "fictitius", "nouitius" e "caementitium" por "suppositicius", "ficticius", "nouicius" e "caementicium"; e, ao contrário, "planicies" e "nunciasse" por "planities" e "nuntiasse"; c) normalização do uso do 'h', em "charus", "aestipherus", "simulachrum", "sepulchrum" e "anchora", para "carus", "aestiferus", "simulacrum”, "sepulcrum” e "ancora”; d) regularização 
das geminadas, designadamente em "litera", "quatuor" por "littera" e "quattuor" e, ao contrario, "litus" por littus".

3. Aglutinação ou separação de vocábulos. Um processo relativamente frequente do Antiquário é a separação dos elementos constitutivos de vocábulos compostos por aglutinação na ortografia consagrada, nos quais interviemos para os normalizar, tanto mais que o autor demonstra muitas vezes um tratamento oscilante. São disso exemplo expressões adverbiais do tipo de "quod ad", "ad prime", "post hac", "ad haec", "ut pote", "ut ut", "ea tenus", "ad modum”, "aliquantis per", ou locuções adjectivas e pronominais como "eius modi", "ist haec", "sibimet ipsis", "qualis qualis"; bem como a separação de enclíticas como '-nam', '-ne' e '-ue' em "qualis nam”, "qui nam”, "quae nam", "quo nam", "non ne”, "metu ne”, "fit ne”, "est ne”, "populus ue”; ou mesmo em formações verbais como "sub notarit" e nominais como "ad colae" (por "adcolae"), "ad gressus", "ad nepos", "ex tructum”, "trium uiri", "iuris consultus", "sub obscuras"; e, ao contrário, casos de aglutinação indevida, como "adhoc", "proculdubio" e "quinetiam".

4. Finalmente, no que respeita às duas semivogais ou formas consonânticas de $i$ e de $u$, representadas pelos grafemas ramistas $j$ e $v$ desde as primeiras décadas do século XVI, o seu uso no De antiquitatibus Lusitaniae mostra que nem sempre o $v$ representa o correspondente fonema consonântico fricativo moderno, mas apenas quando se apresenta no início de palavra e seguido de vogal. Vd., por um lado, "varius", "vestigium", "vita”, "volumen", "vultus"; mas, por outro, "vniuersus", "conuiuium", "vt", "vsus", "vsurpauit" etc. De resto, esta regra ortográfica é a que se verifica nas línguas vernáculas da mesma época, designadamente no português. Basta ver a $1^{\text {a }}$ edição d'Os Lusíadas, para o confirmar.

Quanto ao grafema $j$, ele só aparece no De antiquitatibus Lusitaniae quando em formação geminada, ocupando sempre a segunda posição, v. g. "ij”, "ijs", "conijcio", e portanto sem valor consonântico. A função consonântica está, pois, no grafema $i$ (o primeiro) e não no $j$ (o segundo).

Isto significa, pois, que os grafemas $i$ e $u$, usados na ortografia clássica do latim, aqui adoptada nos Portugaliae Monumenta Neolatina, podem representar a sua função quer vocálica quer consonântica, como tendencialmente acontece cada vez mais em colecções modernas similares e nos dicionários mais recentes.

Note-se que uma grande maioria das cerca de 100 inscrições latinas que esta obra resendiana apresenta está envolvida em cercaduras que pretendem sugerir de algum modo o suporte material em que foram gravadas; por isso, sempre que tal acontece, decidimos fazê-las reproduzir com um filete que vá ao encontro da mesma intenção do nosso humanista.

Finalmente, as notas do aparato crítico do texto latino figuram no radapé da respectiva página, enquanto as respeitantes à tradução vêm no final da obra, agrupadas por livros, ou por secções preliminares. 
TEXTO E TRADUÇÃO 


\title{
AS ANTIGUIDADES DA LUSITÂNIA EM QUATRO LIVROS
}

\author{
Começados em tempos por \\ LúCIO ANDRÉ DE RESENDE \\ Revistos e acabados por \\ Diogo Mendes de VAsconcelos
}

Acrescenta-se-lhes um livro quinto ${ }^{1}$ sobre a antiguidade do municipio Eborense, da autoria do mesmo Vasconcelos, que também aparecerá em breve como autor quando, com a ajuda de Deus, publicar o segundo tomo constituido por cinco outros livros.

Com a autorização de Sua Régia Majestade

e do alto e sagrado Conselho da Santa Inquisição, com privilégio por dez anos.

Imprimiu Martim de Burgos, tipógrafo da Universidade em Évora no ano de 


\title{
LIBRI QVATTVOR \\ DE ANTIQVITATIBVS LVSITANIAE
}

a

\section{LUCIO ANDREA RESENDIO}

olim inchoati, et a

IACObo Menoetio VASCONCELlo recogniti atque absoluti

\begin{abstract}
Accessit liber quintus de antiquitatibus municipii Eborensis, ad eodem Vasconcello conscriptus, quo etiam auctore, secundus tomus quinque alios libros continens, cito, Deo Optimo Maximo fauente, in lucem prodibit
\end{abstract}

Permittente Regia Maiestate et Supremo Sacro Sanctae Inquisitionis Senatu cum priuilegio ad decennium

Excudebat Martinus Burgensis Academiae typographus Eborae anno 


\section{[* 3] SÃO ESTAS AS MATÉRIAS CONTIDAS NESTE VOLUME}

If Primeiramente a carta de Diogo Mendes de Vasconcelos dirigida ao nosso e invencível Rei Filipe, segundo deste nome, a cuja majestade se dedica merecidamente esta obra das "Antiguidades".

I Vida de Lúcio André de Resende escrita pelo mesmo Vasconcelos.

I Carta de Resende ao Cardeal D. Afonso, filho do rei D. Manuel e que diz claramente respeito à notícia das antiguidades.

I Carta de Diogo Mendes de Vasconcelos ao mui pio Rei D. Henrique, a qual representa como que um indício de toda a obra, muito especialmente dos quatro livros que Resende nos deixou.

I Poema do mesmo Vasconcelos em louvor de Resende.

I Alguns epigramas em louvor de Vasconcelos e de Resende.

I Carta de Resende a Bartolomeu Albornoz, na qual trata da história das "Antiguidades".

SEguem-Se Depois QuATro livros de ANDrÉ de Resende Pela SEguinte ordem:

I O primeiro ocupa-se da etimologia da Lusitânia e dos seus limites, e também dos diversos povos, ou tribos, em que outrora esteve dividida, [ 4] a que se segue, no fim, uma breve descrição das suas montanhas.

I $\mathrm{O}$ segundo enumera os nomes dos rios, tanto antigos como modernos, sendolhe inserido um excurso acerca do peixe esturjão, na altura em que se descreve o rio Guadiana, que igualmente é rico em peixes.

I $O$ terceiro descreve as gentes que outrora mandaram na Lusitânia e os feitos dos Lusitanos, a que se acrescenta além disso um breve estudo sobre as estradas militares.

I O quarto começa a tratar dos nomes de cidades e cidadelas, em que existem vestígios da antiguidade romana (parte esta que é a principal da obra).

I Embora o nosso Resende quisesse começar um quinto livro com a sua querida Évora de que era natural, tal como se pode depreender de um seu folheto manuscrito por sua morte (bem triste é), acabou por deixar inacabada uma obra tão ilustre.

I Por conseguinte acrescentou-lhe o livro quinto ${ }^{2}$ sobre a antiguidade da cidade e do município eborense Diogo Mendes de Vasconcelos, que segue as pisadas de Resende, apoiando-se muito nos apontamentos deste. Tem igualmente a intenção de, com a ajuda de Deus, reunir noutro volume os elementos que restam, para satisfação dos que se deleitam com o conhecimento da antiguidade.

I A este livro está apensa a vida do mesmo Vasconcelos, escrita pelo próprio ${ }^{2}$. 


\section{[ 3] HAEC SVNT QVAE HOC VOLVMINE CONTINENTVR:}

I In primis epistola Iacobi Menoetii Vasconcelli, ad inuictissimum regem nostrum Philippum, huius nominis secundi, qua opus antiquitatum illius magestati merito dedicatur.

I Vita L. Andreae Resendii, ab eodem Vasconcello scripta.

I Epistola Resendii ad Alphonsum Cardinalem Emmanuelis regis filium, quae ad antiquitatum notitiam non nihil pertinet.

I Epistola Iacobi Menoetii Vasconcelli ad piissimum regem Henricum, quae instar indicis est totius operis, praesertim quattuor librorum, quos Resendius scriptos reliquit.

I Carmina eiusdem Vasconcelli in laudem Resendii.

I Epirammata quaedam in laudem Vasconcelli et Resendii.

I Epistola Resendii ad Bartholomaeum Albernotium, in qua agit de hac antiquitatum historia.

SEQVVNTVR DEINDE QVATTVOR LIBRI ANDREAE RESENDII HOC ORDINE:

I Primus etymologiam Lusitaniae et eius terminos explicat, praeterea diuersos

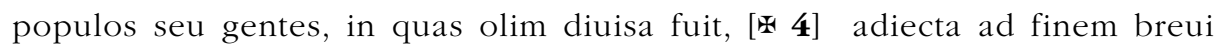
montium descriptione.

I Secundus fluuiorum nomina, tam antiqua, quam noua enarrat, et diuerticulum quodam interserit, de pisce Asturione, sumpta occasione a descriptione Anae fluminis, quod eiusmodi piscibus abundat.

I Tertius disserit de gentibus quae in Lusitania olim imperium obtinuerunt, ac de rebus gestis Lusitanorum, addito praeterea breui compendio de uiis militaribus.

I Quartus urbium et oppidorum nomina, in quibus Romanae antiquitatis extant uestigia (quae pars huius operis praecipua est) explicare incipit.

I Cum autem librum quintum Resendius noster ab Ebora patria sua carissima exordiri uellet, ut apparuit ex foliolo quodam eius manu scripto, morte superueniente, tam praeclarum opus (proh dolor) imperfectum reliquit.

I Adiecit igitur librum quiuntum Iacobus Menoetius Vasconcellos de antiquitate civitatis seu municipii Eborensis, sequutus Resendii uestigia, et ilius schedis plurimum adiutus, qui etiam in animo habet ea quae restant, deo iuuante, alio uolumine complecti, in gratiam eorum qui antiquitatis cognitione delectantur.

I Huic libro quinto praefixa est uita eiusdem Vasconcelli, ab ipso conscripta. 
[ 5] Por ordem e mandado do Reverendíssimo Pai em Jesus Cristo, D. Teotónio de Bragança, Arcebispo de Évora, li todos estes cinco livros de Diogo Mendes de Vasconcelos sobre as Antiguidades da Lusitânia, e nada neles encontrei que pudesse ofender a ortodoxia da Fé e os bons costumes. Na minha opinião, e é esta a verdadeira, os referidos livros são, pelo contrário, feitos com tanta erudição e saber, e com tais documentos de antiguidade, que pareceriam muito mais dignos de ter aparecido mais cedo à disposição de todos.

Évora, um de Fevereiro de 1594

Luís Sílvio de Brito

Tendo em vista esta informação do licenciado Luís Sílvio de Brito, nosso conselheiro, imprimam-se.

E eu, Manuel Coelho de Sousa, que actualmente sou secretário da Câmara do mesmo Senhor Arcebispo, por mandado deste assim o escrevi. Évora, dia 15 de Fevereiro, 1594.

Teotónio, Arcebispo de Évora 
[ 5] Reuerendissimi in Christo patris Domini Theotonii de Bragança Archiepiscopi Elborensis ${ }^{1}$, iussu et mandato perlegi quinque hos libros de Lusitaniae antiquitatibus, D. Iacobi Moenetii Vasconcelli, et nihil in eis offendi quod, uel orthodoxae Fidei, uel sanis moribus possit officere. Immo iudicio meo (qualequale illud est) ea sunt eruditione et doctrina isque antiquarum rerum monumentis referti, ut dignissimi uiderentur qui non tam sero in omnium manus uenirent. Eborae, ipsis Kalendis Februariis. Anno 1594.

Ludouicus Siluius de Brito

Visa hac informatione Licentiati Ludouici Silvii de Brito nostri auditoris, imprimetur. Emmanuel Coelho de Sousa, qui ad praesens gero officium scribae Camerae eiusdem Domini Archiepiscopi, de eius mandato scripsi. Elborae decimo quinto Kalendis Martii M. D. XCIIII.

Theoto. Archiep. Elbor.

1 Elborensis] Elborensensis $E$ 
[ 6]

\section{EPIGRAMA}

a Diogo Mendes de Vasconcelos

e em louvor do livro sobre as Antiguidades

e da autoria de Luís Sílvio de Brito,

natural de Santarém.

Se porventura o egrégio zéfiro soprar, o cisne seu livre

canto entoa, pois sabe que se aproxima o seu fim.

Vasconcelos, a tua velhice, imitando nisto os cisnes,

Produziu um canto ressonante, saído da tua boca eloquente.

Mas - coisa admirável - tu, que assim imitas o cisne branco,

Superas os cantos agradáveis da ave que é o cisne.

Ele cala-se, se o zéfiro recusa brisas suaves,

Tu, ainda que a brisa benigna se cale, cantas. ${ }^{1}$ 
[届 6]

Ad D. D. Iacobum Menoetium Vasconcellum, in laudem libri de Antiquitatibus

\section{EPIGRAMMA}

Auctore Ludouico Siluio de Brito Scallabitano

Egregius forsan zephyrus si flauerit, ultro

Cantat olor, finem cum scit adesse sibi;

Vasconcelle, tua haec cygnos imitata senectus,

Facundo resonum prompsit ab ore melos.

Sed miror canum quod sic imitatus olorem,

Dulcia olorinae guttura uincis auis.

Ille silet placidas zephyrus si deneget auras,

Tu, sileat quamuis aura benigna, canis. 


\section{$[\mathbf{A}]$

\author{
Ao mui poderoso E INVEncível Rei Filipe De EspanHa, \\ SEGUNDO DESTE NOME,
} \\ deseja Diogo Mendes de Vasconcelos eterna felicidade.}

Como todos os pensamentos do teu espírito, ó invencível Rei, estão ocupados em fomentar, manter e aumentar por todas as formas os reinos sob o teu mando, que por tão longe se estendem, e assim também toda a cristandade, nunca desprezas o que possa dizer respeito ao seu bem-estar comum, segurança e prestígio. A fé católica e a religião verdadeira são tua principal preocupação. Sem descanso procuras fazer observar por todos as suas leis e salutares preceitos, e assim também não te cansas de levar ao mais alto nível os assuntos da guerra e da disciplina militar. Além disto também estimas e favoreces os estudos literários e o talento em todas as nobres artes e desejas que refloresçam cada vez mais. Disto mesmo ainda há pouco eu me dei conta, quando em carta me pediste que te informasse da situação em que se encontrava a célebre obra sobre as antiguidades, que outrora começada por André de Resende foi por mim retomada a fim de a emendar e acabar. Por isso fiz imediatamente o que me ordenaste e para que possas ter melhor conhecimento de todo esse assunto desde o princípio, enviei-te uma cópia da carta, que eu próprio escrevera há alguns anos ao mui piedoso Rei D. Henrique e na qual bem largamente expunha as razões que me levaram a meter ombros a esta pesada tarefa de escrever, e as quais penso ser completamente desnecessário repetir, tanto mais que, nessa mesma carta, que se encontra inserida no início deste livro, todos poderão facilmente dar-se conta disso mesmo. Não convém repetir, mais do que for necessário, os mesmos assuntos, sobretudo a ti, cujo tempo deve por todos ser respeitado, a menos que se queira lesar o interesse público. Limitar-me-ei tão-somente a acrescentar que eu, de idade avançada e atreito a tantos achaques, não teria metido ombros a tal tarefa se um certo respeito singular para com a tua majestade e um enorme desejo de te obedecer não me levassem a empreendê-la. Por isso mesmo, deve ser esta obra dedicada a ti e trazida a lume sob os auspicious do teu augustíssimo nome, para que todos os que a lerem, se nela encontrarem algum interesse e honesto prazer, relacionem à tua pessoa [A v] todo este empreendimento. Recebe, pois, ó rei invencível, esta tua Lusitânia, que de nova e actual se tornou em velha e antiga, e da mesma maneira que amas e proteges, com certa benevolência especial, a Lusitânia que hoje floresce sob o teu reino e que abunda em todas as prosperidades, assim também, na medida da tua autêntica grandeza de alma e generosidade, digna-te proteger, amar e abraçar a antiguidade da outra, cujos monumentos foram arrancados das trevas, melhor direi, das fauces do próprio tempo. Que assim aconteça de modo a que, se eu vir que este livro te agradou, possa quanto antes ser trazido à luz tudo o que falta, elaborado ainda com maior profundidade e com maior cuidado. Que Deus bom e grande te mantenha sempre, para nosso bem e de toda a Cristandade, ó Rei invencível, de boa saúde e ao abrigo do mal. Évora, primeiro de Dezembro do Ano da Salvação de 1592. 
$[\mathbf{A}]$

\author{
Potentissimo et inUictissimo Hispaniarum Regi Philippo \\ HUIUS NOMINIS SECUNDO \\ IACOBUS MENOETIUS VASCONCELLUS PERPETUAM FELICITATEM EXOPTAT
}

Cum omnes animi tui cogitationes eo tendant, Rex inuictissime, ut non solum dicionis tuae regna, quae latissime patent, sed uniuersam Christianam Rempublicam omnibus modis iuuare, tueri ac propagare ualeas, nihil praetermittis quod ad communem eius salutem, incolumitatem ornamentumque pertinere posse uideatur. Nam catholicae fidei, et orthodoxae religionis curam praecipue geris; leges, legumque salutaria praecepta ab omnibus obseruari, diligentissime curas, res bellicas et militarem disciplinam in optimum statum redigere non cessas. Ad haec etiam litterarum studia et omnium bonarum artium peritiam foues, diligis, et in dies magis, ac magis reflorescere cupis. Id ego re ipsa nuper sum expertus, cum mihi per litteras significasti, ut tibi exponerem in quo statu esset opus illud antiquitatum, quod ab Andrea Resendio olim inchoatum ipse recognoscendum absoluendumque susceperam. Feci itaque statim, quod imperasti, et ut plenius, et ab ipsa origine rem omnem cognoscere posses, misi ad te exemplar epistolae quam ad piissimum Regem Henricum ante aliquot annos scripseram, in qua satis diffuse eas causas exposui quibus compulsus hoc scribendi onus susceperim, quas hic repetere minime necessarium esse existimo, quoniam ex eadem epistola, quae in huius libri initio apposita est, omnes id facile cognoscere poterunt. Neque enim conuenit eadem saepius inculcare, apud te praesertim, cuius tempori ab omnibus parcendum iudico, nisi in publica commoda peccare uelint. Vnum hoc tantum addam, me hac tam prouecta aetate ac tam multis aegritudinibus iam obnoxia hunc laborem haud quaquam suscepturum fuisse, nisi singularis quaedam mea erga maiestatem tuam obseruantia, et incredibile tibi obsequendi studium id facere coegissent. Quod cum ita sit merito tibi hoc opus dedicari, ac sub tui augustissimi nominis auspiciis in publicum prodire debet; ut quicunque illud legerint, si quid in eo utilitatis aut honestae uoluptatis inesse putabunt, id omne [Av] tibi acceptum referant. Accipe igitur, Rex inuictissime, Lusitaniam tuam, ex noua et recenti ueterem atque antiquam factam; et quemadmodum eam, quae hodie te regnante floret ac fortunis omnibus abundat, amas et peculiari quadam beneuolentia prosequeris, sic etiam eius antiquitatem, et uetusta monimenta e tenebris et, ut ita dicam, ex ipsius aeui faucibus eruta, pro tua uere regia animi magnitudine et beneficentia, tuere, dilige atque amplectere. Sic enim fiet, ut ea quae restant, si haec tibi placuisse intellexero, quam primum in lucem exeant, et diffusius et accuratius elaborata. Deus Optimus Maximus te nobis, Rex inuictissime, et uniuersae Christianae Reipublicae quam diutissime saluum, et incolumem seruet. Eborae Kalendis Decembris. Anno salutis 1592. 
[A2]

\section{VidA DE LúCiO ANDRÉ DE RESENDE POR Diogo Mendes de VASCONCELOS ${ }^{1}$}

André de Resende nasceu em Évora, cidade que depois de Lisboa ocupa em Portugal o primeiro lugar e que outrora foi denominada Liberalitas Iulia, como testemunha Plínio no livro IV, capítulo $22^{2}$ e é confirmado pelas inscrições antigas dos Romanos encontradas na mesma cidade e das quais falaremos na devida altura.

Foi seu pai André Vaz de Resende, cavaleiro da Ordem de Cristo, e sua mãe Leonor Vaz de Gois, mulher de boa condição entre os Eborenses e de todos conhecida pela honestidade e santidade de sua vida; tinha mesmo como outro sobrenome de família o nome de Ângela. Daí tirou, durante certo tempo, o próprio Resende o prenome de Ângelo, o que pode verificar-se pelos títulos dos livros que publicou na juventude ${ }^{3}$.

Transcreverei, contudo, as suas próprias palavras de uma carta que escreveu a Jorge Coelho ${ }^{4}$ em 1534 da nossa era, nas quais afirma a nobreza da família dos Resendes da seguinte maneira:

"Gabar-te-ás talvez dos teus Choélios, ou melhor Coelhos, pois é esse o vosso apelido, muito embora, em vez de Coelho, tivesses preferido numa primeira fase denominar-te Choélio, por influência da língua portuguesa, e depois como se a ti próprio te perfilhasses, Célio, em vez de Coelho. Apresentarei em contrapartida a famflia dos Resendes, outrora famosa e agora também não sem prestígio nem de humilde condição. Começada por Vasco Martim de Resende, de cognome "o Velho", meu quarto avô, continuada por Gil, ou se preferires por Egídio Vaz, meu trisavô, por Vasco Martim "o Moço", meu bisavô, por Martim Vaz, meu avô e André Vaz, meu pai, todos eles Resendes, chegou até mim por via de casamentos legítimos e matrimónios de nobre condição."

E noutro passo da mesma carta: "Eu sou filho de um cavaleiro português que nas guerras de Espanha mais de uma vez derramou o seu sangue pela patria".

[A2v]Tendo ficado órfão de pai, ainda menino e quase no berço, foi educado durante muitos anos pela mãe. Levado pela influência e virtude desta, logo na adolescência, ingressou na Ordem de S. Domingos. Iniciado piedosa e religiosamente nas disciplinas do espírito e nos rudimentos das letras pelos mestres do mosteiro de Évora, em breve por autorização e proposta dos mesmos foi para Alcalá de Henares, onde teve como professor a António de Nebrissa ${ }^{5}$, cuja fama era então pública, e depois ao Português Aires Barbosa ${ }^{6}$, mestre que em Salamanca ensinava o Grego.

Como nele se notassem já indícios evidentes de talento prometedor, por sua mãe e seus parentes foi aconselhado a que procurasse fazer estudos superiores. Escolheu Salamanca onde depois de ter terminado o curso de artes liberais se empenhou em trabalhos de Teologia, na qual, em pouco tempo, muito progrediu. Partiu, contudo, depois para França e frequentou a Universidade de Paris, da qual, 
$[\mathbf{A 2}]$

\section{Vita L. Andreae Resendi \\ AVCTORE \\ IaCobo Menoetio VAsconcello}

Andreas Resendius Eborae natus est, quae ciuitas, post Olisiponem, primum locum in Lusitania obtinet, et olim Liberalitas Iulia cognominata fuit, teste Plinio libro 4. c. 22., quod confirmant antiquae Romanorum inscriptiones in eadem urbe repertae, de quibus suo loco agemus.

Patrem habuit Andream Vasium Resendium, ex equestri ordine, matrem Leonoram Vasiam Gois, feminam, ut honestae inter Eborenses condicionis, ita celebris apud omnes probitatis et uitae sanctimoniae; cui etiam Angelae alterum suae gentis cognomen erat. Vnde ipse Resendius, Angeli praenomen aliquandiu usurpauit, quod ex librorum titulis, quos in prima aetate edidit, colligere licet.

Apponam autem eius uerba ex quadam epistola quam scripsit ad Georgium Coelium anno huius saeculi millesimo quingentesimo trigesimo quarto, quibus nobilitas Resendianae gentis asseritur in hunc modum:

"Iactabis tu forsitan Choelios tuos, aut potius Cuniculos, id enim uestrum cognomen est, quanquam tu Choelium te primum Lusitanae linguae proprietate, deinde quasi te ipse adoptaueris, Coelium, quam Cuniculum cognonominari maluisti.

Opponam ego clarissimam olim, sed et nunc non obscuram nec humilis fastigii Resendiorum gentem, a Vasco Martino Resendio, cui Magno cognomen fuit, atauo, per Gillonem, seu mauis Aegidium Vasium, abauum, Vascum Martinum minorem, proauum, Martinum Vasium, auum, Andream Vasium patrem, Resendios, ad me legitimis nuptiis et liberali matrimonio deriuatam".

Et alibi in eadem epistola: "Ego Lusitani equitis filius sum, qui bello Hispaniensi sanguinem pro patria non semel fudit."

[A2v]Patre orbatus est, cum adhuc infans, et fere in cunis esset, et a matre complures annos liberaliter educatus. Cuius impulsu et uirtute commotus, in ipsa statim adolescentia, ordini Sancti Dominici nomen debit. Et pie ac religiose a praepositis monasterii Eborensis optimis disciplinis ac litterarum rudimentis imbutus, mox ipsorum permissu et auctoritate, Complutum adiit, ubi Antonium Nebrissensem, cuius tunc celebris fama erat, et postmodum Areium Barbosam Lusitanum Salmanticae Graecas litteras docentem praeceptores habuit.

Cumque in illo maxima signa felicioris ingenii apparerent, ab eadem matre, et propinquis admonitus, ut grauiora studia capesseret, Salmanticam elegit, ubi peracto liberalium artium curriculo, Theologiae operam nauaret, in qua breui tempore multum profecit. Deinde uero in Galliam profectus Parisiensem Academiam inuisit, transactisque ibi aliquot mensibus, Louanium se contulit, 
depois de passados alguns meses, transitou para a de Lovaina, onde D. Pedro Mascarenhas ${ }^{7}$, fidalgo de alta estirpe e que em Bruxelas era embaixador do rei português junto de Carlos V, o convidou para sua casa. Como Resende o sentisse altamente desejoso de aprender Latim, deu-lhe lições particulares e conseguiu, por seu esforço e diligência, que esse homem tão importante e investido então em altas funções, já de idade madura e avançada em anos, se não envergonhasse com o nome de aluno, seduzido por autêntico desejo espiritual que colhia da convivência e do saber de tão distinto preceptor.

Foi nessa altura que Solimão ${ }^{8}$, rei dos Turcos, veio com grande número de tropas pôr cerco a Viena, capital da Áustria. Contra ele saiu o Imperador, com forte exército e com o maior aplauso de toda a Cristandade, e não só libertou os Austríacos do medo do cerco como até forçou a debandar o tão feroz tirano que nada pôde fazer e perdeu grande parte das tropas. Mascarenhas estava presente na expedição tendo em sua companhia a Resende, no campo de batalha e no próprio acampamento, a Resende a quem tanto ele como os restantes chefes muito prezavam, visto ser homem de grande erudição e de bons costumes, começou também por diligência de seus amigos a tornar-se notado junto do imperador, pelo qual foi depois sempre considerado como amigo, a tal ponto que muitas vezes, quando a ocasião se lhe oferecia de enumerar os Portugueses que lhe eram caros, contava frequentemente no seu número a Resende, desejando informar-se sobre o seu estado de saúde e ocupações. O próprio Resende relembra nas suas obras, e não só uma vez, [A3] a amizade e benevolência que o imperador para com ele mostrara, benevolência que ele considerava grande felicidade por ter sido adquirida não por empenhes interesseiros, mas pela fama da sua sabedoria e virtude.

Efectivamente, de tal maneira desprezava as riquezas e o luxo e tão dotado era de costumes nobres e puros, acompanhados de uma certa e distinta liberalidade de espírito, que, tendo sempre vivido na privança do imperador Carlos V, na do rei D. João III de Portugal e de outros príncipes, lhes foi sempre caro entre os primeiros, muito embora dispusesse de modesta situação financeira e não aspirasse aos mais altos graus das honrarias nem à ambição das riquezas: sempre foram seu deleite a poesia e o trabalho literário. Disto dá ele testemunho em muitos trechos, principalmente numa ode a Julián de Alva, homem notável, que depois foi bispo de Miranda ${ }^{9}$, e a Pedro Sanches ${ }^{10}$, como amigos íntimos que ambos eram e muito próximos de si, ao convidá-los para jantar, ode composta em versos satumais e em cujo finalizar assim diz:

Vivamos hoje, para amanhã voltarmos ao amargo sobressalto da solene corte,

Se todavia tivesse tanta força, que por fim me aborrecesse de servir aos reis,

5 Seria mais belo almoçar de couve com as musas benignas e conforme os deuses a vida concedessem, 
unde illum in contubernium suum inuitauit Petrus Mascarenius uir nobilissimus, qui apud Carolum quintum imperatorem, regis Lusitaniae legatum Bruxellis agebat. Quem Resendius cum uehementer auidum Latinae linguae addiscendae reperisset, priuatim docuit, et studio, ac diligentia effecit, ut uir grauissimus, et in eo dignitatis gradu collocatus, ac iam maturae et prouectioris aetatis, non erubesceret discipuli nomen, illectus uera animi uoluptae, quam ex tam insignis praeceptoris familiaritate et doctrina percipiebat.

Accidit eo tempore ut Solimanus Turcarum rex, ad obsidendam Vienam, Austriae caput, cum ingentibus copiis aduentaret, cui Caesar, non fine maximo totius Christianae Reipublicae applausu, cum ualido exercitu occurrens, non solum Austriacos obsidionis metu liberauit, sed etiam ferocissimum tyrannum, re infecta et magna copiarum parte amissa, fugam arripere coegit.

Aderat in expeditione Mascarenius, secum ducens Resendium in procinctu, et in ipsis castris, quem tam ipse, quam ceteri magnates plurimi faciebant, ob insignem hominis eruditionem, et inculpatos ${ }^{1}$ mores, coepitque etiam amicorum opera Caesari innotescere, a quo postea inter amicos semper est habitus, adeo ut quoties de uiris Lusitanis, sibi caris, percontandi sese occasio offerret, in eorum numero Resendium frequenter nominaret, de eius ualetudine, et studiis certior fieri cupiens. Quod ipse non semel in opusculis fuis commemorat, [A3] maximi imperatoris erga se amorem et beneuolentiam, non ambitiosis suffragiis, sed doctrinae et uirtutis fama comparatam in magna ponens felicitate.

Sed ita diuitiarum opulentiaeque contemptor fuit, tamque ingenuis, et candidis moribus, nec non egregia quadam animi liberalitate praeditus, ut cum, et apud Caesarem et apud Ioannem Lusitaniae regem, ceterosque principes, assidue semper uersatus fuerit, illisque in primis carus extiterit, tenui nihilominus fortunae condicione sit usus, nec ad altiorem honoris gradum, opumue cupiditatem aspirauerit; musis semper, et litterario otio delectatus. Quod multis in locis ipse testatur, et praecipue in quadam ode ad Iulianum Albium uirum clarissimum, qui postea Mirandensis Episcopus fuit, et Petrum Sancium, ambos ut amicos intimos, et familiarissimos, saturnalibus ad cenam inuitans, ubi ad finem ita canit:

Viuamus hodie, nam cras reddemur amaris

Aulae tumultibus grauis.

Quamquam o si tantum mihi roboris esset, ut uti

Tandem pigeret regibus,

5 Pulchrius esset holus musis prandere benignis,

Vtquumque dii uitam darent,

1 inculpatos $U]$ in culpatos $E$ 
Assim viver, trazendo dos montes as Irmãs Aónias

e passar o tempo a compor versos,

Para que não morresse de todo, e que a melhor parte de nós,

10 viesse algum dia incólume a perdurar

Nada direis destes saturnais. Estai presentes, já pus cobro à severidade ${ }^{11}$.

Com efeito, escreveu muitas obras e muitas deixou por trazer a lume, algumas porque, interrompido pela morte, não as pôde levar a cabo, $[\mathbf{A 3} \mathbf{v}]$ contando-se entre elas a história das antiguidades desta província ${ }^{12}$, que o rei D. Henrique, depois da morte dele, me confiou para emendar e acabar, como pode ver-se pela carta que lhe escrevi e pus no início desta obra ${ }^{13}$. O nosso Resende esteve-me sempre ligado por estreita amizade e familiaridade e foi principalmente a meu conselho que começou a escrever este trabalho, embora muitos anos antes tivesse prometido ao Cardeal D. Afonso ${ }^{14}$ editá-lo, tal como consta nas suas cartas, que adiante apresento. Nunca, todavia, metera mãos ao trabalho com seriedade e decisão, a não ser quatro anos antes de abandonar esta vida. É grato, contudo, neste passo dar a conhecer os seus elegantíssimos versos, nos quais faz honrosa menção à minha pessoa, testemunhando abertamente que foi por minha influência que começara esta obra sobre as antiguidades. É por isso que, um pouco agastado, começa esta sátira:

Essa tal força que a natureza em cada um de nós implantou ou que a vida Acostumada longamente pelo hábito, quase tornou inata,

É difícil, caro Vasconcelos, fazê-la voltar atrás,

A não ser que a força ou a razão nos forcem a desfazer a trama

5 E a despedaçar os fios da teia quase acabada.

É isso que na verdade me está a acontecer, a mim já avançado em idade, Ao ter de abandonar os estudos, para os quais me fizera o meu astro criador E em que sempre prosseguira até aos meus cabelos brancos,

Ao ter de depor a pena e de suportar que meus livros se encham de pó

$10 \mathrm{E}$ que pelas suas prateleiras, livremente trabalhe Aracne.

É disso, Vasconcelos, que tens pena e com incessantes recriminações

Tentas levar a bom caminho, quem já se esquivou

E já aborreceu os sagrados deveres para com Minerva

E julgarás indigno que as memórias da história lusitana,

15 Abandonadas a meio da corrida, não sejam levadas até à gloriosa meta, Pois elas são devidas ao rei, à pátria, à ciência e a ti,

A quem me une, quer a mais alta ciência do direito, quer a própria glória

Da Eloquência em que somos iguais, sem a nódoa

Da furiosa inveja, bem como o carácter e uma igual sinceridade de ambos,

20 Pelos elos recíprocos de uma cadeia indissolúvel.

Não te esforces por saber a causa por que mudei de opinião ${ }^{15}$. 
Exigere, Aonias deducere monte sorores, Aeuum canendo extendere.

Ne totus morerer, sed pars non pessima nostri

10 Olim superstes uiueret.

Dicetis nihil haec ad Saturnalia. Adeste,

Posui seueris iam modum.

Complura igitur scripsit, quorum nonnulla in lucem edere neglexit, aliqua, morte interceptus, perducere ad exitum non potuit, [A3v] inter quae fuit historia de antiquitatibus huius prouinciae, quam mihi, post eius obitum, recognoscendam absoluendamque tradidit rex Henricus, ut ex epistola, ad ipsum a me conscripta, uidere licet quam in operis fronte apponi curauimus. Fuit autem noster Resendius mihi arta amicitia et familiaritate coniunctus, ac me praecipue hortante hoc opus scribere aggressus est, cum multis annis antea illud in lucem se editurum Alphonso Cardinali promisisset, ut ex eius litteris constat, quas inferius subiiciam; sed nunquam serio et ex professo ei manus admouit, nisi quadriennio fere antequam e uita migraret. Libet autem hoc loco elegantissima eius carmina adducere, quibus honorificam mei mentionem faciens aperte testabatur, me impulsore, opus antiquitatum a se inchoatum fuisse. Sic igitur satiram quandam stomachabundus auspicatur:

Quam uim cuique sua inseruit natura, uel aetas

Adsuefacta diu, ingenitam prope reddidit usu,

Vertere difficile est, bone Vasconcelle, retrorsum, Impellat nisi uis, ratioue retexere tramam,

5 Et prope detextae diffringere licia telae.

Id mihi quandoquidem senio contingit adulto,

Vt studia, in quae me genitale adfecerat astrum,

Quaeque ad canitiem fueram sectatus, omittam,

Seponam calamum, patiar puluescere libros,

10 Libera per quorum nidos operetur Arachne.

Vasconcelle, doles, ac per conuicia crebra,

Iam detrectantem, iam munia sacra Mineruae

Exosum, reuocare cupis, monumentaque rerum

Lusitanarum, medio iam desita cursu,

15 Nec summam ad metam perducere, turpe putabis,

Debita iam regi, patriae, studiisque, tibique,

Quem mihi uel iurisprudentia summa, uel ipsum

Eloquii geminum decus, et sine labe furentis

Inuidiae, mores, parilis uel candor utrimque,

20 Nectit inabruptae per mutua uincla catenae.

Mutatae mentis caussam nescire labores. 
[A4] Também não penso que devam ser esquecidos os hendecassílabos com que me saudou na altura em que recebi como hóspede a Mateu Contarelli16, que depois foi Cardeal de Santo Estêvão, quando veio a minha casa no séquito do Reverendíssimo Cardeal Alexandrino que, com grande embaixada, fora enviado ao rei $\mathrm{D}$. Sebastião, pelo sumo Pontífice Pio $\mathrm{V}$, seu tio ${ }^{17}$. Resende, que também fora convidado para jantar, ofereceu-nos, de facto, quando já estávamos sentados à mesa, cidras e outros pequenos presentes e com este epigrama:

Entre o magnífico e majestoso banquete

Preparado para majestoso e magnífico hóspede

Se algum lugar concedes para um pequeno presente,

Ó Vasconcelos, lugar mais modesto ainda deverás reservar.

5 Toma esta ninharia das minhas terras.

Poetas rurais, rurais prendas só podem dar ${ }^{18}$.

Em Portugal não houve nenhum membro da família real, dos fidalgos e poderosos, bem como dos homens cultos, que não o tivesse acarinhado em estreita simpatia e familiaridade, enquanto viveu. Foi, no entanto, muito especialmente apreciado pelo cardeal D. Afonso ${ }^{19}$, irmão do rei D. João III, que de tal maneira gostava da companhia e do saber de Resende que não se sentia de todo diminuído em ir amiúde à sua escola, às suas reuniões literárias, ouvi-lo ensinar, muito embora este tão grande príncipe fosse já pessoa adulta que brilhava pela importância da sua autoridade e majestade de uma ascendência real. A escola estava, além disso, no palácio do próprio Cardeal e era tão contígua à Sé de Évora que podia ir e vir para a mesma, acompanhado de poucos fidalgos, pelo alpendre de seu pátio.

Depois da morte de D. Afonso, contudo, foi tido em não inferior apreço por D. Henrique, que o elevou a alguns cargos sacerdotais e o admitiu no número de seus familiares. Mais teria sido de esperar, se tivesse chegado ao seu reinado, mas faleceu enquanto reinava ainda o rei D. Sebastião.

[A4v] Usufruiu igualmente da amizade de estrangeiros ilustres na sua maioria e que eram recomendados pela fama da sua erudição. Em Lovaina foi amigo, mais do que nenhum outro, do belga Conrado Goclénio ${ }^{20}$, homem ilustre, como testemunha a ode, tão elegante, que compôs em seu louvor. Parece-me que não procederei de modo a desagradar ao leitor se aqui a inserir. É ela assim:

Não hei-de eu gostar de ti, mais do que de meus próprios olhos,

Goclénio, de quem sou mais amigo do que de mim próprio e da minha vida, enquanto a estrela de alva a seu leito de fogo

o astro celeste for buscar?

5 É mais fácil desaparecer astro celeste

e a estrela de alva não ser mais fogo candente 
[A4]Neque praetermittendos puto eius endecasyllabos quibus me falutauit, eo tempore quo hospitio excepi Matthaeum Contarellum, qui postea Cardinalis fuit Sancti Stephani, cum ad nos uenisset in comitatu Reuerendissimi Cardinalis Alexandrini, qui ad regem Sebastianum a Pio quinto Summo Pontifice auunculo fuo, cum amplissima legatione missus fuerat. Nobis igitur ad mensam sedentibus Resendius, ipse quoque ad cenam inuitatus, poma citrea, et alia munuscula obtulit cum hoc epigrammate:

Inter magnificas dapes, et amplas, Amplo et magnifico hospiti paratas, Siquem das quoque muneri pusillo, Vasconcelle, locum, infimum licebit,

5 De nostro id cape qualecumque rure.

Mittunt rustica rustici poetae.

Apud Lusitanos nemo fuit, tam ex regibus et dynastis, ac aliis principibus uiris, quam ex eruditorum hominum coetu, qui illum non arta familiaritate, et beneuolentia, quoad uixit, amplecteretur.

Sed in primis carus extitit Alphonso Cardinali, Regis Ioannis fratri, qui adeo Resendii consuetudine et doctrina delectatus est, ut ad eius scholam et ludum litterarium uentitare, et illum docentem audire, iam aetate adulta, tantus Princeps, ea grauitate, auctoritate regiique stemmatis maiestate praefulgens minime grauaretur.

Erat autem schola aedibus ipsius Cardinalis et Eborensi ecclesiae ita contigua, ut ad eam per atrii sui porticum, paucis nobilibus stipatus, commeare posset.

Post obitum uero Alphonsi, non minori in pretio ab Henrico habitus est, a quo aliquot sacerdotiis auctus, et in familiarium numerum admissus fuit, et maiora sperare potuisset, si usque ad eius regnum peruenisset, sed obiit regnante adhuc Sebastiano.

[A4v] Exterorum etiam hominum, praesertim illustrium et quos insignis fama eruditionis commendaret, amicitia usus est. Louanii Conradum Coclenium Belgam, uirum clarissimum, prae ceteris dilexit, ut testatur ode elegantissima in eius laudem composita, quam si hic adiecero, rem haud ingratam lectoribus, me facturum puto. Ea autem est huiusmodi:

Ten' non plus oculis amem

Cocleni, atque animo, luceque amicius,

Donec sidereum iubar

Exortu referet Phosphorus igneo?

5 Ante et sidereum iubar

Soluetur, nec erit Phosphorus igneus, 
do que eu não gostar de ti mais do que de meus próprios olhos e de ti não ser mais amigo do que de mim próprio e da minha vida.

Poderei eu alguma vez estar esquecido de ti?

10 Mais depressa olvidaria o céu as suas funções,

e para trás voltariam o imóvel império da Natureza

e as suas leis de ferro.

Mais depressa faltariam as sementes aos campos, mais depressa faltariam as ondas aos oceanos,

15 mais depressa faltariam as fontes, nascidas dos montes lá no alto, aos rios que corressem para trás.

Mais depressa se acalmariam ao som chuvoso do vento sul as águas que não sabem permanecer no mesmo sítio, e ao encontro dos veados fugitivos viriam as ondas

20 e dos escamosos cardumes as florestas.

[A5]

Que assim saiba o que eu te devo

a sorte que porventura me esperar, ou a região ou país, quer seja a região de Tanaide a receber-me quer o Tejo, quando eu voltar.

25 Quer eu vá para junto dos Líbios que sofrem de calor, quer por acaso venha a ter-me consigo a índia escura, ficarás na minha lembrança, em traços indeléveis, bem fundo no meu peito.

Calo-me quanto ao regato do meu talento,

30 que corre do Oceano do teu, e hei-de o testemunhar por toda a parte, enquanto eu vir a chama do róseo Hipérion.

Calo a generosidade e o pródigo talento.

Porquê? Porque gostas de me unir

35 com o mesmo laço ao que é meu,

e nem tão-pouco rejeitas os versos do poeta campónio.

Porquê? Porque me conferes honra imortal: que nome mais respeitado e maior glória poderia eu desejar, para além 40 do que me dão os teus livros? 
Quam te non oculis amem

Plus, ipsoque animo, luceque amicius.

Quibone esse tui immemor?

10 Ante oblitus erit sol sua munia,

Flecteturque retro statum

Naturae imperium, iuraque ferrea.

Ante agros sua germina,

Ante undae Oceanum deficient suae,

15 Ante amnes reflui petent

Fontes, aereis montibus editi.

Ante ad nimbisonum Notum

Pigrabunt ${ }^{1}$ freta se stare loco inscia.

Ceruisque unda fugacibus,

20 Siluae conuenient scamigero gregi.

[A5]

De me sic meritum sciet,

Quae me cumque manet sors, regio, aut plaga.

Siue orbis Tanaiticus

Me, siue accipiet iam reducem Tagus.

25 Siue ibo aestiferos Libas,

Seu me fors habeat decolor India,

Haerebis memori, notis

Indelebilibus, pectore conditus.

Mitto riuulus ingeni

30 Quod nostri fluit ex Oceano tuo,

Testaturus id ampliter,

Dum cernam rosei flammam Hyperionis.

Mitto munificentiam,

Et come ingenium. Quid? quod amas pari

35 Nodo, me, meaque omnia,

$\mathrm{Nec}$ uatis reiicis carmina rustici?

Quid? quod concilias mihi

Immortale decus: nam quod honestius

1 Pigrabunt E] Migrabunt $U$ 
Por tua causa, mesmo contra a vontade do destino,

já passámos para além das cinzas:

e pelas rochas de Cianeia

vou dirigir-me ao espólio do velo de ouro.

$[\mathbf{A 5 v}]$

Salve, amigo do coração, Goclénio, alma gémea da minha;

em que versos hei-de eu cantar-te?

Pelo teu valor, estás sempre

para além da meta que o poema alcança ${ }^{21}$.

Foi também amigo dos polacos Júlio Flu ${ }^{22}$ e João Dantisco ${ }^{23}$, do cardeal italiano António Puzzi ${ }^{24}$, do espanhol Graciano Lasso ${ }^{25}$ e de muitos outros. Ficaram-nos poemas a eles dedicados, que pensamos um dia editar.

Na sua mocidade, como já referimos, viajou pelas Espanhas, depois pela França, Alemanha e Itália, sempre com grande renome. Quando daí voltou veio a saber que sua mãe tinha morrido, e esta morte de tal maneira o impressionou que chegou a pensar em regressar de novo sozinho e abandonar a pátria, tal como consta no epitáfio, composto à memória da defunta. Encontrado entre as suas notas pensei que merecia a pena reproduzi-lo aqui. Está escrito em letras maiúsculas e desta maneira: 
Nomen, quodue aluid, tua

40 Quam quod scripta dabunt, malim ego clarius?

Te fortuna uidelicet

Inuita, cineres iam superabimus:

Et per Cyaneas petras,

Contendam ad spolium uelleris aurei.

$[\mathbf{A} 5 \mathbf{v}]$

45 Salue, pectus amabile

Cocleni, o animae dimidium meae.

Quo te carmine prosequar?

Metam qui meritis carminis es super.

Amauit et Iulium Phlu, et Ioannem Dantiscum Polonos, Antonium Puccium Cardinalem Italum, Gratianum Lassum Hispanum, et complures alios, ad quos extant illius carmina, quae aliquando in lucem edere cogitamus.

In primaeua aetate, ut iam attigimus, Hispanias, deinde Gallias, Germaniam, Italiam, non sine magna nominis celebritate peragrauit. Vnde rediens matrem decessisse comperit, cuius obitum ita aegre tulit, ut iterum solum uertere, et patriam relinquere cogitarit, ut constat ex epitaphio, in defunctae memoriam composito, quod inter eius schedas repertum hic ascribere operae pretium ${ }^{1}$ duxi. Erat autem scriptum litteris maiusculis in hunc modum:

1 operae pretium $U]$ operepraecium $E$ 
[A6]

\section{À MEMÓRIA E À PIEDADE}

ADEUS MINHA MÃE, MULHER TÃO PURA A QUEM NO BERÇO ABANDONADO, MEU PIEDOSO PAI À HORA DA MORTE EM DERRADEIRO PEDIDO ME CONFIOU, NÃO DESCONHECENDO A TUA FIDELIDADE. POR TUA PERPÉTUA E CASTÍSSIMA VIUVEZ FUI NOBREMENTE EDUCADO DURANTE 33 ANOS. É ESTA A ORIGEM DE TUDO O QUE EU POSSO SER NESTA ALTURA DA MINHA VIDA, DE TUDO O QUE EU POSSA VIR A SER DEPOIS. AQUI ESTOU VINDO DA LONGÍNQUA ALEMANHA, DEPOIS DE TER OUVIDO A NOTÍCIA DA TUA MORTE, PARA FAZER AS TUAS EXÉQUIAS, CHORANDO TRISTEMENTE. CUMPRI A MINHA OBRIGAÇÃO E PORQUE MÃE HÁ SÓ UMA E ME FOSTE ROUBADA, SINTO-ME POBRE E ÓRFÃO E ABORREÇO-ME DA PÁTRIA OUTRORA TÃO DOCE. DE NOVO VOU ANDAR POR ESSE MUNDO FORA.

LÚCIO ANDRÉ DE RESENDE À MEMÓRIA DE ANGELA LEONOR VAZ, SUA MÃE, TÃO CHEIA DE PIEDADE E DE MERECIMENTO, COM SEU DINHEIRO MANDOU FAZER.

[A6v] Já se preparava para partir, quando foi demovido pela autoridade do Rei D. João III e principalmente do Cardeal D. Afonso e adiou a partida, perdendo a vontade de se ir embora.

Resolveu habitar então em Évora, onde por essa altura a corte permaneceu bastante tempo e onde possuía uma morada de casas modestas, mas muito bem tratadas por Xisto e Hórtulo ${ }^{26}$ e muito aprazíveis. De tal maneira agradavam ao seu dono que não invejava as entradas mais espaçosas dos outros, e decorou-as dispondo lá dentro, à volta do jardim, antigos mármores, que conseguiu arranjar, com inscrições romanas. Dedicou-se tão entusiasticamente a esta actividade, que todas as vezes que ia de viagem, muito embora partisse para lugares bem longe, tinha sempre o cuidado de levar dentro da bagagem uma enxada e outras ferramentas, para que, se 


\section{[A6]}

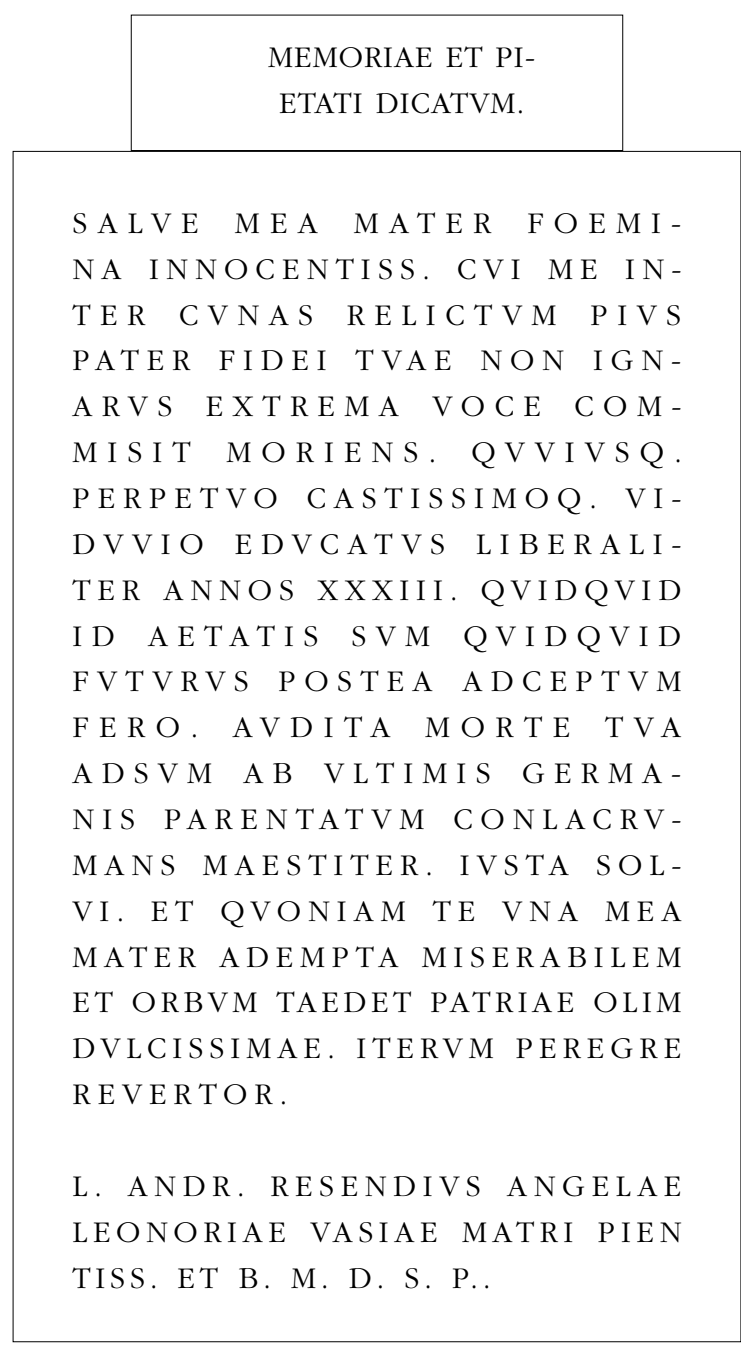

[A6v] Cum itaque discedere pararet, regis Ioannis, et Alphonsi Cardinalis auctoritate praecipue commotus, profectionem distulit, et abeundi animum abiecit.

Ac Eborae, ubi tunc regia sedes aliquandiu permansit, habitare decreuit, ubi aedes habuit modicas, sed Xysto et Hortulo diligenter excultas, ac peramoenas, domino autem ita iucundas, ut minime aliorum spatiosis atriis inuideret, quas ornauit, dispositis intrinsecus, circa ambitum horti, antiquis marmoribus, quae cum Romanorum inscriptionibus conquirere potuit. Cui rei adeo enixe studuit, ut quoties iter esset facturus, quamuis in longinquiora loca proficisceretur, inter sarcinas, ligonem et alia ferrea instrumenta exportari curaret; ut sicubi uestigia antiquitatis sese offerrent, ea sua impensa et industria eruere et in incolarum 
lhe aparecessem nalgum sítio vestígios da antiguidade, os pudesse mandar escavar, pagando do seu próprio bolso e por sua iniciativa, para os dar a conhecer aos seus habitantes. Fez isto em muitos lugares, com tanto cuidado e entusiasmo, que nunca se poupou, para levar a bom fim tal tarefa, nem a despesas nem a trabalhos.

Com licença do sumo pontífice trocou o hábito da Ordem Dominicana pelas vestes seculares, sendo já de meia-idade e depois de o ter envergado durante cerca de trinta anos. Mas foi com renitência e forçado que mudou.de hábito, porque foi intimado pelos superiores daquela tão santa ordem, a que ou despia o hábito ou tinha de voltar ao seu antigo mosteiro. Foi, portanto, contra vontade que mudou de hábito, mas não de prática religiosa e de santa comunidade. Com efeito, sempre a frequentou, e escolheu para si e sua mãe as respectivas sepulturas no mesmo mosteiro de Évora, na arcada, que chama "A crasta" 27 , mesmo à porta do capítulo. Morreu no ano de $1575^{28}$, com oitenta anos de idade. Foi de alta estatura, olhos muito grandes, cabelo crespo, a tez do rosto um pouco morena, mas de fronte prazenteira e não franzida, severo no respeitante a seus criados e alunos. Da sua aula saíram alguns homens notáveis entre os quais Aquiles Estaco ${ }^{29}$. Estes são os factos biográficos do nosso Resende, factos que me pareceram dignos de ser contados e aos quais vou juntar uma carta sua ao Cardeal D. Afonso, na qual é evidente que, já há muito tempo, tinha nascido no seu espírito esta obra sobre as antiguidades. 
notitiam proferre posset, quod plurimis in locis fecit, tanta cura ac diligentia, ut in eo obeundo negotio, nec sumptui, nec labori unquam perpercerit.

Habitum Dominicani instituti, ex Summi Pontificis licentia, in sacerdotalem mutauit, media fere aetatis parte exacta, cum triginta circiter annos illum gestasset, quam uestis mutationem renitens, et coactus fecit, quod a praefectis sanctissimi illius ordinis adigeretur, ut aut habitum dimitteret, aut ad pristinum sodalitium rediret. Inuitus ergo uestem mutauit, sed non religionis et sacrae societatis studium, eam enim perpetuo coluit, et matri ac sibi in eodem Eborensi Monasterio sepulturam elegit, in porticu, quam claustram uocant, in ipso limine capituli. Obiit anno salutis 1575 aetatis suae octuagesimo. Fuit procera statura, praegrandibus oculis, crispo capilo, colore uultus aliquantulum subfusco, sed hilari et minime contracta fronte, in domesticos et discipulos seuerus, ex cuius schola insignes aliquot uiri prodierunt, inter quos fuit Achilles Statius. Haec habui de Resendii nostri uita, quae mihi digna uisa sunt relatu, quibus epistolam eius adiiciam scriptam ad Alphonsum Cardinalem, ex qua patet quanto iam ab hinc tempore hoc antiquitatum opus parturierit. 
$[\mathbf{A 7}]$

\section{Ao Cardeal D. Afonso ${ }^{1}$, Filho do rei D. Manuel, ENVIA AS MAIORES SAUdAÇÕes Lúcio ANDRÉ DE RESEnde.}

Os que admiram e procuram com avidez estas pedras antigas que se encontram, gravadas com letras, nas antigas colónias romanas, são mordazmente criticados, não só por ignorantes grosseiros, mas frequentemente também por gente bastante culta.

Pelos primeiros, porque desprezam, com o maior atrevimento, tudo o que eles próprios não conhecem. A fim de que não sejam mal considerados por ignorarem assuntos tão dignos de conhecimento, procuram esconderijo e refúgio para a sua ignorância, ao procederem como se desprezassem corajosamente as ninharias dos gentios, tal como compete a pessoas piedosas. Por que agem, todavia, do mesmo modo, as pessoas cultas, é que não compreendo, a menos que agrade a ociosos fazer troça do esforço alheio. Falam de modo trocista, pondo tudo a ridículo, mas oxalá que, quanto mais falso for o seu discurso, tanto mais verdadeiro, seja o resultado do que provocam. E porque na verdade a sua tagarelice a ninguém mais ofende do que a um só, recebe piedosíssimo Príncipe o que tenho para dizer em minha defesa e daqueles que compartilham da minha opinião.

Este esforço deve ser mais digno de louvor do que de censura e por muitos motivos.

O primeiro de todos é que, se aceitarmos o testemunho de $\mathrm{Fábio}^{2}$, o sistema da escrita, a que os Gregos chamavam ortografia, está ligado à maneira de falar, e se nós queremos falar e escrever Latim demonstraremos, junto a quem tiver prestado com um pouco mais de justiça maior atenção ao assunto, que assim como a eloquência deve ser procurada em livros que a ensinem bem, assim também a ortografia o deve ser em inscrições de mármore. São os livros maus guardiões da ortografia, pois cada copista escreve à sua maneira e, levado pela sua opinião própria, altera, inverte e corrige a seu bel-prazer. Nem mesmo que o livro mostrasse claramente vir da mão de Cícero ou de Virgílio, isso teria qualquer importância.

Deixo de lado o que Gélio abertamente testemunha sobre as patetices feitas por sabichões no texto de Salústio e de outros ${ }^{3}$ e passo à frente. É por isso que lamentamos as obras dos escritores imortais agora corrompidas? Pois quê? Quando tomamos nas mãos qualquer velho códice, não nos damos conta de uma maneira bem diferente de escrever, da que hoje é frequente e que indiferentemente é usada por cultos e incultos? [A7/v] Mas as pedras, aquilo que nelas se gravou, ou mantêm intacto ou morrem ao mesmo tempo que as letras nelas gravadas. As pedras, digo eu, que aquela época culta deixou para nós lermos. Mas quanto a mim, sou de opinião que não devem ser tidas em consideração as muito antigas nem as muito recentes, ou seja, as que foram gravadas depois da avalanche gótica. Se entretanto encontrar 


\section{Alphonso S. R. E. Cardinali, Emmanuelis Regis filio, L. ANDREAS RESENDIUS \\ S. P. D.}

Illi qui uetusta haec saxa, quae in ueteribus Romanorum coloniis inueniuntur litteris notata, admirantur, cupideue requirunt, mordentur abunde, nec solum iam ab ineruditis istis, crassisque hominibus, sed interdum etiam a doctis adprime uiris.

$\mathrm{Ab}$ illis quidem, quoniam quae non norunt ipsi, summa improbant confidentia, et ne scitu quaeque dignissima, male ignorare uideantur, hinc latebram et perfugium sibi ignorantiae petunt, quasi gentilium nugas, ut pios decet, fortiter spernant. Quur autem a doctis, non uideo, nisi otiosis facetiari sic libet, in alienam diligentiam. Facete illi quidem et nimis ridicula oratione iocantur ${ }^{1}$, tamen utinam quam false, tam uere hoc ab illis fieret. Quoniam uero neminem me plus uno, horum laedit dicacitas, accipe, Princeps piissime, quae pro causa mea, et eorum qui in ea mecum sunt opinione dicenda habeam.

Multas ob res laudari potius, quam reprehendi ea diligentia debet.

Primum omnium, si teste Fabio, scribendi ratio, quam Graeci orthographiam uocant, iuncta cum loquendo est, et nos Romane loqui et scribere uolumus, sicut eloquentiam ex doctissimis libris, ita orthographiam ex marmoribus his petendam, apud illum peruincemus, qui rem paulo aequius animo aduerterit ${ }^{2}$. Mali custodes orthographiae sunt libri, quisque librarius suo more scribit, sua nititur opinione, mutat, inuertit, corrigit, ut lubet. Nec si Ciceronis manum, aut Vergilii prae se liber ferat, pensi quidquam habuerit.

Mitto quod Gellius palam testatur sciolos in Sallustio, et aliis, meras fecisse nugas, illuc eo. Vnde corrupta deflemus immortalium auctorum monimenta. Quid? quum codicem uetustum quempiam in manus adsumimus, nonne longe aliam scribendi cerminus rationem, quam ea est, qua passim nunc docti pariter utuntur, et indocti? [A7v] At saxa, quod semel inscalptum est, aut incorruptum seruant, aut simul cum litteris pereunt. Saxa inquam, quae eruditum illud saeculum legenda reliquit. Nec enim ego aut prisca nimis, aut recentia, hoc est post Gothicam inluuionem incisa, sequenda censeo. Nec si interdum barbarismum inuenero in saxo, aut marmorarii ignauia, aut

1 iocantur $E C^{1} F$ ] loquantur $U$

2 animo aduerterit $E C^{1} F$ ] animo animaduerterit $U$ 
algo de muito bárbaro numa pedra, seja por incompetência do canteiro seja por falta de atenção, tão-pouco o defenderei, mas seguirei o que vir cada vez mais e mais empregado. Nem sou de tal maneira escrupuloso que por encontrar escrito uma vez ou duas VCSOR, VICSIT, PLEPS, COIVGI, formas arcaicas, imediatamente o vá reproduzir ${ }^{4}$. Há que ter prudência e imitar o que agradou à época mais culta, o que constantemente encontramos. Acresce depois outra vantagem e não pequena, por exemplo, quando nelas lemos muitas vezes nomes de cidades, de que há menção em livros e que porventura são agora ignoradas. Porque não só há muitos factos que ajudam à cosmografia e sobretudo aos que vão escrever em latim, como também há outro factor agradável; é que os factos ligados à história nos fornecem muitas vezes instrumentos para embelezar o estilo e para ornamento da pátria. Até agora julgava-se erradamente que Badajoz era Beja ${ }^{5}$; Medóbriga, Cetóbriga, Salácia ${ }^{6}$ eram completamente desconhecidas. Também não havia qualquer referência a Chaves $^{7}$. Quanto à torre de Augusto e ao rio Sarte que se encontram na obra de Pompónio ${ }^{8}$, entrava-se em completo delírio nos comentários e o próprio autor foi, com grande prejuízo, muito mais despedaçado do que corrigido. O que o nosso esforço conseguiu carrear, como que de paragens selváticas, tudo isso tentará salvar da ofensiva de desvairados. Podem dar-se seiscentos exemplos, mas passo adiante para não me alongar. Quanto a mim, julgo o seguinte: quem gostar de outros assuntos, dou-lhe toda a autorização para que, sem este penoso trabalho, possa ressonar profundamente.

Eu, porém, obedeci às tuas ordens, meu Príncipe, e desejo tornar ilustre toda a Lusitânia e dar a conhecer ao mundo, como que ressuscitadas, as suas antigas colónias. Mas nada de notável constróem os que em sua casa são atormentados por uma vida privada mais estéril do que é normal. Damos a conhecer os dados que se me depararam por ocasião das muitas peregrinações. Daremos depois o que o tempo for trazendo. Adeus. Évora, Dia 1 de Outubro de 1533. 
dormitantia, id defendam, sed quod perpetuum magis, magisque usitatum uidero, id sequar. Nec adeo morosus sum, ut quoniam semel, iterumue, scriptum inuenerim VCSOR, VICSIT, PLEPS, COIVGI, quae prisca sunt, statim ita deinceps fecero. Adhibenda prudentia est, et quod eruditiori saeculo placuit, quodque constanter inuenitur, id imitandum. Altera deinde accedit utilitas, nec minima. Videlicet, quod saepe ibi legimus nomina urbium, quarum mentio in libris est, quae nunc forte ignorantur. Quod cum cosmographiae conducat multum, atque adeo Latine scripturis maxime, tum uero illud iucundissimum, quod quae ad historiam attinent, et dicendi supellectilem, patriaeque ornatum, nonnunquam adferunt. Errore antehac Badioza, Pax esse Iulia credebatur; Medobriga, Cetobriga, Salacia, omnino ignoratae. Aquarum Flauiarum ne mentio quidem ulla erat. De Augusti turre, et fluuio Sarte apud Pomponium, ampliter a commentariis deliratum, auctorque ipse summa iniuria laceratus, magis quam emendatus. Quae omnia nostra diligentia ut a situ informi adseruit, ita aliquando ab iniuria hallucinantium uindicabit. Sexcenta suppetunt exempla, quae ne longior sim omitto. Mihi sic uidetur: cui aliud arridet, per me quidem licet illi, sine hac morosa cura, profundum stertere.

Ego iussis tuis parui, mi Princeps, et cupio totam perlustrare Lusitaniam, ueteresque colonias denuo rediuiuas mundo facere. Sed nihil egregium moliuntur, quos familiaris res aequo malignior domi premit. Quae per occasionem oblata sunt peregrinanti, damus. Daturi quae posthac tempus adferet. Vale, Eborae Calendis Octobribus. M. D. XXXIII. 


\section{AO mui sábio e piedoso Rei de Portugal D. Henrique, PRIMEIRO DESTE NOME, FAZ VOTOS DE PLENA FELICIDADE Diogo Mendes de Vasconcelos. ${ }^{1}$}

Foi-me entregue a tua carta, ó valoroso e admirável Rei, não só pelo poder como pelo inacreditável esplendor de coragem e de sabedoria, carta em que me perguntas pelos escritos de Lúcio André de Resende, que este, surpreendido pela morte, deixou já começados, e os quais mandaste me fossem entregues, para que os emendasse e os editasse. Visto ter recusado, como sabes, esse encargo tão desproporcionado para o que meus ombros podem aguentar, consciente que estava da fraqueza do meu talento, de tal modo insististe comigo, não tanto pelo jus do mando (o que poderia ter sido feito), quanto pela bondosa e simpática maneira de falar (como é costume na tua singular humanidade), que, quase contra vontade e renitente, aceitei tal incumbência, que sabia só poder levar a cabo com grandes dificuldades. Pois tão grande é a alegria do meu espírito em cumprir tuas ordens e tão constante minha vontade em te obedecer, que nada existe de tão árduo ou difícil que eu hesite cometer, contanto que me pareça obedecer aos teus desejos.

Ora, antes de eu ter tomado comigo mesmo a inteira decisão de assumir este encargo, veio-me ao espírito que não faltarão os que me censurem por ser de alguma maneira um homem acomodatício e com pouco apreço pela ideia que de mim se faça, visto que, investido em altas funções oficiais e podendo por mim próprio realizar e fazer obra em qualquer género literário, venha eu aplicar meu esforço a obra alheia e me preste a exercer um papel que, pelo comum dos mortais, é considerado indigno de alguém que se dedicou aos estudos de jurisprudência e que durante tanto tempo foi versado na governação do Estado. Mas dentro de mim teve grande peso aquela minha incrível obediência para contigo, de tal modo que mesmo com sacrifício do meu bom nome não hesitei em obedecer-te. Quanto a mim, contrariei e sempre julguei enganarem-se os que pensam que os estudiosos da ciência não devem fazer muito caso $[\mathbf{A 8 v}]$ do conhecimento das Humanidades, sem o qual, eles próprios têm, por força, de reconhecer que se encontram menos preparados para cultivar e assimilar as restantes disciplinas. Nem é de trazer aqui, neste nosso tempo em que já se começou a desterrar a inabilidade rude e gética ${ }^{2}$, o teólogo ou o jurisconsulto ou o médico insigne, que ao mesmo tempo não tenha granjeado cultura e razoável prática nas letras. Mas talvez se ofereça outra ocasião e lugar para falar deste assunto, com maior oportunidade e mais vagar. Por agora, de facto, vou deixar de lado tudo isto, e começarei a dar-te conta das Antiguidades e a expor-te em que situação se encontram esses escritos sobre os quais desejas que te informe. 
[A8]

\section{SAPIENTISSIMO ET PIISSIMO LUSITANIAE REGI HENRICI HUIUS NOMINI PRIMO \\ IACOBUS MENOETIUS VASCONCELLUS PERPETUAM FELICITATEM EXOPTAT}

Redditae sunt mihi litterae tuae, praestantissime Rex, ac non solum potentia, sed etiam incredibili uirtutis et sapientiae splendore admirabilis; in quibus mecum agis de scriptis L. Andreae Resendii, quae, morte praeuentus, inchoata reliquit, et mihi recognoscenda atque in lucem edenda tradi iussisti.

Quod onus, ut scis, tamquam impar umeris meis, cum recusarem, ingenii tenuitatem agnoscens, non tam imperii iure (quod facere poteras) quam benigno ac blando orationis genere (quae tua est singularis humanitas) eo me adegisti, ut fere inuitus et renitens munus illud susceperim, quod non sine magnis difficultatibus me obire posse intelligebam. Tanta est enim ad tua iussa capessenda animi mei alacritas, tam constans tibi obtemperandi uoluntas, ut nihil sit tam arduum tamque difficile, quod aggredi dubitem, dummodo tibi morem gerere uidear.

Antequam uero, eam mihi prouinciam subeundam esse, mecum omnino constituissem, occurrit animo non defuturos, qui me tanquam hominem facilem, et parum de existimatione mea sollicitum reprehenderent, quod cum maximo in republica munere functus essem, et in omni litterarum genere, ipse ex me aliquid moliri, et efficere possim, alienis scriptis operam impendere, et in ea facultate uersari sustineam, quae ut uulgus hominum existimat, indigna est uiro iurisprudentiae studiis addicto, et in gubernaculis reipublicae tandiu uersato.

Sed tantum apud me habuit ponderis incredibilis quaedam mea erga te obseruantia, ut, etiam cum aliqua honoris mei iactura, tibi parere non dubitauerim. Equidem eos uehementer decipi, et errare semper existimaui, qui putant seuerioris litteraturae studiosos, haud magni facere $[\mathbf{A 8 v}]$ debere humaniorum litterarum cognitionem, sine qua ipsi fateantur necesse est se minus idoneos inueniri ad percipiendas atque excolendas ceteras disciplinas.

$\mathrm{Nec}$ ferendus est nostro hoc aeuo, quo iam exulare coepit Getica ac rudis imperitia, Theologus, aut Iurisconsultus, seu Medicus insignis, qui non simul bonarum litterarum cultum, et mediocrem usum sibi comparauerit. Sed de hac re alio forsitan loco, et opportunius et copiosius dicendi sese offeret occasio. Nunc uero ea praetermissa tibi antiquitatum rationem reddere, et quo in statu sint ea scripta, de quibus certior a me fieri desideras, exponere aggrediar.

Antiqua Romanorum monumenta, quae apud Lusitanos extant, primus Andreas Resendius inuestigare coepit, idque cum per quinquaginta ferme annos, quoad per alias occupationes licuit, diligenter fecisset (quod ex ipsius litteris constat) 
Foi André de Resende o primeiro que começou a investigar os monumentos antigos que os Romanos deixaram em Portugal, e conquanto o fizesse com toda a diligência durante quase 50 anos (como consta de suas próprias cartas), quando lhe era possível no meio de outras ocupações; nunca, todavia, tentou abertamente e a sério escrever sobre o assunto, a não ser quase quatro anos antes do dia da sua morte. Decidira que esta obra sobre as antiguidades viria a compreender dez livros, dos quais deixou quatro já acabados, mas ficaram eles tão cheios de rasuras, com tantos comentários nas margens, marcados e apagados com asteriscos e obeliscos, que cheguei a suspeitar estar a mãos com tarefa sem solução, enquanto me esforço por restituir a obra ao seu esplendor depois de limpas as suas manchas e de os conduzir à sua ordem. A esta dificuldade sobreveio outra igual, se não maior, enquanto procurámos transcrever e exarar as antigas inscrições totalmente dispersas e confundidas por várias folhas, num só códice, por ordem alfabética, junto dos nomes das cidades em que tinham sido encontradas. Isto só pôde acontecer com muito tempo e grande trabalho, quer devido à falta de amanuenses, que nesta cidade ou não há ou são pouco competentes, quer também porque era necessário que eu próprio estivesse sempre junto desses copistas, eu que afastado alhures por vários encargos não tinha podido estar livre para me dedicar a este estudo senão nas horas vagas.

Tão-pouco Resende deve ser criticado por estes motivos, mas, muito pelo contrário, conforme creio, deve ser julgado digno do maior louvor. Com efeito, no que respeita a rasuras e riscos, só isto indica que se tratava de um homem consciencioso e diligente, que se habituara a escrever não ao correr da pena, nem de improviso, mas sim depois de ter pensado maduramente. É isto bem necessário para quem prepara qualquer obra que $[\mathbf{B}]$ deva ser dada a lume e submetida à apreciação de todos, quase como o célebre dito de Horácio: "que seja guardada durante nove anos"3. Também de Virgílio chegou até nós a tradição de que costumava gloriar-se amiúde de lamber o que paria ${ }^{4}$, palavras estas cheias de pudor e de modéstia, que de certo modo nos sugerem que na composição dos seus versos se entregava ele menos ao engenho do que à lima.

Presumo, porém, que Resende deixou as inscrições tão dispersas e enredadas, ou porque não sobrará tempo para as transcrever e para as pôr em ordem, a um homem que sem parar trabalhava em todo o género de coisas literárias, ou porque, a fim de ter notícia exacta das antiguidades e devido à sua extraordinária memória, só ficava satisfeito com as folhas originais, que lhe eram mandadas de toda a parte, muitas vezes embora mal copiadas e corrompidas. Na verdade, era-lhe fácil e simples, devido ao contacto assíduo com inscrições, utilizar, sempre que necessitava, com precisão e utilidade, todas aquelas inscrições e epitáfios mesmo mutilados e incompletos. Isto teria sido para mim, ou para quem quer que fosse, extraordinariamente difícil, por causa da obscuridade e da extrema confusão. Por isso me pareceu ser primeiramente necessário reduzir todo o grande acervo de antigas inscrições à ordem que já se referiu e ao método e forma de livro. 
nunquam tamen de ea re, ex professo et serio scribere tentauit, nisi quadriennio fere ante obitus sui diem; proponens animo hoc antiquitatum opus decem libris comprehendere, quorum quattuor tantum absolutos reliquit eosque tot lituris plenos, tantisque in margine scholiis, asteriscis obeliscisque notatos et expunctos, ut inextricabile quodam mihi suscipiendum fuerit negotium, dum eos a maculis tersos, et in ordinem redactos, nitori suo restituere laboro. Cui difficultati, alia non impar, sed fortasse maior successit: dum antiquas inscriptiones uariis in schedis penitus dispersas atque confusas, in unum codicem, ordine alphabetico iuxta oppidorum et urbium nomina, in quibus repertae sunt, transcribi atque exarari curauimus.

Quod neque breui tempore, nec sine maximo labore fieri poterat; tum propter amanuensium paucitatem, qui in hac urbe, aut nulli sunt, aut minus idonei; tum etiam quia necesse erat, ut illis exscribentibus perpetuo ipse adessem, qui alioqui uariis occupationibus distractus, non nisi succisiuis horis huic studio uacare poteram.

Neque eas ob causas Resendius reprehendi debet, imo, ut ego iudico, maiori laude dignus est censendus.

Quod enim attinet ad lituras et expunctiones, indicium est hominis circumspecti, ac diligentis, et qui non cursim et ex tempore, sed adhibita matura deliberatione, scribere solitus esset. Quod ualde necessarium est his qui praeclarum aliquod opus moliuntur, quod $[\mathbf{B}]$ in lucem prodire et omnium iudicio submitti debeat; iuxta Horatianum illud, nonumque prematur in annum. Et de Vergilio memoriae proditum est, solitum eum crebro gloriari, se partus suos lambere. Quibus uerbis pudoris et modestiae plenis, significabat se in componendis carminibus minus ingenio, quam limae indulsisse.

Inscriptiones autem adeo dispersas, et inuolutas reliquisse illum coniicio, uel quia ad eas transcribendas et in ordinem redigendas, tempus non suppetebat homini in omni litterarum genere perpetuo uersanti, uel quia propter exactam antiquitatum notitiam, incredibilemque memoriam, archetypis illis schedis solum contentus erat, quae ad ipsum undique mittebantur, quamuis saepius perperam scriptis et deprauatis. Erat enim illi facile et obuium, propter assiduum usum inscriptionum, quoties opus habebat, etiam mutilatis illis, et imperfectis titulis, atque epitaphiis, commode et utiliter uti. Quod mihi, et cuiuis alii difficillimum fuisset, propter nimiae confusionis perplexitatem. Quare uisum est in primis necessarium, totam illam antiquarum inscriptionum farraginem, quo dictum est ordine in methodum, et uoluminis formam redigere.

Ex qua diligentia illud etiam scire, atque deprehendere contigit, quantam uidelicet, quamque copiosam supellectilem Andreas Resendius reliquisset, ad hanc historiam absoluendam, atque ad optatum finem perducendam. Quae etsi digna est maximo pretio ac laude propter eius uiri solidam et insignem eruditionem, minor tamen spe, quam antiquitatum studiosi de eo conceperant. 
Deste esforço resultou também o dar-me conta e depreender quão grandes e quão abundantes foram os instrumentos deixados por André de Resende para realizar esta história e para a levar à meta desejada. Essa história, ainda que seja digna do maior apreço e louvor, devido à sólida e notável erudição daquele homem, não chega, contudo, à altura da expectativa que os estudiosos de antiguidades por ela sentiam. Quantos haverá que não pensam poder encontrar nas suas folhas todas as informações que dizem respeito a este assunto, marcadas e dispostas nos passos que lhes competem e distribuídas com exactidão e por ordem? Mas isto processou-se bem diferentemente. De facto, com excepção das inscrições dos antigos Romanos, nenhuma informação foi possível encontrar acerca das descrições de cada uma das cidades ou ópidos (o que era a principal razão e escopo desta obra) a não ser bem insignificantes anotações. Porque, se porventura o autor escreveu outras coisas, de modo algum me chegaram às mãos. Tão-pouco renuncio à hipótese de que tivessem podido ser suprimidas [Bv] ou corrompidas por algum acidente. Com efeito, na altura em que por teu mandado me foram confiados os seus escritos, já eles tinham passado pelas mãos dos que por ordem dos magistrados tiveram de estabelecer e registar o inventário dos bens.

Parece, contudo, verosímil que, confiando ele em sua singular memória e no muito exacto conhecimento que tinha de todos os assuntos que confiava aos livros, não se tivesse preocupado com o elaborar, primeiramente, esboços, planos e ensaios da matéria, mas tivesse escrito os quatro livros, conforme os factos lhe ocorriam ao espírito e só com a ajuda da memória. Daí a razão por que até nós chegaram aqueles cobertos de rasuras e embaraços. Os assuntos versados são em resumo os seguintes:

No primeiro livro, estabelece e discute a etimologia do nome da Lusitânia e qual teria sido o seu autor e qual a sua origem. Depois determina os termos e regiões limítrofes desta província, que os geógrafos lhe atribuíram. De passagem toca nalguns problemas de menos importância e um pouco obscuros, compreendidos por autores mais modernos com sentido variado e contraditório, ao mesmo tempo que são interpretados Plínio, Estrabão, Ptolomeu e outros autores de ciências geográficas. Também trata neste mesmo livro das diversas gentes, povos e nações que habitavam a Lusitânia sob o domínio romano, tais como os Turdetanos, os Celtas, os Túrdulos, os Vetões, os Pesuros ou Pesures, os velhos Túrdulos, os Ciscudanos e Transcudanos, os Tamacanos e especial e especificamente os Lusitanos e quais foram outrora os costumes dos Lusitanos. Acaba este primeiro livro depois de acrescentar abundante e elegante descrição de todos os montes que são atribuídos pelos antigos escritores a esta província, como sendo os principais e os mais elevados.

No segundo, enumera os antigos e novos nomes dos rios e assim também os nomes mais comuns. Quando trata do rio Guadiana, intercala pequena digressão não desagradável acerca do peixe esturjão, a que vulgarmente chamamos suilo ou solho, aduzindo várias opiniões dos modernos acerca do nome pelo qual os autores antigos, gregos e latinos, chamaram esse género de peixe.

[B2] O livro terceiro tem o seguinte título: "Que Povos Outrora Dominaram na Lusitânia”; contém a narração difusa, que se relaciona com os historiadores gregos 
Quotus enim quisque est qui non putaret, in eius schedis, ea omnia inueniri posse quae ad hanc rem pertinent suis locis annotata, disposita, atque exacte et suo ordine digesta? Sed longe aliter sese res habet. Exceptis enim ueterum Romanorum inscriptionibus nullam circa singulas urbium et oppidorum narrationes (quod erat huius operis praecipuum munus, et institutum) praeter pauculas annotatiunculas reperiri contigit. Quod si alia fortasse scripsit, ea in manus meas minime peruenerunt. Nec abnuo potuisse supprimi, aut $[\mathbf{B v}]$ aliquo casu corrumpi. Quo enim tempore, tuo iussu, mihi eius scripta tradita sunt, iam illorum manus pertransierant, qui bonorum inuentarium, iure magistratus confici, atque conscribi curauerant.

Verisimile autem mihi fit, illum memoria fretum singulari, et exactissima cognitione rerum omnium, quas litteris mandabat, minime curasse, earum ueluti deliniamenta et praeludia prius deprompta habere, sed memoriter, ita ut quaeque res in mentem uenerat, hos quattuor libros absoluisse. Vnde accidit, ut tot lituris ac salebris referti ad nos peruenerint. Quae uero his libris continentur, in summa haec sunt.

Primo libro etymologiam nominis Lusitaniae, et quis fuerit eius auctor, quaeue origo, exponit. Terminos deinde et confinia huius prouinciae, quae ei ueteres geographi assignarunt, declarat. Obiter tangens difficiles aliquot, et subobscuras ${ }^{1}$ quaestiunculas, a recentioribus uario, ac diuerso sensu intellectas, dum Plinium, Strabonem, Ptolemaeum, ceterosque geographicae scientiae auctores interpretantur. Agit etiam in hoc ipso libro de diuersis gentibus, populis, nationibus, quae sub Romano imperio Lusitaniam incolebant; utpote de Turdetanis, de Celticis, de Turdulis, de Vettonibus, de Barbariis, de Paesuris, seu Pesuribus, de Turdulis ueteribus, de Ciscudanis, et Transcudanis, de Tamacanis, et de peculiariter et proprie Lusitanis. Et qualis olim fuerint Lusitanorum mores. Addita deinde copiosa et eleganti descriptione omnium montium, qui ut praecipui et eminentiores, huic prouinciae $\mathrm{ab}$ antiquis scriptoribus assignantur, librum hunc primum absoluit.

In fecundo fluuiorum nomina, tam antiqua, quam noua ac uulgaria enarrat. Ac dum agit de flumine Ana, diuerticulum quodam non inamoenum interserit de pisce Asturione, quem uulgo Suillum, seu Solho dicimus, referens uarias neotericorum opiniones circa nomen quo antiqui auctores tam Graeci, quam Latini, id piscis genus appellarunt.

[B2] Liber tertius hunc habet titulum, uidelicet, "Quinam olim in Lusitania rerum potiti sint”. Et diffusam narrationem continet, ad Graecas et Romanas historias spectantem, circa res gestas quae ad hanc prouinciam pertinere uidentur, et ad duces in re militari claros, quos olim habuit. Additum est etiam nonnihil de Gothorum seu Getarum gente. Adiecto deinde quodam de uiis militaribus compendio, huic libro finem imponit.

1 Subobscuras $U]$ sub obscuras $E$ 
e romanos, acerca dos acontecimentos históricos, que parecem dizer respeito a esta província e aos chefes que se distinguiram na arte da guerra e que ela outrora possuiu. Também acrescentou bastante acerca dos povos Godos e dos Getas e depois de juntar um compêndio sobre as vias militares dá este livro por acabado.

No quarto, começa a tratar das cidades e ópidos e são estas as palavras com que o inicia: "Agora começarei a tratar das cidades, parte não desprezível do meu intento". Depois trata com pormenor de algumas utilizando em parte os nomes antigos ou os nomes correntes, quando os antigos faltam. Descreve quinze ou, quanto muito, dezasseis ópidos e, depois de apresentar antigas inscrições que nelas encontrou, dá por findo este quarto e último livro dos que escrevera.

O quinto livro, começou-o a escrever numa pequena folha, na qual restam tãosó vinte e cinco linhas, tal como segue: "Comecei este livro por Évora, de que sou natural, mas de forma a que possa agora falar mais sucintamente, visto que em tempos publiquei em língua portuguesa uma pequena história acerca da sua antiguidade e reuni muitos materiais acerca do mesmo assunto no Apologético dedicado a Francisco Nunes de Beja 5 e bastantes coisas no livro dedicado a Quevedo Toledano"6.

Destas palavras e até da maneira de formular o estilo de que fez uso no livro acima indicado, sobre a descrição da cidade, pode facilmente imaginar-se que tinha tido a intenção de acrescentar somente as inscrições romanas a qualquer ópido que tratasse e ao qual parecessem adaptar-se, e depois de, em poucas palavras, expor a sua opinião sobre qualquer delas, nada além disso acrescentar, que dissesse respeito aos fundadores das mesmas cidades, aos acontecimentos históricos e à história dos tempos mais modernos. Deduzo facilmente disto, conforme creio, que nada mais teria sido escrito nem concebido por ele acerca dos ópidos. Com efeito, se algo do género tivesse posto por escrito, dificilmente poderia acontecer que não aparecesse entre os seus escritos e fichas. Disto transparece quão modesto é o que deixou, em comparação com o que tinha intenção de escrever, pois propusera-se tratar um por um todos os ópidos da Lusitânia. [B2v] Dando-se, porém, conta o próprio Resende de quão difícil e árdua era a missão que assumira e quanto esperava dele o público e igualmente temendo a crítica da posteridade, frequentemente dá testemunho no seu livro e declara que não decidira escrever sobre todas as antiguidades desta província, mas tão-somente sobre aquelas que, com seu labor e esforço, tinha conseguido encontrar. Incitando os estudiosos destes assuntos a que, por si próprios, se esforçassem a investigar as restantes, com seu trabalho e diligência. Seguindo eu este conselho, meti ombros, ao mesmo tempo que obedeço às tuas ordens, e levei até ao fim a obra por ele começada, encontrando apoio em parte nos seus apontamentos e em parte nas novas inscrições que eu próprio encontrei.

Quanto aos quatro livros, acabados por ele e revistos por mim poderão ser imediatamente, se assim te aprouver, editados e divulgados, contanto que ordenes ao tesouro real para que sejam atribuídas as verbas necessárias para tal empreendimento. Que Deus muito bom e muito grande te mantenha, ó Rei poderoso, de boa saúde e te guarde. Évora, a 15 de Janeiro de 1580. 
In quarto de urbibus et oppidis agere incipit, cuius prima haec sunt uerba: "Vrbes nunc aggrediar non minimam intentionis meae partem". Deinde nonnullas enarrat, partim antiqua nomina, partim uero uulgaria apponens, ubi uetera deficiunt. Ac quindecim aut ad summum sexdecim describit oppida, adhibitisque antiquis inscriptionibus, quas in illis repertas habuit, hunc quartum librum, et ultimum eorum, quos scripserat, absoluit.

Librum quintum scribere coepit in foliolo quodam, ubi uiginti tantum lineae scriptae extant, in hunc modum: "Ab Ebora patria mea librum hunc auspicabor, sed ita, ut succintius modo loquar, quandoquidem historiolam de eius antiquitate Lusitana lingua pridem edidi, et multa in Apologetico ad Franciscum Nonium, Pacensem, non pauca ad Kebedium Toletanum de eadem re conscripsi". Ex quibus uerbis, atque etiam ex scribendi formula, qua in superiori libro usus est, in enarrandis urbibus, licet facile coniicere, illum in animo habuisse, solas Romanorum inscriptiones cuilibet oppido, cui conuenire uidebantur adiungere, exposita paucis uerbis super qualibet earum opinione sua, nihilque praeterea addere quod ad ipsarum urbium conditores et res gestas, recentiorumque temporum historiam pertineret. Vnde facile adducor, ut credam nihil eum amplius annotatum, aut praemeditatum habuisse circa oppida. Si enim aliquid huiusmodi litteris mandasset, uix fieri poterat quin inter eius scripta et schedas appareret. Ex quibus liquido constat quam modicum est quod reliquit, collatum cum his quae scribere in animo habuit. Proposuerat enim de omnibus Lusitaniae oppidis sigillatim agere.

[B2v] Videns autem ipse Resendius quam difficilem et arduam prouinciam suscepisset, quantumque homines ab eo expectarent, tanquam reformidans posteritatis iudicium, non semel in his libris testatur, et edicit se non omnes huius prouinciae antiquitates, sed eas tantum quas labore suo ac studio reperire potuisset, scribendas suscepisse. Admonens harum rerum studiosos, ut reliquas ipsi, sua industria ac diligentia, inuestigare nitantur. Cuius ego consilium sequutus, opus ab eo inchoatum dum tuis iussis pareo, ad exitum perducere sum aggressus, partim illius schedis, partim nouis inscriptionibus, quas ipse repperi, adiutus.

Quattuor autem libri ab eo absoluti et a me recogniti, confestim, si ita tibi uisum fuerit, in lucem edi atque diuulgari poterunt, dummodo expensas in eam rem necessarias e regio aerario conferri iubeas. Deus Optimus Maximus te nobis, praestantissime rex, incolumem seruet, atque tueatur. Eborae 15 die Ianuarii 1580. 


\section{$[\mathbf{B 3}]$}

\section{Versos de Diogo Mendes de Vasconcelos EM LOUVOR DE LÚCIO ANDRÉ DE RESENDE}

\section{A Lusitânia fala a Resende}

O Rei da Macedónia, o nobre filho do grande Filipe, Ao assediar as terras da Ásia com os seus exércitos vencedores, E tendo visitado os vestígios destruídos da antiga Tróia, Ao beber as águas do Simoente e o líquido do Xanto, 5 Parou, na costa do Sigeu, diante do túmulo do grande Eácida, interpelando o morto com estas palavras:

"Ó jovem mil vezes feliz, a quem coube a maravilhosa Lira do Meónida, graças à qual a tua glória, erguendo-se Ao céu, é exaltada permanentemente pelos anos sem fim".

10 Assim eu agora me proclamo muito feliz E grandemente ditosa, ó Resende, honra do nosso povo, Pelo facto de os teus escritos me engrandecerem com vetustos títulos E, reivindicando a minha glória desde remotas origens, Desvendares monumentos que testemunham os meus louvores.

15 Bravo! Tu não inventas, em meu proveito, honras vãs Ou amplias os meus elogios com palavras de enfeite; Mas, seguindo a verdadeira cronologia e fidelidade históricas,

[B3v] Descobres coisas ocultas aos Romanos, em seus anais, e ocultas Aos Gregos, e revelas coisas desconhecidas de muitos,

20 Narrando os feitos gloriosos dos meus Lusíadas E os valorosos chefes que outrora o poder de Roma Experimentou, tão invencíveis na guerra como fiéis na paz. Por isso, eu própria conseguirei, para os séculos vindouros, um nome Ilustre e sempre serei celebrada por teu intermédio

25 Nos tempos futuros, enquanto o aurífero Tejo passar pelo meio dos meus Campos e descer para o mar em corrida veloz, E enquanto o Sol mergulhar os seus carros fatigados ns minhas praias ${ }^{1}$. 


\section{Carmina IACOBi MenoetiI VASCONCElli IN LAUDEM LUCII ANDREAE RESENDII}

\section{Lusitania Resendium alloquitur}

Rex Macedum clari proles generosa Philippi, Cum terras Asiae quateret uictricibus armis, Dirutaque antiquae lustrans uestigia Troiae, Potaret Simoentis aquas, Xanthique liquorem,

5 Constitit ad tumulum Sigaeo in litore, magni Aeacidae, tali compellans uoce sepultum. O felix nimium iuuenis, cui contigit altum Moeonidae plectrum, quo se tua gloria caelo Attolens, uiget aeternos mansura per annos.

10 Sic ego felicem Resendi maxime, nostrae

Gentis honos, dicam nunc me, nimiumque beatam, Quod tua me titulis decorarint scripta uetustis, Et decus antiqua repetens ab originem nostrum, Erueris, monimenta meas testantia laudes.

15 Macte animi non tu uanos mihi fingis honores, Aut mea fucatis auges praeconia uerbis; Sed ueram historiae seriemque fidemque sequutus,

[B3v] Abdita Romanis, annalibus, abdita Graiis Pandis, et in lucem multis incognitis profers, 20 Lysiadum narrans insignia facta meorum, Magnanimosque duces, olim quos Romula uirtus Vt bello inuictos, sic fidos pace probauit. Ipsa igitur clarum uentura in saecula nomen Consequar, atque aeuo per te celebranda futuro 25 Semper ero, dum nostra Tagus per rura meabit Aurifer, et rapido descendet in aequora cursu, Dumque meo fessos merget Sol litore currus. 


\section{EPIGRAMAS}

em louvor de Diogo Mendes de Vasconcelos e De Resende, Da autoria de Manuel Cabedo de Vasconcelos, CAVAlEIRO DE MALTA, NETO DE UMA IRMÃ SUA.

Enquanto Lúcio se preparava para livrar a Pátria antiga

Da morte, a cruel Parca lançou-lhe a mão.

Mas, ao morrer, deixou livros que hão-de viver depois dele.

Estes, ó Diogo, são aperfeiçoados com o teu trabalho.

Publicas a obra; assim, a libertação da morte aquele te concede

E tu a ele; e ambos são agradecidos à sua Pátria².

\section{Outro}

Enquanto André trabalha para que não desapareçam os monumentos

Da Pátria, desaparece ele para a sua obra.

E como de Atlas, fatigado com o peso, se conta

Que o seu trabalho recaiu sobre os ombros de Hércules,

Assim esta tarefa recaiu sobre os teus, ó Diogo; nem outro

Havia sobre quem este pesado encargo melhor repousasse.

Depois de te ver sob o peso, Lísia disse:

"Não és inferior a Alcides, não és inferior a Atlas"2.

\section{$[\mathbf{B} 4 \mathbf{v}]$}

\section{Outro}

Tendo Apeles de Cós pintado metade de Vénus

E deixando o autor, ao morrer, a obra começada,

Uma só mão de artista aterrou todas as mãos

E nenhuma houve que completasse a obra em meio.

Modelara André uma grandiosa efígie do Reino,

Mas, arrebatado pela morte, deixou a obra começada.

Contudo a ti, ó Diogo, a insigne imagem não te aterra

E queres dar à obra a última demão.

E o fim condiz bem com o princípio, tu tornas

Maior o nome de André e ele o teu ${ }^{2}$. 


\section{EPIGRAMMATA}

In LAUdem IACOBi MenoetiI VASCONCELli, ET ReSEndi, Auctore Emmanuele Cabedio Vasconcello IPSIUS EX SORORE NEPOTE EQUITE MELITENSI

Lucius antiquam patriam dum a morte pararet Eripere, iniecit inuida Parca manum.

Sed moriens post se uictura uolumina liquit:

Haec, Iacobe, tua perficiuntur ope.

Edis opus, sic ille tibi dat morte carere,

Tuque illi, patriae gratus uterque fuae.

\section{Aliud}

Dum ne deficiant patriae monumenta, laborat Andreas, operi deficit ipse suo.

Ac uelut Atlantis lassati pondere fertur, Herculeis umeris incubuisse labor, Incubuit labor iste tuis, Iacobe, nec alter,

Quo melius grauis haec machina staret, erat. Lysia te postquam uidit sub pondere, dixit:

"Non minor Alcide es, non es Atlante minor".

\section{$[\mathbf{B} 4 \mathbf{v}]$}

\section{Aliud}

Cum mediam Cous Venerem pinxisset Apelles,

Et moriens coeptum linqueret auctor opus, Artificis manus una, manus deterruit omnes,

Nec medio finem quae daret ulla fuit.

Finxerat ${ }^{1}$ Andreas simulacrum nobile regni,

Liquit at incoeptum morte peremptus opus.

Non, Iacobe, tamen terret te insignis imago,

Extremamque operi uis adhibere manum.

Et bene conueniunt cum primis ultima, maius

Andreae nomen tu facis, ille tuum.

\footnotetext{
1 Finxerat $E$ ] Pinxerat $U$
} 
[B5]

\author{
LÚCIO ANDRÉ DE RESENDE \\ DESEJA MUITA SAÚDE AO MUI DOUTO JURISTA \\ BARTOLOMÉ FRIAS DE AlBORNOZ ${ }^{1}$
}

Se comparar todo o prazer, ó Albornoz, que senti pela tua chegada até mim, com o desgosto que tive por te ser recusada a entrada na nossa cidade por quem, na ausência do governador desta província transtagana, desempenhou interinamente as suas funções, não há dúvida que este último sentimento deixa o primeiro atrás de si e a grande distância. Na verdade, assim como muito me animou no primeiro caso a consideração que por mim mostraste, assim também no segundo, de tal maneira me deprimiu e encheu de vergonha, que, muito embora o escondesse, ouso afirmar que nada na vida me afectou tão dolorosamente. Veio aumentar esta angústia, depois daquela quase furtiva conversação de um só dia numa casa de campo, o boato de expulsão que se espalhou pela cidade, tendo-se o povo admirado que me fosse negada, a mim, pessoa bem conhecida e apreciada pelos meus concidadãos, a possibilidade de receber visita de tão grande importância. Isto sob o pretexto especioso de evitar a peste, que se temia vir de Sevilha, ainda que nos pusesse ao abrigo desse receio a enorme distância geográfica, entre Sevilha e Talavera, de onde vinhas. As altas personalidades e os vereadores do senado municipal ${ }^{2}$, assim como os apreciadores das belas-letras que entre nós são em número não pequeno e não de desprezar, logo que voltou Rui Fernandes de Castanheda ${ }^{3}$, governador da província, ao qual chamamos corregedor ${ }^{4}$, com a devida vénia dos jurisconsultos como tu, e que é um homem muito culto e fidalgo e espírito muito aberto e liberal e humano, não só levaram muito a mal o procedimento indigno, como também censuraram com palavras, considerando que dizia respeito à honra da cidade o deixar entrar tão grande homem. Com efeito, se nada mais houvesse por estes lados que te agradasse ver e algumas coisas há, a verdade é que, seis dias depois da tua partida, uma jovem de dezassete anos, Públia Hortênsia de Castro ${ }^{5}$, versada invulgarmente nos estudos aristotélicos, ao discutir em público, diante de muitos homens doutos desejosos de destruir as teses que propusera, com grande habilidade e não menor graça conseguiu esquivar-se às subtilezas das argumentações e teria enchido o teu espírito de tal prazer que serias forçado a confessar, se tivesses estado presente, que nunca tinhas visto espectáculo mais belo e não negarias que a cidade que tem tal menina (deixo de lado $[\mathbf{B 5} \mathbf{v}]$ a sua excepcional beleza) merecia que a ela viesses só por esse facto. Mas o bom do tal governador interino, se pôde perturbar tudo isso, não pôde escapar-se a ser castigado pelo seu aspecto carrancudo e espírito estreito, para não dizer selvagem, ao ser apodado até aos gritos de bárbara imbecilidade e eu não pude deixar escapar, quando me lembrava destas coisas, de lhe agradecer, 


\section{Bartholomaeo Friae Albernotio \\ IURISPERITO DOCTISSIMO}

\section{ANDREAS RESENDIUS}

S. P. D.

Quantum, Albernoti, ex aduentu ad me tuo percepi uoluptatis, si contulero cum dolore, negari tibi in urbem nostram ingressus, ab isto, qui pro absente prouinciae huius Transtaganae praeside, uicarium gerebat magistratum, absque dubio posterum hoc, prius illud, longo post se interuallo relinquet. Nam sicut ex altero, mihi honor a te habitus multum me extulisset, ita alterum eo me usque depressit, adfecitque pudore, ut quanquam dissimulaui, acerbius in uita nihil unquam me pertulisse, audeam affirmare. Auxit dolorem hunc, post uillaticam illam et quasi furtiuam unius diei conloquutionem, sparsa per urbem repulsae fama, admirante populo, mihi homini nec ignoto neque ciuibus meis non caro, denegatam recipiendi tanti hospitis facultatem, specioso isto auertendae pestilentiae, quam ab Hispali metuebamus, praetextu; cum tamen de eo metu securos nos redderet, maximum inter Hispalim et Talaueriam, unde ueniebas, terrarum interstitium. Optimates autem, et ex decurionibus triumuiri, ac meliorum litterarum amatores, quorum non est exigua neque cotempnenda apud nos copia, una cum superueniente Roderico Vernandio ${ }^{1}$ Castaneda prouinciae praeside, quem uobis uirisconsultis permittentibus correctorem appellamus, uiro pererudito ac nobili, et ingenii maxime comis atque humani, indignitatem rei, non modo aegerrime ferebant, uerum dictis etiam insectabantur, existimantes ad honorem urbis, intromitti uirum talem, pertinuisse. Nam si nihil aliud hic esset, tibi quod spectare conlibuisset, quum tamen sint nonnulla, certe sexto a recessu tuo die, puella septendecim annorum, Publia Hortensia a Castro, studiis Aristotelicis non uulgariter instructa, publice disputans, multis doctis uiris, quae proposuerat, conuellentibus, cum summa dexteritate nec minore lepore argumentationum cauillationes eluderet, tanta animum tuum perfudisset iucunditate, ut spectaculum pulchrius tu te non uidisse, si adfuisses, utique faterere $^{2}$, et urbem, quae eam habeat puellam (omitto formam [B5v] intra modum uenustam) dignam non negasses, ad quam sola ea gratia deuenires. Sed bonus ille praesidis uicarius, ut ista potuit interturbare, ita euadere non potuit, quin durissimi oris et ingenii perseueri, ne dicam agrestis, poenas daret, usque ad conuicia barbarae inciuilitatis denotatus, et ego mi illi, hisce commemorandis, ut meritus est, gratiam habuisse nolui praeterire. Ceterum redeo ad te, cui pro

1 Vernandio $E C^{1} F$ ] Ferdinandio $U$

2 faterere $E$ ] fatereris $C^{1} F U$ 
como merecia. Mas volto a falar de ti, a quem penso estar devedor por causa da tua extraordinária bondade: mas não vejo, com efeito, o que possa dar a um homem de letras, apoiado em tanta ciência, a não ser uma dádiva literária. Por isso é que vou escrever uma história das antiguidades do nosso Portugal, com antigas inscrições, que já notei serem do teu agrado, tarefa que os nossos estudiosos da antiguidade há muito esperam de mim, mas que até agora foi adiada, porque primeiramente tinham de ser todos os locais visitados por aquele que prometia ir escrever sobre eles todos.

Não me foi possível realizar tudo isto dentro da modéstia dos meus recursos pessoais nem me coube em sorte quem, com sua grande riqueza, erguesse e animasse o meu espírito a construir obra tão custosa. Escreverei, portanto, o que vi e encontrei e, depois de abrir o caminho aos espíritos curiosos, deixarei atrás de mim mais coisas que devem ser completadas por outros ${ }^{6}$. 
singulari tua humanitate, debere me intelligo; sed quid litterato homini, et in re ampla constituto, reddam, praeter litterarium munus, equidem non uideo. Ita ergo faciam, et antiquitatum Lusitaniae nostrae, cum ueteribus inscriptionibus, quibus delectari te animaduerti, scribam commentarium, rem a studiosis apud nos antiquitatis a me diu desideratam, expectatamque, sed hactenus dilatam, quia peragranda uniuersa erat prius ei qui de uniuersa scripturum se polliceatur.

Quod efficere neque priuatis intra tenuitatem opibus ipse potui, neque mihi contigit, qui sua quantaquumque opulentia animum, perdifficile opus molientem, erigeret et incitaret. Nota igitur, ac comperta mihi scribam, et patefacta curiosis uia, aliis supplenda cetera, post me relinquam. 
(Página deixada propositadamente em branco) 
LIVRO PRIMEIRO

LIBER PRIMVS 
Vamos logo dizer de início alguma coisa sobre o nome da Lusitânia. Plínio, cujas palavras se prestaram a diferentes interpretações, diz que "Luso, filho do pai Líber, e Lysa, que com ele celebrava as Bacanais, lhe tinham dado o nome"1. Enquanto uns pensam que Luso e Lysa foram companheiros de Baco, tendo o nome de Lusitânia derivado do primeiro e o de Lysitânia do segundo, pois são estes dois nomes que é costume atribuir-lhe, outros vêem em Luso não o nome de um homem mas a palavra ludus (jogo) ou lusio (brincadeira) ${ }^{2}$. Parece não se terem apercebido antes de que a província não podia ser denominada naquele tempo por palavra latina provavelmente nunca ali ouvida. Ora, a dar fé a Varrão, que Plínio cita, a Lusitânia é assim chamada desde o tempo do próprio $\mathrm{Baco}^{3}$.

Não faltam os que substituem Lysa por Lyssa, ou seja, "raiva" e "fúria" das Bacanais, mas como as Ménades faziam Bacanais em diversas províncias, não vejo porque este nome havia de ser dado aqui e não alhures, em comemoração do furor báquico. Além disso, se admitirmos que a província derivou o nome daquela palavrinha insólita e disparatada, conviria chamar-lhe Lyssitânia e não Lysitânia. Todas estas explicações, todavia, fraquejam, se não recusarmos a velha informação e não considerarmos que Luso e Lysa foram seres humanos e se não nos repugnar que Lusitânia tivesse recebido o nome de Luso e a Lysitânia de Lysa. Pelo menos o autor do Pseudoberoso ${ }^{4}$ identificou Luso com o homem que afirma [2] ter reinado na Ibéria nos tempos de um tal Ascátide, rei da Babilónia, em cuja época, segundo os Gregos, foi descoberta a videira, ao que se diz, aliás, por Dioniso. Assim contribuem Dioniso, o inventor da videira, e Luso, para que seja viável, pela relação cronológica, que Luso possa ter ligação com Dioniso, ou seja, com o pai Líber5.

Se acaso se hesitar sobre o laço de parentesco que teria unido Luso a Dioniso, eu, pela expressão empregada, imagino que tenha sido seu filho. Não deve, efectivamente, parecer estranho o afirmar-se que Dioniso, que de todas as maneiras era um homem, tenha tido um filho, até porque os Gregos também lhe atribuem a paternidade de Aristeu, o inventor do azeite, segundo afirma Cícero em certo discurso contra Verres $^{6}$. No entanto, parece-me que não se deve ler "e Lysa", mas "ou Lysa", para que Luso tenha sido aquele mesmo Lyso que costumava celebrar as Bacanais com o pai Líber. Na verdade, a partir da palavra grega $\lambda \hat{\omega} \omega$, da qual também provém o epíteto Lysio do próprio Baco e dos seus sacerdotes, e o nome Lysios foi um homem cujo nome passou a Luso segundo o costume da língua latina. É que nos parece mais natural que a província tenha recebido o nome de uma só pessoa do que de várias. Mas se agradar manter a forma Lysa, mudaremos apenas a partícula "e" em "ou" de modo a que resulte, como é evidente, que ou foi denominada Lusitânia de Luso, ou Lysitânia de Lysa ${ }^{7}$. 
Principio, ut de nomine Lusitaniae aliquid dicamus, nomen illi dedisse Lusum Liberi Patris, ac Lysam cum eo bacchantem asserit Plinius, cuius uerba nonnulli diuerso sensu intellexere. Dum aliqui Lusum atque Lysam Bacchi fuisse comites credunt, a quorum altero Lusitania uocata sit, ab altero uero Lysitania, utroque enim modo appellari solet, alii Lusum, non hominem, sed ludum potius, seu lusionem interpretantur. Qui parum aduertisse uidentur non potuisse eo tempore a latina uoce, fortassis nondum audita, prouinciam denominari. Denominata est autem Lusitania ex ipso Bacchi aeuo, si Varroni, quem Plinius citat, fidem adhibeamus.

Nec desunt qui pro Lysa, Lyssam reponant, id est bacchantium rabiem atque furorem. Sed cum per diuersas prouincias Maenades bacchatae sint, cur hoc nomen hic potius, quam alibi, tanquam rabiei monumentum sit impositum non uideo. Adde quod si ab illa insolenti et absurda uocula prouinciam dictam esse admittamus, non Lysitaniam, sed Lyssitaniam eam nominari oporteret. Verum cessant ista omnia, si ueterem lectionem non abdicemus, et Lusum ac Lysam homines fuisse intelligamus, et a Luso quidem Lusitaniam, a Lysa uero Lysitaniam esse uocatam, aegre non admittamus. Certe Lusum hominem fuisse suppositicius Berosi auctor intellexit, quem in Hiberia, Ascaridis nescio cuius Babyloniorum regis tempore, [2] regnasse perhibet, sub quo uitis apud Graecos inuenta sit, inuentam autem aiunt a Dionysio. Concurrunt igitur Dionysius uitis inuentor, et Lusus, ut appareat ex ratione temporis, Lusum ad Dionysium, id est Liberum Patrem, potuisse pertinere.

Si uero, qua necessitudine illi coniunctus fuerit, forte dubitetur, ego ex loquendi formula, filium fuisse puto. Nec uero alienum uideri debet, Dionysium, utique hominem, filium genuisse perhiberi, cum ei quoque Aristaeum olei inuentorem filium Graeci tribuant, ut in quadam contra Verrem oratione affirmat Cicero. Quanquam ipse non "ac Lysam", sed "aut Lysam” legendum puto, ut idem fuerit Lusus, qui Lysus is qui cum Libero Patre bacchari sit solitus. Nam a Graeco $\lambda \hat{v} \omega$, unde ipse etiam Bacchus Lysius cognominatus est, et eius sacerdotes Lysii, homo esse Lysus dici potuit, qui Latina consuetudine in Lusum mutatus sit. Et sane magis uidetur consentaneum, ut ab uno potius prouincia nomen acceperit, quam a diuersis. Quin etiam si "Lysam" legere magis libeat, modo particulam "ac", in "aut" commutemus, idem efficietur, ut uidelicet uel a Luso Lusitania, uel a Lysa Lysitania fuerit nominata. 
As obras latinas referem constantemente o nome de Lusitânia, forma que também aparece nalguns autores gregos, como Ptolomeu ${ }^{8}$ e Estêvão9 ${ }^{9}$ A forma Lysitânia é usada por Díon, Estrabão e Ateneu, que a tomaram de Políbio ${ }^{10}$. Não é, porém, insólita entre os latinos. Nas Pandectas, no capítulo dos Censos, estão estas conhecidíssimas palavras do jurisconsulto Paulo: "os habitantes de Beja, na Lusitânia, e os de Mérida gozam do direito itálico." 11 Em Évora, na residência do capitão dos ginetes, há uma lápide com a seguinte inscrição:

[3]

$$
\begin{aligned}
& \text { LIBERIAE. L. F. } \\
& \text { GALIAE FLAMI- } \\
& \text { NICAE. MVNIC } \\
& \text { EBORENSIS. FLA- } \\
& \text { MINICAE LYSITA- } \\
& \text { NIAE }
\end{aligned}
$$

Isto é: A Labéria Gala, filha de Lúcio, flaminia do município de Évora e flaminia da província da Lysitânia.

Muito já falámos acerca desta inscrição no opúsculo que em tempos escrevemos em português sobre a antiguidade dos Eborenses ${ }^{12}$.

Os povos da Lusitânia, embora divididos no particular em muitas tribos, foram todos eles designados, de um modo geral, por Lusitanos. Estêvão, no entanto, no livro que escreveu Acerca das Cidades e fundamentando-se em Artemidoro, diz que lhes é dado também o nome de Belitanos. Como ele próprio não justifica a razão nem é possível descobrir em outros autores qualquer menção daquele nome, eu, levado por conjectura verosímil, penso que os Lusitanos puderam ser chamados Belitanos a partir do nome dos povos Bélios, quer sejam estes os habitantes da cidade de Belon na Bética, quer os do rio Lima, que, segundo Estrabão ${ }^{13}$, se designa também pelo nome de Bélion. Outra hipótese é admitirmos que Estêvão considerou os Belitanos, quem quer que tenham sido, como tendo tido origem nos Lusitanos, o que parece ser confirmado pela sua frase em grego, que assim diz: "Os Belitanos e os Lusitanos são o mesmo povo", conforme afirma Artemidoro no livro terceiro da Geografia ${ }^{14}$. [4] Também Plínio ${ }^{15}$ localiza povos belitanos não longe de Saragoça, o que nos leva a suspeitar de que eles tenham tido origem nos Lusitanos e que assim devem ser interpretadas as palavras de Estêvão. Resta assinalar, para de um modo geral elucidar o leitor, que também existiu uma tribo de Lusões, a qual, segundo informa Estrabão ${ }^{16}$, se localizou outrora junto às nascentes do Tejo; além disto, Pausânias, no livro oitavo ${ }^{17}$, quando descreve os territórios dos Clitórios, refere-se na Arcádia à cidade de Lusos, sobre cujas ruínas, no seu tempo, se erguia Mepsas. Mas a respeito do nome será suficiente o que fica dito. 
Lusitaniae nomine Latini libri pleni sunt, et Graecorum nonnulli, inter quos Ptolemaeus atque Stephanus. Lysitaniae uocabulo utuntur Dion, Strabo, Athenaeus ex Polybio. Neque id latinis est insolitum.

Nam et in Pandectis, sub titulo de censibus, uerba sunt notissima Pauli iuris consulti: "In Lysitania Pacenses, et Emeritences iuris italici sunt." Eborae quoque in aedibus magistri equitum lapis est cum hac inscriptione

[3]

$$
\begin{aligned}
& \text { LIBERIAE. L. F. } \\
& \text { GALIAE FLAMI- } \\
& \text { NICAE. MVNIC } \\
& \text { EBORENSIS. FLA- } \\
& \text { MINICAE LYSITA- } \\
& \text { NIAE }
\end{aligned}
$$

Idest: Laberiae Lucii filiae Gallae flaminicae Municipii Eborensis, flaminicae prouinciae Lysitaniae.

De qua inscriptione in libello, quem De Eborensium antiquitate uulgari lingua iam pridem scripsimus, multa a nobis dicta sunt.

Lusitaniae uero populi etsi in multas speciatim gentes diuisi sunt, tamen uniuersi ac generatim Lusitani appelantur. Stephanus autem in libro De urbibus, fretus Artemidori testimonio, Lusitanos, etiam Belitanos uocari tradit. Sed cum causam ipse minime assignet, nec apud alios scriptores reperire liceat ullam eius nominis mentionem, ego uerisimili coniectura ductus, existimo a Beliis populis, uel ad oppido Bethicae, cui nomen Belon, seu a Lethe flumine, quem alio nomine Beliona dici ait Strabo, Lusitanos potuisse Belitanos uocari; nisi Stephanum Belitanos, quicumque illi fuerint, a Lusitanis originem ducere intellexisse credamus, quod Graeca phrasis magis significare uidetur, quae sic habet: "Belitani iidem sunt cum Lusitanis, iuxta Artemidorum in tertio Geographiae libro."

[4] Enumerat etiam Plinius Bellitanos populos non procul a Caesaraugusta, quos a Lusitanis originem traxisse suspicare possumus, et ita Stephani uerba intelligi debere.

Superest ut obiter admoneam lectorem, fuisse et Lusonum gentem, quae, ut Srabo ait, ad fontes Tagi olim pertineret, et in Arcadia Lusos oppidum, in cuius ruinis Mepsae suo tempore extarent, collocasse Pausaniam libro octauo, ubi Clitoriorum fines describit. Sed haec de nomine satis. 


\section{OS LIMITES DA LUSITÂNIA}

Por outro lado, verificámos que, de autor para autor, sobretudo para os Gregos, assim variavam os limites atribuídos à Lusitânia e a algumas outras províncias. Segundo Estrabão, estende-se a Lusitânia até aos Ártabros, que vivem junto ao cabo Finisterra: "A região que fica ao norte do Tejo - diz ele - é a Lusitânia, uma das maiores tribos hispânicas, contra a qual, durante muitos anos, os Romanos combateram. É delimitada, a sul, pelo Tejo, a ocidente e a norte, pelo oceano, a oriente pêlos bem conhecidos povos Carpetanos, Vetões, Vaceus e Galaicos."18 Pouco mais adiante diz que o Minho bate em grandeza todos os rios da Lusitânia: chama Ártabros mesmo aos mais recuados habitantes da Lusitânia, a norte e a ocidente. Exclui, sem dúvida, desta província a região entre o Tejo e o Guadiana, e é por isso que, quando fala acerca das minas de estanho, afirma que o cabo Espichel fica para lá dos Lusitanos. Delimitando a Lusitânia a oriente com os Carpetanos, os Vetões, os Vaceus e os Galaicos, situa-os fora da Lusitânia, como é evidente, mas, segundo adverte no mesmo passo, há autores que consideram estes povos também Lusitanos. Dos Vetões, voltaremos a falar ${ }^{19}$.

Por agora é suficiente verificar que Estrabão, sem o provar, considera alguns destes povos, Carpetanos, Vetões, Vaceus e Galaicos, hoje todos desaparecidos, como não Lusitanos. Acresce que, ao falar da nascente do Tejo e ao dizer que este rio corre da região dos Celtiberos para o ocidente equinocial, através dos Vetões, Carpetanos e Lusitanos, separa abertamente dos Lusitanos não só os Vaceus e Galaicos como ainda os Vetões. Sobre os Vaceus não há qualquer dúvida, mas quanto aos Galaicos e Carpetanos poder-se-á facilmente levantar objecções. Também convém lembrar que Estrabão estende a Lusitânia até aos Ártabros, embora não esconda que, no seu tempo, mitos já chamavam os Galaicos de Lusitanos ${ }^{20}$.

[5] Assim compreendida, portanto, a Lusitânia de Estrabão, os Galaicos, que, segundo o próprio autor, vieram habitar em último lugar a zona montanhosa e passaram a ser vizinhos dos Vaceus, e alguns deles dos Ástures, a quem chama indistintamente Galaicos por serem povos limítrofes, tornando-se deste modo vizinhos, a oriente, dos Lusitanos. Mas quanto aos Carpetanos, que diz inclinarem-se para Norte a seguir aos Oretanos, não compreendo porque chegaram até à Lusitânia, a não ser que admitamos que Estrabão os prolongasse até esta província ao longo do curso do Tejo, que se dirige de oriente para ocidente. O mesmo se pode dizer dos Vetões, Vaceus e igualmente dos Túrdulos, que se estendiam entre o Tejo e o Guadiana e em cujo território situa Mérida. Tal região, para ele, não pertence à Lusitânia, visto que esta é delimitada a sul pelo rio Tejo.

Noutro passo, porém, isto é, já perto do fim do livro terceiro, diz que as Hispânias foram divididas, por uns, em duas partes, por outros, em cinco, que algumas 


\section{LVSITANIAE TERMI}

Ceterum Lusitaniae, ut nonnullarum aliarum prouinciarum, terminos apud auctores, praesertim Graecos, uariasse comperimus.

Strabo enim a Tago ad Artabros, qui iuxta promontorium Celticum sunt, Lusitaniam protendit. "Tagi uero regio - inquit - ad aquilonem spectans, Lusitania est, inter Hispanos gens amplissima, et annis plurimis Romanorum armis oppugnata. Huius regionis latus australe Tagus cingit, ab occasu uero et septentrione Oceanus, ab aurora Carpetani, Vettones, Vaccaei, et Gallaici, satis notae gentes." Et paulo post Minium amnem omnes Lusitaniae fluuios dicit magnitudine superare. Artabros etiam Lusitaniae postremos, ad septentrionem, et occasum uocat.

Regionem uero, quae inter Tagum et Anam est, a Lusitania excludit. Vnde et Barbarium promontorium super Lusitanos esse commemorat, ubi de stanni fodinis loquitur. Carpetanos etiam, Vettones, Vaccaeos ac Gallaicos, cum ab aurora dicat Lusitaniam cingere, extra Lusitaniam eos procul dubio esse ostendit. Quanquam, ut ibidem ait, nonnulli et hos Lusitanos uocent. De Vettonibus postea.

Satis modo sit istos nonnullos, qui nulli iam sunt, Strabonem non probare, sed pro non Lusitanis Carpetanos, Vettones, Vaccaeos, et Gallaicos habere. Ad haec de Tagi agens origine, eumque ex Celtiberis per Vettones, Carpetanos et Lusitanos in aequinoctialem labi occasum dicens, manifeste a Lusitanis separat, non modo Vaccaeos, et Gallaicos, sed etiam Vettones.

De Vaccaeis quidem dubium nullum est: de Gallaicis, et Carpetanis dubitabit aliquis. Sed meminerit, Strabonem Lusitaniam ad Artabros usque extendisse, tametsi non dissimulat suo tempore multos Lusitanorum Gallaicos iam uocari.

[5] Ita igitur intellecta Strabonis Lusitania Gallaici, qui ipso auctore nouissimi montana habitant, Vaccaeis uicini, et Asturum nonnulli, quos omnes ob uicinitatem Gallaicos appellat, ab aurora Lusitanis fiunt.

Sed Carpetani, quos post Orenatos ad aquilonem declinare commemorat, quid ad Lusitaniam attineant non uideo; nisi dicamus Strabonem eos per defuentem Tagum, ab oriente uersus occasum usque ad Lusitaniam protraxisse.

Similiter et Vettones, et Vaccaeos, quemadmodum et Turdulos inter Anam et Tagum, in quibus Emeritam locat. Quae regio illi Lusitania non est, cum primum australe eius latus Tago determinat.

Alibi tamen, hoc est sub finem tertii libri, cum Hispanias ab aliis in partes duas, ab aliis in quinque fuisse diuisas dicit, earumque alias plebi, Senatuique 
destas eram atribuídas ao Povo e ao Senado, as outras ao chefe militar romano, sendo a Bética, para onde era enviado um pretor, juntamente com um legado e com um questor, atribuída à plebe, e toda a parte restante entregue ao Imperador, que mandava dois legados, um pretorial, acompanhado por sua vez de outro legado para administrar a justiça aos Lusitanos, que se estendiam junto à Bética até ao Douro e sua foz, e um legado consular. Traça assim os verdadeiros limites da província pois diz que se chama Lusitânia à região que no seu tempo tem esse nome e na qual se situa a cidade de Mérida e que a parte restante, aliás a maior parte da Ibéria (ajudemos os autores que traduziram do Grego com menos facilidade), ficava sob a autoridade do chefe consular, que tinha um exército não de desprezar, constituído por três legiões e três legados, o primeiro dos quais, acompanhado por duas legiões, dominava a zona que vai do Douro até ao Norte, "aquela região segundo afirma - a cujos habitantes alguns primeiramente chamaram Lusitanos e que outros agora denominam de Galaicos"21. São estes, pois, os limites da Lusitânia na obra de Estrabão.

Ptolomeu $^{22}$, muito mais de acordo com os geógrafos romanos, delimita o lado austral da Lusitânia pelo Guadiana e o lado setentrional pelo Douro. No que diz respeito à região de Entre Douro e Minho dos Galaicos Brácaros, anexa-a à província da Tarraconense, tal como Plínio. Difere [6] ainda de Estrabão, porque inclui na Lusitânia os Vetões da parte Oriental, como sem dúvida era o caso, mas se estes se estendiam tão amplamente a ponto de incluírem Salamanca no seu território é o que julgaremos mais adiante ${ }^{23}$. O testemunho dos Romanos é, porém, muito mais abalizado e crível.

Pompónio, escrupuloso e eloquente além de profundo conhecedor das coisas da sua terra, como hispânico que era, dividiu a Hispânia concisa e correctamente nas três províncias que então existiam: "Está diferenciada por três nomes - segundo diz -, sendo uma parte chamada Tarraconense, outra Bética e outra Lusitânia. A Tarraconense toca, numa extremidade, as Gálias, noutra, a Bética e a Lusitânia, oferece os flancos ao mar, ao Nosso Mar, na parte meridional, mas ao Oceano Atlântico, nas que olham para o Norte. Estão elas divididas pelo Guadiana”24. E no livro terceiro, ao falar da curvatura que se estende entre o Tejo e o Douro, escreve o seguinte: "Aí estão os Túrdulos Velhos, as cidades dos Túrdulos e também rios o Mondego que corre espraiado, quase no centro do promontório mais afastado, cujo sopé é banhado pelo Douro"25. Com efeito, já referira os três promontórios em que a Lusitânia se projecta.

Plínio diz aproximadamente o mesmo no cap. primeiro do livro terceiro: "A Ulterior", ou seja, a Hispânia Ulterior, "divide-se no sentido longitudinal em duas províncias, visto que pelo lado norte da Bética se estende a Lusitânia, da qual está separada pelo rio Guadiana"26; e no cap. vigésimo primeiro do livro quarto: "A Lusitânia começa a partir do Douro"27. Quando chegamos ao passo de Plínio em que se trata deste assunto, exige o cuidado que ponderemos os dois parágrafos deste 
attributas ostendit, alias Romano duci; et quidem Baeticam plebi attributam, ad quam Praetor mitteretur, qui legatum haberet et quaestorem; reliquam omnem Caesaris esse, qui duos mitteret legatos, praetorium et consularem. E quibus praetorius legatum haberet secum, qui Lusitanis uis diceret, qui Baeticae adiacentes, usque ad amnem Durium et eius ostium extenderentur. Subdit ueros Lusitaniae terminos, Lusitaniam dicens eam regionem appellari, proprio in eum diem nomine in qua regione sita sit Augusta Emerita.

Reliquam autem maximam Iberiae partem (iuuemus enim interpretes, qui Graeca minus commode uerterunt) esse eam quae duci consulari subderetur, non indignum exercitum habenti, tribus instructum ordinibus, ac legatis tribus. Quorum unus duos secum ordines ducens, tractum ultra Durium ad Arctos seruaret uniuersum, "quem tractum", inquit, "prius Lusitanos quidam appellabant, alii uero modo Gallaicos uocant”. Hi itaque iuxta Strabonem Lusitaniae fuere termini.

Ptolemaeus Latinis geographis conuenientius Lusitaniae australe latus Ana disterminat, septentrionale Durio. Quae autem a Durio ad Minium est regio, Gallaicorum Bracarorum, Tarraconensi prouinciae contribuit, quemadmodum et Plinius. Differt [6] etiam a Starbone, quod Vettones ab orientali parte adscribit Lusitaniae, et sane ita sunt; sed an tam late paterent, ut intra se Salamanticam includerent, postea expendemus. At Latinorum multo constantior, et indubitata magis est ratio.

Pomponius scriptor non modo diligens ac disertus, sed etiam, utpote Hispanus, domesticarum rerum peritissimus, breuiter et eleganter treis, quae tunc erant, Hispaniae prouincias diuisit. "Tribus autem - inquit - est distincta nominibus, parsque eius Tarraconensis, pars Baetica, pars Lusitania uocatur. Tarraconensis altero capite Gallias, altero Baeticam, Lusitaniamque contingens, mari latera obiicit nostro, qua meridiem, qua septentrionem spectat, Oceano. Illas fluuius Anas separat".

Et lib. tertio de flexu terrae inter Tagum et Durium quum agit, ita scribit: "In eoque sunt Turduli ueteres Turdulorumque oppida. Amnes autem Munda in medium fere ultimi promontorii latus effluens, et radices eiusdem abluens Durius." In tria enim promontoria dispersam Lusitaniam dixerat.

Plinius similiter libro tertio capite primo: "Vlterior uidelicet Hispania, in duas per longitudinem prouincias diuiditur. Siquidem Baeticae latere septentrionali praetenditur Lusitania, amne Ana discreta." Et lib. quarto cap. uigesimo primo: "A Durio Lusitania incipit." Sed quando in hunc Plinii locum incidimus, exigit res ut duo eius capita expendamus, quae ad Lusitaniae situm rectius percipiendum maxime pertinere censemus. 
autor, os quais consideramos da maior importância para a compreensão correcta da situação da Lusitânia.

Há cerca de quarenta anos, quando eu estava a estudar em Salamanca, discuti muito com Fernando Pinciano ${ }^{28}$, professor público de Grego e de Plínio, por causa do seguinte: mostrou-me um códice muito antigo com o texto de Plínio, que conseguira fazer vir, depois de dadas garantias, da Sé de Toledo para fazer a sua colação, e um outro não tão antigo, mas escrito com grande exactidão, da biblioteca da Universidade de Salamanca. Costumava abri-los diariamente, a hora certa, sob a vigilância de dois guardas. Verificámos em ambos o que eleja demonstrara numa lição: que o copista, por descuido, tinha saltado, como logo me apercebi, cerca de dez ou doze linhas, que Plínio escrevera sobre o cabo Finisterra para o passo em que descreve o cabo da Roca, do que resulta grande confusão e mesmo uma deturpação do próprio Plínio.

[7] Assim, no meio do capítulo vigésimo do livro quarto, ambos os códices rezam desta maneira: "O cabo Finisterra, a que outros chamam Ártabro, separa as terras, os mares e o céu. Com ele termina uma das partes laterais da Hispânia e depois de rondado começa a parte frontal. Do lado norte tem o Golfo da Gasconha, do ocidente tem o Oceano Atlântico. Uns calcularam a distância daqui ao cabo Creus em 60 mil, outros em 90 e não poucos em 1250 milhas, localizando aí os Ártabros, o que é um erro manifesto, pois foi povo que ali nunca existiu. Referiam-se seguramente aos Arótebras, dos quais falámos antes de chegarmos ao cabo Finisterra e cujo nome deturparam e localizaram aqui. Os rios são o Floro e o Nelo, os Célticos são os chamados Nérios e acima deles os Tamarcos, em cuja península estão os três altares de Séstio dedicados a Augusto. Os Céporos, a cidadela de Nela, os Célticos chamados Presamarcos, os Cilenos. Entre as ilhas merecem especial realce as de Corticata e Áunios. Depois dos Cilenos temos o convento dos Brácaros, os Helenos, os Grávios, o castelo de Tui, tudo descendência dos Gregos ${ }^{29}$. As ilhas Secas e a insigne cidadela de Abóbriga. O rio Minho, com a largura de 4 milhas na foz. Os Leunos, os Seurbos, Braga, cidadela dos Brácaros. A norte destes, a Galécia. O rio Lima, o Douro, um dos maiores rios da Hispânia, que nasce entre os Pelendónios, perto de Numância, corre pelos Arévacos e Vaceus, separando os Vetões da Astúria e os Galaicos da Lusitânia no mesmo sítio em que igualmente separa os Túrdulos dos Brácaros. Também se errou acerca dos rios célebres. A 200 milhas do Minho, que acima referimos, está, segundo Varrão, o Emínio, que alguns supõem noutro lado e a quem chamam Lima, denominado pelos antigos de rio de Esquecimento. Toda a região referida desde os Pirenéus é rica em metais, ouro, prata, ferro, chumbo escuro e claro.

A partir do Douro, começa a Lusitânia, os Túrdulos Velhos, os Pesuros, o rio Vouga, o ópido de Talábriga e o rio Águeda, os ópidos de Conímbriga, Leiria, Évora e de Alcobaça. Depois alarga-se para outro promontório de ponta retorcida e larga, a que uns chamam Magno e muitos Olisiponense devido ao nome do ópido. O Tejo está a 200 milhas do Douro e entre ambos encontra-se o Mondego"30. 
Ante annos quadraginta, cum Salmanticae studiorum causa agerem, et Vernando ${ }^{1}$ Pintiano Graecarum litterarum ac Plinii publico professore, eius rei gratia plurimum uterer. Ostendit mihi uetustissimum Plinianum codicem, quem ab Ecclesia Toletana conferendi gratia dato pignore deferendum curauerat; alterum quoque ex Salmanticensis Academiae Bibliotheca, quae certa hora solet quotidie sub duobus custodibus aperiri, non admodum sane ueterem, scriptum tamen perdiligenter.

In utroque deprehendimus, quod in publica lectione testatus ille erat, decem aut duodecim uersus, ut mihi primo uisi sunt, loco suo luxatos, a promontorio Celtico in promontorium Olisiponense, scribae oscitantia immigrasse, magna sensus confusione, cum magna etiam Plinii ipsius iniuria.

[7] In medio igitur uigesimo capite quarti libri ad hunc modum ambo codices habent:

"Promontorium Celticum, quod alii Artabrum appellauere, terras, maria, caelum disterminans. Illo finitur Hispaniae latus, et a circuitu eius incipit frons. Septentrio hinc, Oceanusque Gallicus, occasus illinc et Oceanus Athlanticus.

Promontorii Excursum LX M. prodidere. Alii XC ad Pyrenaeum inde, non pauci XII L millia, et ibi gentem Artabrum, quae nunquam fuit, manifesto errore. Arotebras enim, quos ante Celtium diximus promontorium, hoc in loco posuere, litteris permutatis. Amnes Florius, Nelo, Celtici cognomine Neriae, superque Tamarici, quorum in paeninsula tres arae Sestianae Augusto dicatae. Cepori. Oppidum Noela. Celtici cognomine Praesamarci. Cileni. Ex insulis nominandae Corticata et Aunios. A Cilenis, conuentus Bracarum. Heleni, Grauii, Castellum Tyde. Graecorum sobolis omnia. Insulae Cicae. Insigne oppidum Abobriga. Minius amnis IIII M. passuum ore spatiosus. Leuni Seurbi. Bracarum oppidum Augusta. Quos supra Callaecia. Flumen Limia. Durius amnis ex maximis Hispaniae, ortus in Pelendonibus, et iuxta Numantiam, lapsus deinde per Areuacos, Vaccaeos, disterminatis ab Asturia Vettonibus, a Lusitania Callaecis; ibi quoque Turdulos a Bracaris arcens. Erratum et in amnibus inclitis. Ab Minio, quem supra diximus CC M. pass. ut auctor est Varro, abest Aeminius, quem alibi quidam intelligunt, et Limiam uocant, obliuionis antiquis dictus. Omnisque dicta regio a Pyrenaeo metallis referta auri, argenti, ferri, plumbi nigri, albique.

A Durio Lusitania incipit, Turduli ueteres, Paesuri, flumen Vacca, oppidum Vacca, oppidum Talabriga, oppidum et flumen Aeminium, oppida Conimbrica, Collippo, Eburo, Britium. Excurrit deinde in aliud uasto cornu promontorium, quod alii magnum appellauere, multi Olisiponense, ab oppido. Ab Durio Tagus CC. M. passuum interueniente Munda."

1 Vernando $E R C^{1} F$ ] Ferdinando $C^{2} U$ 
[8] Fiquei então bem contente com a seriedade de Plínio, visto que daquela maneira parecia ficar livre da acusação de negligência, de que sofrem todos os que se ocuparam de assuntos de geografia, e agradeci muito a Pinciano porque o conseguira demonstrar. Deixei, porém, de estar contente ao apreciar com mais cuidado o encadeamento das palavras de Plínio, ao mesmo tempo que o cotejava com Solino, macaco de Plínio, como se diz. Transcreverei as palavras deste velhíssimo códice manuscrito a fim de obter um texto mais fiel: "Na Lusitânia, situada na Hispânia, existe um promontório a que chamam Ártabro, outros Olisiponense, o qual separa o céu, terras e mares. Quanto às terras, domina ele um dos lados da Hispânia e assim divide o céu e os mares, porque rondando-o começa o golfo da Gasconha e a frente setentrional depois de se ter chegado ao fim do oceano Atlântico e do ocidente. Aqui se situa Lisboa, fundada por Ulisses, o rio Tejo, que sobreleva aos outros rios por causa das suas areias auríferas. Na proximidade de Lisboa, as éguas entram em cio com estranha fecundidade, pois, bafejadas pelos Favónios, concebem pelo vento, e tendo desejo de macho cobrem-se com o sopro das brisas" ${ }^{2}$.

Não há dúvida de que Solino foi buscar estas palavras a Plínio, tal como para a mesma opinião convergiram Marciano Capela ${ }^{32}$ e S. Isidoro, no livro décimo quinto das Etimologias ${ }^{33}$. De resto, o próprio encadeamento das palavras mostra suficientemente que a frase é de Plínio. Repare o leitor atento: "Referiam-se certamente aos Arótebras, dos quais falámos antes de chegarmos ao cabo Finisterra e que eles localizaram aqui" ${ }^{4}$. Serão estas as palavras de quem já se afastou do Finisterra ou de quem se detém ainda a descrever o mesmo? "Localizaram-nos aqui". Onde? Acaso no Finisterra? Com certeza. Portanto, aqui os situam os restantes autores e o próprio Plínio. Com efeito, coloca os Arótebras antes do Finisterra. Mas Arótebras e Ártabros são o mesmo povo, como confirma Estrabão ao dizer: "Os homens do nosso tempo chamam Arótebras aos Ártabros"35. E Plínio declara: "trocando as letras" 36 . Foi, por conseguinte, deste modo, que, ocupando-se do cabo Finisterra e como que esquecido de si próprio, acusa de erro manifesto os que aí localizaram o povo dos Ártabros, que nunca teria estado em tal lugar.

Todos estes factos, que puderam ser aqui trazidos pela leitura dos códices de Toledo e Salamanca e que puderam ser sujeitos a críticas, já não podem ser recusados se dissermos simplesmente que Plínio liga ao cabo da Roca tudo o que diz sobre os Ártabros. No entanto, é falso [9] que o mesmo cabo esteja no limite das terras, do céu e dos mares; que aí termine um dos lados da Hispânia ou que, contornando-o, comece a parte frontal, tanto mais que Estrabão disse, com toda a clareza, que esta costa se estende do cabo de S. Vicente até ao monte dos Ártabros, isto é, até ao cabo Finisterra, e que a península tem um quarto lado, desde aqui até ao cabo Creus, parcialmente voltado ao norte. Também é falso o que diz do seu comprimento e da distância que o separa do cabo Creus, se entendermos aquele como o cabo da Roca.

Que havemos pois de dizer a não ser que Plínio identificou erradamente o cabo Finisterra com o da Roca? Poder-se-á, porém, reduzir grande parte da sua 
Exultaui equidem tunc, propter Plinii grauitatem. Illo siquidem [8] pacto calumnia negligentiae, quam patitur ab omnibus qui geographica tractarunt, liberari sane uidebatur, et Pintiano magnas egi gratias, qui id commonstrasset. Verum exultare desii Plinii uerborum seriem pensitatius expendens, simulque sumpto in manus Solino, Plinii ipsius, ut perhibetur, simia; cuius referam uerba, atque ex manuscripto uetustissimo codice, ut sincerius exeant.

"In Lusitania Hispaniae promontorium est, quod Artabrum alii, alii Olisiponense dicunt. Hoc caelum, terras, maria distinguit. Terris Hispaniae latus finit, caelum et maria hoc modo diuidit, quod circumitu eius incipiunt Oceanus Gallicus, et frons septentrionalis, Oceano Atlantico, et occasu terminatis. Ibi oppidum Olisipo ab Vlysse conditum. Ibi Tagus flumen. Tagum ob arenas auriferas ceteris amnibus praetulerunt. In proximis Olisiponis equae lasciuiunt mira fecunditatae. Nam adspiratae fauoniis, uento concipiunt, et sitientes uiros aurarum spiritu maritantur."

Non dubium est haec Solinum ex Plinio esse mutuatum, in eandemque sententiam et Marcianum Capellam abiisse, et Isidorum decimo quinto Etymologiarum libro, et alioqui ipsa uerborum connexio satis indicat Plinium ita scripsisse. Attendat diligens lector. "Arotebras enim, quos ante Celticum diximus promontorium, hoc in loco posuere."

Suntne haec uerba longe a Celtico iam progressi, an adhuc in eodem describendo inhaerentis? "Hoc in loco posuere". Quo in loco? In Celticone? Certe. Ibi enim ceteri eos collocant, et ipsemet Plinius. Ponit enim Arotebras ante Celticum. Arotebrae autem iidem sunt qui Artabri. "Nostrae aetatis homines - ait Strabo - Artabros Arotebras uocant. Litteris permutatis" ut fatetur Plinius. Quomodo igitur in Celtico detentus, quasi sui oblitus, erroris manifesti argueret eos qui ibi gentem Artabrum, quae nunquam eo loci fuerit, posuissent.

Ista, quae admissa Toletani et Salmanticensis codicum lectione, obiici poterant, nequaquam obiicientur, si quod de Artabris hic ait, Olisiponensi promontorio Plinium dicamus tribuisse. At falsum [9] est Olisiponense promontorium terras, caelum mariaque disterminare, illoque Hispaniae latus finiri, et a circuitu eius frontem incipere, clarissime dicente Strabone Hispaniae latus hoc ab sacro promontorio usque ad Artabrorum montem, hoc est, promontorium Celticum extendi, et quartum denique latus ex eo loco usque ad promontorium Pyrenes, quae pars Borean spectat.

Falsum etiam quod de promontorii excursu, et longitudine inde ad Pyrenaeum, si quidem de Olisiponensi intelligas.

Quid ergo dicemus? nisi Plinium male Artabrum promontorium cum Olisiponensi confundisse. Poteratque non minima ex parte culpam eius minuere 
culpa, na medida em que não afirma que o Finisterra é esse promontório, mas sim que alguns autores assim o designaram e que aí localizaram os Ártabros, em erro manifesto, segundo diz, pois foi povo que nunca existiu em tais paragens. E explica a causa do erro: "Referiam-se seguramente aos Arótebras, dos quais falámos, antes de chegarmos ao cabo Finisterra e que eles, trocando as letras, localizaram aqui" 37 . Critica, com razão, aqueles, quem quer que tenham sido, que designaram por Finisterra o cabo da Roca e associa outro erro não insignificante ao continuar com todo o acerto: "Também se errou acerca de rios célebres" - afirma ele, assim como quem diz: "errou-se nisto, porque chamavam Ártabro ao promontório Magno, ou seja, Olisiponense, e aqui colocaram os Artabros, o que é um erro manifesto, pois foi povo que nunca esteve nessas paragens; erraram, do mesmo modo, acerca de rios importantes, como o Minho e o Lima"38. Muito embora estejamos prontos a desculpar Plínio deste passo, visto que acusa de engano os que chamam Finisterra ao cabo da Roca, já não ousamos contudo proteger da censura quem afirma que as terras, os céus e os mares são divididos pelo cabo da Roca e que o lado da Hispânia, voltado a ocidente, é delimitado por ele.

Mas não é de admirar que Plínio, naquela época, tenha sido enganado e induzido em erro, porque, nos nossos dias, em que quase tocamos as coisas com as mãos no contacto diário e em que as observamos até à saciedade [10] com tão grande frequência, Joaquim Vadiano ${ }^{39}$, que tanto se exasperou contra Plínio devido a este erro e que dele não o desculpou, se enganou ele mesmo, ao crer que o promontório Cúneo é o cabo de S. Vicente e que o Sacro e o Barbário são um e o mesmo cabo, além do que diz sobre Alcácer do Sal e Lisboa, afirmações que já foram objecto da minha crítica ${ }^{40}$. Estes assuntos são escorregadios, não muito fáceis de conhecer, e é quase um prodígio não se escorregar em tão grande globo terrestre.

Se me fosse permitido emendar Plínio à minha vontade, ler-se-ia antes assim: "O cabo Finisterra, que separa as terras, os mares e o céu. Com ele termina uma das partes laterais da Hispânia e depois de rondado começa a parte frontal. Do lado norte tem o golfo da Gasconha, do ocidente o oceano Atlântico". Mais à frente, no capítulo da Lusitânia, proporíamos: "Depois alarga-se para outro promontório de ponta retorcida e larga, a quem uns chamam Ártabro, outros Magno e muitos Olisiponense, devido ao nome da cidade. Uns calculam o seu comprimento em 60 mil, outros em 90 mil passos e daí até aos Pirenéus consideram não poucos uma distância de 1250 mil passos, lacalizando aí os Ártabros, o que é erro manifesto, pois foi povo que nunca ali existiu, etc." ${ }^{41}$. Seria então conveniente desculpar Solino e Capela, na medida em que deveriam ter utilizado edições já deturpadas de Plínio. E não sei se isto não se poderia provar.

Eis porque, quanto a mim, se deve ficar agradecido àqueles cópias opriginais e à de Pinciano, porque propositadamente evitam afirmar a existência de erro em Plínio, mas, depois de aceite a lição, devemo-nos ficar por essa tal nodoazita de tão grande homem sem que maltratemos a sua opinião. 
quod non ipse affirmat Artabrum id esse promontorium, sed nonnullos ita uocasse, et ibi gentem Artabrum, quae nunquam ibi fuerit, collocasse, atque hoc manifesto, ut inquit, errore. Et erroris causam subiicit: "Arotebras enim, quos ante Celticum diximus promontorium, hoc in loco posuere, litteris permutatis." Quos iure reprehendit, quicuunque ii fuerint, qui Artabrum promontorium hoc Olisiponense uocarint, additque optima uerborum consequutione alium non minimum errorem.

"Erratum - inquit - et in amnibus inclitis", sicut, ait, "erratum in hoc est, quod promontorium magnum, siue Olisiponense Artabrum appellauere, ibique gentem Artabrum, quae nunquam ibi fuit, manifesto errore posuere, ita erratum $\mathrm{ab}$ is est in amnibus inclitis, uidelicet Aeminio atque Limia. Quemadmodum itaque ex parte hac Plinium excusare possemus, quando erroris arguat eos qui Olisiponense promontorium Artabrum appellauere, ita protegere a culpa non audemus Olisiponensi isto terras, caelum, maria distingui, eoque Hispaniae latus ad occidentem finiri asseuerantem.

Sed mirandum nequaquam est falli ac decipi tempestate ea Plinium, quum nostra hac, quotidiano usu et tanta frequentia, quasi digitis contrectatis rebus, et oculis etiam ad fastidium subiectis $[\mathbf{1 0}]$ atque perlustratis, Ioachimus Vadianius, qui propter erratum hoc in Plinium adeo excandescit, ut iuuari eum etiam prohibeat, deceptus ipse sit, promontorium Cuneum Sancti Vincentii esse caput, et Sacrum idem quod Barbarium opinatus; praeter illa quae de Salaria atque Olisiponense alio ei loco obieci. Lubrica isthaec sunt, et cognitu non nimis facilia, atque in tam uasto terrarum orbe non labi, paene monstri simile.

Mihi si meo arbitratu Plinium emendare liceret sic potius legerem: "Promontorium Celticum, terras, maria, caelum disterminans. Illo finitur Hispaniae latus, et a circumitu eius incipit frons, septentrio hinc, Oceanusque Gallicus, Occasus illinc, et Oceanus Atlanticus." Deinde in capite de Lusitania, sic: "Excurrit deinde in alliud uasto cornu promontorium, quod alii Artabrum appellauere, alii Magnum, multi Olisiponense, ab oppido. Promontorii excursum LX M. prodidere, alii XC M. passuum. Ad Pyreneum inde non pauci XII L. milia. Et ibi gentem Artabrum, quae nunquam fuit, manifesto errore." Et quae sequuntur.

Oporteretque tunc et Solinum et Capellam in iam corruptos Plinii libros incidisse causificari.

Quod nescio an euinci posset. Quare per me quidem autographis libris illis, et Pintiano habeatur sane gratia Plinianum erratum sedulo amolientibus, sed recepta lectione, cum isthac magni uiri labecula contendi simus, neque eius sententiae uim faciamus. 
O que, porém, se segue quanto à Lusitânia, tentámos nós restaurar na medida das nossas forças e diligência, e vamos procurar dar a cada assunto o lugar que lhe compete.

\section{Do Capítulo XXI Do Livro iV De Plínio ${ }^{42}$}

[11] "A partir do Douro, começa a Lusitânia, os Túrdulos Velhos, os Pesuros, o rio Vouga, o ópido do Vouga, o rio Águeda, os ópidos de Conímbriga, Leiria, Évora e de Alcobaça. Depois alarga-se para outro promontório de ponta retorcida e larga a quem uns chamaram Ártabro, outros Magno e muitos outros Olisiponense devido ao nome do ópido, o qual delimita as terras, os mares e o céu. Com ele termina uma das partes laterais da Hispânia e depois de rondado começa a parte frontal. Do lado do norte tem o golfo da Gasconha, do ocidente tem o oceano Atlântico. Uns calcularam o seu comprimento em 60 milhas, outros em 90 e não poucos disseram que deste sítio ao cabo Creus são 1250 milhas, localizando aí os Ártabros, o que é erro manifesto, porquanto foi povo que nunca ali existiu. Referiam-se seguramente aos Arótebras, dos quais falámos antes de chegarmos ao cabo Finisterra e que eles, trocando as letras, aqui localizaram.

Também se errou acerca de rios célebres. A 200 milhas do Minho, que acima referimos, está, segundo Varrão, o Águeda, que alguns supõem noutro lado e ao qual chamam Lima, denominado pelos antigos rio do Esquecimento e muito envolvido na lenda. O Tejo está a 200 milhas do Douro e entre ambos encontra-se o Mondego. O Tejo é muito celebrado por causa das suas areias auríferas. A 160 milhas dele salienta-se, quase do meio do lado frontal da Hispânia, o cabo de S. Vicente. Diz Varrão que daqui ao meio dos Montes Pirenéus se contam 1400 milhas, 121 milhas até ao Guadiana, que dissemos separar a Lusitânia da Bética, às quais se juntam mais 102 milhas se a distância for medida até Cádis. Habitam-na povos Célticos, Túrdulos, junto ao Tejo os Vetões.

Entre o Guadiana e o cabo de S. Vicente, os Lusitanos. Os seus ópidos famosos na orla costeira a partir do Tejo são Lisboa, célebre por causa da fecundação das éguas pelo vento Favónio, Alcácer do Sal, cognominada Cidade do Imperador, e Santiago de Cacém. O cabo de S. Vicente e a seguir o cabo de Santa Maria, com os ópidos de Estói, Tavira e Mértola. Toda a província está dividida em três conventos: o Emeritense, o Pacense e o Escalabitano, com um total de 45 povoações, das quais cinco são colónias, uma delas é um município com direito romano, três com o antigo direito do Lácio e trinta e seis estipendiárias ${ }^{43}$. As colónias são Mérida, sobre a margem do Guadiana, Medellín, Beja, e Cacéres, denominada Cesariana [12] (de que são contribuintes Castra Iulia e Castra Caecilia), e a quinta é Alcácer do Sal, também chamada Praesidium Iulium; município de direito romano é Lisboa, cognominada Felicitas Iulia; os ópidos com o antigo direito do Lácio são Évora, também chamada Liberalitas Iulia, Mértola, Alcácer do Sal, de que já falámos; das estipendiárias, sem falar noutras com nomes idênticos aos de algumas já referidas na Bética, não custa 
Ceterum, quae de Lusitania sequuntur, nos nostro Marte diligentiaque emaculauimus, reddemusque suo cuiusque rei loco rationem.

PLINII LIBRI IV. CAP. XXI:

[11]"A Durio Lusitania incipit, Turduli ueteres, Paesuri, Flumen Vacca. Oppidum Talabrica, Oppidum et flumen Aeminium, Oppida Conimbrica, Collipo, Eburobritium. Excurrit deinde in aliud uasto cornu promontorium, quod alii Artabrum appellauere, alii Magnum, multi Olisiponense ab oppido, terras, maria, caelum disterminans. Illo finitur Hispaniae latus, et a circumitu eius incipit frons. Septentrio hinc Oceanusque Gallicus, occasus illinc et Oceanus Atlanticus. Promontorii excursum LX M. prodidere, alii XC M. passuum.

Ad Pyrenaeum inde non pauci XII L. milia, et ibi gentem Artabrum, quae nunquam fuit, manifesto errore. Arotebras enim, quos ante Celticum diximus promontorium, hoc in loco posuere, litteris permutatis.

"Erratum et in amnibus inclitis. Ab Minio, quem supra diximus CC M. pass., ut auctor est Varro, abest Aeminius, quem alibi quidam intelligunt et Limaeam uocant, Obliuionis antiquis dictus, multumque fabulosus. Ab Durio Tagus CC M. passuum interueniente Munda. Tagus, auriferis arenis celebratur. Ab eo CLX M. passuum promontorium Sacrum e media prope Hispaniae fronte prosilit. XIIII M. passuum, inde ad Pyrenaeum medium colligi Varro tradit. Ab Ana uero, quo Lusitaniam a Baetica discreuimus, CXXI M. pass.

A Gadibus CII M. passuum additis, Gentes Celtici, Turduli, et circa Tagum Vettones.

Ab Ana ad Sacrum Lusitani. Oppida memorabilia a Tago: in ora Olisipo, equarum e fauonio uento conceptu nobile, Salacia cognominata Vrbs Imperatoria, Merobriga, Promontoruim Sacrum, et alterum Cuneus. Oppida: Ossonoba, Balsa, Myrtilis. Vniuersa prouincia diuiditur in conuentus treis: Emeritencem, Pacensem, et Scallabitanum. Tota populorum XLV. In quibus coloniae sunt quinque, municipium ciuium Romanorum unum. Latii antiqui tria, stipendiaria XXXVI. Coloniae, Augusta Emerita, Anae fluuio adposita, Metallinensis, Pacensis, Norbensis, Caesariana cognomine. Contributa [12] sunt in eam Castra Iulia, Castra Caecilia. Quinta est Scallabis, quae Praesidium Iulium uocatur; municipium ciuium Romanorum Olisipo, Felicitas Iulia cognominatum. Oppida ueteris Latii: Ebora, quod item Liberalitas Iulia, et Myrtilis ac Salacia, quae diximus. Stipendiariorum, quos nominare non pigeat, praeter iam dictos in Baeticae cognominibus, Augustobrigenses, Amaienses, Aranditani, Arabrigenses, Balsenses, Caesarobrigenses, Caperenses, Caurienses, Colarni, Cibilitani, Concordienses, qui 
citar as dos Augustobricenses, Amaienses, Aranditanos, Arabrigenses, Balsenses, Cesarobrigenses, Caparenses, Caurienses, Colarnos, Cibilitanos, Concordienses, que também são chamados Bócoros, Interausenses, Lancienses, Mirobrigenses, cognominados Célticos, Meidubrigenses, também chamados Plumbários, Ocelenses, cognominados Lancienses, Túrdulos, cognominados Bárdolos e Táparos. Agripa ${ }^{44}$ calculou que a Lusitânia unida à Astúria e Galécia mede 540 milhas de comprimento e 536 milhas de largura. O perímetro de toda a costa da Hispânia pelo mar, entre os dois cabos dos montes Pirenéus, é calculado por uns em 29 milhas, por outros em 27 milhas". E aqui termina o capítulo sobre a Lusitânia, como há já muito avisei nos comentários à minha obra sobre S. Vicente. ${ }^{45}$

Não parecerá que nos afastámos do assunto se apresentarmos também os limites da Lusitânia dos nossos dias, se bem que agora se lhes deva chamar fronteiras de todo um reino e já não de uma Lusitânia. O reino, como se sabe, estende-se ao norte para lá do Douro, abrangendo os Galaicos Brácaros, não apenas os que estão cercados entre Douro e Minho e entre o Geres e o Marão, mas ainda os que estão para lá destes montes, passando a fronteira pelos Aquiflavienses, Tameganos e restantes povos que pertenciam ao Convento Bracaraugustano. A fronteira corre depois até ao rio Sabor e à povoação do Soutelo, atravessando alguns povos, outrora os Astures. Parando, muda a direcção para Oriente e passa junto de Miranda, cidade edificada sobre o Douro em face de Zamora no sítio em que o rio se curva sobre si mesmo para norte e recebe as águas do Esla, que vem da região de Leão. A fronteira acompanha [13] o curso rápido do rio, fazendo uma curva suave até Freixo; daqui, quase em linha recta, passa ao longo de alguns povos Transcudanos e Vetões, na direcção de Salvaterra; de novo recua, fazendo um ângulo maior junto à entrada do Tejo para o interior, da qual por sua vez se afasta novamente em linha recta, até que um pouco acima de Ouguela se inclina para o Guadiana, ao longo dos seus afluentes Caia e Gaiola, a cerca de 4000 passos de Badajoz, cidade ilustre da província de Bética, situada junto ao próprio Guadiana. Depois de passar para lá do rio, abrange famosas praças fortes a partir da região dos Célticos da Bética que confinavam com a Lusitânia, como Olivença, Mourão, Moura, Serpa e, espalhados por perto do rio, os castelos de Murtigão e Noudar, que devem ser situados mais a interior da Bética, junto às nascentes do Ardila e do Chança, cursos de água sem importância, que deslizam por algumas aldeias desconhecidas. Esta região, que delimitámos, é o chamado Reino de Portugal de acordo com o costume da época.

É altura de explicarmos o que há pouco e a este respeito longamente expusemos a Quevedo ${ }^{46}$. Dizia eu que o todo a que chamamos Portugal abarca duas partes da verdadeira Lusitânia propriamente dita; da província da Tarraconense os Brácaros, alguns Astures para lá do Marão e do Geres e certo número de Vetões; a zona que referimos para além do Guadiana. Em face disto, se déssemos a Portugal só o nome de Lusitânia, por ser este o da maior parte da região, existiria hoje uma Lusitânia a Sul e a Norte bastante mais extensa e mais larga, é verdade, mas muito mais 
et Boccori, Interausenses, Lancienses, Mirobrigenses, qui Celtici cognominantur, Meidubrigenses, qui Plumbarii, Ocellenses, qui et Lancienses. Turduli, qui Barduli, et Tapori.

Lusitaniam cum Asturia et Gallaecia patere longitudine DXL. M. passum, latitudine DXXXVI M. Aggripa prodidit. Omnes autem Hispaniae a duobus Pyrenaei promontoriis per maria totius orae circuitu passuum XXIX M. colligere existimantur. Ab aliis XXVII M."

Et hic terminari caput de Lusiatnia, iam pridem in Vincentii mei scholiis admonui.

Non uidebimur a scopo digredi, si nostri quoque aeui Lusitaniae terminos exponamus, quamquam hi magis regni totius, quam unius Lusitaniae dicendi sunt. Protenditur enim regnum ultra Durium a septentrione, Gallaicos continens Bracaros, non modo eos qui intra Durium, Miniumque Montesque Iuressum, atque Maranum clauduntur, sed qui ultra eos monteis per Aquiflauienseis, Tamacanos, et reliquos qui ad Bracaraugustanum pertinent conuentum. Et deinceps per aliquot Asturum olim populos adscendit usque ad Saborem fluuium, oppidumque Soutellum. Vnde resistens conuertitur limes ad orientem per Mirandam urbem ex aduerso Zamorae, Durio impositam, ubi introrsus ad septentrionem curuatur amnis, excipitque Estulam fluuium e Legionensi agro defluentem. Ex eaque urbe prono [13] flumine descendit flexu modico usque ad Fraxinum. Heinc per Transcudanorum, Vettonumque aliquot populos recto fere margine percurrit ad oppidum Saluaterram, rursumque reducitur maiore interius angulo ad Tagi ingressum.

A quo recto iterum limite procedit, donec paulo supra Ouguellam oppidum ad Anam se inclinat per Caiae, et Caiolae confluenteis, quattuor circiter passuum milibus a Badioza insigni Baeticae prouiniciae urbe Anae ipsi adposita.

Traiecto inde flumine ad austrum uersus, ex Baeticis Celticis, qui Lusitaniam attingunt, oppida complectitur memorabilia: Oliuentiam, Moronem, Mauram, Serpam, non longe ab amne dissita, et Mortiganum, ac Noudar Castella, magis in Baeticam penetrantia, ad fonteis usque Ardillae et Xanthiae non magni nominis fluuiorum, praeter uicos ignobileis quosdam. Atque haec quam circumscripsimus regio saeculi nostri more Portugaliae Regnum appellatur.

Ratio petenda est ex iis quae nuper ad Kebedium super ea re prolixe respondimus. Id ergo totum quod Portugaliam dicimus, Lusitaniae propriae ac uerae partes duas continet, et ex Tarraconensi prouincia Bracaros, ultraque monteis Maranum atque Iuressum Asturum nonnullos, et aliquot ex Vettonibus, accessionemque ultra Anam, quam diximus. Quod si a maiori portione uno id nomine Lusitaniam appellemus, erit hodie Lusitania a meridie quidem, et 
estreita, do que a antiga, a Oriente junto dos Vetões, quase [14] todos separados dos nossos compatriotas.

Habitam, portanto, a região entre Douro e Guadiana, a verdadeiramente dita Lusitânia, povos tais como os especialmente designados por Lusitanos, os Turdetanos, os Célticos, os Túrdulos, os Vetões, os Barbáries, os Pesuros e os Túrdulos Velhos. De modo algum podemos discriminar com exactidão as suas fronteiras e confins, no meio de tão grandes trevas que envolvem as coisas antigas, e no meio dos testemunhos discordantes dos autores. Que ninguém incorra em erro ao basear-se nos números de Ptolomeu ${ }^{47}$, que, por sua natureza, são susceptíveis de deturpação, pois mesmo que estivessem como quando foram anotados, ainda assim não mereciam crédito absoluto, porque o autor não tirou estes números da sua observação no local, mas da narração. Sendo assim, pôde facilmente ter deslizes, e nas cartas geográficas desenhadas e lançadas por ele são mais as coisas que há a rejeitar do que aquelas em que se deva ou possa acreditar.

\section{OS TURDETANOS}

Ptolomeu ${ }^{48}$ diz que entre o Guadiana e o cabo de S. Vicente e regiões limítrofes habitavam os Turdetanos, diferentes dos da Bética, e que as suas cidades marítimas eram Tavira e Estói, situadas antes do promontório. Depois deste, Alcácer do Sal e Tróia, mais acima, depois do alargamento brusco do rio Sado. No interior enumera Beja e Mértola. Estrabão ${ }^{49}$ atribui esta região a Célticos e a muitos dos Lusitanos, como dissemos na epístola a Vaseu em defesa de Beja ${ }^{50}$. [15] Plínio ${ }^{51}$, esquecendo os Turdetanos, localiza Lusitanos entre o Guadiana e o promontório sagrado, referindo-se sem dúvida não aos povos mas à raça, enquanto Ptolomeu nada disto tem em conta, muito embora estenda os limites destes Turdetanos exageradamente ao atribuir-lhes não só o reino do Algarve e toda a zona de Ourique, como ainda zona muito mais ampla aos Célticos e Lusitanos de Estrabão, ou seja, aquela onde se encontram Beja, Alcácer do Sal e Tróia. Esta última, situada outrora no golfo de Alcácer do Sal, agora em ruínas, conserva no entanto muitos vestígios da antiga população, como veremos oportunamente.

\section{OS CÉLTICOS}

Contíguos e misturados com os Turdetanos estão os Célticos, de raça gaulesa, os quais, na região do Guadiana, se expandem largamente até aos territórios dos Túrdulos e Vetões com as suas muitas cidades ${ }^{52}$, entre as quais ainda hoje se distingue Eivas. Atestam a sua própria origem no nome que têm: são eles não só os antepassados dos Célticos que habitaram na Galécia, junto ao cabo Nério a que deram o nome ${ }^{53}$, mas também dos Célticos que, emigrando para a outra margem do Guadiana, fundaram 
septentrione longior non paulo et auctior, ab oriente uero propter Vettones fere [14] omneis a nostris separatos, aliquanto uetere angustior.

Eam ergo quae proprie dicta Lusitania est, inter Durium atque Anam fluuios incolunt gentes, Lusitani peculiariter uocati, Turdetani, Celtici, Turduli, Vettones, Barbarii, Paesuri, Turduli ueteres. Quorum limites atque confinia exacte discriminare nequaquam possumus, in tantis antiquarum rerum tenebris, et inter mutuo se collidentia scriptorum testimonia. Numeris Ptolemaei, per se rei maxime corruptioni obnoxiae, nemo quisquam se astringat. Qui si perseuerarent integri, uti ab illo notati sunt, fidem integram adhuc non facerent, quum is, eos numeros, non additis locis, sed relatione acceptis, subnotarit. In quo labi potuit facillime. Depictae autem tabellae, atque illi adiectae, plura habent, quae reiicias, et adspernere, quam quibus credere merito, uel debeas, uel possis.

\section{DE TVRDETANIS}

Ab Ana igitur ad Sacrum promontorium, circumque illud, Turdetanos alios a Baeticis, Ptolemaeus habitare ait, maritimasque illorum urbeis, Balsam, Ossonobam, ante promontorium, deinde post fluuii Callipodis eruptiones Salaciam atque Caetobrigam. Intus autem Pacem Iuliam, ac Iuliam Myrtilim enumerat. Strabo regionem eam Celticis, et Lusitanorum plerisque tribuit, sicut diximus in Epistola pro Colonia pacensi ad Vasaeum. [15] Plinius, omissis Turdetanis, ab Ana ad sacrum Lusitanos ponit, nimirum ad genus respiciens, non ad speciem, cuius Ptolemaeus rationem habuit. Sed tamen horum Turdetanorum terminos nimis extendit. Tribuit enim illis non modo Algarbii regnum et totum Orichiensem tractum, sed etiam aliquanto amplius, ex Celticis, et Lusitanis Strabonis, uidelicet Pacem Iuliam, Salaciam atque Caetobrigam, olim in sinu Salaciensi positam, dirutam modo, sed multa pristinae frequentiae uestigia retinentem, de qua suo dicetur loco.

\section{DE CELTICIS}

Contigui his sunt atque intermixti Celtici, Gallica natio, iuxta Anam late usque ad Turdulos, et Vettones multis ciuitatibus effusi, inter quas etiam nostro aeuo Heluae clarae sunt, ipso nomine originem prae se ferentes. Parentes fuerunt hi non solum Celticorum, qui Nerium Callaeciae promontorium insedere, cuique nomen dedere, uerum etiam eorum Celticorum qui ad alteram Anae ripam migrantes in Baeturia, Baeticae parte urbeis condidere. De prioribus illis refert 
cidades da Betúria, uma parte da Bética. Aos primeiros refere-se Estrabão com as seguintes palavras: "Os mais recuados, os Ártabros, vivem junto do promontório chamado Nério que é o limite não só do lado ocidental como do setentrional. Na sua periferia, encontram-se os Célticos, da mesma raça daqueles que vivem perto do Guadiana. Contam que quando estes últimos e os Túrdulos organizaram como aliados uma expedição, depois da travessia do rio Lima desertaram, e tendo-se dado nessa deserção a perda do chefe ficaram naquele mesmo local errantes e dispersos e foram eles próprios que deram ao Lima o nome de rio do Esquecimento" 54 .

Acerca dos outros, diz Plínio no livro terceiro, capítulo primeiro: "Esta região, a chamada Betúria, [16] estende-se mais além da que foi referida, entre o Bétis e o Guadiana, dividida em duas partes e outros tantos povos: os Célticos do Convento Hispalense, que confinam com a Lusitânia, e os Túrdulos que vivem junto da Lusitânia e da Tarraconense, dependentes da jurisdição de Córdova. Que os Célticos provieram dos Celtas da Lusitânia é evidente pela identidade de culto, língua e nome de povoações, que na Bética se distinguem pelos cognomes" 55 . Também a este respeito bastante falámos na epístola a Vaseu em defesa de Beja ${ }^{56}$.

\section{OS TÚRDULOS}

Seguem-se os Túrdulos, povo largamente espalhado pela Hispânia Ulterior. Com efeito, ocuparam não só a parte da Bética onde tinham a capital que era Córdova, como na Lusitânia uma zona junto aos Vetões e toda a região marítima do Tejo ao Douro. Alguns foram alcunhados de "Velhos" e deles falaremos mais adiante. Convém recordar já a seu respeito que se trata dos que ficaram separados dos Túrdulos Bélicos pelo rio Guadiana. Deles diz Plínio, no capítulo da Lusitânia: "Os povos são os Célticos, os Túrdulos e, junto ao Tejo, os Vetões" 57.

Não se deve, de modo algum, deixar de referir que houve autores que consideraram os Túrdulos e os Turdetanos o mesmo povo. Entre eles será suficiente nomear Lívio, que no livro quarto da quarta década diz o seguinte: "Constou depois que o cônsul iria levar o exército para a Turdetânia". E mais à frente: "Entretanto, o pretor Públio Mânlio, depois de receber o antigo exército de Quinto Minúcio, a quem sucedera, e tendo-o juntado por sua vez ao de Ápio Cláudio Nero da Hispânia Ulterior, partiu para a Turdetânia. Embora os Turdetanos sejam considerados os mais pacíficos de todos os Hispânicos, fiados no seu grande número, foram ao encontro do exército romano, etc.

E, apesar disso, com esta batalha não foi dominada a revolta. Os Túrdulos, mediante salário, reúnem 10.000 celtiberos e preparam a guerra com forças estrangeiras". [17] Depois: "Enquanto o cônsul e o exército estavam ocupados na guerra Túrdula..."58. Daqui se pode verificar que a terra é designada por Turdetânia, a guerra por Túrdula e os seus habitantes tanto são chamados Turdetanos como logo Túrdulos.

Estrabão, porém, embora apresentando a opinião desses tais autores, nem mesmo assim cala uma diferente: "Por causa do rio, chamam Bética à própria região a 
Strabo hisce uerbis: "Extremi incolunt Artabri circa promontorium quod Nerium uocatur, quod et occidui et septentrionalis terminus est lateris. Circumhabitant ipsum Celtici, consanguinei eorum qui ad Anam sunt. Hos etenim, et Turdulos sociis armis exercitum cum duxissent, ibi post Lemii fluminis transitum seditionem egisse ferunt, in eaque seditione facta ducis amissione palanteis, ac dissipatos ibidem remansisse, et ab iis fluuium Obliuionis esse dictum.»

De alteris his Plinius libro tertio capite primo : "Quae autem regio a Baeti ad fluuium Anam tendit extra praedicta, Baeturia appellatur, [16] in duas diuisa partes, totidemque genteis, Celticos, qui Lusitaniam attingunt, Hispalensis conuentus, Turdulos, qui Lusitaniam et Tarraconensem adcolunt. lura Cordubam petunt.» Celticos a Celtis ex Lusitania aduenisse manifestum est, sacris, lingua, oppidorum uocabulis, quae cognominibus in Baetica distinguntur. Diximus de hoc quoque satis in epistola ad Vasaeum pro Pacensi colonia.

\section{DE TVRDVLIS}

Turduli sequuntur, gens per Hispaniam Vlteriorem late diffusa. Nam et Baeticae partem tenuere, quorum Metropolis erat Corduba, et Lusitaniae portionem iuxta Vettones, et maritimam omnem regionem a Tago usque ad Durium, ex iis quidam Veteres appellati sunt. De quibus postea. Quorum meminisse modo conuenit, ii sunt qui a Turdulis Baeticis amne Ana discreti erant, de quibus Plinius in capite de Lusitânia: "Gentes Celtici, Turduli, et circa Tagum Vettones."

Hoc praetereundum nequaquam est, fuisse qui Turdulos, ac Turdetanos eosdem arbitrarentur. E quibus Liuium nominare fuerit satis lib. quarto quartae decadis in haec uerba: "Fama deinde uulgatur, Cos. in Turdetaniam exercitum ducturum;" et post: "Interim P. Manlius praetor exercitu uetere a Q. Minutio, cui successerat, accepto, adiuncto et Ap. Claudii Neronis ex Vlteriore Hispania, uetere item exercitu, in Turdetaniam proficiscitur. Omnium Hispanorum maxime imbelles habentur Turdetani, freti tamen multitudine sua, obuiam ierunt agmini Romano, etc." "Nec tamen ea pugna debellatum est. Decem millia Celtiberum mercede Turduli conducunt, alienisque armis parabant bellum." [17] Deinde "dum Cos. exercitusque Turdulo bello est occupatus." Vbi cernere licet terram Turdetaniam dictam, incolas, quum Turdetanos, tum etiam Turdulos appellatos, bellum quoque Turdulum.

Strabo autem horum subscribens opinioni diuersam etiam non tacuit. "Regionem - inquit - ipsam a flumine Baeticam uocant, ab incolis autem 
que os naturais dão o nome de Turdetânia. Quanto aos habitantes, designam-nos igualmente por Turdetanos e por Túrdulos. Enquanto uns pensam que são um e o mesmo povo, outros consideram-nos diferentes. Entre estes Políbio, que disse que os Túrdulos eram vizinhos a norte dos Turdetanos. Em nossos dias, porém, não se faz nenhuma distinção entre eles"59.

Não me foi dado apreciar este passo de Políbio, contudo, além dos cinco livros escritos em Grego e vertidos para Latim por Nicolau Perotto ${ }^{60}$, arcebispo da Macedónia, nenhuma outra edição actual me foi dado encontrar. Tenho, todavia, confiança em Estrabão e sou de opinião que Políbio acertou, mesmo que Lívio e outros os confundam por serem povos vizinhos. De facto, Ptolomeu ${ }^{61}$ fez a distinção entre Túrdulos e Turdetanos na Bética propriamente dita, mas na Lusitânia recordou-se apenas dos Turdetanos, como já acima nos referimos, e passou por alto os Túrdulos. Plínio ${ }^{62}$, situado no ponto de vista oposto, sem uma palavra acerca dos Turdetanos na Lusitânia, localiza duas tribos gémeas de Túrdulos, ou seja, uns contíguos ao Guadiana e outros a que chama "Velhos". Destes falaremos mais adiante.

\section{OS VETÕES E OS VECTÕES}

Plínio situa os Vetões junto ao Tejo entre os povos da Lusitânia e escreve assim: "A partir do Guadiana, com o qual separámos a Lusitânia da Bética, os povos são os Célticos, os Túrdulos e, junto ao Tejo, os Vetões" 63 . Resolvamos, se pudermos, este problema já anteriormente abordado no passo em que, ao ocuparmo-nos dos limites da Lusitânia, dela excluímos os Vetões, transcrevendo a opinião de Estrabão. Acerca da grafia e ortografia do nome, calemo-nos [18] até examinarmos o resto. Compare o leitor atento o que diz Estrabão: "Os Oretanos estendem-se ao máximo para o Sul, chegando até à zona marítima de certa parte que está para o lado ocidental das colunas de Hércules. A seguir estão os Carpetanos que se inclinam para norte e depois os Vetões e os Vaceus, por cujo território corre o Douro"; e o passo, um pouco mais à frente, quando diz que a Lusitânia é delimitada a oriente por Vetões, Vaceus e Galaicos ${ }^{64}$; comparemos, como disse, com as palavras de Plínio no cap. terceiro do livro terceiro: "Os primeiros são os Bástulos na costa e a seguir, por ordem e em direcção ao interior, os Mentesanos, os Oretanos e os Carpetanos junto ao Tejo; perto destes os Vaceus, Vectões e Celtiberos"

Do mesmo modo, no cap. décimo do livro quarto: "O Douro, um dos maiores rios da Hispânia, nasce entre os Pelendónios, perto de Numância, corre pelos Arévacos e Vaceus, separa os Vectões da Astúria e os Galaicos da Lusitânia no mesmo sítio em que também separa os Túrdulos dos Brácaros"66. Comparadas entre si, lado a lado, as palavras de ambos, ver-se-á que falam os dois da Hispânia Citerior e que situam os Vectões fora da Lusitânia, como também fez César no primeiro comentário Sobre a Guerra Civil, em que diz: "Os legados de Pompeio - Afrânio, que tinha obtido com o comando de três legiões a Hispânia Citerior; Petreio, que, 
Turdetaniam. Incolas uero ipsos Turdetanos, et Turdulos appellant. Quidam autem eosdem esse existimant, alii uero diuersos, e quibus etiam est Polybius, qui Turdetanis finitimos ad septentrionem dicit esse Turdulos. Verum tempestate hac nulla inter ipsos apparet distinctio."

Mihi non contigit eum Polybii locum expendere, cum praeter quinque eius libros Graece, et a Nicolao Perotto Episcopo Sipontino Latine uersos, ad hoc tempus nihil uiderim. Sed fidem Straboni habeo, et Polybium uere sensisse arbitror, etiam si Liuius et alii eos propter uicinitatem confundant. Siquidem Ptolemaeus distincte Turdulos alios a Turdetanis facit in ipsa Baetica. Nam in Lusitania Turdetanorum tantum meminit, ut superius exposuimus, Turdulos praetermisit. E contrario Plinius de Turdetanis in Lusitania nullum uerbum, Turdulos posuit geminos, uidelicet hos Anae contiguos, et alteros Veteres uocatos. De quibus postea.

\section{DE VETTONIBVS ET VECTONIBVS}

Vettones, inter Lusitaniae populos, circa Tagum, recenset Plinius, ita scribens. "Ab Ana uero, quo Lusitaniam a Baetica discreuimus, gentes Celtici, Turduli, et circa Tagum Vettones." Dissoluamus, si possumus, nodum hic, superius obiter tactum, quum de Lusitaniae terminis agebamus, ubi ex Strabonis sententia Vettones Lusitania exclusimus. Atque de scriptura, uel nominis orthographia quiescamus tantisper, [18] dum cetera examinamus. Conferat diligens lector quae Strabo dicit: "Oretani maxime uergunt ad meridiem, peruenientes usque ad maritimam, aliqua ex parte intra columnas. Post quos Carpetani declinant ad aquilonem; inde Vettones et Vaccaei, per quos Durius labitur."

Et paulo post, ubi Lusitaniam ab aurora cingi ait Vettonibus, Vaccaeis, et Callaeci. Conferat inquam haec cum Plinii uerbis lib. 3. cap. 3 : "Primi in ora sunt Bastulli, post eos, quo dicetur ordine, intus recedentes Mentesani, Oretani, et ad Tagum Carpetani, iuxta eos Vaccaei, Vectones et Celtiberi.»

Libro item quarto capite decimo: "Durius amnis ex maximis Hispaniae, ortus in Pelendonibus, et iuxta Numantiam, lapsus per Areuacos, Vaccaeosque disterminatis ab Asturia Vectonibus, a Lusitania Callaecis. Ibi quoque Turdulos ab Bracaris arcens." Et collatis inter se altrinsecus utriusque uerbis, uidebit utrumque de Hispania Citeriore loqui, Vectonesque extra Lusitaniam ponere, sicut et Caesar fecit in primo Belli Ciuilis Commentario: "Afranius, et Petreius - inquit - et Varro, legati Pompeii, quorum unus tribus legionibus Hispaniam Citeriorem, alter a saltu Gastulonensi ad Anam duabus legionibus, tertius ab 
com duas legiões, dominava a região que vai da serra de Segura até ao Guadiana; e Varrão, a quem coubera a terra dos Vectões a partir do Guadiana e dominava a Lusitânia com número igual de legiões - partilharam as suas funções para que Petreio, vindo da Lusitânia através dos territórios dos Vectões, alcançasse, com todas as suas forças, Afrânio".

E mais à frente: "Petreio chegou até junto de Afrânio atravessando os Vectões"67. Portanto, os Vectões estavam fora da Lusitânia. No entanto, Ptolomeu considera-os como os mais orientais dos Lusitanos; entre as suas cidades, das que são conhecidas na nossa época, cita Salamanca, Caparra e Ávila. Também Plínio diz na descrição da Lusitânia: "E junto ao Tejo os Vetões". Deve-se, por conseguinte, perguntar se esses Vectões ou Vetões são os mesmos ou povos diferentes e se os autores estão de acordo entre si ou não.

[19] "O Douro - diz Plínio - corre pelos Arévacos e Vaceus e separa os Vectões da Astúria e os Galaicos da Lusitânia" ${ }^{68}$. Que distribuição é esta "separa os Vectões da Astúria e os Galaicos da Lusitânia”, se nesse local foram situados por Ptolomeu ${ }^{69}$ Vectões Lusitanos? E aquela afirmação "e junto ao Tejo os Vetões"? Se estão junto ao Tejo não são, portanto, os que pelo curso do Douro são separados dos Ástures e que são localizados pelo mesmo Plínio junto dos Vaceus na Hispânia Citerior. Se de facto são os mesmos foi com pouca propriedade que se disse "e junto ao Tejo os Vetões", pois mais de acordo com as circunstâncias e com igual brevidade se poderia ter dito "e do Tejo ao Douro os Vetões". Mas nesse caso, quem seriam então aqueles Vectões não Lusitanos separados da Astúria pelo rio Douro?

Vamos investigar o assunto um pouco mais a fundo e descobrir quem eram estes a seguir aos Vaceus e separados dos Ástures pelo Douro. Quem quiser siga num mapa da Hispânia o curso do Douro desde Numância, capital dos Pelendónios, através dos Arévacos e suas cidades de Osma, Xigonza, Penalva del Castro e as restantes evocadas por Plínio. Depois o local em que o Areva, causa e origem do nome desse povo, se mistura ao Douro. Seguidamente, a partir do rio Pisuerga, corre o Douro entre os Vaceus e suas cidades de Falência, Coca e as que lhes são atribuídas por Ptolomeu, ou seja, Píncia, Sárabris, Sêntica. E de entre elas Zamora, que se pensa ser a antiga Sêntica ${ }^{70}$, está perto do ângulo formado pelo Douro no sítio em que, perto de Miranda, recebe as águas do Esla, rio das Astúrias que recordámos na descrição da Lusitânia.

Procuremos agora estes Vectões contíguos a eles e separados dos Ástures pelo Douro. Não se apresentam nenhuns a não ser os que se estendiam desde o ângulo em forma de cunha voltado para o interior, de que já falámos, até aos Carpetanos, pela margem sul do Douro, uma vez que estão separados por meio do curso do rio dos Mirandeses, outrora sob o domínio do valente povo Ásture. Pois bem, são estes que Ptolomeu disse serem os mais orientais dos Lusitanos e entre eles situou Salamanca, Ávila e Caparra, para que seja dos Vetões, limítrofes dos Vaceus, como mostrámos, a zona por onde corre para o Douro o Tormes que banha Salamanca. 
Ana Vectonum agrum Lusitaniamque pari numero legionum obtinebat, officia inter se partiuntur, ut Petreius ex Lusitania per Vectones cum omnibus copiis ad Afranium proficiscatur."

Et post:

"Petreius per Vectones ad Afranium peruenit." Extra Lusitaniam ergo Vectones erant. Atqui Ptolemaeus ex Lusitanis, hos maxime orientales facit; interque eorum ciuitates ex nostra aetate notis, Salmanticam, Caperam atque Obilam ponit. Plinius etiam in Lusitaniae descriptione. "Et circa Tagum - inquit - Vettones». Quaerendum igitur sintne iidem isti Vectones, seu Vettones, an diuersi, et an constent sibi auctores, anne secus.

[19] «Durius - inquit Plinius - lapsus per Areuacos, Vaccaeosque disterminatis ab Asturia Vectonibus, a Lusitania Callaecis.» Qualis haec partitio est, "disterminatis ab Asturia Vectonibus, a Lusitania Callaecis», si Vectones isto loco positi Lusitani ex Ptolemaeo sunt? Qualis et illa? «et circa Tagum Vettones», si circa Tagum, non ergo ii sunt qui Durio interfluente ab Asturibus dirimuntur, quique ab eodem ipso Plinio in Citeriori Hispania iuxta Vaccaeos collocantur. Si uero ii sunt, minus apte dictum est «et circa Tagum Vettones» cum magis ex re et aeque breuiter dici potuisset «et a Tago ad Durium Vettones." Sed tunc quinam illi essent Vectones non Lusitani, ab Asturia, amne Durio disterminati?

Paulo expressius rem indagemus, eruamusque, qui sint isti post Vaccaeos Durio ab Asturibus disterminati. Percurrat qui uelit, in Hispaniae pictura Durii cursum usque ex Numantia Pelendonum urbe, per Areuacos, et eorum urbeis Vxamam, Saguntiam, Cluniam, et reliquas a Plinio commemoratas. Tum ubi se Areua, eorum nominis causa et origo, Durio miscet. Deinde a Pisoraca fluuio Vaccaeos eorumque ciuitates Pallantiam, Caucam, et illis a Ptolemaeo tributas Pintiam et Sarabrim et Senticam. Quarum Sentica, quae Zamora existimatur, uicina fluminis angulo est, ubi Estulam, fluuium Asturum, Durius excipit, iuxta Mirandam, cuius in Lusitaniae descriptione meminimus.

Vectones modo istos iis conterminos, ac Durio ab Asturibus disterminatos quaeramus. Nulli apparent, nisi qui ab illo, quern dixi, Durii angulo introrsus cuneato, per meridianum Durii latus ad Carpetanos porriguntur. Siquidem ii a Mirandensibus, qui olim in Asturum ualidae gentis dicione fuere, fluuio medio secernuntur. Atqui hi sunt, quos Ptolemaeus maxime orientaleis Lusitanorum dixit, in quibus Salmanticam, Obilam, et Caperam posuit, ut tractus, per quem meat in Durium Tormis, qui Salamanticam alluit, Vettonum sit, Vaccaeis, uti ostendimus, finitimorum. 
[20] São também estes que Estrabão e Plínio nomeiam na Hispânia Citerior. Mas por que se calcula para os mesmos Vectões uma distância de 160.000 passos até aos Vetões de Plínio, que estão junto ao Tejo, que é a distância que vai desde a margem do Douro, junto aos Vaceus, até ao Tejo? É que os Vetões se estendiam até esse ponto, dirá alguém, sem estar inteiramente contra a razão, pois Estrabão ao falar da nascente do Tejo diz o seguinte: "Nascendo entre os Celtiberos, corre para o Ocidente equinocial através dos Veciões, Carpetanos e Lusitanos e mantém, por pouco tempo, igual distância do Guadiana e do Guadalquivir" ${ }^{71}$. Mas Ptolomeu ${ }^{72}$, embora tenha enumerado cuidadosamente as cidades dos seus Vetões, das quais, a título de exemplo, apenas refiro Salamanca, Ávila e Caparra, levanta um obstáculo ao encher o enorme espaço intermédio, quase lacunar, desde ali até ao Tejo, ou melhor, até ao Guadiana, não já com Vetões mas com Lusitanos propriamente ditos, e com as cidades de Cória, Cáceres, Vila Nova da Coelheira, situadas junto ao Tejo ou não longe das suas margens, e com a própria Mérida, metrópole dos Vetões, e como esta todas ditas dos Vetões, como adiante explicarei.

Será que estes povos são dois, um Lusitano e o outro não, mas pertencentes à Hispânia Citerior, ambos unidos pela semelhança de nome, ou então é apenas um? Não ouso garantir que sejam dois, embora seja bem evidente pelo diverso testemunho dos autores e pela diferença de grafia de uma só letra. Não falo de Estrabã $\mathrm{O}^{73}$, em cujos códices, que parecem brincar estranhamente com este nome, não sei se por culpa dele ou dos copistas, ora são Ovetões, depois Vuetões e logo Oveciões. Examinemos os códices latinos. Segundo Plínio, nos dois passos em que fala da Hispânia Citerior, o nome deste povo escreve-se com -ct-74; assim também no comentário de César acima citado ${ }^{75}$; igualmente segundo Lívio, no livro quinto da quarta Década ${ }^{76}$, quando diz que Marco Fúlvio combateu contra eles e contra os Vaceus e Celtiberos; do mesmo modo, segundo Lucano ${ }^{77}$ e Sílio ${ }^{78}$, cujas palavras citarei em breve. Pelo contrário, o nome dos tais Vetões, que vivem junto ao Tejo, escreve-se com a geminada -tt-, como pode verificar-se mesmo no próprio Plínio e tal como encontrei em muitas inscrições em pedra. Transcrevi duas delas não há muito no livrinho dirigido a Quevedo ${ }^{79}$, cónego de Toledo, e não me envergonho de fazê-lo agora, mesmo que pareça excessivo, já que o assunto a meu ver o exige. Há um enorme cipo na minha casa de Évora, que diz o seguinte:

$[\mathbf{2 1}]$

L. VOCONIO. L. F. Q V I R. PAVLLO. AED. Q. II. VIR. VI. FLAM. ROM. DIVOR. ET. AVGG. PRAEF. COH. I. LVSIT. ET. COH. I. VETTONVM. 
[20] Hi etiam, qui et a Strabone et a Plinio in Hispania Citeriori nominantur. Sed hi quid ad Vettones Plinii circa Tagum, interstitio CLX milium passuum, quae, a Durii iuxta Vaccaeos ripa, ad Tagum numerantur? Eo usque Vettones extendebantur, inquiet aliquis. Non omnino id praeter rationem. Strabo enim Tagi narrans originem, ait : "Ex Celtiberis autem orginem habens, per Vetiones, et Carpetanos, et Lusitanos in aequinoctialem labitur occasum aliquantisper, spatio pari ab Ana et Baeti fluuiis distans.»

Sed Ptolemaeus impedimento est, qui quum Vettonum suorum urbeis Salmanticam, Obilam et Caperam, ut has solas exempli gratia nominem, diligenter recensuerit, inde ad Tagum, immo etiam ad Anam, ingentem quasi lacunam intermediam, non iam Vettonibus, sed Lusitanis proprie ita uocatis oppleuit, Caurio, Norba, Colarno, circa Tagum aut non longe ab eo sitis, et Emerita ipsa, Vettonum, ut dicam postea, metropoli nominatis.

Quid ergo duaene istae sunt gentes, altera Lusitana, altera nequaquam, sed ad Citeriorem pertinens Hispaniam, ambae nominis similitudine congruentes, an tantum una?

Duas esse asseuerare ego non audeo, sed auctorum uarietate, et unius in scriptura litterae differentia, certe apparet. Omitto Strabonem, cuius in hoc nomine codices mire ludunt, ipsiusne, an scribarum culpa nescio. Modo enim sunt Ouettones, modo Vuettones, modo Ouetiones. Latinorum codices expendamus. Vtrobique enim per CT nomen gentis huius apud Plinium scribitur, quum de citeriori loquitor prouincia. Sic apud Caesarem commentario superius citato. Sic apud Liuium in quinto quartae decadis libro, ubi M. Fuluium cum iis atque Vaccaeis et Celtiberis refert dimicasse. Apud Lucanum similiter atque Silium, quorum uerba mox referam. At isti Lusitaniae circa Tagum Vettones geminato TT scribuntur, ut apud ipsum Plinium ibidem liquet, et in multis saxeis inscriptionibus inueni. Quarum duas in libello ad Kebedium Toletanum Canonicum nuper posui, nec pigebit modo repetere, etiam si nimium uideatur, quandoquidem hic locus maxime id exposcere mihi uidetur. Eborae ingens in aedibus meis cippus ita habet:

L. VOCONIO. L. F. Q V I R. PAVLLO. AED. Q. II. VIR. VI. FLAM. ROM. DIVOR. ET. AVGG. PRAEF. COH. I. LVSIT. ET. COH. I. VETTONVM. 
Isto é: A Lúcio Vocónio Paulo, filho de Lúcio, da tribo Quirina, o qual foi edil, questor, duúnviro, flâmine dos Deuses de Roma e Prefeito da primeira coorte dos Lusitanos de Augusto e da primeira coorte dos Vetões ${ }^{80}$.

Em Mérida, na casa de Pedro Mexia, está o seguinte:

P. AELIO. VITALI

AVG. LIB. TABVL.

PROVINC. LVSI-

TANIAE. ET. VE-

TTONIAE. STEP-

HANVS. LIB. ET

HERES. PATRO-

NO FECIT.

[22] Isto é: A Públio Élio Vital, liberto de Augusto, tabulado da província da Lusitânia e da Vetónia, mandada fazer para o patrono por Estêvão, liberto, seu berdeiro ${ }^{81}$.

Em Sagunto, no mosteiro da Santíssima Trindade:

SERGIAE. M. F. PE-

REGRINAE M. SER

GIVS VETTO. AMI-

TAE.

Isto é: A [sua] tia paterna, Sérgia Peregrina, filha de Marco, Marco Sérgio Vetão [erigiu este monumento $]^{82}$.

Na aldeia de Oliva, das ruínas de Caparra:

L. PVBLICIVS. L. F. PAP. THIAMVS. EMERIT. AN. XXVII

H. S. E. S. T. T. L.

CAECILIVS VET-

TO. SODALI CIP-

PVM. D. S. D. 
Id est: Lucio Voconio Lucii filio Quirina Paullo Aedili quaestori duumuiro Sextum ${ }^{1}$ flamini Romae diuorum et Augustorum praefecto cobortis primae Lusitanorum et cobortis primae Vettonum.

Emeritae autem in domo Petri Mexiae, sic:

P. AELIO. VITALI

AVG. LIB. TABVL.

PROVINC. LVSI-

TANIAE. ET. VE-

TTONIAE. STEP-

HANVS. LIB. ET

HERES. PATRO-

NO FECIT.

[22] Hoc est: Publio Aelio Vitali Augusti liberto, tabulario prouinciae Lusitaniae, et Vettoniae Stephanus libertus et haeres patrono fecit.

Sagunti in caenobio Sanctae Trinitatis :

SERGIAE. M. F. PE-

REGRINAE M. SER

GIVS VETTO. AMI-

TAE.

Hoc est: Sergiae Marci filiae peregrinae, Marcus Sergius Vetto amitae.

In pago Oliua ex ruinis Caperensibus.

L. PVBLICIVS. L. F. PAP. THIAMVS. EMERIT. AN. XXVII H. S. E. S. T. T. L. CAECILIVS VETTO. SODALI CIPPVM. D. S. D.

1 Sextum $\left.E R C^{1} F C^{2}\right]$ Sexto $U$ 
[23] Isto é: Lúcio Publicio Tiamo, filho de Lúcio, da tribo Papíria, emeritense, de 27 anos, está aqui sepultado. Que a terra the seja leve! Cecttio Vetão dedicou, à sua custa, [este] cipo ao [seu] camarada ${ }^{83}$.

Na mesma aldeia está outra lápide:

L. DOMITIVS T. F.
GAL. VETTO. OTO
BESANI H.S.E.S.T.
T. L. DOMITIVS
FORTVNAT. PA-
TRONO. D. S. F.

Isto é: Lúcio Domício Vetão, filbo de Tito Oto-besano, da tribo Galeria, está aqui sepultado. Que a terra the seja leve! Domício Fortunato à sua custa erigiu [este monumento] ao [seu] protector ${ }^{84}$.

Também Ptolomeu ${ }^{85}$, referindo estes Vetões Lusitanos, embora sob a forma de Ovetões, usou o -tt- duplo. Mas há ainda outras diferenças. De facto, o nome daqueles Vectões da província Citerior tem a sílaba interior alongada como mostram os dois grandes poetas Lucano e Süio. Lucano, no canto quarto da Farsália, canta assim:

[24]

Com ele, contra o Lácio, estava o activo Ásture,

Os ágeis Vectões e os Celtas foragidos, da velha raça gaulesa

Que misturavam o seu nome ao dos Iberos $^{86}$.

Quanto a Sílio, no canto décimo sexto, ao falar do cavalo Peloro, escreve:

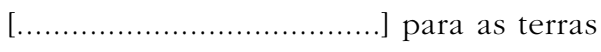

dos Vetões trazido, ali o pariu sua mãe Harpe ${ }^{87}$.

A verdade é que o nome dos Vetões Lusitanos, unidos aos Túrdulos junto do Tejo e que se escreve com um duplo -tt-, tem aquela mesma sílaba breve, proveniente do próprio nome de Vetónia, conforme pode verificar-se em Prudêncio no poema a St. ${ }^{a}$ Eulália: "A Ilustre colónia da Vetónia" 88 . De acordo com ele está Samónico Sereno, quando fala da erva vetónica que Plínio ${ }^{89}$ diz ter sido encontrada na Hispânia pelos Vetões:

"O suco da vetónica quando engolido tira a vida" 90.

Dioscórides ${ }^{91}$ diz que os Romanos lhe chamam Betónica, mas que era designada pelos Gregos de Késtron. 
[23] Hoc est: Lucius Publicius, Lucii fulius Papiria Thiamus Emeritensis annorum uiginti septem hic situs est. Sit tibi terra leuis. Caecilius Vetto sodali cippum de suo dedicauit.

In eodem pago alius lapis.

$$
\begin{aligned}
& \text { L. DOMITIVS T. F. } \\
& \text { GAL. VETTO. OTO } \\
& \text { BESANI H.S.E.S.T. } \\
& \text { T. L. DOMITIVS } \\
& \text { FORTVNAT. PA- } \\
& \text { TRONO. D. S. F. }
\end{aligned}
$$

Hoc est. Lucius Domitius Titi filius Galeria Vetto Otobesani hic situs est, sit tibi terra leuis. Domitius Fortunatus patrono de suo fecit.

Ptolemaeus etiam duplici TT hos Lusitanos Vettonas scribit Ouettonas. Est et alia differentia. Nam illi Vectones citerioris prouinciae mediam syllabam productam habent, ut ostendunt duo summi poetae Lucanus et Silius, ille Pharsaliae, libro quarto, ita canens:

[24]

His praeter Latias acies erat impigir Astur

Vectonesque leues, profugique a gente uetusta

Gallorum Celtae miscentes nomen Iberis.

Hic autem libro decimo sexto de Peloro equo in hunc modum:

$$
[\ldots \ldots \ldots \ldots \ldots \ldots \ldots \text { campis }
$$

Vectonum eductum genitrix effuderat Harpe.

Vettones uero Lusitani, iuncti Turdulis ad Tagum, ac duplici TT scripti, eandem syllabam breuem habere comperiuntur, ex ipso Vettoniae nomine, apud Prudentium in Diua Eulalia, "clara colonia Vettoniae". Cum quo facit et Sammonicus Serenus, de Vettonica herba, quam a Vettonibus inuentam in Hispania dicit Plinius:

Vettonicae mansus siccabit lumina succus.

Dioscorides Bettonicam appellatam a Romanis ait, quum Kestron appellent Graeci. 
E assim verificámos que aquela sílaba é breve. Daí parece concluir-se que um povo é o dos Vetões e que outro é o dos Vectões. Se esta opinião for aceite, será respeitada a autoridade tanto de César'92, como de Estrabão ${ }^{93}$, como ainda de Plínio ${ }^{94}$, os que separam os Vectões da Lusitânia. Deverá, porém, ser emendada a grafia da palavra no códice de Estrabão, corrigindo-se onde está escrito Ovetões, ou Uvetões ou Oveciões para Ovectões ${ }^{95}$. Fraquejará, neste caso, a descrição de Ptolomeu $^{96}$, que parece ter confundido os Vetões com os Vectões devido à semelhança de nomes, ao delimitar a fronteira oriental da Lusitânia com nove partes e meia e quarenta e uma partes e quase dois terços, isto é, com uma linha que passa por Sarabre, cidade dos Vaceus, identificada pelos eruditos com a actual Toro, vai até ao ópido de Medellin, outrora colónia ou pouco mais.

Mas se esta opinião é rejeitada pela sua novidade, que me ensine alguém quem são pois os Vetões separados da Astúria pelo Douro, segundo Plínio, quais são os que rodeiam a Lusitânia a Oriente juntamente com os Carpetanos, Vaceus e Galaicos, segundo Estrabão, e porque fez Ptolomeu tão grande menção daqueles, [25] que são separados da Astúria pelo Douro e que se estendem até Caparra.

Se pudéssemos concluir desta confusão que os Vetões estão parcialmente espalhados pela Hispânia Citerior nas proximidades dos Carpetanos e Vaceus, que habitam o Douro do lado contrário ao dos Ástures, que de tal maneira ficaram dominados pelos Túrdulos que sobressaiu tão-só o nome de Vetões até ao Guadiana, sendo daí que Emérita foi chamada a "ilustre colónia" dos Vetões pelo tão casto e ao mesmo tempo tão sabedor Prudêncio, mandaria então eu próprio que fossem emendados os passos de César, Lívio, Estrabão, Lucano, Sílio e Plínio, nos quais o seu nome está escrito com as letras -ct- e reduziria todos ao duplo -tt-, e aqueles que são divididos dos Ástures pelo Douro, excluí-los-ia com Plínio da Lusitânia, e o limite oriental não o delimitaria eu tão para o interior da Hispânia Citerior, mas, começando pela segunda curva do Douro, que acima já apontei junto a Freixo desde o lugar onde o Tormes, o rio de Salamanca, se lança no Douro e onde o rio já com o leito direito penetra na actual Lusitânia e a divide dos Galaicos Brácaros, como consta em Plínio ${ }^{97}$, eu dirigiria a linha fronteiriça um pouco acima por Ciudad Rodrigo, Placência e Castra Iulia, junto ao ópido de Metellinum .

No que diz respeito à quantidade da sílaba teria pouca confiança tanto em Prudêncio como em Sereno, ou, se isto fosse considerado injurioso, diria que a sílaba é ancípite ${ }^{98}$, tal com em muitos casos que foram analisados pelos gramáticos nas obras dos poetas, o que neste momento não cabe nos nossos propósitos. Manteremos todavia e de novo a mesma opinião devido a Ptolomeu' ${ }^{99}$, que estende em maior longitude a profundidade da Lusitânia a partir do ponto setentrional, de acordo com as abertas reclamações de Plínio, homem romano, ao que é difícil não dar crédito.

Até que ponto é isto verdade afirma-o o próprio Plínio ${ }^{100}$ no fim do capítulo primeiro do livro terceiro: "por um lado muda-se a configuração das províncias, por outro acontece que outros começam a medir em sítios diferentes, de tal modo 
Breuem itaque syllabam eam comperimus. Vnde colligi uidetur gentem aliam esse Vettones, aliam Vectones. Quae si opinio recipitur, integra manebit quum Caesaris, tum Srabonis, tum etiam Plinii auctoritas Vectones a Lusitania separantium. Scriptura tamen Straboniani codicis emendanda erit, ut, ubi Ouettones, uel Ouettônes, uel Ouetiones, scriptum est, reponatur Ouectones. Verum uacillabit tunc Ptolemaei descriptio, qui Vettones cum Vectonibus, nominum similitudine, uidebitur confundisse, terminumque Lusitaniae orientalem partibus nouem cum semisse, et quadraginta et una ac fere besse definiens, hoc est, per Sarabrin Vaccaeorum urbem, quam Taurum nostrae aetatis docti existimant, ducta linea usque ad Metallinense oppidum, olim coloniam, pauloue supra. Sin uero opinio, uti noua, explodatur, doceat me aliquis quinam sint Vettones Durio ab Asturia disterminati apud Plinium, et qui ab oriente una cum Carpetanis, Vaccaeis, et Callaecis Lusitaniam cingant apud Strabonem, et quur Ptolemaeus, Vettonibus circa Tagum [25] omissis, illorum tantum qui Durio ab Asturia distinentur, et usque ad Caperam sunt, mentionem fecerit.

Si ab ea perplexitate extricari possemus, diffusis partim per Citeriorem Hispaniam iuxta Carpetanos et Vaccaeos Vettonibus, Durium ex aduerso Asturum adcolentibus, partim circa Tagum iuxta Turdulos, aut ita supressis Turdulis, ut Vettonum excelleret nomen usque ad Anam, unde Emerita Vettonum «clara colonia», a sanctissimo eodemque doctissimo Prudentio uocata sit, iuberem equidem omnes Caesaris, Liuii, Strabonis, Lucani, Silii ac Plinii emendare locos, in quibus per litteras -ct- scripti sunt, et ad duplex -tt- omneis reducerem, et illos qui ab Asturibus Durio secernuntur Lusitania cum Plinio excluderem, terminumque Lusitaniae Orientalem non tam intus ad Citeriorem Hispaniam limitarem, sed a Durii secundo flexu, quem supra ad Fraxinum notaui, hoc est, a loco ubi Tormis Salmanticensium fluuius in Durium se condit, et amnis recto iam alueo hodiernam Lusitaniam ingreditur, eamque diuidit a Callaecis Bracaris, ut auctor est Plinius, inde per Rodericopolin, Placentiam, et Castra Iulia ad Metallinense oppidum, pauloue supra, lineam dirigerem.

Quod autem ad syllabae mensuram attinet, aut Prudentio Serenoque minus fiderem, aut, si iniurium hoc est, ancipitem eam dicerem, ut permultas obseruarunt grammatici apud poetas, quod instituti nostri modo non est. Haereremus tamen rursus propter Ptolemaeum, qui longius ac penitius a septentrionali capite Lusitaniam extendit, Plinio homine Romano, cui non credere durum est, aperte reclamante.

Vsque adeo uerum est, quod ipse ait Plinius in fine primi capitis libri tertii: "alibi mutato prouinciarum modo, alibi aliis aliunde exordium mensurae capientibus factum esse, ut nulli duo concinant.» 
que não há dois que estejam de acordo". Concluamos, portanto, que os Vetões, quer sejam diferentes dos Vectões, quer sejam os mesmos, [26] o que defendemos como mais provável, devem ter seus nomes escritos com o duplo -tt- e nem todos pertencem à Lusitânia, mas uma grande parte deles espalha-se pelos Carpetanos seus vizinhos da Hispânia Citerior e através dos Vaceus até aos Ástures, no ponto em que eles são divididos da Lusitânia por Estrabão ${ }^{101}$ e Plínio ${ }^{102}$, muito embora Ptolomeu ${ }^{103}$ assim os não divida. A outra parte estaria ligada aos Lusitanos, e o seu nome ter-se-ia estendido até ao Guadiana e teria habitado uma só província com os restantes Lusitanos. Finalmente e muito depois a província da Vetónia teria surgido por si própria e a sua capital e metrópole seria Mérida Augusta, situada noutro ponto do território dos Túrdulos, sendo este o motivo por que o santo Prudêncio lhe chamou a "ilustre colónia de Vetónia", ainda que, noutros trechos, a ela mesma se refira, pensando noutros tempos, como capital dos ópidos dos Lusitanos ${ }^{104}$. Ainda há pouco, no entanto, demonstrámos no livrinho dedicado a Quevedo ${ }^{105}$, tal como se comprovou pelas inscrições um pouco mais acima examinadas, de como a Vetónia por si própria se elevou a província e que foi a partir dessa altura que a Vetónia e os Vetões começaram a ser descritos separadamente dos Lusitanos.

\section{OS BARBÁRIOS}

Muito menos assunto nos fornecerão os Barbários, não só devido à obscuridade do seu povo, como pelo facto de a sua própria localização e suas povoações não serem afectadas por qualquer ambiguidade, na medida em que se estendem do promontório que é chamado pelo seu próprio nome até ao estuário Olisiponense. Falaremos do promontório depois. Quanto ao nome, porém, e devido à sua raridade, vou-me alongar um pouco.

Por vezes dou comigo a pensar por que razão o monte, a que chamamos Arrábida, foi chamado de Barbário e os povos à sua volta de Barbados, pois há que deixar de lado a história de Florião do Campo ${ }^{106}$ sobre a ignomínia da sua denominação, na medida em que distorce o nome para o pôr de acordo com a aspereza de costumes. Não está, contudo, nos meus intentos arquitectar histórias por meio de ficções. Com efeito, nem são chamados Bárbaros mas Barbários, como mostra Estrabão, no livro terceiro em que fala de estanho, que ele diz ser produzido na terra dos Barbários, para lá dos Lusitanos, e nas ilhas Cassitérides, e que é transportado da Bretanha até Marselha. Nesse mesmo livro denomina o promontório de Barbário, nome que é igualmente usado por Ptolomeu ${ }^{107}$.

Ora de "bárbaro" deriva-se para "barbárico" e não "barbado", quando se quer falar [27] do carácter de um povo. Foi pois a esta conclusão que cheguei. Todas as rochas deste monte são de jaspe e entre elas encontram-se jaspes brancos ${ }^{108}$, vermelhos, verdes, variegados e multicolores de admirável brilho. Daí se cortam colunas, postes e outros objectos deste género, que, logo depois de submetidos ao polimento, de 
Concludamus igitur Vettones uel alios esse a Vectonibus, uel si iidem [26] sunt, quod magis probamus, per geminum -tt- debere scribi, nec omneis ad Lusitaniam pertinere, sed magnam eorum partem per Citerioris Hispaniae finitimos Carpetanos atque Vaccaeos ad Astures usque diffundi, quo illos a Lusitania seiungunt Strabo atque Plinius, licet non seiungit Ptolemaeus; partem alteram Lusitanis cohaesisse, protenso etiam usque ad Anam nomine, et cum ceteris Lusitanis prouinciam unam coluisse ; nouissime tandem per se prouinciam effecisse Vettoniam, cuius caput, ac metropolis esset Augusta Emerita, alioqui in Turdulis sita, unde eam sacer Prudentius "claram Vettoniae coloniam» appellarit, quum tamen eandem alibi, diuersa respiciens tempora, Lusitanorum caput oppidorum dixerit.

Factam uero Vettoniam per se prouinciam, ex eoque tempore coepisse Vettoniam et Vettones separatim a Lusitanis scribi, in libello ad Kebedium nuper ostendimus, et ex inscriptionibus paulo ante relatis comprobatur.

\section{DE BARBARIIS}

Longe minus negotii nobis exhibebunt Barbarii, quum propter obscuritatem gentis, tum propter situm et eorum sedes ambiguitate nulla confusas, a promontorio ex ipsorum nomine uocato, usque ad sinum Olisiponensem. Sed depromontorio postea. De nomine propter nouitatem disquiram aliquantulum.

Mihi nonnumquam subiit cogitare, cur mons, quern Rabidam uocamus, Barbarius dicatur, et populi circa eum Barbarii, omissa Floriani Campensis ignominiosae appellationis fabula, ad morum asperitatem denominationem torquentis.

Mei autem instituti non est historias per figmenta concinnare. Neque enim Barbari uocantur, sed Barbarii, ut docet Strabo libro tertio de stanno loquens, quod generari dicit in Barbariis supra Lusitanos, et in Cassiteriis insulis, et e Britannis Massiliam deferri, et eodem libro promontorium Barbarium nominat, quo etiam nomine Ptolemaeus utitur.

A "bárbaro" autem, quum ad ingenium refertur, "barbaricus", non [27] "barbarius" diriuatur. Veni igitur in hanc cogitationem. Montis huius omnes rupes iaspideae sunt, inueniunturque inter eas iaspides albi, purpurei, uirides, uarii ac multicolores, splendore mirabili. Caeduntur inde columnae, postes et similia, quae ubi accedit politio translucent in tantum, ut speculorum uicem et praebeant et 
tal modo brilham que podem ser usados em vez de espelhos e até com vantagem. Mas na verdade o terreno abunda na tão celebrada baga "Emeritense», que Plínio ${ }^{109}$ louvou, e que de modo algum cede o seu lugar. Dela tingem os tintureiros os tecidos, que os nossos contemporâneos chamam de "escarlata" ou "grana", certamente com fundamento nos grãos que nascem nos arbustos em toda aquela região, do mesmo modo que os Antigos, com fundamento no verme que nascia dentro dessas bagas e que era parecido com a barata, começaram a chamar ao tecido "vermiculado", tecido que os mais modernos chamam de blattea, coccinea ${ }^{110}$, querendo dizer com isto "púrpura", embora entre esses tecidos haja diferenças.

Com efeito, "púrpura" propriamente só aparece quando produzida do sangue das púrpuras, ou seja, de moluscos com conchas. A coccinea vem, porém, como já disse, do próprio cocceus. É daí que Suetónio ${ }^{111}$, ao manifestar-se contra a luxúria de Nero o incrimina por ter "pescado com rede dourada, sustida por cabos entrelaçados de púrpura e escarlata". Porque Eutrópio ${ }^{122}$ usou de vocábulo mais moderno, blatteis funibus, muito usaram tal palavra os escritores do seu tempo e, por causa da semelhança da cor muito viva de ambas, começaram a confundi-las. Vou mostrar tal facto fundamentando-me em Sidónio Apolinar ${ }^{113}$, que não deve ser desprezado, posto que monstruosamente se enganou neste poema anacreôntico, que, por nossa iniciativa, foi emendado, assim como os restantes escritos do mesmo autor:

Trazei o brilhante lavrado de linho

$\mathrm{E}$ as brilhantes colchas de púrpura,

Que no latão cozidas duas vezes

A água Melibeia tingiu,

Para enriquecer a lã absorvente

Com a cor sem mistura.

Que as colchas estrangeiras nos seus bordados

Nos mostrem os montes de Ctesifonte e Nifate,

[28] E as feras, que correm no tecido imóvel,

A quem aguçou a raiva a ferida

Bem imitada com escarlate,

Quando pelo furo do dardo

Lhes sai um sangue não ensanguentado.

Neste poema, abertamente confunde "blatta", "purpura" e "coccum". Com efeito, a púrpura melibeia provém de conchas, conforme mostra Lucrécio no canto segundo ${ }^{114}$ :

Nessa altura, toma sentido nos tecidos da Barbária e na brilhante púrpura

Da Melibeia, coberta embora com a cor das conchas da Tessália [...] 
uincant. At uero terrenum laudatissimo abundat cocco Emeritensi, quod laudat Plinius, nullo modo cedente. Ex quo tingunt infectores uestem, quam scarlatam uel granam nostri homines appellant, uidelicet a granis, quae in fruticetis toto eo tractu innascuntur, sicut ueteres a uermiculo in iisdem granis innato blattae simili, uermiculatam uestem dixere, quam recentiores blatteam, coccineam uel purpuream uolentes significare, etsi hae distinctionem capiunt.

Nam purpurea proprie ex sanguine purpurarum, conchiliorumue fit. Coccinea uero ex ipso, quod dixi, cocco. Heinc Suetonius in Neronis luxuriam inuectus, aureo reti, et funibus purpura, coccoque nexis piscatum eum criminatur. Quod recentiori uerbo "blatteis funibus" dixit Eutropius, multumque usi sunt ea uoce illius aeui scriptores; ac propter eminentis coloris in utrisque similitudinem, coeperunt ista confundi. Ostendam hoc ex Sidonio Appollinari, non contemnendo poeta, in hoc Anacreontico monstrose deprauato, nostraque opera, sicut cetera eius auctoris scripta, restituto:

Rutilum toreuma bysso,

Rutilasque ferte blattas,

Recoquente quas aheno

Meliboea fucat unda,

Opulentet, ut meraco

Bibulum colore uellus,

Peregrina det supellex

Ctesiphontis et Niphatis

[28] Iuga texta, belluasque

Rapidas, uacante panno,

Acuit quibus furorem

Bene ficta plaga cocco,

Iaculoque ceu forante

Cruor incruentus exit.

In quibus carminibus aperte confundit blattam, purpuram et coccum. Meliboea namque purpura ex conchis est, ut ostendit Lucretius lib. 2:

Iam tibi barbaricae uestes, Meliboeaque fulgens

Purpura, Thessalico concharum tecta colore. 
Neste passo deve chamar-se a atenção para o facto de Lucrécio ter dito "tecidos da Barbaria" onde Apolinário falou de "colchas estrangeiras". Mas voltemos agora ao nosso assunto. Os tintureiros de tecidos de púrpura, de coccum e de vermiculum, que eram importados de terras bárbaras, ou seja, estrangeiras, começaram a ser chamados de "Barbaricários", como é evidente em Gaio"115 em Das excusas dos Artífices e da distribuição das verbas palatinas, que também anotou Alciato ${ }^{116}$ nos três últimos livros do códice. Mariano Escoto ${ }^{117}$, com o título Mestres de Ofícios e Fábricas, chama-lhes Barbários.

Por conseguinte, todos estes nomes terminados em -eiros, [lat. -arius], significam quase sempre mesteres humanos, como saleiros [sagarius, fabricantes de sagum, saio], tecedeiro [corresponderá ao ciligarius, que é o tecelão de pano grosso, cilicium], bordadeiro [que corresponde a limbolarius, bordador que faz a limba, debrum], e muitos outros que o bom do Megadoro enumera na Comédia das Panelas de Plauto ${ }^{118}$. Deste modo Barbaricarius e Barbarius dizem respeito a esse tipo de artesãos e de fabricações. Por isso, estes povos dos quais falámos são chamados "Barbados". Essa a razão por que eu também pensava se porventura não teria sido devido ao coccum $^{119}$, que apanhavam em grande quantidade [29] e vendiam aos mercadores que para Roma levavam essa mercadoria ou talvez porque tingissem, visto serem conhecedores dessa técnica, que tivessem sido denominados de Barbarias. Isto, contudo, é deitar-se a adivinhar. Por isso, nem peço aos meus leitores que adiram às minhas conjecturas, nem por minha conta e risco tomo a iniciativa de transmitir as causas e origens deste tipo de denominações.

\section{OS PESUROS OU PESURES}

Sem nobreza e obscuros são os Pesuros, lembrados, de entre tantos autores, tão-somente por Plínio ${ }^{120}$. Se se espalharam largamente ou se ficaram confinados a fronteiras apertadas é igualmente desconhecido. Na tão nobre ponte sobre o Tejo que dá acesso à praça forte de Alcântara na Vetónia está escrito para confiar à história que, entre outros municípios da província da Lusitânia que deram o seu contributo para a construção da ponte, os Pesures são nomeados em último lugar. Compreendemos assim claramente que não estariam muito distantes daquele lugar e ao mesmo tempo que o seu nome devia ser emendado, passando da segunda para a terceira declinação nos manuscritos de Plínio. Quanto à inscrição desta ponte, dela nos ocuparemos quando descrevermos as cidades ${ }^{121}$.

\section{OS VELHOS TÚRDULOS}

Por seu lado, todavia, os Velhos Túrdulos são muito célebres e estão aparentados com todos os Túrdulos, que encheram a maior parte da Hispânia Ulterior. Deles com 
Vbi etiam aduertendum, quas "uestes barbáricas" dixit Lucretius, "peregrinam supellectilem" dixisse Apollinarem. Redeamus iam ad institutum. Vestium purpura, cocco, uermiculo, quae a barbaris terris, id est peregrinis, adlata erant, infectores, Barbaricarii adpellari coeperunt, ut patet Caius De excusationibus artificum, et de Palatinis sac. larg., quod etiam annotauit Alciatus in treis posteriores libros codicis. Marianus Scotus in tit. Magistri officiorum, et fabricae, Barbarios eos uocat.

Etenim isthaec nomina in -arius finita, hominum fere officia significant, "sagarius", "caligarius", "limbolarius", et quae multa alia apud Plautum in Aulularia bonus ille Megadorus enumerat. Sic "Barbaricarius", et "Barbarius" ad harum rerum officinas, opificesque pertinent. Populi itaque isti, de quibus loquimur, Barbarii appellantur. Cogitabam igitur si forte a cocco, quod in magna multitudine colligerent, [29] uenderentque negotiatoribus Romam eam mercem conuecturis, aut forte ipsi baphicae gnari tingerent, Barbarii fuerint nuncupati. Verum haec hariolando. Quare huic meae coniecturae addici lectores neque postulo neque parteis suscepi meo periculo istius modi appellationum causas originesue tradendi.

\section{DE PAESVRIS, AVT PAESVRIBVS}

Ignobiles et obscuri sunt Paesuri, ab unoque auctorum omnium Plinio memorati. Late paterent, an terminis angustis concluderentur aeque ignotum. In nobilissimo illo super Tagum ponte ad Vettoniae oppidum Alcantaram, inter cetera prouinciae Lusitaniae municipia, quae stipem ad pontem conficiendum contulisse memoriae proditum ibi est, Paesures ultimi recensentur. Quo fane intelligimus non longe eos inde esse discretos, simulque emendandum eorum in condicibus Plinianis nomen a fecunda in tertiam inflexionem. De inscriptione uero pontis huius, quum urbeis enarrabimus, tunc agemus.

\section{DE TVRDVLIS VETERIBVS}

Contra autem Turduli Veteres ualde celebres, et parentes omnium Turdulorum, qui Vlterioris Hispaniae maximam partem suo nomine repleuerunt. Ab iis enim 
efeito saíram, como que em enxames, os Túrdulos, e na Bética e junto ao Guadiana talvez também os Turdetanos. Disso é indício o seu próprio cognome de "Velhos": pois se estes são os "velhos", é forçoso que os restantes [30] sejam mais novos. Plínio ${ }^{122}$ designa como sua região a que vai da direita do Douro para o Oceano; do lado esquerdo, porém, a partir dos povos que foram referidos no capítulo anterior, pensamos que habitam os Pesures que, por Plínio, foram ligados aos Túrdulos.

Pompónio ${ }^{123}$, a quem justamente se deve dar razão nas descrições da Hispânia, estendeu-os da boca do Tejo até ao Douro. "Daqueles promontórios - diz Pompónio - até à zona que recua, abre-se uma enorme concavidade. É aí que estão os Velhos Túrdulos e os ópidos dos Túrdulos. Os rios são o Mondego, que quase desagua no meio do último promontório, e o Douro que lava as raízes daquele”.

\section{QUAL A ÍNDOLE DO POVO LUSITANO}

Apresentámos sumariamente a Lusitânia com as três diferentes fronteiras e disse-se o suficiente sobre os povos que a habitaram outrora antes da enxurrada dos Godos, da qual falaremos mais adiante. Exige a ordem que revelemos que espécie de gente foi esta e que costumes teve. Que foi um povo valente não o calaram de resto os antigos escritores, para não pormos em primeiro lugar os nossos tempos. Diodoro Sículo afirma que "Os Lusitanos eram os mais corajosos de todos os Celtiberos"124. Diga-se de passagem que neste trecho se deve ler "de todos os Iberos", ou então pensar-se menos bem que Diodoro chamou a todos os Iberos, Celtiberos. Mas como logo a seguir disse que os Lusitanos usavam o elmo e a espada, segundo o costume dos Celtiberos, sem dúvida que os distingue dos Celtiberos.

Eis porque é preferível que se emende esta lição e se leia "de todos os Iberos". De resto relaciona-se com a sua coragem aquilo que diz Estrabão: "a Lusitânia... que durante anos foi combatida pelos Romanos" ${ }^{25}$. Prova [31] também de coragem a resposta firme e muito dura dos habitantes da Cinânia a Décio Bruto, que é citada por Valério no livro sexto, os quais se sentiam feridos no seu orgulho pelo desgosto e talvez pelo despeito: "Melhor teria sido sem dúvida - diz Valério - que homens do nosso sangue tivessem dito isto do que ouvido" ${ }^{126}$. Foi a verdade, contudo, que obrigou este escritor a assim concluir, mas aos Cinanienses foi a sua própria índole que os levou na peugada desta grandeza.

Não deixa de se relacionar com a coragem o que o mesmo Valério, com o título Do que foi dito efeito com esperteza ${ }^{127}$, conta: "Não conseguindo Sertório pela palavra convencer os Lusitanos a desistir de combater contra todo o exército romano, apresentou aos olhos dos que o observavam aquele conhecidíssimo exemplo dos dois cavalos cujas caudas deviam ser arrancadas". Que lhes chame Valério à sua vontade povo bárbaro, feroz, difícil de ser dirigido. Com estas injúrias pouco terá desacreditado os Lusitanos, conhecedores da disciplina militar, pois por aquela mesma narração mostra que não houve entre eles espíritos cobardes ou medíocres. Lívio, na 
prodiisse quasi examina, Turdulos, et in Baetica et iuxta Anam, forsitan et Turdetanos, indicio est ipsum "Veterum" cognomentum. Quum enim "ueteres" isti sint, reliquos omnes [30] recentiores esse oportet. Eorum regionem Plinius a Durio dextrorsus Oceanum uersus designat; sinistrorsus uero ex dictis superiori capite, Paesures Turdulis subiunctos ab Plinio incolere existimamus. Pomponius, cui in Hispaniae rebus multum est merito tribuendum, a Tagi ostio ad Durium eos extendit: "Ab iis - inquit - promontoriis ad illam partem, quae recessit, ingens flexus aperitur, in eoque sunt Turduli ueteres Turdulorumque oppida. Amnes autem Munda, in medium fere ultimi promontorii latus effluens, et radices eiusdem abluens Durius."

\section{QVALIS GENS LVSITANI}

Explicauimus summatim Lusitaniam triplici terminorum differentia, a quibusque populis ante Gothorum inluuionem, de quibus postea, possessa olim sit, dictum satis. Exigit ordo, ut qualisnam fuerit ea gens quibusue moribus, indicemus. Et quidem gentem esse fortem, ut nostra tempora non praeoccupemus, antiqui scriptores non tacuere. Diodorus Siculus "omnium Celtiberorum fortissimos esse Lusitanos" asseruit. Quo loco, ut obiter dicamus, aut legendum "omnium Iberorum", aut Diodorus Iberos omnes Celtiberos appellasse, minus apte est existimandus. Sed cum statim Lusitanos galeam ensemque ferre Celtiberorum more dixerit absque dubio a Celtiberis eos separat.

Quare magis placet ut lectio emendetur legaturque "omnium Iberorum". Ceterum ad fortitudinem pertinet, quod Strabo ait: "Lusitaniam annis plurimis Romanorum armis oppugnatam". Fortitudinem [31] quoque arguit constans ac grauissimum Decio Bruto Cinaniensium responsum, quod affert libro sexto Valerius, neque sine animi quodam exulcerati, et forte ex inuidia, dolore: "Melius - inquit - sine dubio homines nostri sanguinis haec dixissent, quam audissent." Vrsit tamen ueritas scriptorem ita concludere. Sed illos quidem natura in huius grauitatis uestigia deduxit.

Nec ad fortitudinem non pertinet, quod idem Valerius titulo De uafre dictis aut factis commemorat: "Non potuisse Sertorium Lusitanos oratione flectere, ne cum uniuersa Romanorum acie uellent confligere, donec uellendis equorum duorum caudis notissimum illud exemplum oculis mirantium obiecit.» Vocet Valerius suo libito gentem barbaram, asperam, regi difficilem; his opprobriis parum disciplinae militaris peritos Lusitanos arguerit; imbelleis, aut ignauos animos iis minime fuisse eadem illa narratione palam praedicat. Multa Liuius tertia, quarta et quinta decadibus, proelia cum Lusitanis uaria fortuna commissa 
terceira, quarta e quinta Décadas ${ }^{128}$ narra muitos combates travados contra Lusitanos com diferentes resultados, apesar de, com razão, se poder considerar suspeita a boa fé dos escritores romanos. Com efeito, quase sempre diminuem e minimizam os feitos guerreiros dos "bárbaros", como lhes chamam. E aos seus próprios feitos, aumentam-nos ainda imoderadamente, talvez por terem tomado esse mau hábito dos escritores mais antigos. ${ }^{129}$

Estrabão, no livro terceiro, critica com eloquência Políbio, porque para agradar a Tibério Graco lembrou que ele arrasara trezentas cidades dos Celtiberos: "Em verdade, os chefes e os historiadores, para tornarem mais belos os assuntos, são levados a este tipo de mentira"130. Mais do que uma vez o próprio Tito Lívio ${ }^{131}$ censura Valério por ser desmedido e exagerado no elevar dos números, e sobretudo acerca do finalizar da terceira década afirma "que [Anciate] não tem qualquer medida na mentira". Como a maior parte das vezes o tomou como fonte não admira que se enganasse também.

Aprecie-se (para mostrar como exemplo este único caso) a narrativa do livro quinto da quarta Década de um combate travado pelo propretor Públio Cornélio Cipião, filho de Gneu, contra os Lusitanos que, depois de devastarem a Hispânia Ulterior, regressavam a casa carregados com os despojos. Citarei as suas próprias palavras: [32] "Cipião tinha realizado isto em pretor. O mesmo, quando propretor, saindo ao caminho a Lusitanos, que depois de devastarem a província da Ulterior regressavam a casa com enorme despojo, combateu-os com resultado duvidoso desde a terceira hora do dia até à oitava, em situação de inferioridade de número mas em superioridade quanto ao mais. De facto, tinha-se chocado a linha de batalha compacta contra uma coluna longa e embaraçada pela multidão de animais, com soldados repousados contra homens fatigados pela longa marcha. Os inimigos tinham deixado o acampamento à terceira vigília. A esta marcha nocturna tinhamse seguido três horas do dia e, sem qualquer descanso do trabalho da jornada, viera o combate. Assim, pois, só no começo da batalha houve certa energia nos corpos e nos espíritos. A princípio desorientaram os Romanos; depois de algum tempo as forças equilibraram-se. No momento crítico o propretor fez a promessa de instituir jogos em honra de Júpiter se, pela força, pusesse o inimigo em fuga e o massacrasse. Finalmente os Romanos atacaram com mais vigor, os Lusitanos cederam, e depois fugiram voltando as costas. Como os vencedores perseguiram os fugitivos, foram mortos cerca de doze mil inimigos, presos quinhentos e quarenta, quase todos cavaleiros, e capturados cento e trinta e quatro insígnias militares. Do exército romano perderam-se setenta e três homens." 132

Quem não achará abertamente suspeito, ó Tito Lívio, que, num combate de cinco horas e de resultado duvidoso, em que, segundo tu dizes, os primeiros desorientados foram os Romanos, passado algum tempo as forças se equilibrassem; que o propretor, no momento crítico, prometesse jogos em honra de Júpiter, o que sem dúvida costumavam fazer os que desesperavam completamente da vitória; que morressem doze mil Lusitanos e fossem aprisionados quinhentos e quarenta, quase 
refert. Quanquam suspecta scriptorum Romanorum censeri fides merito possit. Fere enim eleuant et attenuant barbarorum, sicuti aiunt, res gestas, suas augent etiam immodice uitio fortasse priorum.

Diserte Strabo Polybium notauit lib. 3 quod trecentas Celtiberorum urbeis in Tiberii Grachi gratiam subuersas ab illo memoriae prodiderit: "Nam Imperatores - inquit - et rerum gestarum scriptores, ut ornatiora efficiant negotia, ad hoc mentiendi genus feruntur." Antiatem Valerium non semel ipse Liuius perstringit, ut in numero augendo intemperantem, atque immodicum, et praecipue circa finem libri sexti tertiae decadis: "adeo nullus - inquiens - mentiendi modus est." Ex quo cum pleraque desumpserit, non mirum si fallat similiter.

Expendatur (ut unum hoc argumentum uerbi causa referam) Publii Cornelii Cneii filii Scipionis propraetoris pugna cum Lusitanis, qui deuastata Vlteriori Hispania onusti praeda domum redibant, narrata in initio quinti libri quartae decadis. Eius ipsius uerba recensebo:

[32] «Praetor haec gesserat Scipio. Idem propraetor Lusitanos, deuastata ulteriori prouincia, cum ingenti praeda domum redeunteis in ipso itinere adgressus, ab hora tertia diei ad octauam incerto euentu pugnauit, numero militum impar, superior aliis. Nam et acie frequenti armatis, ad longum, et impeditum turba pecorum agmen, et recenti milite aduersus fessos longo itinere concurrerat.

Tertia namque uigilia exierant hostes. Huic nocturno itineri tres diurnae horae adcesserant, nec ulla data quiete laborem uiae proelium exceperat. Itaque principio pugnae uigoris aliquid in corporibus animisque fuit. Et turbauerant primo Romanos, deinde aequata paulisper pugna est.

In hoc discrimine ludos Ioui, si ui fudisset cecidissetque hosteis, propraetor uouit. Tandem gradum acrius intulere Romani, cessitque Lusitanus; deinde prorsus terga dedit.

Et cum institissent fugientibus uictores, ad XII millia hostium sunt caesa, capti quingenti quadraginta, omnes ferme equites, et signa militaria capta centum triginta quatuor. De exercitu Romano septuaginta et tres amissi."

Cui enim, Liui, dissertissime suspectum non sit, in proelio continentium horarum quinque incerto euentu, in quo primo turbatos fuisse ais Romanos, deinde paulisper aequatam pugnam, propraetoremque in eo discrimine ludos uouisse Ioui, quod sane solent ii qui de uictoria plane desperant; duodecim Lusitanorum cecidisse millia, captos quingentos quadraginta, omneis ferme equites; de Romano uero exercitu tantum amissos treis et septuaginta? Adgressus, inquis, 
todos cavaleiros, enquanto do exército romano apenas se perdessem setenta e três homens? Também dizes que o propretor se chocou em linha de batalha compacta contra uma coluna longa e embaraçada pela multidão de animais, com soldados repousados contra homens fatigados pela longa marcha, o que aceitamos, para que se acredite com fundamento que os Romanos mataram muitos milhares de Lusitanos. Mas não sei se conseguirás persuadir alguém de que numa chacina em que morreram doze mil, os Romanos só tenham perdido setenta e três homens.

Que coisa em verdade desorientou os Romanos? Por que razão, depois de um espaço de cinco horas com resultado duvidoso, as forças se equilibraram daí a pouco tempo? Os Romanos combateram desde a terceira à oitava hora com resul tado duvidoso; depois, em pouco tempo a batalha equilibrou-se.

[33] Se os Romanos estavam tão invulneráveis a combater, se os Lusitanos tinham os gládios tão enfraquecidos e as forças esvaídas, porque esteve o resultado da batalha incerto durante cinco horas seguidas? Porque matavam e não eram mortos? Que significa as forças terem-se equilibrado, senão que até essa altura os Romanos estiveram em inferioridade? Como consegues convencer de que em situação tão duvidosa se perderam doze mil Lusitanos, ao passo que do exército romano somente setenta e três?

Confessas, no entanto, que o estarem cansados pela longa caminhada, o terem saído do acampamento à terceira hora de vigília e o estarem embaraçados numa longa coluna e pelo produto do saque, deve, de resto, ser tido em pouca fé. Com efeito, a batalha não era contra Arménios fugitivos nem contra o exército do gabarola Tigranes, mas contra Lusitanos habituados a combater Romanos, homens que Aníbal utilizara em acções audaciosas na Hispânia e até na própria Itália e que, junto à cidadela de Lícon, derrotaram o exército do propretor Lúcio Emílio Paulo, tendo morrido num único combate seis mil Romanos e tendo os restantes sido atirados para dentro da paliçada, pois não só defenderam a custo o acampamento como finalmente se refugiaram, em marchas forçadas e como fugitivos, no território pacificado. Isto é o mesmo Lívio que testemunha, no livro sétimo da quarta Década133, e mesmo aqui, reparem os leitores quão piedosamente o escritor habilíssimo dissimula a fuga dos Romanos contando que se refugiaram, em marchas forçadas e como fugitivos, no território pacificado.

Orósio, pelo menos, disse no capítulo vigésimo do livro quarto que "Lúcio Emílio tinha perecido ao ser morto com todo o exército", assunto de que se falará mais largamente noutro passo. No capítulo vigésimo primeiro conta que o pretor Sérgio Galba, "vencido num grande combate contra os Lusitanos, onde perdeu todo o exército, fugiu, escapando por pouco, com alguns companheiros”. Tempos depois, resolvido a vingar-se desta ofensa e fingindo que ia agir no interesse dos Lusitanos, convidou para conferenciar os que viviam para cá do Tejo e se rendiam de livre vontade. 
est propraetor armatorum frequenti acie longum, et impeditum turba pecorum agmen, recenti milite fessos longo itinere, adcipimus, ut merito credantur Romani Lusitanorum multa millia cecidisse. Sed in duodecim millium clade, solos treis et septuaginta amisisse Romanos, nescio an persuadeas.

Quid enim Romanos turbauit? Quid est, post quinque horarum spatium incerto euentu, paulisper aequatam fuisse pugnam? Ab hora tertia diei ad octauam incerto euentu pugnauit Romanus, deinde aequata paulisper pugna est.

[33] Si tam illaesi in proelio erant Romani, si tam obtusis gladiis et exhausto uigore Lusitani, cur horis continentibus quinque incertus fuit euentus? An non quia caedebant et caedebantur? Quid sibi uult aequatam fuisse pugnam, nisi eatenus inferiores fuisse Romanos? Et persuadebis in tanto discrimine, quum Lusitanorum duodecim millia caesa fuerint, solos treis et septuaginta de Romano exercitu fuisse amissos?

Sed bene quod itinere longo fessos, et de tertia uigilia eggressos, praedaque longo agmine impeditos, confessus es, parum alioqui fidei habiturus. Non enim gerebatur res cum fugacibus Armeniis, et uentosi Tigranis exercitu, sed cum Lusitanis assuetis pugnare contra Romanos, quorum forti opera usus fuerat Annibal, non modo in Hispania, sed in ipsa etiam Italia, quique Lucii Aemilii Pauli propraetoris exercitum apud Lyconem oppidum profligarunt, caesis uno proelio sex Romanorum millibus, ceteris intra uallum compulsis ac aegre castra defendentibus, ac tandem admodum fugientium magnis itineribus in pacatum agrum reductis. Quod idem testatur Liuius decadis quartae libro 7, ubi etiam aduertant lectores, quam religiose Romanorum fugam scriptor facundissimus obumbret, "Admodum fugientium magnis itineribus in agrum pacatum reductos" memorans.

Orosius certe "L. Aemilium cum uniuerso exercitu caesum interiisse" dicit libro 4, cap. 20, de quo alibi diffusius, et cap. 21, Sergium Galbam praetorem "a Lusitanis magno proelio uictum, uniuerso exercitu amisso, cum paucis uix elapsum euasisse" narrat. Ex qua ignominia quum se postea ulcisci Galba statuisset, Lusitanos qui citra Tagum habitabant, sponte sua se dedentes ad colloquium uocauit, simulans de eorum se commodis acturum.

Sed circumpositis militibus, inermeis atque incautos per scelus maximum omneis profligauit. "Quae res - inquit Orosius - postea uniuersae Hispaniae propter Romanorum perfidiam causa maximi tumultus fuit." 
Assim que os apanhou descuidados e sem armas, mandou-se cercar por soldados, e criminosamente liquidou-os. "Esta acção - diz Orósio -, motivada pela perfídia dos Romanos, foi posteriormente a razão da maior revolta de toda a Hispânia"134 .

"Depois de ter convocado a população de três cidades lusitanas - como diz Valério Máximo no capítulo acerca Da Perfídia do livro nono -, de nove mil homens entre os quais se encontrava a flor da juventude, trucidou uns e vendeu os outros"135.

[34] M. Catão acusou severamente Sérgio Galba quando falou em favor dos Lusitanos, massacrados apesar da palavra dada, tal como é testemunhado por M. Túlio no Bruto ${ }^{136}$ e, de passagem, no Da Adivinhação ${ }^{137}$, passo que Ascónio Pediano desenvolve com certa extensão ${ }^{138}$, por Lívio no livro quadragésimo nono do epítome ${ }^{139}$ e pelo mesmo Valério Máximo no capítulo primeiro do livro oitavo ${ }^{140}$.

Tinha Catão, no entanto, noventa anos de idade, quando acusou Galba, conforme o testemunho de Lívio no livro nono da quarta Década ${ }^{141}$.

Mas não nos afastemos de Orósio ${ }^{142}$. Este, fundamentando-se em Cláudio, conta que trezentos Lusitanos travaram um combate contra mil Romanos, no qual morreram setenta Lusitanos e trezentos e vinte Romanos. Já os vencedores se afastavam, dispersos e em segurança, quando um deles, que ia a pé e, longe dos outros, se tinha deixado ficar para trás, foi apanhado por cavaleiros que por ali andavam. Com a lança, porém, trespassou ele o cavalo do primeiro e de um só golpe de gládio arrancou a cabeça do próprio cavaleiro, pelo que semeou um tal terror em todos, que muito desdenhosa e calmamente se afastou dos que reunidos observavam de longe.

Estariam à nossa disposição exemplos semelhantes de valentia, se os Romanos exaltassem mais moderadamente a sua. Como, todavia, não temos outros historiadores dos nossos feitos, somos obrigados a aceitar tudo o que lhes agradar dizer a nosso respeito, quer tenham sido imparciais quer parciais. Por vezes, contudo, a verdade escapa sem querer aos descuidados.

Júlio Obsequente, em Acerca dos Prodígios ${ }^{143}$, diz no capítulo décimo quinto que os Romanos sofreram grandes reveses militares contra Gauleses e Lusitanos e, no capítulo quadragésimo, que o exército romano foi desbaratado pelos Lusitanos. Floro, no capítulo décimo sétimo do livro segundo, afirma: "A maior parte das batalhas deu-se contra Lusitanos e Numantinos, não sem razão, pois de todos os povos foram os únicos que tiveram chefes" 144 .

Veja-se, por estas palavras, o grande contributo que os chefes traziam para a vitória. Como os Romanos sempre os tiveram, não admira se venceram uma turba desordenada de homens sem comando.

No entanto, todas as vezes que, da parte contrária, havia chefes que não ignoravam a ciência militar, já os Romanos não se gabavam tanto. Que sirvam de exemplo, no tocante a Lusitanos, quer Viriato, o Rómulo da Hispânia, no dizer do mesmo Floro ${ }^{145}$, caso a fortuna o tivesse permitido, quer Sertório. Justino, por seu lado, faz-se engraçado no último livro, quando diz: «Em tão grande fiada de séculos não tiveram nenhum grande chefe além de Viriato, que durante [35] dez anos atormentou 
"Trium Lusitaniae ciuitatum conuocato populo - ut scribit Valerius Maximus libro nono titulo De perfidia - nouem millia, in quibus flos iuuentutis consistebat, partim trucidauit, partim uendidit."

[34] Accusauit acriter M. Cato Sergium Galbam pro interfectis contra imterpositam fidem Lusitanis, ut testatur in Bruto M. Tullius, et obiter in Diuinatione, quod explicat latiuscule Asconius Paedianus, et Liuii epitome libro quadragesimo nono, et idem Valerius Maximus libro octauo, capite primo.

Nonagesimum autem aetatis annum agebat Cato, quum Galbam accusauit, teste Liuio, decadis quartae libro nono.

Ab Orosio non discedamus. Is ex Claudio narrat trecentos Lusitanos cum mille Romanis pugnam commisisse, in qua septuaginta Lusitani, Romani autem trecentum uiginti ceciderint. Quumque uictores sparsi iam atque securi abiissent, unusque ex illis longe a ceteris segregatus maneret, a circumfusis equitibus pedes ipse est deprehensus; ille tamen unius eorum equo lancea perfosso, ipsius equitis uno gladii ictu caput desecuit.

Quo facto ita omneis metu perculit ${ }^{1}$, ut prospectantibus cunctis ipse contemptius atque otiosius abscederet.

Suppeterent nobis similia fortitudinis exempla, si modestius sua extullissent Romani. Nos autem cum rerum nostrarum scriptores alios non habeamus, ex iis siue aequis siue iniquis cogimur accipere quantum illis prodere de nobis fuit libitum. Nonnunquam tamen ueritas excidit imprudentibus.

"A Gallis, et a Lusitanis Romanos per arma grauiter uexatos" ait Iulius Obsequens cap. decimo quinto De prodigiis, et cap. 40: "A Lusitanis exercitum Romanum caesum."

Florus lib. 2, cap. 17: "Tota certaminum moles cum Lusitanis fuit, et Numantinis, neque immerito. Quippe solis gentium duces contigerunt.” Ex quibus uerbis perspicuum fit duces magnum ad uictoriam afferre momentum. Quos cum semper haberent Romani, non mirum, si turbam hominum, sine duce incompositam uincerent.

At quoties duces contingebant militaris rei non ignari, non tantum se iactabant Romani. Esto indicium uel Lusitanus Viriatus, si fortuna cessisset, Hispaniae Romulus, ut idem scribit Florus, uel Sertorius. Facetus est Iustinus libro ultimo: "In tanta saeculorum serie nullus illis dux magnus praeter Viriatum fuit, qui annos decem uaria [35] uictoria Romanos fatigauit. Adeo feris, quam hominibus

1 perculit $E$ (pro percussit corr. Errat.) ] percussit $R C^{1} F C^{2} U$ 
os romanos com diversas vitórias. As suas qualidades estão mais próximas das dos animais que das dos homens" ${ }^{146}$. Vejamos, Justino, porque consideras as qualidades dos nossos mais próximos das dos animais que das dos homens? Porque durante dez anos atormentaram os Romanos? Porquê? Considerá-las-ias, creio, mais próprias de deuses do que de homens, se fossem os Romanos a atormentarem os Lusitanos com vitórias duvidosas. É ou não verdade o que acima dissemos, que os escritores latinos rebaixaram sempre e de toda a maneira que puderam os nossos feitos? Mas já chega o que dissemos acerca da coragem.

Estrabão anotou cuidadosamente os costumes, tal como os conheceu no seu tempo e que nem eram maus então nem motivo de vergonha para nós agora. Muitos se modificaram com a religião, muitos outros ainda persistem. Passarei a expor alguns.

Que ninguém interprete no pior sentido o ter-se afirmado que "eram hábeis em emboscadas", porque se trata, como observou Júlio Pólux ${ }^{147}$ no capítulo décimo de uma expressão militar. Cícero, no capítulo primeiro do Acerca dos Deveres, louva Q. Fábio Máximo por causa disto: "Sabemos que o hábil Aníbal, entre os Cartagineses, e Q. Máximo, entre os nossos chefes, facilmente enganavam, guardavam segredos, dissimulavam, armavam ciladas, roubavam planos dos inimigos" ${ }^{148}$. No que diz respeito aos Lusitanos, Dion ${ }^{149}$ afirma que os habitantes dos montes Hermínios armaram ciladas a César.

"O punhal está preso ao lado"150. O uso dos punhais, antiquíssimo entre os Hispanos e que, quando eu era criança, gozava ainda de grande apreço entre os homens, deslizou pouco a pouco para os punhais curvos com que são armados mesmo os impúberes antes do uso excessivamente prematuro das espadas, muitas vezes para desgraça deles e desgosto dos pais.

"Cada um leva consigo vários dardos"151. Ainda agora a maior parte da gente do povo dos Galaicos e dos Brácaros conserva o costume de levar, quando vai para os campos, dois dardos e, o que é mais importante, prontos para servir.

"Alguns usam também lanças" 152 . É costume tradicional dos Transtaganos, quando saem das cidades, mesmo a pé, levarem habitualmente consigo lanças compridas. São mais manuseáveis pelos cavaleiros.

[36] "Bebem água." ${ }^{53}$ Isto mantém-se em grande parte na nossa época sobretudo entre os nobres. Pelo menos as crianças, antes da puberdade, são de um modo geral abstémias e é hábito nos nossos reis a abstinência de vinho.

Quanto ao resto, "que os Lusitanos se entretinham, à maneira espartana, que, segundo o costume grego, realizavam hecatombes e competiam em lutas gímnicas. ${ }^{154}$, visa como finalidade mostrar a origem grega dos Lusitanos. Quem queira pode ver o restante no próprio Estrabão.

César, no primeiro Comentário da Guerra Civil155, diz que "os Lusitanos usam uma armadura ligeira”. Receberam dos Romanos, Gauleses e Germanos uma armadura mais pesada, a que se chama panóplia. César, Lívio, Sílio testemunham que os peões combatiam armados de escudo ${ }^{156}$. 
propriora sunt ingenia." Quaeso te, Iustine, cur feris quam hominibus propriora dicis nostrorum ingenia? Quia annos decem Romanos uaria fatigauerunt? Quid? Romanorum, quum Lusitanos uariis fatigabant uictoriis, ingenia diis credo, quam hominibus propriora existimares. Estne, an minime, quod superius dixi, Latinos scriptores semper, ut ut potuerunt, nostra detrectasse? Sed de fortitudine isthaec sufficiant.

Mores Strabo, qualeis suo tempore acceperat, diligenter annotauit, neque tunc quidem malos, neque modo nobis erubescendos; quorum multi cum religione mutati sunt, multi etiam perseuerant. Ex iis exponam aliquos.

Quod "insidiatores" eos dixit, nemo in peiorem partem accipiat. Militare enim uocabulum est, ut admonuit Iulius Pollux capite decimo. Cicero ea re Q. Fabium Maximum laudat libro De officiis primo: "Callidum Annibalem ex gente Poenorum, ex nostris ducibus Q. Maximum, accepimus facile celare, tacere, dissimulare, insidiari, praeripere hostium consilia. Quod ad Lusitanos attinet, Dion Herminii montis incolas Caesari insidias parasse ait.

"Pugio lateri adhaeret." Pugionum usus Hispaniis antiquissimus, qui me puero in magno honore uiris adhuc erat, paulatim defluxit ad sicas, quibus etiam impuberes ante nimis properum ensium usum saepe in suam perniciem, et parentum orbitatem armantur.

"Vnusquisque plura fert iacula." Gallaicorum et Bracarorum etiam nunc plerique ex plebe id seruant, quum ad agros egrediuntur, bina ferentes iacula, et quidem amentata.

"Quidam utuntur et hastilibus." Transtaganorum mos hic est, etiam pedibus euntium, lanceas sane longas extra urbem gestare. Equitibus habiliores sunt.

[36] "Aquae potores." Id ad nostram aetatem etiam magna ex parte durat, praesertim inter nobiles. Certe pueri citra pubertatem abstemii generatim sunt. Regibus ac Principibus nostris solemnis est uini abstinentia.

Ceterum "Spartano ritu degere Lusitanos, et Graeco more hecatombas facere, gymnica certamina exercere", quaeque sequuntur, omnia eo pertinent, ut Graecam Lusitanorum originem ostendant. Cetera possunt qui uelint ex ipso Strabone petere.

"Leui armatura uti Lusitanos" primo Belli Ciuilis Commentario Caesar asserit. Grauiorem, et quae panoplia uocatur, a Romanis, Gallis atque Germanis accepere. Cetratos pugnare pedites, et Caesar, Liuius, et Silius, et plerique alii attetantur. 
Falemos também daquela parte da Galécia, que anteriormente recordámos estar anexa à Lusitânia, a dos denominados Brácaros, evidentemente por causa da capital desse povo. Estes são referidos em Pompónio ${ }^{157}$ e Plínio ${ }^{158}$ pelo nome antigo de Grónios, se bem que a lição em Plínio já esteja emendada, tendo-se substituído Grónios por Grávios com fundamento em Sílio, no canto primeiro:

Tal como o rio (Lima) que sobre os Grávios rola as areias brilhantes Para os habitantes trazendo o esquecimento do subterrâneo Lete.

E no canto terceiro:

E a cidade de Enea mandou os que se chamam agora Grávios Por se ter adulterado o nome de Graios ${ }^{159}$.

Plínio ${ }^{160}$ divide-os em quatro, Helenos, Grávios, Leunos e Seurbos; Ptolomeu ${ }^{161}$, sempre mais minuciosamente, em Túrdulos, Nemetatos, Celerinos, Bíbalos, Límicos, Gruios, segundo outros Grávios, Luangos, Quarquernos, Lubenos e Narbasos. Mas isto são mais nomes de cidades, tendo em vista a coluna de Chaves, de que falaremos a seu tempo e que assim reza:

[37]

$$
\begin{aligned}
& \text { CIVITATES DE- } \\
& \text { CEM AQVIFLAVI- } \\
& \text { ENSES. AOBRIGE- } \\
& \text { NS. BIBALI. COELE- } \\
& \text { RINI. EQVAESIL. I- } \\
& \text { NTERAMICI. LIMI- } \\
& \text { CI. AEBISOC. QVA- } \\
& \text { RQVERN. TAMA- } \\
& \text { CANI. }
\end{aligned}
$$

Isto é: As dez cidades Aquiflavienses: Aobrigenses, Bíbalos, Celerinos, Equesílicos, Interâmnicos, Límicos, Ebisocos, Quarquernos, Tamacanos ${ }^{162}$.

Quanto a Pompónio ${ }^{163}$, englobou-os num só nome, Grónios ou, melhor, Grávios. Justino $^{164}$ acrescenta os Anfílocos, de origem grega, Estrabão ${ }^{165}$ os Helenos e os Anfílocos, "todos de linhagem grega", disse Plínio ${ }^{166}$. Com efeito, além de Teucro, filho de Télamon, que Justino ${ }^{167}$ diz ter estado na Galécia onde deu o nome a um povo, veio ainda Diomedes, trazido por aquele que fundou a cidade de Tui, a que Sílio chamou a etólica no livro terceiro: "e a etólica Tude"168

Estrabão, falando dos Lusitanos que habitavam junto ao Douro e sem dúvida para que estes povos mostrem espontaneamente a origem grega, contou que se 
Prosequamur et illam Callaeciae partem quam adnexam Lusitaniae supra memorauimus, uidelicet Bracaros ab urbe gentis capite nominatos. Vetusto hi nomine Gronii dicebantur Pomponio Plinioque. Quamquam in Plinio emendata iam lectio est, et pro Groniis substituti Grauii ex Silio libro primo:

Quique super Grauios lucenteis uoluit arenas, Infernae populis referens obliuia Lethes.

Et libro tertio

Et quos nunc Grauios, uiolato nomine Graium.

Oeneae misere domus.

Plinius quadrifariam partitur in Helenos, Grauios, Leunos, Seurbos. Adhuc minutius Ptolemaeus, in Turdulos, Nemetatos, Coeletinos, Bibalos, Limicos, Gruios, quos alii Grauios, Luangos, Quarquernos, Lubaenos et Narbasos. Sed haec potius ciuitatum sunt nomina, ut est Aquis Flauiis in columna, de qua suo loco. Vbi legitur:

[37]

$$
\begin{aligned}
& \text { CIVITATES DE- } \\
& \text { CEM AQVIFLAVI- } \\
& \text { ENSES. AOBRIGE- } \\
& \text { NS. BIBALI. COELE- } \\
& \text { RINI. EQVAESIL. I- } \\
& \text { NTERAMICI. LIMI- } \\
& \text { CI. AEBISOC. QVA- } \\
& \text { RQVERN. TAMA- } \\
& \text { CANI. }
\end{aligned}
$$

Hoc est: Ciuitates decem, Aquiflauienses, Aobrigenses, Bibali, Coelerini, Equaesilici, interamici, Limici, Aebisoci, Quarquerni, Tamacani.

Pomponius uero uno nomine Gronios, seu potius Grauios complexus est. Addit Iustinus Amphilocos Graecae originis. Strabo Hellenas et Amphilocos, et "Graecorum sobolis omnia" dixit Plinius. Nam praeter Teucrum, Telamonis filium, quem scribit Iustinus ad Callaeciam uenisse et genti nomen dedisse, etiam Diomedes eo delatus, Tyden urbem condidit, quam propterea Aetolam Silius cognominauit libro tertio: "Aetolaque Tyde".

Durio uicinos amni Spartano ritu degere, Strabo de Lusitanis agens, memoriae prodidit, hecatombas, certamina gymnica, ludos armis, equis, cestibus et cursu 
entretinham à maneira espartana e que costumavam celebrar hecatombes, competições gímnicas, jogos com armas e cavalos, pugilato, corridas pedestres e, além disso, casando segundo um ritual à maneira grega ${ }^{169}$.

[38] Já anteriormente fizemos referência à época bastante remota do pai Líber e de Ulisses ${ }^{170}$. É tão verdade que na Hispânia abundam muitos vestígios da origem grega, como, por exemplo, muitos aspectos linguísticos, nomes de coisas, helenismos, a maior parte dos ditongos, e até os próprios artigos junto dos nomes, e oxalá que o seu uso se preserve e pratique entre nós. Em tempos, levado pelo gosto de saber e aproveitando um momento de ócio nos assuntos do espírito, reuni grande número de palavras, cerca de quinhentas, que nos foram deixadas pelo Grego, com seu matiz dialectal, assunto que de modo algum é de tratar aqui ${ }^{171}$.

\section{OS MONTES}

A Lusitânia tem vários montes, mas só vale a pena fazer menção de montes como Monchique, Arrábida, Montejunto, Hermínio, Sintra, Ansião, Monte Corva, Buçaco, Montemuro, Marão e Geres. Monchique, que começa a partir do ópido de Castro Marim e da foz do Guadiana, é como que um apêndice dos Montes Marianos, corta o reino do Algarve e depois de dar origem a alguns rios que se vão esconder no mar próximo, vem morrer perto de Aljezur, com o rio do mesmo nome, no litoral oceânico ocidental. Da Arrábida já atrás se disse o suficiente ${ }^{172}$.

O monte da Lua, designado entre nós por serra de Sintra devido ao nome do ópido, termina naquele promontório a que os geógrafos chamam Magno ou Olisiponense. No ponto mais alto dos seus penhascos está o templo consagrado à Santíssima Mãe de Deus, venerado com a maior devoção pelos naturais, e assim também um convento de monges que seguem a regra de S. Jerónimo, e que deve ser protegido não tanto pelo número de frades como pela santidade dos seus costumes. Junto ao sopé da serra, mesmo no cimo do promontório, que é cortado abruptamente sobre o oceano, existiu outrora um templo consagrado ao Sol e à Lua, do qual agora apenas existem ruínas nas areias do litoral e cipos, alguns com inscrições reveladoras da antiga superstição. A primeira diz o seguinte:

[39]

SOLI. ET LVNAE

CEST. ACIDIVS

PERENNIS LEG.

AVG. PR, PR. PRO

VINCIAE LVSITA

NIAE. 
solitos celebrare, itemque coniugia Graecanico ritu, ut absque dubio Graecam hi populi prae se ferant originem.

[38] Liberi Patris atque Olyssis uetustiora saecula supra memorauimus. Adeoque uerum est Graecae originis multa in Hispania superesse uestigia, ut etiam linguae complura et uocabula, et Hellenismi, et pleraeque diphtongi, ipsique etiam additi nominibus articuli, eorumque usus apud nos sit, et custodiatur. Aliquando curiositatis studio, atque animi causa otio abusus, siluam collegi uocabulorum fere quingentorum, cum sua dialectico, nobis ex Graeco relictorum. Quae persequi huius loci nequequam est.

\section{DE MONTIBVS}

Montes nonnullos habet Lusitania, sed quorum mentio facienda sit: Cicum, Barbarium, Iunctum, Herminium, Lunae montem, Tapiaenum, Cordibam, Alcobam, Murum, Maranum, et Iuressum. Mons Cicus ab Castro Marino oppido Anaeque fluminis exitu incipiens, tamquam Marianorum montium appendix, Algarbii regnum secat, et nonnullis emissis fluminibus in mare propinquum se condentibus, ad oppidum Algiazur cum fluuio eiusdem nominis in occidentalis Oceani litore deficit. De Barbario superius dictum satis.

Lunae montem, nos Sintriae ab oppido appellamus, efficitque promontorium illud quod magnum, siue Olisiponense appellant geographi.

In quuius summis rupibus templum est Sanctissimae Dei Matri sacrum, ab indigenis maxima religione cultum, simulque coenobium monachorum ad Diuum Hieronymum uitae institutum referentium, non tam numero, quam morum integritate suscipiendum. Ad radices montis in ipso promontorii cacumine, quo in Oceanum praecipitatur, templum olim fuit Soli et Lunae sacrum. Cuius modo inter litoraleis arenas ruinae tantum extant, et cippi aliquot inscripti superstitionis antiquae indices.

[39] Vnus sic habet:

SOLI. ET LVNAE.

CEST. ACIDIVS

PERENNIS LEG.

AVG. PR, PR. PRO

VINCIAE LVSITA

NIAE. 
Isto é: Ao Sol e à Lua dedica Céstio Acídio Perene, Legado Augusta!, Propretor da província da Lusitânia ${ }^{173}$.

A outra, por seu lado, tem assim:

SOLI AETERNO. LVNAE. PRO AE-
TERNITATE IMPERII. ET SALVTE
IMPE. CAI SEPTIMII SEVERI. AV-
G. PII. ET IMP. CAES. M. AVRELI.
ANTONINI AVG. PII
CAES.

ET IVLIAE AVG. MATRIS. CAES. DRVSVS. VALER. COELIANVS VIATI VSI BSI AVGVSTORVM CVMV Bat SVALE IVLIVS. SATVR. QVAL NEIE ET ANTO NIVS.

[40] Isto é: Ao Sol eterno e à Lua, pela eternidade do império e pela boa saúde do impe-rador Gaio Septímio Severo, Augusto e Pio, e do imperador César Marco Aurélio Antonino, Augusto, Pio... César, e de Júlia Augusta, mãe de César, dedicam Druso, Valeríano Celiano... e Quinto Júlio Saturnino e António... ${ }^{174}$

Está também aqui um outro cipo enorme, que tem para cima de trinta linhas em letra bastante pequena, mas com o desgaste do tempo e com a água do mar tornou-se de uma tal aspereza que, na primeira linha, a custo se reconhecem quatro letras. É aqui o local onde os que fizeram publicar na Alemanha As Inscrições da Antiguidade Sagrada ${ }^{175}$ dizem ter sido desenterradas três colunas quadrangulares numa das quais anunciam estar contido o vaticínio da Sibila:

VOLVENTVR SAXA LITERIS, ET ORDINE RECTIS

["Voltar-se-ão as pedras e com as letras ordenadas em linha."176]

Penso que esta profecia é uma mentira e que as três colunas quadrangulares são os três cipos, realmente enormes, de que falei. Eu soube de facto que Valentim da Morávia ${ }^{177}$, o defensor da história, homem de bem e negociante famoso, foi tão ignorante do latim que facilmente poderia ser enganado por um impostor qualquer, e suspeito que, levado pela admiração do recente acontecimento, quis que os seus compatriotas alemães participassem nele. 
Hoc est. Soli et Lunae Cestius Acidius Perennis Legatus Augustalis propraetor prouinciae Lusitaniae.

Alter autem sic:

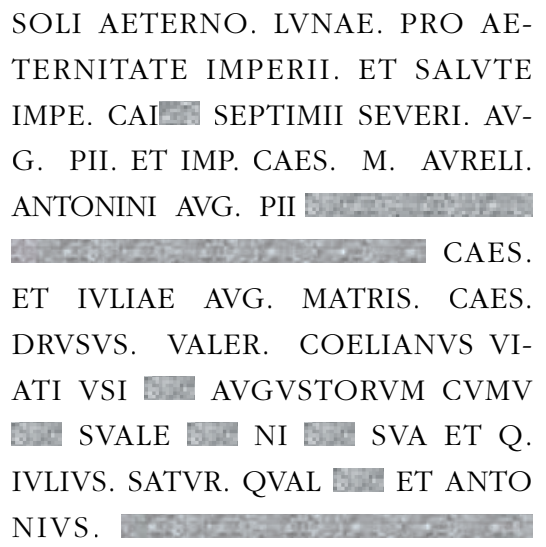

[40] Hoc est: Soli aeterno, Lunae pro aeternitate imperii, et salute imperatoris Caii Septimii Seueri, Augusti Pii, et imperatoris Caesaris, Marci Aurelii Antonini Augusti Pii, Caesaris, et Iuliae Augustae Matris Caesaris, Drusus, Valerius Coelianus, Augustorum sua et Quintus Iulius Saturninus, et Antonius.

Est ibi praeterea ingens alius cippus, qui habet supra triginta lineas littera minutiore. Verum iniuria temporis, et adspergine maris in tantam scabritiem deuenit, ut in unaquaque linea uix litterae quatuor agnoscantur. Atque hic est locus in quo, qui sacrosanctae uetustatis inscriptiones typis in Germania edendas curauerunt, erutas fuisse aiunt quadratas columnas treis, in quarum una uaticinium Sybillae contineri asserunt:

VOLVENTVR SAXA LITERIS, ET ORDINE RECTIS

Quod uatinium ego fictum existimo, et treis illas quadratas columnas treis esse cippos, quos dixi, sunt enim ingentes. Valentinum uero Morauum fabulae assertorem, uirum bonum, negotiatorem splendidum, litterarum tamen Latinarum rudem fuisse accepi, ut facile fuerit ab impostore quodam decipi, et nouae rei admiratione inductum suspicor uoluisse Germanos suos participare. 


\section{O MONTE TAGRO OU O MONTEJUNTO}

[41] Varrão diz que o Tagro é aquele monte perto de Lisboa onde as éguas são fecundadas pelo vento: "Na altura de reprodução, diz ele, uma coisa incrível mas verídica acontece na Hispânia, pois naquela região da Lusitânia junto ao mar, onde está a cidade de Lisboa, em certa altura do ano algumas éguas são fecundadas pelo vento do monte Tagro" ${ }^{178}$. Não discuto a fecundação pelo vento, coisa de que nesta altura não temos conhecimento, mas, porque está no âmbito do meu trabalho, inspira-me uma certa dúvida a semelhança entre Tagro e Tago [Tejo], ou seja o nome do monte e do rio.

Frequentemente me interroguei sobre se não se deveria atribuir ao rio o que diz acerca do monte, com o fim de substituirmos monte Tagro por rio Tejo [Tago], tal como fez Plínio que disse "junto à cidade de Lisboa e do rio Tejo"179 e Justino "na Lusitânia junto ao rio Tejo"180. Duas coisas, no entanto, o impedem: a primeira, porque não faria sentido dizer que as éguas são fecundadas no rio Tejo; a segunda, as palavras de Columela ${ }^{181}$ que também nomeia um monte, embora lhe chame Sacro e não Tagro. Como ele consultou Varrão temos, de qualquer modo, de conservar a lição. Se alguém achar que também em Varrão se deve ler "Monte Sacro", tal não me repugnaria se soubéssemos que existe um Monte Sacro algures na região. Existe um Monte Sacro na Galécia, do qual temos conhecimento por Justino ${ }^{182}$, e um outro na Lusitânia, o qual forma o promontório do mesmo nome. Ambos estão, porém, muito longe de Lisboa e Varrão refere-se a um que está perto. Eis a razão por que não ouso modificar a sua lição nem sou de opinião que isto deva ser feito ao acaso pelos comentadores ${ }^{183}$.

Por outro lado, o que Plínio e Justino disseram "junto ao rio Tejo" não impede que o mesmo tenha acontecido no monte que está perto do próprio rio. Deste modo, todos falaram verdade: uns ao dizerem "unto ao rio", outros, "no monte". Quanto ao resto, parece-me ser claro que este é o monte a que os habitantes da região chamam Junto e que está contíguo ao Albardo, assim designado pela grande quantidade de cavalos selvagens que por ali vagueiam à vontade, sozinhos ou mesmo em manada. São de pequena estatura mas rijos, com cascos sólidos e espantosa agilidade ${ }^{184}$. É por isso que habituados, como é evidente, aos montes, uma vez apanhados e submetidos, quer a trabalhos de carga quer à estrada, são de longe superiores em resistência aos outros cavalos.

[42] Muito embora tenha afirmado que não discutiria a fecundação pelo vento, ainda assim contarei o que me disseram quando andei a investigar o assunto por amor à verdade. Deixei, faz agora sete anos, a casa de um lavrador da região de Bena-vente, junto ao Tejo, a quem perguntei o que ele próprio sabia e se se recordava de ter ouvido contar a outros acerca deste modo de reprodução. Respondeu que nem ele nem os seus vizinhos, proprietários de manadas, se tinham alguma vez preocupado com isso. 


\section{DE MONTE TAGRO, SIVE IVNCTO}

[41] Tagrum montem, in quo equae uento concipiunt Olisiponi uicinum Varro asserit: "In fetura - inquit - res incredibilis est in Hispania, sed est uera, quod in Lusitania ad Oceanum, in ea regione ubi est oppidum Olisipo, monte Tagro, quaedam e uento, certo tempore, concipiunt equae." Non disputo de conceptu ex uento, re nobis modo incomperta, sed quod ad institutum meum attinet, mouet mihi scrupuli nescio quid, similitudo Tagri et Tagi, hoc est montis et fluuii.

Subdubitaui saepe referendumne esset quod de monte ait, ad amnem, ut pro Tagro monte, amne Tago substitueremus. Quemadmodum fecit Plinius, qui "circa Olisiponem oppidum, et Tagum amnem" dixit; et Iustinus "in Lusitania iuxta fluuium Tagum," sed duae res impedimento sunt. Altera quod non bene diceretur, equas concipere amne Tago; altera Collumellae uerba montem quoque nominantis, tametsi sacrum, non Tagrum. Verum quum id a Varrone acceperit ad illius lectionem reuocandus utique est. Quod si quis opinetur etiam apud Varronem legendum "monte sacro" non repugnarem, si montem aliquem sacrum alicubi isto in loco legeremus. Sacrum montem in Callaecia esse nouimus ex Iustino; Sacrum et in Lusitania, qui eiusdem nominis efficit promontorium. Sed horum uterque longissime ab Olisipone distat, quum Varro uicinum dicat. Quare non audeo lectionem eius immutare, neque temere in notae eius auctoribus id faciendum censeo.

Nam quod Plinius et Iustinus "iuxta amnem Tagum" dixere, non tollit, in monte, qui iuxta ipsum amnem sit, idem etiam fieri, ut uere dixerint hi "iuxta amnem", et illi "in monte". Ceterum montem hunc eum esse, quem Iunctum adcolae uocant, contiguumque illi Albardum, uidetur liquere ex equiferorum inibi passim multitudine per montem, quum solitarie, tum etiam gregatim errantium. Corporatura illis mediocris, sed firma. Soliditas ungularum siccissima, pernicitas mirabilis.

Quare capti, ac domiti, ad perferendos labores, tam sarcinae, quam itineris, ceteris duritia, uidelicet rupibus assueti, longe praestant.

[42] Sed quanquam de conceptu ex uento disputandum a me negaui, referam tamen, quod inquirendae rei gratia percontanti, mihi indicatum est. Diuerti abhinc septennium apud colonum agri Beneuentani, iuxta Tagum. Et quum ab illo quarerem ecquid de huiuscemodi conceptu, aut sciret ipse, aut ab aliis auditum meminisset, respondit neque se neque uicinos, qui equarias haberent, de ea unquam re fuisse solicitos. 
Logo que se davam conta de que as fêmeas estavam com cio, mandavam-nas cobrir. No entanto, de uma vez que possuía uma bela égua, desejando que ela estivesse em boas condições para ser vendida na feira seguinte, deixou-a sozinha, antes de a mandar cobrir, no mouchão que está no meio do Tejo, para que ela engordasse com a abundância da pastagem.

Daí a dois meses a égua, que não tornara a ver, foi encontrada prenha. Admirado, porque nenhum garanhão se tinha aproximado daquele local, aguardou o resultado e, quase sete meses depois, a égua pariu, não um animal, mas uma pasta informe de sangue endurecido, um aborto, segundo pensou.

Nada mais soube desta procriação das éguas. Admira-me, porém, que Virgílio ${ }^{185}$ não refira isto em passo algum, para não falar de Sílio no canto terceiro ${ }^{186}$, embora Varrão com tanto saber assevere que ela é verdadeira, Colu-mela a tenha como conhecidíssima e Plínio testemunhe a sua existência. Mas os naturalistas que discutam isto entre si. Voltemos nós ao assunto que nos compete tratar.

\section{O MONTE HERMÍNIO}

Expusemos há muito, não só em carta ao fidalgo e erudito Manuel de Sousa, alcaide de Arronches, como mais tarde a João Vaseu ${ }^{187}$, que o monte Hermínio é aquele em que está situada a cidade de Portalegre, os ópidos de Arronches, Alegrete, Marvão e alguns outros também de certa importância. Junto ao sopé, elevam-se ainda hoje as ruínas da cidade de Meidúbriga ${ }^{188}$, perto de Marvão, e o mais alto cume sobranceiro à cidade destruída conserva o nome primitivo. Com efeito, chamase-lhe Hermínio.

[43] E mesmo a própria cidade em ruínas, que lhe está subjacente, é designada por Hermínia, do nome do monte, ou, para falar em língua portuguesa, Aramenha ${ }^{189}$.

Por todo aquele vale entre os montes abundam, aqui torres, ali pontes sobre os rios, mais além pavimentos de casas patrícias destruídas mas ainda com mosaicos, acolá uma conduta de água da fonte, noutra parte paredes meio desabadas e outros manifestos indícios de uma antiga povoação. Há também minas de chumbo e ouro, segundo dizem os naturais, escavadas em muitos sítios pelas encostas do monte, para que não tenha sido sem razão que Plínio chamou Plumbários aos Meidubrigenses ${ }^{190}$. Cheguei à localização deste local, em primeiro lugar pelo próprio nome do monte, que se conservou até hoje, e pelos vestígios da cidade sepultada entre ruínas; depois pelo confronto das palavras de Hírcio ou Ópio no Comentário da Guerra da Alexandria, livro quarto, sobre as guerras civis ${ }^{191}$, onde se diz que Cássio Longino tomou de assalto a cidade de Meidúbriga e o monte Hermínio onde se tinham refugiado os Meidubrigenses. Confirmou esta minha opinião o Itinerário de Antonino Pio ${ }^{192}$ com o traçado de três vias romanas que vão de Lisboa a Mérida. Na terceira, Meidúbriga dista de Mérida 64.000 passos, ou seja, 16 léguas hispânicas. De facto, as distâncias são agora medidas em tantas léguas. Diz assim: "Depois de 
Tantum ut equire feminas animaduerterent, admitti eas curare. Se tamen cum pulchram equam haberet, cuperetque bene uendibilem in proximas nundinas efficere, ante initum, in insula, quae in medio Tago est, solam inclusisse, ut abundantia pabuli saginaretur.

Inuisam post menses duos reperisse grauidam, miratumque eo quod illuc nunquam accessisset admissarius, euentum expectasse. Septem fere iam menses cum tulisset uterum, enixam non quidem animal, sed concreti sanguinis informem materiam, abortumque suspicatum.

De hac equarum genitura aliud noui nihil; miror tamen ut Virgilium, Siliumque libro tertio taceam, Varronem doctrina tanta esse ueram asseuerantem, Collumellae habitam pro notissima, Plinium constare testatum, nec uno id loco referentem. Verum id inter se agitent physici. Nos ad susceptam materiam reuertamur.

\section{DE MONTE HERMINIO}

Herminium montem, et olim in epistola ad Emmanuelem Sosam Arruncensis castri praefectum, uirum nobilem et eruditum, et post ad Ioannem Vasaeum, ostendi eum esse in quo Alacriportus ciuitas, Aruncis, Alacretum, Maruanum, aliaque oppida non contemnenda sita sunt. Ad quuius radices extant adhuc Meidubrigae urbis ruinae non procul a Maruano Castro, quuiusque editissimum culmen supra dirutam urbem, etiam dum ueterem appellationem retinet. Herminius enim mons uocatur.

[43] Ipsa etiam destructa ciuitas a monte, cui subiecta est, Herminia uulgo dicitur, siue, ut Lusitane loquar, Haraminia.

Supersunt tota illa inter monteis conualle, heic turreis, illic super fluuium pontes, heic aedium nobilium strata pauimenta, etiam Asarotica, illic ductus aquae fortanae, parte alia parietes semidiruti, et alia ueteris frequentiae manifesta indicia. Fodinae quoque plumbi aurique, ut indigenae aiunt, multis locis per latera montis apertae, ut non immerito Meidubrigenses Plumbarios Plinius cognominarit. Veni in huius loci notitiam primum ex ipso seruato ad hanc diem montis nomine, conspectisque inter ruinas sepultae urbis uestigiis. Deinde ex collatis Hircii, aut Oppii uerbis in Commentario Belli Alexandrini, qui est ciuilium bellorum quartus, ubi refertur Cassius Longinus Meidubrigam oppidum, Montemque Herminium, quo Meidubrigenses confugerant, expugnasse. Eamque mihi opinionem confirmauit Antonini Pii Itinerarium, tribus ab Olisipone Emeritam positis itineribus.

Quorum in tertio Meidubriga LXIIII. M. pass. distat ab Emerita, hoc est, Hispanicis leucis sedecim. Tot enim modo numerantur. Sic: "Post Meidubrigam 
Meidúbriga até Sete Altares, onde presentemente está a cidadela de Alegrete, 14.000 passos. Até Plagiária 20.000. Até Mérida 30.000". Na segunda via diz assim: "Depois de Sete Altares: Budua, 12.000 passos". Budua situava-se a cerca de 12.000 passos do lugar em que está agora a povoação de Campo Maior. Aí se eleva uma igreja dedicada à Virgem Maria junto de Bótoa, deturpação compreensível das letras do nome de Budua193: "Partindo de Budua a Plagiária, são 8.000 passos. Daí a Mérida são 30.000 passos". Pensei que isto devia ser explicado de tal modo que o espírito do leitor se aperceba da posição de Meidúbriga em relação a Mérida e não se confunda acerca do monte Hermínio e de Meidúbriga, agora referidos, quando dentro em pouco eu provar que muito longe daqui também há um monte Hermínio.

Sustento pois que a chamada serra da Estrela, famosa em toda a Lusitânia, com inúmeros ópidos, nascente de muitos rios e onde as neves se derretem, cheia de rebanhos por causa da abundância de pasto, também é o Hermínio, o que não obsta a que entre o monte agora referido e esta serra da Estrela [44] haja poucas distâncias não preenchidas por montanhas contínuas.

Mostrar-se-á pelos livros de testamentos, doações, compras e vendas dos cónegos do mosteiro de Santa Cruz de Coimbra ${ }^{194}$, que a serra da Estrela também era designada por Hermínio. Assim, na quarta parte do livro de testamentos, documento primeiro, o Conde Henrique e a rainha Teresa, pais do primeiro rei de Portugal, Afonso Henriques, dizem o seguinte: "Fazemos carta de doação daquela herdade que tem o nome de São Romão e que está situada junto a Seia, nas faldas do monte Hermeno." 195 Ora é bem sabido que as povoações de Seia e de São Romão se situam nas faldas da serra da Estrela, perto da importante cidade [Covilhã] que toma o nome de "Cova Juliana", célebre pelo fabrico de lã e de que falaremos noutra altura ${ }^{196}$.

O documento oitavo ${ }^{197}$ do mesmo livro, onde se trata de uma herdade de Ansedo, dispõe-se assim: "Eu, Ansedo, de metade de toda a nossa herdade que temos na vila de Lagares, no concelho de Seia, no sopé do monte Hermeno...".

No documento décimo terceiro ${ }^{198}$, sobre a herança de João Garcia, lê-se: "Da nossa terra que temos no concelho de Seia, subjacente ao monte Hermeno, no lugar a que se chama Assamassa...".

No artigo décimo quinto ${ }^{199}$ acerca de Santa Maria de Mesquida: "E está situada no sopé do monte Hermeno, na região de Seia."

[45] No documento décimo oitavo ${ }^{200}$, ao tratar da herança de Paio Aires: "De toda aquela herdade que temos na vila de São Romão, no lugar, a saber, que se chama Assamassa, no sopé do monte Concieiro...". Repare-se que o castelo de São Romão e o lugar de Assamassa, anteriormente localizados no sopé do monte Hermeno, são agora situados no sopé do Concieiro, evidentemente porque é este o nome específico daquela parte do Hermínio sobranceira a São Romão e a Assamassa.

No documento vigésimo nono ${ }^{201}$, sobre a herdade de Sancho Vermudes: "De toda aquela minha herdade que tenho no lugar de Paços, concelho de Seia, no sopé do Hermeno." 
ad Septem Aras, ubi nunc Alacretum est oppidum, M. P. XIIII. Plagiaria M. P. XX. Emerita M. P. XXX." In secundo autem sic: "Post Septem Aras, Budua M. P. XII". Eratque Budua fere M. P. XII. ab eo loci ${ }^{1}$, ubi nunc oppidum est Campi Maioris, extatque eo loco sanum Virginis matris ad Botouam appellatum, uidelicet Buduae nominis in Botouae nomen, facili ex cognatione litterarum deprauatione: "A Budua uero Plagiaria M. P. VIII. Inde Emerita M. P. XXX." Hoc ita explicandum censui, ut ab Emeritae ac Meidubrigae propinquitate acquiescat lectoris animus, nec titubet de Herminio monte, ac Meidubriga a me modo expositis, quum paulo post non parum inde remotiorem montem Herminium quoque esse ostendero.

Aio igitur nominatum ac celebrem tota Lusitania, Stellae montem multis oppidis frequentem, multorum fluuiorum patrem, et ubi niues delicuere, ob pabuli abundantiam maxime pecorosum, Herminium quoque esse, neque obstare inter modo expositum et hunc Stellam [44] sine continuis montibus longiusculum interuallum.

Quod autem Stellae mons Herminius uocatus quoque sit, patebit ex libris testamentorum, donationum, emptionum ac uenditionum Coenobii Canonicorum Sanctae Crucis Conimbricensis.

In quarta igitur parte libri testamentorum, instrumento primo, Comes Henricus et Regina Therasia, Alphonsi Henrici primi Portugaliae Regis parentes, ita loquuntur: "Facimus chartam donationis, de illa hereditate nomine Sancto Romano, quae est sita iuxta Senam, sub monte Hermeno." Valde uero notum est Senam oppidum oppidumque Sanctum Romanum sub Stellae monte esse, non longe ab insigni oppido, a Cabia Iuliani dicto, et lanificio celebri, de quo alias.

Instrumento octauo eiusdem libri, ubi agitur de hereditate Ansedi, habetur sic: "Ego Ansedus de medietate totius nostrae hereditatis, quam habemus in uilla Lagaris in terrotorio Senae, subtus monte Hermino."

Instrumento decimo tertio, de hereditate Ioannis Garsiae: "De nostra terra quam habemus in territorio Senae subtus monte Hermeno in loco, qui dicitur Assamassa."

Instrumento quinto decimo de Sancta Maria de Mesquida: "Et est - inquit sita sub monte Hermeno, in partibus Senae.".

[45] Instrumento duodeuigesimo, de hereditate Pelagii Ariei, sic: "De tota illa hereditate quam habemus in uilla Sancti Romani, in loco scilicet qui dicitur Assamassa subtus monte Concieiro." Vbi aduertendum Sanctum Romanum oppidum et uicum Assamassam sub monte Concieiro collocari, uidelicet quia Concieirus Herminii pars sit, peculiari nomine Sancto Romano, et Assamassae imminens.

1 loci $E$ ] loco $R C^{1} F C^{2} U$ 
E ainda na segunda parte do livro de vendas, documento primeiro ${ }^{202}$, lê-se o seguinte a propósito da herança de Mem Pais: "Na vila a que chamam Lagares, no sopé do monte Hermeno, região de Seia." No documento sétimo e igualmente no décimo segundo 203: "Na vila de São Romão e em seu torno, no sopé do monte Hermeno, por onde corre o rio Alba...", e muitas outras referências noutros passos.

O monte é sempre designado por Hermeno e nunca por Estrela, como se este nome não fosse antigo mas recente. Ouvi contar que lhe foi dado esse nome por uns pastores, em razão de uma Estrela, desenhada pela natureza no cimo de uma pedra $^{204}$.

[46] Díon, no final do livro trigésimo sétimo ${ }^{205}$, refere, a seu modo, que os habitantes do monte Hermínio foram submetidos por César, uma vez de posse da província da Lusitânia após a pretura de Roma. Verti as suas palavras do Grego com a precisão que me foi possível: "Por esta mesma altura, Fausto, filho de Sila, mandou realizar em memória do pai um espectáculo de combates singulares e não só acolheu o povo num festim público como ofereceu gratuitamente banhos e óleos. Isto era o que se passava em Roma.

César, por seu lado, terminada a pretura, assumiu as operações da Lusitânia. Embora tivesse podido sem grande esforço acabar com os latrocínios que eram permanentes entre este povo, não quis ficar inactivo. O facto é que, ávido de glória, invejando Pompeio e outros que antes dele tinham tido grande poder, alimentava a ideia de algo grandioso, mas esperava a oportunidade de não só ele próprio poder então actuar e de ser imediatamente nomeado cônsul, como ainda de realizar grandes feitos, entre outras razões, porque, quando em Cádis, onde fez a questura, tinha tido um sonho em que estava a ter relações com a mãe, e tinha sabido por intérpretes e adivinhos que havia de vir a gozar de grande poder. Esse o motivo por que, quando lá viu o retrato de Alexandre suspenso no templo de Hércules, tenha suspirado, lamentando-se por não ter realizado até então nenhum grande feito.

Foi nessa altura, portanto, que, logo que lhe foi possível obter a paz, tal como eu já disse, se dirigiu para o monte Hermínio. Ordenou então aos seus habitantes que o atravessassem para irem habitar as planícies, com o pretexto de que assim não se entregariam a actos de rapina vindos das suas posições fortificadas, mas, para dizer a verdade, porque não ignorava que eles nunca [47] tal fariam e que lhe dariam assim a oportunidade de fazer a guerra. E foi o que aconteceu.

Forçou-os, por conseguinte, a pegar em armas. Como alguns dos povos vizinhos, receando que o ataque fosse também contra eles, tivessem levado clandestinamente para lá do Douro os filhos, as mulheres e tudo aquilo que possuíam de estimação e valor, ocupou-lhes César as cidades, enquanto faziam isto. Seguidamente travou combate. Como eles lançassem contra os Romanos manadas de rebanho para depois melhor os atacarem enquanto estivessem dispersos na rapina do gado, atacou-os César e desbaratou-os.

Entretanto, como tivesse sabido que os que habitavam o monte Hermínio se tinham entrincheirado para, no regresso, o apanharem de surpresa, tomou logo 
Instrumento undetrigesimo de hereditate Sancii Vermuizii, sic est: "De tota illa mea hereditate quam habeo in uilla Pallacios, territorio Senae, sub monte Hermeno."

Is secunda uero parte libri uenditionum, instrumento primo, de hereditate Menendi Pelagii, ita legitur: "In uilla, quam uocant Lagares, subtus montem Hermenum, in territorio de Sena."

Instrumento septimo, itemque duodecimo: "In uilla Sancti Romani, et in circuitu eius, sub monte Hermeno, discurrente fluuio Aluia”, et alias saepe.

Semperque hic mons Hermenus uocatur, non autem Stellae, quasi nomen hoc recens nec ita pridem sit impositum. Audiui a pastoribus inditum, argumento Stellae, in summitate cuiusdam rupis ab natura effigiatae.

[46] Hermenii montis incolas a Caesare Lusitaniam prouinciam post praeturam urbis adepto expugnatos, ad hunc modum scribit Dion sub libri trigesimi septimi finem. Quuius uerba, quanta potui fide ex Graeco ita uerti:

"Hoc eodem tempore Faustus Syllae filius, agonem monomachiae pro patre fecit, et populum publico conuiuio excepit, et lauacra atque oleum gratis praebuit. Et haec quidem in Vrbe facta sunt.

Caesar autem post praeturam, Lusitaniae imperium accepit. Quumque potuisset latrocinia, quae semper apud illos erant, tollere sine magno quopiam labore, otium habere noluit. Etenim gloriae cupidus, et Pompeio aliisque qui ante ipsum multum potuerant inuidens, nihil paruum animo concipiebat, sed sperabat quidpiam, et ipse tunc posse efficere consulque statim decerni et opera ingentia edere, quum propter alia, tum quia in Gadibus, quando quaesturam gessit, somnium uiderat, quasi cum matre coiret, et ab interpretibus ac diuinis didicerat in magna se potentia esse futurum. Vnde et effigiem Alexandri ibi in Herculis templo suspensam uidens, suspirauit, et conquestus est quod nullum adhuc ipse opus magnum fecisset.

Ex eo igitur tempore, cum liceret illi pacem habere, ut dixi, ad montem Herminium uersus est. Iussitque incolas eius in campestria ad habitandum transire, praetextu quidem ne a munitis locis prodeuntes latrocinarentur; re autem uera, quod non ignoraret eos hoc nunquam [47] facturos, atque ex hoc belli occasionem caperet. Quod et factum est.

Eos igitur ad arma uenire compulit. Verum quum finitimorum quidam ueriti ne etiam in ipsos impetum faceret, filios, et uxores, et alia quae cara, ac pretiosa habebant, ultra Dorium ${ }^{1}$ clam exportarunt, interim dum haec faciebant, ipse ciuitates illorum occupauit. Et post haec certamine congressus cum ipsis est. Obiicientibusque armenta sua, ac greges, ut in Romanos ad praedam pecorum dissipatos incurrerent, exercitum transmisit illosque adortus deuicit.

Inter haec, quum cognouisset eos qui Herminium montem habitabant, abscessisse et sibi reuertenti insidiaturos, tunc quidem alio se contulit, rursus

1 Dorium $E R C^{1} F C^{2}$ ] Durium $U$ 
outro caminho e, ao invés, foi ele afinal que os atacou. Vitorioso, perseguiu os próprios fugitivos até ao oceano Atlântico. Mas os fugitivos, deixando o continente, atravessaram para certa ilha, e César, que não tinha barcos, deixou-se ficar por aquela região e enviou contra eles uma parte do exército em jangadas feitas de pranchas unidas. Perdeu, porém, nessa operação muitos homens.

Efectivamente, quando o comandante dos tais soldados se dirigiu para uma língua de terra que da ilha se alonga em linha recta e para ali os encaminhou com a intenção de atravessarem a pé, ele próprio, impelido logo pela força da corrente contrária, foi arrastado e separou-se deles. Outros, depois de se terem vingado, morreram corajosamente. Quanto a Públio Cévio, o único que sobreviveu, privado do escudo e, ainda por cima, ferido por muitos golpes, saltou para a água e a custo se salvou a nado.

[48] Foi na verdade assim que as coisas se passaram.

Mais tarde foi César, que depois de ter mandado vir barcos de Cádis, atravessou para a ilha com todo o exército e sem luta forçou-os à rendição, pois estavam enfraquecidos pela falta de abastecimento de trigo. E daqui navegou ao longo da costa com o comboio de navios até chegar à cidade da Corunha, na Galécia, apavorando aqueles que até então nunca tinham visto uma armada e submetendoos à sua autoridade."

O que Díon aqui nos conta, que César invadiu as cidades dos povos vizinhos do Hermínio, concorda com o que diz Suetónio ${ }^{206}$, segundo o qual "César saqueou como inimigo algumas cidades dos Lusitanos, embora eles não só não recusassem as ordens por ele dadas, como ainda lhe abrissem as portas quando chegou." Mas que parte do Hermínio se entende neste passo não me é ainda suficientemente claro. Com efeito, pelos rebanhos e manadas que os habitantes lançavam aos Romanos com o objectivo de dispersar o exército, parece depreender-se que se trata da serra da Estrela, que, como já disse, apresenta boas condições para a criação de gado, muito embora aquela encosta junto à cidade de Meidúbriga também tenha rebanhos em não pequena quantidade.

O exílio das mulheres e filhos, bem como o transporte dos objectos de valor para lá do Douro, parece dizer respeito à serra da Estrela, que é a que mais perto está do Douro, mas, por outro lado, a fuga dos Hermínios e a perseguição de César até ao Atlântico adapta-se mais ao monte exposto em primeiro lugar. No entanto, em qualquer dos casos, deve tentar-se saber que ilha foi aquela, junto do continente, para onde os fugitivos puderam atravessar, quer a pé quer a nado, e para onde, da mesma forma, também os soldados tentaram passar.

[49] Prova de que não foi a Londobre, mencionada por Ptolomeu ${ }^{207}$ (a que actualmente chamamos Berlenga), é a distância que a separa do continente, e como no nosso tempo nenhuma outra existe junto ao litoral de toda a Lusitânia, esta de que fala Díon ou foi desgastada pelo mar que lhe batia com violência e depois por ele tragada, ou então será de admitir que seja aquela península da cidade de Peniche, perto de Atouguia ${ }^{208}$. Realmente mesmo agora está separada do continente 
uero exercitum in eos duxit, et quum praeualuisset, ipsos ad Oceanum usque fugienteis insequutus est. Postea uero quam illi continentem relinquentes in insulam quandam traiecere, quum ipse naues non haberet, circa regionem mansit, compactisque ratibus partem quandam exercitus aduersus eos misit, multos tamen ibi amisit.

Etenim terram quandam e regione insulae existentem, quum aduertisset militum illorum praefectus, eosque illuc adduxisset perinde ac pedibus transituros, ipse postea aestus reciprocantis ui coactus et subductus est, et illos deseruit. Ex illis autem alii quidem egregie se ulti occubuerunt. Publius uero Scaeuius, solus relictus, et scuto priuatus, ad haec multis uulneribus saucius, in aquam desiliit, ac demum enatauit.

[48] Atque haec quidem tunc sic euenere.

Postea uero Caesar, a Gadibus accersitis nauigiis, in insulam cum toto exercitu transiuit, ipsosque rei frumentariae penuria laborenteis sine pugna ad deditionem compulit. Atque inde cum ad Brigantium Callaeciae ciuitatem praeternauigasset, recto nauigiorum cursu, illos, qui nondum ad id tempus classem uiderant, exterruit, ac in potestatem redegit."

Hoc, quod heic narrat Dion Caesarem finitimorum Herminii ciuitates inuasisse, cum eo congruit quod ait Suetonius "Lusitanorum illum quaedam oppida hostiliter diripuisse, quanquam neque imperata detrectarent et portas aduenienti patefacerent." Sed quaenam Herminii pars heic intelligatur, mihi nondum satis liquet. Nam ex pecorum gregibus, et armentis, quae Romanis incolae separandi exercitus gratia obiiciebant, uidetur significari Stellae mons, ut ante dixi, pecorosus, quamquam pars illa uergens ad Meidubrigam oppidum non parum etiam pecoribus abundet.

Vxorum, filiorum, aliarumque rerum in pretio habitarum exportatio ultra Durium, ad Stellae montem Durio propinquiorem uidetur pertinere. Rursus fuga Herminiensium et Caesaris insequutio usque ad Oceanum, exposito priori loco monti magis conueniunt. Sed quaerendum utrobique, quaenam insula ista fuerit terrae contigua, ad quam siue pedibus siue natatu profugi transire potuerint, ad quam similiter et milites traiicere tentarint.

[49] Non fuisse Londobrin, quuius meminit Ptolomaeus, (Berlengam modo dicimus) indicio est distantia a continente non modica.

Et quum alia iuxta Lusitaniae totius litus nulla nostro aeuo extet, haec de qua Dion loquitor, uel incumbenti uiolentius mari abrasa, deletaque est, uel certe paeninsula illa oppidi Paenisci iuxta Atouguiam, erit intelligenda. Nam etiam nunc alueo quingentis passibus lato a continenti seiungitur, qui pedibus 
por um espaço de 500 passos de largura, que se atravessa a pé na maré-baixa, mas que quando ela sobe e a península se transforma completamente numa ilha, não é possível atravessar a vau. Talvez tenha sido bastante maior nessa época e pudesse estar rodeada por um mar profundo.

Em todo o caso, os piratas tinham conhecimento de que o sítio não era inabordável e, como a armada de César, dirigiram-se para ali. Foi esta a única razão por que Luís de Ataíde ${ }^{209}$, alcaide-mor desta zona e homem que merece ser falado mais longamente, depois de ter exposto perante o rei D. João III os perigos daquela costa, insistiu em que lhe fosse permitido levantar ali um forte muito sólido, preparado para um cerco, com baluartes e bem apetrechado de todo o equipamento necessário que diz o seguinte:

\section{PARA SEGURANÇA E EM MEMÓRIA}

de Manuel, rei da Lusitânia, Piedoso, Feliz, Invencível.

Seu Filho João III, rei da Lusitânia, Piedoso, Feliz, Invencível. [Construiu] este forte com baluartes para

defesa da cidadela e para manter afastados

da costa os piratas. A pedido e por diligência de

Dom Luís de Ataíde, alcaide-mor do termo de Atouguia. ${ }^{210}$

[50] Pareceu-me, para que não tenhamos de voltar ao mesmo assunto mais adiante ao fazer a história das cidades, e uma vez que se ofereceu a ocasião, que não era de omitir aqui um epigrama, qualquer que seja o seu valor, que eu próprio fiz em memória de tão grande homem:

Locais estes outrora devastados, salteadores do mar

Que tanta vez percorríeis os litorais e o oceano,

Ide doravante para outro lado e afastai-vos para bem longe do porto!

Velejai pelo mar imenso afastados daqui,

Enquanto Ataíde defender a nossa costa

Eis que permanecerá de pé esta mole gloriosa, soberba, ameaçadora. Não é dado aos piratas levar daqui despojos.

Nada vos é permitido roubar nesta região. ${ }^{211}$

E já bastante se disse sobre o Hermínio.

\section{A SERRA DE ANSIÃO}

Não li o nome do monte Tapieu em qualquer dos escritores antigos. Encontrei-o, porém, na biografia do presbítero S. Martinho de Soure ${ }^{212}$, escrita por Salviano, seu 
aestu cedente transitur, redeunte uero insula plane fit neque adiri uado potest. Et forte illo saeculo fuerit aliquanto maior.

Certe non importuosum esse locum, ut eo Caesaris classis adpellere, et in salo esse potuerit, piratae nouere. Qua una ex causa Ludouicus Athaidius, tractus eius toparcha, uir dignus, de quo sermo longior haberetur, apud Regem Ioannem tertium expositis illius orae periculis, institit, ut liceret illic sibi castrum firmissimum, operibus, propugnaculis omnique ad arcendos piratas necessaria supellectile munitissimum extruere. Cui huiuscemodi inscriptionem praefixit:

\section{SECVRITATI, ET MEMORIAE}

Emmanuelis. Lusitan. Regis. Pii. Fel. inuicti fil.

Ioannes III. Lusitan. Rex. pius fel. inuictus.

Castrum cum propugnaculis. ad oppidi Munimentum.

Atque ad arcendos ab ora maritima

Piratas. Petente, et curante Domino Ludouico

Athaidio, limitis Atougiaci toparcha.

[50] Eamque rem ne in historia urbium postea repeteremus, hic oblata occasione uisum est non praetermittere. Epigramma quoque in tanti uiri memoriam, hoc qualecumque est, ipsi fecimus:

Haec infesta prius, praedones saepe marini

Qui faciebatis litora, quique mare,

Ite alio posthac, longeque facessite portu;

Longe hinc per uastum uelificate salum.

Donec Athaidius nostram tutabitur oram,

Stabit et haec moles pulchra, superba, minax;

Piratis nullas datur hinc auertere praedas.

Nil rapere hac uobis in regione licet.

Ac de Herminio satis iam multa.

\section{DE TAPIAEO MONTE}

Tapiaei montis nomen apud scriptorum antiquorum quempiam non legi. Inueni tamen in uita Sancti Martini Sauriensis presbyteri, scripta a Saluiano alumno 
aluno e amigo, que descobri na página quadragésima sexta do livro de testamentos e vendas do Mosteiro dos Cónegos de Santa Cruz de Coimbra. [51] Quis anotar isto para recordar o santo homem que foi esquecido. Espero editá-la qualquer dia na mesma língua em que foi escrita para inspirar mais confiança ao leitor. Mas disto falaremos noutro sítio. O que interessa ao assunto de que tratamos é que o tal escritor, não importa quem, quando descreve, com escrúpulo quase supérfluo, o ópido de Soure, que está junto à rápida corrente do rio Soure, afluente do Mondego, diz o seguinte: "Dista da cidade dos Colímbrios, a sul, 18 milhas. A oriente ficam os cumes rochosos do monte Tapieu"213. E o que se segue. Mostra, por estas palavras, que o Tapieu é o monte a que chamamos, com fundamento no nome do ópido, Ansião, que se estende entre as povoações de Rabaçal e Pombal. É bem desagradável este monte para os que fazem viagem entre Tomar e Coimbra, devido ao caminho excessivamente pedregoso. É o que testemunhamos no poema dedicado a Lopo Centil, da maneira que se segue:

Assim trepei a tua encosta soberba, ó pedregoso Ansião. Assim, ó Tapieu, ofeguei, doente e curvado pela idade ao longo dos teus recantos penosos e sem sol. ${ }^{214}$

Segundo soube pelos naturais, dá-se ainda hoje o nome de Porto Tapieu à parte mais elevada do monte.

\section{O MONTE CÓRDOVA}

[52] O monte Córdova, na diocese do Porto, conserva ainda hoje abertamente o nome, com a particularidade de que, por ignorância, a gente inculta começou primeiro a designá-lo abreviadamente por Córdua e depois, com maior deturpação, por monte Corva ${ }^{215}$. Dele e das basílicas aí sitas do Salvador e de S. Miguel Arcanjo será feita referência especial na história dos feitos e da vida do bispo e confessor S. Rosendo ${ }^{216}$, que também um dia, com a ajuda de Deus, nos esforçaremos por trazer da obscuridade para o conhecimento público.

\section{A SERRA DO BUÇACO}

A serra do Buçaco, que se alonga da diocese de Coimbra pela de Viseu até à de Lamego onde se une a Montemuro, não tem outro título de glória que não seja o notável templo da Virgem de Arouca $^{217}$ e os seus rios, riquíssimos em bons peixes, tais como trutas, lampreias, sáveis, além de outras espécies vulgares. Estes 
eius familiari. Eam reperi in libro testamentorum uenditionumque Coenobii Canonicorum S. Crucis Conimbricensis, charta quadragesima sexta.

[51] Quod adnotare uolui, ut memoriam sancti uiri, quae interciderat, renouarem. Quam aliquando spero me editurum iisdem quibus scripta est uerbis, ut lectori maiorem fidem faciam. Sed de hoc alibi. Quod ad rem facit de qua agimus, scriptor ille qualisqualis est, quum oppidum Saurium iuxta decursum Anei fluminis in Mundam labentis paene superflua curiositate describit, ita ait: "Ab urbe Colimbrianorum decimo octauo Austrum uersus, distat milliario. Ad Orientem sunt Tapiaei montis saxosa cacumina." Et alia, quae sequuntur. Ex quibus patet Tapiaeum montem esse quem Ansidianum ab oppido nominamus, et inter Rapaciale et Palumbare oppida excurrit, quique a Thomario Conimbricam euntibus saxoso nimis itinere perquam molestus est. Quod nos in carmine ad Lupum Scintillam testati ita sumus:

Sic ereptaui cliuum lapidose superbum

Ansidiane tuum, sic per sine sole molestos

Anfractus Tapiaee tuos, uergente senecta

Aeger anhelaui.

Summum montis iugum supra Rapaciale oppidum, adhuc, ut ab indigenis didici, portus Tapiaeus dicitur.

\section{DE MONTE CORDVBA}

[52] Corduba mons in Portuensi dioecesi nomen adhuc uulgo retinet, nisi quod rusticorum inscitia, primum concise montem Corduam coepit appellare, postea deprauatius montem Coruam. De quo, et de basilicis in eo Saluatoris ac Sancti Michaelis Archangeli, particularis fiet mentio in rebus, ac historia Sancti Rodesindi episcopi et confessoris, quam etiam aliquando, Deo bene iuuante, ex tenebris in lucem proferendam curabimus.

\section{DE ALCOBA MONTE}

Alcoba mons ex Conimbricensi dioecesi, per Visensem protensus, in Lamecensi, Muro monti coniungitur, nulla re alia magis clarus, quam insigni Virginis Aroccensium parthenone, et fluuiis nobilium piscium troctarum, lampetrarum, alosarumque, praeter alia uulgata genera, feracissimis. Quorum tamen alii in 
rios, porém, vão misturar-se uns no Mondego, outros no Vouga e outros ainda no Douro, e ao perderem então os seus nomes engrossam outros caudais.

\section{AS SERRAS DO MARÃO, GERÊS, SOAJO E MONTEMURO}

Achei que o Marão, o Gerês, e o Muro, mais o Soajo se se quiser, deviam ser referidos apenas devido ao facto de cortarem a meio a província dos Brácaros tão rigorosamente que a parte que deles se estende até ao mar é chamada Entre Douro e Minho (existe um opúsculo, cuja leitura não é de desprezar, sobre as qualidades desta região, sua fertilidade, amenidade, salubridade) ${ }^{218}$, quanto à outra parte fica para lá destes montes, deixando à esquerda o Minho, sobe na direcção do oriente e é chamada vulgarmente a região de Trás-os-Montes.

[53] Parece, por outro lado, que estes montes são como que ramificações do monte Vínduo, de que Floro ${ }^{219}$ e Orósio ${ }^{220}$ fazem menção. Ptolomeu ${ }^{221}$ chama Víndio àquele que se estende largamente a partir dos Pirenéus a norte de Pamplona, cidade dos Cântabros, por Vitória, cidade do mesmo povo, e pelos Gémeos Ástures, até que se divide em duas pontas recurvadas: uma corre para o mar Cantábrico e cabo Finisterra; a outra, flectindo a sul, divide os Brácaros, como se disse, entrando na jurisdição da Lusitânia ${ }^{222}$, junto de Chaves, e logo depois recebe ao acaso nos diferentes lugares nomes também diferentes. 
Mundam, alii in Vaccam, in Durium alii se condentes, suorum nominum interitu, dant incrementum alueis alienis.

\section{DE MONTIBVS MARANO, IVRESSO, SVAIO ET MVRO}

Maranum, Iuressum et Murum, adde, si placet, Suaium ob id tantum referendos putaui quia Bracarorum prouinciam ita mediam secant, ut pars quae ab is tendit ad mare Interduriominia uocetur, de quuius regionis laudibus, fertilitate, amoenitate ac salubritate extat opusculum lectione minime indignum. Altera uero pars, quae ultra eos montes, Minio ab laeua relicto, Orientem uersus adscendit, Transmontana uulgo appellatur.

[53] Videntur autem hi montes quasi rami esse quidam montis Vindui. Cuius Florus et Orosius meminere. Ptolomaeus Vindium uocat qui ex Pyrenaeo supra Pompelonem, Cantabrorum urbem, per Victoriam eiusdem gentis ciuitatem, et Geminos Astures late excurrit, donec in duo diuisus cornua, altero Gallaicum petit Oceanum et Nerium promontorium; altero in meridiem flexus Bracaros, uti dictum est, dissecat, iuxta Aquas Flauias Lusitanam ingressus dicionem, ac uariis subinde locis nomina quoque uaria sortitur. 
(Página deixada propositadamente em branco) 
LIVRO SEGUNDO

LIBER SECVNDVS 


\section{OS RIOS}

A Lusitânia é irrigada por muitos rios, tal como não deixou de referir Estrabão: "A região de que falamos, diz ele, é rica e banhada por grandes e pequenos rios. Todos eles correm de Oriente e são paralelos ao Tejo. Na sua maior parte não só são navegáveis como ricos em areias de ouro"1. É tal a celebridade de alguns, como o Guadiana, o Tejo, o Mondego, o Ave, o Lima e o Minho, que parece supérfluo ocuparmo-nos em descrevê-los. Cada um tem, no entanto, certas particularidades que, segundo penso, não se tornarão aborrecidas para os leitores, como, por exemplo, a do Guadiana, que, apesar da tão grande massa de água, se enconde completamente em galerias subterrâneas por mais de uma vez e reaparece de novo com maior ímpeto em qualquer sítio, numa extensão de 40.000 passos $^{2}$. Graças à sua água e ao pasto, de tal modo pela própria força interior da natureza se desenvolve o gado, que na Hispânia deve ser atribuído o primeiro prémio de corpulência às manadas e bois da região do Guadiana ${ }^{3}$. Embora o rio seja muito rico em peixe, os seus peixes recomendam-se mais pelo tamanho [55] do que pela delicadeza do paladar. Sobem desde o mar até Mértola sáveis e lampreias, quer se acorde em chamar-lhes mustelas, quer se prefira chamar-lhes moreias fluviais, como as designa Tertuliano no Sobre a Tog $a^{4}$, ao referir a crueldade de Védio Polião, que mergulhava em viveiros escravos condenados à morte para que pouco a pouco se fossem esvaindo em sangue, sugados pelas moreias. Que de facto Septímio (Tertuliano) se referia às lampreias, indicam-no as palavras que subscreveu: "animais terrestres sem dentes, sem unhas, sem cartilagens" 5 . Na verdade, se se referisse às moreias marítimas, não seriam elas designadas por animais terrestres, além de que não são desdentadas mas antes muito acentuadamente providas de dentes. Sobem também o Guadiana de meados de Março até ao Estio avançado asturjões de razoável tamanho, mas raramente demasiado grandes para que dois cheguem para carregar um macho com albarda.

\section{INVESTIGAÇÃO SOBRE O ASTURJÃO 6}

Em boa verdade peço aos leitores o favor de não se indignarem por eu empregar neste meu livro a recente designação do excelente peixe, uma vez que não está perto do seu fim a discussão dos médicos ${ }^{7}$, os principais interessados, e dos eruditos que escreveram sobre peixes, nem ainda se concertaram em designação segura as opiniões dos que discordam uns dos outros.

Paulo Jóvio ${ }^{8}$, que se situa entre os que parecem aproximar-se mais da verdade, julga que é o "siluro", e de facto não poucos pormenores parecem dar-lhe razão se 


\section{DE FLVMINIBVS}

[54] Multis fluminibus irrigatur Lusitania. Id silentio non praeteriit Strabo: "Regio - inquit - de qua loquimur, felix est, et amnibus magnis, ac paruis irrigua. Qui omnes ab oriente pariter disiuncti a Tago sunt, et maiori ex parte nauigabiles, atque auri grumulis abundantes." Quibus Anae, Tagi, Mundae, Vaccae, Durii, Aui, Limiae, ac Minii tanta claritas est, ut in eis explicandis operam insumere superfluum uideatur, sunt tamen singulis quaedam peculiaria, quae lectoribus, ut opinor, non iniucunda sunt futura; ueluti Anae tanto flumini cuniculis se totum condere non semel, alicubi interstitio quadraginta millium passuum, rursusque impetu maiori renasci. Potu eius ac pastu, ingenita naturae ui adeo grandescere pecudes, ut Ananis armentis ac bobus, prima ex magnitudine palma, in Hispania tribuatur. Quumque piscosissimus amnis sit, pisces tamen eius non tam iucunditate saporis, [55] quam proceritate commendantur.

Myrtilin usque a mari subeunt alosae et lampetrae, siue mustellas eas, siue fluuialeis muraenas magis conueniat appellare, ut eas appellauit Tertullianus in libro De pallio, notata Vedii Pollionis immanitate, qui damnata mancipia uiuariis earum immergebat, ut muraenarum suctu paulatim absumerentur; et quidem lampetras Septimium intellexisse, indicant uerba, quae subdit: "Terrenae bestiae, exedentulae, exungues et excornes". Marinae siquidem muraenae, ut neque terrenae bestiae erant nuncupandae, ita neque exedentulae sunt, uerum dentatae etiam eminentius. Subeunt et Anam sub Eidus Martias, usque ad iam adultam aestatem, asturiones iusta magnitudine, sed raro maiores quam ut bini mulum onerent clitellarium.

\section{Disqvisitio De Pisce ASTVRIOne}

Peto uero a lectoribus hanc ueniam, ut isto nouicio excellentis piscis nomine heic me usum non indignentur, quando medicorum, quorum maxime interest, et eruditorum qui de piscibus scripserunt, concertatio adhuc finem non reperit, et dissidentium mutuo sententiae in aliqua certa appellatione, nondum conquiescunt.

Eorum qui magis ad ueritatem accedere uidentur, Paulus Iouius Silurum esse existimat, et sane sunt non pauca quae fidem uidentur facere, si e diuerso non 
inversamente não houvesse outros que são manifestamente contrários aos primeiros. Com efeito, desde que se reconheça que o asturjão, completamente desprovido de dentes - assim criado pela natureza porque não se alimenta de peixes -, não é, nem poderia ser, perigoso, este único argumento é o bastante para rejeitar [56] a hipótese de ser o siluro.

É que o siluro é um animal perigoso e, como escreve Plínio no capítulo décimo quinto do livro nono, "ataca onde quer que esteja, por cobiçar toda e qualquer presa e frequentemente arrasta para o fundo cavalos a nadar" 9 . Por outro lado, é vulgar que quando é apanhado com o anzol o despedace, pois morde com seus dentes duríssimos, tal como diz Aristóteles no capítulo trigésimo sétimo do livro nono da História dos Animais ${ }^{10}$. Nada se poderia evocar mais alheio ao asturjão do que os factos que acabamos de referir. Acresce que Aristóteles diz, no mesmo passo, que o siluro é um peixe do rio e Plínio secunda-o no capítulo décimo quinto do livro nono. Com efeito, depois de falar no grande porte dos atuns, diz: "Existem também nalguns rios peixes que em proporções não são inferiores, como seja o siluro do Nilo, o ésox no Reno, o átilo no Pó”; e no capítulo décimo sexto: "O siluro, entre os peixes fluviais, sofre com a chegada da canícula"; e também no capítulo décimo do livro trigésimo segundo: "...colocando por cima carne do siluro fluvial, que tanto nasce do Nilo como noutros rios, etc."11.

Também Estrabão no livro décimo sétimo ${ }^{12}$ dá a entender que o Nilo possui siluros em abundância. E a este respeito, se alguém depreender das palavras de Plínio, que anteriormente citei, que ele se refere ao "siluro fluvial», por existirem também siluros marinhos que sobem pelo curso dos rios, de diversos rios e não só do Nilo, será esclarecido por Estrabão que, no livro décimo quinto, o nega firmemente no que respeita ao Nilo, fundamentado-se em Aristóbulo: "Aristóbulo afirma ainda, diz ele, que, por causa dos crocodilos, nenhum dos peixes marinhos sobe o Nilo a não ser o sável, o mugem e o golfinho"13. Sobre o siluro, que é, por assim dizer, natural do Nilo, nada disse.

Assim, pois, é fluvial. Mas os asturjões são do mar alto, com a particularidade de, na expectativa de alimento mais rico, procurarem águas doces onde não só engordam, como, perdendo o sabor acre da água salgada, se tornam depois de cozinhados muito mais agradáveis ao paladar ${ }^{14}$.

[57] Guilherme Rondelet, no erudito e bem elaborado livro que publicou sobre os peixes ${ }^{15}$, sustenta que o actual asturjão foi o acipenser dos Latinos, o chamado onisco por Dórion ${ }^{16}$, escritor grego, e galáxia por Galeno ${ }^{17}$. Mas que responderia Plínio, que no capítulo décimo sétimo do livro nono diz: "O acipenser [esturjão], considerado entre os antigos como o peixe mais nobre e de todos o único com as escamas voltadas para a cabeça contrariamente ao movimento da natação, não goza agora de qualquer fama, o que na verdade me admira, porque é difícil de ser encontrado. Alguns chamam-lhe elops" 18 .

E que diremos de Plutarco? Este, no livro sobre $A$ actividade dos animais, ao afirmar que todos os peixes têm o cuidado de evitar que o vento batendo por detrás 
essent alia quae manifeste abrogarent. Nam cum asturionem fateatur, maleficum neque esse, neque esse posse, quia dentibus omnino careat, sic ab natura formatus, quoniam piscibus non alatur, hoc uno argumento, suam de siluro [56] opinionem tueri non poterit.

Nam silurus maleficus est, et ut scribit Plinius libro nono, capite decimo quinto "grassatur ubiquunque est, omne animal adpetens, et equos innatanteis saepe demergens". Ad haec, hamo prehensus, morsu durissimi dentis saepe hamum frangit, ut in nono Historiae animalium capite trigesimo septimo inquit Aristoteles. Quibus nihil alienius ab asturione commemorari potest.

Praeterea eodem loco Aristoteles silurum fluuiatilem piscem esse ait, quem sequitur Plinius libro nono capite decimo quinto. Quum enim de thynnorum magnitudine esset locutus: "Sunt - inquit - et in quibusdam amnibus non minores, silurus in Nilo, esox in Rheno, attilus in Pado". Et capite decimo sexto: "Fluuiatilium, silurus caniculae exortu sideratur. Libro quoque trigesimo secundo, capite decimo: "Siluri fluuiatilis, qui et alibi quam in Nilo nascitur, carnes impositae", etc.

Strabo etiam libro decimo septimo siluris abundare Nilum ostendit. Quod siquis propter Plinii uerba postremo a me posita, "siluri fluuiatilis", ideo dictum existimet, quia sint et marini, qui tamen amnes adscendant, tum alios, tum etiam Nilum, id Strabo de Nilo constanter negat Aristobuli auctoritate libro decimo quinto: "Tradit etiam - inquit - Aristobulus nullum ex marinis piscibus in Nilum recurrere, praeter alosam et mugilem et delphinum, propter crocodilos." De siluro tanquam Nili indigena nihil dixit.

Fluuiatilis ergo est. Asturiones uero pelagici, nisi quod pinguioris pabuli gratia, dulceis petunt aquas, quibus et pinguescunt et salsuginis deposita tristitia in obsoniis longe suauiores gustui efficiuntur.

[57] Gulielmus Rondeletius, laborioso, et docto, de piscibus edito uolumine, qui nunc asturio est, acipenserem Latinis fuisse contendit, Dorioni Graeco auctori oniscon dictum, galaxiam Galeno. Sed quid respondebit Plinio, qui libro nono capite decimo septimo ait: "Apud antiquos piscium nobilissimus habitus acipenser, unus omnium squamis ad os uersis contra aquam nando meat. Nullo nunc in honore est quod quidem miror, cum sit rarus inuentu, quidam eum elopem uocant."

Quid etiam Plutarcho? Qui in libro De industria animalium, quum dixisset pisces omneis cauere, ne uentus a tergo incumbens squamas surrigat, cieatque, 
lhes levante as escamas e as agite, acrescenta: "Por consequência, isto é comum a todos os peixes com excepção do acipênser. Este circula a favor dos ventos e das correntes, porque receia que as escamas se voltem, pois a implantação destas dá-se no sentido da cabeça" ${ }^{19}$. Onde estão, portanto, as escamas no asturjão? Isto só para não falar delas como voltadas para a cabeça.

Quanto a mim, não posso concordar com Rondelet que pretende pôr ponto final à discussão, argumentando que isso fora dito por aqueles que pensam ser o acipenser e o elops o mesmo peixe. Esse peixe, quer Plínio o tenha conhecido ou não, é aquele a que os modernos deram o nome de esturjão, e deixemos Plutarco de lado. Mas não parece crível que Plínio o não tenha conhecido, porque tal peixe é natural de todos os mares e de quase todos os rios, além de hóspede assíduo quer do mundo romano quer sobretudo da própria Itália. Se o conhecia e o peixe era o acipenser, quem poderia ignorar que não tinha escamas? Como pode então atribuir ao acipenser não apenas escamas mas ainda para mais voltadas para o lado da cabeça?

Bem entendido que dormia ao consignar tais afirmações por escrito. Talvez não conhecesse por ser difícil de encontrar, o que é sem dúvida verdade no que diz respeito ao acipênser. Com efeito, é muito mais raro de ser capturado, tal como testemunha Cícero no livro Sobre o destino, segundo afirma Macróbio no livro terceiro das Saturnais. É que este livro de Cícero chegou-nos incompleto. As suas palavras indicam que o acipenser [58] também lhe era desconhecido, pois ao dizer que um deles tinha sido oferecido a Cipião acrescenta: “. . .só muito raramente é apanhado, segundo dizem, ilustre entre todos ou superior aos outros todos" ${ }^{20}$. Plutarco, já na citada obra, ao falar acerca do ântias, peixe sagrado segundo Homero, diz: "Erastótenes parece referir-se à dourada ao dizer: 'veloz, dourado nas sobrancelhas, peixe sagrado'. Muitos lhe chamam acipenser. Este só é apanhado rara e dificilmente, embora se veja com frequência junto da Panfília"21. Marcial também diz que é raro:

Enviai o acipenser para as mesas do Palatino,

Que dádivas raras ornem banquetes dignos de deuses. ${ }^{22}$

Mas quem pode acreditar em Plínio e Cícero ou mesmo em Marcial, aceitando que seja raramente apanhado um peixe tão familiar ao Pó e ao Tibre, para só falar destes rios? E, além disso, o acipenser não apenas é muito raro como, numa só palavra, estrangeiro.

Ovídio, no Tratado sobre a pesca, disse:

E tu, nobre acipenser, de águas estrangeiras ${ }^{23}, \ldots$

Mas há a lamentar que o seu livrinho fragmentado nos abandone neste verso, pois talvez fôssemos mais amplamente documentados todos sobre o acipênser. 
addidit: "Hoc igitur commune piscium est omnium, acipensere tantum excepto, secundum uentos et fluctus meat hic, squamae uulsionem ueritus, ut quarum commissuras ad hos uersas habet." Vbi enim squamae in asturione? ut de conuersis ad os sileam.

Nam quod Rondeletius litem se diremisse autumat, respondens, dictum esse hoc ab iis qui acipenserem eundem esse cum elope existimarint, equidem probare non possum. Piscem hunc, cui asturioni nomen fecerunt neoterici, aut norat Plinius, aut non norat. Plutarchum praetereamus. Non nosse, uerissimile non uidetur, cum esset omnium marium indigena, et amnium fere omnium, quum in Romano orbe, tum uero in ipsa Italia hospes assiduus. Si norat, et is acipenser erat, qui poterat squamas eum non habere ignorare? Quomodo ergo acipenseri, non modo squamas, uerum ad os uersas attribuit.

Videlicet dormiens literis ista mandabat. Non norat fortasse, quoniam rarus inuentu esset. Ita certe acipenser. Admodum enim raro capi, etiam in libro De fato, Cicero testis est, ut asserit in tertio Saturnalium Macrobius. Nam nos eum Ciceronis librum imperfectum habemus. Cui ignotum quoque fuisse Acipenserem indicant [58] ipsiusmet uerba. Etenim cum allatum ad Scipionem dixisset: "Raro, inquit, admodum capitur, sed est piscis, ut ferunt, in primis nobilis". Et Plutarchus ipso in libro de anthia sacro pisce apud Homerum: "Eratosthenes inquit - auratam uidetur, pernicemque supercilio flauente, sacrumque dicere. Multi acipenserem. Nam et hic rarus est et aegre capitur. Conspicitur autem circa Pamphyliam saepe". Martialis quoque rarum dicit:

Ad Pallatinas Acipensem mittite mensas, Ambrosias ornent munera rara dapes.

Quis autem uel Plinio, uel Ciceroni, uel etiam Martiali credat, raro capi eum piscem qui Pado, qui Tyberi, ut nihil amplius dicam tam familiaris sit? Acipenser autem non tantum rarus admodum, sed etiam omnino peregrinus.

In Halieutico dixit Ouidius:

Tuque peregrinis acipenser nobilis undis.

Sed dolendum quoniam in hoc uersu fragmentum eius libelli nos destituit. Forte enim de acipensere plenius instrueremur. Illud tamen satis est, peregrinum 
Basta, porém, que o poeta chame ao peixe "estrangeiro" para que este atributo não convenha de modo algum ao esturjão, peixe tão familiar.

"O acipênser não tem escamas", diz Rondelet ${ }^{24}$. Isto nunca se deduzirá da leitura de Plínio, de Nigídio Fígulo (o maior investigador das questões naturalistas, como lhe chama, em sinal de consideração, Samónico Sereno, no livro quarto de Macróbio)25, de Plutarco, de Macróbio e do próprio Sereno, que comeu frequentemente o acipênser nos festins do imperador Severo e que confirmou ser por Nigídio considerado verdadeiro o que Plínio diz sobre as escamas voltadas para o lado da cabeça ${ }^{26}$.

[59] Ora, segundo a opinião de Arquéstrato, referida em Ateneu ${ }^{27}$, o gáleo ródio é o peixe a que se chamava, entre os Romanos, acipenser, e que era levado para os banquetes por escravos coroados e no meio de coroas e de flautas. Que assim seja, pois. Mas Rondelet devia ter feito compreender, e não o fez, que o asturjão era o gáleo de Rodes e que era ele que chegava às mesas com tão grande pompa. No entanto, aquele famoso gáleo ródio parece identificar-se mais com o elops. De facto, Columela ${ }^{28}$ e Eliano ${ }^{29}$ dizem que o elops, que vive apenas no profundo mar panfílico, não é capturado senão rara e dificilmente. Gélio ${ }^{30}$, fundamentado em Varrão, diz, no capítulo décimo sexto do livro sétimo, que os Romanos deram ao ródio o nome de acipenser, para que o gáleo ródio e o elops sejam o mesmo peixe. Eis porque Plínio nos diz que alguns chamaram elops ao acipenser; e entre estes conta-se, segundo Ateneu ${ }^{31}$, o gramático Apião.

Teodoro de $\mathrm{Gaza}^{32}$, homem não menos erudito em latim do que em grego, e que se dispôs, sempre que isso pudesse ser feito, a verter regularmente para latim os nomes gregos, traduziu elops, referido por Aristóteles na História dos Animais, capítulo décimo terceiro do livro segundo, por acipenser. Aristóteles, com efeito, tratando das guelras dos peixes, escreve o seguinte: "Uns têm duas de cada lado, umas simples e outras duplas, como o congro e o sargo; outros têm quatro guelras simples de cada lado como o acipenser, o peixe-serra, a moreia e a enguia"33. Ora, se tivéssemos a certeza de que o acipenser era o mesmo que o elops, como traduziu Teodoro e como disseram muitos gregos, apenas esta descrição das quatro guelras nos seria suficiente para se dever excluir do nome de acipenser o asturjão.

O facto é que, em vez deste grande número, as suas guelras são tão exíguas, simples e dissimuladas, que mais se deve pensar que as não tem. Refresca-se, porém, pelas narinas e expele água, que absorve, pela abertura da boca que se apresenta sempre aberta e alargada para a frente. Mas os Gregos teriam visto se o elops, rodio ou panfílico, [60] ou o "gáleo" ródio eram ou não o acipenser. A verdade é que tanto o acipenser como o elops são estrangeiros. Ovídio, no livrinho acima referido, diz o seguinte:

E o precioso elops desconhecido das nossas águas.

E tu, nobre acipenser, de águas estrangeiras ${ }^{34}$. 
uocasse piscem, ut ea peregrinitatis appellatio asturioni conuenire nullo modo queat, pisci perquam domestico.

"Caret squamis acipensera", inquit Rondeletius. Hoc nunquam euincet per Plinium, neque per Nigidium Figulum naturalium rerum maximum indagatorem, ut eum honoris causa uocat apud Macrobium Serenus Sammonicus, neque per Plutarchum, neque per Macrobium ipsumque Serenum, qui in Seueri principis conuiuio acipenserem crebro esitarit, et quae de squamis ad os uersis a Plinio dicta sunt, uera esse ex Nigidio confirmarit.

[59] At ex Archestrati sententia, Athenaeo referente, galeus Rhodius idem est cum eo qui apud Romanos cum tibiis et coronis, coronatisque ministris cenis inferebatur, uocareturque acipenser. Sit ita sane. Sed ostendendum erat Rondeletio asturionem galeum esse Rhodium, eumque esse qui tanta pompa ad mensas deueniret. Quod ille non facit. Imo ille ipse galeus Rhodius, potius idem esse cum elope uidetur. Nam elopem, quem in profundo tantum Pamphylio mari pasci, nec nisi raro ac uix capi, aiunt Columella, et Aelianus Rhodium quoque esse ostendit ex Varrone Gellius libro septimo capite decimo sexto, ut galeus Rhodius, et elops Rhodius idem piscis sit, a Romanis dictus acipenser.

Vnde et Plinius acipenserem quosdam uocasse elopem dixit. Inter quos fuit Appion grammaticus, ut refert Athenaeus.

Theodorus Gaza, homo non minus Latine quam Graece eruditus, quique Graeca nomina semper Latine, quoad fieri poterat, reddere conatus est, apud Aristotelem De bistoria animalium libro secundo capite decimo tertio elopem acipenserem transtulit. De branchiis enim piscium agens Aristoteles, ita scribit: "Aliis binae utrinque alterae simplices, alterae duplices, ut congro et scaro. Aliis quaternae utrinque simplices, ut acipenseri, dentici, muraenae, anguillae." Quod si certi essemus eundem cum elope esse acipenserem, ut uertit Theodorus, et multi dixere Graecorum, haec una quaternarum branchiarum nota, satis nobis erat, ad excludendum ab acipenseris nomine asturionem.

Etenim pro ea mole, tam exiguae, simplices, et opertae illi branchiae sunt, ut branchiis carere sit potius existimandus. Naribus autem refrigeratur, et quam haustu collegit aquam, eam illo semper patentis proni oris foramine reiicit. Verum sit ne idem elops Rhodius, uel Pamphylius, [60] siue galeus Rhodius cum acipensere, uiderint Graeci. Certe tam elops, quam acipenser peregrini sunt. Ouidius in superius citato libello sic ait:

Et pretiosus elops nostris incognitus undis.

Tuque peregrinis acipenser nobilis undis. 
Plínio, sugestionado por estes versos de Ovídio, disse, no fim do livro trigésimo segundo ${ }^{35}$, que se enganavam os que pensavam que o elops era o acipenser, peixes diferentes se bem que um e outro estrangeiros.

O asturjão, por seu lado e como se disse anteriormente, é tão frequente, não só no Pó e no próprio Tibre como em todos os rios do mundo romano, pelo menos nos grandes, que seria atitude pouco prudente atribuir ao asturjão o que foi dito sobre o acipenser ou elops e pensar que Nigídio, Cícero, Plutarco, Plínio e outros menos importantes do que estes, muito embora eruditos, se enganaram tão puerilmente.

Se o acipenser for, pois, se quisermos, cartilagíneo e se tiver o corpo triangular como Rondelet sustenta, desde que seja pequeno como diz Ateneu e desde que seja estrangeiro, somente originário do mar panfílico ou ródio e não de alhures, e que rara e dificilmente seja capturado, então não pode ser de modo algum o asturjão, que é peixe vulgaríssimo. É isto que deve ser respondido a Rondelet.

Hermolau Bárbaro ${ }^{36}$, célebre pela glória de se dedicar a estudos nobres, ao ser interrogado sobre isto por Paulo Cortesi ${ }^{37}$, respondeu em carta que o asturjão foi na antiguidade a ica de que fala Ateneu ${ }^{38}$, tendo sido levado a esta conjectura por ica significar porquinho e sobretudo porque o asturjão pequeno é ainda chamadoporceleto pelos Italianos, nome sem dúvida formado pelo diminutivo de porco ou porquinho. Santo Ambrósio apoia esta opinião, quando diz no Sermão de Domingo da Paixão: "o comilão ou glutão gosta de leitão para o comer" ${ }^{39}$; [61] e no Hexámeron, afirma que os Judeus se alimentam de porco-marinho, embora se abstenham dos terrestres ${ }^{40}$. Esta conjectura não é tão fraca quanto a considerou Jóvio ${ }^{41}$. No entanto, se nos parecer fraca, podemos fortalecer-nos com as palavras de Santo Isidoro, escritor que nem é estrangeiro nem tão-pouco desconhecido que seja de desprezar.

Este, no livro décimo segundo das Etimologias, no capítulo Sobre os peixes, descreve assim, expressamente e sem quaisquer possibilidades de dúvida, o actualmente chamado esturjão pelos Italianos: "Os porcos-marinhos são vulgarmente chamados suilhos, porque enquanto procuram o alimento foçam na terra sob as águas como os porcos. É que têm a função da boca junto à goela e se não mergulham o focinho nas areias não apanham alimento" 42 .

Não podia apresentar a questão por forma mais simples nem mais evidente. O peixe tem um focinho oblongo como os proboscídeos e sob o queixo, junto à goela, um buraco, mais do que uma boca, sem dentes nem maxilas. Por isso the é necessário mergulhar o focinho no lodo, no fundo do rio, enquanto come, senão, por outra forma nada agarrará. E com isto acontece que, quando se alimenta, o limo revolvido no fundo ao atingir a superfície mostra aos pescadores que ele se esconde naquele sítio. Portanto, Isidoro representou-nos bem o peixe e nem deixou de referir aqui o nome que todos nós os Hispânicos usamos. Chamamos-lhes, com efeito, suilhos ou, para falar pura e lusitanamente, "solhos".

No entanto, se não tiverem confiança no testemunho de Isidoro os que não o consideram como digno de crédito no que respeita as diversas opiniões sobre o siluro, o onisco, a galáxia e o acipenser, que não lhes pareça tão-pouco absurdo que 
Quibus Ouidii carminibus adductus Plinius, in fine libri trigesimi secundi falli eos dixit qui elopem acipenserem existimassent, quum diuersi sint, licet, et hic, et ille peregrinus.

Asturio autem, ut ante dictum est, in omnibus Romani orbis fluminibus, paulo tamen maioribus, atque in Pado ipsoque Tyberi tam frequens est, ut parum considerati fuerit hominis, quae de acipensere siue elope dicta sunt, asturioni tribuere, et Nigidium, Ciceronem, Plutarchum, ac Plinium, illisque minores, doctos tamen et antiquos, tam pueriliter esse hallucinatos existimare.

Acipenser igitur sit, si placet, cartilagineus, sit triangulari corpore, ut eum contendit esse Rondeletius, dummodo sit paruus, ut ait Athenaeus, dummodo peregrinus, nec alibi, quam in Pamphylio, uel in Rhodio mari, et raro ac uix captus, asturio certe uulgatissimus piscis esse non potest. Atque haec responsa sint Rondeletio.

Hermolaus Barbarus nobilium studiorum gloria insignis, a Paulo Cortesio sententiam rogatus, per epistolam respondit asturionem antiquitus hyccam fuisse Athenaei testimonio, hac adductus coniectura, quod hycca porculum significet, et asturio praesertim adhuc paruus "porcelletus" ab Italis nominetur, a porco uel porculo sane per diminutionem facto nomine. Quuius opinionem Diuus iuuat Ambrosius, in Dominicana Passione, cum dicit: "Gutto siue gulo porcellum amat, ut comedat". [61] Et in Hexamero, Iudaeos marinis porcis uesci dicit, quum terrestribus abstineant. Quae coniectura non tam frigida est, quam eam Iouius existimauit.

Si tamen frigida uideatur calefaciamus nos eam uerbis Isidori scriptoris, neque externi neque tanquam ignobilis contemnendi. Is Etymologiarum libro decimo segundo, capite de piscibus, diserte et sine ulla ambiguitate, asturionem modo Italis uocatum, ita describit: "Porci marini, qui uulgo uocantur suilli, quod dum escam quaerunt, more suis terram sub aquis fodiunt. Circa guttur enim habent oris officium, et nisi rostrum arenis immergant pastum non colligunt."

Non potuit neque planius neque euidentius res aperiri. Rostrum habet piscis oblongum, instar proboscidis, sub mento circa guttur foramen, magis quam os, dentes autem nullos neque maxillas. Quare dum pascitur rostrum limo, soloque aluei, ut immergat, necesse est, nihil alioqui comprehensurus. Eoque fit ut cum pascitur, limi reuolutio e fundo ad summam aquam pertingens indicium latentis eo loci faciat piscatoribus. Bene igitur piscem nobis expressit Isidorus. Nec tacuit nomen hoc, quo Hispani omnes utimur. Suillos enim appellamus, siue, ut mere Lusitane dicam, "soilhos".

Quod si de Isidori fide dubitabunt, quibus is auctor idoneus non uidetur, inter uarias de siluro, onisco, galaxia et acipensere sententias, ne uideatur absurdum, si etiam nos scrupulum doctis iniiciamus, adductis duobus piscium generibus, 
nós próprios objectemos com algumas dúvidas aos especialistas, ao apresentarmos duas espécies de peixes que podem parecer, com inteira propriedade, tratar-se de asturjões. Entre os peixes do Nilo, o primeiro a ser enumerado por Estrabão ${ }^{43}$ é o oxirrinco, assim chamado geralmente por ter um focinho oblongo e agudo. É incontestável que assim se afiguram na verdade os focinhos dos asturjões e não é menos certo que a sua pesca é frequente no Nilo.

[62] No Danúbio e também no Dniepre é apanhado um peixe a cujo respeito Plínio no capítulo décimo quinto do livro nono recorda: "E no Danúbio é retirado do mar um peixe muito semelhante ao porco-marinho, e no Dniepre fala-se do seu tamanho notável, sem que tenha ossos nem espinhas entremeadas e da sua carne agradabilíssima" ${ }^{4}$. Gelénio emenda este passo e, em vez de "é retirado do mar", põe "é retirado o mario", de modo que este peixe, que não tem ossos nem espinhas, se chame marião. Aproveitou a ocasião para emendar, primeiro porque estando a ser ali referidos peixes fluviais não parecia haver lugar para um peixe marinho, em segundo lugar porque os Italianos dão ao porco-marinho, conhecido para efeitos de salmoura, o nome semilatino de morone. Jóvio ${ }^{45}$ chama morone, entre as salmouras bem fortes, aos pedaços muito avermelhados de um peixe que lhe é desconhecido.

Mas se de facto quisermos conservar a antiga lição, observemos que Plínio o deixou sem nome, mas que nos deu as suas características, como sejam a grande semelhança com o porco-marinho e o facto de ser pescado no Danúbio e no Dniepre, é verdade, mas retirado do mar. Bem entendido, sobe o Danúbio e o Dniepre saído do mar. Pouco interessa, contudo, qual das duas interpretações sigamos, a não ser que a lição de Gelénio é mais agradável e um pouco mais forçada, "é retirado do mar", com o sentido de "é arrastado do mar", muito embora nem assim o período inteiro deixe de me parecer suspeito. Sinto a falta da ligação e da harmonia na frase pliniana, que aqui me parece frouxa e descuidada. Por isso, até que alguém emende com mais sucesso este passo, hei-de lê-lo assim:

"E no Danúbio, tal como no Dniepre, é retirado o marião, muito semelhante ao porco-marinho. É celebrado principalmente pelo tamanho, sem ossos nem espinhas entremeadas e de carne agradabilíssima."

Procura-se, por conseguinte, o sentido de celebrar neste peixe sobretudo o seu volume, sem ossos nem espinhas entremeadas, mas de carne muito saborosa. De resto, Hermolau no Corolário ${ }^{46}$, no capítulo sobre o homotárico, é de opinião que este peixe, seja ele referido sem nome, seja ele o marião, é o antaceu, assim chamado por causa do rio que corre da região dos Antecatos para o mar de Azof. Estrabão conta, no livro décimo sétimo ${ }^{47}$, que estes peixes são do tamanho de golfinhos. Heródoto, porém, no livro quarto ${ }^{48}$, ao falar sobre o Dniepre diz que tem este rio uns peixes, cetáceos pelo tamanho, desprovidos de espinhas, que são óptimos também para a salga. Pois bem. É sabidíssimo que circulam por toda a Itália as salmouras do Dniepre, Ruão e [63] Don: o vulgarmente chamado caviar, que são as ovas depois 
qui asturiones non inepte uideri queant. Ex Niliacis piscibus, a Strabone primo loco numeratur oxyrinchus, ex eo utique dictus quod oblongum atque acutum rostrum habeat. Talia uero esse asturionum rostra indubitatum, nec minus certum frequentem in Nilo esse capturam.

[62] In Danubio quoque ac Borysthene piscis capitur, quuius ita meminit Plinius libro nono, capite decimo quinto: "Et in Danubio, mari extrahitur porculo marino simillimus, et in Borysthene memoratur praecipua magnitudo, nullis ossibus spinisue intersitis, carne praedulci."

Emendat eum locum Gelenius, et pro, "Mari extrahitur", reponit "Mario extrahitur", ut hic piscis ossibus ac spinis carens, Mario uocetur.

Emendandi occasionem sumpsit partim ex eo, quod quum illic fluuiatici pisces referantur, marino locus esse non uidebatur, partim quod hunc Itali, quibus ob salsamenta notus est, moronem adhuc semilatino appellent nomine. Iouius inter salsamenta praedura, ualdeque rubentia ignoti sibi piscis frusta, moronem uocat.

Sed enim si tueri ueterem lectionem uelimus, intelligemus Plinium innominatum reliquisse, signa autem dedisse maximae cum marino porculo similitudinis, et capi quidem in Danubio ac Borysthene, uerum a mari extrahi.

A mari enim tractus Danubium ac Borysthenem subit. Vtro autem modo legamus non multum refert, nisi quod Gelenii lectio blandior est, "mari extrahitur", pro "trahitur ex mari", et paulo coactior. Quanquam nec sic tota periodus mihi non suspecta est. Desidero enim Plinianae dictionis iuncturam, et concinnitatem, quae languida ac dissoluta heic uidetur. Quare donec alius me felicius locum emendet, ego ita legerem:

"Et in Danubio Mario extrahitur, Porculo marino simillimus, et in Borysthene. Memoratur praecipue magnitudo nullis ossibus, spinisue intersitis, carne praedulci."

Hoc uidelicet sensu: praecipue memorari in eo pisce magnitudinem sine ossibus, sine spinis intersitis, carne autem praedulci. Ceterum hunc piscem, siue innominatum siue marionem dictum, Hermolaus in Corollario capite de homotaricho, antacaeum existimat, sortitum nomen hoc ab amne qui in Maeotin ex regione Antacarum influit. Eos pisces delphinibus magnitudine pareis libro decimo septimo Strabo asserit. Herodotus autem libro quarto de Borysthene agens, magnitudine cetaceos, spinis carentes, et ad salsuram dicit optimos. Atqui a Borysthene, Phasi et [63] Tanai, salsamenta, ex Asturionum ouis salitis: cauiaria uulgo dicta, et ex dorsuali parte quae uocatur schinalia et pleuras, id 
de retiradas dos esturjões, a esquinália, feita da parte dorsal, as pleuras, que provêm dos flancos, e a hipocélia, da região abdominal e genital ${ }^{49}$.

Hermolau ${ }^{50}$ garante que esta salmoura, que todos reconhecem ser do esturjão, é feita da ica ou isca, isto é, do porco-marinho. Diz, porém, que na Itália a ica ou isca é, por comum acordo, chamada de esturjão. Reflictam pois e julguem os eruditos se o oxirrinco de Estrabão ${ }^{51}$, o marião ou peixe sem nome de Plínio ${ }^{52}$, que Hermolau compreendeu como sendo o antaceu, o próprio antaceu de Estrabão ${ }^{53} \mathrm{e}$ de Heródoto ${ }^{54}$, a ica ou isca de Ateneu $^{55}$ e o pórculo não serão, em última análise, o mesmo peixe agora chamado esturjão ou asturjão.

Mas se o marião ou o peixe sem nome de Plínio é o porco-marinho ou outro muito semelhante, não no-lo explica muito claramente o mesmo Plínio. Para mim é suficiente que este peixe sem nome, ou marião ou antaceu, seja caracterizado sem ossos, nem espinhas, mas de carne agradabilíssima e muito semelhante ao porcomarinho. Em verdade já considero a partir deste momento que o porco-marinho carece de ossos e espinhas e que tem uma carne muito saborosa. Quem ignora que o asturjão seja assim, é porque nunca viu nem saboreou um asturjão.

Se alguém, todavia, objectar que o asturjão não é inteiramente desprovido de alguns ossos, por exemplo, na cabeça, responder-lhe-ei que estes não são de modo algum verdadeiros ossos, mas uma cartilagem calosa, e que se o peixe for adulto terá esses ossos um pouco mais duros, mas que isso é tão pouco acentuado que não devem ser considerados verdadeiros ossos. Quanto a ser o mesmo que o marião, ou o antaceu ou o porco-marinho, ou se, pelo contrário, é outro diverso, mas muito semelhante, admita-se que já Isidoro nos elucidou correctamente ${ }^{56}$.

Tantos nomes para um só peixe, dir-se-á! Que esta grande quantidade de nomes não perturbe ninguém. Sabiamente agiu Plínio no passo anteriormente citado. Será conveniente, com efeito, usar na maior parte dos nomes as formas gregas, porque, conforme as regiões, assim os designam por uns e outros nomes. No Egipto, por exemplo, chamaram-lhe oxirrinco por causa da forma do focinho; os povos Antaces junto do Dniepre e do mar de Azof deram-lhe o nome, que lhes é familiar, de antaceu; os Gregos [64] preferiam ica ou isca e os Romanos pórculo ou porco pela razão que apresentou Isidoro.

O extensíssimo reino do Congo na Etiópia ${ }^{57}$ converteu-se à religião de Cristo, vindo de uma religião em que se adoravam ídolos, pela acção e esforço dos mui piedosos reis de Portugal, e nessa religião persiste com admirável devoção. Segundo dizem os habitantes, um braço do Nilo, desmembrado logo nas próprias nascentes, precipitase, mais do que corre, com tal caudal de água e tão grande corrente que excede em largura os 12.000 passos, com um leito de uma profundidade incomensurável. Nele se criam os mesmos peixes e os mesmos animais que naquele braço que corre através do Egipto, peixes contudo mais compridos e todos mais desenvolvidos quanto ao volume dos corpos. Aí se encontram, em proporções gigantescas, não só crocodilos como hipopótamos, como ainda, por todo o rio, grande número de outros peixes vulgares no Nilo. 
est, latera, et hypocaelia, id est, abdominis pubisque partes, per totam Italiam circunferri, uulgatissimum est.

Ea salsamenta, quae ex Asturione esse omnes fatentur, Hermolaus ex hycca, uel hysca, id est porculo marino constanter affirmat. Hyccam autem, siue hyscam sturionem Italiae consensu ait appellari. Considerent igitur et expendant eruditi, num Oxyrinchus Strabonis, Mario, siue innominatus Plinii piscis, quem Antacaeum Hermolaus interpretatur, ipseque Strabonis, et Herodoti Antacaeus, hycca, siue hysca Athenaei, et porculus, idem omnimo piscis sit, sturio, siue asturio modo uocatus.

Verum mario, uel innominatus Plinii piscis, sitne idem qui marinus porculus, an alius illi simillimus liquido nobis non distinxit Plinius. Mihi satis est innominatum hunc, uel marionem, siue antacaeum, sine ossibus, sine spinis, carne autem praedulci, ac simillimum marino porculo indicari. Iam enim hinc habeo porculum marinum ossibus, ac spinis carere, et praedulci esse carne. Isthaec sturioni inesse qui ignorat asturionem neque uidit neque gustauit.

Si uero quis obiiciat asturioni ossa quaedam minime deesse, uidelicet in capite, huic respondero ea nequaquam uera esse ossa, sed callosam quandam cartilaginem, aut si senior piscis est eaque ossa habeat duriuscula, id tam pusillum est, ut pro non ossibus merito habenda sint. Si uero idem est mario et antacaeus et porculus marinus, imo etiam si diuersus est, simillimus tamen, relinquitur recte nos docuisse Isidorum.

Tot nomina, inquiet aliquis, uni pisci? Neminem ea nominum multitudo conturbet. Sapienter enim Plinius loco ante citato. Graecis [64] enim in plerisque nominibus, uti par erit, quando aliis atque aliis eosdem diuersi appellauere tractus. In Aegypto itaque a rostri effigie oxyrinchum dixere ad Borysthenem et Maeotim Antacae gentes sibi domestico Antacaeo nomen fecere. Hyccam Graeci uel hyscam maluerunt. Latini porculum, et porcum nominis ab Isidoro reddita ratione.

Congi latissimum in Aethyopia regnum, cum suis regibus, opera et studio pientissimorum Lusitaniae regum, ab idolorum cultu conuersum est, et in Christi religione mira pietate perseuerat. Per eius medium, ut ferunt incolae, Nili brachium ab ipsis statim fontibus diuisum, tam uasta magnitudine ac tanto impetu non modo fluit, uerum etiam rapitur, ut duodecim millia passuum latitudo excedat, alueo ad immensitatem profundo.

In eo iidem pisces, eademque animalia gignuntur quae in brachio illo quod per Aegyptum meat, proceriora tamen et corporum mole auctiora omnia. Immanes ibi et crocodili, et hyppopotami, et aliorum Nilo domesticorum piscium maxima toto flumine multitudo. 
Há também grande abundância de asturjões, que são no entanto pertença do rei. É um crime capital não levar o peixe real, quando capturado, ao rei, que depois o oferece a quem quiser. Chamam-lhe angulo, que quer dizer porco, mas, para distinguir, dizem angulo amazi, ou seja porco das águas ${ }^{58}$.

Daqui sugerem-se-me duas reflexões: a primeira é que os oxirrincos do Nilo egipcíaco parecem-me ser os asturjões apanhados neste braço etiópico. Com efeito, aqui como ali, penetram e nascem os peixes habituais no Nilo, sendo encontrados os mesmos animais. E este argumento não deve parecer fútil porque Plínio o utiliza duplamente no capítulo nono do livro quinto ${ }^{59}$, quando ao falar da nascente do Nilo diz: "Descobrem-se aqui os mesmos peixes do lago Nílides, lampreias, coracinos, siluros e também crocodilos". Daqui, graças a este argumento sobre a nascente do Nilo, que se imaginava escondida ora logo a seguir ora a alguns dias de viagem, há-de ele concluir que irrompe o rio por entre o povo dos Masséssilos e com os mesmos argumentos que se referem aos [65] animais afirma conhecer o Nilo, que, embora se esconda nos desertos, num espaço que se percorre em vinte e cinco dias de viagem, surge finalmente junto aos Etíopes mais chegados na chamada Fonte Negra. A prova de que está dividido em braços, e deixo de lado o Egipto, é o chamado rio Senegal onde pululam os mesmos animais e que os Portugueses descobriram derivar do Nilo ${ }^{60}$.

A outra reflexão das duas que disse serem-me sugeridas é, por exemplo, o nome de porcos, que lhes dá Isidoro ${ }^{61}$, ser confirmado, com maior validade, pelo testemunho dos Etíopes. Mas, e para finalmente terminar, se parecer que usámos de conjecturas de pouco peso e até se descobrir a verdade, que os Italianos e as restantes nações lhe chamem a seu bel-prazer, usando um nome recente, esturjão ou, melhor, "asturjões" do nome do rio Minho na Astúria, como propôs o nosso Miguel da Silva ${ }^{62}$ ao Papa Clemente VII. Chamemos-lhe nós porcos-marinhos ou, se recearmos a ambiguidade ${ }^{63}$ por existirem outros porcos-marinhos quer em Plínio quer em Estrabão, chamemos-lhe simplesmente "soilhos", usando um nome já com mil anos, mais antigo que a época de Isidoro, peculiar à nossa Hispânia e vernáculo. Mas isto já são pormenores excessivos.

\section{O CALÍPODE}

Só Ptolomeu ${ }^{64}$ recorda o Calípode, rio que corre para o golfo de [Cetóbriga] Setúbal e de Alcácer do Sal e que é navegável até cerca de 12.000 passos acima desta cidade, tanto para embarcações ligeiras como para navios de carga. Chamamos-lhe comummente Sadão. Este nome destronou, por assim dizer, o seu, embora não seja de origem nem dado desde a nascente, mas a partir do local em que o Xarrama, o Odivelas e o Santa Detença, avolumados pela quantidade de torrentes e cursos de água recolhidos de diversos lugares e já verdadeiros rios, se fundem num único leito, um pouco acima de Porto de Rei, onde perdendo os seus nomes lhe cederam 
Asturionum quoque ingens copia, fisci tamen regii. Capitaleque est captum piscem regium ad regem non deferri. Delatum ipse cui uult donat. "Angullum" ibi uocant, id est, porcum. Differentiae tamen causa, "angullum amazi", hoc est aquarum porcum dicunt.

Duo hinc sumo argumenta. Alterum Nili Aegyptiaci oxyrinchos, asturiones in hoc Aethiopico brachio captos mihi uideri. Nam et heic et illic, iidem Nilo familiares immeant et nascuntur pisces, eademque reperiuntur animalia. Neque futile uideri argumentum debet, quum eodem bis utatur Plinius libro quinto, capite nono, tum circa Nili originem ex lacu Nilide: "Ibi - inquit - pisces reperiuntur alabetae, coracini, siluri, crocodilus quoque". Inde ob argumentum hoc Nili ortus creditus, tum mox, quum aliquot dierum itinere conditum, in Massaesylorum gente dicat erumpere, iisdem animalium [65] argumentis, Nilum agnosci tradit. Quumque se rursus condiderit uiginti dierum desertis, prosilire tandem ad proximos Aethiopas, fonte nigri uocato. Diuidi autem in ramos, ut Aegyptum praeteream, indicio est Zanaga appellatus amnis iisdem refertus animalibus, quem a Nilo defluere compertum a nostris est.

Alterum duorum quae me sumere dixi argumentorum, porcorum uidelicet nomen, quod illis tribuit Isidorus, Aethiopicarum gentium consensu ualidius confirmari. Sed ut tandem finiam, si leuioribus coniecturis usi uideamur, interim tamen dum ueritas eruitur, arbitratu suo appellent Itali, ceteraeque nationes, recenti nomine sturiones, siue potius asturiones, a Minio Asturiae flumine, ut apud Clementem Septimum Pontificem Maxixum noster Michael Siluius disseruit, appellemus nos porcos marinos, aut si amphibologiam timemus, quia sunt et alii porci marini, tum Plinio tum Straboni, simpliciter appellemus Suillos, nomine a mille iam annis et supra Isidori aetatem, Hispaniae nostrae peculari ac uernaculo. Sed de his nimis multa.

\section{DE CALLIPODE}

Callipodis meminit solus Ptolemaeus, estque is qui in Cetobrigensem ac Salaciensem sinum ingreditur, ad duodecim millia passuum supra Salaciam, onerariis nauigiis et celocibus nauigabilis.

Nos uulgo Sadanum appellamus. Quod nomen, ut non a fonte, uel ab origine, quasi suum detulit, sed postea quam Examarra, Odiuella, Sancta Detinentia, diuersis ex locis collecta, torrentium ac fluentorum multitudine in amnium iustorum opinionem aucti, et in alueum unum confluentes, paulo supra Portum Regium, suis depositis nominibus honorem illi cesserunt, Sadanus uocari coepit, 
a ele a honra. É desde esse ponto que começou a ser designado por Sadão. Também não conserva o nome por muito tempo, pois daí a 16 milhas ou um pouco mais longe perde o nome de que se apropriou ao adiantar-se no enormíssimo estuário já chamado de Salaciense, sem dúvida para que não se gabasse por soberba à deusa Salácia, da qual provém o nome [66] da cidade, de ser o fim de três rios ${ }^{65}$.

São familiares a este rio os mugens, quer cabeçudos quer beiçudos, os barbos e as enguias de excelente paladar, além das bogas e de outros peixes mais pequenos. E no sítio em que se mistura às águas salgadas é enorme a apanha de camarões e de moluscos. Raramente nele se capturam lampreias ${ }^{66}$.

\section{O TEJO}

O Tejo, que desagua no golfo de Lisboa, pedia pelo seu prestígio um livro só sobre ele, tão grande é o número de cidades, de ópidos fortificados e ricos à volta do golfo e ao longo de uma e outra margem do rio, numa extensão de quase 100 milhas. Não é neste momento, todavia, o assunto apropriado para quem apenas recolhe dados sobre a antiguidade.

Além disso, também não chegou até nós intacto muito do que Estrabão ${ }^{67}$ disse sobre o rio, como prova a sequência confusa de palavras: "Depois o cabo Espichel e as bocas do Tejo, até se dirigem em linha recta os rumos dos navios. São no entanto 10 estádios. Também neste local há estuários e um deles estende-se desde a torre já referida até uma distância superior a 400 estádios. É aqui que se reabastecem de água... etc.”.

Só a frase "desde a torre já referida" prova com segurança que o passo está deturpado. Desde que torre? Não houvera antes alusão a nenhuma outra. E aquilo "é aqui que se abastecem de água. Iponlacia". Como me considero incapaz de reconstituir os passos, teremos de esperar ou por engenhos mais dotados do que o meu, ou por exemplares mais $\operatorname{correctos}^{68}$.

O Tejo mistura-se às águas do mar no interior do golfo junto a Vila Franca. Estrabão, por sua vez, disse que a largura da foz é de 20 estádios, e tão grande a profundidade que pode facilmente ser navegado por barcos com capacidade de 10.000 talentos $^{69}$. Isto é verdade, como também o é ser navegável por dois canais, [67] um velho e um novo, e aquilo que diz sobre as duas cheias que se derramam sobre os campos mais altos com a vinda das marés, de tal maneira que a superfície do mar aumenta para 150 estádios, tornando-se toda a planície navegável, tudo isto conhecemos por experiência desde precisamente Vila Franca até Benavente ${ }^{70}$. Mas qual tenha sido, na verdade, a ilha de 30 estádios de comprimento e de quase a mesma largura, fértil e plantada de belas vinhas, não podemos dizer ${ }^{71}$.

Há ali muitas ilhas e de facto fertilíssimas, mas não plantadas com vinhas, pois são todas semeadas de trigo ou reservadas para pastagem ${ }^{72}$. 
ita nomen id non longe perfert, sed post sedecim aut paulo amplius milliaria usurpatum amittit, Salaciensi aestuario longissimo praeoccupatus. Videlicet, ne recens usurpato nomine, Deae Salaciae, ex qua urbi nomen, [66] de interitu fluuiorum trium superbius se iactaret.

Familiares huic flumini sunt mugiles, tum cephali tum labiones, barbi, et anguillae egregio sapore. Bocae quoque, et minores alii pisces. Atque ubi salsis intermiscetur undis cammarorum pectinumque prouentus ingens. Raro lampetrae in eo capiuntur.

\section{DE TAGO}

Tagus in sinum Olisiponensem ingressus, librum pro sua dignitate poscebat peculiarem. Tot enim urbes, tot ualida et opulenta oppida, in sinus ambitu, et per utrasque amnis ripas, centum fere milium spatio. Tantum uetustatem colligenti, idonea modo materia non est.

Quin et multa quae de fluuio Strabo prodiderat, ad nos integra non peruenerunt. Indicio est confusa uerborum series: "Deinde promontorium Brabarium et eruptiones Tagi, in quas recti nauium cursus. Sunt autem stadia decem. Hoc in loco et maris infusiones ingruunt, quarum una ultra stadia quadrigenta extenditur a turri iam dicta. Ea in parte aquantur, etc.”

Certe corruptum locum uel hoc testatur: "A turri iam dicta". A qua turri? Nullius enim mentio praecesserat. Et illud: "Ea in parte aquantur. Iponlacia". Quibus restituendis locis cum impar ego sim, expectanda erunt uel foeliciora ingenia, uel exemplaria emendatiora.

Miscetur Tagus marinis aquis in intimo sinu ad oppidum Villam Francam. Latitudinem ostii Strabo stadiorum esse uiginti tradit, altitudinem uero permagnam, ut a nauigiis millia decem uectantibus nauigari facile possit. Hoc uerum est, nauigaturque duplici canali, [67] ueteri ac nouo, et quod ait in superioribus campis aestus accessione duas diffundi inundationes, ut ad stadia centum et quinquaginta facies extet pelagi, reddaturque planities tota nauigabilis, hoc nos experimur ab ipso oppido Villa Franca, usque Beneuentum. Sed insula stadiorum triginta longitudinis et aequalis fere latitudinis, fertilis, optimisque uitibus consita, quaenam fuerit, assignare non possumus.

Multae ibi sunt insulae, ac fertilissimae quidem, sed nullis uinetis consitae. Frumentariae enim factae omnes sunt, aut pastionibus seruatae. 
Quanto a dizer que toda a terra em redor é notável pela fertilidade, também sabemos que não é só aqui e que os famosos campos de um e de outro lado do rio até Tancos, devido às cheias lodosas, se tornam tão ricos e férteis que com uma simplicíssima e quase nula lavoura da terra permitem que pelo menos o trigo e a cevada sejam ceifados ao quinquagésimo dia após a sementeira, exemplo único para qualquer solo ${ }^{73}$. E logo a seguir, nas terras muito levemente lavradas, eu direi, gradadas, é semeado o milho-miúdo, de crescimento e colheita muito rápida ${ }^{74}$, ou então, no espaço de pouquíssimos dias, sem qualquer sementeira a não ser as das sementes deixadas cair na ceifa, o campo torna a germinar espontaneamente com novo vigor.

O que Mela disse de Eriteia ${ }^{75}$, ilha junto à Lusitânia e que hoje não se encontra em parte alguma, pode verificar-se, por provas bastante numerosas, que se adapta aos campos e ilhas do rio, quer se procure a riqueza de produtos da terra quer a abundância de pastagem. Tal é a natureza do solo que o Tejo torna produtivo com as cheias. Estrabão disse com verdade: "Os ópidos que estão junto ao Tejo são mais ricos do que os restantes" 76 .

O rio, na verdade, produz peixe em grande quantidade e transborda de ostras. Entre os peixes do Tejo estão em primeiro lugar os sáveis, não só pela delicadeza da carne, como pela abundância. Há outra espécie de sável, objecto de discussão no meu livro sobre Gil de Santarém ${ }^{77}$, as sabogas ou sabelas, bastante mais secas [68] e insípidas, excepto no mês de Maio. Nessa altura, de facto, são acolhidas com certo agrado entre os alimentos, com a condição de serem assadas num grelhador de brasas, assim que saiam do rio e temperadas com salsa picada, pimenta, aipo e sumo de limão, o que prova que Ausónio tinha razão em pensar o que delas disse no Mosela:

E os sáveis que chiam nas lareiras, alimento do povo. ${ }^{78}$

Raramente são apanhadas lampreias no Tejo e mais raramente ainda porcosmarinhos ou "soilhos". Já ouso com efeito apoiar-me em Isidoro79. Mas aquela célebre tradição do ouro, divulgadíssima por todos os poetas, é agora menos conhecida e está quase esquecida pela precaução das leis em evitar que as areias remexidas prejudiquem os campos de trigo afundando-os ainda mais. Com testemunho, porém, da glória cantada, sabemos que o ceptro dos reis de Portugal é feito de ouro do Tejo, mais puro do que nenhum outro, mas nunca de todo o vimos ${ }^{80}$.

\section{O NOME DO TEJO}

Embora eu desejasse também anotar alguma coisa sobre o nome próprio do Tejo, nada se ofereceu à minha investigação, que eu considerasse de algum interesse. Aborrecem-me mesmo as considerações, em que se alarga João Ânio ${ }^{81}$, 
Quod uero dicit agrum circum circa bonitate conspicuum, scimus non solum eo loci, sed ex utroque amnis latere campos illos ad Tancos usque, limosis inundationibus, tam laetos ac fecundos effici, ut simplicissima fereque nulla aratione triticum quidem et ordeum quinquagesimo ab satione die metatur, singulari terrarum omnium exemplo. Statimque in leuiuscule aratis dicam, an scalptis? milium seratur, ubere ocissimoque prouentu, uel inter paucissimos a messe sublata dies, nullo satu, sed sponte seges regerminet, faecunditate restibili.

Vt quod de Erytheia contra Lusitaniam insula, quae nusquam modo est, Mela tradidit, longe in his agris amnisque insulis contingere copiosius experimenta demonstrent; siue frugum ubertas, siue pabuli abundantia requiratur. Tale ingenium glebae est, quam Tagus inundationibus laetificat. Vereque dixit Strabo: "Vicina Tago caeterorum opulentissima sunt oppida."

Amnis quidem piscium feracissimus est, ostreorumque redundans. Inter Taganos pisces principatum obtinent alosae, et propter bonitatem et propter copiam.

Alterum alosarum genus, de quo in Aegidio Scallabitano disputaui, sabogarum uel sabellarum, strigosius [68] insipidiusque est, praeterquam Maio mense, tunc enim aliquam in eduliis habent gratiam, uerum ita, ut recentes a flumine prunis in craticula tostae, petroselini pultario ex piperi ac mali Medici succo condiantur, ut merito de his intellexerit Ausonius, quum in Mossella dixit:

Stridentesque focis obsonia plebis alosas.

Rarae im Tago capiuntur lampetrae, rariores marini porculi, siue suilli. Iam enim audeo Isidoro niti. At celebris illa auri fama per omneis poetas uulgatissima, obscurior modo ac prope exstinta est, cautione legum, ne commotae arenae depressiores frumentarios agros nocumento afficiant. In testimonium tamen cantatae gloriae, regum Lusitanorum sceptrum ex Tagano auro, quo purius reperiri nullum potest, factum et scimus et non semel uidimus.

\section{DE TAGI NOMINE}

De ipso Tagi nomine, quum aliquid etiam cuperem annotare, nihil inuestiganti oblatum est, quod ullum operae esse pretium existimarem. Piget autem fabularum quas Ioannes Annius in ficticium suum Berosum effudit, Tagum dictum fuisse 
no seu Pseudoberoso, sobre o chamar-se o Tejo assim por causa do nome do rei que terá reinado na Hispânia depois de Brigo. Fico admirado a este respeito com S. Isidoro, homem de valor, bom conhecedor de grande número de factos e não tão desprovido do culto das belas-letras que deva ser impedido, com insólito rigor, de dar a sua opinão. Diz, no entanto, no livro décimo terceiro das Etimologias: "A Cartago da Hispânia deu ao rio que ali nasce o nome de Tago [Tejo]. O rio tem grande quantidade de areias auríferas e, por isso, é mais celebrado do que os restantes rios hispânicos" 82 .

[69] Omito o facto de o Tejo não nascer em Cartago, quer a consideremos como Cartago-a-Nova de Asdrúbal, quer mesmo como a Velha dos Ilercáones também na Hispânia e que só é lembrada por Ptolomeu ${ }^{83}$, mas não por Cícero, como, por falta de atenção, pensou e anotou Vadiano no comentário a Pompónio ${ }^{84}$, baseado num passo de Cícero do Sobre a lei agrária: "Com que então até vendem a própria Cartago-a-Velha" 85 . Com efeito, Cícero mostrou claramente no livro segundo da mesma obra, Sobre a lei agrária, qual a cidade que designava por Velha Cartago: "E na África até a própria Cartago-a-Velha consegue vender" 86.

Mas deixando isto, não posso de facto compreender como o rio foi chamado Tejo [Tago] por causa de Cartago. No entanto, não é de espantar que a etimologia de Isidoro pareça bastante artificial e confusa, porque nem mesmo o célebre Marco Varrão foi sempre muito bem sucedido nesse campo ${ }^{87}$.

Deve ter sido nosso compatriota aquele que terá escrito algures que foi o próprio Ulisses, na altura em que fundou Lisboa, que lhe deu o nome de Tejo [Tago], por causa de um seu companheiro Tago, que morreu no rio ${ }^{88}$. E não repugnava aceitálo, devido à perfeita identidade, desde que se fundamentasse em testemunho da antiguidade.

Confesso, portanto, que não sei donde provém este nome de Tejo. Mas donde quer que seja, o nome é antiquíssimo e não se tem notícia de que o rio tenha tido outro. Lívio ${ }^{89}$ escreve que o Guadalquivir era designado pelas gentes da região por Círtio, alguns Gregos, como Estesícoro, diz Estrabão ${ }^{90}$, chamaram-lhe Tartesso, e Estêvão ${ }^{91}$ conta que era chamado Perce pelas populações.

O Tejo não sofreu nenhuma alteração do nome nem entre os Gregos nem entre os Latinos. Que de facto é um nome antiquíssimo no Lácio, mesmo para homens, mostra Virgílio no canto nono da Eneida:

"Enquanto se agitam, uma lança atravessa as têmporas de Tago [Tejo]"92.

Sílio dá testemunho, no canto primeiro, de que existiu, também com o mesmo nome, um certo régulo hispânico, quando os [70] Cartagineses dominavam a Hispânia, ao expor nos seus versos a crueldade de Asdrúbal, a morte bárbara do régulo Tago [Tejo], a corajosa ousadia do escravo em vingar o injusto assassínio do seu senhor, como também a generosa paciência em suportar os sofrimentos infligidos por causa da nobre acção que realizara: 
a nomine regis qui post Brigum in Hispania regnarit. Isidorum demiror uirum magnum et rerum multarum bene peritum, nec elegantiorum litterarum tam expertem, ut insolenti fastidio sit a dicendo testimonio ablegandus.

Is Etymologiarum libro decimo tertio: "Tagum - inquit - fluuium Carthago Hispaniae nuncupauit, ex qua ortus procedit. Fluuius arenis auriferis copiosus, et ob hoc ceteris fluuiis Hispanorum praelatus."

[69] Omitto quod non oritur a Carthagine Tagus, siue Carthaginem nouam Asdrubalis intelligamus, siue ueterem Ilercaonum etiam Hispaniae, cuius solus meminit Ptolemaeus, non autem Cicero, sicut ex non adhibita diligentia existimauit, et adnotauit in Pomponium Vadianus, adducto Ciceronis loco De lege agraria: "Tum ipsam ueterem Carthaginem uendunt". Cicero enim quam ueterem Carthaginem uocarit, satis aperuit libro secundo De eadem agraria lege: "Et in Africa ipsam ueterem Carthaginem uendit".

Verum hoc omisso, intelligere non possum quonam modo Tagus a Carthagine sic nuncupatus. Neque tamen mirum, si Isidori coactior ac contortior etymologia uideatur, quum M. illi Varroni non perbene semper res ea successerit.

Fuit ex nostris, qui alicubi scripserit Olyssem quo tempore Olisiponem condidit, a socio "Tago", qui in flumen ceciderit, ipsum Tagi nomen fluuio indidisse. Nec abhorrebat a uera similitudine, si antiquitatis fundamento niteretur.

Fateor igitur non nosse me unde isthaec "Tagi" originatio processerit. Sed unde unde sit, antiquissimum nomen est, nec aliud flumini fuisse comperitur. "Baetin Cirtium" ab incolis apellatum scribit Liuius. Graecorum quidam "Tartessum" dixere, ut Stesichorus apud Strabonem. Stephanus ab indigenis "Percen" uocari tradit.

Tago nulla nominis contigit mutatio, neque apud Graecos, neque apud Latinos. Esse uero nomen uetustissimum etiam uiris proprium in Latio, ostendit Virgilius Aeneidos libro nono:

Dum trepidant, iit hasta Tago per tempus utrumque.

Hispano quoque regulo cuidam nomen idem fuisse, quum rerum in [70] Hispania Carthaginienses potirentur, auctor est Silius libro primo Asdrubalis crudelitatem, Tagi reguli saeuum interitum, et serui non minus magnanimam in uindicanda iniusta domini caede audaciam, quam in perferendis ob patratum nobile facinus cruciatibus generosam patientiam his carminibus prosequutus: 
Entretanto confiam as rédeas do comando a Asdrúbal,

Que abalava as riquezas da terra ao sol-poente, o povo ibero

E os homens que a Bética habitam impondo-lhes cruel destino.

Tinha um coração sinistro de chefe, aliado a ira incontrolável,

Para ele o fruto de reinar era a própria crueldade. Selvagem no amor

Ao sangue, confia o tresloucado na glória trazida pelo medo.

Jamais se conheceu pena suave que saciasse os seus furores.

A Tago [Tejo], de antiga estirpe, de grande beleza

E famoso por corajosos feitos, pregou-o ele em alto poste,

E, esquecido dos deuses e dos homens, em triunfo passeou

Pelos povos contristados o corpo de seu rei morto sem exéquias.

A Tago [Tejo], que recebera o nome de aurífera fonte,

Ululando o choraram pelas margens e cavernas as ninfas ibéricas.

Não quererá ele jamais para si as águas da Meónia, nem os pântanos

Da Lídia ou a planície que pelo ouro fluido é banhada e

Que enlourece com as areias do Hermo para ali trazidas.

Era ele o primeiro a atacar e o último a deixar o combate,

Quando do alto da sela largava as rédeas ao veloz corcel.93

\section{O MONDEGO}

Segue-se o Mondego que corre espraiado quase para o meio do último promontório, como diz Mela ${ }^{94}$. Situado entre o Douro e o Tejo, dista quase o mesmo de um e outro. "O Tejo - diz Plínio - está a 200.000 passos do Douro e entre ambos encontra-se o Mondego" 95 .

[71] Não nasce longe e também ele é aurífero e navegável até certa altura por barcos bastante pequenos, em verdade barcaças fluviais que vão até à actual Coimbra ou um pouco mais acima. Tem grande quantidade de sáveis, de lampreias também, e, por todo o lado, a montante do rio, pululam mesmo as apreciadíssimas trutas. O rio é de forte corrente e poucas chuvas bastam para que desmedidamente suba.

Fertiliza os campos cultivados de trigo, cevada, centeio, espelta, milho, milhopainço e sobretudo de grande quantidade de linho finíssimo, comparável em qualquer lado ao melhor. Ainda hoje existe a pouca distância a povoação de Catina ${ }^{96}$ (assim se deve ler), vulgarmente chamada Cadima, em cuja região estão aquelas fontes recordadas por Plínio no livro segundo ${ }^{97}$, uma repelindo todo e qualquer objecto, a outra absorvendo; aquela porque tem uma natureza quase comum à das outras, de modo algum é motivo de espanto, esta última, pela estranheza, é frequentada diariamente por visitantes. O povo chama-lhe Fervença ${ }^{98}$.

Eu próprio quando lá fui com o célebre Cardeal Afonso ${ }^{99}$, príncipe famoso, vi uma árvore bastante grande, cortada, ser atirada para a pequena bacia de areia onde 
Interea rerum Asdrubali traduntur habenae.

Occidui qui solis opes, et uulgus Iberum, Baeticolasque uiros fatis agitabat iniquis.

Tristia corda ducis, simul immedicabilis ira, Et fructus regni feritas erat. Asper amore Sanguinis, et metui demens credebat honorem.

Nec nota docilis poena satiare furores,

Ore excellentem, et spectatum fortibus ausis,

Antiqua de stirpe Tagum, superumque, hominumque

Immemor, erecto suffossum robore, maestis

Ostentabat ouans populis sine funere regem.

Auriferi Tagus adscito cognomine fontis,

Perque antra, et ripas nymphis ululatur ${ }^{1}$ Iberis.

Maeonium non ille uadum, non Lydia mallet

Stagna sibi, nec qui riguo perfunditur auro

Campum, atque illatis Hermi flauescit arenis.

Primus inire manum, postremus ponere Martem,

Quum rapidum effusis ageret sublimis habenis.

\section{DE MVNDA}

Munda sequitur, in medium fere ultimi promontorii latus effluens, ut Mela tradidit. Inter Durium atque Tagum, aequis fere ab utroque spatiis separatus. "A Durio Tagus - inquit Plinius - CC. M. pass. interueniente Munda.”

[71] Non longe oritur, aurifer et ipse, minoribusque nauigiis aliquatenus, cymbis uero fluuiaticis, usque Conimbricam hodiernam et supra nauigabilis. Abundat alosis, lampetris autem ubique scatet laudatissimis in superioribus etiam troctis. Rapax est, ac modicis imbribus excrescit ad insaniam.

Agros fecundat tritico, hordeo, secale, alyra, milio, panico, et praecipue lini magna copia tenuissimi, et quum quouis optimo conferendi. Non procul Catina oppidum (ita enim legendum) uulgo Catima dictum, etiam adhuc extat, in quuius agro fontes illi sunt Plinio libro secundo memorati, alter omnia respuens, alter absorbens, ille quia fere communem cum reliquis naturam habet, miraculo nequaquam est. Hic propter mirabilitatem quotidie a uisentibus frequentatatur, "Feruentiam" uulgus appellat.

Vidi egomet, cum illo issem cum Alphonso Cardinale principe memorabili, caesam arborem bene magnam in lacunculum arenae, in quo ebulliens fons

1 ululatur ER (pro ululatus corr. Errat.) ] ululatus $C^{1} F C^{2} U$ 
a água em ebulição se eleva à altura de um pé e, pouco a pouco, ser sorvida entre as areias até que daí a pouco tempo se deixou de ver.

O rio é chamado Mulíadas por Estrabão. Efectivamente, quase a meio do livro quarto escreve assim: "Continuando, os rios mais famosos depois do Tejo são o Mulíadas que tem pouca navegação e o Vouga"100.

\section{O RIO VOUGA}

Quase a meia distância entre o Mondego e o Douro desagua no mar o Vouga, [72] ele próprio, segundo Estrabão ${ }^{101}$ e tal como o Mondego, com pouca navegação; não nasce longe e possui sáveis, lampreias e trutas em abundância. Estrabão chamalhe Vacua e Ptolomeu Vaco ${ }^{102}$. Não tem origem em país estrangeiro mas, um pouco apertado antes da serra do Buçaco e correndo a partir daí com um caudal moderado, recolhe em si muitos rios de pouco significado e o Águeda, que lhe é quase igual. Já relativamente grande mistura-se com o mar.

Alguns pensaram que os povos Vaceus tinham sido denominados assim por causa do seu nome, mas é um erro, pois nascendo ele na Lusitânia não pôde dar o nome aos dilatadíssimos povos Vaceus da província da Tarraconense. É preferível, portanto, admitir que da cidade de Vaca, que existiu junto aos Pirenéus, tal como afirma Isidoro no livro nono das Etimologias ${ }^{103}$, se tenha formado o nome de Vaceu que foi largamente espalhado pela Hispânia Citerior.

Não deixaremos, contudo, de referir o que for oportuno sobre a foz do rio Vouga e zona marítima, ao serem passadas em revista as cidades.

\section{O DOURO}

O Douro, celebradíssimo pela sua beleza e pelo testemunho dos escritores, supera o Tejo na massa de água com a diferença que esta vem mais comprimida, dado que corre quase sempre por um leito entre montanhas, enquanto o Tejo se expande até à ostentação por campos desimpedidos e planos. Daí aquilo que é costume dizer-se entre nós à laia de provérbio: "O Tejo leva a fama e o Douro arrasta as águas".

Dos restantes rios, exceptuando o Minho, é o que produz maiores sáveis, lampreias e trutas, preferidas pelos que, com razão, as consideram de sabor mais delicado, [73] mas é mais parco em salmões e asturjões ${ }^{104}$

É navegável contra a corrente cerca de 100.000 passos até à queda de água donde, com grande fragor, ele se precipita de uma rocha que impede a subida dos pequenos barcos. Ali, sob a água que cai em arco, é enorme a apanha de lampreias que aderem com a boca à rocha. Chamam vulgarmente a este local e ao pequeno ópido, S. João da Pesqueira. Quando eu era rapaz, Martim de Figueiredo ${ }^{105}$, jurisconsulto e bom conhecedor das letras latinas, a cujo estudo, sob a orientação de Policiano de 
diffunditur pedali altitudine, iniectam, paulatim inter arenas sorberi, et post paruam moram non comparuisse.

Amnis Straboni Muliadas appellatur. Sic enim libro quarto circa medium fere scribit: "Deinceps post Tagum nobilissima flumina sunt Muliadas, paruas habens nauigationes. Itidem Vacca fluuius."

\section{DE VACCA FLVVIO}

Medio fere inter Mundam et Durium interuallo, Vacca in mare influit, [72] et ipse, ut Strabo ait, quemadmodum et Munda paruas habens nauigationes. Nec longe ortus, alosarum, lampetrarum, troctarumque ferax. "Vacuam" illum Strabo uocat, "Vacum" Ptolemaeus. Oritur non peregre, sed paulo supra Alcobam montem collectus, indeque leni alueo illapsus multos nec exiguos fluuios ac fere parem Agatham in se condit. Iamque intra modum magnus miscetur mari.

Errore putauere quidam Vaccaeos populos ab eo denominatos, quum intra Lusitaniam ortus, latissimis Vaccaeorum Tarraconensis prouinciae populis dare nomen non potuerit. Potius igitur a Vacca oppido, quod fuit iuxta Pyrenaeum, ut refert nono Etymologiarum libro Isidorus, Vaccaeum nomen est factum et late per Citeriorem Hispaniam propagatum.

Sed de Vaccae fluminis ostio, maritimoque tractu, inter recensendas urbeis, quod ad rem faciat non omittemus.

\section{DE DVRIO}

Durius claritate sua et scriptorum testimonio celebratissimus, aquarum mole Tagum superat, nisi quod compressiore, ut fere inter monteis, alueo fluit, Tago per liberos, et planos campos ad ostentationem se dilatante. Heinc apud nos uice prouerbii usurpatum: "Tagus tulit famam, sed Durius uehit aquas."

Ceteris amnibus, Minio excepto, grandiores fert alosas, lampetras, et troctas, quas iure praeferunt delicatioris gulae aestimatores, [73] salmonum parcior et asturionum.

Nauigatur aduerso amne M. Pass. fere centum, usque ad cataractam, unde ex rupe lenunculorum adscensum impediente, magno fragore praecipitatur. Ingens ibi Lampetrarum rupi sub cadente in arcum aqua oribus adhaerentium captura est. Locum cum oppidulo, Sanctum Ioannem ad Piscariam uulgo appellant.

Nobis adolescentibus Martinus Ficaretus iurisconsultus, et Latinarum litTerarum non imperitus, quibus operam non ignauam sub Politiano Florentiae dederat, 
Florença, não pouco se aplicara, pensou que, removida a queda de água, poderiam as barcaças com pouco trabalho ser levadas sobretudo até aos campos de trigo de Toro e Zamora e regressarem, rio abaixo, carregadas de cereal. Como obtivesse a autorização do rei, devido à esperança de uma descida significativa no preço do trigo e vantagens de âmbito nacional, ele próprio, como simples particular e de posses não comparáveis com a grandeza do empreendimento, tentou realizar a obra e, com grande trabalho, tinha conseguido forçar uma boa parte do obstáculo.

Escarneceram, contudo, do excelente homem não só aqueles que ainda não estavam porventura apaziguados de alguma velha inimizade, como os que mais facilmente censuram os feitos de valor realizados por outrem do que por si próprios realizam seja o que for de notável, e junto ao rei o incriminaram como pessoa meio louca e propuseram que o não ajudasse com a régia generosidade e que até proibisse aquele projecto insensato. Não há dúvida que aquela queda de água e a passagem subterrânea perto da cidade de Bragança onde o rio, tragado pela terra e pelas rochas, mergulha, durante o tempo estival, por cerca de 1000 passos, devem ser consideradas obra divina, porque recusam aos Espanhóis a possibilidade de se infiltrarem desde os Vaceus até ao meio de Portugal, como se a segurança de toda a pátria se apoiasse naquela única rocha ${ }^{106}$. Por fim, tendo perdido parte dos seus bens de família e sentindo que o favor real se afastara por maldade dos seus rivais, Martim de Figueiredo perdeu a esperança de terminar a obra e desistiu.

[74] Se ignorássemos que o Douro leva ouro, poderíamos ser lembrados por Sílio, quando diz: "Destes lados, Pactolo, vencem-te o Tejo e o Douro"107. As suas terras foram, contudo, poupadas, por uma útil proibição legal, que já anterior mente referimos a propósito do Tejo ${ }^{108}$. Quanto ao nome, chamaram-lhe os Romanos unanimemente Douro, mas em Ptolomeu é Dórias, em Díon Dório e em Estrabão tanto Dúrio como Dúrias ${ }^{109}$.

Houve quem erradamente confundisse Túria com Dúrio, criando um mesmo nome para ambos, creio que por ignorância das coisas hispânicas, visto o Túria não ser um rio tão conhecido. Por outro lado, o Túria corre junto a Valência e sobre ele diz Pompónio no livro segundo: "Recebe as águas de rios pequenos, o Sorobi, o Túria e o Júcar"110; e Plínio no capítulo terceiro do livro terceiro: "A colónia de Valência dista do mar 3000 passos. O rio Túria..."111. Hermolau sustenta com verdade e erudição que assim, com efeito, se deve ler tanto em Pompónio como em Plínio ${ }^{112}$.

Prisciano, nos livros quinto e sexto ${ }^{113}$, cita um passo do livro segundo das Histórias de Salústio: "Entre as muralhas à esquerda e o Túria que à direita corre, a pouca distância de Valência".

Também Gneu Pompeio na epístola ao Senado (que circula apensa aos fragmentos salustianos ${ }^{114}$ ) diz, segundo o testemunho do velho códice que tenho junto a mim: "Reconquistei a Gália, os Pirenéus, a Lacetânia, os Indigetes e sustive, é verdade que com soldados inexperientes e em muito menor número, o primeiro embate de Sertório vencedor". E um pouco mais à frente: "Que o acampamento perto de Júcar foi capturado, que houve uma batalha junto do rio Túria e que o chefe inimigo, 
cum intelligeret, amota cataracta, posse cymbas usque ad maxime frumentarios Sarabris Senticaeque agros paruo negotio subuehi, et frumento onustas prono amne redire, non minima laxioris annonae praetenta spe, patriae emolumento, rege permittente, priuatus ipse, et impari tantae rei censu moliri opus attentauit, bonamque obstaculi partem summo labore irruperat.

Verum illudentibus optimo uiro, uel qui ex uetere forte simultate nondum illi erant pacati, uel quibus mos est, facilius aliorum egregios reprehendere conatus, quam egregium aliquid ex se conari, hominemque tanquam semidelirum apud Regem criminantibus, neque modo principali munificentia non iuuandum, sed coepto temerario etiam prohibendum obloquentibus. Cataractam enim illam, et meatum subterraneum non procul a Brigantia urbe, ubi terrae et rupibus mersus amnis aestiuo tempore fere per mille passus subterlabitur, diuinum non sine prouidentia esse opificium, negata Hispanis in mediam Lusitaniam usque ex Vaccaeis ea illabendi facultate. Quasi uero una illa rupe totius patriae securitas niteretur, tandem familiari sua re attenuatus, interuersoque aemulorum malignitate regali fauore, desperata perficiendi spe destitit.

[74] Aurum uehere Durium, si nos ignoraremus, a Silio poteramus admoneri, dicente: "Hinc certant Pactole tibi Duriusque Tagusque". Terris tamen parcitum est, salutari legum interdicto, quemadmodum de Tago ante diximus. Nomen amnis Latini magno consensu Durium appellauere. Ptolemaeo Dorias est. Dioni, Dorios. Straboni, tum Durios, tum Durias.

Non bene quidam miscuerunt Turiam cum Durio, idem ambobus nomen facientes, credo ob Hispanicarum rerum ignorationem, quia Turia non tam celebris est. Fluit autem Turia iuxta Valentiam, de quo Pomponius libro secundo: "Saetabin, et Turiam, et Sucronem non magna excipit flumina". Et Plinius libro tertio, capite tertio: "Valentia colonia tribus M. pass. a mari remota. Flumen Turia”. Ita enim legendum, et apud Pomponium et apud Plinium, erudite et uere contendit Hermolaus.

Citat locum Priscianus libro quinto, et sexto ex secundo Historiarum Salustii: "Inter laeuam moenium, et dextrum flumen Turiam, quod Valentiam paruo interuallo praeterfluit".

Cn. quoque Pompeius in epistola ad senatum (quae una cum Sallustianis fragmentis circumfertur) ex fide ueteris codicis, quem apud me habeo: "Recepi Galliam - ait - Pyrenaeum, Lacetaniam, Indigetes, et primum impetum Sertorii uictoris nouis quidem militibus, et multo paucioribus sustinui." Et paulo post: "Castra hostium apud Sucronem capta, et proelium apud flumen Turiam, et 
Gaio Herénio, juntamente com a cidade de Valência e o exército foram aniquilados, são factos sobejamente conhecidos" 115 .

No códice lê-se deturpadamente "junto ao rio Douro". Plutarco no Sertório mostra que o rio de que fala Pompeio se chama em boa verdade Túria ao dizer: "Os expedientes nas derrotas tornavam mais notável a sua coragem, como naquela batalha que se travou junto ao [75] Júcar contra Pompeio e de novo naquela que se deu perto do Túria, simultaneamente contra Metelo e Pompeio"116.

Alguns citam também Claudiano nos Louvores a Serena:

Quando nasceste, dizem, que o Tejo encheu e com riquezas Inundou os férteis campos cultivados, sorriu a Galécia, Por meio das flores e o Túria formoso pelas margens com rosas, De púrpura em todo o lado tingiu o velo das ovelhas ${ }^{117}$.

Pareceu, porém, à maior parte das pessoas que o poeta não olhou suficientemente à estrutura interna do poema. Porque escolheria, de facto, com tanta solenidade um rio pequeno, desconhecido aliás, esquecendo o Ebro, o Guadalquivir, o Guadiana, o Douro e o Minho quando desejava celebrar acontecimento tão importante, e ao Tejo o associa chamando-lhe "formoso pelas margens com rosas", epíteto conhecidíssimo dos rios da Hispânia ${ }^{118}$, e lhe atribui a qualidade que é própria do Guadalquivir, como diz Marcial: "Que nas águas brilhantes tinges de ouro os velos"119? Eis a razão por que houve quem emendasse a lição do texto e em vez de Túria pusesse Dúria, como se Claudiano recebesse este nome de Estrabão ${ }^{120}$ que, como já disse, lhe chama Dúrio ou Dúria, o que parece adaptar-se ao sentido. Com efeito, tinha dito que "Sorriu a Galécia por meio das flores" e assim ligou ao poema o rio que separa a Galécia da Lusitânia.

Por outro lado, pensa-se que alongou a primeira sílaba do nome porque em Grego era um ditongo e evidentemente porque ele próprio era Grego. Nós, porém, argumentamos com Sílio, para quem este nome não designa apenas o rio, mas também é nome de homens e vem sempre expresso com a primeira sílaba breve ${ }^{121}$. Assim, no canto quinto:

[76]

[...] A qual, sendo ele o vencedor às muralhas de Sagunto, retirara a Dúrio $[\ldots]^{122}$.

E no canto décimo sexto:

O nobre Dúrio fustigava nas águas este carro $^{123}$.

A verdade é que não ousamos mudar a palavra Túria de Claudiano e pensamos que é preferível, tomando em consideração a estrutura do poema, perdoar-lhe esta nódoa sem importância, do que ir salpicá-lo com a acusação de falta de cuidado 
Dux hostium C. Herennius cum urbe Valentia, et exercitus deleti satis clara uobis sunt."

Vbi corrupte legitur "apud flumen Durium". Turiam enim uocari id flumen, de quo Pompeius loquitur, ostendit Plutarchus in Sertorio. "Remedia (inquit) in rebus aduersis, magis claram eius uirtutem faciebant, ueluti in ea pugna quae apud [75] Sucronem contra Pompeium commissa est, et rursus in ea, quae apud Turiam aduersus Metellum simul et Pompeium."

Et adducunt quidam Claudianum in Laudibus Serenae:

Te nascente, ferunt, per pinguia culta tumentem

Diuitiis undasse Tagum, Callaecia risit,

Floribus, et roseis formosus Turia ripis

Vellere purpureo, passim mutauit ouile.

Plerisque tamen uisus poeta est non satis oeconomiae prospexisse. Nam cur fluuium paruum, et alias ignobilem, praetermissis Ibero, Baeti, Ana, Durio, ac Minio maximae rei, quam efferre gestiebat, tanta pompa seligeret, ac formosum roseis ripis uocatum Tago copularet, fluminum Hispanorum famae uulgatissimae, et dotem, quae pecularis Baeti est, ut ait Martialis, "Aurea qui nitidis uellera tingis aquis", illi tribueret? Quare lectionem emendarunt, et pro Turia substituerunt Duria, quasi acceperit Claudianus hoc ex Strabone, qui, ut dixi, Durion et Durian appellat, uideturque congruere sensui. Nam dixerat "Callaecia risit floribus", adnexuitque fluuium qui Callaeciam et Lusitaniam dirimit.

Primam autem nominis syllabam propter Graecam diphthongon produxisse creditur, uidelidet homo Graecus.

Nos tamen Silium praeponimus, qui nomen id non tantum cum flumen significat, uerum etiam cum uirorum proprium est prima syllaba breui semper enunciat, ut libro quinto:

[76]

[...] Quam uictor sub moenibus ille Sagunti abstulerat Durio [...]

Et libro decimo sexto:

Nobilis hunc Durius stimulabat in aequore currum.

Claudiani uero Turiam mutare non audemus, potiusque circa Oeconomiam labeculam illi condonandam, quam audaciae nimiae, tum circa declinationem, tum circa mensuram syllabae, adspergendam tam bono poetae notam existimamus. 
extrema, por causa da declinação e da quantidade silábica. Portanto, se é Túria que Túria seja e que o Douro goze do seu nome, tal como agradou aos Romanos. Com efeito, os Gregos variam muito e nem mesmo com eles próprios estão de acordo no que concerne os nomes latinos de homens, rios e cidades, que aparecem nas suas citações.

\section{OS RIOS DOS BRÁCAROS}

A seguir ao Douro, pelo qual, conforme fizemos saber anteriormente, são separados os Lusitanos dos Galaicos, e através dos Grávios, mais tarde chamados de Brácaros, "correm - diz Pompónio - o Ave, o Leça, o Neiva, o Minho e o Lima, que tem o cognome de rio do Esquecimento"124. Pompónio não respeitou a ordem e contentou-se em enumerar todos os rios.

A ordem é a seguinte: Leça, Ave, Neiva, Lima, Minho, pois assim se seguem a partir do Douro. Quanto ao Leça, é o rio que desagua no mar junto aos ópidos de Leça e Matosinhos e que é navegável mesmo para navios, quando a maré ajuda.

O Avo ou Ave, como agradou dizer a Ptolomeu ${ }^{125}$, é mais conhecido e oferece melhores condições para os barcos.

O Neiva é aquele que deu o nome ao ópido e à ponte de Neiva (de que Antonino faz menção no Itinerário ${ }^{126}$ ), mas desagua no mar junto à vila de Fão com o nome de Cávado, nome que toma a partir do local em que se junta ao Cávado.

[77] O Lima conserva o nome, mas Estrabão menciona outro nome: "O rio do Esquecimento, diz ele, a que alguns chamam Lima e outros Bélion" ${ }^{127}$. Engana-se, porém, Estrabão ao dizer que o Lima corre dos Celtiberos e dos Vaceus. Na realidade não nasce longe, vem de certos terrenos pantanosos entre a cidade de Orense e a vila de Monterrei. Chama-se vulgarmente àquela zona Límia e aos seus habitantes Límicos, como é evidente pela coluna de Chaves que apresentei anteriormente ${ }^{128}$.

O mesmo Estrabão mostrou a causa do cognome Esquecimento e nós, baseados nele, aflorámo-la ligeiramente quando nos ocupámos dos Célticos que estão junto ao Guadiana. No entanto, voltamos ainda a ela, porque parece ser aqui o lugar adequado.

Quando os Célticos Lusitanos, que se estendem até ao Guadiana, e os Túrdulos Velhos chegaram a estas paragens como aliados, perderam o chefe numa sedição que rebentou depois da travessia do Lima e instalaram-se naquela região desgarrados e dispersos. Por este motivo é o rio chamado do Esquecimento, porque esquecidos da expedição que tinham empreendido e da mútua discórdia, ali ficaram em paz depois disso ${ }^{129}$.

A fantasia aumentou o escrúpulo religioso a ponto de se acreditar que, pelo contacto com as águas do rio, sobrevinha o esquecimento, de tal maneira que, segundo lemos no Epítome de Lívio ${ }^{130}$ e segundo referiu de passagem Plutarco na secção trigésima terceira dos Problemas ${ }^{131}$, como Décio Júnio Bruto ali tivesse chegado com 
Turia igitur Turia sit, et Durius suo fruatur nomine, ut Latinis placuit. Nam Graeci, in recensendis Latinis uirorum, fluuiorum, et urbium nominibus, mire uariant, neque sibimetipsis constant.

\section{DE FLVMINIBVS BRACARORVM}

Post Durium, quo Lusitanos a Callaecis separari supra docuimus, per Grauios, qui Bracari postea dicti sunt, "fluunt - inquit Pomponius - Auo, Celandus, Naebis, Minius, et cui Obliuionis cognomen est Limia. Non seruauit ordinem Pomponius, sed satis habuit omneis nominare.

Ordo sic habet: Celandus, Auo, Naebis, Limia, Minius; ita enim a Durio sequuntur. Est autem Celandus is fluuius, qui ad oppida Laeciam et Matusinos mare ingreditur, aestu iuuante, etiam nauigiis aptus. Auo, siue Auus, ut Ptolemaeo placuit, notior est, et nauigiorum capacior.

Naebis is est qui et oppido, et ponti Naebiae (quuius mentionem facit in Itinerario Antoninus) nomen debit, sed ubi Cadauo iungitur, sub Cadaui appellatione exit in mare, ad oppidum Fanum.

[77] Limia nomen retinet. Strabo alterius nominis mentionem facit:

"Obliuionis - inquit - fluuius quem quidam Limaeam, alii uero Belionem uocant. Decipitur autem Strabo in eo, quod ait, Limiam a Celtiberis, et Vaccaeis fluere". Non longe enim oritur, ex palustribus quibusdam locis inter Aquicaldensem urbem, et oppidum Montem Regium, tractusque ille uulgo Limia dicitur et incolae Limici, ut ex columna Aquiflauiensi, quam supra posui, apparet.

Cognominis "Obliuionis" causam Strabo idem prodidit, et nos ab illo, quum de Celticis ad Anam ageremus, summatim attigimus; quam tamen, quoniam huic loco propria uidetur esse, etiam reddemus.

Celtici Lusitani ad Anam pertinentes, et Veteres Turduli, quum sociis armis ad haec loca peruenissent, traiectoque Limia coorta seditione ducem amisissent, pallantes ac dissipati ea in regione consedere. Quam ob causam flumen obliuionis est appellatum. Nempe quia expeditionis, quam susceperant, et mutuae seditionis obliti, ibidem postea quieuere.

Auxit religionem uanitas, ut crederent a contactis fluuii aquis obliuionem incurri, adeo, ut cum D. Iunius Brutus cum exercitu eo deuenisset, et milites fluuium transire nollent, raptum signifero signum ipse transtulerit, et sic ut 
o exército e os soldados não tivessem querido passar o rio, ele próprio o atravessou depois de arrebatar o estandarte ao porta-estandarte, assim os persuadindo a passar. Eis a razão por que Plínio diz que este rio está muito envolvido pela lenda ${ }^{132}$.

\section{O MINHO}

[78] Segue-se o Minho, que Justino, no último livro ${ }^{133}$, mostrou designar-se assim por causa do mínio, que nele existe em inúmeros veios. Estrabão deu-lhe dois nomes, escrevendo o seguinte: "Depois destes o Bénis. Outros, porém, chamam-lhe Minho"134. Penso eu, no entanto, que há aqui um duplo erro: o primeiro é o da escrita, admitindo que não se deva ler Bénis, mas Névis; o segundo é o da situação, de tal modo que a vizinhança teria levado Estrabão ao erro. Com efeito, dissemos, apoiados em Pompónio, que o Neiva é o rio vizinho do Minho e do Lima e que desagua no litoral do Fão, misturado com o Cávado. Mas que cada um pense como quiser.

De resto, todos estes rios e em primeiro lugar o próprio Minho são abundantes em peixes apreciados, lampreias, sáveis, trutas, trutas assalmonadas, trutas arco-iris e salmões. O Lima produz salmões e soilhos, ou seja, asturjões, mas bastante pequenos. O Minho, por seu lado, tem-nos notáveis, de tamanho enorme e muito bons. Todos estes rios, de que até agora falei, foram conhecidos dos antigos cosmógrafos.

\section{ALGUNS OUTROS RIOS}

Outros rios existem em grande número e não desconhecidos. No entanto, visto que se lançam noutros maiores e não desaguam no mar em leitos próprios, ou foram desconhecidos dos geógrafos ou omitidos. Referirei alguns deles dignos de chegarem ao conhecimento dos nossos compatriotas, com os nomes antigos e latinos, quando me for possível, e se o não for, com os nomes pelos quais são agora designados, depois de tentar atenuar tanto quanto puder algum barbarismo de linguagem que neles subsista.

De qualquer maneira, são eles o Côa, o Tâmega, o Nabão, o Zêzere, o Soure, o Caia, o Canha, o Ceira, o Sor, o Tera e o Seda.

Os Portugueses chamam ao Cuda, Côa ${ }^{135}$. Apercebi-me que era designado por Cuda [79] pela inscrição da ponte de Alcântara ${ }^{136}$, onde foram nomeados os Transcudanos. Pelo mesmo processo tirei o nome de Tâmega da coluna de Chaves ${ }^{137}$, onde são citados os povos Tamacanos; quanto ao Nabão e ao Zêzere, esclareço que os nomes foram extraídos da hagiografia da virgem e mártir St. a Iria escrita há mais de oitocentos anos ${ }^{138}$. Do Nabão falaremos noutro passo quando, entre as cidades a referir, chegar a vez de Nabância' ${ }^{139}$. 
transgrederentur persuaserit, ut in Liuii Epitome legimus, et obiter attigit Plutarchus in Problematis sectione trigesima tertia. Qua ex causa Plinius eum fluuium multum fabulosum appellat.

\section{DE MINIO}

[78] Sequitur Minius, quem Iustinus libro ultimo a minii frequentibus uenis sic uocatum prodidit. Strabo duo illi nomina tribuit, ita scribens: "Post hos Baenis. Alii autem Minium uocant". Verum ego duplicem errorem inesse coniicio. Alterum scripturae, ut non Baenis, sed Naeuis legendum sit. Alterum situs, ut uicinitas Strabonem fefellerit. Nam diximus ex Pomponio Naebis fluuium esse Minio Limiaeque uicinum, qui mixtus Cadauo in Fanuensi litore erumpit. Verum qui uelit suo fruatur iudicio.

Ceterum omneis ii fluuii piscium lautiorum feracissimi sunt, lampetrarum, alosarum, troctarum, troctisalmonum, iridum, atque salmonum, inprimisque ipse Minius. Fert Limia salmones et suillos, siue asturiones, sed minores. Minius uero praegrandi magnitudine, et excellenti praestantia. Atque omnes hi quos hactenus exposui, ueteribus cosmographis noti fuerunt.

\section{DE ALIIS NONNVLLIS FLVMINIBVS}

Sunt alii, et perquam multi neque ignobiles. Qui quoniam in maiores influunt, nec suo alueo in mare egrediuntur, Geographiae scriptoribus, aut ignorati sunt, aut suppressi. Horum aliquot, dignos qui in notitiam ueniant hominum nostrorum, referam. Nominibus ubi licuerit priscis ac Latinis, ubi minus, iis, quibus modo appellantur, quam maxime potero, barbarie, siqua inerit mitigata.

Quuiuscemodi sunt, Cuda, Tamaca, Naban, Ozecarus, Ancus, Caia, Cania, Seila, Subur, Thera, Saeta.

"Cudam" Lusitani Coam uocant. "Cudam" autem uocari, ex inscriptione [79] pontis Alcantarae, ubi Transcudani notati sunt, animaduerti.

Tamacae similiter nomen ex Aquiflauiensi columna accepi, ubi Tamacani populi recensentur. Nabanem et Ozecarum historiae Sanctae Virginis et Martyris Irenes, quae ante annos octingentos scripta est, acceptos refero. De Nabane alias, quum inter urbes ad Nabantiam uentum erit. 
O Ozécaro é o rio a que os Portugueses vulgarmente chamam Zêzere. Recebe em si o Nabão e lança-se ele próprio, com tal ímpeto, no Tejo, que rasga as águas taganas até à outra margem e, como que indignado por ser consumido por um rio maior, resiste obstinadamente à fusão das águas no leito inclinado pelo espaço de quase 1000 passos, tal como se reconhece pela $\operatorname{cor}^{140}$. Com efeito, o Tejo leva águas amarelas e mesmo esbranquiçadas, ao passo que o Zêzere as tem de um azul a tender para o negro. Pensa-se que deveu a cor à grande quantidade de linho que se afunda por causa da maceração e todo aquele que é levado na corrente. E mais ainda, há quem considere, com subtileza, que o nome se explica pelo facto de subir à cabeça o cheiro fétido da água suja ${ }^{141}$.

O nome de Anco (Soure) tirei-o da vida do presbítero S. Martinho de Soure, escrita há mais de quatrocentos e cinquenta anos e que já anteriormente recordei ao tratar da serra de Ansião ${ }^{142}$.

Não deve omitir-se o Sor. Interrogado a seu respeito por João de Barros $^{143}$, homem fidalgo e literato nos momentos livres, respondi que ignorava o nome antigo. No entanto, como em Português se diz Soor, mostrando que a letra -o- tem um som indeciso entre o - $O-$ e $-u$-, ousei reconstituir a forma Subur, interpondo um -b- à semelhança de dois rios chamados com o mesmo nome: um, de facto, em África, mas o outro na Hispânia Citerior ${ }^{144}$.

O nosso Subur [Sor], visto isso, depois de unido ao Raia recebe o nome de Sorraia, que mantém até se perder no Tejo, no local onde nós, Alentejanos, [80] fazemos um célebre comércio de sáveis ${ }^{145}$

O nome antigo do Ceira foi escolhido por ser o do ópido que ele banha e que está sob a autoridade do mosteiro Urbanense ${ }^{146}$. Desagua no Mondego e possui os mesmos peixes que aquele tem em abundância.

\section{A FERTILIDADE DA LUSITÂNIA}

Considero que é inútil dissertar aqui sobre o estado actual desta província, seu admirável clima e abundância e produtividade em frutos de toda a espécie. Por outro lado, seria longo repetir o que, desde a antiguidade, os escritores transmitiram, nas suas diferentes obras, sobre este tema ${ }^{147}$.

Invocarei apenas um único testemunho, o de Ateneu, pelo qual facilmente se poderá verificar que a região que tratamos sempre foi considerada como mui fecunda, fértil e privilegiada.

Escreveu Ateneu no capítulo primeiro do livro terceiro do Jantar dos Sofistas: "Políbio de Megalópolis, ó Timócrates, meu querido amigo, escreve no livro trigésimo quarto das Histórias, no passo em que afirma a fertilidade da Lusitânia, região da Ibéria que os Romanos designam por Hispânia, que ali, graças à óptima temperatura do ambiente, os animais e as gentes são fecundos e que jamais faltam produtos da 
Ozecarus est quem Lusitani Zezarum uulgo dicunt. Is Nabanem, excipit, et ipse in Tagum erumpit, tanta ui, ut Taganas aquas ad alteram usque ripam proscindat, et quasi indignatus, quod a maiore fluuio extinguatur, fere ad mille passus prono alueo contumaciter mixtioni resistens, a colore dignoscitur. Nam Tagus flauas ac subalbas uehit aquas, hic autem caeruleas, ad nigrorem tendenteis. Arbitrantur a multitudine lini quae macerandi causa, quaquunque fluit, immergitur, eum traxisse colorem. Quin, et arguti quidam nomen factum inde putant, quod infecti liquoris graueolentia caput tentet.

Anci nomen, ex uita Sancti Martini Sauriensis presbyteri, abhinc annos supra quadrigentos quinquaginta scripta, accepi. De quo, quum de Tapiaeo monte agerem, superius memini.

Non tacendus est Subur, de quo a Ioanne Barrho uiro nobili et inter negotia litterato interrogatus respondi uetus me nomen ignorare. Sed quum Lusitane Soor dicatur, o littera obscure sono inter o et u prolata, ausus ego sum Subur formare, interposita $\mathrm{b}$, ad similitudinem duorum eodem nomine uocatorum, alterius quidem in Africa, alterius uero in citeriore Hispania.

Noster itaque Subur postea Raiae iunctus, Suburraiae nomen accepit, quod perfert, donec exit in Tagum, ubi alosarum mercatura [80] nobis Transtaganis factus celebris.

Seilia nomen priscum sortitus est, ab oppido quod praeterfluit dicionis Vrbanensis coenobii. Ingrediturque Mundam, iisdem quibus Munda piscibus abundans.

\section{DE FERTILITATE LVSITANIAE}

De hodierno huius prouinciae cultu, deque eius admirabili tum amoenitate, tum etiam omnis generis frugum copia, atque ubertate, superuacaneum existimo hic uerba facere.

Quae autem antiquitus de ea re scriptores uariis in locis tradiderunt longum esset repetere.

Vnum tantum Athenaei testimonium adducam, ex quo facile constare poterit, quam fecunda, fertilis, ac felix regio haec de qua agimus semper habita fuerit.

Is igitur libro octauo Dipnosophistarum capite primo ita scribit: "Vbi Lusitaniae fertilitatem (est autem Iberiae, quam Hispaniam Romani appellant) declarat Polybius Megalopolitanus, o omnium hominum optime Timocrates, scribit libro Historiarum trigesimo quarto, quod ibi ob optimam aeris temperiem animalia 
terra naquela região: com efeito, as rosas, as violetas brancas, os espargos e produtos similares aparecem $[\mathbf{8 1}]$ em espaço não superior a três meses.

Por outro lado, o pescado, no que diz respeito à quantidade, boa qualidade e beleza, difere muitíssimo do que existe no Mediterrâneo.

Em verdade também, o siglo de cevada, que contém um medimno, vende-se por um dracma, por nove óbulos alexandrinos se for de trigo; uma metreta de vinho custa um dracma; um cabrito pequeno, um óbulo, tal como a lebre. Mas era costume o preço do borrego ser de três ou quatro óbulos.

Um porco que se aproximasse em peso das cem libras é comprado para os jantares por cinco dracmas e a ovelha por dois; um talento de figos compra-se por três óbulos.

Um bezerro custa cinco dracmas, um boi apto a receber a canga, dez; quanto à carne de caça, consideram-na, na verdade, sem valor, mas trocam-na entre eles, quer por amabilidade oferecendo-a, quer simplesmente negociando-a"148.

$\mathrm{Na}$ verdade, o bom Larêncio ${ }^{149}$ providencia para que Roma esteja presente, como se fosse a Lusitânia, e todos os dias nos cumula de diferentes bens, forcejando por mostrar que tudo se realiza com facilidade e grandeza, mesmo quando para casa nada mais trazemos senão palavras. 
sunt fecunda atque homines; nec unquam fructus desunt in ea regione: rosae enim, albaeque uiolae, asparagi, resque huiusmodi non desunt per maius [81] temporis spatium, quam trium mensium.

At marinum obsonium, quod ad multitudinem, bonitatem, pulchritudinemque spectat, maxime differt ab eo quod est in nostro mari.

Nam et hordei siclus, qui medimnum continet, drachma uenundatur, et tritici nouem Alexandrinis obolis; uini metreta drachma; haedus mediocris obulo, sic et lepus; at agnus trium, uel quattuor obolorum pretium esse consueuit.

Sus qui ad centum librarum pondus accedat quinque drachmis in cenas emitur, ouisque duabus; ac ficuum talentum tribus obolis emitur.

Vitulus drachmis quinque, bos iugo aptus, decem; siluestrium uero animalium carnes neque pretio quidem ullo dignae putantur, sed has inter se conferunt, benigneque admodum uicissim largiuntur ac mutant."

Nobis uero bonus Larensius Romam Lusitania adesse facit, quotidieque uariis implet bonis, ut cum suauitate magnificentiaque omnia conficiantur, studet, cum nihil domo afferamus, praeter sermones. 
(Página deixada propositadamente em branco) 
LIVRO TERCEIRO

LIBER TERTIVS 
$[\mathbf{8 2}]$

\section{QUE POVOS DOMINARAM OUTRORA NA LUSITÂNIA}

Não me será fácil dizer a quem terá estado sujeita a Lusitânia antes dos Cartagineses e dos Romanos, a menos talvez que acreditemos na existência do régulo Luscínio, sobre o qual, assim como sobre Cuíca, diz Lívio no livro terceiro da quarta Década: "Enquanto era esta a situação na Ásia, Grécia e Macedónia, apenas terminada a guerra e ainda não inteiramente concluída a paz, uma enorme guerra rebentou na Hispânia Ulterior, e Marco Hélvio, que obteve esta província, informou, por carta, o Senado, de que os régulos Cuíca e Luscínio tinham pegado em armas. Culca tinha a seu lado dezassete ópidos, e Luscínio as poderosas cidades de Cardo e Bardo, além da orla marítima que até aí não mostrara a intenção de se associar à rebelião dos vizinhos" 1 .

Tudo isto é excessivamente obscuro e na verdade as fábulas aborrecem. Eis porque deixo o catálogo dos reis, quer o que se tira do Pseudoberoso quer o imaginado por Ânio de Viterbo ou pelos historiadores da Hispânia em épocas [83] recuadas ${ }^{2}$, para aqueles a quem muito agradam esses inventores da guerra.

Penso eu que sempre existiram por toda a Hispânia, em diversos locais, muitos reis, ou melhor, régulos, tais como Gargor, Hábis, Argantónio e Gérion ${ }^{3}$, apesar de o historiador Hecateu, segundo Arriano no livro segundo ${ }^{4}$, ter contado que Gérion de modo algum pertencia à Ibéria, mas sim a Ambrácia e aos Anfílocos, e o próprio Arriano diz que não havia Hispano algum que soubesse ter existido entre os seus reis algum com esse nome. Deve não obstante ter existido, visto que muitos outros autores o referem e que não devemos desautorizar a tradição transmitida 5 .

Existiu também Téron, o qual Macróbio recordou no livro primeiro dos Saturnais ${ }^{6}$ e, segundo Lívio na terceira década, do mesmo modo Mandónio e Indíbil, também celebrados por Sílio: Mandónio, por exemplo, no canto terceiro, no catálogo dos Hispanos que seguiram o partido de $\mathrm{Aníbal}^{7}$, e Indíbil, no canto décimo sexto:

E Indíbil, durante muito tempo feliz por combater os Romanos, Mas agora aliado, ${ }^{8}$.

A este, se não me engano, chama Políbio, no livro terceiro9", Andóbal, quando diz, falando de Gneu Cornélio Cipião: "Por outro lado capturou vivos Anão, chefe dos Cartagineses e Andóbal dos Iberos”.

Também Plutarco no Cipião ${ }^{10}$ conta que existiram não apenas estes dois mas igualmente Corbe e Orsua, primos do lado paterno, que disputavam entre si o reino. 


\section{QVINAM RERVM IN LVSITANIA POTITI OLIM SINT}

[82] Quibus subdita fuerit Lusitania ante Carthaginienses atque Romanos haud facile dixerim, nisi forte Luscinio regulo putemus, de quo et Culca, Liuius libro tertio decadis quartae: "Quum is status rerum in Asia Graeciaque, et Macedonia esset, uixdum terminato cum Philippo bello, pace certe nondum perpetrata, ingens in Hispania Vlteriore coortum est bellum. Marcus Heluius eam prouinciam obtinebat. Is litteris senatum certiorem fecit Culcam et Luscinium regulos in armis esse. Cum Culca decem et septem oppida, cum Liscinio ualidas urbeis Cardonem et Bardonem, et maritimam oram, quae nondum animos nudauerat, ad finitimorum motus consurrecturam.”

Obscura nimis haec sunt, taedet enim fabularum. Quare catalogum regum uel ex ficto Beroso, uel ab Annio Viterbiensi, uel a superioris aetatis Hispanicarum rerum scriptoribus excogitatum, illis relinquo, [83] quibus belli isti concinnatores ualde placebunt.

Ego multos per totam Hispaniam diuersis in locis reges, aut potius regulos semper fuisse existimo. Quales fuere Gargoris, Habides, Argantonius et Geriones. Etsi Hecataeus historicus, ut est apud Arrianum libro secundo, Gerionem nihil ad Iberiam pertinere tradiderit, sed potius ad Ambraciam, et Amphilocos, ipseque Arrianus neminem extare Hispanum dicit qui id nomen sciret regibus suis fuisse.

Veruntamen fuerit, quum multi alii id tradant auctores, neque receptae antiquitati derogemus. Fuit quoque Theron, quuius in primo Saturnaliorum meminit Macrobius. Mandonius item et Indibilis apud Liuium decade tertia, quos etiam celebrat Silius. Mandonium quidem libro tertio, in catalogo Hispanorum, qui Annibalis sequuti sunt parteis. Indibilem autem libro decimo sexto:

Indibilisque diu laetus bellare Latinis

Iam socius.

Hunc, nisi ego fallor, Polybius libro tertio Andobalem uocat, de Cn. Corn. Scipione loquens, cum inquit: "Viuos autem cepit Annonem Carthaginiensium ducem, et Andobalem Iberorum."

Plutarchus etiam in Scipione, non hos duos solum, uerum et Corbin, et Orsuam inuicem patrueleis, de regno inter se narrat dissidenteis. 
Ainda Hilermo, capturado por Marco Fúlvio Nobílior num combate junto a Toledo, de quem fala Lívio no livro quinto da quarta década ${ }^{11},[\mathbf{8 4}]$ e, finalmente, Turro, de longe o mais poderoso de todos os Hispanos, no dizer de Lívio no livro décimo da quarta década ${ }^{12}$.

Existiram também muitíssimos outros, mas querer enumerá-los por ordem de sucessão parece-me imoderado desejo de mentir. Como a maior parte, que se encontra aqui e além nalguns escritores, se dissolve na mais remota antiguidade, de modo algum se integra no meu objectivo específico sobre a Lusitânia.

A Hispânia, para não falarmos de Gregos, Iberos, Persas e Celtas à procura de novas terras, de Fenícios e dos próprios Tírios atraídos pela fama das suas riquezas, esteve exposta à degradação dos Romanos e Púnicos, consoante eram estes ou aqueles pelas armas os mais fortes, antes do conflito entre os dois povos, motivado pelo império que se expandia.

A Lusitânia, sabe-se por Lívio ${ }^{13}$, esteve com a restante Hispânia sob o domínio dos Cartagineses por altura do começo da segunda guerra Púnica. Com efeito, depois que os Púnicos foram destroçados pelos Romanos na guerra e devido às circunstâncias adversas abandonaram a Sicília, logo que se recompôs a situação em África invadiram a Hispânia. Amílcar, a quem foi dado o cognome de Barca, foi enviado com o exército juntamente com Aníbal, seu filho, de quase nove anos de idade e com Asdrúbal seu companheiro no comando e genro.

Amílcar recuperou, portanto, grande parte da península outrora perdida na guerra, conservando cerca de nove anos o comando da Hispânia. Morreu finalmente na guerra contra os Vetões (assim de facto se deve ler no Aníbal ${ }^{14}$ de Plutarco) combatendo corajosamente junto de Castro Alto, nome que Lívio dá ao local da sua morte, no livro quarto da terceira década ${ }^{15}$.

Depois de Amílcar ter sido morto e de Aníbal regressar a casa, sucedeu-lhe Asdrúbal, [85] que, segundo os testemunhos de Políbio ${ }^{16}$, Mela ${ }^{17}$ e Estrabão ${ }^{18}$, fundou Cartago-a-Nova. Sílio Itálico, porém, no canto terceiro, atribuiu-a a Teucro, como seu fundador:

Cartago, fundada pelo velho Teucro, envia homens ${ }^{19}$.

E não julgamos que isto foi dito acerca da outra velha Cartago na Hispânia, que Ptolomeu mal recordou e também nós dela já falámos, quando tratámos do nome do Tejo ${ }^{20}$. O mesmo Sílio descreve à perfeição, nestes versos do canto décimo quinto, a localização e o porto:

A cidade, pelo velho Teucro outrora fundada, honra

De Cartago o nome; o povo Tírio suas muralhas guarda,

Como na líbia cidade. Assim ela é famosa nas terras ibéricas,

É ela a capital 21. 
Hilermus quoque a M. Fuluio Nobiliore captus in proelio apud Toletum, de quo Liuius libro quinto, decade quarta.

[84] Thurrhus item longe potentissimus omnium Hispanorum, ut ait Liuius libro decimo, decade quarta.

Fuere et alii permulti, quorum seriem per continuas successiones uelle describere, intemperans mentiendi libido mihi uidetur. Quum maxima eorum pars uetustate nimia exoleuerit, pars, quae apud auctores nonnullos sparsim reperitur, nihil ad peculiare meum de Lusitania pertineat institutum.

Romanorum Poenorumque praedae pro ut, aut hi, aut illi plus armis ualuere, exposita Hispania fuit, ut Graecos, Iberos, Persas atque Celtas nouas sedes quaerenteis, et Phoenices Tyriosque ipsos diuitiarum fama inuitatos, ante duarum harum gentium de imperio propagando contentionem praetereamus.

Sub Carthaginiensium dicione cum reliqua Hispania fuisse Lusitaniam, sub initia secundi belli Punici, ex Liuio cognoscitur. Postea enim quam Romanis Poeni bello fracti, Siciliam reliquerunt, cedentes tempori, compositis Africae rebus, Hispaniam inuasere, misso cum exercitu Amilcare, cui Barcha cognomen fuit, una cum Annibale filio, fere nonum aetatis annum agente, et genero Asdrubale rerum gerendarum socio.

Amilcar igitur bonam Hispaniae partem olim amissam bello recuperauit, nouem circiter annis cum imperio in Hispania commoratus. In bello tandem contra Vettones, (sic enim legendum apud Plutarchum in Annibale) fortiter pugnans interiit apud Castrum Altum. Nam ita Liuius locum caedis eius appellat libro quarto tertiae decadis.

Quo interfecto, et Annibale domum reuerso, successit Asdrubal, [85] qui Nouam condidit Carthaginem, ut auctores sunt Polybius, Mela et Strabo. Quamquam Silius Italicus ad Teucrum conditorem eam retulit, libro tertio:

Dat Carthago uiros Teucro fundata uetusto.

Et ne putemus hoc de altera ueteri Carthagine in Hispania dictum esse, cuius solus meminit Ptolemaeus, et nos superius, quum de Tagi nomine ageremus. Idem Silius lib. 15, ad unguem, situm, et portum describit his carminibus:

Vrbs collitur Teucro quondam fundata uetusto, Nomen Carthago, Tyrius tenet incola muros Vt Libye sua, sic terris memorabile Iberis Haec caput est. 
Por outro lado, as palavras do poema de Sílio são explicadas pormenorizadamente por Lívio no livro sexto da terceira década ${ }^{22}$.

Justino $^{23}$ não diz que fosse Teucro a construir a cidade, mas sim que aportando aos litorais da Hispânia ocupou o local onde agora ela está, daí tendo passado à Galécia. Pode, no entanto, ter acontecido que alguns edifícios, deixados por Teucro, tivessem chegado até aos nossos dias por se terem ali conservado com pouca gente e sem nome. O nome de Cartago propriamente dito, quer se compreenda uma ou outra Cartago, não pode tê-lo dado Teucro, na medida em que ainda não existia nenhuma Cartago, da qual ele pudesse ter escolhido o nome.

Quer, no entanto, se aceite a versão de Justino sobre a origem de Cartago e, por consequência, se admita que decorreu não pequeno número de anos desde a conquista de Tróia, quer se aceite a opinião de [86] Aurélio Cassiodoro ${ }^{24}$, que diz que foi fundada por Tírios, facto por todos reconhecido, mas que o seu chefe era Carquédone, no tempo em que o latino Sílvio reinava entre os Itálicos, a verdade é que de ambas as formas se obtém, como data, para cima de 135 anos depois da conquista de Tróia 25 .

Eusébio tem opinião diferente ${ }^{26}$. Efectivamente, num passo da sua obra, diz, fundamentando-se em Filisto, que Cartago foi fundada pelos tírios Zaro e Cartago para cima de 30 anos antes da queda de Tróia. Noutro passo, porém, seguindo opinião diferente, afirma que é posterior de muitos anos à conquista de Tróia.

Timeu da Sicília ${ }^{27}$ conta que, quase na mesma altura em que Rómulo fundou Roma, foi Cartago fundada pelos Tírios. Não acrescento aqui o testemunho de Virgílio, porque, forçosamente, para tornar verosímil a chegada imaginária de Eneias junto a Dido, pouco depois da destruição de Tróia, apresenta Cartago já fundada. E, por este motivo, põe a rainha a dizer de Teucro:

E recordo-me bem de que Teucro veio a Sídon, etc. ${ }^{28}$

Mas os historiadores pensam de outra maneira, tão grande é a incerteza que sobre estes factos reina.

Para seguirmos, contudo, como Justino a versão mais divulgada, seja ela lenda ou história, a de Dido e da pele de boi ${ }^{29}$, admitamos que Cartago foi fundada por Dido setenta e dois anos antes da fundação de Roma. Assim, com efeito, se lê em Justino ${ }^{30}$.

Veleio Patérculo, por sua vez, diz no livro primeiro: "Cartago foi fundada por Elisa, a quem alguns chamam Dido, natural de Tiro, sessenta e cinco anos antes de a cidade de Roma ter sido fundada" 31 .

Quanto a Sérvio, o gramático, disse ele que "a cidade antiga existiu setenta anos antes"32.

[87] Admitindo então, como faz Solino no capítulo segundo do livro primeiro ${ }^{33}$, que desde a queda de Tróia até à fundação de Roma decorreram quatrocentos e trinta e três anos, se a estes se tirarem os setenta e dois anos nos quais, segundo Justino, 
Quae autem heic Silius canit, explicat copiose Liuius libro sexto tertiae decadis.

Iustinus Teucrum aedificasse non dicit, sed Hispaniae litoribus appulsum, loca occupasse, ubi nunc Noua Carthago est, inde in Callaeciam trasiisse. Fieri tamen potuit ut aliquid ibi manserit aedificii parum frequentis, et sine nomine, a Teucro usque relictum. Carthaginis enim ipsum nomen, utramlibet in Hispania intelligas, Teucer ponere non potuit, quum nondum ulla extaret Carthago ad quuius exemplum id nomen sumeret.

Siue enim originem Carthaginis ex Iustino petas, non parum multos post Troiam captam interfluxisse annos intelliges, siue ab Aurelio [86] Cassiodoro, qui conditam dicit a Tyriis, quod fatentur omnes, sed duce eorum Carchedone, regnante apud Italos Latino Siluio, a capta Troia anni colligentur ultra centum triginta quinque.

Eusebius uariat. Alibi enim auctore Philisto a Zaro et Carthagine Tyriis conditam dicit, ante Troiae captionem annis supra triginta. Alibi autem iuxta aliorum opinionem diu post captam Troiam.

Timaeus Siculus eodem fere tempore Romam a Romulo, quo Carthaginem a Tyriis tradit fuisse conditam. Non hic addo Virgilium, quia necessario, ut uerisimilem faceret fictum Aeneae ad Didonem aduentum, paulo post Ilii excidium, exorientem facit Carthaginem. Eaque gratia reginam inducit de Teucro ista dicentem:

Atque equidem Teucrum memini Sidona uenire, etc.

Sed historici aliter: tanta rei est incertitudo.

Tamen ut Iustini de Didone et bubulo corio, seu fabulam, siue historiam, ut receptiorem sequamur, ante Romam conditam, annis septuaginta duobus fundatam a Didone Carthaginem admittamus, ita enim Iustinus.

Velleius autem Paterculus libro priore: "Ante annos quinque et sexaginta, quam ubrs Roma conderetur, ab Elissa Tyria, quam quidam - inquit - Dido autumant, Carthago conditur."

Seruius uero grammaticus super illud "urbs antiqua fuit ante annos septuaginta" dixit.

[87] Iam, cum a capta Troia usque ad conditam Romam anni fuerint quadrigenti triginta tres, ut Solinus asserit libro primo capite secundo, si ex iis demas septuaginta duos quibus Iustinus Carthaginem ait Romam antecessisse, 
Cartago precedeu Roma, não se concluirá que a origem de Cartago data do ano tricentésimo sexagésimo segundo a contar da destruição de Tróia?

Não existia, pois, nenhuma Cartago quando Teucro abordou os litorais da Hispânia, pouco depois da queda de Tróia, não se podendo, por conseguinte, dar a este local o nome de Cartago, a não ser que alguém nos prove que Teucro imaginou tal nome por outra qualquer razão particular. Não penso, todavia, que tal possa ser provado.

Asdrúbal, porém, elevou à categoria de cidade e fortificou uma aldeia que, devido ao favorável condicionalismo da sua situação, talvez se tivesse desenvolvido mais rapidamente, e depois de a ter feito chamar Cartago para imitar a sua cidade natal fê-la povoar por grande número de habitantes púnicos, para que, com razão, fosse considerado como fundador da cidade.

O mesmo Asdrúbal, portanto, conseguindo conciliar pela amizade os ânimos dos régulos e príncipes, mais pelo bom senso do que pela força, aumentou significativamente a supremacia púnica. Foi um chefe de notável habilidade e tão receado pelos Romanos que, tendo-lhes estes enviado embaixadores, concluíram um tratado pelo qual, entre outras coisas, se estipulava, conforme referiu Políbio no livro segundo ${ }^{34}$ e Lívio no início da terceira década ${ }^{35}$, que não fosse permitido aos Cartagineses atravessar armados o rio Ebro mas que pudessem passar por onde quisessem nas restantes partes da Hispânia, desde que se mantivessem afastados de Sagunto.

Sob o comando de Asdrúbal serviu Aníbal, apenas adolescente, durante três anos até que foi chamado por carta de Cartago. Mas quando Asdrúbal foi assassinado pelo tal escravo, cujo ódio era motivado por ele ter assassinado o seu amo, tal como ao de leve referimos anteriormente [88] quando falámos do nome do rio Tejo, Aníbal foi proclamado chefe pelo exército.

Reuniu ele, sob as suas ordens, não apenas aquela parte da Hispânia que está mais perto de África, mas ainda a Lusitânia. Testemunham que esteve na Lusitânia tanto o ópido de Porto Aníbal, no cabo de S. Vicente, assim denominado por sua causa segundo Mela ${ }^{36}$, quanto as palavras que Lívio lhe atribui no livro primeiro da terceira década: "Já vistes suficientemente que até aqui nenhum proveito tirastes de todos os trabalhos e perigos de seguirdes o gado pelos vastos montes da Lusitânia e da Celtibéria" 37.

Do mesmo modo, quando já a guerra tinha começado na terra e no mar, os Lusitanos combateram a favor de Aníbal, conforme mostra Lívio com as seguintes palavras do livro primeiro da terceira década: "Foram nomeados cônsules Gneu Servílio e Gaio Flamínio. De resto, nem mesmo o acampamento de Inverno era calmo para os Romanos, com cavaleiros númidas vagueando aqui e além e por causa dos Celtiberos e Lusitanos, o que para eles era bastante embaraçoso ${ }^{38}$.

Também Asdrúbal, irmão de Aníbal, a quem tinha sido entregue a defesa da Hispânia, "se retirou para a Lusitânia, para muito perto do oceano Atlântico", como diz Lívio no livro citado 39 . 
nonne relinquitur Carthaginem anno a capta Troia tercentesimo sexagesimo altero fuisse exortam?

Nulla ergo extabat Carthago, quo tempore, paulo post euersionem Troiae, Hispaniae litoribus Teucer applicuit. Nec igitur ei loco Carthaginis nomen potuit imponere.

Nisi quis nos doceat, alterius peculiaris rei causa, id illum confinxisse nomen. Quod ostendi non posse ergo arbitror.

At Asdrubal uicum forte parum prius cultum propter loci commoditatem, in urbis dignitatem auxit, atque muniuit, Carthaginemque uocatam ad imitationem patriae, Poenis habitatoribus frequentem reddidit, ut merito urbis conditor perhibeatur.

Is ergo Asdrubal consilio magis quam ui regulorum ac principum conciliandis per amicitiam animis Punicum ualde auxit imperium, dux arte mira et Romanis formidolosa, adeo, ut missis ad illum legatis, foedus percusserint, in quo inter cetera cauebatur ne Carthaginiensibus liceret, Iberum fluuium cum armis traiicere, per Hispaniae reliquum, ab Saguntinis tamen abstinentes, qua uellent progrederentur, ut libro secundo retulit Polybius, et in initio decadis tertiae Liuius.

Sub hoc imperatore Annibal uixdum puber, triennio meruit, litteris accersitus Carthagine. Sed obtruncato Asdrubale a seruo quodam ob iram interfecti ab eo domini, sicut superius attigimus, $[\mathbf{8 8}]$ quum de Tagi nomine ageremus, dux ab exercitu Annibal est declaratus.

Is non modo eam Hispaniae partem, quae propius Africam est, sed etiam Lusitaniam suo iunxit imperio. Fuisseque eum in Lusitania testatur uel oppidum ab ipso dictum, portus Annibalis in promontorio Sacro apud Melam, uel illius uerba quae refert Liuius primo tertiae decadis libro: "Satis adhuc in uastis Lusitaniae Celtiberiaeque montibus pecora consectando, nullum emolumentum tot laborum periculorumque uestrorum uidistis."

Coepto quoque iam terra marique bello militasse pro Annibale Lusitanos, ostendit Liuius decadis tertiae libro primo his uerbis: "Creati consules Cn. Seruilius et C. Flaminius. Ceterum ne hiberna quidem Romanis quieta erant, uagantibus passim Numidis equitibus, et quae his impeditiora erant Celtiberis Lusitanisque."

Quin Asdrubal Annibalis frater, cui relicta erat custodienda Hispania, ut eodem libro inquit Liuius, "in Lusitaniam ac propius Oceanum concessit." 
Pouco depois, tendo-se reunido ao irmão que fazia a guerra na Itália, ficaram a dirigir os interesses púnicos na Hispânia dois outros Asdrúbais, com Mago e Masanissa, e parece que a um dos dois, o filho de Gisgo, coube a mais recuada orla da Hispânia, aquela que se inclina para o Atlântico e para Gades, ou seja, os Transtaganos e Turdetanos lusitanos, e que a Mago, por seu lado, couberam os restantes.

Quando ambos partiram dali e levaram já tarde ajuda ao outro Asdrúbal, depois de este ter travado combate contra Cipião junto à cidade de Bécula, resolveram de comum acordo que Asdrúbal fosse com o exército ao encontro de Aníbal na Itália e que as baixas [89] se preenchessem com soldados hispânicos.

Mago, depois de entregar a Asdrúbal, filho de Gisgo, o contingente militar que comandava, partiu com grande soma de dinheiro para recrutar tropas auxiliares das Baleares.

Quanto a Asdrúbal, filho de Gisgo, embrenhou-se com o exército no interior da Lusitânia, levando os soldados hispânicos para a parte mais recuada da Hispânia, com o objectivo de evitar que eles se passassem para os Romanos. Isto, segundo Lívio, no livro sétimo da terceira década e no início do oitavo ${ }^{40}$.

E mais adiante: "Os Cartagineses vencidos num combate em que perderam o chefe foram empurrados para o mais afastado litoral hispânico até junto do Atlântico ${ }^{41}$.

Não apenas deduzimos por Lívio que os Lusitanos seguiram Aníbal até à Itália, como o facto é ainda confirmado por Sílio no canto terceiro, quando apresenta o catálogo dos povos que o Púnico reuniu para a guerra na Itália:

A estes e aos Lusitanos, arrancados às longínquas florestas,

Condu-los Viriato, Viriato ainda no princípio da vida,

E cujo nome é célebre depois dos reveses aos Romanos infligidos ${ }^{42}$.

No canto quinto, ao falar da batalha junto ao Trasímeno, conta como o portaestandarte Telo e o nobre Mamerco foram mortos pelos Lusitanos:

E melhor destino não teve Mamerco, pois em todo o corpo

Vingança sofreu; não houve inimigo que o não ferisse.

Porque ele, no campo inimigo, por onde o terrível batalhão

Dos Lusitanos o combate animava, tendo arrancado o estandarte

[90] Manchado com o sangue de Telo, o porta-estandarte, enorme o levava

E às fileiras chamava, por infelicidade sua, as medrosas insígnias dos seus.

A coorte enlouquecida e provocada pela arrogante audácia,

Sobre ele lançava toda a arma de arremesso que o batalhão levava,

E o que quer que a terra, juncada de dardos dispersos, que impeliam

[o movimento, lhes oferecia.

De forma idêntica o trespassou até não haver mais espaço no seu corpo ${ }^{43}$. 
Quumque postmodum ad fratrem in Italia bellum gerentem se contulisset, ac duo alii Asdrubales, cum Magone ac Masanissa, in Hispania rem Punicam generent, alterum ex iis Gisgonis filium ultimam Hispaniae oram, quae ad Oceanum, et Gades uergit, hoc est transtaganos, et Turdetanos Lusitanos tenuisse apparet.

Magonem autem reliquos.

Vnde cum ambo ad Asdrubalem alterum, post factum cum Scipione ad urbem Baetulam proelium, auxilium iam sero deuenissent, capto in commune consilio ut Asdrubal ad Annibalem in Italiam cum exercitu iret, imminutumque quod erat [89] Hispanis militibus repleretur.

Mago traditis Asdrubali Gisgonis, quibus praeerat, copiis, cum grandi pecunia ad conducenda ex Balearibus auxilia est profectus.

Asdrubal uero Gisgonis cum exercitu penitus in Lusitaniam abiit, ut ad ultima Hispaniae traducti Hispani milites, a transitionibus ad Romanos prohiberentur. Haec ex Liuio septimo tertiae decadis libro, et in initio octaui.

Et post: "Proelio uicti Carthaginienses, duce amisso in ultimam Hispaniae oram, usque ad Oceanum compulsi erant."

Annibalem sequutos fuisse Lusitanos in Italiam, non modo ex Liuio colligimus, sed id etiam confirmat Silius libro tertio in catalogo populorum, quos ad Italicum bellum Poenus contraxit:

Hos Viriatus agit Lusitanumque remotis

Extractum lustris, primo Viriatus in aeuo,

Nomen Romanis factum post nobile damnis.

Et libro quinto in pugna ad Trasymenum, Tellum signiferum ac nobilem Mamercum ab iis interemptos ita narrat:

Nec fati melior Mamercus, corpore toto

Exoluit poenas, nulli non saucius hosti.

Namque per aduersos, qua Lusitana ciebat

Pugnas dira manus, raptum cum sanguine Telli

[90] Signiferi, magna uexillum mole ferebat,

Et trepida infelix reuocabat signa suorum.

Sed furiata cohors, ausisque accensa superbis,

Quodquumque ipsa manus gestabat missile, quidquid

Praebebat tellus, sparsis non peruia telis,

Iniecit pariter, pluresque in corpore nullo. 
Também no canto décimo diz que Gneu Servílio foi morto naquela memorável batalha de Canas por Viriato, chefe dos Lusitanos, e o próprio Viriato pelo cônsul Paulo Emílio:

[................ Contra as armas dos vencedores

Acorria o cônsul: já só o ardor guerreiro de bem morrer, E a certeza da morte coragem davam.

Eis quando Viriato, o rei magnânimo da ibera terra, Agitando os dardos e mesmo junto, mesmo diante do olhar De Paulo enfurecido, decapita o inimigo cansado do combate. Ó Dor! Ó lágrimas! Servílio, o melhor elemento na guerra, Depois de Paulo o elemento melhor, sucumbiu sob o golpe Do bárbaro, e só com a sua morte, ao cair, maior Tornou o ódio em Canas. Não conteve o cônsul a ira Sombria, e mal-grado a força contrária do furioso vento Que o enfraquece e apesar da poeira que lhe tolda a vista, Ameaçador irrompe através da nuvem escura da areia levantada, Avança, agarra aquele que à guisa e costume dos Iberos Entoando canções guerreiras no bárbaro escudo batia, E trespassa-lhe os órgãos vitais no lado esquerdo do peito» ${ }^{44}$

[91] E para que ninguém fique perturbado pela narrativa de Sílio sobre Viriato, advirta-se que este foi um Viriato, mas que houve um outro, o grande e célebre, e que foi ele, que com os Lusitanos combateu durante anos contra os Romanos.

Com efeito, este é apresentado pelo poeta como régulo, aqueloutro, conforme contam todos os que escreveram a seu respeito, foi um ladrão, primeiramente pastor e caçador, e depois chefe de exército. O primeiro foi abatido pelo cônsul Paulo na batalha de Canas, o outro morreu devido ao ardil e traição de Servílio Cépio. Por outro lado, entre a morte de um e o início das guerras do segundo decorreram cerca de 70 anos, ou seja, desde 540 a contar da fundação de Roma até ao ano $607{ }^{45}$.

E se alguém insistir novamente sobre a razão por que Sílio afirma que o nome se tornou rapidamente conhecido por causa dos reveses dos Romanos, responderei que este nome não deve ser atribuído ao primeiro Viriato, embora também a ele, que não só junto a Trasimeno como em Canas se distinguira, mas de preferência ao Viriato que veio depois, ao maior dos chefes. E, por isso, o poeta não disse que o chefe se tornou conhecido, mas sim que o próprio nome de Viriato, até então desconhecido, rapidamente, isto é, poucos anos depois, se tornou conhecido pelos reveses dos Romanos.

Quem tenha pensado que contemporaneamente existiram tantos Aníbais, e Asdrúbais em maior número ainda, não se admirará na verdade de que dois chefes lusitanos tenham tido o mesmo nome em épocas diferentes. Até porque o nome 
Libro quoque decimo in memorabili illa Cannensi pugna, Cn. Seruilium a Viriato Lusitanorum duce interfectum ait, Viriatum uero ipsum ab Aemilio Paulo consule:

[............... Incurrebat in arma

Vincentum Consul: pereundi Martius ardor,

Atque animos iam sola dabat fiducia mortis

Quum Viriatus agens telis, regnator Iberae

Magnanimus terrae, iuxta, atque ante ora furentis

Obtruncat Pauli fessum certaminis hostem.

Heu dolor, heu lacrimae! Seruilius, optima belli,

Post Paulum belli pars optima, corruit ictu

Barbarico magnamque cadens leto addidit uno

Inuidiam Cannis. Tristem non pertulit iram

Consul, et insani quamquam contraria uenti

Exarmat uis atque obtendit puluere lucem,

Squalentem rumpens ingestae toruus arenae

Ingreditur nimbum, ac ritu iam moris Iberi

Carmina pulsata fundentem barbara caetra

Inuadit, laeuaeque fodit uitalia mammae.

[91] Et nequem turbet haec Silii de Viriato narratio, aduertat alterum fuisse Viriatum hunc, alterum magnum illum qui cum Lusitanis aduersus Romanos, annos quattuordecim pugnauit.

Nam hic regulus a poeta perhibetur, ille alter ex pastore ac uenatore latro, et inde dux exercitus ab omnibus qui de eo scripsere fuisse narratur. Hic a Paulo consule in Cannensi pugna occisus est, ille alter Seruilii Caepionis dolo atque insidiis periit. At inter mortem unius, atque initium bellorum alterius fluxerunt anni circiter septuaginta, uidelicet ab anno conditae urbis DXL ad annum DCVII.

Iterum si quis urgeat, quonam modo Silius Viriati nomen mox factum nobile Romanorum damnis asserat? Respondebo non referendum hoc ad priorem Viriatum, quanquam et ad hunc qui et ad Trasymenum et ad Cannas, Romanorum damnis inclaruerat, sed potius ad posteriorem Viriatum ducem maximum.

Ideoque poeta non dixit ducem factum nobilem, sed ipsum nomen Viriatum, ignotum prius, mox, idest post paucos annos, Romanorum damnis factum nobile.

Fuisse uero idem nomen duobus Lusitanis ducibus, diuersis temporibus, non mirabitur qui una tempestate tot Annibales et plures aduerterit extitisse Asdrubales. 
de Viriato, criado sem dúvida devido à imponência da força física, pôde por esta mesma razão ser atribuído a um e a outro pelos seus compatriotas ${ }^{46}$.

Essa a razão por que Lucílio, como se lê em Nónio Marcelo, tenha chamado Viriato a Aníbal ${ }^{47}$.

Terminada a guerra púnica e expulsos da Hispânia os Cartagineses por Públio Cornélio Cipião, como as províncias ainda não estivessem completamente pacificadas, os Romanos desgastaram-nas com guerras sucessivas, em que umas vezes eram vencidos, sobretudo por terem sido mortos, no espaço de um mês, os dois irmãos Públio e Cornélio Cipião, mas mais frequentemente vencedores.

[92] No que diz respeito aos Lusitanos, a acreditarmos em Políbio citado por Plutarco ${ }^{48}$, parece que Marco Pórcio Catão, o que foi denominado Censor, se transferiu da Hispânia Citerior, que lhe coubera, para a Ulterior. Em todo o caso, manteve os Lusitanos em obediência não sei se pelo medo se por meio de regalias. Encontrei dois fragmentos de mármore com inscrições a seu respeito, mas nada de certo pude decifrar. Um está em Lisboa, nos degraus do palácio que se encontra no ponto mais alto do castelo, e diz:

M. PORTIVS. M. F. M. N. CATO

Isto é: Marco Pórcio Catão, filho de Marco, neto de Marco 49

O outro está na região de Sintra, numa aldeia de que falaremos noutra altura, que tem o nome de Fão, e é a parte superior de um cipo quebrado. E diz:

M. PORCIO. M. F. CATONI

OB SINGVL EI

Isto é: A Marco Pórcio Catão, filho de Catão, pela sua singular...50.

[93] Depois da partida de Marco Catão da Hispânia, como se tivessem revoltado muitas cidades da província Citerior, por volta do ano 560 da fundação de Roma, o pretor Sexto Digício travou combates mais frequentes do que dignos de serem contados, e bastante desfavoráveis na sua maioria, tal como diz Lívio no início do livro quinto da quarta década, que a custo entregou ao sucessor metade dos soldados que tinha recebido. Não há dúvida que toda a Hispânia se teria sublevado se o outro pretor, Públio Cornélio Cipião, filho de Gneu, não tivesse travado muitos combates favoráveis para lá do Ebro, onde, levados pelo terror, se entregaram nada menos de cinquenta ópidos. Cipião era pretor quando fez isto ${ }^{51}$. 
Praeterquam quod Viriati nomen, nempe a uirium magnitudine dictum, utrique inditum ${ }^{1}$ a suis esse potuit, eadem gratia; unde et Lucilius Annibalem Viriatum appellauit, ut est apud Nonium Marcellum.

Finito Punico bello, et a P. Corn. Scipione pulsis Hispania Carthaginiensibus, quum nondum perpacatae essent prouinciae, frequentibus eas bellis Romani attriuerunt, interdum uicti, maxime interfectis intra mensem duobus fratribus $P$. et Cor. Scipionibus, saepius tamen uictores.

[92] Quod ad Lusitanos attinet, M. Porcius Cato, is qui Censorinus cognominatus est, ex Hispania Citeriore, quam fuerat sortitus, ad Vlteriorem descendisse uidetur, si Polybio apud Plutarchum assentiamur.

Lusitaniam certe in officio continuit, metune, an beneficiis non scio. Reperi de eo fragmenta marmorea duo, sed ex quibus nihil certi diuinare potui. Alterum Olisipone in gradibus Palatii, quod est in summa arce:

M. PORTIVS. M. F. M. N. CATO

Id est: Marcus Portius Marci filius Marci nepos Cato

Alterum in agro Sintriensi, in uico cui nomen est Fanum de quo alias, et est cippi fracti superior pars.

M. PORCIO. M. F. CATONI

OB SINGVL EI

Hoc est: Marco Porcio Marci filio Catoni ob singularem eius.

[93] Post M. Catonis ex Hipania profectionem, quum multae in Citeriore prouincia ciuitates rebelassent circa Vrbis annum DLX Sex. Digitius praetor crebra magis, quam digna dictu proelia fecit, et adeo pleraque aduersa, inquit Liuius in initio libri quinti quartae decadis, ut uix dimidium militum, quam quod acceperat, successori tradiderit. Nec dubium fuit quin omnis Hispania sublatura animos fuerit, ni alter praetor P. Cornelius Cn. F. Scipio, trans Iberum multa secunda proelia fecisset. Quo terrore non minus quinquaginta oppida ad eum defecerunt. Praetor haec gesserat Scipio.

1 inditum $F U\rfloor$ indictum $E R C^{1} C^{2}$ 
Ora foi este mesmo que, já propretor, travou contra os Lusitanos o violentíssimo combate de que falámos anteriormente ao dissertarmos sobre o carácter do povo Lusitano ${ }^{52}$.

No consulado de Lúcio Cornélio Cipião, mais tarde chamado Asiático, e de Gaio Lélio Nepos, por volta do ano 564 da fundação de Roma, os Lusitanos derrotaram o propretor Lúcio Emílio Paulo com todo o exército numa batalha em que, segundo Orósio $^{53}$, teria morrido o próprio Emílio, a quem chama procônsul. Não sei em que autor se fundamentou. A verdade é que não morreu, porque, depois desta batalha, de novo em combate regular, infligiu aos Lusitanos enormes perdas e dirigiu mais tarde a guerra da Macedónia com grande glória, como o próprio Orósio reconhece no mesmo capítulo, a não ser que tenha pensado tratar-se de outro. Sabe-se, no entanto, por Lívio que foi o mesmo ${ }^{54}$.

Quanto ao facto de Orósio lhe chamar procônsul, a razão é talvez a seguinte: foi enviado para a Hispânia, província que lhe coube por decreto, não apenas com os seis lictores à maneira dos outros pretores, mas com doze, em sinal de consideração, para que assim o seu comando tivesse a dignidade consular, segundo conta Plutarco ${ }^{55}$ na biografia que sobre ele escreveu.

[94] Mas mais vale ouvir o que diz Lívio no livro sétimo da quarta década: "Diminuiu a alegria do seu triunfo" - ou seja, o de Marco Acílio Glabrião sobre os Etólios - "a triste notícia vinda da Hispânia de que em combate desfavorável contra os Lusitanos e sob o comando do propretor Lúcio Emílio, junto ao ópido de Lico, no território dos Vascetanos, tinham morrido seis mil homens do exér cito romano e que os restantes, amedrontados, foram compelidos para dentro das paliçadas, onde defenderam a custo o acampamento, e afastados como fugitivos e em marchas forçadas para território pacificado" 56 .

Quando João Vaseu, homem sabedor e escrupuloso, compunha a Crónica de Espanha ${ }^{57}$, perguntou-me um dia quem pensava eu que fossem na realidade os Vascetanos, em cujo território os Lusitanos tinham alcançado tão brilhante vitória; respondi que a lição me parecia algo deturpada, com troca de letras, e que se devia ler "entre os Bastetanos". Com efeito, alguns costumavam pronunciar o -bcom o mesmo som que - $\mathrm{v}$ - consonântico, como ainda a maior parte dos Gregos e Hispânicos; quanto ao -t- escrito com letra minúscula (que agora estamos a usar), pôde facilmente ser mudado em -c-. É que não conheço nenhuns Fascetanos na Hispânia Ulterior e muito menos na Citerior.

Encontrei em Plínio ${ }^{58}$ e em Ptolomeu ${ }^{59}$ o ópido de Vesco na Bética, cognominada Favência, donde poderia derivar Vescetanos, se no contexto se falasse de habitantes de uma cidadela e não de povos. Ora Lívio pensava em povos, quando disse "entre os Vascetanos, junto ao ópido de Lico". Se este ópido ainda existisse ou pelo menos traços do nome, seria trabalho fácil conhecer a verdadeira lição. Entretanto pareceme bem que se substitua Vascetanos por Bastetanos.

Mas, para voltarmos a Lívio, diz ele, perto do fim do mesmo livro, ao falar de Públio Júnio [95] Bruto, que foi enviado para a Hispânia Ulterior no consulado de 
At idem postea propraetor accerrimum illud proelium cum Lusitanis gessit, de quo superius multa diximus, quum qualisnam gens Lusitanorum esset disputaremus.

L. Corn. Scipione, qui postea Asiaticus appellatus est, et C. Laelio Nepote coss. circa Vrbis annum DLXIIII Lusitani L. Aemilium Paulum propraetorem cum uniuerso exercitu ceciderunt, in qua pugna ipsum Aemilium interiisse dicit Orosius, qui eum proconsulem uocat, nescio quem sequutus auctorem.

Non enim interiit, quum post hanc pugnam, iterum collatis signis, ingenti clade Lusitanos affecerit, et postea bellum Macedonicum cum magna gloria gesserit, ut idem Orosius fatetur eodem capite, nisi alium existimauerit; constat autem ex Liuio eundem fuisse.

Nam quod Orosius illum proconsulem uocat, id forte est quoniam in Hispaniam sibi decretam prouinciam, non cum sex tantum securibus, aliorum praetorum more, sed cum duodecim honoris causa missus est, ita ut dignitas consularis in imperio eius inesset, ut in ipsius uita narrat Plutarchus.

[94] Sed praestat Liuium audire libro septimo quartae decadis: "Huius triumphi" - uidelicet M. Acilii Glabrionis de Aetolis - "minuit laetitiam, nuntius ex Hispania tristis, aduersa pugna in Vascetanis ductu L. Aemilii propraetoris apud oppidum Lyconem, cum Lusitanis, sex milia de exercitu Romano cecidisse, ceteros pauentes intra uallum compulsos aegre castra defendisse, et admodum fugientium magnis itineribus in agrum pacatum reductos."

Quaesiuit aliquando a me Ioannes Vasaeus uir doctus ac diligens, quum Hispanicarum rerum chronicon commentaretur, quosnam arbitrarer esse Vascetanos, in quibus tam insignem uictoriam adepti essent Lusitani.

Respondi, uideri mihi lectionem nonnihil fuisse deprauatam, litterarum commercio, legendumque "in Bastetanis". Nam solebant nonnulli B eo sono quo V, quum est consonans, pronuntiare, ut etiam modo Graeci et Hispanorum plerique.

T, uero minutiore littera (qua nunc utimur) scriptum, facile mutari potuit in C. Vascetanos enim in Vlteriore Hispania populos, scire me nullos, immo neque in Citeriore.

Vesci oppidum Fauentiam cognominatum legi apud Plinium in Baetica, et apud Ptolemaeum ex quo Vescitani fieri potuissent, si de oppidanis, non autem de populis sermo esset. At Liuius populos intellexit, "in Vascetanis - inquiens - apud oppidum Lyconem". Quod oppidum si extaret, aut saltem nominis uestigium exiguae esset operae lectionem ueram agnoscere. Interea placere mihi Bastetanos pro Vascetanis substitui.

Sed ut redeamus ad Liuium circa eiusdem libri finem de P. Iunio [95] Bruto in Vlteriorem Hispaniam misso Cn. Manlio, Cn. F. Vulsone, M. Fuluio M. F. 
Gneu Mânlio Vulso, filho de Gneu, e de Marco Fúlvio Nobílior, filho de Marco, por volta do ano 565 da fundação de Roma, diz: "E partiu para a Hispânia o propretor Públio Júnio. Nesta província, um pouco antes de o seu sucessor chegar, Lúcio Emílio Paulo, que mais tarde venceu o rei Perseu com grande glória, como no ano anterior não fosse bem sucedido, recrutou à pressa um exército e, em combate regular, lutou contra os Lusitanos.

Os inimigos foram derrotados e postos em fuga. Dos que levavam armas foram mortos 18.000 , aprisionados 3.300 , e os acampamentos foram tomados. A notícia desta vitória tornou mais tranquila a situação na Hispânia"60.

Concluem alguns das palavras de Veleio Patérculo, no livro primeiro, que Lúcio Emílio Paulo obteve o triunfo por causa desta vitória sobre os Lusitanos: "Então o Senado e o povo romano escolheram como cônsul Lúcio Emílio Paulo, que já tinha obtido o triunfo como pretor e cônsul, homem digno de tanto louvor quanto o valor se lhe pode atribuir e que era filho do cônsul Paulo que, em Canas, etc"61.

Mas Lívio, depois de narrar esta vitória sobre os Lusitanos, diz: "Em seguida, por deliberação do Senado, foram dadas acções de graças porque Lúcio Emílio tinha sido bem sucedido na Hispânia"62. Nem ele, nem Plutarco, extremamente propenso a elogiar este homem, nem ainda as Tábuas Capitolinas de Marco Vérrio Flaco mencionam o triunfo ${ }^{63}$.

Onofre de Verona ${ }^{64}$, porém, no comentário aos heróis que obtiveram o triunfo, parece concluir, e não sem fundamento, das palavras que há pouco citei de Patérculo, de certo pedestal do Capitólio e de algumas moedas, que Lúcio Emílio triunfou.

"A notícia desta vitória" - diz Lívio - "tornou mais tranquila a situação na Hispânia" 65. Mas não por muito tempo. Com efeito, quando exerciam os seus cargos nas Hispânias, Gaio Catínio e Lúcio Mânlio, por volta do ano 568 da fundação de Roma, os Celtiberos na província Citerior e os Lusitanos na Ulterior submetiam pelas armas [96] os aliados dos Romanos e devastavam os seus campos. Eram nessa altura cônsules Espúrio Postúmio Albino e Quinto Márcio Filipo.

Por isso, Gaio Catínio, que no biénio anterior tinha partido como pretor para a província da Ulterior e que, devido a ter sido prorrogado o seu comando, a obtinha agora como propretor, lutou em combate regular contra os Lusitanos na região de Asta. "Foram mortos cerca de 6.000 inimigos", como refere Lívio no livro nono da quarta década, "e os restantes foram derrotados, postos em fuga e arrancados do acampamento" 66 .

Depois disto Catínio dirigiu as legiões para o ataque a Asta, que tomou depois de uma batalha não muito maior que a travada contra o acampamento, mas foi ferido quando, sem tomar precauções, subia as muralhas, e morreu do ferimento poucos dias mais tarde. Ao saber disto, o Senado ordenou a Gaio Calpúrnio Pisão, que o ia substituir, que se apressasse a partir para que a província não estivesse sem comando.

Tomou Gaio Calpúrnio Pisão o caminho da Hispânia Ulterior, por causa da sublevação dos Lusitanos, e Lúcio Quíncio Crispino o da Citerior, e na Primavera 
Nobiliore coss. circa Vrbis annum DLXV: "Profectusque in Hispaniam est. P. Iunius propraetor, in qua prouicia prius aliquanto, quam successor uenisset, L. Aemilius Paulus, qui postea regem Persea magna gloria uicit, quum priore anno haud prospere rem gessisset, tumultario exercitu collecto, signis collatis, cum Lusitanis pugnauit.

Fusi fugatique sunt hostes, caesa decem et octo millia armatorum, tria millia, CCC capti, et castra expugnata. Huius uictoriae fama, tranquilliores in Hispania res fecit."

Lucium Aemilium Paulum de Lusitanis propter hanc uictoriam triumphasse opinantur nonnulli ex uerbis Velleii Paterculi libro priore: "Tum Senatus Populusque Romanus, L. Aemilium Paulum, qui et praetor, et consul triumphauerat, uirum in tantum laudandum in quantum intelligi uirtus potest, consulem creauit filium eius Pauli, qui ad Cannas, etc."

Sed Liuius post narratam hanc de Lusitanis uictoriam: "Supplicationes inquit - deinde fuerunt ex S. C. quod Lucius Aemilius in Hispania prospere rem gessisset." De triumpho non meminit. Neque Plutarchus, in hominis laudem mire propensus; neque item Capitolinae M. Verrii Flacci Tabulae.

Onuphrius autem Veronensis in commentario uirorum triumphalium, ex Paterculi a me modo citatis uerbis, et basi Capitolina quadam, atque aliquot nummis non male uidetur colligere illum triumphasse.

"Huius uictoriae fama - inquit Liuius - tranquilliores in Hispania res fecit."

Verum non diu. Nam. C. Catinio et L. Manlio in Hispaniis rempublicam gerentibus, circa annum ab Vrbe condita DLXVIII in Citeriore prouincia Celtiberi, in Vlteriore Lusitani armis Romanorum [96] socios uexabant, eorumque agros populabantur Sp. Posthumio Albino, Q. Marcio Philippo coss.

C. ergo Catinius, qui $\mathrm{cum}^{1}$ biennio ante praetor in ulteriorem prouinciam esset profectus, et tum ex prorogato imperio eam pro praetore obtineret, in Astensi agro cum Lusitanis signis collatis pugnauit. "Ad sex millia hostium sunt caesa", ut refert Liuius libro nono quartae decadis. "Ceteri fusi, fugati, castrisque exuti."

Catinius inde ad Astam oppugnandam legiones duxit, eamque haud multo maiore certamine cepit, quam castra, sed dum incautius subit muros, ictus ex uulnere paucos post dies mortuus est. Qua re cognita Senatus censuit, ut C. Calpurnius Piso, qui erat successurus, maturaret proficisci, ne sine imperio prouincia esset.

Profecti igitur C. Calpurnius Piso in Vlteriorem Hispaniam, propter Lusitanorum

1 qui cum biennio $\left.R C^{1} F C^{2} U\right]$ qui biennio $E$ 
juntaram os contingentes trazidos dos acampamentos de Inverno na Betúria. É esta a parte da Bética que se estende dos montes Marianos até ao Guadiana.

Daqui avançaram para a Carpetânia, onde estava o acampamento dos inimigos, resolvidos a combaterem juntos e com decisões tomadas em comum. O desentendimento começou entre forrageadores, não longe das cidades de Yepes e Toledo.

Enquanto para estes foram chegando reforços de ambos os acampamentos, formam-se pouco a pouco todas as tropas em linha de combate. Nesta batalha feita à pressa, não só o local, seu conhecido, como o tipo de combate, favoreceram o inimigo, diz Lívio no livro nono da quarta década, e os dois exércitos romanos foram derrotados e atirados para o acampamento. Os inimigos não perseguiram os vencidos.

[97] Os pretores romanos para evitarem o ataque ao acampamento no dia seguinte, a um sinal tácito e no silêncio da mesma noite, retiraram o exército. Pela madrugada os Hispanos aproximaram-se da paliçada em linha de combate e, entrando no acampamento, que, contra a expectativa, encontraram vazio, saquearam o que tinha sido abandonado precipitadamente durante a noite. Depois de regressarem ao acampamento mantiveram-se alguns dias em descanso.

Foram mortos nesta batalha e na fuga cerca de 5.000 romanos e aliados, com cujos despojos os inimigos se armaram, partindo depois em direcção ao rio Tejo. Assim diz Lívio ${ }^{67}$.

Depois disto, os pretores, como tivessem gasto todo este tempo a reunir tropas auxiliares das cidades aliadas e a reanimar a coragem dos soldados aterrados pela batalha infeliz, depois de completado o exército, de novo em combate regular, travaram um sangrento recontro, no qual, de um lado, estavam os Hispanos inchados com a recente vitória, do outro, os soldados romanos assanhados pela anterior afronta.

Foram trucidados os Hispanos de tal modo que, de um número superior a $35 \mathrm{mil}$, fugiram quatro mil e destes apenas três mil conservaram as armas e se refugiaram num monte próximo, enquanto mil se espalharam semi-armados pelos campos. Entre os Romanos e aliados morreram pouco mais de seiscentos e das tropas auxiliares provinciais aproximadamente cento e cinquenta; perderam-se cinco tribunos militares e alguns cavaleiros romanos. No dia seguinte foram louvados e presenteados com fáleras, cadeias e fíbulas, em público, cavaleiros e centuriões por cujo esforço, sobretudo, tinham os inimigos sido derrotados.

Estes acontecimentos deram-se naquele ano em que foram cônsules Ápio Cláudio e [98] Marco Semprónio ${ }^{68}$.

No ano que se seguiu e em que foram cônsules Públio Cláudio e Lúcio Pórcio, segundo diz Lívio ${ }^{69}$, manteve-se a situação na Hispânia Ulterior, com a derrota dos Lusitanos na última guerra. Deduzimos daqui que os dois combates, que há pouco referimos, se travaram contra Lusitanos e Celtiberos. Isto mesmo é evidente pelo facto de, ao chegarem a Roma os antigos pretores Gaio Calpúrnio Pisão e Lúcio Quíncio Crispino, que tinham combatido nestas batalhas, ser a ambos decretado o triunfo com a unanimidade dos senadores. 
motus; in Citeriorem L. Quintius Crispinus, primo uere ex hibernis eductas copias in Baeturia iunxere. Ea est pars Baeticae a Marianis montibus ad Anam pertingens.

Inde in Carpetaniam, ubi castra erant hostium, progressi sunt, communi animo consilioque parati rem genere. Haud procul Hippone et Toleto urbibus, inter pabulatores pugna orta est.

Quibus dum utrimque subuenitur a castris paulatim omnes copiae in aciem eductae sunt. In eo tumultuario certamine, et loca sua et genus pugnae, pro hoste fuere, ait Liuius libro nono decadis quartae. Duo exercitus Romani fusi, atque in castra compulsi sunt. Non institere perculsis hostes.

[97] Praetores Romani, ne postero die castra oppugnarentur, silentio proximae noctis tacito signo exercitum abduxerunt.

Luce prima Hispani acie instructa ad uallum accesserunt, uacuaque praeter spem castra ingressi, quae derelicta inter nocturnam trepidationem erant, diripuerunt, regressique in sua castra paucos dies quietis statiuis manserunt.

Romanorum sociorumque in proelio fuga ad quinque millia occisi, quorum se spoliis hostes armauerunt. Inde ad Tagum flumen profecti sunt. Ita Liuius.

Praetores posthac cum omne id tempus contrahendis sociarum ciuitatum auxiliis; recreandisque ab terrore aduersae pugnae militum animis consumpsissent, suppleto exercitu iterum collatis signis atrox proelium inierunt, heinc inflatis recenti uictoria Hispanis, illinc Romanis militibus priore ignominia ac,censis

Caesi Hispani adeo, ut ex numero supra XXXV Millium, quattuor millia effugerint, tria tantum millia qui arma retinuerunt, in propinquum montem se receperint, mille semiermes per agros palati sint.

Romani sociique paulo plus sexcenti, et prouincialium auxiliorum CL ferme ceciderunt, Tribuni militum quinque amissi, et pauci equites Romani. Pro contione postero die laudati, donatique phaleris, catellis ac fibulis, equites et centuriones, quorum maxime opera fusi essent hostes.

Haec eo anno quo App. Claudius, M. Sempronius Coss. fuerunt, [98] sunt gesta.

In sequenti anno, quo P. Claudius, L. Porcius erant coss. in Hispania Vlteriore, fractis proximo bello Lusitanis, res quietae fuerunt, ut tradit Liuius.

Ex quo intelligimus proelia duo, quae paulo ante retulimus, cum Lusitanis ac Celtiberis fuisse.

Id etiam ex eo patet, quod ueteres praetores C. Calpurnius Piso et L. Quintius Crispinus, qui eas pugnas pugnauerant, Romam cum rediissent, utrique magno patrum consensu triumphus est decretus. 
Primeiro triunfou Gaio Calpúrnio pela vitória sobre os Lusitanos e Celtiberos; poucos dias depois, Lúcio Quíncio por causa dos mesmos Lusitanos e Celtiberos.

"No ano seguinte a Hispânia Ulterior esteve em paz, porque Públio Semprónio Longo, a quem a província tinha sido atribuída, foi atacado por longa doença e, como nada os provocasse, muito oportunamente os Lusitanos conservaram-se tranquilos." São estas as palavras de Lívio, no fim do livro nono da quarta década ${ }^{70}$.

Mesmo por aqui se verifica que naquele tempo os motivos da guerra e da paz estiveram sobretudo nas mãos dos Lusitanos. Depois disso, no ano 572 da fundação de Roma, durante o consulado de Gneu Bébio Pânfilo e de Lúcio Emílio Paulo, a Hispânia Ulterior, que estivera até então sem comando devido à morte do propretor Públio Semprónio, coube a Públio Mânlio que, diz Lívio ${ }^{71}$, a obtivera também na pretura anterior. Este travou contra os Lusitanos algumas [99] batalhas favoráveis que Lívio não descreve ${ }^{72}$.

No consulado de Aulo Postúmio Albino e de Calpúrnio Pisão, os pretores tiraram à sorte as Hispânias, cabendo a Posterior a Lúcio Postúmio Albino e a Citerior a Tibério Semprónio Graco. Este último, bem sucedido, obrigou cento e cinco cidades à rendição. Lúcio Postúmio, por seu lado, combateu magnificamente na mesma campanha por duas vezes contra os Vaceus na Hispânia Ulterior, tendo morto, segundo escreve Lívio ${ }^{73}$, cerca de 35 mil homens.

Soube, por um amigo meu, que existe um códice de Lívio manuscrito, onde se encontra não "contra os Vaceus", mas "contra os Brácaros", tal como se lê também na edição Badiana ${ }^{74}$, segundo verificação de Henrique Glareano, homem sabedor e escrupuloso ${ }^{75}$. Falei nisto um dia a João $V^{2} \operatorname{seu}^{76}$ e estava inclinado para esta lição principalmente porque os Vaceus não estão na Hispânia Ulterior, enquanto os Brácaros, situados junto ao limite dos mais antigos territórios, tal como na nossa época, se estendem até à Lusitânia. E se isto assim fosse, conviria ser corrigido também o epítome de Lívio no livro quadragésimo primeiro ${ }^{77}$, repondo Brácaros em vez de Vaceus.

Analisei, contudo, depois disso as palavras de Lívio num passo um pouco anterior, onde se diz: "No mesmo ano, na Hispânia, os propretores Lúcio Postúmio e Tibério Semprónio decidiram de comum acordo que Albino atacasse os Vaceus, passando através da Lusitânia, e que voltasse daí para a Celtibéria; Graco penetrou até aos confins da Celtibéria, porque nessa região estava a guerra mais acesa"78. Não ouso, pois, mudar seja o que for.

[100] Com efeito, parece que Lívio considerou seguramente como objectivo do plano, que os pretores tinham acordado entre si, que Albino fosse contra os Vaceus, através da Lusitânia, do mesmo modo que o próprio Tibério Graco atacou e tomou Munda, que é da província da Ulterior. Ambos pensaram que assim haviam de servir a república.

O pretor Graco, na mesma região e de novo, tomou de assalto e submeteu duzentos ópidos. Na mesma região, isto é, na Hispânia Citerior e de novo, porque 
Prior C. Calpurnius de Lusitanis et Celtiberis, paucos post dies L. Quintius ex iisdem Lusitanis ac Celtiberis triumphauit.

"In sequenti anno Vlterior Hispania in pace fuit, quia P. Sempronius Longus, cui ea decreta erat, diutino morbo esset implicitus, et nullo lacessente peropportune quieuerant Lusitani."

Haec Liuius in fine libri noni, quartae decadis. Ex quo etiam patet illa tempestate, belli, pacisque momenta praecipue penes Lusitanos fuisse.

Inde coss. Cn. Baebio Pamphilo, L. Aemilio Paulo, anno ab Vrbe condita DLXXII P. Manlio Hispania Vlterior obuenit, quam et priore praetura obtinuerat, inquit Liuius, quae tunc P. Sempronii propraetoris morte sine imperio fuerat. Is secunda aliquot proelia cum [99] Lusitanis fecit, quae Liuius non explicat.

A. Posthumio Albino et Calpurnio Pisone coss. Hispanias sortiti praetores. L. Posthumius Albinus posteriorem, citeriorem Tib. Sempronius Gracchus, qui bene re gesta centum quinque oppida ad deditionem coegit.

L. autem Posthumium eadem aestate in Hispania Vlteriore bis cum Vaccaeis egregie pugnasse, et ad XXXV millia hominum occidisse scribit Liuius.

Codicem ego Liuii manu scriptum ab amico quodam accepi, in quo non cum Vaccaeis, sed cum Bracaris habebatur, sicut et in Badiana editione legitur, probante Henrico Glareano docto ac diligenti homine.

Hoc aliquando Ioanni Vasaeo indicaui, eramque in eam lectionem propensus uidelicet, quia in Vlteriore Hispania Vaccaei non sunt, Bracari autem iuxta uetustiorum terminationem, sicut et nostro aeuo ad Lusitaniam pertinuerint.

Quod si ita esset, emendari oporteret Liuii quoque epitonem, libro quadragesimo primo, ac pro Vaccaeis, reponendi Bracari.

Verum postea expendens Liuii paulo superius uerba, ubi sic scribit: "Eodem anno in Hispania. L. Posthumius et Tib. Sempronius propr. conparauerunt ita inter se, ut in Vaccaeos per Lusitaniam iret Albinus, inde in Celtiberiam reuerteretur; Gracchus, quod maius ibi bellum esset, in ultima Celtiberiae penetrauit.” Non audeo quidquam immutare.

[100] Videtur enim Liuius finem consilii, quo inter propraetores conuenerat, posuisse, nempe, ut in Vaccaeos per Lusitaniam iret Albinus, sicut et Tib. ipse Gracchus Mundam Vlterioris prouinciae urbem oppugnauit ac cepit. Ita enim e rep. fore uterque existimauit.

Gracchus praetor ibidem iterum ducenta oppida expugnauit, et cepit. Ibidem, hoc est, in Citeriore Hispania, iterum, quia iam ibi centum quinque ad deditionem coegerat. Ergo in citeriore, non in Vlteriore prius legendum. 
já aí forçara à rendição cento e cinco. Portanto, na Citerior e não na Ulterior, se deve ler de preferência.

Como se diz então que houve guerra na Hispânia Ulterior? Evidentemente, porque, sendo Albino propretor da Ulterior e os Vaceus vizinhos dos Lusitanos e Ástures, como, baseados em Estrabão, mostrámos num dos livros anteriores, quando determinámos os limites da Lusitânia ${ }^{79}$, mesmo se estas batalhas fossem travadas fora da Lusitânia, o mesmo Albino as teria combatido. A não ser que sejamos levados a emendar nesse passo o códice de Lívio, de modo a ler-se: "que Albino fosse contra os Brácaros, passando através da Lusitânia”. De facto, se estes combates tinham sido contra Vaceus e não contra Brácaros, ou seja, contra Lusitanos, com que direito foi decretado um triunfo a Postúmio Albino sobre os Lusitanos e não sobre os Vaceus?

É o que Lívio diz, no livro primeiro da quinta década: "Depois disso, celebraramse, um a seguir ao outro, dois triunfos sobre a Hispânia. Primeiro triunfou Semprónio Graco sobre Celtiberos e aliados; no dia seguinte Lúcio Postúmio sobre Lusitanos e outros Hispanos da mesma região" 80 .

Acrescentarei, ainda, que em Orósio as províncias foram trocadas por engano. Escreve ele que Tibério Semprónio levou à rendição na Hispânia Ulterior cento e cinco ópidos, como se lê no velho códice, e não os cento e cinquenta da edição divulgada, e que, por seu lado, no mesmo Verão, Postúmio massacrou em combate quarenta mil inimigos na Citerior. [101] Triunfaram no ano 575 da fundação de Roma $^{81}$.

Júlio Obsequente ${ }^{82}$, no seu opúsculo Sobre os Prodígios, escreve que, no consulado de Quinto Opímio Nepos e de Lúcio Postúmio Albino, por volta do ano 600 da fundação de Roma, os Romanos foram derrotados pelas armas lusitanas. Mas os prenomes dos cônsules foram mal colocados. Na verdade, o prenome Quinto foi de Opímio e Lúcio foi de Postúmio, como é evidente pelas Tábuas Capitolinas, onde se lê: "Quinto Opímio Nepos, filho de Quinto, e Lúcio Postúmio Albino, filho de Espúrio, neto de Lúcio"83. Como Postúmio, no entanto, morresse durante a sua magistratura, foi substituído por Marco Acílio Glabrião.

Segundo o mesmo autor, no consulado de Marco Marcelo e de Lúcio Valério "combateu-se com sorte diversa na Lusitânia"84, com o que concorda o epítome de Lívio, no livro quadragésimo sexto $^{85}$. Quanto a Marco Cláudio Marcelo e a Lúcio Valério Flaco, foram eles cônsules no ano 601 da fundação de Roma ${ }^{86}$.

Apiano, tal como os que publicaram os comentários às Tábuas Capitolinas ${ }^{87}$, mostra, na parte que dedicou à Ibéria, que sob estes cônsules triunfou o propretor Lúcio Múmio, filho de Lúcio, neto de Lúcio, sobre os Lusitanos ${ }^{88}$.

Em Eutrópio, no livro quarto, lê-se erradamente: "Lúcio Mémio combateu com bravura na Hispânia"89. Como na realidade se trata daquele a quem mais tarde os Aqueus e Coríntios, vencidos, deram o nome de Acaico, não há dúvida de que foi Lúcio Múmio, filho de Lúcio e neto de Lúcio, e não Lúcio Mémio90. 
Quonam igitur modo in Vlteriore Hispania gesta res fuisset narratur? Videlicet quia propraetor Vlterioris erat Albinus, et finitimi Lusitanis Asturibusque Vaccaei, uti superiore libro, quum terminos Lusitaniae definiebamus, ex Strabone ostendimus, etiam si eas pugnas idem extra Lusitaniam Albinus pugnauerit.

Nisi et illic emendandus Liuii codex sit, ut legatur "in Bracaros per Lusitaniam iret Albinus". Nam si cum Vaccaeis, et non cum Bracaris, hoc est cum Lusitanis ea pugnae fuissent, quo iure Posthumio Albino de Lusitanis decretus est triumphus, non autem de Vaccaeis?

Verba Liuii haec sunt decadis quintae lib. primo: "Triumphi ex Hispania deinde duo continuo acti. Prior Sempronius Gracchus de Celtiberis, sociisque eorum; postero die L. Posthumius de Lusitanis aliisque eiusdem regionis Hispanis, triumphauit." Docti examinent.

Vnum addam, apud Orosium perperam mutatas esse prouincias. Tiberium enim Sempronium in Vlteriore Hispania centum quinque oppida, ut uetus habet codex, non centum quinquaginta, ut uulgata editio, ad deditionem coegisse scribit. Eadem autem aestate L. Posthumium in Citeriore quadraginta millia hostium bello interfecisse. [101] Triumpharunt anno ab Vrbe condita quingentesimo septuagesimo quinto.

Quinto Opimio Nepote, Posthumio Albino coss. circa sexcentesimum Vrbis annum a Lusitanis per arma uexatos fuisse Romanos scribit Iulius Obsequens in libello De Prodigiis. Quamquam Consulum praenomina perperam sint posita. Quinti enim praenomen Opimio fuit, Lucii uero praenomen Posthumio, ut patet ex Tabulis Capitolinis, sic: "Q. Opimius. Q. F. Nepos. L. Posthumius. SP. F. L. N. Albinus."

Posthumio tamen in magistratu mortuo, in eius locum M. Acilius Glabrio suffectus est.

Eodem auctore, M. Marcello et L. Valerio coss. "in Lusitania uarie pugnatum." Consentit Epitome Liuii lib. 46. Hi autem coss. M. Claudius Marcellus et L. Valerius Flaccus fuere anno ab Vrbe condita DCI.

His coss. L. Mummi. L. F. L. N. propraetorem de Lusitanis triumphasse ostendit in Iberico Appianus, et qui in Capitolinas Tabulas commentarios edidere.

Mendose legitur apud Eutropium libro quarto: "L. Memmius in Hispania bene pugnauit." Nam cum hic sit qui postea a deuictis Achaeis et Corinthiis, Achaicus sit appellatus, certum est Achaicum L. Mummium L. F. L. N. fuisse, non L. Memmium. 
Por esta mesma altura, no consulado de Lúcio Licínio Luculo e de Aulo Postúmio Albino, como a guerra hispânica não fosse por vezes bem sucedida e de tal modo [102] tivesse desconcertado os cidadãos romanos que não se encontrava quem aceitasse o tribunado nem legados que quisessem partir, Públio Cornélio Cipião Emiliano, filho de Lúcio Paulo, neto do Africano, mas adoptivo, e também ele próprio mais tarde chamado Africano, adiantou-se e declarou que aceitaria qualquer espécie de campanha desde que lho ordenassem. E com este exemplo suscitou em todos o desejo de combater ${ }^{91}$.

"Sob os mesmos cônsules combateu sem sucesso o pretor Sérvio Sulpício Galba contra os Lusitanos" $" 92$, diz o abreviador de Lívio. Parece ser aqui o sítio indicado para repetir com pormenor e com base no capítulo trigésimo primeiro do livro quarto de Orósio este assunto que já aflorámos num livro anterior"3 . "O pretor Sérgio Galba, porém, foi vencido pelos Lusitanos numa grande batalha, em que perdeu todo o exército e da qual ele próprio fugiu, escapando-se a custo com alguns companheiros" 94 . Como Galba estivesse resolvido a vingar-se mais tarde desta afronta, cometeu o crime desumano e mais do que bárbaro, que Orósio conta da maneira que se segue: "Como o pretor Sérgio Galba, então na Hispânia, tivesse aceite em rendição voluntária os Lusitanos que vivem junto ao rio Tejo, massacrou-os criminosamente. $\mathrm{Na}$ verdade, fingindo que ia agir no interesse deles, mandou-os cercar por soldados e apanhando-os todos juntos, sem armas e descuidados, esmagou-os. Esta acção, motivada pela perfídia dos Romanos, foi posteriormente a razão da maior revolta de toda a Hispânia"95.

Valério Máximo, no capítulo Sobre a Perfídia do livro nono, diz o seguinte: "Sérvio Galba também foi da maior perfídia. Com efeito, tendo convocado o povo de três cidades lusitanas, como se fosse agir no interesse delas, de nove mil homens escolhidos, despojados das armas e que constituíam a flor da juventude, trucidou parte e vendeu outra parte. Com este feito, ultrapassou na dimensão do crime a maior destruição (o códice manuscrito tem "parte") dos bárbaros" 96.

Marco Catão acusou severamente Galba, quando falou em favor dos Lusitanos massacrados [103] apesar da palavra dada, como testemunham Marco Túlio no Bruto e de passagem em Da Adivinhação, o que Ascónio Pediano desenvolve um pouco mais claramente e, assim também, o Epítome de Lívio, no livro quadragésimo nono ${ }^{97}$. E, no entanto, Catão tinha noventa anos de idade, segundo o testemunho de Lívio no livro nono da quarta década ${ }^{98}$, quando acusou Galba, em discurso inflamadíssimo, que depois reproduziu nas suas Origens ${ }^{99}$.

Mas quando o réu Galba compreendeu que ia ser condenado, abraçado aos dois filhos, vestidos já com a toga pretexta, e ao filho de Gaio Sulpício, de quem era tutor, defendeu-se tão pateticamente que a demanda foi rejeitada ${ }^{100}$.

"Foi a misericórdia", diz Valério Máximo no capítulo primeiro do livro oitavo, "e não a equidade que protegeu a questão"101. De resto, quanto ao prenome de Galba, não sei se posso dar cabal resposta, a quem acaso pergunte porque se encontra umas vezes Sérvio e outras Sérgio. 
Per haec ipsa tempora, L. Licinio Lucullo, Aulo Posthumio Albino coss. Hispaniense bellum, quum parum prospere aliquoties gestum, ita [102] confudisset ciuitatem Romanam, ut ne ii quidem inuenirentur qui aut tribunatum exciperent, aut legati ire uellent, P. Cornelius Scipio Aemilianus, L. Pauli F. Africani nepos, sed adoptiuus, qui, et ipse postea Africanus est appellatus, processit, et excepturum se militiae genus, quodcumque imperatum esset, professus est. Quo exemplo ad militandi studium omnes inuitauit.

"Iisdem coss. Seruius Sulpicius Galba praetor male aduersus Lusitanos pugnauit", inquit Liuii abbreuiator. Quam rem superiori uolumine a nobis tactam hic suo loco latius repetere est uisum, ex quarto Orosii libro, capite XXXI

"Sergius autem Galba praetor a Lusitanis magno proelio uictus est, uniuersoque exercitu amisso, ipse cum paucis uix elapsus euasit." Ex qua ignominia, quum ulcisci se postea Galba statuisset, immane ac plusquam barbarum facinus perpetrauit. Quod Orosius ita narrat.:

"Igitur in Hispania Sergius Galba praetor, Lusitanos circa Tagum flumen habitantes, quum uoluntarios in deditionem recepisset, per scelus interfecit. Simulans enim de commodis eorum se acturum fore circumpositis militibus, cunctos inermes incautosque prostrauit. Quae res Hispaniae uniuersae, propter Romanorum perfidiam, causa maximi tumultus fuit." Valerius Max. libro nono, cap. De perfidia, sic ait:

"Seruius quoque Galba summae perfidiae. Trium enim Lusitaniae ciuitatum conuocato populo, tanquam de commodis eius acturus, nouem millia, in quibus flos iuuentutis consistebat, electa, et armis exuta, partim trucidauit, partim uendidit. Quo facinore maximam cladem (codex manu scriptus habet "partem") barbarorum, magnitudine criminis antecessit."

Accusauit acriter M. Cato Galbam pro interfectis [103] contra interpositam fidem Lusitanis, ut testatur in Bruto M. Tullius, et obiter in Diuinatione, quod explicat apertius Asconius Pedianus, et Liuii epitome libro quadragesimo nono.

Aetatis autem nonagesimum annum agebat Cato, teste Liuio, decadis quartae libro nono, quum Galbam accusauit ardentissima oratione, quam in Origines suas retulit.

Reus uero Galba, quum se damnari uideret complexus duos filios praetextatos, et C. Sulpitii filium, cuius tutor erat, ita miserabiliter pro se loquutus est, ut rogatio antiquaretur.

"Misericordia ergo - inquit libro 8, cap. I, Valerius Maximus - illam quaestionem non aequitas texit." Ceterum de praenomine Galbae, quod alias Seruius, alias autem Sergius habetur, si quis forte inquirat, nescio an facere satis omnino possim. 
$\mathrm{Na}$ verdade, Cícero, no passo que efectivamente citei, tem Sérvio; Pediano e Orósio, Sérgio; o Eptiome de Lívio, primeiramente Sérvio e depois Sérgio; o próprio Lívio, no passo da acusação de Galba, lembra-o como Sérgio ${ }^{102}$, mas no livro quinto da quarta década, quando escreve que Galba tentou impedir que fosse decretado o triunfo a Lúcio Emílio Paulo pela captura do rei Perseu e pela submissão da Macedónia, e, quando apresenta Servílio a fazer um discurso ao povo em honra de Lúcio Emílio, onde quer que seja, designa-o por Sérvio Sulpício Galba ${ }^{103}$.

Valério Máximo, num dos passos há pouco citados, tem Sérgio, noutro, porém, Sérvio, como no capítulo nono do livro sexto, quando fala a respeito de Cipião e começa "Sérvio Sulpício Galba"104. Mas esta variedade existe nos códices impressos, pois no manuscrito encontro Sérvio em todo o lado. [104] Plutarco, no Catão ${ }^{105}$, chama-lhe Servílio, que pouco diferente é de Sérvio; Suetónio, porém, na vida do imperador Galba, cuja família faz descender deste Galba, chama-lhe sempre Sérgio. "Ilustrou a família Sérgio Galba", diz ele, "o consular mais eloquente do seu tempo e que, segundo dizem, se evidenciou por causa da guerra de Viriato, quando, depois de obter a Hispânia, massacrou à traição 30.000 Lusitanos”106. Nomeia também os seus filhos, um Gaio, o outro Sérgio.

Por causa desta citação de Suetónio Tranquilo já ia eu, quase a passos largos, adoptar o prenome Sérgio, se Eutrópio, no livro sétimo, me não dissuadisse. Com efeito, falando da morte de Nero, diz: "A este sucedeu Sérgio Galba, senador, de nobreza antiquíssima"107. Não descansei, pois, até que consultando em Díon, autor grego, o livro quinquagésimo sétimo descobri que é denominado por este de Sérvio e não de Sérgio ${ }^{108}$. Eis porque me inclino mais para o prenome Sérvio. Por outro lado, julgo que a variação provém da abreviatura. Como, de facto, os prenomes são normalmente em abreviatura, aconteceu que SER. foi lido por uns Sérgio, mas por outros Sérvio. No entanto, segundo a minha opinião, SER. representa realmente mais Sérvio do que Sérgio. Eu escreveria o prenome Sérgio com quatro letras, SERG., como verifico que fez Díon no início do mesmo livro ${ }^{109}$.

E, se alguém objectar a esta minha opinião de que a tribo SÉRGIA também se escreve só com três letras e que como tribo Sérgia deve ser entendida, tal como observei num cipo de Tarragona - P. FABIO. P. F. SER. LEPIDO [A Públio Fábio Sérgio Lépido, filho de Públio] -, responderei que uma tribo tão conhecida não necessitava de mais letras, mas que para um prenome que podia ser interpretado de uma ou outra maneira, se tornou necessária a quarta letra no caso de Sérgio ${ }^{110}$.

Soubemos tanto por Suetónio como por Orósio ${ }^{111}$ que a perfídia e crueldade de Sérvio Galba [105] foi a causa da maior sublevação de toda a Hispânia e, em suma, da guerra de Viriato, e de tal modo que Roma quis dar castigo ao impune Galba que, contra o direito sagrado e inviolável, mesmo entre inimigos da maior barbárie, se manchou com o abominável assassínio de nove mil homens, como pretende Valério, ou trinta mil, segundo Suetónio Tranquilo ${ }^{112}$, e que, graças à piedade provocada pelas três crianças, foi poupado à pena capital, apesar da justa acrimónia do grande homem que foi Catão. 
Nam Cicero loco a me citato Seruium habet; Pedianus et Orosius, Sergium. Epitome Liuii prius Seruium, deinde Sergium. Liuius ipse, ubi de accusatione eius, meminit Sergium. At libro quinto decadis quintae quum scribit Galbam impedire conatum, ne de capto rege Perse, deuictaque Macedonia L. Aemilio Paulo triumphus decerneretur, ac M. Seruilium pro L. Aemilio ad populum uerba facientem inducit, ubique eum Seruium Sulpicium Galbam nominat.

Valerius Maximus in altero locorum modo citatorum Sergium, in altero uero Seruium, quemadmodum libro sexto, capite quarto, de Scipione cum ait "Seruius Sulpicius Galba", quae uarietas in impressis codicibus est. In manu autem scripto ubique Seruium inuenio.

[104] Plutarchus in Catone Seruilium, quod parum abest a Seruio. Suetonius uero in Galba Caesare, quuius familiam ab hoc Galba deducit, Sergium semper uocat: "Familiam - inquit - illustrauit Sergius Galba consularis temporum suorum eloquentissimus, quem tradunt Hispaniam obtinentem triginta Lusitanorum millibus perfidia trucidatis, Viriatini belli causam extitisse." Eius quoque filios, alterum Gaium, alterum Sergium nominat.

Ex quibus Tranquilli locis, in praenomen Sergium pedibus prope iam ibam, nisi me Eutropius libro septimo reuocasset. Scripto enim Neronis obitu, "huic - ait - Seruius Galba successit antiquissimae nobilitatis Senator."

Non ergo quieui donec Dione Graeco auctore consulto, libro quinquagesimo septimo inueni Seruium, non Sergium ab illo nominari.

Quare magis ad Seruii praenomen animus iam inclinat. Varietatem autem ex compendio scribendi euenisse puto. Nam praenomina cum fere compendio notentur, factum est ut SER. a quibusdam Seruius, ab aliis autem Sergius legeretur.

Sane tamen SER. magis Seruium notat, quam Sergium, ut mea fert opinio. Ego Sergium praenomen quattuor litteris scriberem, sic SERG. ut Dionem uideo fecisse in initio eiusdem libri.

Quod si opinioni huic meae obiiciatur etiam tribum SERGIAM litteris tantum tribus scribi et Sergiam intelligi, ut in Tarraconensi cippo uidi - P. FABIO. P. F. SER. LEPIDO - respondebo in tam nota tribu nihil opus fuisse pluribus litteris. At in praenomine quod ad hoc, uel ad illud trahi poterat in Sergio quartam litteram fuisse necessariam.

Tam ex Suetonio, quam ex Orosio, Seruii Galbae perfidiam ac crudelitatem [105] maximi tumultus uniuersae Hispaniae, ac demum Viriatini belli causam fuisse didicimus, ut dederit Roma poenas impuniti Galbae, qui contra ius, etiam inter extremae barbariae hosteis, sanctum et inuiolabile, uel nouem millium, ut Valerio placuit, uel millium triginta, ut Tranquillo, nefaria se caede polluerit, et quem contra summi uiri Catonis iustam acrimoniam, trium puerorum misericordia noxae capitali exemerat. 
Por isso, no ano 607 da fundação de Roma, no consulado de Gneu Cornélio Lêntulo e de Lúcio Múmio Nepos, Viriato incitou os Lusitanos à revolta. A este respeito dizem os autores o que se segue.

Floro: "Homem de uma sagacidade agudíssima, que, de caçador, se tornou salteador e, sem transição, de salteador, chefe e general. Teria sido o Rómulo da Hispânia se a fortuna o tivesse permitido. Não satisfeito com defender a liberdade dos seus compatriotas durante catorze anos, devastando a ferro e fogo tudo para cá e para lá do Ebro e do Tejo e atacando mesmo o acampamento de pretores e chefes, quando venceu Cláudio Unímano, quase até à exterminação do exército, expôs nos seus montes troféus feitos de insígnias, como capas consulares e varas, das quais se apoderara. Finalmente vencera-o o cônsul Fábio Máximo, mas a vitória foi maculada pelo seu sucessor Servílio que, certamente desejoso de terminar a guerra, atacou, com má fé, com traições e recorrendo a assassínios nas próprias casas, o chefe vencido e reduzido à solução extrema de se render, dando assim ao inimigo a glória de parecer que, por outra forma, não poderia ser vencido" 113 .

Justino: "Em tão grande sucessão de séculos não tiveram nenhum grande chefe além de Viriato, que durante dez anos atormentou os Romanos com diversas vitórias. As suas qualidades estão mais próximas das dos animais do que das dos seres humanos. E a este mesmo seguiram-no não por ter sido eleito por escolha do povo, mas por saber furtar-se e ser hábil em evitar os perigos. Foi tal esta sua virtude e moderação que, embora tenha vencido frequentemente os exércitos consulares em tão grandes batalhas, não mudou o género de armas ou do vestuário, nem tão-pouco o modo de comer, mas conservou aquela aparência que tinha, quando primeiramente começou a combater, [106] a ponto de qualquer soldado raso parecer ainda mais rico do que o próprio chefe»" 114 .

Veleio, no princípio do livro segundo: "Seguiu-se na Hispânia uma triste e ultrajante guerra com Viriato, chefe de ladrões, porque de tal forma foi combatida com diferentes resultados, que estes, na maior parte das vezes, se tornaram contrários aos Romanos. E depois da morte de Viriato, mais graças à traição de Servílio Cepião do que à coragem, reacendeu-se bem penosa a guerra de Numância" 115 .

Eutrópio: "Também Quinto Cepião foi enviado para a mesma guerra que nessa altura Viriato fazia na Hispânia contra os Romanos. Devido ao medo suscitado por isto, foi ele assassinado pelos seus companheiros, depois de ter hostilizado os Romanos durante catorze anos. Primeiro foi pastor, logo depois chefe de salteadores e, por último, considerado como o libertador da Hispânia, tão grande fora o número de povos que incitou à guerra contra os Romanos"116.

Plínio, no opúsculo Sobre os Homens Ilustres: "Viriato, de raça lusitana, primeiro jornaleiro por necessidade, depois caçador por entusiasmo, salteador por audácia e finalmente chefe, empreendeu contra os Romanos uma guerra em que desbaratou os generais Cláudio Unímano e posteriormente Gaio Nigídio. A Popílio preferiu pedir a paz enquanto em pleno vigor, a fazê-lo depois de vencido. Mas como fossem conservadas as armas, embora tivesse cedido noutras coisas, recomeçou a guerra. 
Anno igitur ab Vrbe condita DCVII Cn. Cornelio Lentulo, L. Mummio Nepote coss. Lusitanos Viriatus erexit. De quo haec auctores:

Florus: "Vir calliditatis acerrimae, qui ex uenatore latro, ex latrone subito dux atque imperator et, si fortuna cessisset Hispaniae Romulus, non contentus libertatem suorum defendere per quattuordecim annos, omnia citra ultraque Iberum et Tagum igni ferroque populatus, castra etiam praetorum et praesidum aggressus, cum Claudium Vnimanum paene ad internicionem exercitus cecidisset. Insignia, trabeis et fascibus nostris, quae ceperat in montibus suis, tropaea fixisset. Tandem eum Fabius Maximus consul oppresserat, sed ab successore Seruilio uiolata uictoria est. Quippe qui conficiendae rei cupidus, fractum ducem et extrema deditionis agitantem per fraudem et insidias et domesticos percussores aggressus, hanc hosti gloriam dedit, ut uideretur aliter uinci non potuisse."

Iustinus: "In tanta saeculorum serie, nullus illis dux magnus praeter Viriatum fuit, qui annos decem Romanos uaria uictoria fatigauit. Adeo feris propiora, quam hominibus ingenia sunt. Quem ipsum non iudicio populi electum, sed ut cauendi scientem, declinandorumque periculorum peritum, sequuti sunt. Quuius ea uirtus continentiaque fuit, ut quum consulareis exercitus frequenter uicerit tantis rebus gestis, non armorum, non uestis cultum, non denique uictum mutauerit; sed in eo habitu, quo primum bellare coepit, [106] perseuerauerit ut quiuis gregarius miles, ipso imperatore etiam opulentior uideretur."

Velleius in posterioris uoluminis initio: "Triste deinde et contumeliosum bellum in Hispania, duce latronum Viriato, sequutum est, quod ita uaria fortuna gestum est, ut saepius Romanorum gereretur aduersa. Sed interempto Viriato fraude magis, quam uirtute Seruilii Caepionis, Numantinum grauius exarsit."

Eutropius: "Quintus quoque Caepio ad idem bellum missus est quod quidem Viriatus contra Romanos in Lusitania gerebat. Quo metu Viriatus a suis interfectus est, quum quattuordecim annos Hispanias aduersus Romanos mouisset. Pastor primo fuit, mox latronum dux, postremo tantos ad bellum populos concitauit, ut adsertor contra Romanos Hispaniae putaretur."

Plinius in libello De Viris Illustribus: "Viriatus genere Lusitanus, ob paupertatem primo mercenarius, deinde alacritate uenator, audacia latro, ad postremum dux, bellum aduersum Romanos sumpsit, eorumque imperatorem Claudium Vnimanum, deinde C. Nigidium oppressit. Pacem a Popillio maluit integer petere, quam uictus. Et quum alia dedisset, et arma retinerentur, bellum renouauit. Caepio quum uincere aliter non posset, duos satellites pecunia corrupit, qui Viriatum 
Cepião, porque não podia vencê-lo de outra maneira, subornou com dinheiro dois companheiros para que matassem Viriato quando deitado no chão. Esta vitória não mereceu a aprovação do Senado, porque tinha sido comprada"117.

Orósio, no capítulo quarto do livro quinto: "Na Hispânia, Viriato, de raça lusitana, pastor e salteador, primeiro infestando os caminhos, depois devastando as províncias e finalmente vencendo, pondo em fuga e submetendo os exércitos dos pretores e cônsules, inspirou o maior terror em todos os Romanos. De facto, quando ele vagueava [107] e passava muito além do Ebro, do Tejo e dos maiores rios de diversas regiões, saiu-lhe ao encontro o pretor Gaio Vetílio, com o que foi logo desbaratado até quase à aniquilação todo o seu exército. A custo o próprio pretor escapou com alguns, por ter recorrido à fuga.

Em seguida, Viriato em pessoa pôs em fuga o pretor Gaio Plâncio, vencido em muitos combates. Posteriormente Cláudio Unímano, que tinha sido enviado, como que para apagar a nódoa anterior, com grande equipamento de guerra contra Viriato, ainda tornou, ele próprio, a infâmia mais vergonhosa. Com efeito, ao bater-se com Viriato perdeu todas as tropas que trouxera consigo e a maior parte das forças do exército romano. Viriato expôs nos seus montes, como trofeus, capas senatoriais, varas de lictores e outras insígnias romanas.

$\mathrm{Na}$ mesma altura, trezentos Lusitanos travaram, em certo desfiladeiro, uma batalha contra mil Romanos, na qual, conta Cláudio, morreram setenta Lusitanos para trezentos e vinte Romanos. E quando os Lusitanos, vencedores, se afastavam dispersos e já seguros, um deles que se tinha deixado ficar para trás longe dos outros foi apanhado, ele que ia a pé, por cavaleiros que por ali andavam. Depois de trespassar o cavalo de um deles com a lança, decepou a cabeça do próprio cavaleiro com um único golpe de gládio, pelo que semeou um tal pânico em todos que muito desdenhosa e calmamente se afastou dos que reunidos o observavam de longe"118.

E um pouco mais adiante: "No consulado de Lúcio Cecílio Metelo e de Quinto Fábio Máximo Serviliano... Combatendo, por conseguinte, o cônsul Fábio contra os Lusitanos e contra Viriato, libertou, depois de ter escorraçado o inimigo, o ópido de Bácia, que Viriato cercava, e recebeu a sua submissão juntamente com a de muitos outros castelos. Cometeu um feito odioso mesmo para os mais remotos bárbaros da Cítia, para não falar da honra e moderação romanas, pois cortou as mãos a quinhentos chefes que, convidados para sua companhia, acolhera sob o privilégio da rendição.

Pompeio, cônsul no ano seguinte, invadiu o território dos Numantinos, mas bateu em retirada depois de sofrer estrondosa derrota, em que não só foi aniquilado [108] quase todo o exército, como ainda morta a maior parte dos nobres que faziam parte daquela campanha. Viriato, porém, foi assassinado por traição dos seus, depois de ter durante catorze anos esmagado os chefes e exércitos romanos. Numa coisa apenas agiram os Romanos correctamente para com ele e foi em considerarem os seus assassinos indignos de prémio"119. 
humi depositum perimerent. Quae uictoria, quia empta erat, a Senatu non fuit probata."

Orosius libro quinto, capite quarto: "Viriatus in Hispania, genere Lusitanus, homo pastoralis et latro, primo insectando uias, deinde uastando prouincias, postremo exercitus praetorum et consulum Romanorum uincendo, fugando, subigendo, maximo terrori Romanis omnibus fuit. Siquidem Iberum, et [107] Tagum maxima et diuersorum locorum flumina late transgredienti et peruaganti, C. Vetilius praetor occurrit, qui continuo caeso usque ad internicionem paene omni exercitu suo, uix ipse praetor cum paucis fuga lapsus euasit.

Deinde C. Plautium praetorem ipse Viriatus multis proeliis fractum fugauit. Post etiam Claudius Vnimanus cum magno instructu belli contra Viriatum missus, quasi pro abolenda superiore macula, turpiorem ipse auxit infamiam. Nam congressus cum Viriato uniuersas quas secum adduxerat copias maximasque uires Romani amisit exercitus. Viriatus trabeas, fasces, ceteraque insignia Romana, in montibus suis tropaea praefixit.

Eodem tempore trecenti Lusitani cum mille Romanis in quodam saltu contraxere pugnam. In qua septuaginta Lusitanos, Romanos autem trecentos uiginti cecidisse, Claudius refert. Et cum uictores Lusitani sparsi ac securi abiissent, unus ex iis longe a ceteris segregatus, quum a circumfusis equitibus pedes ipse deprehensus, unius eorum equo lancea perfosso, ipsius equitis ad unum gladii ictum caput desecuisset, ita omnes metu perculit, ut prospectantibus cunctis ipse contemptius atque otiosius abscederet."

Et paulo post: "L. Caecilio Metello, Q. Fabio Max. Seruiliano coss. Igitur Fabius consul contra Lusitanos et Viriatum dimicans, Bacciam oppidum, quod Viriatus obsidebat, depulsis hostibus, liberauit, et in deditionem cum plurimis aliis castellis recepit. Fecit facinus etiam ultimis barbaris Scythiae, non dicam Romanae fidei et moderationi execrabile. Quingentis enim principibus eorum, quos societate inuitatos, deditionis iure susceperat, manus praecidit.

Pompeius sequentis anni consul fines Numantinorum ingressus, accepta maxima clade discessit, non solum exercitu paene omni [108] profligato, uerum etiam plurimis nobilium, qui ei militiae aderant, interemptis. Viriatus autem cum per quattuordecim annos Romanos duces atque exercitus protriuisset, insidiis suorum interfectus est. In hoc solum Romanis circa eum fortiter agentibus, quod perquussores eius indignos praemio iudicarunt." 
Sexto Júlio Frontino, no capítulo quinto do livro segundo dos Estratagemas: "Viriato que passou de salteador a chefe dos Celtiberos, fingindo que cedia aos cavaleiros romanos, atraiu-os para um sítio pantanoso e de grande profundidade. Depois de ele próprio se ter posto a salvo por caminhos firmes que conhecia, matou os romanos, desconhecedores do local e enterrados na lama" ${ }^{\text {120. }}$.

Chama-lhe "chefe dos Celtiberos" porque, não contente de ter privado os Romanos de toda a Lusitânia, levando a guerra para lá do Ebro, impôs-se aos povos da Celtibéria e incitou-os contra os Romanos. Frontino apresentou nesta obra muitos outros testemunhos, que dela podem ser tirados, de Viriato como grande e experiente chefe ${ }^{121}$.

Epítome de Lívio, no livro quinquagésimo segundo: "Primeiramente, na Hispânia, Viriato que de pastor passou a caçador, de caçador a salteador e logo foi feito também chefe de um exército regular, apoderou-se de toda a Lusitânia. Capturou o pretor Marco Vetílio depois de desbaratar o seu exército. E o pretor Gaio Pláucio, depois deste, em nada foi mais bem sucedido, e tão grande foi o terror inspirado por tal inimigo que seria preciso contra ele não só um chefe como um exército de consulares" 122 .

E no livro quinquagésimo quarto: "O procônsul Quinto Fábio, tendo sido bem sucedido na Hispânia, cobriu-se de vergonha ao fazer com Viriato uma paz em igualdade de condições. Viriato foi assassinado por traidores, a conselho de Servílio Cepião. Muito chorado pelo seu exército, foi sepultado com todas as honras. Foi grande homem e chefe máximo durante os catorze anos em que combateu os Romanos, mais frequentemente com vantagem"123.

[109] Foi isto o que escreveram os escritores antigos sobre Viriato, que todos reconhecem ter sido inicialmente salteador e chefe de salteadores. Assim, Estrabão no livro terceiro ${ }^{124}$ e também o nosso Cícero no livro segundo de Sobre os Deveres: "Além disso, segundo se diz, mesmo entre os salteadores há leis a que eles obedecem e que respeitam. Por exemplo, foi graças à divisão equitativa do despojo que não só o ilírico Bárgulo, segundo diz Teopompo, teve grandes riquezas, como muito maiores teve o lusitano Viriato, perante o qual recuaram os nossos exércitos e generais. Gaio Lélio, a quem chamaram de sábio, quando pretor, desbaratou-o, esmagou-o e reprimiu de tal modo a sua arrogância que entregou aos que ficaram uma guerra fácil"125.

Deve-se também reparar aqui a que ponto o grande orador minimiza as vitórias de Viriato: "perante o qual recuaram os nossos exércitos e chefes". "Recuaram discretamente", diz alguém quando pretende dizer "foram vencidos". Mas com que período enaltece Lélio, com que amplificação de palavras!: "desbaratou-o, esmagou-o e reprimiu a sua arrogância". E no Bruto: "Sabemos que Lélio foi notável na guerra de Viriato" 126.

E, no entanto, se Servílio Cepião, colega de Lélio no consulado, não tivesse subornado com dinheiro os que assassinaram Viriato, por certo que ainda não tinha acabado a guerra. De resto, por que razão diz Plínio "Cepião, porque não podia 
Sex. Iulius Frontinus Stratagematum libro secundo, capite quinto: "Viriatus ex latrone dux Celtiberorum, cedere se Romanis equitibus simulans, usque ad locum uoraginosum et praealtum eos perduxit, et cum ipse per solidos ac notos sibi transitus euaderet Romanos ignaros locorum immersosque limo cecidit."

"Celtiberorum illum ducem" appellat, quoniam non contentus uniuersam Lusitaniam ademisse Romanis, ultra Iberum bella transferens, Celtiberiae etiam populos occupauit, et aduersus Romanos erexit. Multa alia in libris his magni ac sapientis ducis argumenta Frontinus de Viriato prodidit, quae peti inde possunt.

Epitome Liuii libr. 52: "Viriatus primum in Hispania, ex pastore uenator et ex uenatore latro, mox iusti quoque exercitus dux factus est et uniuersam Lusitaniam occupauit. M. Vetilium praetorem, fuso eius exercitu, cepit. Post quem C. Plautius praetor nihilo felicius rem gessit, tantumque terrorem is hostis intulit, ut aduersus eum consulari opus esset et duce et exercitu."

Et libro quinquagesimo quarto ${ }^{1}$ : "Quintus Fabius proconsul, rebus in Hispania prospere gestis, labem imposuit pace cum Viriato aequis condicionibus facta. Viriatus a proditoribus consilio Seruilii Caepionis interemptus est, et ab exercitu eius multum imploratus ac nobilissime tumulatus, uir duxque maximus per quattuordecim annos, quibus cum Romanis bellum gessit, frequentius superior."

[109] Haec scriptores de Viriato, quem omnes latronem latronumque ducem initio fuisse dicunt. Quemadmodum Strabo libro tertio. Noster quoque Cicero libro De officiis secundo:

"Quin etiam leges latronum esse dicuntur, quibus parent, quas obseruent. Itaque propter aequabilem praedae partitionem, et Bargulus Illyricus, de quo est apud Theopompum, magnas opes habuit, et multo maiores Viriatus Lusitanus, cui quidem exercitus nostri imperatoresque cesserunt. Quem C. Laelius, is qui sapiens usurpatur, praetor fregit et comminuit, ferocitatemque eius ita repressit, ut facile bellum reliquis traderet."

Vbi quoque aduertendum, quam Viriati attenuet summus orator uictorias: "Cui quidem exercitus nostri, imperatoresque cesserunt". "Cesserunt uerecunde - inquit quidam - quum 'uictos' significet.” At uero C. Laelium quo ambitu, qua uerborum amplitudine atollit? "fregit et comminuit, ferocitatemque eius repressit."

Et in Bruto: "Egregium Viriati bello reperimus fuisse Laelium."

Atqui nisi Seruilius Caepio, Laelii in consulatu collega, pecunia, qui Viriatum interimerent, corrupisset, nondum sane debellatum erat. Alioqui quid est quod

1 quinquagesimo $E R C^{1} C^{2}$ ] quadragesimo quinto $F U$ 
vencê-lo de outra maneira, subornou com dinheiro dois companheiros para que matassem Viriato quando deitado no chão"? ${ }^{127}$

Volto à designação de salteador que me parece ter sido sugerida pelos Romanos no seu ódio, bastante invejoso, ao grande homem. Entendo, porém, de outra maneira palavras como salteador ou chefe de salteadores, como também Lívio, que no livro nono da terceira década diz acerca de Masinissa: "A partir deste momento, todo o território em redor esteve exposto aos ataques, primeiro em incursões nocturnas e furtivas, depois em assaltos às claras, sobretudo nos campos de Cartago, porque não só ofereciam mais despojos do que os dos Númidas, como o latrocínio era mais seguro. E logo pareceu pouco digno de um rei imitar um salteador vagabundo pelos montes"128. No entanto, o "salteador vagabundo" era Masinissa, que procurava [110] retomar o reino que lhe era devido.

Assim, portanto, como os Lusitanos estivessem numa disposição muito diferente da dos Romanos devido à perfídia de Galba, uniram-se alguns a Viriato para que fizesse transporte a troco de dinheiro, a esse homem, primeiro pastor, depois caçador, homem de argúcia extrema e hábil em evitar os perigos, que com eles se ocupava em incursões e latrocínios contra Romanos e aliados dos Romanos.

A sua ousadia bem sucedida foi favorecida por muitos depois da última injúria dos Romanos, e como cada dia que passava maiores se tornavam as suas tropas, tendo-se finalmente reunido um exército regular, foi ele eleito como chefe, e com o exército avançou já intrepidamente não para o latrocínio mas para a guerra e para a libertação da pátria. Com efeito, Justino celebra a sua admirável coragem e moderação a ponto de, depois de ter travado tantas batalhas, nem sequer usar armas mais cuidadas do que as dos outros nem mudar o vestuário ou a alimentação, de tal modo que qualquer soldado parecia mais rico do que o próprio chefe. Este equilíbrio de alma não costuma existir nos hábitos dos ladrões.

Depois de Viriato ter sido assassinado, graças a Servílio Cepião, por dois guardas de corpo e quando os seus assassinos vieram pedir a recompensa ao cônsul Cepião, foi-lhes respondido, segundo diz Eutrópio, que "nunca agradou aos Romanos que os generais fossem mortos pelos seus soldados"129.

Valério Máximo, no capítulo sexto do livro nono ${ }^{130}$, censura a respeito do assassínio de Viriato uma dupla traição: em primeiro lugar, a dos seus amigos, porque foi morto às mãos destes; em segundo, a de Quinto Servílio Cepião, porque foi ele o autor deste crime ao prometer-lhes impunidade. Não ganhou uma vitória, comprou-a.

Em suma, os chefes romanos que se lê terem sido vencidos por Viriato são [111] os seguintes: o pretor Gaio Vetílio, segundo Orósio, ou Marco Vetílio, como diz o Epítome de Lívio ${ }^{131}$; Gaio Pláucio, Cláudio Unímano; Gaio Nigídio como Popílio Lenas $^{132}$, então pretor, segundo penso. Com efeito, não obteve o consulado senão depois de Quinto Servílio Cepião por cuja intervenção Viriato morreu vítima de uma cilada na própria casa. Com Popílio, pois, ainda em pleno vigor, tratou da paz, mas porque se exigia que entregasse as armas recomeçou a guerra, visto que entregá-las seria confessar que tinha sido vencido. 
ait Plinius "Caepio quum uincere aliter non posset, duos satellites pecunia corrupit, qui Viriatum humi depositum perimerent.”?

Redeo ad latronis nomen. Mihi uidetur inuidiosius id a Romanis in magni uiri odium inculcatum; latronem autem, aut latronum ducem, aliter intelligo, ut et Liuius de Masinissa decadis tertiae libro nono ait: "Inde nocturnis primo ac furtiuis incursionibus, deinde aperto latrocinio infesta omnia circa esse, maxime uero Carthaginiensis ager, quia et plus pradae, quam inter Numidas, et latrocinium tutius erat. Et statim uix regium uidebatur, latronem uagum in montibus consectari." "Latro" autem "uagus" Masinissa erat, debitum sibi [110] regnum reposcens.

Ita ergo quum propter Galbae perfidiam, alienissimo a Romanis essent animo Lusitani, Viriato pastori primum inde uenatori, et qui mercenariam uecturam faceret, uiro tamen calliditatis acerrimae, periculorumque declinandorum perito adhaesere nonnulli, cum quibus incursiones, ac latrocinium aduersus Romanos Romanorumque socios exercebat.

Quuius felici audaciae, quum ex Romanorum recenti iniuria multi fauerent, et copiae indies maiores accrescerent, iusto tandem exercitu congregato, electus dux, ad bellum iam intrepide patriamque liberandam, non autem ad latrocinium processit. Quippe quuius miram uirtutem, continentiamque adeo Iustinus praedicet, ut tantis rebus gestis neque cultioribus armis, quam ceteri, sit usus, neque uestitum, neque uictum mutauerit, ut quiuis gregarius miles ipso imperatore opulentior uideretur. Quae animi moderatio in latronum moribus esse non solet.

Interfecto Seruilii Caepionis opera a duobus domesticis satellitibus Viriato, quum interfectores eius praemium a Scipione consule peterent, responsum est, "nunquam Romanis placuisse, Imperatores a suis militibus interfeci", ut ait Eutropius.

Duplicem in eius caede perfidiam accusat Valerius Maximus libro nono, capite sexto. Alteram amicorum eius, quod eorum manibus interemptus est. Alteram Quinti Seruilii Caepionis, quod is sceleris huius auctor, promissa impunitate, fuerit, uictoriamque non meruerit, sed emerit.

Imperatores igitur Romani, quos Viriatus deuicisse legitur, fuere [111] hi: praetores C. Vetilius, ut Orosius, siue M. Vetilius, ut Epitome Liuii habet. C. Plautius, Cl. Vnimanus C. Nigidius, cum M. Popillio Laenate, tunc praetore, ut arbitror. Nam consulatum non iniit nisi post Quintum Seruilium Caepionem, quo agente domesticis insidiis periit Viriatus. Cum Popillio ergo, adhuc integer de pace agitauit. Sed quia tradere arma poscebatur, quod ea res uideretur uicti esse confessio, bellum renouauit. 
Combateu com sorte variada contra Lélio. Se Lélio na verdade o tivesse enfraquecido tanto quanto gaba Cícero com a intenção de lhe agradar, de modo algum o senado teria deliberado que a guerra contra Viriato fosse dirigida já não sob o comando de pretores mas de cônsules.

Também com sorte diversa lutou contra o cônsul Fábio Máximo e de novo contra este, depois de procônsul igualmente com sorte diversa. Eis porque Fábio fez com ele uma paz com equidade de condições, embora o tenha privado de boa parte da Lusitânia. Por isso se julga que Fábio veio macular uma campanha que tinha levado a cabo com sucesso. Fábio, nessa altura, era procônsul como mostra o Epítome de Lívio ${ }^{133}$. Convém, portanto, emendar o passo de Floro há pouco citado, "finalmente vencera-o o cônsul Fábio Máximo"134, pois não há dúvida que se deve ler procônsul. Fábio, de facto, foi cônsul no ano 612 da fundação de Roma e a seguir Gneu Servílio Cepião e Quinto Pompeio Rufo. No ano destes, foi prorrogado o comando a Fábio para que, na qualidade de procônsul, terminasse finalmente a guerra contra Viriato, já parcialmente enfraquecido.

No ano seguinte, foram designados cônsules Gaio Lélio, o sábio, e Quinto Servílio Cepião, o autor do assassínio de Viriato, como se mostrou anteriormente com o passo de Eutrópio ${ }^{135}$. Assim, quando a paz foi de novo perturbada, era evidente que Fábio ia ser vencedor se Quinto Servílio Cepião, designado cônsul depois de seu irmão Gneu Servílio Cepião e Quinto Pompeio Rufo e sucessor na guerra contra Viriato não tivesse conspurcado a vitória com uma traição. [112] Conservam-se ainda hoje em Portugal monumentos de soldados romanos que foram mortos na guerra de Viriato, como aquele de que sou testemunha ocular da herdade de Pomares na região de Évora:

\author{
L. SILO. SABINVS. BELLO CONTRA \\ VIRIATVM. IN EBOR. PROV. LVSIT. \\ AGRO. MVLTITVDINE TELOR. CON- \\ FOSSVS AD. C. PLAVT. PRAET. DELA- \\ TVS HVMERIS. MILIT. H. SEP. E. PEC. \\ MEA. M. F. I. IN QVO NEMIN. VELIM \\ MECVM, NEC SERV. NEC LIB. INSERI. \\ SI SECVS FIET. VELIM. OSSVA QVO- \\ RVM QVOMQ. SEPVLCRO MEO ERVI, \\ SI PATRIA LIBERA ERIT.
}

Isto é: Aqui jaz Lúcio Silão Sabino que, em luta contra Viriato nos campos de Évora, da província da Lusitânia, foi trespassado por grande quantidade de dardos e trazido para junto do pretor Gaio Plaucino aos ombros dos soldados. Ordenei que com o meu dinheiro me fosse erigido este monumento no qual ninguém quero comigo, seja ele escravo ou liberto. Se isto não for cumprido e se a pátria for livre quero que retirem do meu sepulcro os ossos, sejam eles de quem forem ${ }^{136}$. 
Cum Laelio uarie pugnauit. Nam si eum Laelius tam fregisset, quam in eius gratiam iactat Cicero, nequaquam censuisset Senatus, ut bellum aduersus Viriatum, non iam per praetores, sed per consules administraretur.

Cum Q. Fabio Maximo consule etiam uarie pugnauit. Cum eodem postea Proconsule uarie quoque. Quare cum eo Fabius aequis condicionibus pacem fecit, quum tamen bonam ei Lusitaniae partem ademisset. Vnde labem prospere gestis a se rebus imposuisse Fabius est iudicatus. Proconsul tum erat Fabius, ut patet ex Liuii Epitome. Emendandusque est Flori locus paulo ante citatus. Tandem eum Fabius Maximus consul oppresserat. Sine dubio enim legendum proconsul: nam Fabius anno Vrbis DCXII consul fuit, postquam fuere Cn. Seruilius Caepio, et Q. Pompeius Rufus. Quorum anno prorogatum Fabio imperium est, ut proconsule aduersus Viriatum ex parte affectum bellum tandem conficeret.

Anno sequenti designati Coss. C. Laelius sapiens et Quintus Seruilius Caepio auctor caedis Viriati, ut ex Eutropio ostensum ante est. Igitur pace rursus turbata futurus uictor apparebat Fabius, nisi Q. Seruilius Caepio, qui post Cn. Seruilium Caepionem fratrem et Q. Pompeium Rufum consul est designatus, bellique cum Viriato successor insidiis uictoriam corrupisset.

[112] Manent adhuc in Lusitania aliquot monumenta militum Romanorum, qui in Viriatino bello occisi sunt, ut in territorio Eborensi, Pomariensi praedio, hoc, quuius ego testis sum oculatus.

\author{
L. SILO. SABINVS. BELLO CONTRA \\ VIRIATVM. IN EBOR. PROV. LVSIT. \\ AGRO. MVLTITVDINE TELOR. CON- \\ FOSSVS AD. C. PLAVT. PRAET. DELA- \\ TVS HVMERIS. MILIT. H. SEP. E. PEC. \\ MEA. M. F. I. IN QVO NEMIN. VELIM \\ MECVM, NEC SERV. NEC LIB. INSERI. \\ SI SECVS FIET. VELIM. OSSVA QVO- \\ RVM QVOMQ. SEPVLCRO MEO ERVI, \\ SI PATRIA LIBERA ERIT.
}

Id est: Lucius Silo Sabinus bello contra Viriatum in Eborensi prouinciae Lusitaniae agro, multitudine telorum confossus, ad Caium Plautinum praetorem delatus bumeris militum, hic sepultus est. Pecunia mea mibi fieri iussi, in quo neminem uelim mecum, nec seruum, nec liberum inseri. Si secus fiat, uelim ossua quorum quomque sepulchro meo erui. Si patria libera erit. 
Honorato João Valentim, homem nobre não só pelo nascimento como pela brilhante [113] erudição ${ }^{137}$, mostrou-me em Lisboa este monumento e os três que abaixo apresentarei, tal como os recebeu de Florião do Campo ${ }^{138}$. Ora este, entreguei-lho eu bastante emendado, mas o outro que diz ter sido encontrado no mesmo local e na mesma altura, até agora não o consegui ainda encontrar embora tenha procurado cuidadosamente. Diz ele, porém, que reza assim:

\section{Q. LONGINVS. TARTAREO ABSORPT. \\ HIATV. ANTE TEMPVS. ARM. HOST \\ IN CAMPIS LVSITAN \\ M. REGVLVS. TRIB. MIL. MAR. SARCOPH. \\ OSSA CONTEXIT. VALETE MILIT. ROMANI.}

Isto é: Quinto Longino foi devorado prematuramente nos campos da Lusitânia pelas fauces do Tártaro devido a armas inimigas. Marco Régulo, tribuno militar, cobriu os seus ossos com este sarcófago. Salve, soldados romanos! ${ }^{139}$

[114] E este, perto da cidade de Viseu:

L. AEMIL. L. F. CONFECT. VVLNERE. HOST. SVB

NIGIDIO. COS. CONT. VIRIATVM LATRONEM

LANCIENS. QVOR. REMP. TVTARAT. BASIM

CVM VRNA. ET. STATVAM IN LOCO PVBL. EREX.

HONORIS. LIBERAL. QVE ERGO.

Isto é: A Lúcio Emílio, filho de Lúcio, abatido por golpe inimigo, sob o comando do cônsul Nigídio, na guerra contra o salteador Viriato. Os Lancienses, cuja república defendera, levantaram-lhe num lugar público um pedestal com a urna e uma estátua em sinal de consideração e generosidade ${ }^{140}$.

Também não vi esta inscrição nem tenho conhecimento de que Nigídio fosse cônsul na guerra de Viriato, a não ser que queiramos dizer que tinha feito a guerra com os poderes consulares o Nigídio que Plínio afirmou ter sido desbaratado por Viriato ${ }^{141}$.

Fala-se ainda de que foi encontrado na Lusitânia o testamento de Galo Favónio, que Marliano refere na descrição da cidade de Roma ${ }^{142}$, o qual declara ter recebido de Giácomo Simonetta, bispo de Pesaro e auditor da Rota, nestes termos:

"Eu galo FaVÓNio Jocundo, FILHO De públio FaVÓNIO,

que caí na guerra de Viriato, instituo herdeiros dos bens de Jocundo, meu pai, e daqueles que eu próprio por mim adquiri, a Jocundo e Pudente, meus filhos e dos de Quíncia Fábia, minha mulher, com a condição no entanto de aqui se deslocarem, 
Honoratus Ioannes Valentinus, uir et natalibus et luculenta eruditione [113] nobilis, et hoc et tria quae subiiciam a Floriano Campensi accepta mihi Olisipone ostendit. Sed ego illi hoc emendatius tradidi. Alterum etiam ibidem simul inuentum esse narrabat, quod ego etsi diligenter perquisiui, hactenus tamen inuenire non potui, esse autem ferebat istiusmodi:

\section{Q. LONGINVS. TARTAREO ABSORPT HIATV. ANTE TEMPVS. ARM. HOST IN CAMPIS LVSITAN \\ M. REGVLVS. TRIB. MIL. MAR. SARCOPH. OSSA CONTEXIT. VALETE MILIT. ROMANI.}

Hoc est: Quintus Longinus Tartareo absorptus biatu ante tempus armorum hostilium in campis Lusitaniae. Marcus Regulus Tribunus militum marmoreo sarcophago ossa contexit. Valete milites Romani.

[114] Et hoc prope Visaeum urbem:

L. AEMIL. L. F. CONFECT. VVLNERE. HOST. SVB NIGIDIO. COS. CONT. VIRIATVM LATRONEM LANCIENS. QVOR. REMP. TVTARAT. BASIM

CVM VRNA. ET. STATVAM IN LOCO PVBL. EREX. HONORIS. LIBERAL. QVE ERGO.

Hoc est: Lucio Aemilio Lucii filio confecto uulnere hostili sub Nigidio consule contra Viriatum latronem, Lancienses, quorum Remp. tutarat, basim cum urna, et statuam in loco publico erexerunt honoris liberalitatisque ergo.

Hoc quoque neque ergo uidi, neque C. Nigidium consulem Viriatino bello fuisse inuenio, nisi consulari potestate bellum gessisse dicamus, quem a Viriato oppressum dicit Plinius. Fertur etiam testamentum Galli Fauonii, quod retulit Marlianus in Vrbis descriptione, in Lusitania repertum, quod ab Iacobo Simoneta Pisauriensi episcopo et Rotae auditore, se accepisse ait, in haec uerba:

"Ego Gallvs FaVOnivs IOCVNDVS, P. FAVONiI F.,

qui bello contra Viriatum obcubui, Iocundum et Pudentem filios e me, et Quintia Fabia coniuge mea ortos, et bonorum Iocundi patris mei, et eorum, quae ipse mihi acquisiui, heredes relinquo, hac tamen condicione, ut ab urbe Roma huc 
da cidade de Roma, e de, no prazo de cinco anos, levarem deste local os meus ossos [115] e os depositarem no sepulcro de mármore que foi erigido na via Latina por minha ordem e vontade. Nele não quero ninguém comigo, seja escravo ou liberto. Exijo que os ossos de quem quer que lá esteja sejam imediatamente retirados do meu sepulcro. Que se observem as leis romanas, pois se deve respeitar, à maneira dos nossos maiores, a vontade do testador no que se refere à conservação dos túmulos. E se fizerem de outro modo, exceptuando-se o caso de surgirem causas legítimas, ordeno que tudo aquilo que deixo aos meus filhos seja dado para reparação do templo do deus Silvano, que está no sopé do monte Viminal. Que os meus Manes implorem o auxílio do sumo pontífice e dos sacerdotes de Júpiter que estão no Capitólio para castigarem a impiedade dos meus filhos; que os sacerdotes do deus Silvano se comprometam a trazer-me para a cidade e a depositar-me no sepulcro. Mais ordeno que todos os escravos de nascença, que estão na minha casa, sejam libertados assim como as suas mães pelo pretor urbano e que a cada um seja dada um libra de prata pura e uma veste. Na região da Lusitânia, no dia 2 do mês de Julho, na guerra de Viriato".

Honorato João declarou-me que este testamento foi transcrito de maneira um pouco diferente pela mão de Florião do Campo, deste modo ${ }^{143}$ :

[116] "Eu Galo Favónio Jocundo, Filho de lúcio,

que caí na guerra de Viriato, instituo herdeiros dos bens de Jocundo, meu pai, e daqueles que eu próprio por mim adquiri, a meus filhos Jocundo e Pudente, com a condição no entanto de se deslocarem aqui, partindo da cidade de Roma, e de, no prazo de cinco anos, levarem os meus ossos da Lusitânia e de os depositarem no sepulcro de mármore que, por minha vontade, foi erigido na via Latina. Se fizerem de outro modo, exceptuando-se o caso de surgirem causas legítimas, ordeno que tudo aquilo que deixo a meus filhos seja dado para reparação do templo do deus Silvano, que está no sopé do monte Viminal. Que os meus Manes implorem o auxilio do sumo pontífice e dos sacerdotes de Júpiter que estão no Capitólio, contra os meus filhos para os castigarem da impiedade. Que os sacerdotes do deus Silvano se comprometam a trazer-me para a cidade e a depositar-me no sepulcro. Mais ordeno que os escravos de nascença que estão em minha casa, qualquer que seja o número, sejam libertados com suas mães pelo pretor e que a cada um seja dada uma libra de prata e uma veste. Lavrado no dia 2 de Julho, sendo cônsules //// R Galba e Quinto Aurélio. Os decuriões transcudanos ordenaram que este testamento, ouvido da boca do próprio Galo Favónio, fosse gravado em pedra”. 
ueniant, et ossa hinc mea intra [115] quinquennium exportent, et uia Latina condant in sepulchro iussu meo condito, et mea uoluntate.

In quo uelim neminem mecum, neque seruum, neque libertum inseri. Et uelim ossa quorumcumque sepulchro statim meo eruantur, et iura Romana seruentur, in sepulchris ritu maiorum retinendis uoluntate testatoris.

Et si secus fecerint, nisi legitimae oriantur causae, uelim ea omnia, quae filiis meis relinquo, pro reparando templo Dei Siluani, quod sub Viminali monte est, attribui. Manesque mei a Pontifice Max. et a flaminibus Dialibus, qui in Capitolio sunt, opem implorent, ad liberorum meorum impietatem ulciscendam.

Teneanturque sacerdotes Dei Siluani me in urbem referre, et sepulchro meo condere.

Volo quoque uernas, qui domi meae sunt omneis a praetore Vrbano liberos cum matribus dimitti, singulisque libram argenti puri, et uestem unam dari. In Lusitania in agro. VIII Cal. Quintiles bello Viriatino."

Testamentum hoc paulo diuersius mihi Honoratus Ioannes, Floriani Campensis manu descriptum, communicauit, hoc modo:

[116] "Ego Gallvs Favonivs Iocvndvs L. F,

qui bello cont. Viriatum occub. Iocundum et Pudentem

fili. ex test. herr. relinquo. et bonor. Iocundi patr. mei, et eor. quae mihi adquaesiui. Hac tamen condicione, ut ab urbe Roma huc ueniant, et ossa mea intra quinquen. e Lusitan. export. uia Latina condant, sepulch. marm. cond. mea uoluntate, si secus fec. nisi legitimae oriant. causae, uelim ea omn. quae fili. relinquo, pro templo Dei Siluani reparando adtribui. Manesque mei opem pont. Max. Et Flaminum Dial. qui in capitolio sunt, implorent, ad impiet. contra fili. ulciscendam. Teneanturque sacerdd. Dei Siluani me in urb. referre, et sepulch. me cond.

Velim quoque quotquot domi meae uernae sunt, liberos a praetore, cum matrib. dimitti, singul.que libram arg. et uestem dari. Act. VI. Kalend. Quint. [...] R Galba. Q. AVREL.coss. DECVRR. Transcudani hoc testam. ore eiusd. Galli FAV. emiss. lapide iussere adsculpi." 
Desagradam-me aqui, no entanto, algumas abreviaturas que foram concebidas contra o costume daquela época. Tão-pouco sei se é assim que está no mármore ou se foi Florião que assim preferiu transmitir, para que conseguisse dar, na sua opinião, uma ideia de maior antiguidade ao desejar expressar ao leitor este assunto com frases mutiladas.

Onofre Panvínio, no livro primeiro dos Fastos, recorda também o mesmo assunto como sendo do ano 610 da fundação de Roma: "No testamento de Galo Favónio Segundo, que morreu na guerra de Viriato, faz-se menção destes cônsules, do modo seguinte: "Lavrado no dia 2 de Julho, [117] sendo cônsules Sérvio Galba e Lúcio Aurélio” "144.

E sobre Viriato já falámos o suficiente.

Depois destes acontecimentos, Décio Júnio Bruto, que era filho de Marco Júnio Peno, como desempenhasse o consulado por volta de 616 da fundação de Roma juntamente com Públio Cornélio Nasica, cognominado o Serápio, veio à Hispânia e deu terras aos que tinham combatido sob as ordens de Viriato, além de um ópido que recebeu o nome de Valência. É o que diz o Epítome de Lívio ${ }^{145}$. Sabélico, no livro nono da quinta Enéada ${ }^{146}$, recorda também este facto, assim como nós igualmente o fizemos no Mártir S. Vicente ${ }^{147}$, para que se saiba bem que Valência foi fundada e denominada por Lusitanos e pelos soldados de Viriato que sobreviveram.

É, pois, sem fundamento a história do Pseudomanéton de ter sido fundada antes de Roma e denominada Romis por causa de um rei Romo descoberto não sei onde $^{148}$. E, no entanto, esta lenda não desagradou a Florião do Campo ${ }^{149}$ nem a alguns autores modernos que escreveram sobre antiguidades hispânicas ${ }^{150}$.

Bruto, portanto, subjugou, por esta altura, a Lusitânia até junto do oceano Atlântico, embora, como diz Valério Máximo no capítulo quarto do livro sexto151: "Quase toda [a Hispânia] se tinha entregado de livre vontade, excepto a cidade de Cinânia, que tenazmente conservava as armas", conforme dissemos mais atrás quando mostrámos que espécie de carácter tem o povo lusitano ${ }^{152}$.

Atacando mesmo os Brácaros da Galécia, povo dos Galaicos, que tinha vindo em auxílio dos Lusitanos, esmagou num combate crudelíssimo e penoso sessenta mil homens, e tantos quantos pôde apanhar desprevenidos. Nesta batalha, afirma Orósio no capítulo quinto do livro quinto, "diz-se que foram mortos cinquenta mil homens, capturados seis mil, e que poucos se salvaram, fugindo" 153 .

Foi, portanto, devido a esta vitória sobre os Brácaros Galaicos [118] que Bruto recebeu o cognome de Galaico, e não devido à restante Galécia. Concluo isto, porque Estrabão ao fazer menção do rio Minho, no livro terceiro, escreve o seguinte: "É aqui o limite máximo da expedição de Bruto" ${ }^{154}$. É de facto por falta de cuidado que o tradutor verte "O fim da pretura de Bruto"155. E note-se de passagem que Bruto já não combateu ali como cônsul, mas como procônsul, e que isto se passou na altura em que chegou ao rio Lima, acontecimento que referimos atrás, quando enumerámos os rios dos Brácaros ${ }^{156}$. 
Displicent tamen mihi affecta hic aliquot compendia contra saeculi illius morem. Ac nescio an ita in marmore sit, an magis ita Florianus tradere uoluerit, quo antiquitatem suo iudicio maiorem repraesentaret, si lectori mutilatis dictionibus negotium facesseret.

Onuphrius Panuinius in primo Fastorum anno Vrbis conditae DCX huius etiam meminit: "Horum - inquit - consulum mentio est, in testamento Galli Fauonii Secundi, qui bello Viriatino ceciditi, ita: ACTVM VI. KAL. QVINTILEIS. SER. [117] GALBA. L. AVRELIO coss.

Et de Viriato satis iam multa.

Decius inde Iunius Brutus M. Iunii Poeni filius, quum circa Vrbis annum DCXVI una cum P. Corn. Nasica, qui Serapio appellatus est, consulatum gereret, in Hispaniam uenit, et ii qui sub Viriato militauerant, agros oppidumque dedit, quod Valentia nuncupatum est. Ex Epitome Liuii. Meminit etiam huius rei Sabellicus, quintae Aeneados libro nono. Et nos in Vincentio Martyre, ut liqueat Lusitanis ceterisque Viriati militibus Valentiam esse conditam, et nominatam.

Fabulam uero inanem esse, eam conditam ante Romam, et Romin appellatam a Romo rege nescio quo, apud commenticium Manethonem reperio. Quae tamen fabula Floriano Campensi, et quibusdam ex neotericis Hispanicarum antiquitatum scriptoribus non displicuit.

Brutus igitur hic Lusitaniam usque ad Oceanum perdomuit. Quamquam ut Valerius Maximus libro sexto, capite quarto ait: "Paene tota se ei sponte dediderat, praeter Cinaniam urbem, quae pertinaciter arma retinebat" uti in superioribus diximus, quum qualisnam gens Lusitani fuissent, disseruimus.

Adortus etiam Bracaros Callaeciae gentem Callaicorum, qui Lusitanis auxilio uenerant, sexaginta millia bello asperrimo atque difficili, quamuis incautos circumuenisset, oppressit, in eo proelio, inquit Orosius libro quinto, capite quinto: "Quinquaginta millia occisa, sex millia capta referuntur, pauci fuga euasere."

Propter hanc igitur de Callaicis, Bracaris uictoriam, Callaici cognomen [118] non autem a cetera Callaecia Brutum esse adeptum. Hinc colligo, quod Srabo libro tertio, ubi amnis Minii mentionem fecit, ita scribit. "Hic expeditionis Bruti terminus est." Negligenter enim uertit interpres "Bruti praeturae terminus" obiterque notandum, iam non consulem Brutum, sed Proconsulem, illic rem gessisse, eoque tempore illi ad Limiam contigisse, quod supra retulimus, quum Bracarorum flumina recenseremus. 
Obteve, além disso, um triunfo sobre os Lusitanos e os Galaicos, no ano 617 da fundação de Roma, o qual foi gravado nas Tábuas Capitolinas da maneira que se segue:

D. IVNIVS. M. F. M. N. BRVTVS. CALLAICVS. ANNO DCXVII. PRO. COS. DE LVSITANEIS. ET CALLAICEIS. EX HISPANIA. VLTE RIORE.

Isto é: Décio (ou Décimo) Júnio Bruto Galaico, filho de Marco, neto de Marco, procônsul, no ano 617, [triunfou] dos Lusitanos e Galaicos [vindo] da Hispânia Ulterior $^{157}$.

No ano 645 da fundação de Roma, o propretor Quinto Servílio Cepião, filho de Quinto Servílio Cepião-o-Velho e neto de Gneu, obteve um triunfo sobre os Lusitanos e sobre a Hispânia Ulterior. Mas no ano 649, quando eram cônsules Públio Rutílio Rufo e Gneu Mânlio, o exército romano foi desbaratado pelos Lusitanos. Se isto não fosse anotado [119] em quatro palavras apenas por Júlio Obsequente ${ }^{158}$, ter-nos-iam deixado os restantes escritores romanos na mais completa ignorância. Se bem que Obsequente e Cassiodoro ${ }^{159}$ variem um pouco quanto ao nome dos cônsules, eu sigo Onofre Panvínio, que investigou este assunto com bastante cuidado ${ }^{160}$.

Depois disto, no ano 652 da fundação de Roma, quando eram cônsules Gaio Mário, que obtinha o consulado pela quarta vez, e Quinto Lutácio, "toda a Hispânia Ulterior foi pacificada, depois de vencidos os Lusitanos"161, escreve Obsequente, embora não diga com clareza por quem foram vencidos. Panvínio pensa que o foram por Décio Júnio Silano, devido às palavras de Sexto Rufo: "Conquistámos, graças a Bruto, os Lusitanos que se tinham revoltado na Hispânia e chegámos até Cádis e até ao oceano Atlântico. Depois disto, Silano foi enviado contra os Hispanos revoltosos e venceu-os"162.

Quanto a mim, interpreto de forma diversa não só as palavras de Obsequente como as de Rufo, ou seja, que, vencidos os Lusitanos por Bruto, a Hispânia Ulterior foi pacificada até Cádis e até ao oceano Atlântico; quanto a Silano, foi este enviado contra Hispanos revoltosos, mas não especificadamente contra Lusitanos. Não esclarece, por outro lado, contra que povos em revolta se deve entender que tenha sido enviado. Mas como pareceu assim a Panvínio e aos restantes comentadores das Tábuas Triunfais, deles não vamos discordar.

No ano 655 da fundação de Roma, triunfou Lúcio Cornélio Dolabela sobre os Lusitanos. As tábuas de Vérrio Flaco registam-nos da maneira seguinte:

L. CORNELIVS. L. F. L. N. DOLABELlA. PRO. COS. EX HISPANIA. VLTERIOR. DE LVSIT

AN. V. K. FEB. 
Triumphauit autem de Lusitanis et Callaecis, anno Vrbis DCXVII. quod in Tabulis Capitolinis ita notatur:

D. IVNIVS. M. F. M. N. BRVTVS. CALLAICVS. ANNO DCXVII. PRO. COS. DE LVSITANEIS. ET CALLAICEIS. EX HISPANIA. VLTE RIORE.

Hoc est: Decius uel Decimus Iunius Marci filius Marci nepos Brutus Callaicus anno sexcentesimo decimo septimo proconsul de Lusitaneis et Callaiceis ex Hispania Vlteriore.

Anno ab Vrbe condita DCXLV. Q. Seruilius Caepio, Q. Seruilii Caepionis superioris filius, Cn. epos propretor de Lusitanis, ex Hispania Vlteriore triumphauit.

At anno DCXLIX P. Rutilio Rufo, Cn. Manlio coss. exercitus Romanus a Lusitanis caesus est. Quod nisi a Iulio Obsequente [119] quattuor tantum uerbis esset notatum, per ceteros Romanos scriptores penitus ignoraremus. Tametsi de nominibus consulum Obsequens et Cassiodorus nonnihil uariant, sed ego Onuphrio Panuinio, qui eam rem exquisitius indagauit, adhaereo.

Anno inde conditae Vrbis DCLII C. Mario IIII, Q. Luctatio coss. "deuictis Lusitanis, pacatam Vlteriorem Hispaniam," scribit Obsequens. Non tamen a quo deuicti sint, expressit. Opinatur Panuinius a D. Iunio Syllano, propter Sexti Rufi uerba: "Rebellantes in Hispania Lusitanos, per D. Brutum obtinuimus, et usque Gades ad Oceanum peruenimus. Post, ad Hispanos tumultuantes Syllanus missus, eos uicit."

Ego tamen et Obsequentis, et Rufi uerba aliter intelligo. Nempe deuictis a Bruto Lusitanis, ulteriorem Hispaniam fuisse pacatam, usque ad Gades, et Oceanum.

Sullanum uero ad tumultuantes Hispanos missum, non autem singillatim ad Lusitanos. Ad quos autem tumultuantes missum intelligat non explanauit. Verum quia Panuinio et ceteris Tabularum Triumphalium explicatoribus ita uidetur, ab illis non discedamus.

Anno Vrbis DCLV, L. Cornelius Dolabella de Lusitanis triumphauit. Quod Verrii Flacci tabulae ita ostendunt:

L. CORNELIVS. L. F. L. N. DOLABElla. PRO. COS. EX HISPANIA. VLTERIOR. DE LVSIT AN. V. K. FEB. 
[120] Isto é: Lúcio Cornélio Dolabela, filho de Lúcio, neto de Lúcio, procônsul da Hispânia Ulterior [triunfou] sobre os Lusitanos no quinto dia antes das Calendas de Fevereiro ${ }^{163}$.

Cinco anos depois, ou seja, em 660 da fundação de Roma, triunfou Públio Licínio Crasso sobre os Lusitanos. Vérrio Flaco testemunha assim:

P. LICINIVS. M. F. P. N. CRASSVS. ANNO. DCLX. PRO. COS. DE LVSITANEIS. PRID. IDV. IVNI.

Isto é: Públio Licínio Crasso, filbo de Marco, neto de Públio, procônsul no ano 600, [triunfou] sobre os Lusitanos na véspera dos Idos ${ }^{164}$.

Como Estrabão diz no fim do livro terceiro ${ }^{165}$ que aquele levou também a paz às ilhas Cassitérides da região do cabo Finisterra, concluímos daí que combateu na Lusitânia e naquela parte da Galécia que pertence aos Brácaros.

No ano 673 da fundação de Roma, como os Romanos estivessem empenhados em guerras dispersas pela Macedónia, Panfília e Dalmácia, e como, por isso, se combatesse bastante frouxamente na que tinham na Hispânia, sossegaram os Lusitanos durante algum tempo até que rebentou, motivada pelas guerras civis, a guerra de Sertório, herança da proscrição de Sula, tal como diz Floro ${ }^{166}$.

Quinto Sertório, homem da maior e também da mais funesta coragem, chefe de grande experiência militar, visto ter sido proscrito por Sula, porque tinha ingressado no partido de Mário, [121] retirou-se da Urbe e da Itália e foi arrastado por muito sítio em diferentes empresas ${ }^{167}$. Como Plutarco descreveu com pormenor e cuidado a sua vida e combates ${ }^{168}$ e se lhe referiram longamente Apiano, no livro primeiro das Guerras Civis ${ }^{169}$, Lúcio Floro no segundo ${ }^{170}$, e Paulo Orósio no quinto, ${ }^{171}$ além do que aqui e ali disseram Plínio-o-Moço nos seus Homens Ilustres, Valério Máximo, Frontino, Obsequente e outros ${ }^{172}$, de modo algum é necessário que, neste particular, me esforce. Apresentarei em resumo o que dizem Plutarco, Apiano e Orósio.

Chamaram-no de África os Lusitanos e veio dali com dois mil e seiscentos homens a que chamava Romanos, trazendo contudo neles misturados setecentos africanos. Juntaram-se-lhes quatro mil peões lusitanos e setecentos cavaleiros. No entanto, com tão pequeno contingente, combateu contra quatro chefes romanos sob cujas ordens estavam duzentos mil peões, sete mil cavaleiros, dois mil archeiros e fundibulários, além de inúmeras cidades, quando ele próprio de início tinha apenas vinte cidades lusitanas do seu lado.

Submeteu não só povos e cidades poderosas, como ainda generais romanos enviados contra ele. Venceu Cota num combate naval perto de Fuente Ovejuna e o pretor Fídio junto ao Gualdaquivir, luta em que tirou a vida a dois mil cidadãos romanos. [122] Esmagou Domício, devido à acção do seu chefe Hirtuleio, sendo este igualmente quem, para falar como Orósio ${ }^{173}$, despojou de acampamentos e 
[120] Hoc est: Lucius Cornelius Lucii filius, Lucii nepos Dolabella proconsul ex Hispania Vlteriore de Lusitanis quinto Calendas Februarii.

Quinto post anno, id est ab Vrbe condita DCLX, P. Licinius Crassus de Lusitanis triumphauit, testatur hoc Verrius Flaccus, sic:

P. LICINIVS. M. F. P. N. CRASSVS. ANNO. DCLX.

PRO. COS. DE LVSITANEIS. PRID. IDV. IVNI.

Hoc est: Publius Lucinius Marci filius Publii nepos Crassus anno sexcentesimo proconsul de Lusitanis pridie Idus Iuni.

Hunc in Lusitania, et ea Callaeciae parte quae Bracarorum est, bellum gessisse inde coniicimus, quod Strabo in calce libri tertii tradit illum etiam Cassiteridas insulas e regione Celtici promontorii, pace conciliasse.

Sexcentesimo septuagesimo tertio Vrbis anno sparso per Macedoniam, Pamphiliam atque Dalmatiam Romanorum bello, quum quod in Hispania erat, ob id remissius gereretur, paulisper interquieuerant Lusitani, donec discordiis ciuilibus Sertorianum ${ }^{1}$ exarsit, Syllanae proscriptionis hereditas, ut inquit Florus.

Quintus enim Sertorius, uir summae quidem, sed calamitosae uirtutis ac magnae in rebus bellicis peritiae dux, quod Marii partes fuerat [121] sequutus, quum proscriptus a Sylla esset, excessit Vrbe atque Italia uariis casibus ubique iactatus. Cuius quia uitam, resque gestas accurate perscripsit Plutarchus, et de eo multa Ciuilium Bellorum libro primo Appianus, et libro tertio L. Florus, quinto P. Orosius, praeter ea quae sparsim Plinius Iunior De illustribus uiris, Valerius Maximus, Frontinus, Obsequens, et alii adnotarunt, minime opus est in ea re me laborare ${ }^{2}$. Summatim ex Plutarcho, Appiano atque Orosio dicam.

Adscitus ex Africa a Lusitanis, cum duobus millibus et sexcentis, quos Romanos uocabat, admixtis Afris septingentis, illinc uenit. Adiunxit Lusitanorum quattuor millia peditum, et equites septingentos. Atque tam exiguis copiis aduersus quattuor Romanorum duces, sub quibus erant peditum millia centum uiginti, equitum septem millia, sagitariorum et funditorum duo millia, et urbes innumerae, bellum gessit, quum ipse initio uiginti tantum Lusitanorum urbes in sua dicione haberet.

Validas non solum gentes et urbes, sed missos etiam aduersum se Romanos duces subegit. Cottam nauali proelio ad Mellariam superauit.

Phidium praetorem ad Baetin, interfecitque in ea pugna duo millia Romanorum ciuium.

1 Sertorianum $E R$ ] Sertorianorum $C^{1} F C^{2} U$

2 laborare $R C^{1} F C^{2} U$ ] labore $E$ 
de soldados Manílio, procônsul da Gália, que tinha passado à Hispânia com três legiões e mil e quinhentos cavaleiros, e forçou-o a refugiar-se quase sozinho em Ilerda. Desbaratou o procônsul Lúcio e aniquilou Torânio, enviado por Metelo, e assim também todo o seu exército. Criou ao próprio Metelo uma situação tão difícil, que Lúcio se viu obrigado a trazer-lhe auxílio da Gália Narbonense e que Pompeio Magno teve de ser a toda a pressa enviado de Roma por causa dele. Não sabia, com efeito, Metelo para onde se voltar ${ }^{174}$.

Destruiu Aquílio e os seus mil homens, com que este tinha sido enviado por Metelo. Recebeu em pé de guerra Pompeio que já tinha atravessado os Pirenéus e, colocados lado a lado os acampamentos, mostrou que lhe era superior. Repeliu Pompeio que cercava Palência e, assaltando os acampamentos que estavam perto da Calahorra, matou cerca de três mil homens. Capturou e incendiou a cidade de Lauro, sob a vista do mesmo Pompeio, não ousando este, que tão altivamente se tinha comprometido com os Lauronenses, levar auxílio a aliados em vias de soçobrar. Sertório concedeu a vida aos habitantes da cidade incendiada e trouxe-os para a Lusitânia em deplorável escravidão. Junto ao Júcar pôs de tal modo em fuga a Pompeio, vencido no combate, que este, ferido e atirado para debaixo do cavalo, quase foi morto e capturado. [123] Como Afrânio, que comandava a ala esquerda, repelisse os Sertorianos, cujo chefe perseguia Pompeio, compreendeu Sertório o perigo em que estavam os seus e, acorrendo, facilmente venceu aquele, matandolhe os soldados já dispersos.

Castigou duramente Pompeio junto do rio Túria e, se não tivesse surgido Metelo, tinha sido o fim daquele. É daqui que provém a célebre fanfarronada de Sertório: "Teria mandado este menino para casa, depois de o ter mandado açoitar, se não tivesse aparecido aquela velha"175.

Némio, questor de Pompeio e casado com uma sua irmã, foi morto perto de Sagunto num combate de que Sertório saiu vencedor. E como tivesse conseguido, no meio do maior massacre, chegar vitorioso até junto de Metelo, devia ter este morrido trespassado por uma lança, se o não tivesse protegido o grande sentido de vergonha dos seus companheiros ${ }^{176}$.

Dídio Lelo, legado de Pompeio, que tinha ido buscar forragem, foi morto, segundo escreve Obsequente ${ }^{177}$, pelos Sertorianos.

Não há dúvida de que os chefes do partido de Sertório eram geralmente os melhores, sobretudo Hirtuleio, que a princípio tinha desgastado Metelo em muitos combates antes de se juntar a Pompeio, mas, por fim, ao encontrar-se com o mesmo Metelo junto a Sevilha-a-Velha, cidade da província da Bética, levado, segundo creio, pela confiança que lhe deram as antigas vitórias, travou um combate em que perdeu vinte mil homens e de onde fugiu, vencido, para a Lusitânia com alguns companheiros. Mas Sertório, travando, depois destes acontecimentos, batalha com Pompeio, matoulhe dez mil soldados, embora ele próprio tenha perdido outros tantos. E assim levou aqueles dois generais notáveis, Metelo e Pompeio, a um tal desespero que Metelo instituiu publicamente como prémios para quem matasse Sertório, cem talentos em 
[122] Domicium per Hirtuleium ducem oppressit. Qui etiam Manilium Galliae procoss. cum tribus legionibus, et mille quingentis equitibus in Hispaniam transgressum, castris, copiisque nudauit, ut Orosii uerbis dicam, et paene solum Ilerdam compulit refugere.

Lucium procoss. contriuit. Toranium a Metello missum cum toto exercitu deleuit.

Ipsum Metellum in tantam compulit necessitatem, ut L. Lollius ex Narbonensi Gallia ei ferre auxilium cogeretur, et Pompeius magnus ex Vrbe cum summa festinatione ea de causa mitteretur. Neque enim habebat Metellus quo se uerteret.

Aquilium a Metello missum cum sex millibus cecidit.

Pompeium iam Pyrenaeos montes transgressum bello excepit, positisque iuxta castris superior fuit. Pompeium Palantiam obsidentem ui repulit. Et castra quae ad Calagurrim erant, adortus, ad tria millia interfecit. Eodem Pompeio spectante Lauronem urbem expugnauit atque incendit, neque ille tam magnifice Lauronensibus de se pollicitus, sociis pereuntibus auxilium ferre ausus est.

Quibus uitam ex incensa urbe dedit Sertorius, in Lusitaniam miserabili captiuitate traduxit.

Ad Sucronem Pompeium proelio superatum fugauit, ita, ut uulneratus et ex equo prostratus, paene interfectus et captus sit.

[123] Afranium, qui cornu sinistrum regebat, quum Sertorianos intento in Pompeium duce pelleret, suorum intellecto periculo accurrens facile superauit, eiusque milites dispersos occidit.

Ad flumen Turiam Pompeium male multauit, et nisi Metellus superuenisset actum de eo erat. Vnde illa Sertorii gloriatio: "Ego puerum hunc, nisi uenisset anus illa, castigatum uerberibus, domum remisissem."

Memmius Pompeii quaestor, et sororis eius maritus, ad Saguntum Sertorio superante, est interfectus. Et cum magna strage uictor ad Metellum usque peruenisset, pilo percussus Metellus interierat, nisi a suis pudore nimio affectis protectus esset.

Didium Laelium Pompeii legatum, qui pabulatum exierat, scribit Obsequens, a Sertorianis interfectum.

Et certe Sertoriani duces fere superiores erant. Praecipue Hirtuleius, qui initio Metellum, antequam se Pompeio iungeret, multis proeliis fatigarat, tandem cum eodem Metello apud Italicam Baeticae prouinciae urbem congressum, ex fiducia credo praeteritarum uictoriarum elatus, commissa pugna, uiginti millibus amissis uictus in Lusitaniam cum paucis profugit.

At Sertorius post id cum Pompeio congressus decem millia militum eius interfecit, licet totidem, et ipse amiserit. In tantamque desperationem duos egregios illos duces Metellum atque Pompeium adduxit, ut publice Metellus praemia statuerit ei, qui Sertorium necaret, centum argenti talenta et uiginti 
prata e vinte mil jeiras de terra, e prometia o perdão e o regresso se de um exilado se tratasse, para conseguir, naturalmente, ao menos pela traição, o que não podia obter pelas armas. [124] De facto, Pompeio, queixoso, escreveu ao Senado que se não the enviassem o dinheiro retiraria os soldados da província. Recolhia entretanto aos quartéis de Inverno. Sertório, por seu lado, recolhia para a Lusitânia, de onde rapidamente, ao aproximar-se a Primavera, tinha saído, com o seu legado Marco Perpena, no encalço dos inimigos e na direcção da Celtibéria, sempre utilizando muitíssimo os serviços dos Lusitanos, como eloquentemente afirma Apiano ${ }^{178}$.

Escolhera Sertório em especial a cidade de Évora para passar o Inverno, escolha acertada, porque se situa a cidade no meio da Lusitânia e tem solo fértil, podendo, em caso de necessidade, partir dela e rapidamente colocar-se em todo o lado. Aí tinha a sua casa, ainda hoje de pé, a escrava Júnia Donace e três libertos. Daí tinha conduzido a primeira coorte para a guerra, como diremos mais pormenorizadamente, logo que se tiver chegado à descrição das cidades ${ }^{179}$.

Tão favoravelmente decorria na Hispânia a guerra conduzida por Sertório, que a sua fama também chegou ao Ponto. Mitridates comprometia-se a alcançar facilmente vitória sobre o povo romano se, mediante um acordo, conseguisse unir à sua causa um general tão conhecedor da arte militar. Que o leitor não se aborreça de consultar a este respeito Plutarco ${ }^{180}$. Por ele compreenderá com limpidez não só que homem foi Sertório, como com que probidade, com que amor, acompanhou a pátria de onde estava banido; verá ao mesmo tempo quão dignos de ódio foram Perpena e aqueles que com ele tramaram a morte do grande general. [125] No entanto, o fim deles não tardou, fim como deve ser o dos traidores, totalmente miserável e infeliz.

Veleio Patérculo falando de Perpena recorda com elegância e brevidade: "Foi diz ele - à mesa e em Osca que matou Sertório, e com este crime tão repugnante preparou para os Romanos uma vitória certa, para os seus partidários a ruína e para si próprio uma vergonhosíssima morte" ${ }^{\prime 181}$.

Igualmente Marcelino, no fim do livro vigésimo sexto: "A exemplo do velho Perpena que depois de Sertório ser assassinado durante um banquete se apoderou do poder por algum tempo, mas foi arrancado das florestas onde se escondia, foi trazido à presença de Pompeio e morto por ordem deste" ${ }^{182}$.

Assim Sertório, morto por traição dos seus companheiros, depois de ter começado a guerra, deu na verdade a vitória aos Romanos, mas sem qualquer glória, porque ela proveio não do mérito mas da fraude.

Com a sua morte, todas as cidades da Hispânia se entregaram espontaneamente aos Romanos, excepto Calahorra e El Burgo de Osma, mas esta arrasou-a Pompeio e aquela, segundo escreve Orósio ${ }^{183}$, gasta pelo cerco contínuo e obrigada pela falta de víveres a consumir os mais repugnantes alimentos, foi, por fim, completamente destruída pela chacina e incêndio ateado por Afrânio ou, segundo refere Valério no capítulo sexto do livro sétimo ${ }^{184}$, pelo mesmo Pompeio. 
millia agri iugera, et si exul esset, ueniam reductionemque promitteret. Nempe, ut saltem proditione consequeretur quod armis non poterat.

[124] Pompeius uero querulus ad Senatum scripsit, nisi sibi pecuniae mitterentur se milites e prouincia deducturum.

Recipiebat se in hiberna Sertorius in Lusitaniam, unde appetente uere, cum M. Perpenna legato suo, ad hosteis usque in Celtiberiam properabat, Lusitanorum maxime opera semper usus. Hoc diserte asserit Appianus.

Eboram uero urbem ad hiemandum peculiariter elegerat, sagaci consilio, cum fere in medio sita sit Lusitaniae, et solo fertili unde in omnes partes praesto esse poterat, si usus eueniret.

Ibi domum, quae adhuc extat, et Iuniam Donacen domesticam, et libertos tres habebat.

Inde cohortem unam ad bellum duxerat, uti dicemus latius, quum uentum erit ad Vrbeis.

Ita prospere in Hispania bellum gerentis Sertorii quum fama etiam Pontum complesset Mithridates, si ducem rei militaris peritissimum sibi foedere conciliasset, facilem de populo Romano uictoriam se adepturum pollicebatur. De qua re non pigeat lectorem consulere Plutarchum.

Ex quo, et qui uir, et qua probitate fuerit Sertorius, et quo amore patriam, unde exulabat, prosequeretur, liquido intelliget.

Simul quanto digni fuerint odio Perpenna et qui cum eo in caedem magni ducis coniurauere.

[125] Quorum tamen omnium exitus, ut proditorum esse conueniebat, miser atque infelix non multo post omnino fuit.

Id breuiter atque eleganter Velleius Paterculus de Perpenna loquens commemorat: "Sertorium - inquit - inter cenam Oscae interemit, Romanisque certam uictoriam, partibus suis excidium, sibi turpissimam mortem pessimo auctorauit facinore."

Item Marcellinus sub libri XXVI finem: "Ad ueteris Perpennae exemplum, qui post Sertorium inter epulas obtruncatum dominatione paulisper potius e frutetis, sub quibus latebat extractus, oblatusque Pompeio eius iussu est interfectus."

Sic decimo inchoati belli anno suorum dolis interfectus Sertorius uictoriam quidem Romanis dedit, uerum sine ulla gloria, quod non uirtute sed fraude obuenisset.

Quo interempto, Hispaniae uniuersae ciuitates ultro se Romanis dedidere, praeter Calagurrim et Vxamam, sed hanc Pompeius euertit, illam siue Afranius, ut scribit Orosius, iugi obsidione confectam atque ad infames escas ex inopia coactam, ultima tandem caede incendioque deleuit; siue idem Pompeius, ut in libro septimo, capite sexto refert Valerius. 
Eis porque sossegaram os Lusitanos e tanto Metelo Pio como Gneu Pompeio Magno, até aí cavaleiro romano, triunfaram no ano 682 da fundação de Roma, conforme as Tábuas Capitolinas ${ }^{185}$.

[126] Marco Cícero, no discurso contra Rulo Sobre as Leis Agrárias ${ }^{186}$, queixa-se por não ter sido pago, durante todo o período da guerra de Sertório, nenhum tributo pelos Hispanos.

Após tudo isto, Júlio César, a quem, depois da pretura urbana, tinha cabido em sorte a Hispânia Ulterior, onde anteriormente fora questor sob as ordens do pretor Tuberão, submeteu a Lusitânia e a Galécia ao império romano. Que o leitor se não enfade de eu recordar o que disse a este respeito, baseado em Díon, quando descrevi o monte Hermínio ${ }^{187}$.

Tendo-se seguido o Triunvirato pouco depois, César invadiu as Gálias, Crasso a Ásia e Pompeio as Hispânias, as quais administrava por meio de três legados, Marco Petreio, Lúcio Afrânio e Marco Varrão, até à altura em que rebentou a guerra civil.

Vindo César nessa ocasião às Hispânias, forçou-as consoante as circunstâncias à paz, tendo obtido o procônsul Marco Lépido a Citerior e o propretor Gaio Cássio Longino a Ulterior. Nesse momento cercava César a Pompeio em Dirráquio.

Este Cássio Longino, homem de insaciável ganância e consequentemente de crueldade não difícil de compreender, como sabia do ódio em que era tido na província e como, dia a dia, se tornasse mais forte esta aversão contra ele, procurava escudar-se contra a inimizade dos provinciais com a dedicação do exército ao fazer distribuições exageradas de donativos e promessas de prémios provenientes de rapinas e de tributos pesadíssimos. Assim, depois de prometer cem sestércios aos soldados, tomou de assalto Medóbriga, vila fortificada na Lusitânia, e o monte Hermínio para onde os Medobrigenses se tinham refugiado. Aí foi aclamado general e de novo gratificou os soldados com cem sestércios.

[127] Tempos depois, no ano 710 da fundação de Roma, César após ter vencido Pompeio marchou em direcção da Hispânia contra os dois jovens filhos de Pompeio Magno, os quais tinham recomeçado a guerra.

A Lusitânia estava mais inclinada para o partido de Pompeio, quer porque o Senado e o povo romano apoiassem sobretudo este, como mais justo, quer pela recordação das ofensas de César, em cuja pretura os Lusitanos tinham sido tratados com excessivo rigor "apesar de não terem recusado as suas ordens e de lhe terem aberto as portas quando chegou”, segundo diz Suetónio ${ }^{188}$. É isto que em poucas palavras indica um bem mordaz jambo de Catulo:

O segundo saque no Ponto, depois de um terceiro

Na Ibéria, que bem o sabe o Tejo, rio aurífero ${ }^{189}$.

Marco Petreio ocupava pois a região dos Vetões e a Lusitânia, que estavam a favor de Pompeio, antes de partir com as suas forças militares, cavaleiros e tropas auxiliares de toda a Lusitânia até junto de Afrânio na Celtibéria, para que juntamente 
Quieuere itaque Lusitani, ac de Hispanis tam Metellus Pius, quam Cn. Pompeius Magnus adhuc eques Romanus triumpharunt, anno Vrbis DCLXXXII, ut Tabulae referunt Capitolinae.

[126] Toto autem Sertoriani belli tempore nullum populo Romano uectigal ex Hispanis fuisse, in oratione De agrariis legibus contra Rullum conqueritur M. Cicero

Iulius inde Caesar, post urbanam praeturam, Vlteriorem sortitus Hispaniam, in qua prius sub Tuberone praetore quaestor fuerat, Lusitaniam ac Callaeciam imperio Romano subdidit. De qua re non pigeat lectorem repetere quae ex Dione retulimus, quum de Monte Herminio ageremus.

Sequuto paulo post Triumuiratu, Caesar Gallias, Asiam Crassus, Pompeius inuasit Hispanias, quas per legatos treis, M. Petreium, L. Afranium, et M. Varronem administrabat, donec ciuille bellum conflatum est.

Ac Caesar in Hispanias ueniens, eas pro tempore quiescere coegit, M. Lepido procos. Citeriorem, Q. Cassio Longino Vlteriorem propraetore obtinentibus. Quo tempore ad Dyrrachium Caesar Pompeium obsidebat.

Is Cassius Longinus inexplebilis auaritiae, nec ob eam obscurae crudelitatis homo, quum se prouinciae odio haberi non ignoraret, magnasque indies eius odii accessiones faceret, contra prouincialium offensionem, exercitus amore sese munire studebat, donatiuorum largitionibus immoderatis, et praemiorum pollicitationibus, ex rapinis grauissimisque oneribus.

Sestertia igitur centum militibus pollicitus, Medobrigam oppidum in Lusitania, Montemque Herminium, quo Medobrigenses confugerant, expugnauit. Ibique imperator appellatus, iterum sestertiis centum milites donauit.

[127] Anno inde ab Vrbe condita DCCX Caesar post deuictum Pompeium, in Hispanias est profectus aduersus duos adolescentes Pompeios Magni filios, qui bellum instaurauerant.

Pronior in Pompeii partes erat Lusitania, siue quia S. P. Q. R. magis eas fouebat, ut iustiores, siue recordatione iniuriarum Caesaris, a quo in praetura direpti nimis hostiliter fuerant Lusitani, quamquam nec imperata detrectarent, et aduenienti portas patefacerent, ut inquit Suetonius. Et paucis uerbis Catulli mordacissimus iambus innuit:

Secunda praeda Pontica, inde tertia

Ibera, quam scit ${ }^{1}$ amnis aurifer Tagus.

Vettonum igitur agrum Lusitaniamque pro Pompeio tenebat M. Petreius, antequam cum suis copiis et equitibus auxiliisque totius Lusitaniae ad Afranium in Celtiberiam proficisceretur, ut irrumpentem Caesarem pariter reprimerent.

1 scit $E R C^{1} C^{2}$ ] cit $F$, sit $U$ 
repelissem o avanço de César. O próprio César chama aos Lusitanos beneficiários de Petreio no primeiro Comentário de A Guerra Civil ${ }^{190}$, o que confirma que este sempre os teve para montarem a sua guarda.

O mesmo fez Munácio Flaco na Bélica, mais violento do que louvável defensor do partido de Pompeio. Mas devemos esta informação a Valério Máximo, no capítulo Sobre a Crueldade do livro nono ${ }^{191}$. Efectivamente, quando, com uma escolta de Lusitanos, entrincheirados numa paliçada resistia obstinadamente a César, perto de Átega, exerceu bárbara vingança naqueles que soube serem simpatizantes de César e assim também nas suas mulheres e filhos.

[128] Quem assim desejar, que veja Valério e o Comentário da Guerra Hispânica, ${ }^{192}$ mas de passagem emende o códice de Valério, onde se lê erradamente "Numácio" por "Munácio" e "Atinquenses" por "Atequenses".

Deve ser suficiente fundamentarmo-nos em Díon, que escreve assim no livro quadragésimo terceiro: "Sabendo, por outro lado, que na cidade de Átegua havia grande abundância de víveres". E passadas algumas linhas: "De facto, depois que os soldados se acolheram dentro da cidade, mandou-lhes Munácio Flaco”. O nome, portanto, era Munácio Flaco e é também assim que lhe chama Plutarco no Catão 193.

Depois disso, diz ele, como Pompeio proibisse por lei que nos julgamentos fossem dadas as recomendações habituais aos réus e ele próprio tivesse escrito uma recomendação para Munácio Flaco, Catão, que era juiz nesta causa, quando começou a ser lida em voz alta a recomendação de Pompeio, tapou os ouvidos com as mãos e proibiu que aquela fosse lida ${ }^{194}$.

Deve igualmente haver erro do próprio Plutarco na vida de Pompeio ${ }^{195}$, onde, referindo o mesmo acontecimento narrado na vida de Catão, chama àquele Planco e não Flaco. Isto só seria admissível se os mesmos Munácios se chamassem tanto Flacos como Plancos. É possível que a família Munácia estivesse dividida em dois ramos, ou seja, o dos Flacos e o dos Plancos, e que por esta razão na vida de Pompeio de Plutarco se tenha modificado Flaco para Planco.

[129] É evidente pelo exemplo de Lúcio Munácio Planco, que obteve o consulado com Marco Lépido, triúnviro encarregado de organizar o governo, e pela ode sétima do livro primeiro ${ }^{196}$ das Poesias de Horácio, que um certo número de Munácios teve o cognome de Planco. Além disto, pela inscrição que Onofre Panvínio, no livro segundo dos Fastos e no opúsculo Sobre os Nomes Romanos ${ }^{197}$ assegura estar à vista em Gaeta, confirma-se o que foi dito. Reza ela assim:

L. MVNATIVS. L. F. L. N. L. PRON.

PLANCVS. COS. IMPER. ITER. VII. VIR.

EPVLON. TRIVMPH. EX RAETEIS.

AEDEM SATVRNI FECIT, DE MANVBIIS.

AGROS DIVISIT. IN ITALIA BENEVENTI.

IN GALLIA COLONIAS DEDVXIT

LVGDVNVM. ET RAVRICAM. 
Lusitanos Petrei beneficiarios uocat ipse Caesar, in primo Belli ciuilis commentario, quos custodiae suae causa semper habuisse confirmat.

Fecit idem Munatius Flaccus in Baetica, Pompeiani nominis acrior, quam probabilior defensor, sed id credimus Valerio Maximo libro nono, capite De crudalitate.

Lusitanorum enim praesidio uallatus Caesari cum resisteret pertinaciter ad Attegam, barbarum in modum saeuiit in eos quos Caesaris studiosos esse comperit, et in eorum uxores ac liberos.

[128] Videat qui uelit Valerium, et Hispaniensis belli commentarium, atque obiter Valerii codicem emendet, in quo perperam legitur "Numatius" pro "Munatius", et "Attinguensium" pro "Atteguensium".

Sufficiet hoc ex Dione ostendisse libro quadragesimo tertio ita scribente: "Audiens autem in Attegua ciuitate magnam esse copiam commeatus."

Et paucis interiectis. "Posteaquam uero milites intra urbem recepti sunt, Munatium Flaccum ad eos misit."

Munatius ergo Flaccus uocabatur, atque ita eum appellat Plutarchus in Catone: "Praeterea - inquit - quum Pompeius commendationes reis dari in iudiciis consuetas, per legem uetuisset, ac postea ipse Munatio Flacco commendationem scripsisset", Cato, qui in ea causa uidex erat, quum recitari coepta est Pompeii commendatio, aures manibus clausit, legique illam prohibuit.

Vt mendum quoque sit apud eundem Plutarchum in Pompeio, ubi idem Catonis factum referens, Plancum eum non autem Flaccum appellat.

Nisi forte iidem Munatii, tam Flacci, quam Planci appellarentur. Probabile est Munatiam gentem in duas familias, Flaccorum uidelicet et Plancorum, fuisse diuisam. Et ideo apud Plutarchum in Pompeio ex Flacco factum Plancum.

[129] Plancorum enim cognomen aliquot ex Munatiis habuisse, liquet ex L. Munatio Planco, qui cum M. Lepido triumuiro R. P. C. consulatum gessit, et ex Ode septima libri primi Carminum Horatii. Praeterea ex inscriptione, quam extare Caietae Onuphrius Panuinius in secundum Fastorum, et in libello De Romanorum nominibus, asseuerat.

Ea est huiusmodi:

L. MVNATIVS. L. F. L. N. L. PRON.

PLANCVS. COS. IMPER. ITER. VII. VIR.

EPVLON. TRIVMPH. EX RAETEIS.

AEDEM SATVRNI FECIT, DE MANVBIIS.

AGROS DIVISIT. IN ITALIA BENEVENTI.

IN GALLIA COLONIAS DEDVXIT

LVGDVNVM. ET RAVRICAM. 
Isto é: Lúcio Munácio Planco, filho de Lúcio, neto de Lúcio, bisneto de Lúcio, cônsul, general por duas vezes, septênviro dos epulões, triunfou dos Récios, fez com o dinheiro do saque um templo para Saturno, dividiu os campos de Benavente na Itália, na Gália fundou as colónias de Lugduno e Ráurica ${ }^{198 .}$

Mas afastámo-nos muito do nosso assunto por causa do passo de Valério. Volto a Munácio Flaco que se tinha protegido com uma guarda escolhida de Lusitanos, os quais Valério desmente terem sido os cúmplices da sua crueldade. [130] Díon cala-se. A descrição do Comentário da Guerra Hispânica é um pouco obscura e não faz menção nem de Munácio nem dos Lusitanos ${ }^{199}$.

Os soldados de Petreio e de Afrânio, como estavam acostumados aos Lusitanos, habituaram-se a combater à maneira deles, escreve César no primeiro Comentário de A Guerra Civil ${ }^{200}$.

Por seu lado, os Lusitanos apoiavam tanto o partido de Pompeio que mesmo depois da morte daquele se mantiveram fiéis a seus filhos, Gneu e Sexto Pompeio, em todas as eventualidades. Não falo de Cotão, ou Catão, como têm outros códices, que sob as ordens de Munácio estava em Atégua com a escolta de Lusitanos e que se passou para César com o legado Túlio 201.

Foram acérrimos defensores do partido pompeiano, Fílon, conhecidíssimo em toda a Lusitânia, e Cecílio Niger, que, com um contingente de lusitanos bem grande, com extraordinário ardor trabalharam em Sevilha contra César a favor do jovem Gneu e incendiaram os navios que estavam no Guadalquivir. Vencido este finalmente e ferido junto de Munda, não o abandonaram e seguiram-no quando se refugiou em Carteia. Quando os habitantes desta, a fim de o atraiçoarem, enviaram embaixadores a César, Pompeio, prevenido, tomou uma barca e fugiu para os navios que aí tinha na sua escolta. Tendo, porém, enlaçado acidentalmente um pé nas amarras, enquanto se esforçava por cortar o cabo com o gládio, cortou com este a planta do pé, segundo diz Apiano no livro segundo das Guerras Civis ${ }^{202}$, ou torceu o pé, como refere o Comentário da Guerra Hispânica ${ }^{203}$. [131] Procurado pelos inimigos, à frente dos quais vinha Dídio, prefeito em Cádis da armada de César, fugiu do navio onde se tratara e quando fugia para a Lusitânia era transportado numa liteira. Mas, como as feridas e o pé torcido o atrasassem na fuga, foi apanhado por Dídio no caminho e morto, depois de se ter defendido, diz Apiano, não sem coragem ${ }^{204}$. César ordenou que a sua cabeça, que tinha sido levada para Sevilha, fosse exposta à vista do povo e assim se assenhoreou da cidade.

Os lusitanos que sobreviveram a este combate, como se reorganizassem em tropas regulares, voltaram a atacar Dídio, agora valorizado por aquela glória, prejudicando-o em lutas quotidianas. Com os soldados divididos em três grupos de combate, incendiaram-lhes navios, e o próprio Dídio foi morto pelos que não estavam na batalha, quando acorreu com as tropas para os escorraçar, e desbarataram todas as suas tropas, das quais poucos escaparam com vida. Os que fugiam quer na barca 
Hoc est: Lucius Munatius Lucii filius, Lucii nepos, Lucii pronepos Plancus consul imperator, iterum septemuir epulonum triumphauit ex Raeteis. Aedem Saturni fecit de manubiis, agros diuisit in Italia Beneuenti, in Gallia colonias deduxit Lugdunum, et Rauricam.

Sed multum ab instituto diuertimus, propter Valerii locum.

Redeo ad Munatium Flaccum, qui se Lusitanis stipatoribus munierat, quos tamen suae crudelitatis satellites habuisse queritur Valerius, [130] Dion tacet, subobscure narrat Hispaniensis belli commentarius, neque Munatii neque Lusitanorum facta mentione.

Petreianos Afranianosque milites, quod assuefacti cum Lusitanis essent, eorum more pugnare solitos, scribit Caesar in primo Belli ciuilis commentario. In tantum autem Pompeii partes fouebant Lusitani, ut etiam illo iam interfecto, filiis Cn. et Sext. Pompeiis, in omnem euentum adhaeserint.

Transeo Cotonem, uel potius Catonem, ut alii habent codices, qui Atteguae cum Lusitanorum praesidio sub Munatio erat, et cum Tullio legato ad Caesarem uenit.

Acerrimi Pompeianarum partium defensores fuere Philo, tota Lusitania notissimus, ac Caecilius niger, qui cum bene magna Lusitanorum manu Hispali contra Caesarem, pro Cn. adolescente mire laborarunt, multas ad Baetin naues incenderunt. Tandem uictum ad Mundam sauciumque non deseruere; sed quum se Carteiam recepisset, sequuti sunt.

De quo tradento quum ciues legatos ad Caesarem misissent, re intellecta Pompeius, ut in naues, quas ibi in praesidio habebat, confugeret, scapham ingressus est.

Sed pede casu funibus implicito, dum funem gladio secare nititur, pedis plantam gladio abscidit, ut libro Bellorum ciuilium secundo ait Appianus. Vel talum intorsit, ut Hispaniensis belli commentarius refert.

[131] Quum ab hostibus quaereretur, occurrente ad id Didio, qui Caesarianae classis Gadibus praefectus erat, ex naui, in qua curabatur, eggressus est, et in Lusitaniam profugiens lectica ferebatur.

Sed uulneribus et intorto talo quum ad fugiendum tardaretur, in itinere a Didio deprehensus interfectus est, non ignaue sese protegens, inquit Appianus.

Cuius caput Hispalin allatum Caesar in conspectum iussit dari populo, et sic urbe potitus est.

Lusitani, qui ex pugna superfuere, quum se ad signa recepissent, aduersus Didium elatum ea gloria redierunt, et quotidianis eum pugnis lacessentes, tripertito distributis signis, illius naues incenderunt, ipsum qui ad propellendum cum copiis processisset, proelio excipientes interfecere, omnesque eius copias deleuerunt, paucis exceptis qui aut in schapha, quae ad litus erat, aut nando ad naues quae in salo erant, confugientes, sublatis ancoris, uitae subdium remis quaesiuerunt. 
que estava na margem quer nadando para os navios que estavam ao largo, pediram aos remos a continuação da vida, depois de levantadas as âncoras.

Os lusitanos apoderaram-se de grande despojo, como refere aquele Comentário da Guerra Hispânica ${ }^{205}$, mutilado, de resto, em mau estado e confuso pelo estilo obscuro. E isto quem quer que tenha sido o seu autor. De facto, não penso que deva atribuir-se a sua autoria a Hírcio ou a Ópio, homens bastante eloquentes. Aquele, contudo, visto que era soldado de César, é imoderado no elogio e escreve de tal modo que não é possível compreender o que pretende e, nem mesmo que se tente adivinhar, o seu estilo é coerente em si próprio.

Com a morte de Gneu Pompeio e com o regresso da maior parte da Hispânia [132] à autoridade de César, este, que tinha pressa de dominar na cidade de Roma, deixou na Hispânia Sexto Pompeio, o segundo dos filhos de Pompeio Magno e o mais novo, por não lhe dar importância nem valor devido à sua juventude, não pensando que ele, com a idade que tinha, fosse tentar qualquer grande feito. Mas tudo aconteceu diferentemente.

Com efeito, o jovem desconhecido dedicou-se primeiramente com alguns companheiros à pirataria. Depois, libertando-se pouco a pouco do medo e apresentandose a si próprio como Pompeio Magno, formou exército poderoso fundindo nele os que tinham combatido sob as ordens de seu pai Pompeio ou de seu irmão Gneu e tinham abandonado as armas, porque vencidos, mas que nessa altura vinham juntar-se a ele, considerando-o seu chefe, pois o nome de Pompeio lhes era grato.

Engrandecido, pois, pelo contingente militar que era cada vez maior, começou a inspirar um tal terror nos chefes que, sob o mando de César, tinham obtido as Hispânias, que estes recearam defrontá-lo. Quando César soube disto, enviou Carrinas com forças militares mais poderosas, a fim de submeter Pompeio.

Em Apiano encontra-se escrito nestes passos, não sei se por erro do tradutor, Carrina em vez de Carrinas. Fala-se, na realidade, de Gaio Álbio Carrinas que depois obteve o consulado, porque Augusto abdicou ${ }^{206}$. O jovem, porém, logo que soube da chegada de Carrinas, acorreu imediatamente e desbaratou-o. Por esse motivo, César enviou um sucessor de Carrinas, Gaio Asínio Polião, que ainda chefiava a guerra na Hispânia Ulterior, quando César foi morto. Além disso, o Senado mandou chamar Pompeio.

Este, no entanto, embora já tivesse sido trazido para Marselha, de modo algum voltou a Roma, pois atento esperava o que nela iria acontecer, [133] e sendo eleito almirante, como fora seu pai, juntou aos navios que foram tomados aqueles que tinha consigo na Hispânia e navegou rumo à Sicília contra o domínio dos triúnviros. Muitos gauleses, iberos e mesmo muitos lusitanos o seguiram por amor a seu pai, Pompeio, e pelo ódio que ainda ressentiam por César. Na verdade, mesmo Bruto, quando, proscrito pelos triúnviros, preparava com Cássio no golfo de Melas a guerra contra António tinha consigo, escreve Apiano ${ }^{207}$, quatro mil cavaleiros celtas e lusitanos.

Pompeio, portanto, depois de se apoderar da Sicília, combateu, as mais das vezes vitorioso, contra Octávio e António, e teria na realidade deixado para a posteridade uma reputação de grande chefe se não tivesse tentado mais nada. De facto a sorte 
Lusitani praeda ingenti potiti sunt, ut refert ille Hispaniensis belli commentarius, alioqui mutilus, corruptus, impeditoque sermone confusus, quisquis auctor illius fuerit.

Neque enim ad Hircium aut Opium disertos satis homines referendum ego existimo. Miles tamen Caesaris quum esset, et in eius laudes immodicus ita scripsit, ut saepe, neque quid uelit intelligas, neque si diuines, oratio ipsa sibi congruat.

Cn. Pompeio extincto, et maxima ex parte Hispania in potestatem [132] redacta, Caesar ad Vrbanam dominationem festinans, Sext. Pompeium alterum ex Pompeii Magni filiis iuniorem, contempta eius adolescentia, neglexit in Hispania, non arbitratus eum aliquid magnum propter aetatem esse ausurum, sed aliter res euenit.

Nam iuuenis primo cum paucis piraticam exercuit ignotus. Deinde paulatim timorem exuens, seque Pompeii Magni filium professus, ex iis qui uel sub patre Pompeio, uel sub $\mathrm{Cn}$. fratre militauerant, uictique cesserant, ualidum conflauit exercitum, ad eum tanquam ad ducem suum confluentibus, quibus Pompeii nomen erat gratiosum.

Adauctus igitur amplioribus copiis, formidini esse cepit praesidibus, qui sub Caesaris imperio Hispanias obtinebant, ita ut uererentur cum eo ad manus uenire.

Qua re intellecta Caesar Carrinatem cum ualidioribus copiis misit, qui Pompeium debellaret.

Apud Appianum Carrinam in his locis scriptum pro Carrinate reperias, nescio an iuterpretis uitio. Nam sermo est de C. Albio Carrinate, qui postea consulatum gessit, quum Augustus abdicasset.

At uero iuuenis cognito Carrinatis aduentu, statim aduolans illum oppressit. Ea ex causa Caesar successorem Carrinati misit. C. Asinium Pollionem, quo in Vlteriore Hispania bellum gerente, Caesar interemptus est, et Senatus Pompeium ultro reuocauit.

Ille uero, quum Massiliam esset delatus, ad urbem nequaquam rediit, sed quae ibi fierent intentus expectabat.

[133] Atque electus maris imperator, ut pater eius fuerat, assumptis, quae in portu erant, nauibus, una cum iis, quas uel secum, uel in Hispania habebat, contra triumuirorum dominationem in Siciliam nauigauit. Multi illum Galli, multi Iberi, multi etiam Lusitani sequuti sunt, Pompeii patris amore, et Caesaris adhuc odio.

Nam etiam Bruto a triumuiris proscripto, quum una cum Cassio ad nigrum sinum aduersus Antonium bellum pararet, quattuor millia Celtarum, ac Lusitanorum equitum illi fuisse scribit Appianus.

Pompeius igitur Sicilia potitus contra Octauium, et Antonium pugnauit plerumque uictor. 
habitual transformou-se como que indignada pela insolência com que ele, vestido de azul e com palavras orgulhosas, se tinha gabado de ser filho de Neptuno, como se fosse pouco sê-lo de Pompeio Magno, e, vencido, entregou-se a Tício, general de António, que o matou em Mileto.

Quem quiser saber estes factos com mais pormenor, leia os livros quarto e quinto das Guerras Civis de Apiano ${ }^{208}$. Nós atardámo-nos neles bastante mais largamente, porque Orósio, baseado não sei em que autor, escreve que a morte de Sexto Pompeio se seguiu imediatamente à batalha de Munda ${ }^{209}$. São estas as suas palavras no capítulo décimo sexto do livro sexto: "O último encontro travou-se junto da cidade de Munda, onde se combateu com tal força e foi tanta a mortandade, que César uma vez que os seus veteranos não tinham vergonha de recuar -, como visse a sua linha de batalha em risco de ser trucidada e desbaratada, teria pensado [134] em evitar com o suicídio o futuro opróbrio de ser vencido, quando inesperadamente o exército dos Pompeianos se pôs em debandada e cedeu". E logo a seguir: "Gneu Pompeio fugiu com o centésimo cavaleiro. O seu irmão, Sexto Pompeio, reuniu rapidamente um não pequeno contingente de lusitanos, travou batalha com Cesónio e foi vencido e morto quando fugia. A cidade de Munda, depois de atacada por César, foi capturada a custo com enorme massacre de homens" 210 .

Não tenho, porém, a menor dúvida de que este passo está corrompido. Com efeito, um pouco mais à frente, no décimo oitavo e décimo nono capítulos, lembra Orósio a quarta guerra de Octávio, que também foi contra Sexto Pompeio, filho de Gneu Pompeio, e conta que Sexto tinha ocupado a Sicília mas que, finalmente vencido por Tício e Fúrnio, generais de António, foi capturado e pouco depois morto $^{211}$, como dissemos anteriormente fundamentando-nos em Apiano.

Eis porque eu leria de bom grado no passo anterior: “...travou batalha com Cesónio e foi vencido e quase morto quando fugia". Fugiu de facto e depois disso voltou-se para a pirataria, o que o próprio Orósio confirma com as seguintes palavras: "Sexto Pompeio, depois que descobriu que o tinham colocado no número dos proscritos, voltou-se para o latrocínio e devastou toda a costa da Itália com mortes e rapinas, tendo-se apoderado da Sicília”212.

Para voltarmos, contudo, a Asínio Polião, existem três cartas dele entre as de Cícero aos amigos, no livro décimo, numa das quais se diz: «De resto, segundo calculo, Pansa começou o combate no mesmo [135] dia em que os navios partiram de Cádis. É que depois do Inverno não houve qualquer navegação antes desse dia. E, por Hércules, longe de toda a suspeita que ia levantar-se, eu tinha posto as legiões nos quartéis de Inverno lá para o interior da Lusitânia. A sorte inclinouse, depois disto, para César Augusto e, obtido o poder sobre o mundo romano, pacificou a Hispânia em quatro anos, quer pelo seu esforço, quer pelo dos seus generais. Fundou umas colónias e engrandeceu outras" 213 . Destas falaremos com alguma demora quando tratarmos das cidades ${ }^{214}$.

No primeiro volume, quando assinalávamos os limites da Lusitânia ${ }^{215}$, dissemos que a Bética era uma província atribuída à plebe, para onde era enviado um pretor 
Et quidem magni famam ducis posteris reliquisset, si nihil tentasset ulterius.

Verum mutata priori fortuna, quasique insolentiam eius indignante, qua se, et amictu caeruleo et uerborum uanitate, Neptuni filium esse iactauerat, tamquam Magni Pompeii esse fuisset parum, uictus Antonii se duci Titio dedidit, a quo Mileti interfectus est.

Qui copiosius ista scire uelit, legat Appiani Ciuilium bellorum libros quartum et quintum. Nos in his immorati prolixius aliquanto sumus, propter Orosium, qui Sext. Pompeii mortem post Mundensem pugnam statim sequutam scribit, nescio quem sequutus auctorem.

Eius haec sunt uerba libro sexto, capite decimo sexto: "Vltimum bellum apud Mundam urbem gestum est, ubi tantis uiribus dimicatum, tantaque caedes acta ut Caesar quoque ueteranis suis cedere non erubescentibus, quum caedi, cogique aciem suam cerneret, praeuenire [134] morte futurum uicti dedecus cogitarit, quum subito uersus in fugam Pompeiorum cessit exercitus."

Et statim: "Cn. Pompeius cum centesimo equite aufugit.

Frater eius Sex. Pompeius contracta celeriter non parua Lusitanorum manu, cum Caesonio congressus, et uictus fugiensque interfectus est. Munda ciuitas cum immensa hominum caede Caesare oppugnante uix capta est."

Dubium tamen apud me non est, corruptum Orosii locum hunc. Nam paulo post capite decimo octauo et capite decimo nono, Octauii quartum bellum aduersus Sex. Pompeium Cn. Pompeii filium commemorat, narratque eum Siciliam occupasse, et tandem a Titio et Furnio Antonianis ducibus uictum, et captum, post paululum fuisse interfectum uti ex Appiano ante diximus.

Quare priori loco libenter legerem. "Cum Caesonio congressus, et uictus fugiens paene interfectus est." Euasit enim atque ad piraticam inde se conuertit, quod etiam Orosius ipse confirmauit, his uerbis.

"Sex. Pompeius postquam se in proscriptorum numerum relatum comperit, conuersus ad latrocinia, omnem oram Italiae caedibus, rapinisque uastauit, Sicilia praerepta."

Ceterum ut ad C. Asinium Pollionem redeam, eius tres extant epistolae inter Ciceronis familiares libro decimo, in quarum una sic habetur: "Sed ut rationem ineo, quo die proelium Pansa commisit, eodem a [135] Gadibus naues profectae sunt. Nulla enim post hiemem fuit ante eam diem nauigatio. Et hercule longe remotus ab omni suspicione futuri ciuilis tumultus, penitus in Lusitania legiones in hibernis collocaueram.

Inclinauit post haec ad Caesarem Augustum fortuna, et Romani orbis imperium adeptus, Hispaniam, quum per se, tum per suos duces, intra annos quattuor pacatam reddidit. Colonias partim deduxit, partim ampliauit.” De quibus nonnihil inter urbes referemus.

In primo uolumine, quum terminos Lusitaniae signabamus, diximus Baeticam prouinciam plebi attributam, ad quam praetor mitteretur, qui legatum, et 
com direito a um legado e a um questor e que todas as restantes províncias na Hispânia eram de César, que mandava dois legados, um pretoriano e outro consular. Destes, o pretoriano tinha consigo um legado para ministrar justiça aos Lusitanos que se estendiam desde junto da Bética até ao Douro; o consular administrava a parte restante da Hispânia. Augusto, com efeito, dividiu a administração de todas as províncias súbditas do império romano de tal maneira que umas eram proconsulares, outras pretórias e outras ainda presidiais. Confiou as proconsulares ao Senado, as pretoriais ao povo e ele próprio tomou a seu cargo as presidiais para onde mandava legados, que tanto eram chamados governadores como legados de César ou legados de Augusto. [136] Estes governadores ou legados de César eram reforçados algumas vezes, devido às suas altas funções, com o poder consular, para que tivessem a mesma autoridade que os procônsules. De facto, a dignidade dos procônsules era superior à dos legados ou governadores, porque estes podiam ser escolhidos dentro da ordem equestre e aqueles só podiam obter em sorte as províncias se fossem da ordem senatorial ou consular.

Foram, pois, feitas proconsulares e pretoriais aquelas que ou já estavam pacificadas ou que não tinham necessidade de protecção militar. Aquelas, porém, que ainda revoltadas pareciam só poderem ser mantidas com a presença de legiões e armas, essas atribui-as César a si próprio com o pretexto, delicado de facto, de ser agradável ao Senado e ao povo romano, como se lhes tirasse trabalho, mas a verdadeira razão, tal como Díon deixou escrito ${ }^{216}$, era a de ter ele próprio, sob o seu comando, todos os exércitos e contingentes militares para que nunca o Senado ou o povo ousassem restabelecer o sistema republicano por ele invadido.

As Hispânias foram, portanto, divididas mais tarde em seis províncias: a da Bética, a Lusitânia e a Galécia foram transformadas em consulares, e em presidiais a Tarraconense, a Cartaginense Insular e a Tingitânia que, do outro lado do estreito, foi anexada à Hispânia. Finalmente a Lusitânia foi dividida em duas províncias, uma das quais, evidentemente a maior parte da antiga província, conservou para si o nome de Lusitânia, enquanto a outra foi chamada Vetónia como referimos extensamente no primeiro livro 217 .

Pouco a pouco começaram a aparecer os companheiros [condes] e os seus representantes a partir de Adriano, que manteve no palácio uma espécie de senado doméstico que o devia acompanhar [137] quando ia para o estrangeiro. Por isso se lhes chamou "Comitatus" [condado] de César e aos próprios senadores "comités" [condes] palatinos, até que o divino Constantino transferiu para os herdeiros deles as cidades ou províncias que lhe estavam atribuídas. É esta a origem da dignidade de condes e duques ${ }^{218}$.

Os reis dos Langobardos ${ }^{219}$ seguiram este costume e dividiram a Itália, que lhes estava sujeita, em vários condados e ducados. Os chefes que estavam junto às fronteiras também eram designados por "marchiones" [marqueses], porque se chamava vulgarmente marcha à fronteira ${ }^{220}$. 
Quaestorem haberet; reliquas omnes in Hispania Caesaris fuisse, qui duos mitteret legatos, praetorium et consularem.

Ex iis praetorius legatum secum habebat, qui Lusitanis Baeticae adiacentibus, et ad Durium usque protensis, ius diceret.

Consularis, quod reliquum erat Hispaniae administrabat.

Augustus enim omnium prouinciarum Romano imperio subditarum administrationem ita diuisit, ut aliae proconsulares essent, aliae praetoriae, aliae praesidiales. Proconsulares Senatui, praetorias populo demandauit.

Praesidiales sibi ipse sumpsit, in quas legatos mittebat, qui modo praesides, modo Caesaris, uel Augusti Legati dicebantur.

[136] Iique praesides legatiue Caesaris, nonnunquam honoris causa consulari potestate augebantur, ut eiusdem essent auctoritatis quuius proconsules. Proconsulum namque dignitas amplior, quam legatorum praesidumue erat, quoniam hi ex equestri ordine eligi poterant, illi nonnisi ex senatorio, consulariue prouincias sortiebantur. Proconsulares ergo, et praetoriae illae sunt factae, quae uel pacatae iam essent, uel militari praesidio non indigerent.

Quae uero adhuc rebelles, legionibus armisque retinendae uiderentur, sibi attribuit Caesar, specioso quidem praetextu gratificandi Senatui populoque Romano quasi eis laborem adimeret, re autem uera ut ipse exercitus copiasque militares omnes in sua potestate haberet, ne unquam Senatus populusue inuasam rempublicam repetere auderent, ut scriptum reliquit Dion.

Hispaniae igitur postea in sex prouincias diuisae: Baetica, Lusitana et Callaecia, consulares factae; Tarraconensis, Carthaginiensis Insularis et Tingitania, quae trans fretum Hispaniae est contributa, praesidiales.

Tandem Lusitania in duas diuisa prouincias, quarum altera, uidelicet maior ueteris prouinciae pars, suum sibi Lusitaniae nomen retinuit. Altera Vettonia dicta est, uti in primo libro abunde retulimus.

Paulatim emersere comites, eorumque uicarii, usque ex Hadriano, qui Senatum quendam domesticum in palatio suo habuit, qui peregre euntem [137] comitaretur, Caesaris comitatus ideo nuncupatus, et illi ipsi senatores, comites palatini.

Donec diuus Constantinus oppida, uel prouincias illi attributas ad eorum transtulit heredes.

Atque haec origo est dignitatis comitum, ducumque.

Morem eum sequuti Longobardorum reges Italiam sibi subiectam in comitatus uarios atque ducatus diuiserunt.

Limitanei quoque duces marchiones nuncupati sunt, quoniam limitem, "marcham" uulgus appellaret. 
De Augusto, pois, até aos Godos nada encontrei de especial a respeito da Lusitânia na tão deplorada decadência dos escritores antigos, a não ser que se aquietou sob o domínio romano e que se mostrou obediente às suas leis e que Otão, mais tarde imperador, foi, por ordem de Nero, governador da Lusitânia para que este, escreve Tácito no livro terceiro, afastado o marido de Roma, gozasse mais facilmente a companhia de Popeia, mulher de Otão. "Onde [na Lusitânia] - diz o historiador serviu até às guerras civis, não devido a qualquer antecedente desonroso, mas com integridade e lealmente. Sem freio na vida privada, foi bastante moderado no uso do poder." Repete quase o mesmo no livro décimo sétimo ${ }^{221}$.

Suetónio Tranquilo também diz na vida de Otão: "Afastado para a Lusitânia [138] devido às funções de governador" 222 . Correu mesmo um dístico a este respeito:

Porquê, pergunta-se, está Otão exilado com enganadora honra?

É que começara a ser amante da sua própria mulher ${ }^{223}$.

Há testemunhos, contudo, de que Otão administrou a Lusitânia durante dez anos com moderação e invulgar isenção e de que os Lusitanos ainda combateram na Itália a favor dos Romanos ${ }^{224}$. De facto, Tácito, no mesmo livro, escreve que houve coortes lusitanas que prestaram juramento a Vitélio 225.

Alciato, nas anotações ao livro décimo sexto de Tácito ${ }^{226}$, recorda a sétima coorte de Lusitanos com base numa inscrição de mármore, que ainda hoje existe em Como, feita em memória de Calpúrnio Fabado Novocomense, avô da mulher de Gaio Cecílio Plínio 227.

Chama-se Sorranal a cidade que está entre Tortona e Génova, não longe das montanhas. Aí vi eu a inscrição, que dizem ter sido trazida de uma cidade destruída perto da povoação de Antília, ou, melhor, Atília, e que diz assim:

[139]

Q. ATTIO. T. F.

MAEC. PRISCO

AED. II VIR. QVINQ.

FLAM. AVG. PONTIF.

PRAEF. FABR. PRAEF. COH. I.

HISPANORVM. ET. COH. I.

MONTANORVM. ET. COH. I.

LVSITANO R. TRIB. MIL. LEG. I.

ADIVTIC. DONIS. DONATO.

AB IMP. NERVA. CAESARE AVG.

GERM. BELLO SVEBIC. CORON.

AVREA. HASTA. PVRA. VEXILL.

PRAEF. ALAE. I. AVG. THRACVM.

PLEPS. VRBANA. 
Ab Augusto igitur usque ad Gothos, nihil quod magnopere ad Lusitaniam pertineat in tam deplorato scriptorum antiquorum interitu, ego reperi. Nisi Lusitaniam in Romanorum acquieuisse dominatu, eorumque legibus domitam paruisse. Othonem postea Caesarem fuisse a Nerone Lusitaniae praefectum, ut Popaea illius uxore, amoto ex Vrbe uiro, liberius frueretur, libro tertio scribit Tacitus. "Vbi - inquit - usque ad ciuilia arma, non ex priore infamia, sed integre sancteque egit, procax otii, et potestatis temperantior." Eadem fere repetit libro decimo septimo.

Suetonius quoque Tranquillus in Othone: "Sepositus - inquit - est per [138] causam legationis in Lusitaniam." Iactatum etiam de hac re distichum:

Quur Otho mentito sit quaeritur exsul honore

Vxoris moechus coeperat esse suae.

Illum tamen per decem annos moderatione atque abstinentia singulari, prouinciam administrasse testatur.

Et pro Romanis etiam in Italia militauere Lusitani. Eodem enim libro scribit Tacitus, Lusitanorum cohortes sub Vitelii sacramento fuisse.

Septimae Lusitanorum cohortis meminit Alciatus in annotationibus in Taciti librum decimum sextum, ex inscriptione marmorea, quae Comi adhuc sit in memoriam Calpurnii Fabati Nouocomensis, C. Caecilii Plinii prosoceri.

Sorranale uocatur oppidum inter Dertonam Genuamque non procul a montibus. Ibi ego inscriptionem uidi, quam aiebant ex diruto iuxta oppido Antilia, seu potius Attilia fuisse allatam. Ea est huiusmodi:

[139]

Q. ATTIO. T. F.

MAEC. PRISCO

AED. II VIR. QVINQ.

FLAM. AVG. PONTIF.

PRAEF. FABR. PRAEF. COH. I.

HISPANORVM. ET. COH. I.

MONTANORVM. ET. COH. I.

LVSITANO R. TRIB. MIL. LEG. I.

ADIVTIC. DONIS. DONATO.

AB IMP. NERVA. CAESARE AVG.

GERM. BELLO SVEBIC. CORON.

AVREA. HASTA. PVRA. VEXILL.

PRAEF. ALAE. I. AVG. THRACVM.

PLEPS. VRBANA. 
Isto é: A Quinto Átio Mecenas Prisco, filho de Tito, duúmviro, cinco vezes flâmine augustal, pontífice, prefeito dos operários, prefeito de cavalaria da primeira coorte dos Hispanos e da primeira coorte dos Montanos e da [140] primeira coorte dos Lusitanos, tribuno militar da primeira legião auxiliar, presenteado pelo imperador Nerva Augusto Germânico na guerra contra os Suevos com uma coroa de ouro, um dardo [em ferro] puro e um vexilo [estandarte], prefeito da primeira ala augustal dos Trácios, a Plebe Urbana $[\text { Dedica }]^{228}$.

Considerei, nesta inscrição, digno de reparo o facto de os Lusitanos estarem separados dos Hispanos. É que os Lusitanos se tinham finalmente adaptado aos costumes romanos e aceitaram, como também os Turdetanos, a sua civilização e língua, tal como analisei no opúsculo a Vaseu sobre a "colónia pacense"229, de modo que não deve ser ouvida certa pessoa que pensou iria fazer trabalho inestimável se, depois daquela minha discussão, subscrevesse a afirmação de Genésio de Sepúlveda de que Badajoz tinha sido Pax Augusta ${ }^{230}$. Remetemos o leitor para aquele opúsculo e para o que mais à frente comentaremos a respeito das cidades ${ }^{231}$.

Erigiram mesmo estátuas à maior parte dos imperadores, como mostraremos noutro $\operatorname{lugar}^{232}$. Além disso, se surgia algo de aprazível aos olhos ou ao espírito, imediatamente comunicavam aos Romanos, como fizeram os Olisiponenses ao imperador Tibério, a quem, segundo escreve Plínio no capítulo quinto do livro nono, informaram, por meio de embaixada especialmente enviada, que tinha sido visto e ouvido um tritão com a forma que lhe é conhecida a soprar a concha em certa caverna ${ }^{233}$.

Mostrámos anteriormente na descrição da Lusitânia segundo Plínio e voltaremos, mais adiante, a falar ${ }^{234}$, que a província foi dividida em três conventos jurídicos, o Emeritense, o Pacense e o Escalabitano, de tal modo que formam quase um triângulo equilátero ${ }^{235}$. E que das cidades, umas foram chamadas colónias, outras municípios, ou seja, de cidadãos romanos ou do Lácio antigo ou que outras ainda foram conservadas como estipendiárias. [141] Também, por mais de uma vez dissemos que tinha sido dividida em dois.

Existiram, contudo, na Lusitânia alguns régulos, ou dinastas ou toparcas, súbditos do império romano, como foi o pai de Engrácia ${ }^{236}$, nobilíssima virgem e mártir de Saragoça, muito conhecida em toda a Celtibéria, e já ao tempo da dominação goda, o príncipe Castinaldo de Nabância ${ }^{237}$.

\section{OS GODOS}

Quanto à origem dos Godos, de modo algum pertence ao objectivo do meu trabalho apresentá-la, principalmente porque os autores que sobre eles escreveram não estão de acordo entre si. No entanto, visto que este assunto lança certa luz sobre o que temos de apresentar, contentemo-nos em dizer resumidamente que eles foram constituídos por Getas, Sármatas e por alguns outros povos seus vizinhos. 
Hoc est: Quinto Attio Titi filio Maecenati Prisco aedili, duumuiro quinque Flamini Augustali pontifici praefecto fabrum, praefecto cohortis primae [140] Hispanorum, et cohortis primae Montanorum, et cohortis primae Lusitanorum, tribuno militum legionis primae adiutricis donis donato ab imperatore Nerua Caesare Augusto Germanico bello Suebico corona aurea, hasta pura, uexillo; praefecto alae primae Augustalis Thracum, plebs urbana.

Vbi illud animaduersione dignum iudicaui, Lusitanos separatim ab Hispanis esse positos.

Abiere tandem in Romanorum mores Lusitani, et ciuilitatem linguamque Latinam, sicut et Turdetani accepere, uti in libello ad Vasaeum pro colonia Pacensi disputaui, ut audiendus quidam non sit qui se operae pretium facturum existimauit, si post disputationem illam meam Genesio Sepuluedae Badiozam pacem fuisse Augustam asserenti subscriberet.

Nos ad libellum illum remittimus lectorem, et ad ea quae postea in urbes commentabimur.

Caesaribus etiam plerisque statuas erexere, ut alibi ostendemus. Quin si qua mira res suboriretur quae aut animum pasceret aut oculos, ad illos protinus mittebant, ut Tiberio principi Olisiponenses, missa ob id legatione, nuntiasse tritonem qua noscitur forma, in quodam specu canentem concha uisum auditumque scribit Plinius libro nono capite quinto.

Prouinciam in tres iuridicos conuentus diuisam, Emeritensem, Pacensem et Scallabitanum, sic, ut triangulum aequalium prope laterum facerent.

Et urbium alias colonias appellatas, alias municipia, uel ciuium Romanorum, uel antiqui Latii, uel stipendiarias relictas, ex Plinio in Lusitaniae descriptione, supra ostendimus, et postea ostendemus, [141] diuisam quoque in duas non semel diximus.

Erant nihilominus in Lusitania aliquot siue reguli, siue dynastae, aut toparchae, imperio Romano subditi, qualis pater fuit Encratidis nobilissimae uirginis et martyris Caesaraugustae, et in tota Celtiberia notissimae: et iam dominantibus Gothis, Castinaldus Nabantiae princeps.

\section{DE GOTHIS}

De Gothorum autem origine ad institutum meum scribere nequaquam pertinet, maxime non conuenientibus inter se, qui de illis scripsere, auctoribus. Verum quia lucem aliquam iis quae dicenda sunt, ea res afferet, in summa, Getas eos fuisse ac Sarmatas, nonnullosque alios populos illis finitimos, dixisse sufficiat. 
Com efeito, muitos povos, quer da Escândia, ilha do Quersoneso Címbrico, quer da Vicínia, assumiram o nome de povo Gótico, desconhecido dos autores antigos e confundido sob a denominação de povo Gético, até que os próprios naturais, devido à sua importância, começaram a aparecer e com eles o vocábulo em toda a sua celebridade, o qual tiraram à sorte e era derivado do nome de um seu chefe chamado Godo, segundo afirma Vitichindo no livro primeiro de Sobre os Saxónicos $^{238}$. A não ser que prefiramos seguir a versão de Ptolomeu, segundo o qual foram primeiro denominados Gutos, nome derivado dos povos Gutos, da mesma Escândia, que depois deu Godos 239 .

"Os povos góticos - diz Procópio no livro segundo de As Guerras dos Vândalos - [142] foram na verdade muitos, e mais diferentes nos tempos antigos do que nos de agora. Os maiores e mais fortes de todos eram, porém, os Godos, os Vândalos, os Visigodos e os Gépedes, chamados ainda há pouco de Sármatas e Melanclénios.”240

Por nossa parte devemos acrescentar que os Godos se dividiram em Ostrogodos e em Visigodos, isto é, em Orientais e Ocidentais. Assim diz Jordanes na História dos Getas $^{241}$. Os do lado oriental receberam o nome de Ostrogodos, os que ficaram na parte ocidental e frequentemente noutras regiões o de Visigodos.

A razão é evidente para os que não desconhecem a língua germânica. Com efeito, os Godos foram povos da antiga Germânia, entre os quais "ocidente" se diz West e, se tiver de ser pronunciado em germânico, Westgothen, significa o mesmo que Godos Ocidentais, ao passo que no oriente se diz Oster ${ }^{242}$. Por isso é que Carlos Magno ao mudar os nomes dos ventos para a sua língua chamou ao subsolano, que é um vento de leste, Ostrenwindt, mas Westren ao zéfiro que sopra do oeste, como anotou o que escreveu a sua biografia ${ }^{243}$. Devo advertir de passagem que os nomes de ventos que hoje empregam os marinheiros portugueses foram postos por Carlos Magno ${ }^{244}$

Dos Godos salientaram-se duas famílias nobilíssimas, a dos Amalos que existiu entre os Ostrogodos e a dos Baltos entre os Visigodos. [143] Jordanes na História dos Getas diz: "Os povos estavam divididos em famílias [clãs]. Os Visigodos estavam sob a dependência da família dos Baltos, os Ostrogodos da dos ilustres Amalos"245. Os Amalos, é verdade, glorificavam-se de o rei Amalo ter sido o autor da sua estirpe e nome; os Baltos, por seu lado, derivaram o seu nome de Alarico que tinha recebido entre os seus, devido à sua ousadia, o cognome de Baltha, isto é, ousado ${ }^{246}$. De resto, nobilitaram os Visigodos Alarico, que referi, Vália e Teodorico, o mesmo que, combatendo com Écio ao lado dos Romanos e contra Átila, tombou vitorioso nos campos da Catalunha. Alguns dos nossos chamaram-lhe Teodoreto, e Gregório de Tours designa-o por Teudão ${ }^{247}$. Quanto a estes nomes bárbaros é evidente que os autores não estão de acordo entre si, nem quando os apresentam à sua maneira, nem quando amaciam a sua pronúncia.

Muito mais célebres se tornaram os Ostrogodos, ilustrados pela família dos Amalos, devido àquele grande Teodorico Amalo, adoptado por Zenão Augusto e designado como se fosse outro imperador de Roma e de Itália ${ }^{248}$. 
Multae ssquidem gentes, siue ex Schandia, Cimbricae Chersonesi insula, siue ex Vicinia, Gothicum effecere nomen priscis scriptoribus ignoratum et sub Getica appellatione confusum, donec uiribus ipsi suis emersere magna uocabuli claritate, quod a duce proprio, qui Gothus uocabatur, ut asserit Vitichindus Saxonicorum libro primo, sortiti sunt.

Nisi malimus a Gutis ipsius Schandiae iuxta Ptolemaeum gentibus eos prius Guthos, deinde Gothos fuisse denominatos.

"Gothicae gentes - inquit Procopius, Belli Vandalici libro tertio - [142] multae quidem, et aliae prius fuere, quam nunc.

Omnium autem maximae ac potissimae, Gothi et Vandali et Vesoghoti et Gepedes, iam dudum Sarmatae et Melanchlaeni appellati."

Addamus et nos, Gothos in Ostrogothos et Vesoghotos, hoc est, in Orientales et Occidentales fuisse diuisos. Ita Iordanes in Geticis. A loco Orientali dicti sunt Ostrogothi, residui uero Vesogothi in parte occidua, et saepe alias.

Ratio in promptu est Germanicam linguam non ignorantibus, Gothi enim ueteris Germaniae fuere populi apud quos "West" Occidens dicitur, et si Germanice pronunciandum sit, "Westgothi", idem est, quod occidentales Gothi, et contra "Oster" Oriens uocatur.

Vnde Carolus Magnus cum uentorum nomina in suam linguam mutaret, subsolanum orientalem uentum "Ostrenwindt" appelauit.

Zephyrum uero, qui ab Occidente spirat "Westren", sicut adnotauit is qui uitam eius mandauit litteris. Vt obiter admoneam, uentorum nomina quibus hodie nautae Lusitani utuntur, a Carolo fuisse imposita.

Inter Gothos duae nobilissimae excellebant familiae, Amalorum uidelicet inter Ostrogothos, et Balthorum inter Vesogothos.

[143] Iordanes in Geticis: "Diuisi (inquit) per familias populi Vesogothi, familiae Balthorum, Ostrogothi praeclaris Amalis seruiebant.” Et quidem Amali, regem Amalam suae stirpis et nominis auctorem fuisse gloriabantur. Balthi uero ab Alarico, qui ob audaciam "Baltha", id est, audax inter suos cognomen acceperat, diriuati sunt.

Ceterum Vesogothos nobilitarunt Alaricus, quem dixi, et Vallia et Theodoricus, is qui pro Romanis una cum Aetio in Catalaunicis campis contra Attilam pugnans uictor occubuit. Quem ex nostris quidam Theodoretum uocant, Gregorius Turonensis Theudonem.

Videlicet in barbaris his nominibus, uel suo more proferendis, uel paulo mollius pronuntiandis, mutuo non consentiunt scriptores.

Ostrogothos, quos Amalorum excellens familia illustrabat, longe illustriores reddidit magnus ille Theodoricus Amalus a Zenone Augusto adoptatus, et quasi alter imperator Romae, et Italiae destinatus. 
Não omitamos, além disto, que segundo o mesmo autor Procópio, os Alanos também foram da mesma raça gótica ${ }^{249}$, os mesmos que Amiano Marcelino, no vigésimo terceiro livro ${ }^{250}$, diz terem sido os Massagetas. Embora aparentados, estes povos, divididos entre si por secessões e partidos, combatiam frequentemente uns contra os outros. [144] Aconteceu com isto que os Alanos, Suevos e Vândalos, expulsos da sua região pelos Godos, seus vizinhos e do mesmo sangue, se uniram por um tratado e penetraram primeiro nas Panónias, depois nas Gálias e finalmente nas Hispânias. Desse grupo foram os Vândalos que ocuparam a Bética, denominada depois Vandália ou Vandalícia por eles próprios, tendo sido daí escorraçados para África pelos Visigodos, que mais tarde tudo vieram a submergir, e pelo seu rei Vália, já federado de Honório Augusto ${ }^{251}$. Os Alanos obtiveram Mérida e a maior parte da Lusitânia incluindo Lisboa, que se remiu por uma vez com dinheiro. Os Suevos ocuparam toda a Galiza.

Os que se fixaram em Mérida foram, porém, vencidos em duro combate por Constâncio, primeiramente "conde" 252 e depois declarado imperador por Honório, seu parente depois do casamento com Placídia já restituída, e ajudado por tropas auxiliares do mesmo Vália e dos Visigodos. Como tivessem perdido na batalha o seu rei Atace, parte dos Alanos resignou-se a pedir a paz, enquanto outros se refugiaram junto dos Suevos que ocupavam Lisboa e ali repousaram sob a sua tutela ${ }^{253}$.

Aterrados todos eles pelo receio dos Romanos e discutindo projectos de paz, pediam a Honório, segundo diz Orósio, o seguinte: "Mantém-te em paz com todos e de todos exige reféns. Nós lutamos uns contra os outros, matamo-nos, mas damos-te vitórias. Será uma imortal vantagem para a tua república se ambos morrermos" 254 . Assim falavam eles então, mas ao terem conhecimento da morte de Constâncio, rejeitaram o plano da petição de paz e voltaram [145] às suas disposições naturais. Logo os Alanos que regressavam a Mérida reivindicaram para si toda a Lusitânia, sendo encorajados pelos Vândalos que ainda restavam na Bética.

Exaltaram-se, bem entendido, os ânimos com o regresso de Vália a Tolosa, que Honório the confiara com algumas outras cidades da Auxitânia. Por isso se chamou Visigótia a esta região que os Hispanos preferiram designar por Gália Gótica ${ }^{255}$.

A morte de Honório, logo a seguir, também fez aumentar a ousadia. Mas quando Teodósio-o-Moço nomeou imperador a Valentiniano, filho da sua tia paterna Placídia e de Constâncio, enviou para a Lusitânia, contra os Alanos e os Suevos, o "conde" Sebastião. Este, sem dúvida bem sucedido, tinha-se apoderado completamente da Lusitânia, mas, aspirando ao poder absoluto, lançou-se num tratado com os Vândalos que restavam e com os Visigodos. Pouco depois foi cercado por eles e morto 256

Os Suevos, deixando portanto a Lusitânia aos Alanos, seus aliados, como se dirigiram ao encontro dos seus compatriotas, que estavam na Galiza, engrossaram a comunidade e formaram um reino que, segundo Isidoro ${ }^{257}$, durou cento e setenta e sete anos, de Hermerico a Leovegildo, rei dos Visigodos.

Os Visigodos levaram-lhes, porém, vantagem, pois cavando mais fundo as suas raízes, estenderam-se [146] pela Hispânia Citerior e mesmo pela Gália Narbonense 
Alanos praeterea, Gothicum et ipsum genus, eodem Procopio auctore, minime praetereamus, quos Massagethas fuisse scribit Ammianus Marcellinus libro uigesimo tertio.

Tametsi cognatae gentes eae, secessionibus ac factionibus inuicem diuisae, etiam inter se frequenter bella gessere.

[144] Quo factum est ut Alani, Sueui et Vandali a Gothis uicinis et consanguineis pulsi sedibus, foedere inter se iuncti, primum in Pannonias, deinde in Gallias, postremo in Hispanias immigrarent.

Ex quibus Vandali Baeticam occuparunt, ab ipsis deinde Vandaliam et Vandaliciam nominatam. Vnde a Vesogothis, qui postea inundarant, et eorum rege Vallia, Honorio Augusto iam foederato, eiecti in Africam sunt.

Alani Emeritam maioremque Lusitaniae partem, cum Olisipone, quae semel pecunia se redemerat, tenuere. Sueui, Callaeciam omnem.

Verum qui ad Emeritam consederant, a Constantio prius comite, deinde Caesare ab Honorio declarato, et restitutae Placidiae matrimonio affine facto, cum eiusdem Valliae et Vesogothorum auxiliis graui proelio superati; quum in pugna Athacem regem amisissent, pars ad petendam pacem inclinarunt, pars ad Sueuos, qui Olisiponem tenebant, confugientes, sub eorum tutela acquieuere.

Omnesque ii metu Romanorum territi, consilia pacis agitantes, haec ab Honorio postulabant, ut Orosius ait:

"Tu cum omnibus pacem habe, omniumque obsides accipe. Nos nobiscum confligimus, nobis perimus, tibi uincimus. Immortalis uero quaestus erit Reipubicae tuae, si utrique pereamus." Ita illi tunc.

Verum audita Constantii morte, repudiato petitae pacis consilio, [145] ad ingenium redierunt.

Et quidem Alani Emeritam reuersi, totam sibi Lusitaniam uindicabant, Vandalis, qui in Baetica superfuerant, adhortantibus.

Erexerant enim animos, Vallia Tolosam reuerso, quam ei Honorius permiserat, cum nonnullis aliis Auxitanae prouinciae ciuitatibus. Vnde Vesogothia regio ea est nuncupata. Hispani nostri, Galliam Gothicam dicere maluerunt. Audaciam quoque auxit insequuta Honorii mors. Sed quum minor Theodosius, Valentinianum Placidiae amitae suae, et Constantii filium Caesarem declarasset, is contra Alanos atque Sueuos in Lusitaniam comitem misit Sebastianum.

Qui sane gesta bene re Lusitania potitus erat, tyrannide tamen affectata, cum Vandalorum reliquiis, et Vesogothis iniit foedus. A quibus paulo mox circumuentus et intersectus est.

Sueui ergo relicta sociis Alanis Lusitania, ad suos, qui in Callaecia erant, quum se contulissent, atque in maius corpus coaluissent, regnum constituere.

Quod ab Hermerico ad Leouigildum Vesogothorum regem, per annos CLXXVII durauit, ut Isidorus testatur.

Praeualuere autem Vesogothi, et actis altius radicibus, quum in [146] Citeriorem Hispaniam, tum etiam in Narbonensem Galliam se extendentes, per 
e reinaram durante trezentos e oitenta anos e mais, honra e glória que perderam no reinado de Rodrigo.

Desta maneira estiveram abertas as Hispânias aos povos Cíticos que sempre se misturavam nestas emigrações com povos das nações vizinhas que porventura tivessem aborrecido o céu sombrio e o solo bastante estéril das suas pátrias ${ }^{258}$. O nome de Gótico, pelo seu carácter geral, abrangia, porém, todos.

Oxalá se tenha dito com brevidade e resumidamente aquilo que parecia ser necessário à obra por nós empreendida.

\section{AS VIAS MILITARES}

Os Romanos esforçaram-se por fazer vias militares e públicas que proporcionassem comodidade e rapidez tanto na Itália como nas províncias. Neste capítulo, Trajano, mais do que os restantes príncipes, prestou um serviço inestimável e excepcional, segundo observou o médico Galeno no livro nono de $O$ Método ${ }^{259}$. Cobriam então as vias públicas com lajes por causa da lama. Lucrécio disse no canto primeiro:

E observamos o pavimento em pedra das ruas, pelos pés

Da multidão já gasto... ${ }^{260}$.

[147] É por isso que nós, os Portugueses, lhes chamamos "estradas reais" 261. Cobriam-nas, porém, nuns sítios, com pedras irregulares e grosseiras, noutros, para lustre da cidade, com lápidas quadrangulares quase em excessiva profusão, como me recordo de ter visto na Gália Narbonense. Erguiam-se colunas dividindo a via de mil em mil passos, com a inscrição dos que a tinham mandado fazer ou reparar. Daí provém aquela forma conhecidíssima "o primeiro a partir da Vrbe", no primeiro marco depois de cada cidade e outras coisas semelhantes. Todavia, nos locais pantanosos e fundos deitavam sobre a terra o agger [entulho], para em cima estenderem a camada de pedra. Aconteceu por isso algumas vezes que a própria via pública e militar era designada por agger público, sobretudo por escritores gauleses, como é o caso de Sidónio Apolinar, que no Adeus ao Meu Livro diz:

E não desgastes a antiga calçada

Ao longo da qual, pelas colunas bem velhas,

Se enche de musgo o nome de César ${ }^{262}$.

E o mesmo em muitos outros passos.

E até Virgílio disse no canto quinto da Eneida:

Qual a serpente, tantas vezes apanhada na calçada da rua... ${ }^{263}$. 
annos tercentos et octoginta atque amplius regnauerunt, quod decus, et gloriam Roderico regnante amiserunt.

Ad hunc modum Hispaniae Scythicis nationibus patuerunt, admiscentibus se semper, in istiusmodi demigrationibus, uicinarum gentium populis quos tristis caeli glebaeque infecundioris taedium cepisset.

Vniuersos tamen propter amplitudinem Gothicum nomen amplectebatur.

Haec breuiter, et summatim dicta sint quae ad susceptum a nobis opus facere uidebantur.

\section{DE VIIS MILITARIBVS}

Vias militaes atque publicas faciles, et expeditas, quum in Italia, tum in prouinciis efficere Romani conabantur. Qua in re praecipuam et supra reliquos principes egregiam nauauit operam Traianus, ut etiam annotauit medicus Galenus Methodi libro nono. Vias igitur publicas propter lutum sternebant lapidibus. Lucretius libro primo dixit:

Strataque iam uulgi pedibus detrita uiarum, Saxea conspicimus [...]

[147] Vnde eas nos Lusitani stratas regias appellamus.

Sternebant autem ${ }^{1}$ alibi impolito rudique lapide, alibi pro urbium claritate quadratis saxis, paene insana profusione, ut memini in Narbonensi Gallia me uidisse. Millia passuum erectae columnae distinguebant, cum inscriptionibus eorum qui eas fecerant, eorumue qui refecerant.

Inde illa formula uulgatissima, "primo ab Vrbe", ad primum ab urbe lapidem, et similia.

Locis autem uliginosis ac depressis, addebant terrae aggerem, super quem lapideam crustam insternerent; eoque factum, ut aliquando ipsa publica uia ac militaris, "agger" publicus diceretur, praecipue a scriptoribus Gallis, qualis Appolinaris est Sidonius, qui in Propemptico ad libellum dixit:

Antiquus tibi nec teratur agger,

Quuius per spatium, satis uetustis

Nomen Caesareum uiret columnis.

Et saepe alias. Virgilius etiam dixit Aeneidos quinto:

Qualis saepe uiae deprehensus in aggere serpens.

1 autem $E R C^{1} F C^{2}$ ] om. $U$ 
Mas adoçou e atenuou a estranheza da palavra dizendo "na calçada da rua" e de modo algum apenas "na calçada".

[148] Subsistem ainda hoje sete destas vias na Lusitânia e na terra bracarense e uma na Vetónia, outra província da Lusitânia, mas estão em grande parte invadidas pela terra, com as pedras desgastadas e com os marcos miliários caídos.

A primeira a ser recordada por Antonino Pio no Itinerário conduzia de Lisboa a Mérida. Apresentarei as suas palavras bastante mais corrigidas do que normalmente circulam:

"Igualmente de Lisboa a Mérida, 204 mil passos, assim:264

$\begin{array}{llll}\text { A Equabona } & 12 \mathrm{~m} . \mathrm{p} . & \text { A Cetóbriga } & 12 \mathrm{~m} . \mathrm{p} . \\ \text { A Ceciliana } & 12 \mathrm{~m} . \mathrm{p} . & \text { A Malceca } & 16 \mathrm{~m} . \mathrm{p} . \\ \text { A Alcácer do Sal } & 12 \mathrm{~m} . \mathrm{p} . & \text { A Évora } & 44 \mathrm{~m} . \mathrm{p} . \\ \text { Ao rio Guadiana } & 60 \mathrm{~m} . \mathrm{p} . & \text { A Evandriana } & 17 \mathrm{~m} . \mathrm{p} . \\ \text { A Dipo } & 12 \mathrm{~m} . \mathrm{p} . & \text { A Mérida } & 9 \mathrm{~m} . \mathrm{p} .\end{array}$

Omito os nomes das cidades de que a seu tempo se tratará. Neste itinerário, na propriedade do Ilustríssimo Duque de Aveiro, à qual chamam "Pinheiro" e que fica à distância de 20 mil pasos de Tróia e a 16 mil passos de Alcácer do Sal, subsistem ruínas de uma povoação ${ }^{265}$. Encontra-se aí um cipo, nada grosseiro, em que se lê:

[149]

\begin{tabular}{|l|}
\hline L. AELIO. AVRELI \\
O. COMMODO. \\
IMP. ANTONI \\
NI. AVG. PII. P. P. \\
FILIO. COS. DE \\
SIGNATO. P. M. \\
D. D. \\
\hline
\end{tabular}

Isto é: A Lúcio Élio Aurélio Cómodo, filho do imperador Antonino Augusto Pio, pai da pátria, cônsul designado, pontífice máximo, dedicaram ${ }^{266}$.

Entre Alcácer do Sal e Évora, na colina sobranceira ao pequeno rio que tem o nome de Mourinho, está, ainda hoje, uma coluna gravada, que diz assim: 
Sed uerbi insolentiam mitigauit ac molliuit, quoniam nequaquam simpliciter in aggere, sed in aggere uiae dixit.

[148] Talium uiarum septem in Lusitania atque in Bracaris supersunt adhuc, et una in Vettonia, altera Lusitaniae prouincia. Verum magna ex parte adgestionibus stratisque uetustate corruptis, et collapsis milliariorum collumnis.

Prima quuius meminit Antonius Pius in Itinerario, ab Olisipone ducebat Emeritam. Cuius uerba apponam aliquanto emendatius, quam uulgo circumferuntur:

"Item ab Olisipone Emeritam m. p. CCIIII, sic:

$\begin{array}{llll}\text { Equabona } & \text { M. P. XII. } & \text { Cetobrica. } & \text { M. P. XII. } \\ \text { Ceciliana. } & \text { M. P. XII. } & \text { Malceca. } & \text { M. P. XVI. } \\ \text { Salacia. } & \text { M. P. XII. } & \text { Ebora. } & \text { M. P. XLIIII. } \\ \text { Ad Anam flumen. } & \text { M. P. LX. } & \text { Euandriana. } & \text { M. P. XVII. } \\ \text { Dippone. } & \text { M. P. XII. } & \text { Emerita. } & \text { M. P. IX.” }\end{array}$

Ommito oppidorum nomina, de quibus suo agetur loco. In hoc itinere in praedio quod Pinarium uocant, Illustrissimi Ducis Auiariensis, XX. Mil. P. a Cetobriga, a Salacia uero XVI. M. P. Oppidi ruinae supersunt et ibi cippus non inelegans:

[149]

\begin{tabular}{|l|}
\hline L. AELIO. AVRELI \\
O. COMMODO. \\
IMP. ANTONI \\
NI. AVG. PII. P. P. \\
FILIO. COS. DE \\
SIGNATO. P. M. \\
D. D. \\
\hline
\end{tabular}

Hoc est: Lucio Aelio Aurelio Commodo Imperatori, Antonini Augusti Pii patris patriae filio, consuli designato, pontifici maximo, dedicarunt.

Inter Salaciam, atque Eboram, in colle super flumen, cui riuo Maurino nomen est, columna adhuc extat ad hunc modum inscripta: 


\title{
[150]
}

\author{
IMP. CAES. DIVI \\ SEPTI HEII SEVERI PII \\ ARAB. ADIAB. PARTHI \\ CI. MAX. BRIT. BSI AX. F \\ DIVI M. ANTON. PII \\ GERM. SARM. NEP. \\ DIVI ANTONINI PII PRONEP. \\ DIVI HADR BSTEA ABNEP. \\ DIVI TRAIANI PARTHIC \\ ET DIVI NERV BSER AD NEP. \\ M. AVR. ANTONIN \\ P. F. AVG. PAR. MAX. \\ BRI MAX MAX. GERM. MAX. \\ PATER MILITVM. TRIB. \\ POT. XX. IMP. III. COS. IIII. \\ P. P. PROC. REST
}

[151] Isto é: O Imperador César Marco Aurélio Antonino, Pio, Feliz, Augusto, Pártico Máximo, Britânico Máximo, Germânico Máximo, Pai dos soldados, vinte vezes com poder tribunício, três vezes general, quatro vezes cônsul, Pai da Pátria, procônsul, filho do Divino Septímio Severo Pio, Arábico, Adiabénico, Pártico Máximo, Britânico Máximo, neto do Divino Marco Antonino Pio, Germânico, Sarmático, bisneto do Divino Antonino Pio, trineto do Divino Adriano, tetraneto do Divino Trajano e do Divino Nerva, reparou-a ${ }^{267}$.

Junto ao décimo segundo miliário da mesma estrada, a contar de Évora, estão duas colunas na propriedade a que chamam "Tabuleiros". Uma tem as letras completamente corroídas pelo tempo, a outra conservou-se em melhor estado com esta inscrição:

\begin{tabular}{|l|}
\hline IMP. CAES. \\
MAXI \\
MIANO \\
PIO. FELI \\
CI. AVG. EBO \\
RA. M. P. \\
XII. \\
\hline
\end{tabular}

[152] Isto é: Ao Imperador César Maximiano, Pio, Feliz, Augusto. A doze mil passos de Évora ${ }^{268}$. 
[150]

IMP. CAES. DIVI

SEPTI HSIII SEVERI PII

ARAB. ADIAB. PARTHI

CI. MAX. BRIT. 매표 AX. F

DIVI M. ANTON. PII

GERM. SARM. NEP.

DIVI ANTONINI PII PRONEP.

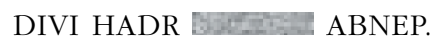

DIVI TRAIANI PARTHIC

ET DIVI NERV MSET AD NEP.

M. AVR. ANTONIN

P. F. AVG. PAR. MAX.

BRI MAX. GERM. MAX.

PATER MILITVM. TRIB.

POT. XX. IMP. III. COS. IIII.

P. P. PROC. REST

[151] Hoc est: Imperator Caesar, Diui Septimii Seueri Pii, Arabici, Adiabenici, Parthici Maximi, Britannici Maximi filius, Diui Marci Antonini Pii Germanici, Sarmatici nepos, Diui Antonini Pii pronepos, Diui Adriani abnepos, Diui Traiani Parthici et Diui Neruae abnepos, Marcus Aurelius Antonius Pius Felix, Augustus, Parthicus, Maximus Britannicus, Maximus Germanicus, Maximus pater militum, tribunicia potestate uigesimum, imperator tertium, Consul quartum, pater patriae, proconsul restituit.

Ad duodecimum ab Ebora lapidem, itineris eiusdem, in praedio quod uocant "Tabularios", duae sunt columnae, altera omnino corrosas uetustate litteras habet, altera cum hac inscriptione mansit integrior:

\begin{tabular}{|l|}
\hline IMP. CAES. \\
MAXI \\
MIANO \\
PIO. FELI \\
CI. AVG. EBO \\
RA. M. P. \\
XII. \\
\hline
\end{tabular}

[152] Hoc est: Imperatori Caesari Maximiano Pio, Felici, Augusto. Ebora millia passuum duodecim. 
No mesmo caminho existe num velho edifício uma igreja consagrada a Nossa Senhora Mãe de Deus e frequentada com grande piedade. Este lugar chama-se Toureja, e muito escrevi sobre ele no opúsculo dedicado a Quevedo Toledano ${ }^{269}$. Encontra-se aí uma mesa de mármore que Calpúrnia Sabina, mulher de Quinto Júlio Máximo, mandou colocar num sepulcro em que foram colocados também os seus dois filhos, curadores das vias. Diz assim:

\begin{tabular}{|l|c|c|}
\hline & \multicolumn{3}{c|}{ M. } \\
Q. IVL. MAXIMO. $\quad$ C. V. & Q. IVL. ClARO. C.V.IIII. VIRO. \\
QVAESTORI. PROVIN. SICI- & VIARVM CVRANDARVM \\
LIAE. TRIB. PLEB. LEG. & \multicolumn{2}{c|}{ ANNO. XXI. } \\
PROV. NARBONENS. GALLIAE & Q. IVL. NEPOTIANO. C. I. \\
PRAET. DESIG. ANNOXLVIII. & IIII VIRO VIARVM CVRAN- \\
CALPVRNIA. SABI- & DARVM. ANNO. XX. \\
NA. MARITO OPTIMO. & CALP. SABINA. FILIIS. \\
\hline
\end{tabular}

[153] Isto é: Consagrado aos deuses Manes. A Quinto Júlio Máximo, homem ilustríssimo, questor da província da Sicília, tribuno de plebe, legado da província Narbonense da Gália, pretor designado, de quarenta e oito anos. Dedica Calpúrnia Sabina ao seu óptimo marido.

A Quinto Júlio Claro, bomem ilustríssimo, quatuórviro encarregado das estradas, de vinte e um anos. A Quinto Júlio Nepociano, jovem ilustríssimo, quatuórviro encarregado das estradas, de vinte anos. Dedica Calpúrnia Sabina aos seus filhos ${ }^{270}$.

Há duas colunas na região de Estremoz, não longe da aldeia de Barbacena. Uma, caída, tem as letras completamente apagadas excepto na primeira e na segunda linhas, e diz:

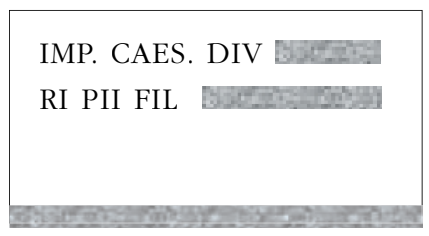

Ito é: Ao Imperador César... filho do Divino Severo Pio... ${ }^{271}$. 
Eodem itinere in ueteri aedificio templum est Virgini Dei Matri sacrum, et magna religione cultum. Turegiam locum eum uocant. De quo multa in libello ad Kebedium Toletanum scripsi.

Ibi mensa marmorea est, quam sepulchro Q. Iulii Maximi Calpurnia Sabina uxor imponendam curauit. In quo sepulchro duo etiam filii eius uiarum curatores fuere conditi. Ea sic habet:

\begin{tabular}{|l|l|l|}
\hline & \multicolumn{3}{c|}{ M. } \\
Q. IVL. MAXIMO. $\quad$ C. V. & Q. IVL. ClARO. C.V.IIII. VIRO. \\
QVAESTORI. PROVIN. SICI- & VIARVM CVRANDARVM \\
LIAE. TRIB. PLEB. LEG. & \multicolumn{1}{c}{ ANNO. XXI. } \\
PROV. NARBONENS. GALLIAE & Q. IVL. NEPOTIANO. C. I. \\
PRAET. DESIG. ANNOXLVIII. & IIII VIRO VIARVM CVRAN- \\
CALPVRNIA. SABI- & DARVM. ANNO. XX. \\
NA. MARITO OPTIMO. & CALP. SABINA. FILIIS. \\
\hline
\end{tabular}

[153] Hoc est: Diis Manibus sacrum. Quinto Iulio Maximo, clarissimo uiro, quaestori prouinciae Siciliae, tribuno plebis, legato prouinciae Narbonensis Galliae, praetori designato, annorum quadraginta octo. Calpurnia Sabina marito optimo.

Quinto Iulio Claro, clarissimo uiro, quartum uiro uiarum curandarum, annorum uiginti unius. Quinto Iulio Nepotiano, clarissimo iuneni, quartum uiro uiarum curandarum, annorum uiginti. Calpurnia Sabina filiis.

In agro Stermotiensi, non procul a pago Borbacena columnae duae sunt, altera collapsa, erasis omnino litteris praeter primum et secundum uersum:

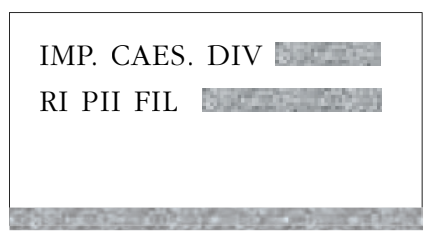

Hoc est: Imperatori Caesari Diui Seueri Pii filio. 
[154] A segunda conserva-se com esta inscrição, que já se lê, porém, a custo e que diz:

IMP. CAES. DIVI ANTONI
NI PII MAGNI FIL.
DIVI SEPTIMI SEVERI
PII NEPOTI M. AVRE
LIO ANTONINO
P. FEL. AVG. PONT. MAX.
TRIB. POT. II. COS. II.
PROC. P. P.
FORTISSIMO FELICISSI
MOQVE PRINCIPI
ORA M. P.
XXII.

[155] Isto é: Ao Imperador César Marco Aurélio Antonino Pio, Feliz, Augusto, Pontífice Máximo, duas vezes com o poder tribunício, duas vezes cônsul, procônsul, pai da pátria, príncipe valentíssimo e felicíssimo, filho do Divino Antonino Magno, neto do Divino Septímio Severo Pio. A vinte e dois mil passos de Évora ${ }^{272}$.

Em Elvas, na casa de certo fidalgo, estão por terra duas colunas para ali levadas da estrada, mas com as letras tão deterioradas que dificilmente em cada linha são visíveis duas ou três. Além disto nada mais vi desta estrada.

São evidentes ainda os vestígios de uma estrada calcetada de Évora a Beja. Há colunas por vários sítios, umas, mesmo agora, de pé, outras tombadas, partidas e cobertas de terra. De resto, subsistem duas pontes arruinadas sobre os rios Xarrama, Murtária e Odivelas, aqui escoras, além pilares e bases de pilares. As letras desapareceram das colunas e apenas numa dificilmente consegui ler estas, apesar de as ter examinado durante bastante tempo, e dizem: 
[154] Altera stat cum inscriptione hac, quae tamen aegre iam legitur:

IMP. CAES. DIVI ANTONI
NI PII MAGNI FIL.
DIVI SEPTIMI SEVERI
PII NEPOTI M. AVRE
LIO ANTONINO
P. FEL. AVG. PONT. MAX.
TRIB. POT. II. COS. II.
PROC. P. P.
FORTISSIMO FELICISSI
MOQVE PRINCIPI
PanA M. P.
XXII.

[155] Hoc est: Imperatori Caesari, Diui Antonini Pii Magni filio, Diui Septimii Seueri Pii nepoti, Marco Aurelio Antonino Pio, Felici, Augusto, Pontifici Maximo, tribunitia potestate secundum, consuli secundum, proconsuli, Patri patriae, fortissimo felicissimoque principi. Ebora millia passuum uiginti duo.

Heluis in aedibus cuiusdam uiri nobilis columnae duae scriptae iacent, ex itinere eo delatae, sed litteris tam corruptis, ut uix in quoque uersu duae, aut tres appareant. Ex ea uia nihil amplius uidi.

Ab urbe autem Ebora Pacem usque Iuliam etiam apparent stratae uiae uestigia. Columnae extant multis in locis, partim adhuc erectae, partim collapsae, fractae et terra opertae.

Item super Exarramam, Murtariam et Odiuellam fluuios pontium dirutorum hic sublicia, illic pilae, pilarumque bases. Litterae in columnis intercidere. In una tantum has quum diutius considerassem, aegre potui legere: 


\section{[156]}

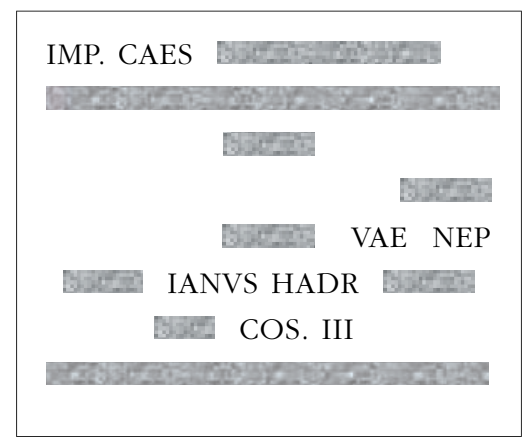

Isto é: Ao Imperador César... neto de Nerva, Trajano, Adriano, três vezes cônsul... ${ }^{273 .}$

O Itinerário de Antonino apresenta muito alterado o caminho que vai de Castro Marim a Beja e, embora eu tenha tentado compreendê-lo de cinco ou seis maneiras, quase nada consegui no meio de tanta deturpação. [157] Eis porque o deixei tal como está e talvez que esse livrinho apareça um dia escrito com menos erros ou que resolvam a dificuldade engenhos mais felizes:

"Igualmente de Castro Marim a Beja 257 mil passos, assim²74:

$\begin{array}{ll}\text { A Tavira } & 24 \mathrm{~m} . \mathrm{p} . \\ \text { A Estói } & 16 \mathrm{~m} . \mathrm{p} . \\ \text { A Arani } & 60 \mathrm{~m} . \mathrm{p} . \\ \text { A Rarapia } & 35 \mathrm{~m} . \mathrm{p} . \\ \text { A Évora } & 44 \mathrm{~m} . \mathrm{p} . \\ \text { A Serpa } & 13 \mathrm{~m} . \mathrm{p} . \\ \text { A Fines } & 20 \mathrm{~m} . \mathrm{p} . \\ \text { A Aroce } & 25 \mathrm{~m} . \mathrm{p} . \\ \text { A Beja } & 30 \mathrm{~m} . \mathrm{p} .\end{array}$

E deve seguir-se logo outro caminho, que está bem assinalado, de Castro Marim a Beja por atalho. É assim:

"Igualmente de Castro por atalho, de Beja 66 mil passos, assim²75:
De Mértola
40 m. p.
De Beja
36 m. p."

Também viciada por grande deturpação está uma distância no caminho que descreve Antonino de Alcácer do Sal a Estói. De facto tem: "De Alcácer do Sal, [158] de Estói 16 m. p." 276 . São, no entanto, para cima de 116 mil passos. 
[156]

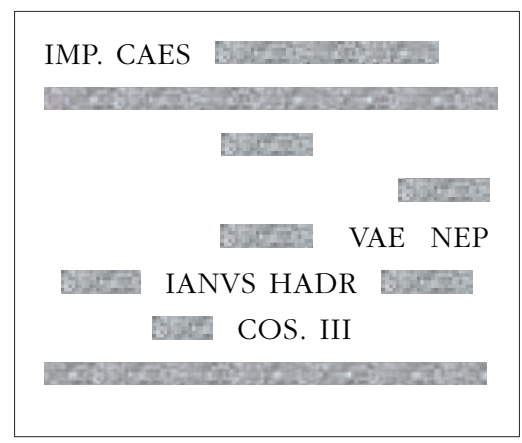

Hoc est: Imperatori Cesari Neruae Nepoti Traianus Hadrianus consul tertium.

Iter quod ab Esuri Pacem Iuliam corruptissimum Antonini Itinerarium ponit, ego quinque, aut sex modis intelligere quum tentassem, nihil fere in tanta deprauatione confeci.

[157] Quare ita ut apud illum habetur reliqui, si forte aliquando prodeat is libellus minus mendose scriptus, aut feliciora nodum explicent ingenia.

"Item de Esvri Pace Ivlia, m. p. CCLVII. sic:

$\begin{array}{ll}\text { Balsa } & \text { M. P. XXIIII. } \\ \text { Ossonoba } & \text { M. P. XVI. } \\ \text { Arani } & \text { M. P. LX. } \\ \text { Rarapia } & \text { M. P. XXXV. } \\ \text { Ebora } & \text { M. P. XLIIII. } \\ \text { Serpa } & \text { M. P. XIII. } \\ \text { Fines } & \text { M. P. XX. } \\ \text { Arucci } & \text { M. P. XXV. } \\ \text { Pace Iulia } & \text { M. P. XXX." }\end{array}$

Et statim sequi debet alterum iter per compendium ab Esuri Pacem Iuliam, quod bene signatum est. Ita enim habet:

"Item ab Esuri per compendium, Pace Iulia. M. P. LXVI. Sic:
Myrtili
M. P. XL.
Pace Iulia
M. P. XXXVI."

Magna quoque deprauatione uitiatus numerus est in itinere, quod a Salacia Ossonobam describit. Habet enim: "A Salacia [158] Ossonoba M. P. XVI." Quum sint supra CXVI. 
No mesmo percurso, numa colina à esquerda, junto à semidestruída povoação da Oriola, está o marco que outrora separava o termo de Évora do de Beja. Sobre este marco falámos bastante no opúsculo dedicado a Quevedo Toledano ${ }^{277}$. Diz, porém, o seguinte:

\begin{tabular}{|l|}
\hline D. D. N. N. \\
AETERN. IMPP. \\
C. AVRE. VALER- \\
IO. IOVIO. DIOCLE \\
TIANO. ET \\
M. AVR. VALERI \\
O. ERCVLEO \\
MAXIMIANO \\
PIIS. FEL. SEMPER AVGG. \\
TERMINVS INTER \\
PACENS. ET EBORENS. \\
CVRANTE. P. DATIANO \\
V. P. PRAESIDE. HH. \\
N. M. Q. EORVM \\
DEVOTISSIMO \\
HEINC PACENSES.
\end{tabular}

[159] Isto é: Pela eternidade dos nossos Senhores. Sendo Imperadores Gaio Aurélio Valério Jóvio Diocleciano e Marco Aurélio Valério Hercúleo Maximiano, Pios, felizes, sempre Augustos, estabeleceu-se o termo entre Pacenses e Eborenses por diligência de Públio Daciano, homem patrício, governador das Hispânias, muito zeloso da divindade e majestade deles. Deste lado os Pacenses, deste os Eborenses. ${ }^{278}$.

Antonino apresenta depois um caminho duplo de Lisboa a Mérida, mas um e outro não só com os números muito deturpados, como com cidades que ou já não existem ou estão muito arbitrariamente trocadas. Um deles, é assim:

"Por outro caminho de Lisboa a Mérida 145 mil passos. Assim²79:

$\begin{array}{lr}\text { Benavente } & 38 \mathrm{~m} . \mathrm{p} . \\ \text { Alter do Chão } & 28 \mathrm{~m} . \mathrm{p} . \\ \text { Ponte de Sor } & 27 \mathrm{~m} . \mathrm{p} . \\ \text { Açumar ou Alegrete } & 8 \mathrm{~m} . \mathrm{p} . \\ \text { Nossa Senhora de Betove } & 12 \mathrm{~m} . \mathrm{p} . \\ \text { Plagiária } & 8 \mathrm{~m} . \mathrm{p} . \\ \text { Mérida } & 30 \mathrm{~m} . \mathrm{p} .\end{array}$


Eodem itinere in colle sinistrorsum, iuxta semidirutum oppidum Aureolam, meta est quae olim terminum Eborensem a Pacensi dirimebat. De qua meta in meo ad Kebedium Toletanum libello, satis multa. Ea autem est huiusmodi:

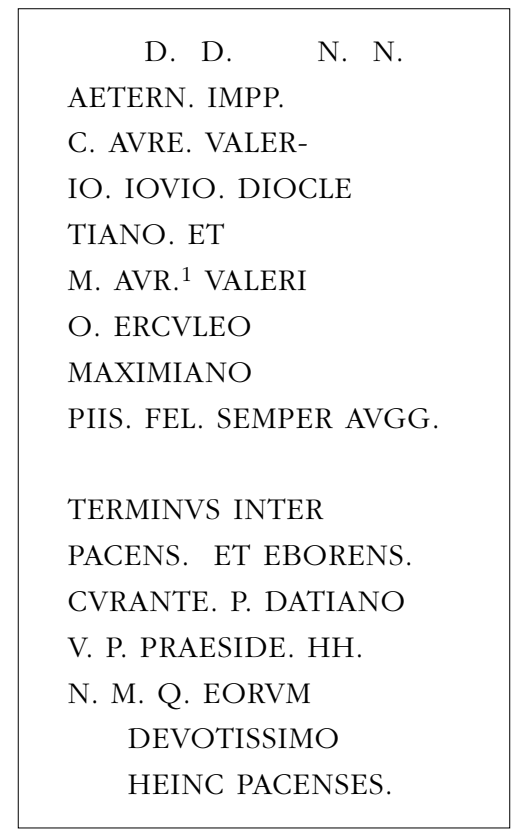

[159] Hoc est: Dominorum nostrorum aeternitati, imperatoribus Caio Aurelio Valerio Iouio Diocletiano, et Marco Aurelio Valerio Erculeo Maximiano, Piis, Felicibus, semper Augustis, terminus inter Pacenses et Eborenses curante Publio Datiano uiro patricio praeside Hispaniarum, numini maiestatique eorum deuotissimo. Hinc Pacenses, hinc Eborenses.

Duplex inde iter Antoninus ponit ab Olisipone Emeritam, sed utrumque numeris corruptissimis, oppidisque aut iam non extantibus aut diuersissime commutatis. Alterum sic:

"Alio Itinere ab Olisipone Emeritam m. p. CXLV. sic:

Aritio Praetorio.

Abelteri.

Matusaro.

Ad septem Aras.

Budua.

Plagiaria.

Emerita.
M. P. XXXVIII.

M. P. XXVII.

M. P. XXVII.

M. P. VIII

M. P. XII.

M. P. VIII.

M. P. XXX."

1 M. AVR. $R C^{1} F C^{2} U$ ] MAVR. $E$ 
É evidente que as distâncias estão enganadas, pois indo a direito por ali, de [160] Lisboa a Mérida, contamos cinquenta e três léguas e estas perfazem 220 mil passos, assim: de Lisboa a Benavente, atravessando o Tejo junto a Vila Franca, 8 léguas; dali a Salvaterra, que uns pensam será Arício, outros Pretório, 1 légua; depois Culucos, que outros admitem que seja Tubucos (Abrantes), e daí todo o caminho suburipontano 280 .

O outro, por Santarém, é assim:

"Igualmente por outro caminho de Lisboa a Mérida, 220 mil passos. Assim"281:

$\begin{array}{ll}\text { Povos } & 30 \mathrm{~m} . \mathrm{p} . \\ \text { Santarém } & 32 \mathrm{~m} . \mathrm{p} . \\ \text { Abrantes } & 32 \mathrm{~m} . \mathrm{p} . \\ \text { Alpalhão } & 32 \mathrm{~m} . \mathrm{p} . \\ \text { Aramenha } & 30 \mathrm{~m} . \mathrm{p} . \\ \text { Açumar ou Alegrete } & 13 \mathrm{~m} . \mathrm{p} . \\ \text { Plagiária } & 20 \mathrm{~m} . \mathrm{p} . \\ \text { Mérida } & 30 \mathrm{~m} . \mathrm{p.}\end{array}$

[161] As colunas desta estrada, umas quebradas pela acção do tempo, outras calcinadas por inúmeros fogos, apenas deixam ver vestígios de letras desgastadas. Aconteceu que as vi e é assim que as têm.

Por outro lado, o caminho, a partir de Santarém, sobranceiro ao ópido de Almeirim, era conduzido através das nascentes do rio Alpiarça. Em qualquer lado se vêem grosseiros fragmentos de colunas, das quais nada havia a transcrever. Depois, apesar de ter encontrado no caminho quatro colunas caídas, apenas pude ler numa delas o seguinte:

[162]

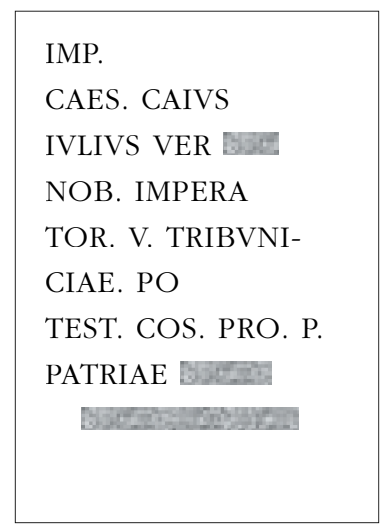

Isto é: O Imperador César Gaio Júlio Vero, nobre general vencedor cinco vezes, com o poder tribunício, cônsul, procônsul, pai da pátria... ${ }^{282}$. 
Corruptos esse numeros hinc apparet. Nam recto isthac itinere ab [160] Olisipone Emeritam, numeramus tres et quinquaginta leucas, eae conficiunt ducenta duodecim millia passuum. Sic:

Ab Olisipone Beneuentum, traiecto ad Villam Francam Tago, leucae octo. Inde Saluaterram, quae an Aritium Praetorium sit, alii expendant, leuca una. Inde Culucci, ad, quod an Tubucci sit, alii quoque expendant, et inde tota uia suburipontana.

Alterum per Scallabin, sic:

"Item Alio Itinere ab Olisipone Emeritam. m. p. CCXX. sic:

$\begin{array}{ll}\text { Hierabriga } & \text { M. P. XXX. } \\ \text { Scallabis } & \text { M. P. XXXII. } \\ \text { Tubucci } & \text { M. P. XXXII. } \\ \text { Fraxinum } & \text { M. P. XXXII. } \\ \text { Medobriga } & \text { M. P. XXX. } \\ \text { Ad septem Aras } & \text { M. P. XIII. } \\ \text { Plagiaria } & \text { M. P. XX. } \\ \text { Emerita } & \text { M. P. XXX." }\end{array}$

[161] Huius uiae columnae partim uetustatis iniuria diffractae, partim crebris ignibus adustae tantum abrasarum litterarum uestigia demonstrant. Quas mihi uidere contigit, ita habent.

Iter autem a Scallabi supra Almerinum oppidum, per Alpiarsae fluuii initia ducebatur.

Alicubi fragmenta rudia columnarum apparent, ex quibus nihil erat quod scriberem. Postea quum quattuor collapsas inuenissem, in una earum haec tantum potui legere:

$$
\text { IMP. }
$$

CAES. CAIVS

IVLIVS VER

NOB. IMPERA

TOR. V. TRIBVNI-

CIAE. PO

TEST. COS. PRO. P. PATRIAE

Hoc est: Imperator Caesar Caius Iulius Verus, nobilis imperator, quintum tribuniciae potestatis, consul, proconsul, pater patriae. 
[163] Mil passos depois estão tombadas três colunas:

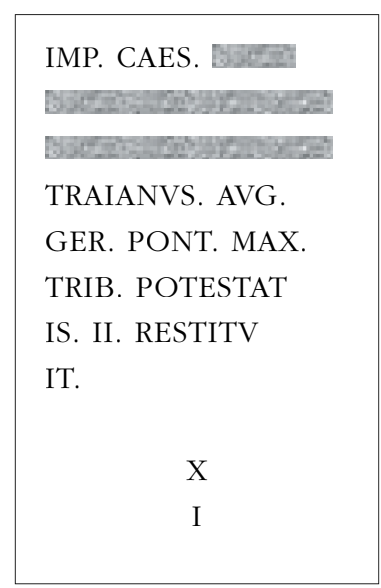

[164] Isto é: O Imperador César.. Divino Trajano Augusto, Germânico, pontífice máximo, duas vezes com o poder tribunício, restaurou onze 283.

A segunda estava partida e apenas tinha no fim estas letras:

RESTITV

TOR VRBIS.

[Restaurador da cidade de Roma ${ }^{284}$.]

[165] [Na terceira]:

\begin{tabular}{|l|}
\hline \multicolumn{1}{|c|}{ IMP. } \\
CAESARI \\
CLAVDI \\
O. TACITO \\
PIO. F. IN. \\
VICTO. \\
AVG. \\
PONT. M. \\
TRIB. PO \\
TESTA \\
TIS. II \\
COS. PRO. \\
\hline
\end{tabular}


[163] Post mille passus collumnae tres collapsae:

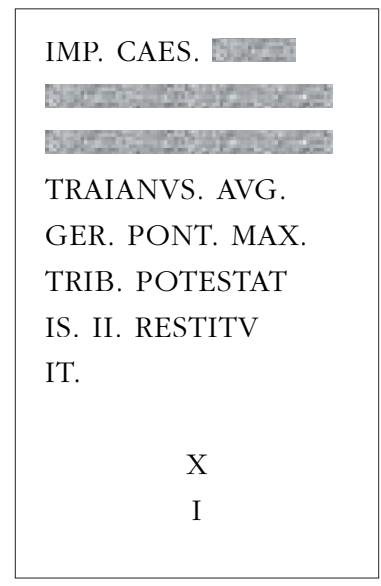

[164] Hoc est: Imperator Caesar Diuus Traianus Augustus, Germanicus, pontifex maximus, tribuniciae potestatis secundum, restituit undecim.

Secunda fracta erat, et has tantum litteras habebat in fine:

RESTITV

TOR VRBIS.

[165]

\begin{tabular}{l}
\multicolumn{1}{c}{ IMP. } \\
CAESARI \\
CLAVDI \\
O. TACITO \\
PIO. F. IN. \\
VICTO. \\
AVG. \\
PONT. M. \\
TRIB. PO \\
TESTA \\
TIS. II \\
COS. PRO.
\end{tabular}


Isto é: Ao Imperador César Cláudio Tácito, Pio, feliz, invicto, Augusto, pontífice máximo, no segundo poder tribunício, cônsul, procônsul... ${ }^{285}$

[166] Mil passos depois e estavam três colunas, duas caídas, com letras desgastadas pelo tempo, e uma de pé que tem o seguinte:

\begin{tabular}{|c|}
\hline IMP. \\
CAESARI \\
M. \\
CLAVDIO \\
TACITO \\
PIO. F. IN \\
VICTO \\
AVG. PONTIF. \\
M. TRIB. \\
POTESTA \\
TIS. II. COS. \\
P. P. \\
\end{tabular}

[167] Isto é: Ao Imperador César Marco Cláudio Tácito, pio, invencivel, Augusto, pontífice máximo, no segundo poder tribunício, cônsul, pai da pátria ${ }^{286}$.

Mil passos a seguir estão duas colunas tombadas e no fim de uma delas apenas podem ser lidas estas palavras:

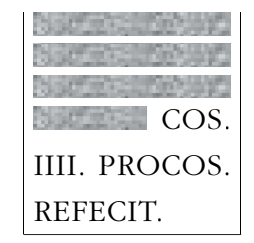

[Cônsul pela quarta vez, procônsul, refez ${ }^{287}$ ]

[168] Mil passos adiante, junto à encruzilhada a que chamam Mestas, estão quarto colunas caídas. Três têm inscrições inutilizadas, mas numa lê-se: 
Hoc est: Imperatori Caesari Claudio Tacito, Pio, felici, inuicto, Augusto, pontifici maximo, tribuniciae potestatis secundum, consuli, proconsuli.

[166] Post mille passus, tres columnae: duae collapsae abrasis uetustate litteris, una erecta, quae sic habet:

\begin{tabular}{|c|}
\hline IMP. \\
CAESARI \\
M. \\
CLAVDIO \\
TACITO \\
PIO. F. IN \\
VICTO \\
AVG. PONTIF. \\
M. TRIB. \\
POTESTA \\
TIS. II. COS. \\
P. P. \\
\end{tabular}

[167] Hoc est: Imperatori Caesari Marco Claudio Tacito pio, felici, inuicto, Augusto, pontifici maximo, tribuniciae potestatis secundum, consuli, patri patriae.

Post mille passus duae collapsae, in fine unius hae tantum legi possunt litterae:

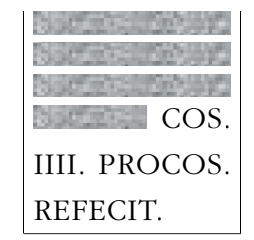

[168] Post mille passus, iuxta diuersorium quod uocant Mestas, quattuor sunt columnae collapsae: tres corruptas habent inscriptiones; in una sic legitur: 


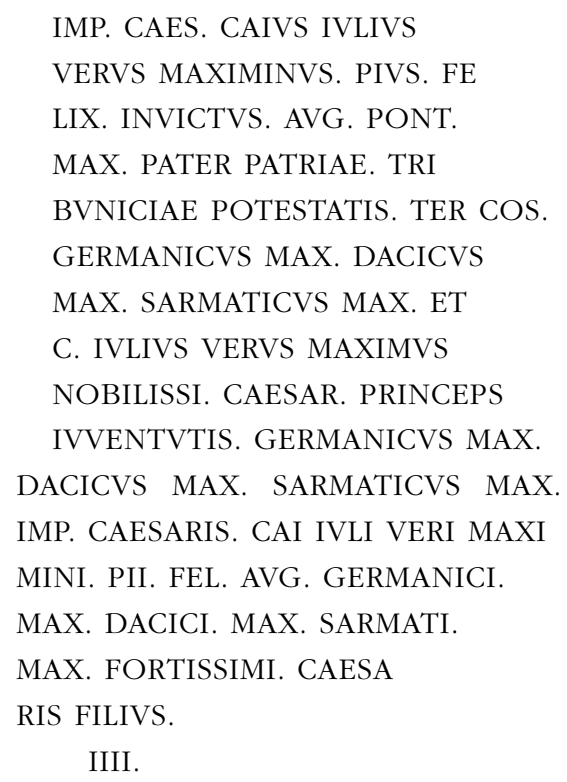

[169] Isto é: O Imperador César Gaio Júlio Vero Maximiano, Pio, Feliz, invencível, Augusto, pontífice máximo, pai da pátria, três vezes com o poder tribunício, cônsul, Germânico Máximo, Dácico Máximo, Sarmático Máximo, e Gaio Júlio Vero Máximo, nobilíssimo César, príncipe da juventude, Germânico Máximo, Dácico Máximo, Sarmático Máximo, quarto filho do Imperador César Gaio Júlio Vero Maximino, Pio, Feliz, Augusto, Germânico Máximo, Dácico Máximo, Sarmático Máximo, valentíssimo. ${ }^{288}$ 
IMP. CAES. CAIVS IVLIVS

VERVS MAXIMINVS. PIVS. FE

LIX. INVICTVS. AVG. PONT.

MAX. PATER PATRIAE. TRI

BVNICIAE POTESTATIS. TER COS.

GERMANICVS MAX. DACICVS

MAX. SARMATICVS MAX. ET

C. IVLIVS VERVS MAXIMVS

NOBILISSI. CAESAR. PRINCEPS

IVVENTVTIS. GERMANICVS MAX.

DACICVS MAX. SARMATICVS MAX.

IMP. CAESARIS. CAI IVLI VERI MAXI

MINI. PII. FEL. AVG. GERMANICI.

MAX. DACICI. MAX. SARMATI.

MAX. FORTISSIMI. CAESA

RIS FILIVS.

IIII.

[169] Hoc est: Imperator Caesar Caius Iulius Verus Maximinus pius, felix 1 , inuictus, Augustus, pontifex maximus, pater patriae, tribunitiae potestatis ter, consul, Germanicus Maximus, Dacicus Maximus, Sarmaticus Maximus, et Caius Iulius Verus Maximus nobilissimus Caesar, princeps iuuentutis, Germanicus Maximus, Dacicus Maximus, Sarmaticus Maximus, imperatoris Caesaris Cai Iuli Veri Maximini, Pii, Felicis, Augusti, Germanici Maximi, Dacici Maximi, Sarmatici Maximi, fortissimi Caesaris filius quattuor. 
(Página deixada propositadamente em branco) 
LIVRO QUARTO

LIBER QVARTVS 
[170] Passarei agora às cidades que constituem parte não desprezível do meu plano. Grande número delas perdeu os nomes antigos ainda ao tempo dos Romanos. Lívio nomeia muitas, tal como as recebeu dos escritores antigos, as quais actualmente ou é impossível ou é difícil reconhecer, porque os Romanos posteriormente lhes deram outros nomes.

Comecemos por aquela parte da Bética, que é agora um apêndice da Lusitânia e onde, conforme lembrámos no livro I, estão Olivença, Mourão, Moura, Mortigão e Noudar ${ }^{1}$.

Da cidade de Olivença, entretanto, nada tenho até agora que interesse à sua antiguidade a não ser a inscrição que me enviaram de um cipo ali encontrado e onde está escrito:

[171]
D. M. S.
C. ANTESTIVS CALVVS
C. ANTESTIVS PROCV
LVS. H. S. S. CORNELIA
TERTVLLA. VIRO ET FILIO
DE. S. P. F. C.

Isto é: Consagrado aos deuses Manes. Aqui jazem Gaio Antéscio Calvo e Gaio Antéscio Próculo. Cornélia Tertula mandou fazer à sua custa para o marido e filho ${ }^{2}$.

Nada tenho também de Mourão.

\section{MOURA}

Estou convencido de que o insigne ópido de Moura foi Nova Aroche pelo seguinte cipo que aí li. Diz ele:

[172]

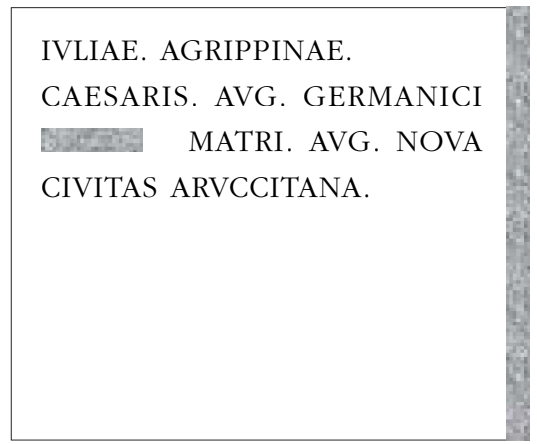

Isto é: A Júlia Agripina, mãe augusta de César Germânico dedica a nova cidade Arucitana ${ }^{3}$. 
[170] Vrbes nunc aggrediar, non minimam intentionis meae partem. Quarum pleraeque, etiam Romanis temporibus, prisca nomina amiserunt. Multas nominat Liuius a uetustioribus acceptas, aut nullo nunc modo, aut aegre intellectas, quoniam iis alia Romani postea uocabula imposuerunt.

Incipiamus ab illa parte Baeticae quae modo appendix est Lusitaniae, in qua Oliuentiam, Mauranum, Mauram, Serpam, Mortiganum, ac Noudarem esse primo libro commemorauimus.

Ac de Oliuentia urbe nihil, quod ad antiquitatem faciat, adhuc habeo, nisi cippi ibi inuenti inscriptionem ad me illinc missam:

[171]
D. M. S.
C. ANTESTIVS CALVVS
C. ANTESTIVS PROCV
LVS. H. S. S. CORNELIA
TERTVLLA. VIRO ET FILIO
DE. S. P. F. C

Hoc est: Diis Manibus sacrum. Caius Antestius Caluus, Caius Antestius Proculus hic siti sunt. Cornelia Tertulla uiro et filio de sua pecunia fieri curauit.

De Maurano aeque nihil.

\section{DE MAVRA}

Mauram insigne oppidum, nouum fuisse Arucci, ex cippo istius modi, quem ibi legi, persuasum habeo:

[172]

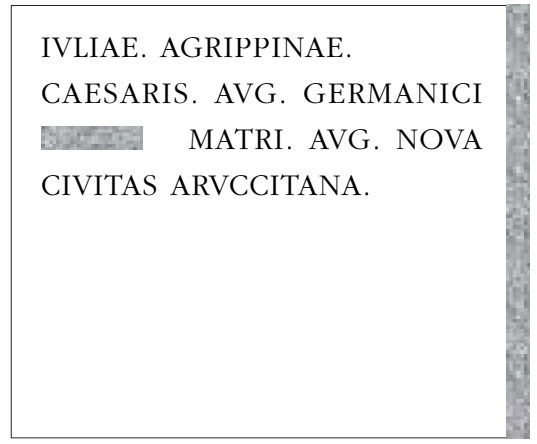

Hoc est.: Iuliae Agrippinae, Caesaris Augusti Germanici Matri Augustae, noua Ciuitas Aruccitana. 
[173] Ora, eu penso que se dizia nova Arouche porque subsiste até agora, e conserva o nome, a antiga Aroche. Em realidade, diz-se vulgarmente Arouche, que é como é chamada por Ptolomeu ${ }^{4}$, e deixa-se ver claramente que é em língua grega. A velha Aroche já é contudo pouco populosa.

Os naturais de Moura ajustam ao novo nome aquilo a que não sei se chame fábula. Existiu certo pequeno rei mouro, senhor daquela zona, que foi morto quando, por uma questão de fronteiras, combatia contra outro mais poderoso. Embora o vencedor já tivesse procurado frequentemente seduzir a mulher daquele, que era de extrema beleza, e até recorresse a ameaças, caso não quisesse ceder, com ódio tenaz deixou ela sempre sem resposta os pedidos do assassino. Não tendo confiança na antiga Aroche por causa da proximidade do inimigo, partiu para a nova cidade Arucitana não só mais segura pela localização como mais apropriada pela boa qualidade de um solo mais fecundo. Como os naturais de Aroche lhe chamavam vulgarmente moura, aconteceu que mesmo a própria cidade foi a partir desse facto denominada Moura 5 .

Também na área da mesma cidade subsistem muitos vestígios da antiguidade. Entre Moura e Ficalho, povoação meio destruída junto à aldeia a que chamam Vale de Vargo, encontrei entre as ruínas de um antigo templozinho - onde os vindouros, com melhor religião, elevaram uma capela dedicada a S. Miguel - quatro cipos quebrados e já deformados, com as letras carcomidas pelo tempo. Um deles, que é o único completo, foi fielmente transcrito por mim e diz o seguinte:

[174]

DIS. MAN

IBVS. AVRIILIAII

M. F. GALLAII. A

NNO. XII.

H. S. E. S. T. T. L.

Isto é: Aos deuses Manes. Aurélia Gala, filha de Marco, de 12 anos, aqui jaz. Que a terra te seja leve ${ }^{6}$.

E para evitar que alguém acaso se admire com a forma desacostumada de escrita de AVRIILIAII GALLAII, em vez de AVRELIAE GALLAE, saiba que também nas Inscrições da velha Roma se lê na página 149, em vez do que seria correcto, o que se segue:

[175] 
[173] Nouum autem Arucci dici puto, quoniam adhuc superest Arucci uetus, nomenque retinet. Vulgo enim "Arouche" dicitur, proferturque plane Graece, ut a Ptolemaeo uocatur.

Parum tamen iam frequens est Arucci uetus.

Accommodant Maurenses nouo nomini, haud scio an fabulam appellem.

Fuisse Maurum regulum quendam tractus illius dominum, qui cum de finibus cum altero potentiore bellum gereret, atque in proelio cecidisset, eiusque uxorem forma luculenta mulierem saepe uictor interpellasset, additis nisi acquiesceret minis, illam contumaci odio interfectoris postulata respuisse.

Quumque Arucci ueteri, propter hostis uicinitatem, dissideret, migrasse ad nouam ciuitatem Aruccitanam, ut tutiorem situ, ita bonitate uberioris agri magis accommodam.

Quumque ab indigenis Maura ex Arucci uulgo appellaretur, factum esse, ut etiam urbs Maura exinde nominata sit.

In territorio quoque oppidi eiusdem multa antiquitatis supersunt uestigia. Inter Mauram atque Ficalium semidirutum oppidum, ad pagum quem uocant Vallemuargi, in fani antiqui ruinis, ubi sacellum Michaeli sacrum posteri meliori religione extruxerunt, quattuor cippos fractos exesisque uetustate literis deformatos inueni. Vnus qui relinquus integer est, fideliter a me descriptus ita habet:

$[\mathbf{1 7 4}]$

DIS. MAN

IBVS. AVRIILIAII

M. F. GALLAII. A

NNO. XII.

H. S. E. S. T. T. L.

Hoc est: Diis Manibus, Aureliae Marci filiae Gallae annorum duodecim, bic sita est, sit tibi terra leuis.

Et nequis forte miretur inusitatam scripturae rationem, AVRIILIAII GALLAII pro AVRELIAE GALLAE, sciat in Epigramatis quoque Antiquae Vrbis, pagina 149, legi:

[175] 
"Marco Pôncio Hedisto mandou fazer para a sua mulher Dene, que bem o mereceu. Viveu comigo três anos" 7 .

E o corrector anotou que encontrara ainda noutro lado postos dois II em vez de E. Também é de Ficalho o seguinte cipo, onde está escrito:

\author{
D. M. S. \\ VLPIA. M. F. \\ MARCELLA \\ ANNORVM \\ LIII. \\ H. S. E. S. T. T. L.
}

Isto é: Consagrado aos deuses Manes. Aqui jaz Úlpia Marcela, filha de Marco, de 53 anos. Que a terra te seja leve ${ }^{8}$.

[176] Junto à Aldeia de Galego, entre Ficalho e a antiga Aroche, há um cipo na capela de S. Mamede onde está escrito:

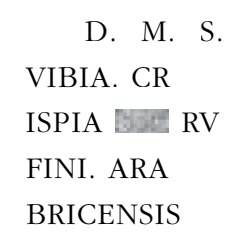

ANNOR.

LXVII.

H. S. E. S. T. T. L.

Isto é: Consagrado aos deuses Manes. Aqui jaz Víbia Críspia [filha] de Rufino Arabricence, de 67 anos. Que a terra te seja leve 9.

A também célebre cidade de Serpa não me suscitou muito embaraço. Conserva, com efeito, desde a época antiga o nome intacto tal como está no itinerário de Antonino e no cipo encontrado perto da cidadela. Diz-se aí:

[177]

D. M. S.

FABIA PRISCA

SERPENSIS. C. R.

ANN. XX. H. S. E. S. T. T. L.

C. GEMINIVS. PRIS

CVS PATER. ET

FABIA CADILLA MA

TER. POSVERVNT. 
pro eo quod esse deberet.

"M. Pontius Hedistus Daeni coniugi bene merenti fecit. Vixit mecum annis tribus".

Et annotauit corrector, alibi etiam duo II pro E posita se inuenisse.

Ficalii quoque cippus hic est:

\author{
D. M. S. \\ VLPIA. M. F. \\ MARCELLA \\ ANNORVM \\ LIII.
}

H. S. E. S. T. T. L.

Hoc est: Diis Manibus sacrum. Vlpia Marci filia Marcella annorum quinquaginta trium, bic sita est, sit tibi terra leuis.

[176] Ad Pagum Callaecum inter Ficalium et Arucci uetus in fano S. Mametis, cippus:

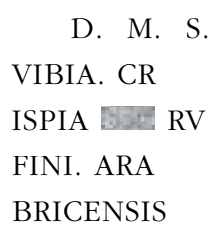

ANNOR.

LXVII.

H. S. E. S. T. T. L.

Hoc est: Diis Manibus sacrum. Vibia Crispia Rufini Arabricensis annorum sexaginta septem, bic sita est, sit tibi terra leuis.

Insigne quoque oppidum Serpa non multum mihi negotii exhibuit, nomen enim illaesum usque ex antiquo retinet, ut apud Antoninum in Itinerario est, et in cippo iuxta oppidum reperto:

[177]

D. M. S.

FABIA PRISCA

SERPENSIS. C. R.

ANN. XX. H. S. E. S. T. T. L.

C. GEMINIVS. PRIS

CVS PATER. ET

FABIA CADILLA MA

TER. POSVERVNT. 
Isto é: Consagrado aos deuses Manes. Aqui jaz Fábia Prisca de Serpa, cidadã romana, de 20 anos. Que a terra te seja leve. Seu pai, Gaio Gemínio Prisco, e sua mãe, Fábia Gadila, mandaram erigir ${ }^{10}$.

\section{O ALGARVE DA LUSITÂNIA}

Atravessemos agora o Guadiana e exponhamos aos estudiosos da antiguidade as cidades da Lusitânia sobre as quais se julgará sem margem de dúvida ou pelo menos por conjectura provável.

"Por outro lado - diz Pompónio - a Lusitânia, que dá para o mar Atlântico, prolonga-se primeiro com grande ímpeto para o alto mar, depois deixa de avançar e retrai-se ainda mais $[\mathbf{1 7 8}]$ do que a Bética. Nos sítios em que se estende, por duas vezes formando golfo, dispersa-se em três promontórios. O que está mais perto do Guadiana é dito Campo Cúneo [cabo de Sta. Maria], porque partindo de uma base larga se alonga a si e a seus lados pouco a pouco em ponta. Ao que se segue chamam Sagrado [cabo de S. Vicente], e Magno [cabo da Roca] ao que está mais afastado." 11

Reparem os leitores que aqui não se designam por promontórios apenas as próprias extremidades elevadas de terra que estejam sobranceiras ao mar, mas todas as zonas, mesmo com grande extensão, que terminem por fim em ponta alcantilada no mar. Assim, Lívio, no livro primeiro da década terceira: "Aníbal que tinha passado à frente das insígnias em certo promontório..." 12. O mesmo é evidente na própria descrição de Pompónio: "É dito Campo Cúneo [região do cabo de Sta. Maria] porque partindo de uma base larga se alonga a si e a seus lados pouco a pouco em ponta" ou seja, à semelhança de uma cunha com que se cortam as lenhas.

Os Gregos chamaram a este promontório Esfina e os Latinos Cúneo. Na nossa época tem o nome de cabo de Sta. Maria, como também o que se segue e que se chamava Sacro é vulgarmente dito cabo de S. Vicente. Ainda hoje ali persiste, porém, um vestígio do velho nome no ópido de Sagres. Estrabão ${ }^{13}$ disse que ambos os promontórios eram habitados por Célticos e por muitos Lusitanos. [179] Ptolomeu ${ }^{14}$ acrescenta ainda os Turdetanos tal como foi por mim discutido com bastante extensão no opúsculo a favor de Beja ${ }^{15}$.

Nós chamamos a esta região reino do Algarve por causa do nome dado pelos Mouros quando a ocuparam.

É de facto neste Cúneo (região do cabo de Sta. Maria) que Pompónio ${ }^{16}$ recorda situarem-se os ópidos de Mértola, Tavira e Estói.

\section{MÉRTOLA}

Mírtilis, a quem chamamos Mértola, situada sobre o rio Guadiana, está cheia de grande número de monumentos da antiguidade como cipos, colunas e estátuas 
Hoc est: Diis Manibus sacrum. Fabia Prisca Serpensis ciuis Romana annorum uiginti, hic sita est, sit tibi terra leuis. Caius Geminius Priscus pater et Fabia Cadilla mater posuerunt.

\section{LVSITANIAE ALGARBIVM}

Transgrediamur nunc Anam, et Lusitaniae urbes de quibus uel indubitato constabit, uel certe probabili coniectura, antiquitatum studiosis explicemus.

"At Lusitania - inquit Pomponius - qua mare Atlanticum spectat, primum ingenti impetu in altum abit, deinde resistit, ac se magis [178] etiam, quam Baetica abducit. Qua prominet bis in semet recepto mari, in tria promontoria dispergitur.

Anae proximum, quia lata sede procurrens, paulatim se, ac sua latera fastigiat, Cuneus ager dicitur: sequens Sacrum uocant; Magnum, quod ulterius est."

Aduertant lectores promontoria hic non uocari ipsa tantum terrae acumina, quae mari imminent, sed totos late etiam tractus, qui tandem acumine in mare desinunt.

Ita Liuius decadis 3, libro primo: "Praegressus signa Annibal in promontorio quodam."

Patet hoc ex ipsa Pomponii descriptione: "Quia lata sede procurrens paulatim se ac sua latera fastigiat, Cuneus Ager dicitur", uidelicet ad similitudinem cunei quo ligna scinduntur.

Graeci Sphina uocarunt promontorium hoc, Latini Cuneum.

Nostra aetas Sanctae Mariae caput appellat, sicut et sequens, quod sacrum dicebatur, Sancti Vincentii caput uulgo dicitur.

Prisci tamen nominis uestigium ibi in oppido Sacri adhuc perseuerat.

Promontorium utrumque Strabo Celticos ac Lusitanorum plerosque habitare dixit. [179] Ptolemaeus etiam Turdetanos adiungit. Sicut latius a nobis pro Pacensi colonia disputatum est.

Nos Algarbii regnum uocamus a Mauris, quum id tenuere indito uocabulo.

In Cuneo uero hoc, Myrtilis, Ossonobae atque Balsae oppidorum meminit Pomponius.

\section{DE MYRTILI}

Myrtilis, quam Mertolam appellamus, Anae fluuio est imposita, multis antiquitatum monumentis plena, cippis, collumnis, statuis, quibus tam Gothi, 
que Godos e Mouros, por serem uns e outros de inteligência perfeitamente bárbara, utilizaram largamente para reparar as muralhas em vez de pedra de alvenaria. Os habitantes de Mértola permitiram, há alguns anos, que levassem dali oito ou dez estátuas, escavadas da terra, artisticamente esculpidas mas sem cabeça. Admite-se que as cabeças fossem de bronze e inseridas nos corpos e que tivessem mesmo sido arrancadas para outro uso.

Dista de Beja 36 mil passos rigorosos, ou seja, 9 das nossas léguas tal como disse Antonino no Itinerário ${ }^{17}$.

Plínio $^{18}$ deixou escrito que Mértola, assim como Évora e Alcácer do Sal, foi município com o direito do velho Lácio. Ptolomeu ${ }^{19}$ deu-lhe o cognome de Júlia.

[180]

\section{TAVIRA}

Conjecturamos que a outrora chamada Balsa é aquela a que no nosso tempo se dá o nome de Tavira e que é a maior cidade do Algarve. Além de Pompónio ${ }^{20}$, recordam-na Plínio ${ }^{21}$, Ptolomeu ${ }^{22}$ e Antonino ${ }^{23}$ no Itinerário.

\section{ESTÓI}

Quanto a Ossónoba, foi quase destruída. São visíveis ainda alguns vestígios da sua antiga grandeza aqui e ali pelos arredores, sobretudo nas muralhas da cidade de Faro, sua vizinha e mais litoral.

Esta cidade foi sede episcopal como é evidente pelos concílios em que assinou o bispo de Ossónoba ${ }^{24}$.

O nome modificou-se um pouco no tempo dos Mouros. O mouro Rasis chama-lhe Exúbana por deturpação natural da língua púnica. É este o seu testemunho acerca dessa cidade, testemunho não literal mas de sentido: "Exúbana está situada numa região de solo fértil, com aptidão cerealífera, plano e com árvores de fruto. Tem ainda pinhais, montes extremamente favoráveis para a criação de gado e também, em grande número, hortas irrigadas, pois abunda em fontes e cursos de água. Produz um óptimo âmbar. Está perto do mar, onde se encontram algumas [181] ilhotas favoráveis para o tráfego de embarcações e para importações. A cidade, entre as que lhe são iguais pelo tamanho, é das melhores de todo o mundo. Tem sob a sua jurisdição e soberania alguns ópidos, um dos quais é Silves, situado sobre o estuário que saindo do mar se mistura com um pequeno rio" ${ }^{25}$. Escreveu ele até aqui.

Por vicissitudes da fortuna, Silves foi adornada com a autoridade pontificial e Ossónoba reduziu-se a simples aldeia. Também Faro, na sua proximidade, se torna famosa e cresce à custa das suas ruínas. Nem o próprio nome escapou a ser exposto à injúria. De Ossónoba passou a Exúbana e hoje, embora já não esteja próxima, chama-se Estói ${ }^{26}$. 
quam Mauri, ad reficiendos muros pro caementis abutebantur, ut erant et hi et illi ingenio plane barbaro.

Octo, uel decem statuas annis abhinc aliquot terra effossas Myrtilenses homines inde tollere permiserunt affabre insculptas, sed sine capitibus. Arbitrantur capita fuisse aenea, et insiticia, atque adeo a corporibus in alium usum euulsa.

Abest a Pace Iulia iustis XXXVI passuum millibus, hoc est, nostratibus nouem leucis, quod Antoninus in Itinerario dixit. Myrtilin Plinius, sicut et Eboram et Salaciam ueteris Latii municipium fuisse, scriptum reliquit. Ptolemaeus Iuliae cognomen illi attribuit.

$[\mathbf{1 8 0}]$

\section{DE BALSA}

Olim uocatam Balsam, eam esse coniicimus, quae nostro tempore Tauilla nominatur, maxima Algarbii ciuitas. Eius, praeter Pomponium, meminere Plinius, Ptolemaeus, et in Itinerario Antoninus.

\section{DE OSSONOBA}

Ossonoba uero diruta paene est, quuius priscae nobilitatis nonnulla adhuc extant uestigia, passimque per uiciniam praecipue in muris Phari propinquae ciuitatis, magisque litoralis.

Haec urbs sedes fuit episcopalis, ut liquet ex Conciliis, in quibus Ossonobensis Episcopus subscripsit.

Nomen Maurorum temporibus paululum inuersum est. Rasis Maurus Exubanam eam uocat, ingenito linguae Punicae uitio.

Quuius de ea testimonium, non ad uerbum, sed ad sensum istiusmodi est:

"Exubana solo fertili ac frumentario sita est, plano et fructiferis arboribus consito. Habet etiam pineta, et montes ad alenda pecora maxime accomodatos. Hortos quoque irriguos multos, quoniam fontibus ac fluentis abundat. Electrum producit optimum. Mari uicina est, ubi aliquot sunt $[\mathbf{1 8 1}]$ insulae paruae, cymbis ac nauiculis ad usum et inuectiones opportunae. Ciuitas inter eadem magnitudine pares de melioribus totius est orbis. Sub iure ac dominio suo habet oppida nonnulla, e quibus Siluis est, sita super aestuarium quod a mari egressum paruo fluuio commiscetur."

Hactenus ille.

Fortunae uicissitudine facta, Siluis pontificio exornata est. Ossonoba uero in uicum redacta, de quuius quoque ruinis proxima Pharus nobilitatur et crescit. Nec ipsum nomen iniuriae non patuit. Ex Ossonoba in Exubanam transiit, et 
$\mathrm{Na}$ muralha de Faro, entre o baluarte novo e outro levantado por Rui Barreto, há um cipo onde está escrito:

[182]

IMP. CAES. P. LICINIO

VALERIANO. P. F. AVG.

PONT. MAX. P. P. TR. POT.

III. COS. RESP. OSSON. EX D

ECRETO ORD. DEVOT.

NVMINI MAIESTAT

IS. EIVS. D. D.

Isto é: Ao Imperador César Públio Licínio Valeriano, Pio, Feliz, Augusto, pontífice máximo, pai da pátria, no seu terceiro poder tribunício, cônsul, a República Ossonobense, por decreto da ordem, ofereceu e dedicou, com a maior devoção ao seu génio e majestade ${ }^{27}$.

[183] Em certa torre do lado do mar existe um cipo, onde está escrito:

D. M. S.

CATVRISAE PRI

MAE. CONIVGI PIISSIMAE

QVAE. VIXIT. ANN. XXV.

M. VIII. L. CALP. THE

ODORVS. MARIT.

Isto é: Consagrado aos deuses Manes. A Caturisa Prima, modelo de esposa, que viveu vinte e cinco anos e oito meses, dedica Lúcio Calpúrnio Teodoro, seu marido 28.

[184] Entre Faro e Tavira, na torre a que chamaram Torre Marinha, há um cipo onde está escrito:

D. M. S.

C. ANNIVS

ROMVLVS

ANNORVM

XXVIII.

H. S. E. S. T. T. L.

Isto é: Consagrado aos deuses Manes. Aqui jaz Gaio Ânio Rómulo de vinte e oito anos. Que a terra te seja leve ${ }^{29}$. 
quum iam prope non sit, Estoi nuncupatur. Phari in muro inter propugnaculum nouum et alterum a Roderico Barreto extructum cippus est:

[182]

IMP. CAES. P. LICINIO

VALERIANO. P. F. AVG.

PONT. MAX. P. P. TR. POT.

III. COS. RESP. OSSON. EX D

ECRETO ORD. DEVOT.

NVMINI MAIESTAT

IS. EIVS. D. D.

Hoc est: Imperatori Caesari Publio Licinio Valeriano, Pio, Felici, Augusto, pontifici maximo, patri patriae, Tribunicia potestate tertium, consuli, Respublica Ossonobensis ex decreto ordinis deuotissima numini maiestatis eius dedicauit.

[183] In quadam turri ex parte maris, cippus:

D. M. S.

CATVRISAE PRI

MAE. CONIVGI PIISSIMAE

QVAE. VIXIT. ANN. XXV.

M. VIII. L. CALP. THE

ODORVS. MARIT.

Hoc est: Diis Manibus sacrum. Caturisae primae coniugi piissimae, quae uixit annos uiginti quinque, menses octo. Lucius Calpurnius Theodorus maritus.

[184] Inter Pharum et Tauillam in turri quam uocant Marini, cippus:

D. M. S.

C. ANNIVS

ROMVLVS

ANNORVM

XXVIII.

H. S. E. S. T. T. L.

Hoc est: Diis Manibus sacrum. Caius Annius Romulus annorum uiginti octo, bic situs est, sit tibi terra leuis. 
Junto à porta do mar, em Faro, encontra-se um cipo, onde está escrito:

M. CORNELIVS ERIDIMVS. C.

IVNIVS. RECEPTVS. OB HONO

REM. IIIIII VIR. D. S. P.

D. D.

[185] Isto é: Marco Cornélio Eridimo e Gaio Júnio Recepto em honra do Sevirato ofereceram à sua custa ${ }^{30}$.

Segue-se o romontório Sagrado [cabo de S. Vicente], assim chamado por causa do templo de Hércules e porque os naturais tinham como rito religioso o passearem durante as horas da noite nesse local, que se dizia ser então ocupado pelos deuses, como deixou escrito Estrabão ${ }^{31}$ no início do livro terceiro.

O mesmo promontório precipita-se para o alto mar em forma de dois cornos, formando-se entre um e outro um golfo regular cujo âmbito é de cerca de cinco milhas. No corno da esquerda está o ópido de Sagres, que ainda agora tem consigo o nome do promontório, no da direita a famosa igreja de São Vicente, mártir e levita. De que maneira, pois, foi o seu corpo trazido de Valência para aqui, quando Abdarramão tinha em seu poder tirânico as relíquias dos santos, já expliquei eu largamente tanto no meu poema sobre o mesmo santo ${ }^{32}$ como no opúsculo a Quevedo Toledano ${ }^{33}$

Os antigos geógrafos não fazem qualquer referência às cidades desta região. Apenas Pompónio, como bético e não de muito longe, lembra as cidades marítimas de Lagos e Portimão. "No cabo de S. Vicente - diz ele - Lagos e Portimão."34

\section{LAGOS}

[186] O vulgo designa Lacóbriga pelo nome mutilado e algo modificado de Lagos, que é no nosso tempo uma povoação conhecidíssima e populosa, há pouco elevada pelo rei D. Sebastião ao título e honra de cidade, como também, devido a D. João III, avô de D. Sebastião, aconteceu a Faro.

Li há muitos anos já nos Agelários de Baptista Mantuano, que, quando eu era criança, andava na boca de todos, um grande testemunho sobre Lagos:

Diz-se que Lagos a Ardíbur elevou sete estátuas.

Número igual ao das suas vitórias, igual às vezes em que, graças a ele, foi poupada ao levantar da guerra com o furacão dos Vândalos ${ }^{35}$.

Só não sei donde terá tirado isto. Como a fama deste poeta já esfriou muito, poderão ver, se quiserem, o que diz mais a respeito de Lagos aquelele em cujas mãos tenha vindo a parar este livro. 
Phari ad portam maris, cippus:

M. CORNELIVS ERIDIMVS. C.

IVNIVS. RECEPTVS. OB HONO

REM. IIIIII VIR. D. S. P.

D. D.

[185] Hoc est: Marcus Cornelius Eridimus, Caius Iunius receptus ob honorem Seuiratus de sua pecunia dedicarunt.

Sequitur promontorium Sacrum, ita uocatum propter Herculis templum et quia religio indigenis erat locum nocturnis inambulare temporibus, quod eum tunc ab diis possideri fabularentur, ut initio tertii libri Strabo scriptum reliquit.

Promontorium ipsum duobus cornibus in altum se precipitat, effecto inter utrumque modico sinu, quuius est ambitus quinque fere millium.

In sinistro cornu Sacris oppidum est quod adhuc promontorii nomen refert. In dextro nobile Diui Martyris ac Leuitae Vincentii templum, quuius corpus, quonam pacto ex Valentia delatum eo sit, tyrannidem exercente in Sanctorum reliquias Abderramene, quum in meo de eodem Diuo poemate, tum in libello ad Kebedium Toletanum, late explicaui.

Veteres geographi urbium huius tractus nequaquam mentionem faciunt. Vnus Pomponius, utpote Baeticus, et non longo interuallo dissitus, Lacobrigae ac Portus Annibalis maritimarum ciuitatum meminit. "In sacro - inquit - Lacobriga, et Portus Annibalis".

\section{DE LACOBRIGA}

[186] Lacobrigam mutilato atque nonnihil deflexo nomine Lagos appellat uulgus, nobilissimum nostro aeuo frequensque oppidum, ac nuper a

Sebastiano rege in ciuitatis titulum et honorem euectum, sicut et Pharus ab Ioanne tertio, Sebastiani auo.

Legi ante multos iam annos in Agelariis Baptistae Mantuani, qui me puero per omnium ora uolitabat, magnum de Lacobriga testimonium:

Dicitur Ardiburi posuisse Lacobriga septem

Victori toties statuas, totiesque per illum

Eruta Vandalicis bello insurgente procellis.

Quod nescio unde fuerit mutuatus. Quuius poetae, quoniam multum iam fama refrixit, cetera quae ad Lacobrigam attinent uidere poterunt, si uelint, quorum in manus liber is deuenerit. 


\section{PORTO DE ANÍBAL}

Apresentavam-se duas fozes a quem hesitava sobre Porto de Aníbal. Uma, junto a Vila Nova, por cognome Portimão, é a foz daquele rio que, correndo pela cidade de Silves para onde foi transferida de Ossónoba a sede episcopal, se lança no mar; a outra junto à bem conhecida povoação do Alvor, e ambas num golfo capaz de conter grandes e muitos navios. Não havia, porém, acesso ao interior das suas fozes a não ser com o fluxo da maré.

O rio de Vila Nova, que corre a direito, é bastante acessível, [187] o de Alvor é um pouco mais difícil por causa dos vários meandros e das areias que assoreiam a foz à semelhança do que acontece na Sirte. Mas desde que se penetre quando o estuário se abre, depara-se com um óptimo ancoradouro de navios. No interior está uma pequena ilha, bastante elevada e plana no cimo, onde existiu outrora um ópido. Subsistem por todo o lado muros, desde as fundações até meia altura de alvenaria e daí para cima de taipa como a construção púnica. Todo o alto desse terreno plano, cheio de entulho, paredes, pedaços de cerâmica e telhas, tem à vista ruínas de edifícios. Porque ele entretanto desapareceu devido à muita antiguidade, construíram os nossos antepassados Alvor, ali perto, na orla interna do estuário.

Pensamos que, de preferência a Vila Nova, cidade realmente recente, foi este o chamado Porto de Aníbal por causa da situação do local donde os navios podiam ser defendidos perfeitamente e os inimigos impedidos de avançar, tal como convinha a um chefe experimentadíssimo na guerra e que tinha de prever.

Não ouso de modo algum afirmar com segurança em que data teria Aníbal fundado este ópido. Mostrei contudo no terceiro volume ${ }^{36}$ que Aníbal esteve na Lusitânia. Vindo de Gades, "depois de ter cumprido as promessas a Hércules e de se ter comprometido a outros", como escreve Lívio no livro primeiro da década terceira ${ }^{37}$, pôde chegar Aníbal a este promontório por causa de um templo dedicado a Hércules e da crença geral de que os deuses dominavam esse lugar. Assim também, segundo o testemunho de Estrabão ${ }^{38}$, e como acima referimos, pôde chegar devido à tão convidativa amenidade do mar daquela zona e da situação favorável para as operações militares.

$[\mathbf{1 8 8}]$

\section{MERÓBRIGA}

Do cabo de S. Vicente à foz do rio Sado, ou seja, até ao golfo de Alcácer do Sal, há sem dúvida muitos ópidos que não são de desprezar mas de que os Antigos não fizeram menção. Plínio recorda Meróbriga, mas admira-me que tenha omitido Tróia, situada à beira-mar, embora não tenha esquecido Alcácer do Sal, localizada muito mais a interior, nem tão-pouco Meróbriga separada do litoral por cerca de seis mil passos. São dele as seguintes palavras: "Os ópidos famosos na orla costeira a partir do Tejo são Lisboa, célebre por causa da fecundação das éguas pelo vento 


\section{DE PORTV ANNIBALIS}

De Portu Annibalis dubitanti, duo se ostia obiiciebant. Alterum ad Villam Nouam cognomine Portimanam, eius fluuii qui urbem Siluin, ad quam Ossonobense Pontificium translatum est, praeterfluens in mare delabitur.

Alterum ad Alborem oppidum non obscurum, utrumque in sinu magnarum multarumque nauium capaci, sed quarum interius per ostia ingressus nonnisi aestu accedente fiat.

Facilior Villanouanus recto cursu.

[187] Paulo Alboritanus difficilior, propter flexus uarios et in modum Syrtis obstruentes ostium arenas. Verum ubi penetrarint pandentes se aestuario, comodissima statio est nauigiorum.

Parua insula intus est situ editior, in summo plana, in qua olim oppidum fuit,

Supersunt undique muri, a fundamentis usque ad mediam altitudinem caementicii, in superioribus formacei Punico opere. Summa planitities, ruderibus, parietinis, fractis testis tegulisque tota plena, aedificiorum monstrat ruinas.

Hoc nimia uetustate extincto, Alborem nostri maiores ibi iuxta intima aestuarii ora construxerunt.

Hunc fuisse Annibalis uocatum Portum potius arbitramur, quam Villam Nouam, oppidum reuera bonum propter loci situm, unde defendi naues egregie poterant, et aditu arceri hostes, quod a peritissimo bellicae rei duce conueniebat prouideri.

Quando autem oppidum hoc Annibal condiderit, pro comperto ego asserere nequaquam audeo. In Lusitania fuisse Annibalem, tertio uolumine ostensum a me est.

Potuit quoque ex Gadibus, quum uota Herculi exsoluisset, nouisque se obligasset, quod primo tertiae decadis libro scribit Liuius, ad promontorium hoc Annibalem accedere propter dicatum Herculi templum, et dissipatam de Diis locum tenentibus famam. Sicut Strabone referente paulo ante narrauimus, maxime inuitante maritima tractus illius amoenitate, et ad res gerendas opportunitate.

[188]

\section{DE MEROBRIGA}

A Sacro promontorio usque ad Callipodis fluuii eggressum, hoc est ad sinum Salaciensem, multa sane sunt oppida neque contemnenda, sed quorum mentionem ueteres non fecerunt. Plinius Merobrigae meminit, ac mirum est Cetobrigam omisisse in ora positam, quum Salaciam multo interius locatam non praeterierit, neque Merobrigam sex millibus passuum ab litore separatam. Verba illius sunt: "Oppida memorabilia a Tago in ora, Olisipo, equarum e Fauonio 
favónio, Alcácer do Sal cognominado Urbe Imperatória e Meróbriga. O cabo de S. Vicente e a seguir o de Sta. Maria"”39.

Meróbriga desíapareceu, porém, e nas proximidades veio tomar o seu lugar a povoação de Santiago, com o cognome de Cacém, situada em colina mais apropriada. Falaremos dela a seguir.

As muralhas com torres, em certas partes bem conservadas mas noutras meio destruídas, o aqueduto, a ponte no vale que corre a meio, a fonte de água corrente com uma lápide quadrangular, advertiram-me da antiga cidade. Tenho mesmo uma pequena imagem de Vulcano em cobre cíprio, lá encontrada, e um bonito candelabro de bronze. Existe ali um templo dedicado a São Brás e sobre o altar encontra-se uma mesa [189] de pedra com esta inscrição:

\section{G. COCILICO. FVSCO PATRI \\ EX TEST. COCILICI \\ A PASTOS}

Isto é: Gaio Cocílico Fusco, seu pai, por disposição testamentária, Cocilícia Pastos... ${ }^{40}$.

[190] Na torre meio tombada existe um cipo, onde está escrito:

\begin{tabular}{|c|}
\hline C. NVMISIO. C. F. FVSCO \\
VI. VIRO. SEN \\
TATINIA. Q. F. \\
FVLVIANILLA \\
VCSOR \\
PERMITTENTE. ORD. \\
MEROBRIG. \\
\hline
\end{tabular}

Isto é: A Gaio Numísio Fusco, filho de Gaio, séviro [dedica] a mulher, Sentacínia Fulvianila, filha de Quinto, com autorização da ordem senatorial de Meróbriga ${ }^{41}$.

\section{SANTIAGO DO CACÉM}

Disse eu que a Meróbriga tinha sucedido o ópido de Santiago numa colina mais alta que oferece vista para o mar e que não chega a distar 200 passos de Meróbriga. [191] Dominava nesse local o tirano mouro Cacim quando o ópido foi retomado pelos Cristãos. Deu origem ao nome uma imagem em mármore do apóstolo Tiago 
uento conceptu nobile. Salacia cognominatata Vrbs Imperatoria, Merobriga, Promontorium Sacrum, et alterum Cuneus."

Interiit autem Merobriga, in quuius locum successit iuxta oppidum S. Iacobus cognomine Cacem, opportuniore colle positum, de quo postea.

Muri cum turribus, alibi integri, alibi uero semidiruti, aquaeductus, pons in intermedia ualle, et quadrato lapide perennis fons, antiquae me ciuitatis admonuerunt. Habeo etiam ex aere Cyprio Vulcani paruum simulacrum ibi repertum, et elegans aeneum candelabrum.

Templum ibi est Diuo Blasio dicatum, et super aram lapidea [189] mensa cum hac inscriptione:

\section{G. COCILICO. FVSCO \\ PATRI. \\ EX TEST. COCILICI \\ A PASTOS}

Hoc est: Gaio Cocilico Fusco patri ex testamento Cocilicia Pastos.

[190] In semicollapsa turri, cippus:

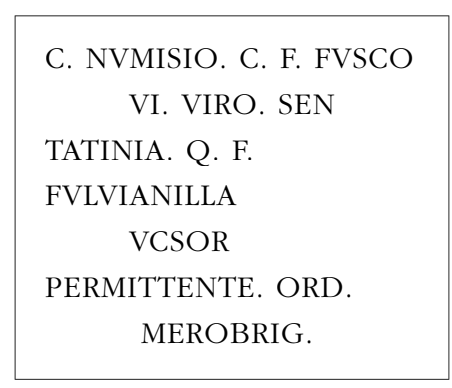

Hoc est:: Caio Numisio Caii filio Fusco sextum uiro Sentatinia Quinti filia Fuluianilla uxor permittente ordine Merobrigensi.

\section{SANCTVS IACOBVS DE CACEM}

Dixi successisse Merobrigae oppidum Sanctum Iacobum in excellenti colle qui maris prospectum aperit, nec a Merobriga distat ducentis integris passibus.

[191] Loco dominabatur Cacem tyrannus Maurus, cum a Christianis receptum oppidum est. Causam nomini dedit Apostoli Iacob marmorea sub terra effigies 
que ali foi encontrada debaixo da terra e que ainda agora é religiosamente honrada na região, cujo nome foi tirado da imagem do santo e o cognome do régulo sob cuja autoridade estivera ${ }^{42}$.

Os habitantes atribuem a reconquista à heroína Vataça ${ }^{43}$ e porque a sua fama está meio sepultada no esquecimento não deixará de ter interesse dedicar-lhe um pouco de trabalho. Tinha-nos aberto caminho Jerónimo Zurita Valentim ${ }^{44}$, homem sabedor e historiador escrupuloso, mas como parece confundir João Vatatzes com João Comeno, a que alguns chamam Coloiane, pai de Manuel Comeno, procuremos o mesmo assunto em Nicetas Coniate, autor grego que viveu nessa época, e em Baptista Egnácio ${ }^{45}$.

Como o imperador da Grécia, Aléxio Ângelo, tivesse duas filhas muito novas e viúvas e parecesse desejar para elas segundas núpcias devido à sua extrema juventude e beleza, segundo diz Nicetas ${ }^{46}$, ajustou o casamento de Irene com Alésio Paleólogo e o de Ana com Teodoro Láscaris, jovem corajoso e muito aguerrido. "Como forma de dote - diz Egnácio - deu ao genro títulos de comando.» ${ }^{47} \mathrm{E}$, de facto, quando Láscaris escorraçou e venceu Manuel Maurozomes, que estava calçado com os sapatos vermelhos, foi saudado com o título de imperador por todas as cidades orientais, [192] segundo testemunha Nicetas ${ }^{48}$. Todavia "não teve da mulher nenhum filho varão mas tão-só uma filha, Irene, que uniu pelo casamento a João Diplobatásio e a quem assim legou pessoalmente o império". É isto que diz Egnácio. No entanto, este a quem Egnácio chama João Diplobatásio é denominado João Vatatzes por outros, que até são gregos, entre os quais Nicéforo Calisto ${ }^{49}$. Mas tanto Zonaras como Nicetas lhe chamam Vatatzes ${ }^{50}$. Por conseguinte, João Vatatzes deixou como sucessor o filho mais novo Teodoro Láscaris que ao morrer confiou a Miguel Paleólogo, na qualidade de tutor, seu filho João e a sua filha Láscara. Mas Paleólogo, tendo morto de forma altamente criminosa a criança, reivindicou para si o império ${ }^{51}$.

Voltemos agora a Zurita ${ }^{52}$, ao último capítulo do livro quinto da História de Aragão. Láscara, ainda menina, receando incorrer também ela na violência do tirano, veio para Génova com o auxílio de mercadores lígures. [193] Desposou na Ligúria o conde Guilherme de Entemélio ou, como vulgarmente se diz, de Ventimiglia, de quem teve um filho, João Láscaris, e três filhas. Quando o marido deixou em Génova o filho que sucedeu ao pai no poder de Entemélio e, levando consigo as filhas, dirigiu-se a Pedro, rei de Aragão, que tinha grande fama, para saber se acaso se dignaria a prestar-lhe auxílio a fim de recuperar o império paterno de que, pela tirania, havia sido despojada. O nobre rei acolheu-a com muita deferência e teve-a como hóspede no reino de Valência. Deu em casamento a filha mais velha, Violante, cognominada da Grécia, a Pedro, barão de Aierba e neto do rei Tiago; a segunda, chamada Beatriz da Grécia, passamo-la por alto porque não é necessária a este trabalho. Vataça, também da Grécia, não esteve casada muito tempo e teve uma filha a quem pôs o seu nome e que Violante, sua tia materna, tratou de casar assim que a idade o permitiu. [194] Como entretanto tivesse casado Isabel, filha do rei Pedro, com Dinis de Portugal, Vataça, já viúva, veio também ao mesmo tempo devido à 
eo loci reperta, quae nunc quoque religiose ibi colitur. Factumque nomen ab Diui simulacro, cognomen autem a regulo sub cuius fuerat potestate.

Expugnationem referunt oppidani ad heroidem Batazam, cuius quia semisepulta fama est, non abs re fuerit operae pauxillum impendere. Viam nobis aperuit Hieronymus Zurita Valentinus ${ }^{1}$ uir doctus et historiae diligens scriptor.

Sed quia Ioannem Batazen cum Ioanne Comneno, quem Caloiannem quidam appellant, Manuelis Commeni patre, confundere uidetur, ex Niceta Choniate Graeco auctore, qui ea tempestate fuit, et ex Baptista Egnatio rem ipsam petamus.

Graeciae imperator Alexius Angelus cum duas haberet filias adolescentulas ac uiduas, et eas ob adolescentiam et formam, ut ait Niceta, secundas nuptias desiderare uideret, Irenem Alexio Palaeologo, Annam Theodoro Lascari, adolescenti animoso et bellicosissimo despondit, "dotisque nomine - inquit Egnatius - imperii titulos genero tribuit."

Et quidem Lascaris, depulso et profligato Manuele Maurozome rubro calceo induto, ab omnibus orientalibus urbibus imperator [192] consalutatus est, ut testatur Niceta. Ceterum "ex uxore mascula illi proles nulla fuit. Femina tantum Irene. Hanc Ioanni Diplobatazio in matrimonium iunxit, imperiumque illi per manus tradidit." Ita Egnatius. Sed quem Ioannem Diplobatazium ipse uocat, Ioannem Batazem appellant alii, et quidem Graeci, inter quos Nicephorus Callistus. Et Batazem² tam Zozaras quam Niceta saepe nominant.

Ioannes itaque Batazes filium Theodorum Lascarem minorem successorem reliquit. Qui moriens Ioannem filium et filiam Lascaram Michaeli Palaeologo, tutorio nomine commendauit. Verum Palaeologus, interfecto puero, per summum scelus, sibi imperium uindicauit.

Redeamus modo ad Zuritam in Aragonicis libro quinto, capite ultimo. Lascara puella, uerita ne et ipsa in tyranni saeuitiam incurreret, Ligurum mercatorum auxilio Genuam uenit. [193] Nupsitque in Liguria Wilelmo Comiti Entemelii, uel, ut uulgo dicitur, Vigintimilii. Peperitque ex eo filium Ioannem Lascarem, et tres filias.

Mortuo marito, filium Genuae reliquit, qui patri in Entemelii dicione ${ }^{3}$ successit. Ipsa filias secum ducens, ad Petrum Aragoniae regem, cuuius ingens erat fama, se contulit, si forte dignaretur auxilium ferre, ad recuperandum paternum imperium sibi per tyrannidem ereptum. Suscepit illam Rex nobilis honorificentissime, et in Valentiae regno retinuit. Filiarumque maximam Iolanthen ex Graecia cognominatam, uxorem dedit Petro Baroni Aierbae, regis Iacobi nepoti.

Secundam Beatricem ex Graecia uocatam praetermitto, huic operi non necessariam. Bataza quoque ex Graecia, in matrimonio non diu fuit, peperitque

\footnotetext{
1 Valentinus $E$ ] Caesaraugustanus $R C^{1} F C^{2} U$

2 Batazem $R C^{1} F C^{2} U$ ] Batazes $E$

3 dicione ] dictione $E$, ditione $R C^{1} F C^{2} U$
} 
austeridade de costumes e de vida, e esteve em Portugal até que Constança, filha do mesmo Dinis e de Isabel, casou com Fernando, rei de Castela. Também então Vataça, senhora de reconhecida virtude, acompanhou a nova desposada como orientadora da sua pouca idade. Como tivesse dado à luz Afonso, mais tarde rei, e o marido não sobrevivesse muito tempo, ocupava-se zelosamente com a ajuda de Vataça em criar o filho do rei. Mas como o infante tivesse sido retirado dos cuidados maternos por conselho da avó que preferiu passá-lo para a sua tutela, a rainha mãe, ferida não só pela viuvez recente como sobretudo por ter sido privada do consolo de amamentar o filho e para mais sem possibilidade de sustentar os que a rodeavam porque os meios de vida que lhe punham à disposição eram muito apertados e até escassos e não em proporção com a sua dignidade real, adoeceu de desgosto e morreu na cidadela de S. Facundo. Como os seus bens e objectos pessoais femininos de modo algum fossem suficientes para pagar às amas, pediu por testamento a seus pais, Dinis e Isabel, que fossem eles a suprir o que lhe faltava.

Vataça, por seu lado, como se sentisse, de dia para dia, profundamente frustrada pela falta da passada influência, tendo combinado tudo com os seus, deu ordens para que se preparasse um navio. Tomando este, bem equipado tanto com as suas forças militares como com o auxílio enviado pelas irmãs, fez-se ao mar pelo Mediterrâneo e depois de contornar Cádis e o cabo de S. Vicente desembarcou junto à curva onde está o ópido de Sines. [195] Reuniram-se-lhe então muitos cristãos e não poucos cavaleiros da ordem da Espada da Terra Santa, que ocupavam as redondezas. Aumentados agora para um contingente não de desprezar, expulsaram do ópido Cacim.

Vataça, ao construir-se a igreja, encerrou em determinada coluna do templo grande parte do lenho da Santa Cruz que tinha sido trazida de Constantinopla por Láscara, sua mãe, de quem o tinha recebido. Ignorada, passou despercebida durante muito tempo até que milagrosamente foi revelada. Por isso, é hábito, aos domingos e dias santificados, quando, depois do evangelho do santo ofício da missa, o padre fala ao povo, exortar ainda a que rezem por Vataça, neta do imperador da Grécia.

Deixando o ópido em poder dos Cristãos, a venerável senhora dirigiu-se para Coimbra, cidade em que se encontrava ainda naquela altura a Corte, e aí, depois de distribuir privilégios e riquezas pelos que a tinham servido e sem que de modo algum tenha esquecido os pobres, enriqueceu a igreja catedral com oferendas e muitas terras. Está lá sepultada num monumento de pedra pouco trabalhado e com uma inscrição simples:

HEIC SITA EST BATAZA IM

PERATORIS GRAECIAE NEPTIS.

["Aqui jaz Vataça, neta do imperador da Grécia"53.] 
filiam, cui sui nomen imposuit. Hanc Iolanthe matertera, ubi per aetatem licuit, nuptui collocandam curauit.

[194] Interea cum Isabella Petri regis filia nupsisset Dionysio Lusitaniae regi, Bataza iam uidua, propter morum et uitae probitatem, una etiam uenit, fuitque in Lusitania, quoad Constantiam ipsius Dionysii et Isabellae filiam, Ferdinandus Castellae rex duxit in matrimonium. Tunc quoque Bataza spectatae uirtutis matrona, nouam nuptam comitata est, tanquam moderatrix eius adolescentiae. Quae quum partu edidisset Alphonsum postea regem, non diu superstite marito, regis filii cum Bataza nutricationem sedulo curabat. Sed subducto a materna cura infante auiae consilio, quae ad suam potestatem transferre maluit, regina mater et recenti uiduitate maesta, et praecipue nutriendi filii solatio destituta, insuper alendae familiae impar, quod peranguste admodumque tenuiter, nec pro regia dignitate, sumptus suppeditaretur, ex dolore morbum incurrit decessitque in oppido Sancto Facundo. Et cum eius suppellex mundusque muliebris ad satisfaciendum alumnis minime sufficeret, testamento a Dionysio patre atque Isabella matre petiit, ut quod illi deerat, ipsi supplerent.

Bataza autem quum se inuidiosam ex praeterita potentia indies persentiret, re cum suis communicata, nauem adornari praecepit. Beneque tam ex suis copiis, quam sororum auxilio instructam, conscendens per Mediterraneum mare exiit, ac circumitis Gadibus et Sacro promontorio, ad flexum ubi oppidum Sinis est, excensionem ${ }^{1}$ fecit.

[195] Conuenerunt ad illam Christiani multi, et ex Sacra Spathophororum Militiae equites non pauci, qui uicina loca tenebant, atque ad non spernendas copias aucti, Cacem regulum oppido exuerunt. Extructoque templo Bataza bonam ligni Sanctae Crucis partem, quam a Lascara matre Constantinopoli delatam acceperat, in quadam templi pila conclusit, quae diu ignorata latuit, donec miraculo fuit prodita.

Ob hoc solemne ibi est, dominicis ac celebrioribus diebus, quum post sacrificii euangelium populum sacerdos alloquitur, etiam adhortari ut precentur Deum pro Bataza Lascara, Graeciae imperatoris nepte.

Relicto in potestate Christianorum oppido, uenerabilis matrona Conimbrigam se contulit, adhuc ilia tempestate urbem regiam, ubi facultates opesque suas iis qui sibi inseruierant distribuens, pauperum nequaquam immemor, Ecclesiam Cathedralem donariis multis ac praediis locupletauit. Sepulta ibi est in lapideo, nec operoso monumento inscriptione simplici.:

HEIC SITA EST BATAZA IM

PERATORIS GRAECIAE NEPTIS.

1 excensionem $E R C^{1} C^{2}$ ] extensionem $F U$ 
[196]

\section{TRÓIA}

Cetóbriga, a que Ptolomeu chama Cetóbrix ${ }^{54}$, elevou-se outrora no litoral e na embocadura do golfo de Alcácer do Sal. Existe agora um leve vestígio da cidade, coberta pelas areias, a não ser quando são postos a descoberto edifícios, umas vezes, sob a água, pela violência do mar que invade as terras, outras vezes pelos ventos que levantam as areias de colina em colina.

O nome teve a sua origem em "cetus" e em "briga", visto que "briga" significa "cidade" na velha língua dos Hispanos, como em Arábriga, Conímbriga, Cetóbriga, Lacóbriga e muitas outras. Quanto à primeira parte deste nome composto é ela constituída pelo vocábulo "cetáceo". É sabido que a palavra "cetáceos" se aplica a peixes grandes como os atuns, sem falarmos dos grandes monstros marinhos, e que se dá o nome de "cetários" àqueles que salgam e vendem estes peixes. Quanto aos tanques em que são salgados chama-se-lhes cetaria, e daí Horácio:

Muitos atuns virão nadando e crescerão as salgadeiras ${ }^{55}$.

E porque na cidade de que estamos a falar era célebre a pesca e salmoura destes peixes - tal como ainda agora em Sesimbra, que é uma vila da região quase no litoral extremo do cabo Espichel -, chamou-se-lhe Cetóbriga.

Subsistem ainda hoje no litoral de Tróia os próprios tanques de salga feitos na antiguidade de argamassa signina. [197] No meio da cidade coberta de areia está um templo antiquíssimo que a religião cristã dedicou, depois de arranjado, à Virgem, mãe de Cristo. Junto à entrada, sobre a porta, observa-se a cabeça de um carneiro com os chifres retorcidos, feita de mármore, na verdade com grande arte. Não é impossível que este templo e a imagem tivessem sido outrora de Júpiter Amon aí venerada pelos pagãos para evitar os frequentes turbilhões de areia. Foi levada dali para Setúbal uma estátua vestida de manto, também em mármore mas sem cabeça, e igualmente esta inscrição de uma pedra quadrangular de jaspe branco que se pode ver em Setúbal no convento de freiras que professam a regra de S. Domingos, e onde está escrito:

L. IVLIVS. L. ET. T. LIB

VALENS. ANNOR.

XXV. H. S. E. S. T. T. L. COPIRVS. FRATRI.

[198] Isto é: Aqui jaz Lúcio Júlio Valente, liberto de Lúcio e Tício, de 25 anos. Que a terra te seja leve. Copiro ao irmão ${ }^{56}$. 
[196]

\section{DE CETOBRIGA}

Cetobriga, quae Ptolemaeo Cetobrix appellatur, in ora et ostio sinus Salaciensis quondam stetit. Vrbis tenue uestigium modo est, arenis obrutae, nisi qua irrumpentis maris uiolentia, sub aqua nonnunquam, nonnumquam uero a tumulo in tumulum arenas radentibus uentis, deteguntur aedificia.

Causa nominis a "cetis", et "briga" orta est. Briga siquidem uetere Hispanorum lingua urbem significat, ut Arabriga, Conimbriga, Cetobriga, Lacobriga et multae aliae. Prima uero compositi nominis pars, a "cetis" est facta. Cete magnos pisces ut thynnos, omissis marinis belluis significare, et qui pisceis eos saliunt, condiunt ac uendunt, cetarios appellari, notum est; lacus autem in quibus saliuntur, cetariae et cetaria dicuntur; unde Horatius:

Plures adnabunt thunni, et cetaria crescent.

Quoniam uero in urbe hac, de qua nobis sermo est, celebris erat piscatio et salsura talium piscitum, sicut etiam nunc Cecimbrigae, quod oppidum e regione est, in extimo fere Barbarii promontorii litore, Cetobriga uocata ciuitas est. Durant adhuc in Cetobrigensi litore ipsa cetaria, signino opere antiquitus fabricata.

[197] In medio obrutae arenis ciuitatis, fanum peruectus est, quod instauratum Virgini Christi matri sacrauit Christiana religio. Ad quuius ingressum, supra portam, arietis caput uisitur contortis cornibus, factum ex marmore et quidem elegantissime.

Neque dissentaneum est fanum id, atque simulacrum Iouis Ammonis olim fuisse, contra frequentes arenarum turbines, ab ethnicis ibi culti. Statua quoque marmorea stolata illinc Neocetobrigam delata est, absque tamen capite. Inscriptio quoque haec in quadrato iaspidis albi lapide, in parthenone uirginum Diui Dominici institutum profitentium, Neocetobrigae extat:

L. IVLIVS. L. ET. T. LIB

VALENS. ANNOR.

XXV. H. S. E. S. T. T. L. COPIRVS. FRATRI.

[198] Hoc est : Lucius Iulius Lucii et Titi libertus Valens annorum uiginti quinque bic situs est. Sit tibi terra leuis. Copirus fratri. 
Na antiguidade, Tróia terminava a ocidente o episcopado de Évora, segundo a divisão do bom rei Vamba que, com a demarcação dos limites das igrejas catedrais, quis acabar com as disputas dos bispos: "Que o episcopado de Évora - diz ele - vá de Tróia a Pedra e de Rutela a Parada" 57.

Também nos nossos tempos a velha Tróia é limite da diocese de Évora. O nome começou a ser corrompido em Cetobra de que mais tarde o vulgo ignorante fez, muito mais deturpadamente, Tróia ${ }^{58}$.

\section{SETÚBAL}

Depois de Tróia se ter arruinado, a colónia mudou-se há cerca de 450 anos para a outra margem do golfo voltado a norte, tendo-se juntado os pescadores neste local. E é tão grande, não só aqui como em Sesimbra, situada, como disse, quase no litoral extremo do cabo Espichel, a recolha de peixes de boa qualidade, visto que o mar é muito piscoso, que acorrem enchendo as estradas mercadores mesmo do interior da Hispânia. [199] Acresce enorme abundância de sal branquíssimo devido à grande quantidade de salinas por todo o golfo. Por causa dele sai e entra sempre grande número de navios, mesmo estrangeiros.

O ópido tornou-se tão famoso pelo comércio tanto de importações como de exportações e tão rico que de modo algum tem inveja ao brilho das grandes cidades.

Esta colónia foi também chamada Cetóbriga Posterior, mantendo o antigo nome, mas correntemente Cetobra. Como, porém, de dia para dia aumentasse a corrupção, ficou Cetóbala.

Florião do Campo ${ }^{59}$ imaginou, nas origens fantasiadas a seu respeito e a partir do nome corrompido Cetóbala, que havia um cetáceo de Túbal e conta a origem do ópido a partir de Túbal. Costumo designá-la, para estabelecer distinção, por Neocetóbriga mas cada qual é livre de usar um ou outro nome, pois quer diga Cetóbriga quer Neocetóbriga falará com erudição.

\section{BEJA}

Apresentou-se a costa desde a foz do Guadiana até ao golfo de Alcácer do Sal e, antes de passarmos além, convém voltar ao interior, pelas cidades, embora não por todas. [200] Com efeito, não me propus enumerar todas, mas tão-só aquelas que ou foram nomeadas pelos escritores antigos ou que, graças a velhas inscrições ou a um feito muito notável, tornaram em qualquer lado e por seu mérito os nomes conhecidos. Os meus amáveis leitores hão-de recordar que eu o anunciei de uma vez por todas neste lugar. 
Antiquitus Cetobriga ab occidente Eborensem episcopatum terminabat, ex Bambae optimi regis diuisione, qui finium cathedralium ecclesiarum terminatione, episcoporum lites uoluit dirimere. "Episcopatus - inquit ille - Eborensis habeat a Cetobriga usque ad Petram, et a Rutella usque Paratam."

Nostris quoque temporibus, Eborensis dioecesis finis, Cetobriga uetus est. Corrumpi coepit nomen in Cetobram, quam postea multo corruptius uulgus ineruditum Troiam fecit.

\section{DE NEOCETOBRIGA}

Post dirutam Cetobrigam, mutata colonia est, ad alteram sinus oram Septentrionem uersus, ab heinc annos circiter quadringentos quinquaginta, conuenientibus eo loci piscatoribus. Tantaque et ibi et Cecimbrigae sitae, uti dixi, in extimo fere Barbarii promontorii litore, nobilium piscium captura est, quum mare piscosissimum sit, ut etiam ex intima Hispania plenis uiis confluant mercatores.

[199] Accedit ingens candidissimi salis copia, propter salinarum toto sinu multitudinem. Quuius gratia, externarum quoque nauium magnus semper numerus aut exit, aut ingreditur. Commercio itaque tam inuectionum, quam reuectionum, factum insigne oppidum est opulentissimumque, adeo ut magnarum urbium nequaquam inuideat claritati.

Vocata quoque Cetobriga posterior haec colonia est, retento prisco nomine, et uulgo Cetobra. Indies autem pergente corruptione, Cetobala. Florianus Campensis in commenticiis suis originibus, a Cetobala corrupto nomine, cetum Tubalis confinxit, originemque oppidi usque a Tubale fabulatur. Ego Neocetobrigam soleo nominare distinctionis gratia, liberum cuique est alterutro uti: siue enim Cetobrigam, siue Neocetobrigam dixerit, erudite loquetur.

\section{DE PACE IVLIA SIVE AVGVSTA}

Dicta ora est, ab exitu Anae usque ad Salaciensem sinum. Quem priusquam transgrediamur, redire ad continentem oportet, per ciuitates, non quidem omnes. [200] Neque enim omnes recensere propositum mihi est, sed eas quae uel a ueteribus auctoribus nominatae sunt, uel quae inscriptionum uetustarum beneficio, aut maxime insigni quopiam facto, nomina sibi suo merito prodiderunt. Idque semel hoc loco praefatum ${ }^{1}$ esse me, candidi lectores meminerint.

1 praefatum $R C^{1} F C^{2}$ ] praefactum $E U$ 
Estava disposto de resto a descrever agora Beja se não o tivesse já feito suficientemente, e até mais do que isso, na bem longa epístola a Vaseu ${ }^{60}$, Em defesa de Beja, no opúsculo a Francisco Nunes ${ }^{61}$ e em não poucos passos da minha obra. De facto, mostrei que era aquela a que vulgarmente se chama Beja, por corrupção do nome pelos Mouros, e que estava situada entre os povos Célticos da Lusitânia, diz Estrabão ${ }^{62}$, ou no limite entre Célticos e Turdetanos, nas palavras de Ptolomeu ${ }^{63}$. Expus ainda com certa extensão que foi uma colónia e segundo convento da Lusitânia. Contei também a maneira como a dignidade pontifícia foi dali transferida para Badajoz.

Antes do colapso geral da Hispânia, brilhou nesta cidade o bispo Apríngio, escritor erudito cujo Comentário ao Apocalipse ${ }^{64}$ Isidoro prefere ao de todos os antigos; brilhou ainda Isidoro ${ }^{65}$, cognominado o Pacense, cujos opúsculos, em linguagem difícil e pouco cuidada, [201] circulam por aí não só incompletos como cobertos de erros bem espinhosos; salientaram-se também o jovem Sisenando, coroado pelo martírio em Córdova, e o presbítero Tiberino ${ }^{66}$.

Encontra-se ali grande número de monumentos romanos dos quais considerarei alguns dos que se observam dispersos pelas muralhas da cidade. De frente para as novas Portas de Moura, há um que diz:

\section{IVLIVS. C. F. \\ II. VIR. BIS PRA \\ VTRIQVE. SEN}

Isto é: Gaio Júlio, filho de Gaio, duúnviro ${ }^{67}$.

Depois um fragmento na muralha, que se lê:

EQVIT. PRAEF.

FABRVM.

Isto é: Ao cavaleiro, prefeito dos artífices ${ }^{68}$.

[202] Um cipo meio quebrado, que assim reza:

M. AVRELIO. C. F. GAL. II. VIR. FLAMIN.

TI. CAESARIS. AVG.

PRAEF. FABR.

D. D.

Isto é: A Marco Aurélio, filbo de Gaio, da tribo Galéria, duúnviro, Flâmine de Tibério César, Augusto, prefeito dos artífices, por decreto dos decuriões [ou dedicaram] ${ }^{69}$. 
Ceterum Pacem Iuliam, siue Augustam descripturus modo eram, nisi satis superque id fecissem, in bene longa ad Vasaeum epistola, Pro Pacensi colonia, et in libello ad Franciscum Nonium, et aliis non paucis scriptorum meorum locis.

Siquidem ostendi eam esse quae uulgo Bexa dicatur ${ }^{1}$, corrupto a Mauris nomine, sitam uero in Celticis Lusitaniae populis, iuxta Strabonem, uel in confinio Celticorum Turdetanorumque, iuxta Ptolemaeum. Coloniam fuisse et secundum Lusitaniae conuentum, et quo pacto ab ea Pontificatus dignitas translata Badiosam sit, prolixe etiam exposui.

Ante uniuersalem Hispaniae cladem, floruit in hac urbe Apringius episcopus scriptor eruditus, quuius In Apocalypsin interpretationem ueteribus omnibus praefert Isidorus. Floruit etiam Isidorus Pacensis cognominatus, quuius opuscula horrido parumque culto sermone, eaque imperfecta et mendis senticosissimis scatentia circumferuntur.

[201] Floruere quoque iuuenis Sisenandus martyrio Cordubae coronatus, et Tyberinus presbyter. Extant ibi complura Romanorum monumenta, ex quibus aliquot adscribam quae per muros ipsius ciuitatis dispersa uisuntur.

Ad portam Maurensem, uersus nouam:

$$
\begin{aligned}
& \text { C. IVLIVS. C. F. } \\
& \text { II. VIR. BIS PRA } \\
& \text { VTRIQVE. SEN }
\end{aligned}
$$

Hoc est: Caius Iulius Cai filius duumuir.

Postea fragmentum in muro:

EQVIT. PRAEF.

FABRVM.

Hoc est: Equiti prafecto fabrum.

[202] Cippus semifractus:

M. AVRELIO. C. F. GAL. II. VIR. FLAMIN. TI. CAESARIS. AVG. PRAEF. FABR.

D. D.

1 dicatur $\left.E R C^{1} F C^{2}\right]$ dicitur $U$ 
Junto às Portas de Mértola, lê-se:

$$
\begin{aligned}
& \text { Q. PETICIO. T. F. } \\
& \text { RVFO } \\
& \text { MATER. FILIO. }
\end{aligned}
$$

Isto é: A seu filho, Quinto Petício Rufo, filho de Tício, dedica a mãe ${ }^{70}$.

Do outro lado das Portas de Moura está um fragmento com letras de oito polegadas. As pedras estão incompletas em ambas as extremidades e dizem:

[203]

CVRIAE PONT.

FLAM. PACIS IVLIAE

VE. FLAMI

Isto é: Pontífices da Cúria, Flâmines de Beja ${ }^{71}$.

Fora das muralhas, lemos:

D. M. S.

HEL. AERIA

NVS. ANN

ORVM XII.

H. S. E. S. T. T. L.

Isto é: Consagrado aos deuses Manes. Aqui jaz Élio Eriano de 12 anos. Que a terra te seja leve ${ }^{72}$.

[204] Num quintal, encontra-se:

C. IVLIO. L. F. GAL,

AVITO. FRATRI

VS. SABINVS,

Isto é: A Gaio Júlio Avito, filho de Lúcio, da tribo Galéria, Sabino cumpriu sua promessa ao irmão ${ }^{73}$.

Nos degraus da sé, vemos:

PAX. I V L I

Q. PETRON

Isto é: Beja. A Quinto Petrónio ${ }^{74}$. 
Hoc est: Marco Aurelio Cai filio, Galeria ${ }^{1}$, duumuiro, Flamini Tiberii Caesaris Augusti, praefecto fabrum decreto decuriorum, uel dedicarunt.

Ad portam Myrtilensem:

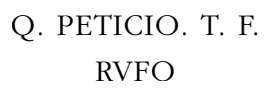

MATER. FILIO.

Hoc est: Quinto Petitio Titi filio Rufo mater filio.

Fragmentum, ultra portam Maurensem, littera bessali. Desiderantur lapides in utroque capite [203]:

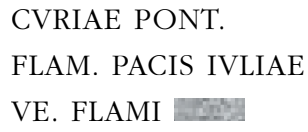

Hoc est : Curiae pontifices, Flamines Pacis Iuliae.

Extra muros:

HEL. AERIA
NVS. ANN
ORVM XII.

H. S. E. S. T. T. L.

Hoc est: Diis Manibus sacrum. Helius Aerianus annorum duodecim, hic situs est, sit tibi terra leuis.

[204] In quodam horto:

$$
\begin{aligned}
& \text { C. IVLIO. L. F. GAL. } \\
& \text { AVITO. FRATRI } \\
& \text { VS. }^{2} \text { SABINVS. }
\end{aligned}
$$

Hoc est: Caio Iulio Lucii filio Galeria Auito fratri votum soluit ${ }^{3}$ Sabinus.

In gradibus summi templi.

PAX. I V L I

Q. PETRON

Hoc est: Pax Iulia Quinto Petronio.

\footnotetext{
1 Galeria $E$ ] Galerio $\left.R C^{1} F C^{2} U\right|^{2}$ VS. $R C^{1} F C^{2} U$ 」 om. $\left.U\right|^{3}$ uotum soluit ] om. $E R C^{1} F C^{2} U$
} 
[205] Junto de S. Salvador está escrito:

\begin{tabular}{|c|}
\hline D. M. S. \\
IVL. PATERNA \\
ANN. XV \\
IVLIA \\
TERSPICORE \\
LIBERTAE OB \\
SEQVENTISSIMAE \\
H. S. E. S. T. T. L. \\
\hline
\end{tabular}

Isto é: Consagrado aos deuses Manes. Aqui jaz Júlia Paterna de 15 anos. Júlia Terpsicore [dedica] à liberta obedientíssima. Que a terra te seja leve ${ }^{75}$.

Por erro do gravador que não quis corrigir, está Terspícore em vez de Terpsícore.

[206] Na praça, um cipo, que podemos ler:

\begin{tabular}{|l|}
\hline L. AELIO AVRELIO \\
COMMODO \\
IMP. CAES. AELI. HA \\
DRIANI ANTONI \\
NI. AVG. PII. P. P. FILIO \\
COL. PAX. IVLIA \\
D. D. D. \\
Q. PETRONIO MATERNO \\
C. IVLIO IVLIANO \\
II. VIR. \\
\hline
\end{tabular}

Isto é: A Lúcio Élio Aurélio Cómodo, filho do Imperador César Élio Adriano Antonino, Augusto, Pio, pai da pátria, dedicou a colónia de Beja, sendo duúnviros Quinto Petrónio Materno e Gaio Júlio Juliano ${ }^{76}$. 
[205] Ad Sanctum Saluatorem:

D. M. S.

IVL. PATERNA

ANN. XV

IVLIA

TERSPICORE

LIBERTAE OB

SEQVENTISSIMAE

H. S. E. S. T. T. L.

Hoc est : Diis manibus sacrum. Iulia paterna annorum quindecim, Iulia Terpsicore libertae obsequentissimae, hic sita est. Sit tibi terra leuis.

Errore sculptoris positum est Terspicore pro Terpsicore, sed ego mutare nolui.

In foro, cippus:

L. AELIO AVRELIO
COMMODO
IMP. CAES. AELI. HA
DRIANI ANTONI
NI. AVG. PII. P. P. FILIO
COL. PAX. IVLIA
D. D.
Q. PETRONIO MATERNO
C. IVLIO IVLIANO
II. VIR.

Hoc est: Lucio Aelio Aurelio Commodo, Imperatoris Caesaris Aelii, Adriani, Antonini, Augusti, Pii patris patriae filio, Colonia Pax Iulia dedicauit, Quinto Petronio Materno, Caio Iulio Iuliano duumuiris. 
[207] Na torre da sé, diz assim:

\begin{tabular}{|l|}
\hline \multicolumn{1}{|c|}{ A } \\
SEVERVS \\
PRESBIT. FAM \\
VLVS. CHRISTI VI \\
XIT. ANN. LV. \\
REQVIEVIT I \\
N PACE DOMINI \\
XI. KAL. NOVEMBRIS. ERA \\
DCXXII. \\
\hline
\end{tabular}

Isto é: Alfa e ómega. O presbitero Severo, servidor de Cristo que viveu 55 anos, descansou na paz do Senhor no décimo primeiro dia das calendas de Novembro da era 62277

[208] No campo, a 4 mil passos da cidade, na herdade a que chamam Represa, lemos:

D. M. S.

MERCATOR

ANN. XXXII.

VXOR MARITO

MERENTI POSV

IT. H. S. E. S. T. T. L.

Isto é: Consagrado aos deuses Manes. Aqui jaz Mercador de 32 anos. A mulher ao marido merecedor colocou. Que a terra te seja leve ${ }^{78}$.

Existem nesta cidade outros fragmentos mas mais pequenos; a cabeça de uma imagem de Vespasiano; dez cabeças de touro; um aqueduto subterrâneo nuns sítios intacto, noutros destruído; três portas de muralhas ainda segundo a arquitectura romana. [209] Foi encontrada uma lápide de mármore de dois côvados em que estavam competindo numa corrida equestre um rapaz e uma rapariga com admirável elegância ${ }^{79}$.

\section{CAMPO DE OURIQUE}

Campo de Ourique, unido por Turdetanos e Célticos, abrange uma pequena região com oito ou dez cidades no máximo, além de aldeias desconhecidas. Recebeu o nome do mais famoso ópido da região, Ourique, e como é zona rural, cerealífera e 
[207] In cochlea summi templi:

A

SEVERVS

PRESBIT. FAM

VLVS. CHRISTI VI

XIT. ANN. LV.

REQVIEVIT I

N PACE DOMINI

XI. KAL. NOVEMBRIS. ERA

DCXXII.

Hoc est: Alpha, et omega. Seuerus presbiter famulus Christi uixit annos quinquaginta quinque, requieuit in pace Domini undecimo Kalendas Nouembris era sexcentesima uigesima secunda.

[208] In agro, quattuor mil. pass. ab Vrbe. Represam praedium uocant:

D. M. S.

MERCATOR

ANN. XXXII.

VXOR MARITO

MERENTI POSV

IT. H. S. E. S. T. T. L.

Hoc est : Diis Manibus sacrum. Mercator annorum triginta duorum: uxor marito merenti posuit. Hic situs est, sit tibi terra leuis.

Sunt in ea urbe fragmenta alia, sed minutiora. Caput imaginis Vespasiani. Taurorum capita decem. Aquaeductus alicubi sub terra integer, alibi confractus. Murorum portae tres adhuc Romana architectura. [209] Inuentus marmoreus lapis duorum cubitorum, in quo erant uir et puella equestri cursu certantes, mirabili elegantia.

\section{DE ORICHIENSI AGRO}

Orichiensis ager, Turdetanis $\mathrm{ac}^{1}$ Celticis iunctus, regionem paruam efficit, octo uel ad summum decem oppidorum, praeter uicos ignobiles. Nomen accepit

\footnotetext{
1 Ac $\left.R C^{1} F C^{2} U\right]$ ab $E$
} 
boa de pastagem, chama-se-lhe vulgarmente Campo de Ourique. Não me contraria recordá-lo por ali ter tido origem o nosso reino. Como vou recuar um pouco mais atrás peço aos leitores amigos que me perdoem.

Afonso o Grande, rei da Hispânia que tomou Toledo e que recebeu o nome de Imperador, teve de diferentes esposas três filhas, Elvira, Teresa e Urraca. É verdade que Rodrigo de Toledo, pouco imparcial para com os Portugueses, e os que a ele aderiram, diz que Elvira e Teresa eram filhas da amante Ximena Múnio, mas tenho em minha casa um cronicão na velha língua espanhola feito setenta anos antes de Rodrigo, no qual a mesma Ximena [210] é apresentada claramente, não como amante mas como mulher legítima e rainha. Escrevi a este respeito, e em verdade extensamente, a João de Barros ${ }^{80}$.

Por conseguinte, para junto do Imperador Afonso que se encontrava em dificuldades porque a Hispânia estava a caminho de ser tomada, acorriam homens ilustres que tinham dedicado a Cristo os seus feitos de armas. Salientaram-se entre eles Raimundo, conde de Sto. Egídio, e Henrique, conde de Lorena, segundo filho da irmã de Raimundo e do rei da Hungria com quem ela era casada. Pensou Afonso em ligar estes a si casando-os com as filhas para que, com a amizade de tais homens, reforçasse mais estreitamente a sua posição. Deu, pois, Elvira em casamento ao conde de Sto. Egídio, Teresa a Henrique, conde de Lorena, e Urraca, segundo escrevem uns a mais velha das três, segundo agrada a outros a mais nova, filha de Constança, sua mulher depois da morte de Ximena, a Raimundo, conde ou da Borgonha ou de Tolosa. Com efeito, os próprios historiadores de Espanha não estão bem de acordo entre si. Passando por alto as opiniões destes, falaremos apenas de Henrique a quem deu Teresa, sua filha muito querida. E, para ter por um laço mais apertado o grande homem por assim dizer à mão, confiou-lhe a título de dote os Bracarenses, parte da Galiza que vai do Minho ao Douro e toda a zona que era então designada pelo vocábulo bastante recente de Portugal e que ia do Douro até Coimbra, cidade da Lusitânia; deu-lhe a liberdade de reconquistar pelas armas a Lusitânia aos Sarracenos $[\mathbf{2 1 1}]$ e de a juntar à região que estava sob o seu domínio e autoridade.

Teve ele de Teresa, sua mulher, sempre designada como rainha, Afonso Henriques que sucedeu ao pai na soberania e que, quando a idade o permitiu, dirigiu o maior número possível de batalhas, tomou muitas cidades e aniquilou o poder dos Sarracenos.

Ismar, rei de grande parte da África e da Bética, perturbado com isto, convocou quatro outros reis tanto de África como de toda a Hispânia Ulterior e reuniu um tal contingente, que o exército tinha para mais de 400.000 homens. Confiado nestes apressou-se a ir ao encontro de Afonso em jornadas morosas mas com o espírito excitadíssimo para a vingança. Também aquele não se atrasou e assim, em Campo de Ourique, um pouco abaixo do ópido de Castro Verde e não longe da confluência dos rios Cobre e do Terges, encontrando-se face a face, assentaram arraiais. 
ab Orichio, regionis nobiliori oppido, et quia campestris ager est, frumentarius ac pascuus, uulgo Campus Orichiensis nominatur.

Non piget eius meminisse, propter regni nostri illic coeptam originem. Quam ut paulo altius repetam, ab aequis lectoribus condonari mihi postulo.

Magnus Alphonsus Hispaniae rex, qui Toletum expugnauit, et Imperator est appellatus, ex diuersis uxoribus tres filias habuit, Eluiriam Therasiam, atque Orracam. Et quidem Eluiriam, ac Therasiam, Rodericus Toletanus, parum Lusitanis aequus, quique illi adhaeserunt, ex concubina Simena Munione natas aiunt.

Verum apud me chronicon Hispanica uetusta lingua habeo, factum septuaginta annos ante Rodericum, in quo eadem Simena [210] minime concubina, sed iusta uxor et Regina, diserte perhibetur. De qua re ad Ioannem Barrum scripsi, et quidem prolixe.

Ad Alphonsum igitur Imperatorem, in adserenda Hispania laborantem, conueniebant magni uiri, militiam suam Christo deuouentes. Inter quos emicuere Raimundus comes Sancti Aegidii, et Henricus Lotharingiae comes, ex Germana Raimundi natus, quem illa Vngariae regi, cui nupta erat, secundo edidit partu. Hos, ut talium necessitudine artius se muniret, Alphonsus filiarum connubiis sibi deuinciendos existimauit.

Eluiram igitur comiti Sancti Aegidii, Therasiam Henrico Lotharingiae comiti, Orracam uero trium, ut alii scribunt, natu maximam, ut aliis autem placet minimam, atque post Simenam defunctam, ex Constantia uxore natam, Raimundo comiti siue Burgundiae, siue Tolosae, neque enim inter ipsos Hispanicarum rerum scriptores satis conuenit, in matrimonium dedit. Quorum nos, opinionibus praetermissis, de Henrico tantum loquamur, cui ualde dilectam sibi Therasiam tradidit.

Atque ut nexu deuinctiore uirum maximum quasi ad manum haberet, Callaeciae partem Bracaros, a Minio usque ad Durium, totumque id, quod recentiore uocabulo Portugale tunc dicebatur, a Durio usque ad Lusitaniae urbem Conimbrigam, dotis nomine adsignauit liberumque ei reliquit, ut de Saracenis Lusitaniam armis recuperaret, [211] suoque dominio et dicioni adderet.

Is ex Therasia coniuge, quae semper Regina appellata est, filium genuit Alphonsum Henricum, qui patri successit in principatu, et ubi per aetatem licuit, bella gessit quamplurima, urbes multas expugnauit, Saracenorum potentiam fregit.

Qua re commotus Ismarius, magnae partis Africae, Baeticaeque rex, conuocatis quattuor aliis regibus, tam ex Africa, quam ex tota Vlteriore Hispania, tantas congregauit copias, ut millia quadringenta exercitus superaret. His confisus, in Alphonsum properabat, lentis itineribus, sed animo ad uindictam concitatissimo. Nec ille segniter processit obuiam. In Agro igitur Orichiensi, paulo infra Castrum Viride oppidum, non procul a confluente Cobris et Tergis fluuiorum, in mutuum conspectum uenientes castra posuerunt. 
Afonso ocupou a colina onde estava uma antiga ermida em que determinado velho, de provecta idade, vivia entre os mouros como um ermitão e que, devido à pobreza e à santidade de vida, por ninguém era provocado injustamente. $O$ quase infindável contingente militar de Ismar enchia todos os campos em redor e já esperançadamente se via a tragar os adversários cercados. Não parecia aos nossos soldados ser decisão avisada combater contra tão grande multidão pois cada um deles teria de defrontar no combate [212] para cima de cem inimigos. Mas o príncipe robusteceu o espírito dos seus soldados por meio de um discurso cheio de esperança e firmeza. Ao mandá-los dispersar ordenou que tratassem de seus corpos e que aguardassem alegremente o dia seguinte que era santificado ao apóstolo Tiago, padroeiro das Hispânias.

Como tivesse anoitecido, veio aquele anacoreta à presença de Afonso e exortou-o a ter coragem com a revelação de uma profecia. Disse-lhe que à hora da noite em que ouvisse o som de uma sineta que estava na capelinha deveria sair da tenda pois lhe iria aparecer no ar Cristo suspenso da cruz.

Afonso, contente com uma notícia tão desejada e tão inesperada, velou toda a noite aguardando o prometido. E assim, ao romper da alva e antes do dia, ao sair da sua tenda real quando tinia a sineta, pôde olhar para o Senhor crucificado, suspenso no ar. Arrastado, quase fora de si, pelo prazer desta visão, adorando-o dizia assim: "Será verdade, ó Salvador do mundo, que me apareces a mim neste momento? Mas por que razão apareces àquele que em ti crê e que te honra com a maior devoção? Antes te dignasses a aparecer a estes infiéis, ignorantes da tua divindade, inimigos teus e portanto meus, para que compreendam o mistério da tua cruz e deixem de ser insensatos".

[213] Quando com estas e outras palavras semelhantes prosseguia, como que em êxtase, foi muito agradavelmente surpreendido pela voz de Cristo que lhe falava e prometia vitória. Logo que a divina aparição se recolheu ao céu, pediu as armas, ordenou que se armassem os soldados, que se formassem as linhas de batalha e que as tubas em uníssono dessem o sinal.

Alguns dos chefes procuraram-no em nome do exército, dizendo:

- Os teus homens, valente chefe, pedem que lhes permitas saudar-te como rei.

Mas ele respondeu-lhes:

- Fidelíssimos companheiros de armas! Coube-me a mim, entre vós, o nome e título suficientemente honroso de príncipe. Não ambiciono outro. E ainda que o desejasse muitíssimo ou quisesse aceder ao que pedis, nem o momento nem o local o permitem. Esforçar-me-ei por que não vos desagrade como vosso chefe; esforçaivos vós para que eu como chefe não tenha a lamentar a perda de soldados. 
Insedit tumulum Alphonsus, ubi uetus sacellum erat, in quo senex quidam prouectae aetatis heremiticam uitam agebat, inter Mauros, et ob paupertatem, et ob uitae sanctimoniam, nullius iniuria lacessitus. Ismarii copiae prope infinitae undequaque campos opplebant, iamque agmina circumclusa spe deuorabant.

Non uidebatur militibus nostris sani esse consilii, cum tanta multitudine confligere. Vnus enim quisque supra centum hosteis aduersum [212] se in proelio erat habiturus. Sed militum animos oratione spei, ac fiduciae plena princeps confirmauit. Dimissosque curare corpora iubet, et crastinum diem, qui Iacobo Apostolo Hispaniarum patrono sacer erat, laetos exspectare.

Quum aduesperauisset, anachorita ille ad Alphonsum uenit, atque oraculi denunciatione, forti esse animo admonet, ut qua noctis hora tintinabuli, quod in sacello erat, sonum audiret, tentorium eggrederetur, appariturumque illi Christum in aere cruci subfixum. Laetus tam optato, tamque insperato nuntio Alphonsus, totius noctis peruigilio promissum exspectabat.

Primo itaque ante lucem diluculo, ad tintinabuli sonum praetorium eggressus, suspexit in aere Crucifixum Dominum. Quuius uisi uoluptate propemodum extra mentem absortus, ita adorans dicebat: "Ecquid Seruator mundi, tunc mihi, tunc appares? Quid eo opus est, in te credenti, et te summa pietate colenti? Perfidis his, tuis atque ideo meis hostibus, tuae diuinitatis ignaris, potius apparere digneris, ut Crucis tuae mysterium intelligant, ac desinant insanire.”

[213] Haec atque alia his similia, cum ex mentis quasi abstractione prosequeretur, Christi colloquentis et uictoriam pollicentis uoce iucundissime affectus, in caelum recepta diuina illa specie, arma postulat, armari milites, acies ordinari, et canoro tubarum concentu imperat signum dari. Quem ex proceribus quidam exercitus nomine adeuntes:

- Postulant (inquiunt) fortissime imperator, milites tui, ut regem te salutari permittas.

Quibus ille:

- Ego, fidissimi commilitones, honorificum satis inter uos nomen, titulumque principis sortitus sum, alium non ambio. Neque si maxime expeterem, uel poscentibus uobis morem gerere uellem, id tempus aut locus, patiuntur. Sed operam dabo, ut uos ducis uestri non paeniteat; uos date, ut milites dux non desiderem. 
A resposta foi a seguinte:

- Não só prometemos o que pedes como, quanto a nós, não faltaremos ao dever. Mas pelo rei combateríamos com mais ardor, venceríamos com mais honra e morreríamos mais alegremente.

Então, depois de quase terem forçado a quem se escusava, foi aclamado por três vezes em altos brados e ao som de tubas, clarins e tambores:

"Vida e vitória para Afonso Henriques, primeiro rei de Portugal!"

Depois de darem aos soldados o santo-e-senha, passam-se para o campo dos inimigos.

[214] Da parte contrária, porém, aquele inumerável exército de bárbaros estrondeava com tão dissonantes clamores e com tão terrível estrépito, que parecia que o céu vinha abaixo e que a terra era abalada por um sismo.

Principiou o combate, sangrento, implacável, interminável, da primeira hora do dia até ao meio-dia, até que o próprio Ismar, cuja vida já corria risco, vida que os nossos mais que tudo cobiçavam, encontrando-se em situação desesperada e tendo perdido na peleja o primo de nome Omar Atagor, neto do rei Ali, a quem constituíra seu guarda de corpo, fugiu com os reis que com ele estavam. Verteu-se, porém, tanto sangue que do local da batalha correram regos na direcção do Cobre e do Terges. E, mais ainda, chovendo poucos dias depois, como a água tivesse lavado o chão sujo de sangue escuro e engrossado os regos, o Terges que desagua no confluente Cobres levou as águas poluídas até mesmo ao Guadiana ${ }^{81}$.

Foi isto que descrevemos em poucos versos no Mártir Vicente:

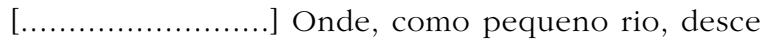

Do Campo de Ourique o indolente Terges,

Tombaram os chefes derrotados

E em fuga se puseram os bárbaros exércitos.

Embebeu-se a terra de tanto sangue

Que, depois das chuvas lavarem essa carnagem,

Um rio viscoso correu poluindo, ao seu contacto,

Grande extensão por onde passou,

E manchando com a morte as águas do Guadiana procuradas.

Esse rio que até então corria ingloriamente

E que era desigual no curso de água, que em Julho se evapora,

Pelos naturais foi depois disso tornado conhecido

Por causa da derrota ao soberbo Ismar infligida ${ }^{82}$. 
Contra illi:

- Et quae postulas pollicemur, et nobis non deerimus. Sed pro rege pugnabimus ardentius, uincemus honestius, moriemur alacrius.

Quum igitur prope intulissent uim recusanti, magnis uocibus, et tubarum, lituorum, tympanorumque sonitu ter acclamatum:

- Alphonso Henrico primo Lusitaniae Regi uita, \& uictoria.

Data inde militibus tessera, ferebatur in hostes. [214] At parte ex alia innumerabilis ille Barbarorum exercitus, tam dissonis clamoribus, tam terribili fragore perstrepebat, ut caelum ruere, terra quassari tremoribus uiderentur. Commissum proelium est, sanguinolentum, pertinax, diuturnum, a prima diei hora usque ad meridiem. Donec Ismarius, quuius iam uita periclitabatur, quamque maxime nostri appetebant, rebus desperatis, et amisso in conflictu consobrino, cui sui corporis custodiam mandauerat, nomine Homar Atagor, Halli regis nepote, fugit ipse, et una reges, qui cum eo erant.

Tantum autem sanguinis effusum est, ut ex caedis loco riuuli in Cobrin atque Tergem decurrerent. Quin insequuta paucos post dies pluuia, quum tinctam atro sanguine superficiem lauisset, creuissentque riui, Terges, qui ad confluentes Cobrin recipit, etiam usque ad Anam aquas infectas pertulit.

Id nos in Vincentio Martyre hisce carminibus breuiter adnotauimus:

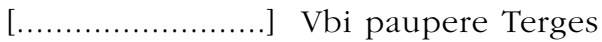

Flumine, ab Orichio segnis delabitur agro,

Excepti cecidere duces, fusaeque cohortes

Barbaricae. Ac tellus tanto est imbuta cruore,

Vt postquam pluuiae caedem elauere, pigerque

Riuus iit, contage sua, quacumque meabat,

Polluerit spatium late, fluctusque petitos

Funestarit Anae, torrens inglorius ante,

Atque uaporatis aestu Quintilibus impar.

Post illa, indigenis factus de clade superbi

Nobilis Ismarii. 
[215] Afonso, o novo rei, portanto, ficou nos arraiais durante três dias conforme era hábito dos vencedores, tendo deixado o despojo para os soldados.

Ele próprio, que até então usava um escudo branco, imaginou insígnias que representassem o combate que ali se passou. Em primeiro lugar, porque no ar olhara para Cristo pregado na cruz, desenhou no escudo de prata uma cruz da cor do céu; depois, porque tinha vencido cinco reis, separou com a própria cruz cinco escudos; em cada um destes representou trinta moedas de prata, porque se considerara que por essa soma fora vendido o Salvador do mundo.

O desenho das moedas foi modificado por uma questão de comodidade pelos reis que se seguiram e em cada um destes escudos foram colocadas cinco moedas em forma de cruz, aproximadamente com a forma da letra $\mathrm{X}$, de maneira que, contando duas vezes o que está no meio e como a conta é feita desde cima e de lado a lado, se perfaz o número trinta.

Foram estas as insígnias que naquele momento e naquele lugar se adoptaram. Quanto aos sete castelos que no campo rubro do escudo régio rodeiam as orlas, relacionam-se com outra história.

Expusemos, com toda a brevidade possível, o início e a causa [216] dos nossos reis e do reino há 434 anos. Com efeito, a batalha travou-se, segundo informam os meus velhos anais, na era de 1177 e, se a este número se retirarem 38 anos, ficará o ano de 1139 da era cristã. Como quando eu contava isto se estava em 1573, verse-á, fazendo a conta, que decorreram os 434 anos a que me referi ${ }^{83}$.

\section{Sobre o Arco Elevado pelo Rei D. Sebastião NO LOCAL DA VITÓRIA}

Já teria partido de Ourique se não fosse pena deixar por mencionar o que o nosso rei D. Sebastião ainda há pouco fez. Foi ele, no início deste ano, ao reino do Algarve para observar com os seus próprios olhos como estavam fortificadas as cidades marítimas. E se algo, segundo o seu juízo exactíssimo e segundo o conselho dos peritos militares, parecia faltar para a defesa, na sua presença se completava, renovava ou corrigia.

Ora, fazendo caminho por Campo de Ourique e percorrendo todos os locais da memorável vitória, [217] não encontrou ali erigido nenhum troféu nem nenhuma inscrição, mas apenas aquela ermida de construção grosseira, mais de uma vez reparada, que era contudo objecto de culto dos camponeses. Envergonhou-o aquele descuido e indiferença dos séculos anteriores. Merece no entanto ser desculpada a época daqueles homens que passavam a vida em contínuas guerras e que tinham as mãos direitas mais prontas para combater do que talentos inclinados para as letras, nesses tempos como que sepultadas. Não é, porém, de admirar tão longo esquecimento, visto que depois floresceram as artes e renasceu a filologia, senão que 
[215] Alphonsus igitur nouus rex, consueto uictoribus more in castris triduo permansit, et concessa militibus praeda, ipse qui eatenus niueo scuto utebatur, insignia commentus est, quae rem ibi gestam designarent. Ac primum, quia Christum in aere cruci subfixum conspexerat, in argenteo scuto caeruleam crucem formauit. Deinde quod quinque reges uicisset, scuta quinque per ipsam crucem distinxit. In unoquoque triginta numos argenteos figurauit, quod totidem mundi Seruator uenditus exstitisset.

Mutata a posteris regibus numorum figuratio est, commodiori ratione, et in singulis quibusque scutis, singuli quinque numi positi, decussatim, ad figuram litterae $\mathrm{X}$ bis numerato, quod in medio est, et quum a summo deorsum, et quum a latere ad latus fit supputatio, ut numerus triginta expleatur.

Haec tum ibi sumpta insignia. Castella uero aurea septem, quae in rubro campo scuti regii oras ambiunt, ad alterius historiae tractationem pertinent.

Exposuimus, quanta potuimus breuitate, regum nostrorum, regnique $[\mathbf{2 1 6}$ initium, et causam, ab hinc annos quadringentos triginta quattuor. Gesta enim res est, ut mei ueteres annales habent, aera millesima centesima septuagesima septima. Cui annorum numero si demantur triginta et octo, manebit Seruatoris annus millesimus centesimus trigesimus nonus. Quum haec proderem, agebatur annus MDLXXIII. Subducta ergo ad calculos ratione apparebit, interfluxisse quadringentos triginta quattuor, quos dixi, annos.

De arcv exstrvcto a Sebastiano Rege

IN VICTORIAE LOCO

Iam discessissem ab Orichio, nisi piaculum esset regis nostri Sebastiani recens factum non commemorare. Is initio huius anni Algarbii regnum adiit, ut oppida omnia maritima, quam munita essent, suis oculis perspiceret. Et siquid ad munimentum deesse uideretur exactissimo suo iudicio, et rei bellicae peritorum consilio praesens uel suppleret, uel nouaret, uel corrigeret.

Fecit autem iter per Orichiensem agrum, et uictoriae memorabilis loca omnia perlustrauit. [217] Nullum ibi erectum trophaeum, nullam inscriptionem, tantum sacellum illud ignobili fabrica, non semel refectum, rusticorum tamen cultu religiosum reperit. Puduit illum incuriae ac socordiae seculi superioris.

Atqui, ut excusari mereatur aetas hominum illorum qui in continuis bellis uitam agebant, et promptiores ad proeliandum dextras habebant, quam ad litteras illa tempestate sepultas, inclinatiora ingenia; non tamen miranda non est, florentibus postea rebus, et renata Philologia, obliuio tam diuturna; nisi 
a Natureza assim tenha decidido para que as coisas que são óptimas não apareçam todas juntas, mas com intervalos de tempo.

Por isso D. Sebastião, tomado de grande piedade e com o objectivo de fazer reviver a lembrança, não só da aparição de Cristo como da célebre vitória do maior dos reis, deu instruções para que, depois de demolida a velha ermida, se edificasse uma igreja e, depois de levantado o arco comemorativo, confiou-me a composição de uma inscrição de modo a que numa parte se lesse em latim [218] e na outra em língua portuguesa.

A parte latina [que aqui traduzimos em português] tem assim:

Aqui pelo exército foi aclamado primeiro rei de Portugal

AFONSO HENRIQUES QUANDO IA COMBATER ISMAR

E QUATRO OUTROS REIS SARRACENOS ACOMPANHADOS

DE INUMERÁVEL MULTIDÃo DE BÁRBAROS. FoI EXORTAdo

POR APARIÇÃO DE CRISTO CRUCIFICADO A AGIR CORAJOSAMENTE.

COM UM PEQUENO CONTINGENTE CAUSOU TÃo GRANDE MORTANDADE

nos inimigos, Que os CONfluentes dos Rios Cobre E Terges

com o sangue saíram dos leitos. Para Que, no local onde SE Deu,

NÃO CAÍsSE NO ESQUECIMENTO, POR FALTA DE VISITANTES,

o grande e admirável feito, D. Sebastião i, rei de Portugal,

ADMIRADOR DA CORAGEM GUERREIRA E DIVULGADOR

DA GLÓRIA DOS SEUS MAIORES, MANDOU REAVIVAR A LEMBRANÇA

AO ERIGIR ESTA INSCRIÇÃO ${ }^{84}$.

[219]

\section{COLA}

Cola existiu mais a interior, no meio da província de Ourique, não longe de Messejana, entre colinas. Não sei se terá vindo das colinas o seu actual nome ${ }^{85}$. Era um ópido de certa importância de que subsistem muralhas e torres em argamassa não muito perfeita. O acesso é dificílimo mas vantajoso para a defesa. Não é habitada, apenas aos domingos e noutros dias solenes os camponeses da vizinhança afluem ali, à igreja dedicada à Virgem, mãe de Cristo, onde um sacerdote nesses dias sacrifica nos altares.

No ângulo da torre meio destruída existe uma bonita mesa de mármore, onde está escrito: 
quod Natura comparatum ita est, ut quae optima sunt, non omnia simul, sed per temporum interualla emergant.

Sebastianus igitur mira pietate affectus, ut et apparitionis Christi, et regis maximi, inclitaeque uictoriae memoriam rediuiuam faceret, diruto ueteri sacello, templum inaedificari praecepit, atque exstructo nobili arcu, mihi inscriptionem curam demandauit, ita ut altera ex parte Latine, ex altera [218] Lusitano idiomate legeretur.

Latina sic habet:

HeIC CONTRa Ismarivm, QUATVORQUe Alios SARACENORVM REGES, INNVMERAMQVE BARBARORVM MVLTITVDINEM PVGNATVRVS FELIX ALPHONSVS HENRICVS AB EXERCITV PRImvs Lvsitaniae Rex adpellatvs est, et a Christo, QVi EI CRVCIFIXVS ADPARVIT AD FORTITER AGENDVM COMMONITVS, COPIIS EXIGVIS TANTAM HOSTIVM STRAGEM EDIDIT, VT COBRIS, AC TERGis FLVVIORVM CONFLVENTES CRVORE INVNDARINT. INGENTIS, AC STVPENDAE REI, NE IN LOCO, VBI GESTA EST, PER INFREQVENTIAM OBSOLESCERET, SEBASTIANVS I. LVSITANIAE REX, BELLICAE VIRTVTIS ADMIRATOR, ET MAIORVM SVORVM GLORIAE PROPAGATOR, ERECTO TITVLO MEMORIAM RENOVAVIT.

[219]

\section{DE COLLA}

Colla fuit interius in media Orichiensi prouincia, non procul a Messagena inter colles, nec scio an hodiernum nomen hoc inde traxerit. Non mediocre erat oppidum. Extant muri et turres caementicio opere, neque satis polito. Aditus perdifficilis est et ad defensionem accommodatus. Non habitatur. Tantum dominicis et solemnibus aliis diebus rusticorum uicinia eo confluit, ad templum Virgini Christi matri dicatum, ubi sacerdos iisdem diebus sacris altaribus operatur.

In angulo turris semidirutae mensa elegans marmorea: 
$[\mathbf{2 2 0}]$

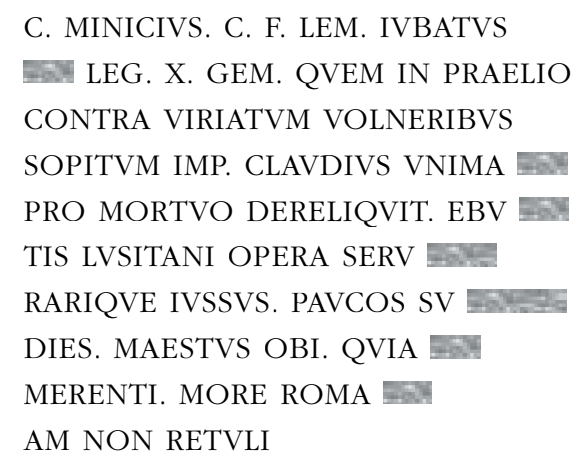

Isto é: Gaio Minúcio Jubato, filbo de Gaio, da tribo Lemónia, tribuno da décima legião Gémea, que o general Cláudio Unímano abandonou desmaiado pelas feridas como se estivesse morto. Fui recolbido pelos cuidados do soldado lusitano Ebúcio e até levado a curar-me mas poucos dias sobrevivi. Morri desgostoso porque não testemunhei reconbecimento ao benfeitor segundo o costume romano ${ }^{86}$.

[221] Junto às portas da igreja, entre colunas caídas, está um enorme cipo, ali colocado outrora por motivo da ornamentação, que durante três horas me ocupou até à saciedade. Foi tão maltratado pela gente bárbara, que perdi completamente a esperança de perceber o sentido completo. Nele é representada uma ave semelhante ao gaio e outra parecida olhando-se mutuamente, e está escrito:

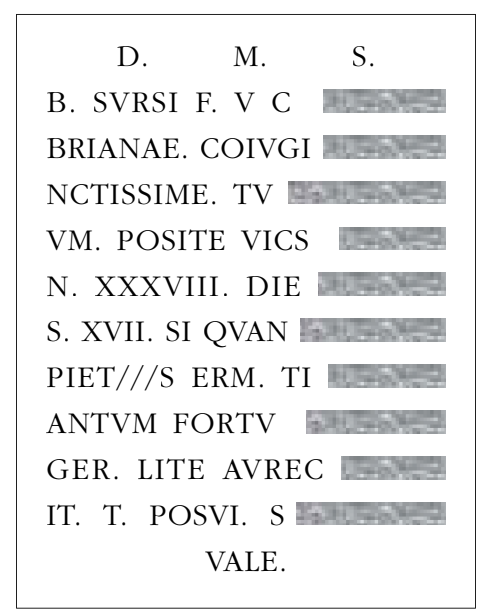

[222] Isto é: Consagrado aos deuses Manes. Balbo, filho de Surso, elevou um túmulo para sua mulher virtuosíssima que viveu 38 anos e 17 dias ${ }^{87}$. 

C. MINICIVS. C. F. LEM. IVBATVS
EN LEG. X. GEM. QVEM IN PRAELIO
CONTRA VIRIATVM VOLNERIBVS
SOPITVM IMP. CLAVDIVS VNIMA
PRO MORTVO DERELIQVIT. EBV
TIS LVSITANI OPERA SERV
RARIQVE IVSSVS. PAVCOS SV
DIES. MAESTVS OBI. QVIA
MERENTI. MORE ROMA
AM NON RETVLI

Hoc est: Caius Minicius Cai filius Lemonia Iubatus Tribunus legionis decimae Geminae, quem in proelio contra Viriatum uulneribus sopitum imperator Claudius Vnimanus pro mortuo dereliquit, Ebutii militis Lusitani opera seruatus, curarique iussus, paucos superuixi dies, maestus obii, quia benemerenti more Romano gratiam non retuli.

[221] Ab ianuam templi ingens cippus est, inter columnas ibi iacentes olim ornatus causa positus, qui me amplius horis tribus ad fastidium detinuit. Tam male a barbaris hominibus habitus est, ut spem percipiendi integre sensum plane deposuerim.

Auis in modum gracculi, altera similis mutuo se respicientes.

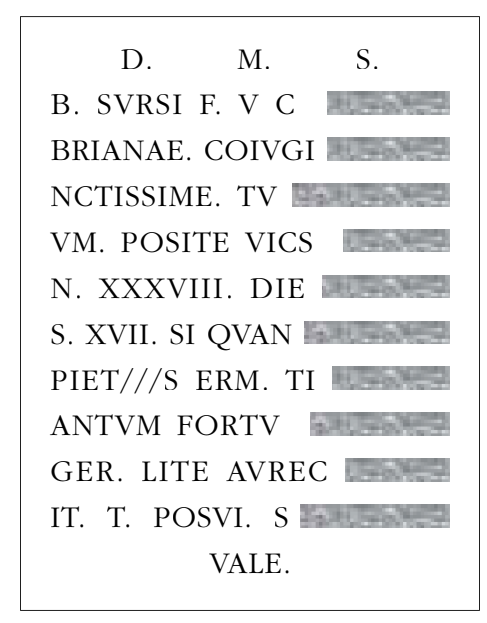

[222] Hoc est : Diis Manibus sacrum. Bolbus Sursi filius coniugi sanctissimae tumulum posuit. Vixit annos triginta octo dies septendecim. 


\section{SINES}

Não é de esquecer o ópido marítimo de Sines, não pouco útil, pela pesca, à região vizinha.

Existe aí, na igreja, um cipo quebrado com estas letras, onde está escrito:

AN. L. CLAVD.
THALASSINVS
MARITE ME-
RENTISSIME
H. S. E. S. T. T. L

Isto é: Aqui jaz ... de cinquenta anos, Cláudio Talassino, à esposa tão cheia de merecimento. Que a terra te seja leve ${ }^{88}$.

[223] No chão, junto à muralha e já coberto pelo entulho, há a seguinte inscrição:

D. M. S.

FVLVIVS. L. F. QVIN

TIANVS FABER

MATERIARIVS

PIVS IN SVOS

VIXIT ANN. XLVI.

RVBRIA Q. F. SER

GILLA. MEROBR.

MARITO B. M. FEC.

H. S. E. S. T. T. L.

Isto é: Consagrado aos deuses Manes. Aqui jaz Fúlvio Quinciano, filho de Lúcio, carpinteiro, devotado aos seus. Viveu 46 anos. Rúbria Sergila, filha de Quinto, Merobrigense, fez para o marido merecedor. Que a terra te seja leve ${ }^{89}$.

[224] Em determinada torre, está escrito:

D. M. S.
IVLIA. C. FIL.
MARCELLIN
A. AN. XXX.
H. S. E. S. T. T. L.




\section{DE SINI}

Non omittenda Sinis est, maritimum oppidum, et propter piscationem non parum uicinae regioni conducibile.

Ibi in templo cippus fractus est cum his litteris:

AN. L. CLAVD.
THALASSINVS
MARITE ME-
RENTISSIME
H. S. E. S. T. T. L

Hoc est: Annorum quinquaginta, Claudius Thalassinus marite merentissime, bic situs est, sit tibi terra leuis.

[223] Per murum, iuxta terram, et quasi iam ruderibus coopertum:

\begin{tabular}{|l|}
\hline D. M. S. \\
FVLVIVS. L. F. QVIN \\
TIANVS FABER \\
MATERIARIVS \\
PIVS IN SVOS \\
VIXIT ANN. XLVI. \\
RVBRIA Q. F. SER \\
GILLA. MEROBR. \\
MARITO B. M. FEC. \\
H. S. E. S. T. T. L. \\
\hline
\end{tabular}

Hoc est: Diis Manibus sacrum. Fuluius Lucii filius Quintianus faber materiarius, pius in suos uixit annos quadraginta sex. Rubria Quinti filia Sergilla Merobrigensis marito benemerenti fecit, hic situs est, sit tibi terra leuis.

[224] In quadam turri:

D. M. S.
IVLIA. C. FIL.
MARCELLIN
A. AN. XXX.
H. S. E. S. T. T. L.


Isto é: Consagrado aos deuses Manes. Aqui jaz Júlia Marcelina, filha de Gaio, de 30 anos. Que a terra te seja leve ${ }^{90}$.

\section{ELVAS}

Recordei no livro primeiro ${ }^{91}$ que a cidade de Elvas se situava entre os Cél-ticos, nossos compatriotas. Deve o nome aos Hélvios, povo da Gália Céltica que habitava entre o Garona e o Loire e de quem se ocupa Estrabão no livro quarto ${ }^{92}$. Plínio93 chama à sua cidade Alba. Assim, a partir dos Hélvios, povo de raça céltica que outrora, no meio de outros Celtas, veio até nós, [225] foi a cidade designada de Elvas conservando ainda hoje o nome que recebeu dos fundadores.

A cidade, assim como não é a última em fertilidade do solo nem em renome dos cidadãos, do mesmo modo tem sem discussão o primeiro lugar, na boa qualidade do azeite. Pertenceu até agora à diocese de Évora mas, por intervenção do rei D. Sebastião, obteve a dignidade episcopal, mas nem por isso deixou de reconhecer a metrópole de que se separou.

Nela não existem muitos monumentos romanos, e os que há encontrei-os como estão, pessimamente tratados por bárbaros.

Junto à porta do forte a que chamam alcáçova, um fragmento diz-nos:

FEL. CEPAL

ONIS. F. SE

VERVS. AN

Isto é: Félix Severo, filho de Cepalão, de ...anos ${ }^{94}$.

[226] Na casa de um fidalgo, numa bela placa, está escrito:

C. AXONIVS. Q. F. PAP. LEG. XX. NAT. COL.

FIR. PICENO. SE VIVO

MONIMENT. FEC. SIBI. ET

FR. Q. AX. Q. F.

Gaio Axónio, filbo de Quinto, da tribo Papíria, da vigésima legião, natural da colónia Fírmica no Piceno, fez, enquanto vivo, este monumento para si e para o irmão Quinto Axónio, filbo de Quinto ${ }^{95}$. 
Hoc est: Diis Manibus sacrum. Iulia Cai filia Marcellina annorum triginta, bic sita est, sit tibi terra leuis.

\section{DE HELVIS}

Primo libro admonuimus urbem Heluas in Celticis nostratibus esse. Nomen accepit ab Heluis Celticae Galliae populis, inter Garumnam et Ligerim habitantibus. De quibus quarto libro Strabo agit. Plinius Albam eorum ciuitatem nominat.

Ab Heluis igitur Celtarum populis, qui inter Celtas olim ad nos [225] uenere, Heluae ciuitas nominata, quod nomen a conditoribus obtinuit, etiam hodie retinet. Vrbs fertilitate soli et nobilitate ciuium, ut postremas non fert, ita olei bonitate sine controuersia primas obtinet. Dioecesis Eborensis hactenus fuerat, uerum agente Sebastiano rege, episcopalem dignitatem adepta, metropolim, unde excisa est, nihilominus agnoscit. Non multa ibi sunt Romanorum monumenta, et quae sunt, pessime a barbaris habita, ita inueni.

Iuxta portam arcis, quam Alcassauam uocant, fragmentum:

FEL. CEPAL

ONIS. F. SE

VERVS. AN

Hoc est: Felix Cepalonis filius Seuerus annorum.

[226] In domo cuiusdam uiri nobilis, tabula elegans:

C. AXONIVS. Q. F. PAP. LEG. XX. NAT. COL.

FIR. PICENO. SE VIVO

MONIMENT. FEC. SIBI. ET

FR. Q. AX. Q. F.

Hoc est: Caius Axonius Quinti filius Papiria legionis uigesimae natus Coloniae Firmicae Piceno se uiuo monimentum fecit sibi et fratrei Quinto Axonio, Quinti filio. 
Junto ao convento de freiras da regra de S. Domingos, num cipo, pode ler-se:

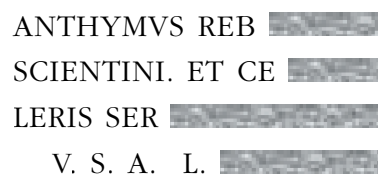

[227] Isto é: Antimo, escravo de Reburro Cientino e de Celere, de boa vontade cumpriu o voto 96 .

No campo a que chamam da Ventosa está uma lápide oblonga, ou seja, de sete côvados para côvado e meio de largura, tosca e rugosa, que se diz ser o sepulcro de Beltrão, um dos doze pares de França. Nela está escrito:

\begin{tabular}{|c|}
\hline CACALO \\
AVIOLI \\
LIB. \\
HIC \\
SIT. \\
\hline
\end{tabular}

Isto é: A Cacalo. Aqui jaz o liberto de Avioli ${ }^{97}$.

[228] Tenho em minha casa uma placa de mármore partida, gravada com letra elegante:

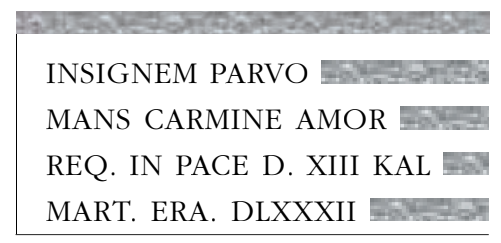

Isto é: Para que sempre eu exprima num pequeno poema um amor que há-de perdurar. Descansou na paz do Senhor no $13 .^{\circ}$ dia das Calendas de Março da era 58298 .

\section{VILA VIÇOSA}

Apresenta-se, a quem vem de Elvas, uma nobilíssima cidade, residência dos Duques de Bragança, que um idiotismo português denominou, devido à sua beleza, de Vila 
Iuxta parthenonem Virginum instituti diui Dominici cippus:

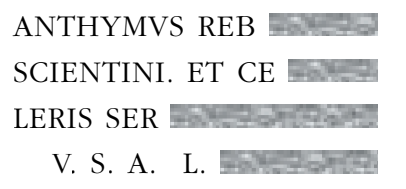

[227] Hoc est: Anthymus Reburri Scientini et Celeris seruus uotum soluit animo libenti, uel libens.

In agro quem uocant Ventosae, lapis, oblongus, uidelicet cubitorum septem, latus cubitum et semissem, rudis atque impolitus, quem fabulantur sepulchrum esse Bertrandi, unius ex duodecim Franciae paribus.

\begin{tabular}{|c|}
\hline CACALO \\
AVIOLI \\
LIB. \\
HIC \\
SIT. \\
\hline
\end{tabular}

Hoc est: Cacalo Auioli libertus bic situs.

[228] In domo tabula marmorea fracta, eleganti littera:

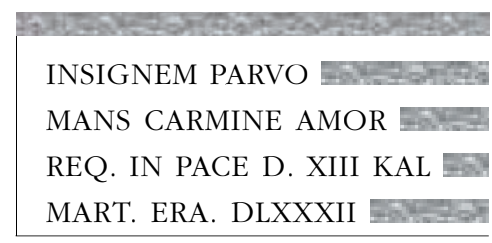

Hoc est: Insignem paruo mansurum carmine amorem requieuit in pace Domini decimo tertio Kalendas Martias, era quingentesima octogesima secunda.

\section{VILLA VIZOSA}

Ab Heluis digredientem intercipit nobillissimum oppidum, Brigantii ducum sedes, quod ab amoenitate Lusitanus idiotismus Villam Vizosam nominauit. 
Viçosa. Não é possível dizer-se com um só nome latino. A não ser que imaginemos em grego, Calípole, exemplo ousado mas que de modo algum desagradará aos leitores depois de terem ouvido com assiduidade esta palavra. Existiu aí, nos arredores, onde actualmente se encontra a igreja de Santiago, um santuário de Prosérpina. Encontrei lá estes monumentos, onde está escrito:

[229]

\begin{tabular}{|l|}
\hline PROSER \\
PINAE \\
SANCTAE \\
G. IVLIVS \\
PARTHENOP \\
AEVS. VOT. \\
QVOT FECIT \\
A. L. P. \\
\hline
\end{tabular}

Isto é: A Prosérpina Sagrada. Gaio Júlio Partenopeio, cumpriu de bom grado o voto que fizera ${ }^{99}$.

[230]

Q. HELVIVS
SILVANVS
PROSERPIN
AE VOTVM
S. AN. L. P.

Isto é: Quinto Hélvio Silvano, cumprindo um voto a Prosérpina, levantou [este monumento] de boa vontade ${ }^{100}$.

P ROSERPINAE
SERVATRICI
C. VETTIVS SIL
VINVS. PRO EV
NOIDE PLAVTIL
LA CONIVGE SIBI
RESTITVTA
V. S. A. L. P.

Isto é: A Prosérpina Salvadora. Gaio Vétio Silvino, cumprindo uma promessa por sua mulher, Eunóide Plautila que lhe foi restituída, levantou [este monumento] de boa vontade ${ }^{101}$. 
Vno nomine Latine dici non potest, nisi Callipolin Graece confingamus, audaci fortassis exemplo, sed lectoribus postquam ea uox assiduitate percrebuerit, minime displicituro. Proserpinae ibi delubrum fuit, ubi modo Diui Iacobi aedes est, in suburbio, ubi haec inueni monumenta:

\section{[229]}

\begin{tabular}{|l|}
\hline PROSER \\
PINAE \\
SANCTAE \\
G. IVLIVS \\
PARTHENOP \\
AEVS. VOT. \\
QVOT FECIT \\
A. L. P. \\
\hline
\end{tabular}

Hoc est: Proserpinae sanctae Caius Iulius Parthenopaeus uota quot fecit animo libenti posuit.

[230]

$$
\begin{aligned}
& \text { Q. HELVIVS } \\
& \text { SILVANVS } \\
& \text { PROSERPIN } \\
& \text { AE VOTVM } \\
& \text { S. AN. L. P. }
\end{aligned}
$$

Hoc est: Quintus Heluius Siluanus Proserpinae uotum soluens animo libens posuit.

PROSERPINAE
SERVATRICI
C. VETTIVS SIL
VINVS. PRO EV
NOIDE PLAVTIL
LA CONIVGE SIBI
RESTITVTA
V. S. A. L. P.

Hoc est: Proserpinae Seruatrici Caius Vettius Siluinus pro Eunoide Plautilla coniuge sibi restituta uotum soluens animo libens posuit. 


\section{[231]}

D. M. S.
PVLTARIVS
AN. XXIII. H. S. E. S. T. T. L.
SEMNE. ET. SEMN
MATRI POSVERVNT.

Isto é: Consagrado aos deuses Manes. Aqui jaz Pultário de 23 anos. Que a terra te seja leve. Semne e Semnine dedicaram à mãe ${ }^{102}$.

Também aí se vêem agora inscrições a Endovélico, que o muito ilustre Duque Teodósio mandou trazer do antigo templo que existe junto ao pequeno castelo de Terena e inserir no frontispício do convento de frades da ordem de St. ${ }^{\circ}$ Agostinho. Rezam elas assim:

[232]

\begin{tabular}{|l|}
\hline DEO. ENDOVEL \\
LICO. PRAESTAN \\
TISSIMI. ET PRAESEN \\
TISSIMI NVMINIS \\
SEXTVS. COCCEIVS \\
CRATERVS. HONORI \\
NVS. EQVES. ROMA \\
NVS EX. VOTO. \\
\hline
\end{tabular}

[Isto é: Ao Deus Endovélico, de sempre auxiliador e sempre presente, Sexto Coceio Cratero Honorino, cavaleiro romano, por voto] ${ }^{103}$.

Num cipo quebrado está escrito:

ENDOVELLICO

ALBIA

IANVARIA.

[Isto é: A Endovélico, Álbia Januária...] $]^{104}$. 


\section{$[\mathbf{2 3 1}]$}

D. M. S.

PVLTARIVS

AN. XXIII. H. S. E. S. T. T. L.

SEMNE. ET. SEMN

MATRI POSVERVNT.

Hoc est: Diis Manibus sacrum. Pultarius annorum uiginti trium, bic situs est, sit tibi terra leuis. Semne et Semnine matri posuerunt.

Ibi etiam modo uisuntur inscriptiones Endouellici, quas clarissimus dux Theodosius ex antiquo fano, quod extat iusta oppidulum Therennam, asportari curauit et inseri in frontispicio coenobii Fratrum Ordinis Diui Augustini. Sunt autem huiusmodi:

$[\mathbf{2 3 2}]$

DEO. ENDOVEL

LICO. PRAESTAN

TISSIMI. ET PRAESEN

TISSIMI NVMINIS

SEXTVS. COCCEIVS

CRATERVS. HONORI

NVS. EQVES. ROMA

NVS EX. VOTO.

Cippus fractus:

ENDOVELLICO

ALBIA

IANVARIA. 


\section{[233]}

\section{ENDOVELLICO \\ SACRVM. MAR \\ CVS. IVLIVS. \\ PROCVLVS \\ ANIMO. LI \\ BENS. VOTVM \\ SOLVIT.}

[Isto é: Consagrado a Endovélico, Marco Júlio Próculo pagou a sua promessa de bom grado] $^{105}$.

\section{[234]}

DEO. ENDOVELLICO. SAC.

IVNIA. ELIANA. VOTO. SVCCEPTO

ELVIA. YBAS. MATER. FILIE

SVAE. VOTVM. SVCCEPTVM.

ANIMO. LIBENS. POSVIT.

[Isto é: Consagrado ao deus Endovélico. Júnia Eliana por ter feito promessa. Élvia Ibas, a mãe, cumpriu de boa vontade a promessa feita por sua filha] ${ }^{106}$.

Estas inscrições são de tal modo simples que não carecem de especial leitura. Outras dizem:

D. ENDOVELLICO. SA.

AD RELICTICIVM. EX

T. NVMIN. ARRIVS. BA

DIOLVS. A. L. F.

Isto é: Consagrado ao deus Endovélico, para a posteridade e por testamento levantou de boa vontade à divindade, Árrio Badiolo ${ }^{107}$. 


\section{[233]}

$$
\begin{aligned}
& \text { ENDOVELLICO } \\
& \text { SACRVM. MAR } \\
& \text { CVS. IVLIVS. } \\
& \text { PROCVLVS } \\
& \text { ANIMO. LI } \\
& \text { BENS. VOTVM } \\
& \text { SOLVIT. }
\end{aligned}
$$

[234]

DEO. ENDOVELLICO. SAC.

IVNIA. ELIANA. VOTO. SVCCEPTO

ELVIA. YBAS. MATER. FILIE

SVAE. VOTVM. SVCCEPTVM.

ANIMO. LIBENS. POSVIT.

Hae inscriptiones adeo clarae sunt, ut expositione non indigeant.

D. ENDOVELLICO. SA.

AD RELICTICIVM. EX

T. NVMIN. ARRIVS. BA

DIOLVS. A. L. F.

Hoc est: Deo Endouellico sacrum ad relicticium ex testamento numini Arrius Badiolus animo libens fecit. 
[235]

Q. SEVIVS. Q. F. PAP. FIRMANVS

VOTVM DEO

ENDOVELLICO

S. L. M.

Isto é: Quinto Sévio Firmano, filho de Quinto, da tribo Papíria, cumpriu de boa vontade a promessa ao deus Endovélico ${ }^{108 .}$

\section{ENDOVELLICO \\ CRITONIA \\ MAXVMA \\ EX. VOTO. PRO \\ CRITONIA. C. F.}

Isto é: [A Endovélico, Critónia Máxima,] mandou fazer [em cumprimento duma promessa a favor de Critónia] ${ }^{109}$.

[236] O cipo que se segue foi levado daqui para o castelo do ópido do Alandroal onde agora se encontra. Diz assim:

\begin{tabular}{|l|}
\hline C. IVLIVS. NOVATVS \\
ENDOVELLICO \\
PRO. SALVTE \\
VIVENNIAE \\
VENVSTAE \\
MANILIAE SVAE. \\
VOTVM. SOLVIT. \\
\hline
\end{tabular}

[Isto é: Gaio Júlio Novato, para a sua promessa a Endovélico, pela saúde da sua Vivénia Venusta Manília] $]^{110}$.

A causa ou origem do nome Endovélico ${ }^{111}$, ignoro-a completamente. A não ser que o nome lhe tenha sido dado por causa de uma povoação próxima que acaso se chamasse Endovélia. Se na época nebulosa do infeliz paganismo os Lusitanos foram dados a superstições, pelo menos ao brilhar a luz evangélica não demoraram muito tempo que não abraçassem o culto e a religião do verdadeiro Deus.

Os Eborenses glorificam-se de Mâncio, discípulo de Cristo que os iniciou na doutrina celeste ${ }^{112}$. [237] Os Bracarenses devem-no a Pedro de Rates, discípulo do 


\title{
[235]
}

Q. SEVIVS. Q. F. PAP. FIRMANVS

VOTVM DEO

ENDOVELLICO

S. L. M.

Hoc est: Quintus Seuius Quinti filius Papiria Firmanus uotum Deo Endouelico soluit libens merito.

\author{
ENDOVELLICO \\ CRITONIA \\ MAXVMA \\ EX. VOTO. PRO \\ CRITONIA. C. F.
}

Hoc est: Curauit faciendum.

[236] Hic cippus allatus est, illinc ad arcem oppidi Lendroalis, ubi nunc extat:

C. IVLIVS. NOVATVS
ENDOVELLICO
PRO. SALVTE
VIVENNIAE
VENVSTAE
MANILIAE SVAE.
VOTVM. SOLVIT.

Nominis Endouellici causam aut originem ego penitus ignoro. Nisi si ab oppido propinquo, quod Endouellia forte diceretur, nomen esset impositum. Quod si nebuloso infelicis gentilitatis aeuo superstitionibus addicti Lusitani fuere, certe euangelica luce radiante morati diu non sunt, quin ueri Dei cultum, et religionem amplecterentur.

Mancio Christi discipulo gloriantur Eborenses, a quo caelesti doctrina sunt initiati. [237] Debent hoc Bracarenses Petro Ratensi, Apostoli Iacobi discipulo. 
apóstolo Tiago ${ }^{113}$. A religião propagou-se em pouco tempo e, mesmo sem assentimento dos déspotas, cresceu com admirável piedade. A nação portuguesa conservou-a até à nossa época incorrupta, tal como a recebeu dos santos padres. Além disso, facto que não sem grande dom de Deus nos acontece e que não sem grande prazer refiro, mantém a religião incólume e com a autoridade da sacrossanta cadeira apostólica intacta. E não apenas isto como ainda não deixa de propagar o próprio nome do Salvador longamente e largamente pelos recantos do vasto oceano, por lugares nunca antes conhecidos dos predecessores, por todo o Oriente e antípodas.

[238]

D. M. S.
P. PETRONI
VS CAVTIN
ANN. LXXXXI
LAVDICE
MARITO PIIS
SIMO POSVIT

H. S. E. S. T. T. L.

Isto é: Consagrado aos deuses Manes. Aqui jaz Públio Petrónio Gautinense, de noventa e um anos. Laudice levantou ao marido, exemplo de piedade. Que a terra te seja leve ${ }^{114}$.

\section{O TEMPLO DE JÚPITER}

Sobre o rio Xarrama, 2 mil passos abaixo da vila de Torrão, existiu outrora um templo de Júpiter. Este foi transformado, quando a fé cristã já fortalecera, na igreja dos santos mártires Justo e Pastor. Falei a este respeito no opúsculo a Ambrósio Morales $^{115}$ de Alcalá de Henares, homem que merece ser nomeado nestas notas entre outras razões pela sua brilhante erudição.

[239] Sobre a porta do templo está uma inscrição do tempo dos Godos, que significa:

HVNC DENIQVE EDIFI
CIVM SANCTORVM NO
MINE CEPTVM IVSTI ET
PASTORIS MARTIRVM
QVORVM CONSTAT ESSE
SACRATVM CONSVMA
TVM EST OC OPVS ERA
DCCXX.


Propagata breui religio est, et inuitis tyrannis mira pietate adoleuit. Quam natio Lusitana incorruptam, ut a Sanctis Patribus accepit, ad nostra haec tempora custodiuit. Et quod non sine magno Dei munere nobis contigit, nec sine magna mea uoluptate refero, quassantibus orbem sectis, incolumi religione, integraque sacrosanctae Apostolicae Sedis auctoritate perseuerat. Nec solum id, sed longe lateque etiam per uasti Oceani recessus, et ante nunquam prioribus cognitas regiones, orientemque totum, et antipodas, ipsum Seruatoris nomen propagare non cessat.

[238]

D. M. S.

P. PETRONI

VS CAVTIN

ANN. LXXXXI

LAVDICE

MARITO PIIS

SIMO POSVIT

H. S. E. S. T. T. L.

Hoc est.: Diis Manibus sacrum. Publius Petronius Cautinensis annorum nonaginta unius. Laudice marito piissimo posuit; bic situs est, sit tibi terra leuis.

\section{DE IOVIS FANO}

Super Exarramam fluuium, duobus pass. millibus infra Terranum oppidum, Iouis fuit olim fanum. Quod adulta iam Christiana pietate in templum sanctorum martyrum Iusti et Pastoris conuersum est. De quo egi in libello ad Ambrosium Moralem Complutensem, uirum saepe alias, luculentae eruditionis gratia, in his commentariis nominandum.

[239] Supra ianuam templi Gothica inscriptio:

$$
\begin{aligned}
& \text { HVNC DENIQVE EDIFI } \\
& \text { CIVM SANCTORVM NO } \\
& \text { MINE CEPTVM IVSTI ET } \\
& \text { PASTORIS MARTIRVM } \\
& \text { QVORVM CONSTAT ESSE } \\
& \text { SACRATVM CONSVMA } \\
& \text { TVM EST OC OPVS ERA } \\
& \text { DCCXX. }
\end{aligned}
$$


Isto é: Este edifício iniciado em honra dos santos mártires Justo e Pastor, a quem foi dedicado, finalmente foi terminado este trabalbo na era de $720^{116}$.

$[\mathbf{2 4 0}]$

IOVI. O. M.

FLAVIA. L. F. RVFINA

EMERITENSIS. FLA

MINICA. PROVINC.

LVSITANIAE. ITEM COL.

EMERITENSIS. PERPET.

ET MVNICIPI. SALACIEN.

D. D.

Isto é: A Júpiter, Óptimo, Máximo, Flávia Rufina, filha de Lúcio, natural de Mérida, Flaminia da província da Lusitânia e assim como perpétua da colónia Emeritense e do município Salaciense por decreto dos decuriões ${ }^{117}$.

De um lado está representada uma árvore que não reconheço; do outro lado uma águia de asas abertas, como se fosse levantar voo, segurando nas garras um raio de três pontas.

[241] Um cipo bastante menor mas mais perfeito, em que está escrito:

I. O. M.

OB PVLSOSAQ. SER

TORIO METELLVM

ADQ. POMP.

IVN. DONACE

CORON. ET SCEPTRVM

EX ARG. MVNVS

ADTVLIT

FLAMINICAE PHIA

LAM CAELATAM

HIERODVLIS COE

NAM DEDIT.

Isto é: A Júpiter Óptimo e Máximo. Por terem sido escorraçados Metelo e Pompeio por Quinto Sertório, Júlia Donace trouxe, como oferenda, uma coroa e um ceptro de prata. À Flamínica ofereceu uma fíala cinzelada, aos escravos do templo, uma ceia ${ }^{118}$. 
Hoc est: Hunc (pro boc) denique aedificium sanctorum nomine ceptum Iusti et Pastoris martyrum, quorum constat esse sacratum, consumatum est oc (pro boc) opus era septingentesima uigesima.

[240]

IOVI. O. M.

FLAVIA. L. F. RVFINA

EMERITENSIS. FLA

MINICA. PROVINC.

LVSITANIAE. ITEM COL.

EMERITENSIS. PERPET.

ET MVNICIPI. SALACIEN.

D.

D.

Hoc est: Ioui optimo maximo. Flauia Lucii filia Rufina Emeritensis, Flaminica prouinciae Lusitaniae, item coloniae Emeritensis perpetua et municipii Salaciensis, dedicauit.

Ex uno latere est arbor mihi incognita, ex altero latere Aquila est expansis alis, quasi subuolatura, in unguibus trisulcum fulmen habens.

[241] Cippus aliquanto minor sed elegantior:

I. O. M.

OB PVLSOSAQ. SER

TORIO METELLVM

ADQ. POMP.

IVN. DONACE

CORON. ET SCEPTRVM

EX ARG. MVNVS

ADTVLIT

FLAMINICAE PHIA

LAM CAELATAM

HIERODVLIS COE

NAM DEDIT.

Hoc est: Ioui optimo maximo. Ob pulsos a Quinto Sertorio Metellum, atque Pompeium, Iunia Donace coronam et sceptrum ex argento munus adtulit, Flaminicae phialam caelatam, hierodulis coenam dedit. 
Outro cipo, em letra muito cuidada, diz-nos:

L. RVBRIVS

PRISCINVS

ANN. XXVI. H. S. E.

[242] Isto é: Aqui jaz Lúcio Rúbio Priscino de 26 anos 119.

Há três outros cipos mas foram postos nas paredes da igreja com as letras escondidas pelo lado de dentro.

Em Cuba, não longe de Beja, há um cipo na igreja, onde está escrito:

D. M. S.

TERENTI

VS. CRYS

OGONVS.

ANN. XXXII. H. S. E. S. T. T. L.

Isto é: Consagrado aos deuses Manes. Aqui jaz Terêncio Crisógono de 32 anos. Que a terra te seja leve ${ }^{120}$.

Na região de Ferreira, para lá do rio Calípode que já dissemos anteriormente chamar-se na nossa época Sado ou Sadão, está uma igreja dedicada a St.a Margarida, onde outrora tinha havido um santuário da Fortuna Obsequente mandado construir por Flávia Modestina, mulher do centurião Sérgio Terêncio Emiliano, [243] que, como se depreende, combatera sob as ordens de Lúcio Postúmio Albino e que licenciado e rico se recolheu ao sossego na propriedade da mulher. Deduz-se isto de dois cipos que aí se encontram, um dos quais tem o seguinte:

\begin{tabular}{|l|}
\hline FORTVNAE OBSEQVEN \\
TI. SACRVM \\
FLAVIA MODESTINA \\
PERP. EIVS ANTISTES \\
EX VOLVNTATE TEREN \\
TI. AEMILIANI VIRI \\
SVI. IN PRAEDIO \\
A PATRE FL. MODESTO \\
SALACIENSI SIBI \\
RELICTO. A. L. F. \\
\hline
\end{tabular}

Isto é: Consagrado à Fortuna Obsequente. Flávia Modestina, sacerdotiza vitalícia deste [templo] mandou fazer [este monumento] de boa vontade por desejo de seu marido Terêncio Emiliano na propriedade que lhe foi deixada pelo pai, Flávio Modesto Salaciense ${ }^{121}$. 
Alter cippus elegantissima littera:

\section{RVBRIVS}

PRISCINVS

ANN. XXVI. H. S. E.

[242] Hoc est: Lucius Rubrius Priscinus, annorum uiginti sex, bic situs est.

Sunt tres alii cippi, sed positi in parietibus templi, contectis interius litteris.

Cubae non procul a Pace Iulia in templo cippus:

D. M. S.

\section{TERENTI}

VS. CRYS

OGONVS.

ANN. XXXII. H. S. E. S. T. T. L.

Hoc est: Diis Manibus sacrum. Terentius Crysogonus, annorum triginta duorum, bic situs est, sit tibi terra leuis.

In territorio Ferrariensi, super Callipodem fluuium, quem Sadanum uocari nostra aetate superius diximus, templum Diuae Margaritae dicatum est, ubi olim Fortunae Obsequentis delubrum fuerat, a Flauia Modestina Sergii Terentii Aemiliani centurionis uxore aedificatum. [243] Qui, ut apparet, sub L. Posthumio Albino militauerat, et emeritus ac diues ad quietem se contulit, in praedio uxorio.

Hoc ex duobus ibi cippis colligitur, e quibus alter sic habet:

\begin{tabular}{|l|}
\hline FORTVNAE OBSEQVEN \\
TI. SACRVM \\
FLAVIA MODESTINA \\
PERP. EIVS ANTISTES \\
EX VOLVNTATE TEREN \\
TI. AEMILIANI VIRI \\
SVI. IN PRAEDIO \\
A PATRE FL. MODESTO \\
SALACIENSI SIBI \\
RELICTO. A. L. F.
\end{tabular}

Hoc est: Fortunae Obsequenti sacrum. Flauia Modestinae Perpetua eius antistes ex uoluntate Terentii Aemiliani uiri sui, in praedio a patre Flauio Modesto Salaciensi sibi relicto, animo libens fecit. 
[244] Quanto ao outro, partido em duas partes, tem o seguinte:

\begin{tabular}{|l|}
\hline D. M. S. \\
SERG. TERENTIV S \\
SERG. F. AEMI LIANVS. \\
CENTVR. EMER. VIX. N ESIXX. \\
ORDIN. DVX. SVB \\
L. POST EI VMIO. MODES \\
MEINA. MARITO \\
MEREN TIS S IMO \\
P. H. S. E. S. T. T. L. \\
\hline
\end{tabular}

Isto é: Consagrado aos deuses Manes. Aqui jaz Sérgio Terêncio Emiliano, filho de Sérgio, centurião licenciado. Viveu 70 anos e comandou tropas sob as ordens de Lúcio Postúmio. Modestina ao marido, muito merecedor, colocou. Que a terra te seja leve ${ }^{122}$. 
[244] Alter uero in duas partes fractus sic:

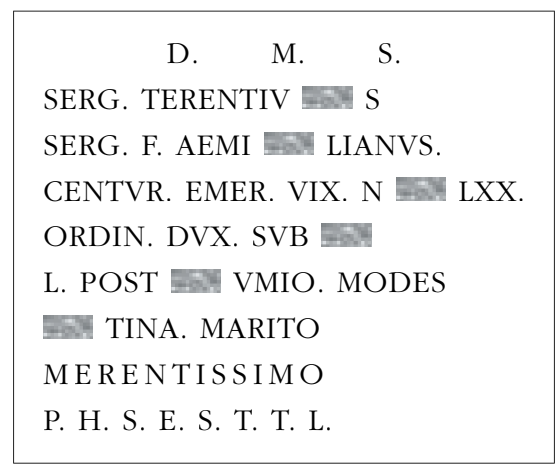

Hoc est: Diis Manibus sacrum. Sergius Terentius, Sergii filius Aemilianus, centurio emeritus, uixit annos septuaginta, ordines duxit sub Lucio Postumio. Modestina marito merentissimo posuit. Hic situs est, sit tibi terra leuis. 
(Página deixada propositadamente em branco) 
E S C Ó L I O S

S C H O L I A 


\section{E S C Ó L I O S}

$\mathrm{DE}$

\section{DIOGO MENDES DE VASCONCELOS AOS QUATRO LIVROS DE RESENDE}

Na Vida de André de Resende, na Ode a Goclénio: phosphorus igneus, ou seja a Estrela da Manhã. Cf. Marcial, livro oitavo, epigrama vigésimo primeiro, "A Lúcifer»:

Fósforo devolve-nos o dia. Por que motivo atrasas a nossa alegria? César está a chegar. Fósforo devolve-nos o dia. 


\section{S C H O L I A}

\section{IACOBI MOENETII VASCONCELLI IN QVATTVOR LIBROS RESENDII}

In Vita Andreae Resendii, in Ode ad Coclenium: "Phosphorus igneus", hoc est, Lucifer Stella. Martialis libro octauo, epigrammate uigesimo primo ad Luciferum:

Phosphore redde diem, quid gaudia nostra moraris?

Caesare uenturo, Phosphore redde diem. 


\section{$[245]$}

\section{LIVRO PRIMEIRO}

Página 92, linha 1: Plínio, no livro terceiro, primeiro capítulo, exprime-se com estas palavras: "Marco Varrão conta-nos que para toda a Hispânia chegaram os Iberos, os Persas, os Fenícios e os Cartagineses. Que Luso [divertimento] [246] do pai Líber ou Lysa [frenesim], que com ele celebravam Bacanais, tinham dado o nome à Lusitânia e que Pã era o governador de tudo isso"1.

Na mesma página, linha 6: outros interpretam Luso não como um homem, mas de preferência como "jogo" ou então "brincadeira". Marciano Capela no livro sexto, cujo título é Da Geometria, tem uma frase onde, ao tratar da Lusitânia, assim nos diz (628-629): "deu-lhe a lenda o nome tirado de Luso, filho do pai Líber e assim também associou-lhe o das Bacantes”. Acrescenta outra opinião não menos ridícula, quando crê que o rio Guadiana é denominado a partir do nome de Lusitânia e dilo com estas palavras: "Ela [Lusitânia] também é atravessada por um rio quanto ao nome, embora seja o Tejo que a ilustra devido às areias de ouro" 2 .

Na mesma página, linha 11: Não falta quem substitua Lysa por Lyssa. Foi desta opinião Segismundo Gelénio no primeiro capítulo do livro terceiro das suas Observações a Plínio $^{3}$.

Na mesma página e linha 18: "Pelo menos o autor do Pseudoberoso identificou", Cf. João Ânio no livro sobre os reis da Hispânia, capítulo vigésimo 4 .

$\mathrm{Na}$ mesma página, linha 28: "segundo afirma Cícero em certo discurso contra Verres". Na sexta acção, que começa: "Venio nunc ad istius, quemadmodum ipse appellat studium”. E não longe do fim do discurso, são estas as suas palavras: "Aristaeus qui ut Graeci ferunt, Liberi filius inuentor olei fuit 5 .

Na mesma página, linha 31: "da qual também provém o epíteto Lysio do próprio Baco, etc.”. Pausânias, na descrição da Beócia, por volta do meio do livro nono, quando descreve os antigos monumentos da cidade de Tebas, escreve assim: "próximo do teatro está o templo de Dioniso a quem dão o cognome de Libertador (Lysios). A razão do cognome é devida ao facto de que outrora os Trácios tinham levado presos vários cativos tebanos. Quando chegaram ao território de Haliárcia, Dioniso libertou-os [247] das cadeias e seguidamente entregou-lhes os Trácios para serem mortos depois de os ter dominado pelo sono". (IX, 16, 6) É isto o que ele diz. Outros, porém, julgam que deriva do facto de os espíritos se perturbarem e perderem a força, o que costuma acontecer com o excesso de vinho, ou então porque os liberta de cuidados é que Baco é assim chamado ${ }^{6}$.

Pag. 94, linha 19: Estêvão, porém, no livro sobre as cidades. Na sua versão: Belitanos. De facto nem é de admirar que Estêvão se enganasse quanto a isto, uma vez que era um escritor grego que pessoalmente nunca tinha atravessado nem a região da Hispânia, nem as suas cidades, razão do engano de outros gregos, como nos atesta Políbio. 


\section{LIBER PRIMVS}

Pag. prima, linea 2: "Asserit Plinius." Libro uidelicet tertio, capite primo, his uerbis: "In uniuersam Hispaniam Marcus Varro peruenisse Iberos, et Persas, et Phoenicas, et Poenos tradit. Lusum [246] enim Liberi patris, aut Lysam cum eo bacchantes, nomen dedisse Lusitaniae, et Pana praefectum eius uniuersae".

Eadem pag., lin. 5: “Alii Lusum, non hominem, sed 'ludum' potius, seu 'lusionem' interpretantur." Marcianus Capella libro sexto, qui De Geometria inscribitur in ea fuit sententia, ubi ita tradit agens de Lusitania: "Cui nomen fabula a Lusu Liberi patris, uel cum eo bacchantium sociauit". Addit et aliam non minus ridiculam opinionem, credens Anam fluuium a Lusitaniae uocabulo cognominari, hisce uerbis: "Haec quoque cognominis sui, fluuio permeatur, licet eam Tagus quoque arenis illustret auratis".

Eadem pag., lin. 10: "Nec desunt, qui pro Lysa, Lyssam reponant." Fuit in ea sententia Sigismundus Gelenius in Obseruationibus in Plinium libro tertio, capite primo.

Ead. pag. lin. 17: "Suppositicius Berosi auctor intellexit." Ioannes Annius in libro de regibus Hispaniae, capite uigesimo.

Eadem pag., lin. 26: "Vt in quadam contra Verrem oratione affirmat Cicero." In sexta actione, quae incipit, "Venio nunc ad istius, quemadmodum ipse appellat studium", non longe a fine orationis; eius autem uerba sunt haec: "Aristaeus, qui, ut Graeci ferunt, Liberi filius inuentor olei fuit".

Eadem pag. lin. 29: "Vnde, ipse etiam Bacchus Lysius cognominatus est." Pausanias in Boeoticis circa medium libri noni dum Thebanae urbis antiqua monimenta enarrat, ita scribit: "Theatro proxima est Liberi patris aedes cognomento Lysii. Cognominis causa, quod cum olim captiuos complures ex Thebanis uinctos Thraces abducerent, eos cum ad Haliartiorum fines uentum esset, uinculis [247] solutos dimisit, moxque illis Thracas sommo oppressos occidendos praebuit." Haec ille. Aliqui uero credunt a dissoluendis et eneruandis animis, quod ex uini copia accidere solet; uel quod curis liberos eos reddat ita Bachum fuisse appellatum.

Pag. 95, lin. 18: "Stephanus autem in libro de urbibus." In dictione "Belitani". Nec mirum est in hoc errasse Stephanum, utpote Graecum scriptorem, et qui Hispaniae situm ac urbes minime ipse peragrasset, quod alios quoque Graecos decipit, teste Polybio.

Extat etiam similis error apud eundem Stephanum in dictione "Lusitania" dum eam asserit partem esse Baeticae, cum Vlterior Hispania in duas prouincias diuisa 
Aparece um erro semelhante na obra de Estêvão na sua versão da Lusitânia, quando afirma ser ela parte da Bética, quando a Hispânia Ulterior foi dividida outrora em duas províncias, nomeadamente a Bética e a Lusitânia. Quis anteriormente advertir para este facto, a fim de evitar que a autoridade do autor pudesse enganar alguém. Também Resende chama a atenção para este assunto ${ }^{7}$.

Pag. 96, linha 14: é com efeito Estrabão, no livro terceiro, pág. $103^{8}$.

Pag. 98, linha 16: Ptolomeu, no livro segundo, onde trata da geografia da Lusitânia 9 .

Pag. 100, linha 3: "Há cerca de quarenta anos, etc.". O que se refere ao promontório Ártabro é tão vago que sempre me pareceu inútil, até porque nem Pinciano nem o próprio Resende conseguiram compreender exactamente o sentido deste passo de Plínio. Por essa razão aconteceu que houve quem tentasse conferir sentido às suas palavras. Plínio, com efeito, quando teria escrito no capítulo vigésimo do livro quarto acerca do cabo Finisterra ou Nério deve ter chegado dos rios Minho e Lima ao Douro. É então que começa a tratar da Lusitânia no vigésimo capítulo, cujo início é: "A partir do Douro começa a Lusitânia". Nada do que depois se segue pode dizer respeito [248] ao promontório Nério. Admiro-me que espíritos tão ilustres não se tenham dado conta de que o promontório Céltico nunca foi chamado de Ártabro pelos antigos geógrafos, mas sempre Nério ou Céltico, embora todos estejam de acordo que nas suas proximidades habitam os povos Átabros, Arrotebras ou Arotebras. Deixaram-se enganar pelo facto de acreditarem que o Nério era a frente da Hispânia, quando Plínio abertamente e no mesmo capítulo vigésimo afirma que a frente da Hispânia é constituída por três promontórios, nomeadamente o Olisiponense, o Sacro e o Junónio, de forma a que o Sacro se saliente a partir do meio da frente. É certo que também o Olisiponense ou Ártabro divide o céu, as terras e o mar, como nos conta Plínio. Com efeito, da mesma forma que o Junónio ou Calpe divide o lado austral e ocidental da Hispânia, assim também o Magno, ou seja Olisiponense ou Ártabro é o termo da frente ocidental e nele começa o lado setentrional, muito embora pareça desviar-se ligeiramente poente até ao contorno do promontório Nério, a partir do qual a terra se volta mais profundamente para o Setentrião, tal como Pompónio Mela descreve no capítulo primeiro do livro terceiro. Para que tudo isto mais facilmente se entenda, examinemos as palavras do mesmo Pompónio, no seu livro segundo, capítulo sexto, que dizem assim. "A Lusitânia está exposta tão-somente ao oceano Atlântico, um lados seus lados contudo dá para o Norte e a frente para o Ocidente...". Destas palavras se verifica abertamente que aqueles litorais que se estendem do promontório Olisiponense até ao rio Minho constituem o lado setentrional da Lusitânia. Os litorais, porém, que se estendem do Céltico ou Nério ao golfo da Gasconha, constituem o lado setentrional de toda a Hispânia e não da Lusitânia ${ }^{10}$.

Pag. 100, linha 40: "O ópido e o rio Águeda, etc.". Para Ptolomeu o ópido de Águeda é na Lusitânia, para Plínio são o ópido e o rio, no livro quarto, capítulos vigésimo primeiro e vigésimo segundo. Também faz menção dele Antonino no 
olim fuerit, Baeticam uidelicet et Lusitaniam, quod obiter admonere uolui, ne eius auctoritas quemquam decipiat. Hoc Resendius etiam animaduertit.

Pag. 97, lin. 4: "Strabo enim." Vide Strabonem libro tertio fol. 103.

Pag. 99, lin. 15: "Ptolemaeus." Libro secundo, ubi agit de Lusitaniae situ.

Pag. 101, lin. 1: "Ante annos quadraginta", etc. Haec de Artabro promontorio tam diffuse tradita mihi semper superuacanea sunt uisa, quia meo iudicio, neque Pintianus neque ipse Resendius exacte sensum Plinii hoc in loco sunt assequuti. Vnde accidit ut eius uerbis uim inferre sint conati. Plinius enim, cum prius de Celtico seu Nerio promontorio libro 4, capite 20, uerba fecisset, et a Minio ac Limia fluuiis ad Durium peruenisset: "Tuc demum de Lusitania agere coepit in ipso uigesimo capite, cuius initium est: "A Durio Lusitania incipit". Nec aliquid eorum quae mox sequuntur, ad Nerium [248] promontorium pertinere potest $^{1}$. Miror autem tam insignes uiros non aduertisse Celticum promontorium nunquam apud geographos Artabrum appellari, sed semper Nerium aut Celticum, quamuis omnes consentiant iuxta illud Artabros populos, seu Arrotrebas uel Arotebras habitare. In eo etiam decepti sunt quod crediderint Nerium frontem esse Hispaniae, cum aperte Plinius eodem capite uigesimo asserat, frontem Hispaniae tribus effici promontoriis, uidelicet Olisiponensi, Sacro et Iunonio, ita ut Sacrum e media prope fronte erumpat. Certum est etiam Olisiponense, seu Artabrum, caelum, terras et maria disterminare, ut tradit Plinius. Nam quemadmodum Iunonium, seu Calpe australe et occidentale latus Hispaniae diuidit, ita Magnum, seu Olisiponense, uel Artabrum frontis occidentalis est terminus, et ab eo septentrionale latus incipit, quamuis ad occasum etiam aliquantulum uergere uideatur usque ad circuitum Nerei promontorii, a quo penitus ad septentrionem terra conuertitur, ut Pomponius Mela tradit libro 3, cap. primo. Quod ut facilius intelligatur, expendantur uerba eiusdem Pomponii libro secundo, capite sexto, quae sic habent: "Lusitania Oceano tantummodo obiecta est, sed latere ad septentriones, fronte ad occasum, ex quibus aperte constat ea litora quae a promontorio Olisiponensi, usque ad Minium amnem extenduntur, latus septentrionale Lusitaniae efficere. Quae uero a Celtico seu Nerio ad Gallicum Oceanum tendut, latus septentrionale Hispaniae totius, non autem Lusitaniae constituunt."

Pag. 101, lin. 34: "Oppidum et flumen Aeminium”, etc. Aeminium Ptolemaeo oppidum est in Lusitania, Plinio oppidum et flumen libro 4, cap. 21 et 22. Fit etiam illius mentio ab Antonino in Itinerario, cum illud iter describit, quod ab

1 potest $R C^{1} F C^{2} U$ ] possunt $E$ 
Itinerário, quando descreve o caminho que conduzia de Lisboa a Braga. Estava contudo naquele lugar, onde hoje se encontra o ópido a que vulgarmente se chama Ágata ou Águeda, que é banhado pelo rio com o mesmo nome, e caso esta constatação for aceite, tal como fizeram Vaseu e Barreiros, deve então o códice de Antonino ser emendado na seguinte ordem: de Conímbriga a Águeda, quarenta mil passos, a Talábriga [Cacia?] dez mil passos. Conímbriga é contudo aquele ópido antigo, que hoje vemos em ruínas e que vulgarmente é denominado Condeixa-a-Velha. Talábriga [Cacia?], porém, estava perto [249] do ópido marítimo, que hoje é denominado Aveiro. Desta forma está certo o número de passos por mim calculado, pois de Condeixa a Águeda são cerca de dez léguas e de Águeda a Talábriga [Cacia?] são duas e meia. Este número foi contudo ultrapassado no códice de Antonino e escandalosamente alterado. Por isso parece de rejeitar a opinião daqueles que pensaram ser o ópido de Emínio [Águeda] o mesmo que hoje chamamos Conímbriga ou Colíbria e o rio Mondego o mesmo que Emínio [Águeda]. Com efeito, para que omita outros argumentos por motivos de brevidade, o que relatámos briga abertamnente com as palavras de Plínio, que no já citado capítulo vigésimo segundo do livro quarto, logo que denomina o rio Emínio e o ópido, imediatamente acrescenta estas palavras: "Do Douro ao Tejo, duzentos mil passos, com o Mondego pelo meio." Além disso tenho em meu poder um antiquíssimo códice, de que Vaseu e Resende fazem muitas vezes menção, cujo título é Crónica dos Godos, onde entre outras acções, que se descrevem como tendo sido realizadas por D. Afonso IV, filho de Ordonho, de grande fama, se escrevem estas tal-qualmente assim: "Muitos foram os territórios dos inimigos que este rei conquistou. Tomou com efeito o castro, que se chama Nasão, mas Antense obteve-o por meios pacíficos. Esvaziou Coimbra, possuída pelos inimigos, e depois povoou-a com galegos. Mas também submeteu muitos outros castros. Na sua época cresceu em importância a Igreja, e o reino aumentou. Essas cidades são também povoadas por cristãos, nomeadamente, a Bracarense, a Portugalense, a Eminiense e a Lamecense." Eis o que ele nos diz. Destas palavras deduzimos claramente que Emínio e Conímbriga foram cidades diferentes e, por conseguinte, o Mondego e o Emínio diferentes rios ${ }^{11}$.

Pag. 114, linha 16: "Acerca dos Vetões, etc...". Florião do Campo, no livro segundo, capítulo décimo, diz que os Vetões foram denominados a partir de um nome corrompido de Berões e que a sua região, parte da Lusitânia, tinha a forma triangular ou "triquetra", por tal forma que o lado setentrional começava no lugar em que o rio Pisuerga se mistura com o Douro, até vinte mil passos, ou seja, cinco léguas abaixo do ópido vulgarmente chamado Fermosel, que está situado nas margens do mesmo Douro, dentro dos termos da antiga [250] Lusitânia, que se estendiam em cerca de vinte e seis léguas a partir desse lado. O outro lado estende-se desde o já citado ópido de Fermosel por Ciudad Rodrigo e Caparra até ao rio Guadiana, pelo qual a Lusitânia é separada da Bética. Contudo, o lado oriental, diz-nos ele, estende-se desde o rio Guadiana até ao Douro, onde começa Pisuerga, e que a linha deve ser conduzida até ao ponto onde está o ópido, que hoje se chama Villa Nueva de la 
Olisipone Bracaram ducebat. Fuit autem Aeminium eo loci ubi hodie est oppidum dictum uulgo Agatha, seu Águeda, quod flumine eiusdem nominis alluitur, et recepta hac sententia, in qua etiam fuerunt Vasaeus et Barrerius, emendari debet codex Antonini hoc ordine: "Conimbrica Aeminium quadraginta millia passuum, Talabricam decem millia passuum”. Est autem Conimbrica oppidum antiquum quod dirutum cernitur ${ }^{1}$, et uulgo Condexa Vetus dicitur. Talabrica uero fuit prope oppidum [249] maritimum quod hodie Aueiro dicitur, et sic bene quadrat passuum numerus a me restitutus, nam a Condexa Agatham sunt decem circirer leucae, et ab Agatha Talabricam duae cum dimidia. Erat autem in codice Antonini numerus transpositus, et praepostere mutatus. Hinc apparet reiiciendam esse illorum opinionem, qui existimarunt idem esse oppidum Aeminium, et illud quod hodie Conimbrigam, seu Colibriam appellamus, et eundem fluuium Mundam, et Aeminium. Nam ut cetera argumenta breuitatis causa omittam, id aperte Plinianis uerbis repugnat, qui in allegato cap. 22 libri quarti cum prius Aeminium flumen, et oppidum nominasset, statim haec uerba adiecit: "A Durio Tagus ducentis millibus passuum, interueniente Munda." Praeterea habeo apud me codicem uetustissimum cuius saepe mentionem faciunt Vasaeus et Resendius, qui inscribitur Chronica Gothorum. Vbi inter cetera, quae gesta fuisse narrantur ab Alphonso quarto Ordonii filio, cognomento magno, haec ad uerbum scripta sunt:

"Multos quin etiam inimicorum terminos acquisiuit rex iste. Cepit namque castrum, quod dicitur Nazan. Antensam uero pace acquisiuit. Conimbriam ab inimicis possessam hereditauit, et ex Gallaecis postea populauit. Multa quoque alia castra sibi subiecit. Eius tempore Ecclesia creuit, regnumque ampliauit. Vrbes quoque istae a Christianis populantur: scilicet Bracharensis, Portugallensis, Aeminiensis, atque Lamecensis." Hactenus ille. Ex cuius uerbis aperte colligitur Aeminium et Conimbriam diuersas fuisse ciuitates, et ex consequenti Mundam et Aeminium diuersa flumina.

Pag. 115, lin. 14: "De Vettonibus," etc. Florianus Campensis libro 2, cap. 10, ait Vettones a Beronibus corrupto uocabulo denominatos fuisse, et eorum regionem, quae Lusitaniae pars erat, fuisse figura triangulari, seu triquetra, ita ut latus septentrionale inciperet ab eo loco, quo Pisorga fluuius Durio miscetur, usque ad XX. M. passuum, seu quinque leucas infra oppidum uulgo dictum Fermosel, quod ad ripas ipsius Durii situm est, intra terminos antiquae [250] Lusitaniae, ubi uiginti sex leucis circiter extendebantur ab eo latere. Alterum uero latus a dicto oppido Fermosel per Rodericopolin et Caparam usque ad Anam fluuium, quo Lusitania a Baetica diuiditur, extendit. Latus uero orientale describit a flumine Ana usque ad Durium, ubi Pisorgam excipit, ducta linea per eum tractum in quo est oppidum dictum hodie Villa Noua de la Serena, ita ut

1 cernitur $E R C^{1} F C^{2}$ ] cernimus $U$ 
Serena, por tal forma que esta região incluía dentro das nossas fronteiras Salamanca, Bletise, Fermosel, Bejar, Ciudad Rodrigo ou Miróbrigua, muito embora alguns pensem que Miróbriga ou Miróbrica é o ópido vulgarmente chamado Gonadramiro e que Civitatense, ou Ciudad Rodrigo [Rodericopolin] seja Augustóbriga [Badajoz]. Ver Vaseu no tomo primeiro, capítulo décimo ${ }^{12}$.

Pag. 140, penúlyima linha: "os peões combatiam armados de escudo, etc.". Muitos julgaram que a "cetra" era o género de escudo a que vulgarmente se chama "adarga", e entre eles se contam o nosso Resende e Ambrósio de Morales, no livro oitavo, capítulo vigésimo quinto. Mas a opinião deles é nitidamente contestada pelo passo de Ś́lio Itálico no canto terceiro onde escreve:

Mandou a rica Galiza a sua mocidade capaz de entender as entranhas, o voo das aves, e os raios sagrados, que ulula agora seus bárbaros cantos na língua pátria, que bate em ritmo alternado com os pés na terra alegre por aplaudir com ritmo das cetras ressoantes.

Efectivamente, quando chama "cetras ressoantes" o que significa que elas emitem um tilintar e um som, depreendo manifestamente que se trata de escudos pequenos, que se chamam Bluquerías feitos à mão, de madeira e cobertos de bronze, os quais, ao baterem entre si, emitem um som muito nítido, com o qual (tal como os Coribantes com os sistros) os soldados hispanos costumavam dançar, facto que de forma alguma poderia ser compatível com os tais escudos maiores feitos de coiro ou com os escudos pequenos e redondos.

Adapta-se a esta descrição a imagem da própria Hispânia ou a sua efígie, que o mesmo Ambrósio de Morales teve o cuidado de pôr no princípio da sua obra, imagem que tem numa mão [251] os dardos e a cetra ou seja o Bluquério e na outra espigas ${ }^{13}$.

\section{[LIVRO TERCEIRO]}

Pág. 280, linha 9: "Igualmente de Lisboa," etc. Parece que Antonino, devido à importância da Colónia Emeritense, que no seu tempo quase detinha o commando na Hispânia, quis descrever vários caminhos que de diversos lugares para ali conduziam. Entre eles, lembra três saídos de Lisboa, dois pelos lados maiores e portanto mais longos e um terceiro quase pelo meio e mais curto. Neste passo estão os exemplares francamente deteriorados. 
includeret haec regio intra fines suos Salmanticam, Bletisam, Fermosel, Beiar, Rodericopolin seu Mirobriguam. Licet aliqui putent Mirobrigam seu Mirobricam esse oppidum uulgo dictum Guadramiro; Ciuitatensem autem, seu Rodericopolin esse Augustobricam. Vide Vasaeum tomo primo, capite decimo.

Pag. 141, lin. paenultima: "Caetratos pugnare pedites," etc. Caetram nonnulli crediderunt esse illud scuti genus quod uulgo adargua dicitur, inter quos fuere noster Resendius et Ambrosius Moralis lib. 8, cap. 25. Sed illorum opinioni aperte refragatur locus Silii Italici libro tertio, ubi ita canit:

Fibrarum et pennae, diuinarumque sagacem

Flammarum misit diues Callaecia pubem,

Barbara nunc patriis ululantem carmina linguis,

Nunc, pedis alterno percussa uerbere terra,

Ad numerum resonas gaudentem plaudere Caetras.

Cum enim Caetras resonas, hoc est, tinnitum et sonitum edentes uocet, manifeste innuit esse illa parua scuta, quae "Bluqueria" dicuntur ex ligno fabrefacta atque aere contecta, quae clarissimum sonitum inter se collisa edunt, ad quem (ueluti sistris olim Corybantes) Hispani milites tripudiare solebant, quod coriaceis illis et maioribus scutis, seu parmis nequaquam conuenire potest. Adstipulatur huic sententiae imago ipsius Hispaniae, seu effigies, quam idem Ambrosius Moralis apponi curauit in principio operis sui, quae altera manu [251] iacula et caetram, hoc est Bluquerium, altera uero spicas gerit.

\section{[LIBER TERTIVS]}

Pag. 281, lin. 9: "Item ab Olisipone," etc. Videtur Antoninus propter Emeritensis Coloniae dignitatem, quae eius tempore in Hispania fere principatum obtinebat, complura itinera ad eam ducentia ex diuersis locis describere uoluisse, inter quae tria ab Olisipone commemorat, duo per extrema latera, et ita longiora, tertium uero quasi medium et compendiosum. Sunt autem hoc loco exemplaria mire deprauata. 


\section{A PRIMEIRA VIA DEVE SER EMENDADA ASSIM:}

De Lisboa a Mérida 212 mil passos, ou então 208. Deste modo:

$\begin{array}{lcl}\text { Equabona } & 12 \text { mil passos } & \text { Coina } \\ \text { Cetobrica } & 12 \text { mil passos } & \text { Setúbal } \\ \text { Ciciliana } & 12 \text { mil passos } & \text { Agualva } \\ \text { Malceca } & 8 \text { mil passos } & \text { Marateca } \\ \text { Salacia } & 20 \text { mil passos, ou talvez } 16 & \text { Alcácer } \\ \text { Ebora } & 40 \text { mil passos } & \text { Évora } \\ \text { Até ao rio Guadiana } & 60 \text { mil passos } & \text { Guadiana por Badajoz } \\ \text { Euandriana } & 12 \text { mil passos } & \text { Talaveruela } \\ \text { Emerita } & 36 \text { mil passos } & \text { Mérida }\end{array}$

São 212 mil passos, ou talvez 208. São, porém, 53 léguas.

$[252]$

\section{A SEGUNDA VIA DEVE SER LIDA E EMENDADA ASSIM:}

De Lisboa a Mérida 212 mil passos, ou talvez 210. São, porém, 53 léguas e desta forma:

$\begin{array}{lll}\text { Hierabriga } & 30 \text { mil passos } & \text { Povos } \\ \text { Scalabi } & 22 \text { mil passos } & \text { Santarém } \\ \text { Tubucci } & 32 \text { mil passos } & \text { Abrantes } \\ \text { Fraxinum } & 32 \text { mil passos } & \text { Alpalhão } \\ \text { Medobriga } & 30 \text { mil passos, } & \text { Aramenha } \\ \text { Ad septem Aras } & 14 \text { mil passos, ou talvez 16 } & \text { Assumar ou Alegrete } \\ \text { Plagiaria } & 20 \text { mil passos } & \\ \text { Emerita } & 30 \text { mil passos } & \end{array}$

\section{A TERCEIRA VIA DEVE SER EMENDADA ASSIM:}

De Lisboa a Mérida 186 mil passos ou 196, e desta forma:

\begin{tabular}{lll}
\multicolumn{1}{l}{ Arito praetorio } & 38 mil passos & Benavente \\
Matusaro & 50 mil passos & Ponte de Sor \\
[253] Elteri & 20 mil passos & Alter do Chão \\
Ad septem Aras & 28 mil passos, ou talvez 38 & Açumar ou Alegrete
\end{tabular}


PRIMVM ITER ITA EMENDARI DEBET:

Ab Olisipone Emeritam M. P. 212, uel 208. Sic:

$\begin{array}{lll}\text { Equa Bona } & \text { M. P. } 12 & \text { Couna } \\ \text { Cetobrica } & \text { M. P. } 12 & \text { Setúbal. } \\ \text { Ciciliana } & \text { M. P. } 12 & \text { Agualva } \\ \text { Malceca } & \text { M. P. } 8 & \text { Marateca } \\ \text { Salacia } & \text { M. P. } 20 & \text { Alcácer } \\ \text { Ebora } & \text { M. P. } 40 & \text { Évora } \\ \text { Ad Anam fl. } & \text { M. P. } 60 & \text { Guadiana por Badajóz } \\ \text { Euandriana } & \text { M. P. } 12 & \text { Talaveruela } \\ \text { Emerita } & \text { M. P. } 36 & \text { Mérida }\end{array}$

Sunt M. P. 212, fors 208. Leucae autem 33.

[252]

SECVNDVM ITER ITA LEGI ET EMENDARI DEBET:

Ab Olisipone Emeritam M. P. 212, fors 210. Leucae uero quinquaginta tres, in hunc modum:

$\begin{array}{lll}\text { Hierabrica } & \text { M. P. } 30 & \text { Povos } \\ \text { Scalabi } & \text { M. P. } 22 & \text { Santarém } \\ \text { Tubucci } & \text { M. P. } 32 & \text { Abrantes } \\ \text { Fraxinum } & \text { M. P. } 32 & \text { Alpalhão } \\ \text { Medobriga } & \text { M. P. } 30 & \text { Aramenha } \\ \text { Ad septem Aras } & \text { M. P. } 14 \text { fors } 16 & \text { Açumar ou Alegrete } \\ \text { Plagiaria } & \text { M. P. } 20 . & \\ \text { Emerita } & \text { M. P. } 30 & \end{array}$

TERTIVM ITER SIC EMENDANDVM EST:

Ab Olisipone Emeritam M. P. 186, uel 196. In hunc modum:

$\begin{array}{lll}\text { Aritio praetorio } & \text { M. P. } 28 & \text { Benavente } \\ \text { Matusaro } & \text { M. P. } 50 & \text { Ponte do Sor } \\ \text { Elteri } & \text { M. P. } 20 & \text { Alter do Chão }\end{array}$




$\begin{array}{lrl}\text { Budua } & 12 \text { mil passos, } & \begin{array}{l}\text { N. Senhora de Betoue } \\ \text { [Budua actualmente] }\end{array} \\ \text { Plagiaria } & 8 \text { mil passos } & 20 \text { mil passos } \\ \text { Emerita } & 30 \text { mil passos } & \end{array}$

186 mil passos ou 196. São 46 léguas e meia ou 49.

E assim este caminho abreviado é mais curto na distância de 16 mil passos, que correspondem a quatro léguas.

Tenho as minhas dúvidas de que Antonino tenha querido descrever outro caminho entre Alcácer e Faro (entre Salada e Ossonoba), cujas paragens faltam totalmente, a menos que em vez de Alcácer ponhamos Tavira (Balsa em vez de Salada), por forma a termos os 16 mil passos. Embora se enquadre bem, parece-me que não é verosímil, devido a ter-se de calcular um intervalo tão curto para o caminho.

\section{NOMES LATINOS E VERNÁCULOS DAS CIDADES, POVOAÇÕES E ÓPIDOS}

Forum Limicorum

Bretolaeum

Naebis

[254] Bracara Augusta

Aquae Flauiae

Concia seu Contium

Calem

Lama \& Lameca

Lancobriga

Talabrica

Aeminium

Conimbrica

Seilia

Eburobritium

Collipo

Scallabis seu lulium praesidium

Ierabrica

Moro

Olisipo felicitas Iulia

Tubucci

Fraxinum
Ponte de Lima

Viana do Castelo

Neiva

Braga Colónia

Chaves

Miranda do Douro

O Porto

Lamego

A Feira ${ }^{14}$

Aveiro ${ }^{15}$

Águeda ${ }^{16}$

Condeixa-a-Velha

Seire

Évora de Alcobaça

Leiria $^{17}$

Santarém

Povos

Almourol ou Punhete [Constança]

Lisboa

Abrantes ${ }^{18}$

Alpalhão 


$\begin{array}{lll}\text { Ad septem aras } & \text { M. P. 28, fors 38 } & \text { Açumar ou Alegrete } \\ \text { Budua } & \text { M. P. } 12 & \text { Nossa S. de Betoue } \\ \text { Plagiaria } & \text { M. P. } 8 & \\ \text { Emerita } & \text { M. P. } 30 & \end{array}$

M. P. 186, uel 196. Leucae uero 46 et dimidia, uel 49.

Et ita compendiosum hoc iter breuius erat spatio sedecim P. M. quae leucas quattuor constituunt.

Suspicor etiam Antoninum describere uoluisse aliud iter a Salacia Ossonobam, cuius mansiones omnino desunt, nisi pro Salacia Balsam reponamus, ut numerus sedecim M. P. recte quadret, licet mihi non fiat uerisimile, tam exiguum locorum iuteruallum pro itinere esse computandum.

VRBIVM CIVITATVM ET OPIDORVM NOMINA LATINA, ET VVLGARIA

Forum Limicorum

Bretolaeum ${ }^{1}$

Naebis

[254] Bracara Augusta

Aquae Flauiae

Concia seu Contium

Calem

Lama et Lameca

Lancobriga

Talabrica

Aeminium

Conimbrica

Seilia

Eburobritium

Collipo

Scallabis seu Iulium Praesidium

Ierabica

Moro

Olysipo Felicitas Iulia

Tubucci

Fraxinum
Ponte de Lima

Viana de Caminha ${ }^{1}$

Neiva

Bragua, Colónia

Chaves

Miranda de Douro

O Porto

Lamego

A Feira

Aveiro

Águeda, ubi etiam flumen

Condeixa a Velha

Seire

Évora de Alcobaça

Leiria, ex ruinis

Santarém

Povos

Almourol ou Punhete

Lisboa

Abrantes

Alpalhão ${ }^{2}$

1 Bretolaeum / Viana de Caminha $E U$ ] om. $R C^{1} F C^{2}$

2 Alpalhão $E U$ ] Alpalhano, ou Gauiau $R C^{1} F C^{2}$ 
Igaedita

[255] Amaea

Medobrica

Ad septem Aras

Elteri

Matusarum

Aritium Praetorium

Equa Bona

Cetobrica

Ciciliana

Malteca

Salacia urbs Imperatoria

Ebora liberalitas Iulia

Calantica

Coellium

Saurium

Heluii

Noua ciuitas Aruccitana

Serpa unde populi Serpenses

Pax Iulia

Myrtilis Iulia

Merobrica

[256] Lacobriga

Portus Annibalis

Ossonoba

Balsa
Idanha-a-Velha

Portalegre

Aramenha

Açumar ou Alegrete

Alter do Chão

Ponte de Sor

Benavente

Coina

Setúbal

Agualva ou Águas de Moura

Marateca

Alcácer do Sal

Évora

Arraiolos

Ceice junto de Tomar

Soure

Elvas

Moura

Serpa (de onde provêm os Serpenses) ${ }^{19}$

Beja

Mértola

Santiago do Cacém

Lagos

Portimão

Estói próximo de Faro

Tavira

\section{NOMES DOS POVOS OU DAS PROVÍNCIAS NAS QUAIS}

\section{SE DIVIDE A LUSITÂNIA}

Os povos Turdetanos, que hoje são os Algarvios, estendem-se entre os rios Guadiana, o oceano Atlântico e Beja, de forma a que ocupem o campo de Ourique. Algarves e campo de Ourique. São chamados Lusitanos, com este nome próprio e que lhes é peculiar, os povos que chegam até ao lado setentrional dos Turdetanos e que se estendem desde os Célticos ou Hélvios até aos Cetobricenses e Olisiponenses, passando pelos Eborenses e povos vizinhos. Vulgo, entre Tejo e Guadiana. Os 
Igaedita

[255] Amaea

Medobrica

Ad Septem Aras

Elteri

Matusarum

Aritium Praetorium

Equa Bona

Cetobrica

Ceciliana

Malceca

Salacia Vrbis Imperatoria

Ebora Liberalitas Iulia

Calantica

Coellium

Saurium

Heluii

Noua Ciuitas Aruccitana

Serpa, unde populi Serpenses

Pax Iulia

Myrtilis Iulia

Merobrica

[256] Lacobriga

Portus Annibalis

Ossonoba

Balsa
Idanha Velha, A Guarda

Portalegre

Aramenha

Açumar ou Alegrete ${ }^{1}$

Alter do Chão ${ }^{2}$

Ponte do Sor

Benavente

Couna

Setúbal

Agualva, ou Ágoa de Moura

Marateca

Alcácer do Sal

Évora

Arraiollos ${ }^{3}$

Ceice, junto de Tomar

Soure

Elvas

Moura

Serpa

Beja

Mértola

Santiago de Cacém

Lagos

Villa Nova de Portimão, ou Alvor

Estoi prope Pharum

Tauila

\section{POPVLORVM NOMINA, SEV PROVINCIARVM, IN QVAS LVSITANIA DIVIDITVR}

Turdetani populi, qui hodie Algarbienses inter Anam fluuium et Oceanum usque ad Pacem Iuliam extenduntur, ita ut etiam Orichii campum occupent. Algarues et Campo de Ourique. Lusitani dicuntur proprie et peculari nomine, illi, qui Turdetanorum latus Septentrionale contingunt, et a Celticis seu Heluiis usque ad Cetobricenses et Olisiponenses, per Eborenses, et finitimos populos extenduntur. Vulgo Entre Tejo et Guadiana. Pesures seu Paesuri, ultra Tagum per Herminios montes usque ad Cudam fluuium incolunt. Comarca de Couilham

\footnotetext{
1 Açumar ou Alegrete $E U]$ Azumar $\left.R C^{1} F C^{2}\right|^{2}$ Chão $E U$ ] Chano $R C^{1} F C^{2}$

3 Arraiolos $E U]$ Arraiollas $R C^{1} F C^{2}$
} 
Pesures ou Pesuros habitam aquém do Tejo, pelos montes Hermínios até ao rio Côa. Comarca da Covilhã e Serra da Estrela. Os povos Transcudanos são os que hoje habitam em Côa, para além do rio Côa. Vulgo Riba de Côa. Os Barbários devem ser colocados imediatamente depois dos Lusitanos, a seguir a Cetóbriga e até ao mar, onde se encontra o promontório Barbário. Os povos Túrdulos pertencem à região entre o Douro e o Mondego, não longe do mar, no espaço que hoje se chama Beira. Os Brácaros são os povos que habitam entre o Minho e o Douro. Por isso são chamados interamnenses. Entre Douro e Minho. Os Aquiflavienses são os povos que se estendem para além dos Brácaros em direcção ao Oriente e ao Norte, até Bragança e à povoação de Miranda, sita junto ao Douro, e são vulgarmente chamados Transmontanos. É aí a maior latitude da Lusitânia. Trás-os-Montes.

\section{$[257]$}

\section{NOMES DOS RIOS}

Ana fluuius

Auus

Minius

Tagus

Callipus

Durius

Lima seu Lethe

Vacua

Munda

Tanaca

Cuda

Ozecarus

Subur

Ancus

Seilia

Aeminium

Naebis

Celandus

Cadauus

[258]
Malceca

Ciciliana

Naban
Guadiana

Rio Ave

Minho

Tejo

Cadão

Douro

Lima

Vouga

Mondego

Tâmega

Côa

Zêzere

Sor

Rio de Soure

Seire, que também é ópido

Rio Águeda, também ópido

Neiva, rio e ópido

Rio de Grefões

Rio Cávado, entre Fão e Esposende

Marateca, ribeira e ópido

Agualva ou Águas de Moura

Rio que corre por Tomar (Nabão) 
et serra da Estrella. Transcudani populi qui ultra fluuium Cudam, hodie Coam inhabitant. Riba de Coa uulgo. Barbarii statim post Lusitanos a Cetobrica usque ad mare collocandi sunt, ubi etiam Barbarium promontorium. Turduli populi a Durio usque ad Mundam pertinent non procul a mari, qui tractus hodie Beira dicitur. Bracari Populi sunt qui a Minio usque ad Durium incolunt. Et ideo Interamnenses appellantur. Antredoraminho. Aquiflauienses populi sunt, qui ultra Bracaros ad Orientem solem et uersus Septentrionem extenduntur usque ad Brigantium et Mirandensem ciuitatem iuxta Durium sitam, et ultramontani uulgo dicuntur, ibique maxima est Lusitaniae latitudo, Tralos Montes.

\section{FLVVIORVM NOMINA}

Anas fluuius

Auus

Minius

Tagus

Callipus

Durius

Limia seu Lethe

Vacua

Munda

Tamaca

Cuda

Ozecarus

Subus

Ancus

Seilia

Aeminium

Naebis

Celandus

Cadauus

[258]

Ciciliana

Naban

Godiana

Rio ${ }^{1}$ Ave

Minho

Tejo

Cadam

Douro

Lima

Vouga

Mondego

Tâmaga

Côa

Zêzere

Sor

Rio $^{1}$ de Soure

Seire. Est etiam oppidum

Rio $^{1}$ d'Agueda, et oppidum.

Neiva, rio ${ }^{1}$ et oppidum.

Rio $^{1}$ de Grefões.

Rio $^{1}$ Cávado, inter Fam et Sposende.

Marateca, ribeira ${ }^{2}$ et oppidum.

Agualva ou Ágoa de Moura.

Fluuius qui Tomarium interfluit. 


\section{[LIVRO QUARTO]}

Pag. 314, linha 30: "Diz-se que Lagos a Ardibur" etc. No livro de crónicas que se intitula História dos Vândalos, cujo autor é Alberto Krantz, no capítulo vigésimo do livro primeiro, faz-se menção de Ardibur, chefe militar altamente capaz, dos tempos do imperador Valentiniano. Pelo cálculo cronológico, porém, verifica-se ser aquele e o que Baptista Mantuano denomina de Ardibur, uma e a mesma pessoa ${ }^{20}$.

Pag. 346, primeira linha: "Gaio Minícío," etc. Esta inscrição parece-me sempre, de todas as que até hoje se encontraram na Lusitânia, a mais digna de ser conhecida pela humanidade e de ser conservada pelos Portugueses na sua memória para todos os tempos. Com efeito, contém uma determinada e ilustre acção de um certo soldado lusitano, de nome (tanto quanto se pode concluir das letras partidas) Ebúcio, que protegeu a vida e tratou com cuidados de grande humanidade o tribuno militar Gaio Minício, que pelos seus tinha sido abandonado como morto. Este exemplo para com um inimigo é tão raro e tão admirável que o povo português, muito justamente, não pode orgulhar-se menos com a piedade de Ebúcio do que com as glórias de Viriato. Este o motivo por que o próprio Minício, como compete a um herói digno do nome romano, se esforçou, dando exemplo memorável de um espírito agradecido, na medida do que sentia, por celebrar e conservar na sempiterna memória dos homens tão insigne coragem do varão lusitano, aliada ao mais extremo cumprimento do seu dever.

Deduz-se também desta inscrição, o que até agora era incerto na opinião dos sábios, a saber, que naquele lugar foi travada a [259] batalha na qual Viriato derrotou quase até à destruição total Cláudio Unímano e todo o seu exército. Quem pois já duvidará que a batalha se travou no campo de Ourique, não longe do sítio onde se pode ver este cipo? ${ }^{21}$

Pag. 354, linha 2: "Vila Viçosa" (Callipolin). Pompónio Mela, no capítulo quarto do livro segundo, relata que há uma cidade na Calábria com um nome igual. Plínio também no capítulo duodécimo do livro quarto, em que enumera as ilhas Cíclades, coloca uma Callípolis em Naxos, que alguns, devido à fertilidade das vinhas, chamavam de Dionisíada, e outros Sicília Menor. De facto se é devido à amenidade e beleza da situação que aos ópidos e cidades cabe em sorte nome tão belo, com razão o nosso Resende denominou Viçosa Amena de Callípolis [cidade bela] ${ }^{22}$.

Pag. 360, linha 26: "A causa ou origem do nome Endovélico," etc. Há quem pense que Endovélico provém da palavra grega Balos, ou Valos, ou seja "caminho", mais endon, que significa "dentro", e que era ele que os pagãos julgavam presidir aos caminhos pensando-se de certa forma que ele presidia como termo aos espaços rurais. Mas as inscrições parecem induzir algo diferente, na medida em que o consideram como deus por toda a parte presente, o que pouco se conforma com um 


\section{[LIBER QVARTVS]}

Pag. 315, lin. 29: "Dicitur Ardiburi posuisse Lacobrica septem," etc. In chronico, quod Wandalia inscribitur, cuius auctor fuit Albertus Krantz, libro primo, capite uigesimo, fit mentio Ardaburi ducis rei militaris peritissimi, tempore Valentiniani imperatoris. Constat autem ex ratione temporis eundem fuisse illum et hunc quem Baptista Mantuanus Ardiburem nominat.

Pag. 347, linea prima: "C. Minucius," etc. Haec inscriptio mihi omnium, quae hactenus in Lusitania repertae sunt, dignissima semper est uisa, quae in hominum notitiam deuenire, et a Lusitanis perpetua memoria conseruari deberet. Continet enim pium quodam et illustre facinus cuiusdam militis Lusitani, cui (quantum ex confractis litteris coniicere licet) Ebutio nomen fuit, a quo Caius Minicius tribunus militum qui a suis pro mortuo derelictus fuerat, seruatus, et omnibus humanitatis officiis excultus fuit. Quod exemplum in hoste tam rarum tamque admirabile est, ut gens Lusitana non minus Ebutii pietate, quam Viriati uictoriis gloriari merito possit.

Vnde Minicius ipse, ut uirum fortem decuit, et Romano nomine dignum, tam insignem Lusitani uiri uirtutem, cum summa pietate coniunctam, memorabili etiam grati animi exemplo, quantum in ipso fuit, celebrare, et ad perpetuam hominum memoriam conseruare studuit.

Colligitur etiam ex hac inscriptione, id quod apud eruditissimos uiros hactenus incertum erat, quo loco uidelicet commissa fuit ea [259] pugna, in qua Viriatus Claudium Vnimanum cum uniuerso exercitu fere usque ad internicionem profligauit. Quis enim iam dubitet in Orichiensi campo non procul ab eo loco ubi cippus hic uisitur proelium fuisse commissum.

Pag. 355, lin. 1: "Callipolin." Simili nomine uocatam urbem in Calabria tradit Pomponius Mela libro secundo capite quarto. Plinius etiam libro capite duodecimo, ubi Cycladas insulas euumerat, in Naxo Callipolin collocat, quam aliqui Dionysiada a uinearum fertilitate, alii Siciliam minorem appellabant. Quod si ob amoenitatem et situs pulchritudinem, tam speciosum nomen oppida et urbes sortiri queunt, merito noster Resendius Vizosam Amoenam, seu Callipolin nominauit.

Pag. 361, lin. 23: "Nominis Endouellici causam, et originem," etc. Sunt qui putent Endouellicum dici a dictione Graeca "Balos", seu "Valos," id est "uia "et "Endon", hoc est "intus", et esse eum quem ethnici uiis praeesse crederent, quemadmodum terminus agris praeesse credebatur.

Sed inscriptiones aliud innuere uidentur, dum eum praesentissimi numinis uocant, quod uiarum custodi parum conuenit. Quare potius a uellendo dictum 
guardião dos caminhos. Por isso julgo ser preferível derivá-lo de vellendo [arrancar, N.T.], porque aqueles tempos cegos julgavam e mal que ele arrancava ou extraía dardos, setas, ossos e coisas semelhantes que saíam ou estavam espetadas nos corpos. E então a partícula endo deveria ser interpretada com o sentido de "muito", como costumavam admitir os antigos, segundo o testemunho de Festo. Com efeito, não podemos de forma alguma aceitar com Resende, o que foi dito de um ópido Endovélia, que então podia ter existido, uma vez que os geógrafos e restantes autores dele não fazem menção ${ }^{23}$.

QUE DEUS MUITO GRANDE E MUITO BOM SEJA LOUVADO 
fuisse puto, quod caeca illa aetas iacula, fagittas, ossa, et similia corporibus affixa et haerentia eum auellere atque extrahere falso existimaret. Et tunc particula "endo", pro "ualde", accipi debet, ut antiqui accipere solebant, teste Festo. Nam ut cum Resendio suspicemur, ab oppido Endouellia, quod tunc extare potuit, dictum fuisse, adduci nullo pacto possum, cum apud geographos, et ceteros auctores nulla eius fiat mentio.

LAVS DEO OPTIMO MAXIMO 
(Página deixada propositadamente em branco) 
NOTAS E COMENTÁRIOS 
(Página deixada propositadamente em branco) 


\section{INTRODUÇÃO}

1 p. 98 ss. e livro I, n. 18.

${ }^{2}$ Vita Sancti Theotonii, P. M. H., Scriptores, vol. I, p. 83. Citações colhidas de António José Saraiva, História da Cultura em Portugal, Lisboa, s.d. (1981), vol. I, p. 21.

3 Ver R. M. Rosado Fernandes, "André de Resende e o Humanismo Europeu", in O Humanismo Português, 1500-1600, Lisboa, 1988, p. 593 s.s.; "La rupture entre le Portugal et l'Europe au XVIe siècle», Arq. Cent. Cult. Port., XXXII, p. 59 ss.

${ }^{4}$ Rondelet e Jóvio aparecem na discussão sobre o esturjão, livro II, p. 166 ss.; os outros, alguns deles amigos pessoais, são utilizados na discussão histórica e epigráfica ao longo do livro (ver Índice).

5 É um livro que será largamente utilizado pelos escritores eborenses, com os Padres Manuel Fialho e António Franco. Ver a obra deste, Évora Ilustrada, Évora, 1945.

${ }^{6}$ Foi o que se constatou no manuscrito ainda hoje existente na Academia das Ciências.

${ }^{7}$ Leitão Ferreira, Vida de A. R., A. H. P., VII (1909), pp. 348-9, 361; VIII (1911), pp. 63-64; Diogo Mendes de Vasconcelos, Vida de A. R., p. 68 desta edição.

8 Basta lembrar os títulos citados na bibliografia por Virgínia Soares Pereira, José d'Encarnação, ou, no século passado, Emil Huebner.

9 Ver p. 74

10 p. 53.

11 p. 74.

12 Theodor E. Mommsen, "Petrarch's Conception of the 'Dark Ages'», Speculum, 17 (1942), pp. 226-242; trad. em alemão em Zu Begriff und Problem der Renaissance, ed. A. Burck, Darmstadt, 1969, pp. 151-179.

13 p. 82.

14 pp. 70-73

15 p. 86-89.

16 p. 70.

17 p. 52.

18 p. 80.

19 p. 78.

20 p. 76.

21 p. 80.

22 p. 78.

23 p. 78.

${ }^{24}$ Ocupa na edição de 1593 pp. 1-9 impressas em letra pequena e com paginação própria. Tudo o que é redigido por Mendes de Vasconcelos, a sua autobiografia e o livro V sobre as antiguidades de Évora, obedece a paginação diversa, o que mostra o seu intuito de distinguir, ou por modéstia ou individualismo, o que era da sua autoria em relação à obra do autor que editava.

25 p. 76.

26 Basta percorrer a obra de Frei Bernardo de Brito e o diálogo sobre a grandeza dos Lusitanos de Frei Amador Arrais para nos darmos conta do facto. 
27 pp. $166-181$.

28 p. $190-192$.

29 Ver o comentário de A. Schulten, F. H. A., II, p. 140 e IV, pp. 97, 102 e o seu Viriato, em que aponta para a pobreza como causa determinante do bandoleirismo lusitano. De facto Apiano, 58-60, transmite-nos as palavras de paz de Galba aos Lusitanos: «São a desgraça e a pobreza que vos forçam a isto". E por isso lhe oferece terra boa para cultivarem e assim manter a paz.

30 Ver as referências a Onofre Panvínio, a Marliano, a Florião do Campo, a Ambrósio de Morales e a Vaseu, entre muitos outros.

31 Ver p. ex. pp. 94, 140 e n. 154, 168.

32 Ver o que diz sobre a índole dos Lusitanos no livro I, p. 132 ss. e sobretudo no livro III, p. 206 ss., em que descreve com pormenor a resistência contra os Romanos invasores.

33 Resende começa a apresentar de forma racional e cronológica as transformações por que vai passar o Império Romano, a partir da p. 266 do livro III.

34 Ver sobretudo o uso que faz da ciência de St. ${ }^{\circ}$ Isidoro no livro II ao tratar do esturjão.

35 Livro III, p. 278 ss. sobre as vias militares.

36 Queixa-se Resende da "usurpação» feita por Barreiros, na carta a Quevedo, ed. V. Soares Pereira, p. 133 , n. 85 .

37 No livro IV quando trata de Santiago de Cacém, p. 318 ss.

38 Livro IV, p. 234 ss., quando fala de Campo de Ourique e apresenta a figura de D. Afonso Henriques, o seu discurso e o comportamento dos seus soldados em tons épicos de grande nacionalismo e seguidamente fala do arco mandado construir por D. Sebastião.

39 Livro IV, p. 356 ss.

40 São inúmeras as notas do C. I. L., II, em que Huebner manifesta a sua desconfiança. Ver sobretudo p. 14 e confrontar com o artigo de José d'Encarnação que trata eufemisticamente da "invenção" de Resende (ver bibliografia).

41 p. 272.

42 p. 70.

43 Vida, p. 66-69.

44 R. M. Rosado Fernandes, "Etimologia e sua Finalidade em André de Resende" (ver bibliografia).

45 Ver p. 100 , p. ex

46 p. 106 ss.

47 Cf. p. 176 (Gelénio e Plínio); 186 (Vadiano e Cícero); 226 (ed. Badiana de Lívio); 266 (emenda a Apiano).

48 p. 142.

49 p. 344 sobretudo.

50 Ver p. 134 (contra Lívio); 138-139 (contra Justino).

51 p. 207 ss.

52 Ver a bibliografia citada de Resende sobre a cidade de Évora.

53 p. 140.

${ }^{54}$ Ver a tese de licenciatura de A. Borges Nunes, Paulo Orósio Bracarense, Faculdade de Letras de Lisboa, 1958; introdução de Lúcio Craveiro da Silva a P. Orósio, História contra os Pagãos, Univ. Minho, 1986.

55 p. 150 ss.

56 p. 263 ss. e sobretudo a Carta a Quevedo editada por V. Soares Pereira.

57 p. 334 ss.

58 Cf. n. 40

59 Ver n. 40.

60 C. I. L., II, p. 14. Huebner afirma peremptoriamente que a habilidade de Resende era tanta que podia enganar os olhos dos maiores especialistas.

61 Ver o livro editado por E. F. Jacob, Italian Renaissance Studies, Londres (1960).

62 p. 130 e n. 121 (Alcântara); p. 196 e n. 128 (Chaves). 
63 Basta ler o aparato contido das inscrições publicadas no C. I. L., II, e por J. d'Encarnação (do Conventus Pacensis), para nos darmos conta deste facto.

${ }^{64}$ Cf. J. d'Encarnção, "Da Invenção de Inscrições Romanas, etc.», p. 200.

65 p. 334 e n. 79.

66 Publicado em Lisboa, 1977 (descrição de Portugal em 1416).

67 Ver n. 36.

68 p. 196 n. 129 e o trabalho citado de Suzanne Daveau sobre história da geografia portuguesa.

69 p. 162, n. 218

70 Ver n. 29.

71 Ver bibliografia.

${ }^{72}$ A Geografia Universal escrita em latim perdeu-se, diz-nos António José Saraiva no art. sobre João de Barros do Dic. Hist. Port.

73 Ver p. 188.

74 p. 148 ss.

75 p. 180.

76 p. 178 ss. e respectivas notas.

77 pp. 272 (Tritão) e 200 (Zézere).

78 p. $190-191$.

79 Ver António José Saraiva, História da Cultura em Portugal, I, p. 81 ss. (ver n. 2).

80 Haverá mesmo o que se poderá chamar de literatura da Resistência em Portugal, como a intitulou Hernâni Cidade. Ver R. M. Rosado Fernandes, "Ulisses em Lisboa" (cit. bibliografia).

\section{TITULO DA OBRA E ÍNDICE}

${ }^{1}$ Não traduzido, nesta edição, por ser obra alheia a Resende. O mesmo fizeram os diferentes editores da obra nos sécs. XVI, XVII e XVIII. Seguem-se aparecer, o imprimatur e o privilégio régio, que não transcrevemos por se encontrarem redigidos em Português no texto-base desta edição.

${ }^{2}$ É evidente que os dois itens se referem a duas obras do editor Mendes de Vasconcelos e que, portanto, não serão traduzidos.

\section{EPIGRAMA}

\section{A DIOGO MENDES DE VASCONCELOS}

${ }^{1}$ Tradução de José Geraldes Freire, Obra Poética de Diogo Mendes de Vasconcelos, Coimbra, 1962, p. 74 .

\section{VIDA DE LÚCIO ANDRÉ DE RESENDE}

POR DIOGO MENDES DE VASCONCELOS

1 Desta biografia fez Bento José de Sousa Farinha uma excelente tradução na Collecção das Antiguidades de Évora, Lisboa, 1785, pp. 11-36, de que aproveitamos largamente nesta edição. Quanto à actividade do biógrafo de Resende e editor do De antiquitatibus, Diogo Mendes de Vasconcelos, ver além da sua autobiografia publicada na ed. de Évora de 1593 do De antiquitatibus, pp. 1-9, Barbosa Machado, Bibl. Lus., sv. Nicolau António, Bibl. Hisp. N., s. v., Hislampa, e José Geraldes Freire, Obra Poética de D. M. V., Coimbra, 1962, p. 30 ss.

${ }^{2}$ Pl., H. N., IV, 22, 11, 117-118: "oppida ueteris Latii Ebora, quod idem liberalitas Iulia, et Myrtilis ac Salacia, quae diximus«. Tanto Resende em vernáculo, como Mendes de Vasconcelos em latim escreveram sobre as antiguidades de Évora. O primeiro, na História da Antiguidade de Évora, Évora, 1. ${ }^{\mathrm{a}}$ ed., 1553, 2. ${ }^{\mathrm{a}}$ ed. 1576; editada igualmente por J. Pereira Tavares em André 
de Resende, Obras Portuguesas, Lisboa, 1963, pp. 1-70. Desta edição fez-se tradução latina, De antiquitatibus Eborae, ex Lusitanico nunc primum Latine redditus ab Andr. Schotto Antuerp., Colónia, 1600 e 1613; Francoforte, 1603; finalmente Coimbra, 1790; o segundo, no De Eborensi Municipio, livro quinto do De antiquitatibus, e publicado em Évora também em 1593. Bento José Farinha fez deste opúsculo uma tradução, na Collecção das Antiguidades de Évora, Évora, 1785, pp. 37-111.

3 A biografia mais completa de Resende é ainda hoje a de F. Leitão Ferreira, que A. Braamcamp Freire editou, anotou e corrigiu, "Vida de André de Resende. Biografia Inédita", $A$. H. P., VII (1909), 339-417; VIII (1910), 62-69; 161-184; 338-366; IX (1914), 177-334; Na B.N.L., há também uma Vida de André de Resende (Apontamentos Biográficos), de José Soares da Silva, Res. C. 641, 51 ss. Quanto ao nome de Resende, o trabalho mais actualizado é de A. Costa Ramalho, "Lucius Andreas Resendius. Porquê Lucius?»,Humanitas, XXI-XXII (1969-70), 353-364, reproduzido em Estudos sobre o Séc. XVI, Lisboa, 1983, 203-213.

${ }^{4}$ Jorge Coelho, humanista e poeta (actividade literária c. 1536), amigo de Resende, de Jerónimo Cardoso e outros, bem como do círculo de letrados ligados ao Cardeal D. Henrique; Barbosa Machado, Bibl. Lus., Nicolau António, Bibl. Hisp. N., s. v., Sousa Rebelo, Poesia Neolatina, in Dic. Lit. Port.; A. Costa Ramalho, Enc. Verbo, s. v.; Isaltina Figueiredo Martins, O Poema "De Patientia Christiana" de Jorge Coelho, Coimbra, 1974 (diss. dactil); J. da Silva Terra, "O Humanista Português Jorge Coelho e a sua Correspondência com os Cardeais Bembo e Sadoleto", Mélanges André Joucla - Ruan, Ed. Univ. Provence (1978), pp. 1133-1160.

5 Élio António de Nebrija, helenista e linguista de influência internacional, Nicolau António, Bibl. Hisp. N., s.v.; J. Lopez Rueda, Helenistas Españoles del siglo XVI, Madrid, 1973, pp. 56-59, 156-159, 161-169, 290-298, 354-356 e passim.

6 Aires Barbosa, 1470-1540. Humanista conhecido internacionalmente, professor em Salamanca, pensador católico ortodoxo, cuja posição perante a obra de Erasmo variou, sendo, como diz A. Costa Ramalho, "medianamente anti-erasmista", que é a definição que melhor se lhe adapta, sobretudo no que respeita ao seu poema Antimoria, i. e., "Contra a Loucura", bem entendido, de Erasmo e do seu Elogio da mesma. Ver Barbosa Machado, Bibl. Lus., Nicolau António, Bibl. Hisp. N.; Hislampa, s. vv., bem como sob o mesmo nome o art. de A. Costa Ramalho, no Grande Dic. de Lit. Port., Lisboa, I (1977). Quanto a textos e mais bibliografia, ver Isaltina Figueiredo Martins, Bibl. do Humanismo em Portugal no séc. XVI, Coimbra, 1986, n. ${ }^{\text {os }}$ 1454-1464; J. Lopez Rueda, ob. cit., 53-59 (Aires Barbosa em Salamanca).

7 Pedro ou Pêro Mascarenhas, militar e diplomata (1484?-1555), embaixador português na corte de Carlos V em Bruxelas (1539-1533), Vice-Rei da Índia, 1554; E. Sanceau, Dic. Hist. Port., s. v.; Domingos Maurício, Enc. Verbo, s. v.; Diogo de Couto, Décadas da Ásia, VII, liv. 1., col. 13, Lisboa, 1782, 30 e ss., A. Herculano, Hist. Inquis., II, Lisboa, 1907, 207-304; Luís de Matos, L'Expansion Portugaise, 43, n. 61; 427.

8 Solimão II pôs cerco a Viena em 1529 e depois em 1532, quando D. Pedro Mascarenhas representava Portugal na corte de Carlos V; Luís de Matos, L'Expansion Portugaise, p. 430; Leitão Ferreira, Vida de André de Resende, A. H. P., VII (1909), 346, 412.

9 Julián de Alva era espanhol e veio no séquito de D. Catarina, irmã de Carlos V, quando se casou D. João III, e foi preceptor da Princesa D. Maria, filha de D. Manuel I, juntamente com Joana Vaz e Luísa Ligeia. Será Bispo de Miranda e de Portalegre; ver Luís de Matos, "O Ensino na Corte durante a Dinastia de Avis", in O Humanismo Português, 1500-1600, Primeiro Simpósio Nacional, Lisboa, 1988, pp. 501, 503 e 567 n. 39; José da Silva Terra, «Espagnols au Portugal au temps de la Reine D. Catarina, I - D. Julião de Alva (c. 1500-1570), Arch. Cent. Cult. Port., IX (1975), pp. 417-506.

10 Poeta neolatino e amigo dos humanistas portugueses mais eminentes: ver Barbosa Machado, Bibl. Lus., s. v.; A. Costa Ramalho, Enc. Verbo, s.v.; Cândido Aparício Pereira, Subsídios para a História do Humanismo em Portugal - Pedro e Rodrigo Sanches, Coimbra, 1955 (tese lic. dact.); Isaltina Figueiredo Martins, Bibl. Hum. Port., n. ${ }^{\text {os }} 3100-3103$.

11 A influência horaciana e epicurista é evidente, p. ex., a Ode, III, 30 non omnis moriar, etc.

12 Subentende-se província da Lusitânia, equivalente a Portugal.

13 Ver p. 74. 
14 Ver p. 70.

15 Trad. de J. G. Freire, ob. cit., p. 69.

16 Vid. J. G. Freire, ob. cit, p. 21-22; 28; 57-58; 64; 69.

17 Trata-se da passagem por Évora, em 1571, do legado pontifício e dominicano, Michele Bonelli "Cardinale Alessandrino", tal como o seu tio-avô, Pio V, também dominicano. Tinha então o Cardeal 30 anos, pois nascera em Bosco no Piemonte a 25 de Novembro de 1541 (ver J. Quétif et J. Échard, Scriptores ordinis praedicatorum, II, Paris, 1721, p. 306; New Catholic Encyclopaedia, s. v. Pius V). Vem tratar do casamento de Margarida de Vallois com D. Sebastião; cf. Visconde de Santarém, Quadro Elementar, Paris, 1843, vol. III, p. 449 ss.

18 O poema é escrito em hendecassflabos falécios. Ver J. G. Freire, ob. cit., pp. 70-71.

19 Ver n. 1 à carta referida.

${ }^{20}$ Conrad Goclenius era alemão e professor no Colégio Trilingue de Lovaina, onde ocupava a cátedra de Latim desde 1519. Com ele manteve Resende relações de amizade. Deve ter-se interessado por Portugal e pelas conquistas portuguesas dessa altura. Ver Luís de Matos, L'Expansion Portugaise, p. 428-431; O. Sauvage, L'Itinéraire Érasmien d'André de Resende, Paris, 1971, pp. 23, 46, em que se encontram duas cartas de A. R. a Goclénio discutindo dois dos seus poemas, um sobre Lovaina e outro sobre os detractores de Erasmo.

21 Este poema, cujo início é imitado de Catulo, 14 (Nei te plus oculis méis amaram, ) Iocundissime Calue..., por sua vez, imitado de Mecenas, fr. 3 (Morei): ni te uisceribus meis, Horati, plus iam diligo...), e utiliza uma profusão de impossibilia, como perífrases para a noção de nunca, bem como de imagens tiradas dos movimentos perenes da Natureza, como p. ex. o sidereum iubar (que Mendes de Vasconcelos nos escólios a Resende identifica com a estrela de Alva, ver p. 372), como perífrase da noção sempre. É um texto de retórica retumbante, em que até aflora o animae dimidium meae que Horácio, Odes, I, 3, 8, dedica ao seu amigo Virgílio. Também horaciano é o metro usado, o quarto asclepiadeu.

De notar a erudição geográfica herdada dos Antigos, p. ex. com Tanaiticum (empregue por Sidónio Apolinar, Carm., XI, 96) de Tanais, o rio Don, como rio mais oriental da Europa em relação ao Tejo, ou mitológica: Hipérion, filho de Úrano e de Geia, pai do Sol, da Lua e da Aurora; As rochas Cianeias, já celebradas por Lucano, Fars., II, 716, Cyaneas...cautes, são duas ilhotas à entrada do Ponto Euxino, por onde passou Jasão na procura do velo de ouro (P. Grimal, Dict. Myth., s.v. Cyane).

22 Deve tratar-se do bispo de Naumburg-Zeit Júlio Pflug e não Flu que desempenhou importante papel na Alemanha no tempo da Reforma e cujas relações com a Lovaina de Resende e com contemporâneos de Resende são uma realidade. Era alemão e não polaco. Ver Julius Pflug, Correspondance, 4 vols., Leiden, 1969-1979.

23 João Dantisco era o polaco Joh. von Hoefen (1485-1548) de Danzig (daí Dantiscus), bispo de Ermland e de Culm. Era embaixador da Polónia, em Bruxelas, na corte de Carlos Quinto. Resende publicou em Lovaina, no ano de 1529, o elogio desta cidade e da sua universidade, juntamente com um poema De nostrorum temporum calamitatibus Sylva de Dantisco; Leitão Ferreira, Vida de Resende, A. H. P., IX (1914), 286 (Bibl. Resendiana); Luís de Matos, L'Expansion Portugaise, pp. 428, n. 10-430 e 444. O poema de Dantisco tratava do perigo que os Turcos representavam para a Europa católica. Ver Julius Pflug, Correspondance, I, Leiden, 1969, p. 249, n. 3.

24 António Pucci foi, segundo Fortunato de Almeida, Hist. Igr. Port., II, Porto, 1968, o primeiro Núncio residente em Portugal (p. 584), onde já estava antes de 1514; cf. pp. 114, 385-388; 392-396; 408-411.

25 Trata-se de Garcilaso de la Vega, 1501-1536, "el más insigne de los poetas españoles», como o descreve o Dicionario de literatura española, ed. G. Bleiberg - J. Marías, Madrid, 1972 (4), s.d., s.v. É filho de Garci-Lasso, o que deve explicar o nome latino usado por Vasconcelos: Gra-tianus Lassus.

26 Os seus dois escravos.

27 "Crasta" ou "Claustra", ver J. P. Machado, Dic. Etim. Ling. Port., s. v.; Augusto Pinho Leal, Portugal Antigo e Moderno, III, Lisboa, 1874, p. 191: refere-se à Claustra da Sé de Évora, obra de D. Pedro IV, seu bispo, em 1376. A Crasta referida parece ser a do mosteiro de S. Domingos, hoje já não existente. 
28 A data é, porém, de 1573, o que já foi sugerido por Leitão Ferreira, Vida de André de Resende, A. H. P., VII (1909), 339, e aceite pelos eruditos que da sua vida e obra trataram.

29 Aquiles Estaço, natural de Vidigueira (1524-1581), foi, como diz Luís Sousa Rebelo, no artigo do Dic. Lit. Port., "um dos mais brilhantes humanistas portugueses do seu tempo". Estudou em várias universidades europeias (Paris, Lovaina), o que lhe permitiu entrar no convívio internacional dos humanistas da sua época. Deixou uma obra importante que ainda merece a pena ser conhecida pelo saber filosófico e literário que revela. A bibliografia mais recente sobre a sua vida e obra encontra-se em Isaltina Figueiredo Martins, Bibl. Hum. Port., Coimbra, 1986, n. ${ }^{\text {os }} 2111-2126$.

\section{CARTA AO CARDEAL D. AFONSO}

${ }^{1}$ O cardeal-infante D. Afonso, Bispo de Évora, Guarda e Viseu, é filho de D. Manuel I e irmão de D. João III. Nascido em 23 de Abril de 1509 é elevado à púrpura cardinalícia em 1517 e desempenhou funções de alta importância política e militar. Parte da sua actividade desenvolver-se-á em Évora. Fortunato de Almeida, Hist. Igreja em Portugal, II, p. 580 e o recente e bem informado trabalho de S. Tavares de Pinho, "André de Resende e o cardeal D. Afonso em torno do sermão pregado no sínodo de Évora de 1534", Eborensia, I (1988) n. ${ }^{\text {os }} \mathrm{l}$ e 2, pp. 39-70.

2 Inst. Or., I, 7, 1-35 (a ortografia como domínio da Gramática): "Nunc, quoniam diximus, quae sit loquendi regula, dicendum, quasi scribentibus custodienda, quod Graeci ỏ $\rho \theta \gamma \rho \alpha \varphi$ í $\alpha$ v vocant, nos recte scribendi scientiam nominemus». Tece seguidamente Quintiliano as considerações que julga necessárias quanto aos problemas ortográficos da sua época, como por exemplo o valor da oclusiva gutural sonora de $C$ (oc. gut. surda) no que respeita a Gaius e Gnaeus (o $C$ como letra do alfabeto romano provém da sonora $\Gamma$ do alfabeto grego).

3 Noctes Atticae, IV, 15, 1.: «Elegantia orationis Sallustii uerborumque fingendi et nouandi studium cum multa prorsus inuidia fuit, multique non mediocri ingenio uiri conati sunt reprehendere pleraque et obtrectare in quibus plura inscite aut maligne uellicant». De salientar a metáfora com o verbo uellicare "mordiscar, beliscar, espicaçar», com que muitos criticaram sem razão a beleza do discurso salustiano, bem como a capacidade revelada pelo historiador romano de inovar no que toca ao léxico latino.

${ }^{4}$ É evidente que A. R. não está consciente das razões fonéticas que presidem às variações ortográficas que apresenta como erro e que pretende corrigir ao gosto clássico, fazendo exactamente o contrário do que pretende actualmente a metodologia científica. Quanto a COIVGI, trata-se de uma inscrição de Roma a que se refere no livro IV, n. 7.

5 O nome de Beja vai ser tratado pormenorizadamente e etimologicamente numa cartatratado, publicada vinte anos depois, em 2 de Fevereiro de 1553 e dedicada ao flamengo e humanista João Vaseu, intitulada "Pro colonia Pacensi», que está incluída na edição de obras históricas, publicada em Coimbra, vol. II, 1790, pp. 7-33. V. Soares Pereira, Carta a Bartolomeu Quevedo, Coimbra, 1988, elucida-nos sobre o assunto, 156, n. 203 e 164, n. 244.

6 Ver pp. 150, 182 e 324 desta edição.

7 No cap. sobre "os Diversos Rios" refere o A. a coluna Aquaflaviense que teria estudado e na qual conheceu o nome do Tameca, Tâmega. À inscrição de Chaves se tinha igualmente referido no livro I, p. 35. Quanto à leitura de Resende e dúvidas que levanta, ver Huebner, citado na n.137 do livro u.

8 Trata-se do passo da Chorographia, III, 11, em que Pompónio trata da zona a norte do Lima: "perque eos (Praesamarchos) Tamaris et Sars flumina non longe orta decurrunt, Tamaris secundum Ebora portum, Sars iuxta turrem Augusti titulo memorabilem». Nela cita, porém, ainda mais duas Eborae, uma no Guadalquivir (III, 4) e outra no Promontório Magno (III, 4). Da primeira nada resta, a segunda deverá ser identificada, apesar da incompatibilidade geográfica, com Évora (ver García-Bellido, La España del Siglo Primero, Com. a Pomp. Mela, pp. 55-56, notas 89, 105, 125 (rio Sars, o Sar actual), 126 (Ebora «seria, pues, una ciudad de la ria de Noya»), 127 ("Esta Turris Augusti hubo de estar cerca de Padrón. Acaso llevó inscripción recordatoria de la victoria del Emperador sobre los galaicos, como la de Mónaco, etc.»). 
A. R. recorda a discussão sobre o nome Ebora que se verifica no Cap. I Do vero nome desta cidade do seu livro História da Antiguidade da Cidade de Évora, editado pela primeira vez em Évora em 1553 (ed. moderna de J. Pereira Tavares, Lisboa, s.d. [1963], p. 11 ss.).

\section{CARTA DE DIOGO MENDES DE VASCONCELOS AO CARDEAL D. HENRIQUE}

${ }^{1}$ Diogo Mendes de Vasconcelos foi sempre tido em alta conta pelo cardeal D. Henrique. Esta carta de 15 de Janeiro de 1580 provavelmente nem foi lida pelo destinatário, que morreu em 31 do mesmo mês. Ver José Geraldes Freire, Obra Poética de Diogo Mendes de Vasconcelos, Coimbra, 1962, pp. 24-25.

${ }^{2}$ Era bem conhecida a rudeza dos Getas sobretudo pelo testemunho de Ovídio que esteve exilado nas suas paragens: Trist., V, 10, 38; V, 12, 53-58; Pont., IV, 13, 13, 22.

3 Hor., A.P., 387.

4 Donato, Vita Verg., 80, 81-82: "non absurde Carmen se ursae more parere dicens et lambendo demum effingere».

${ }^{5}$ Francisco Nunes de Beja vai ser citado igualmente no livro IV, p. 328. Cf. n. 61. Apesar de ser conhecido como correspondente de Resende, não é identificável.

6 Trata-se da Carta a Bartolomeu Quevedo, de 1567, com várias edições e recentemente publicada e estudada por Virgínia Soares Pereira, André de Resende, Carta a Bartolomeu Quevedo, Coimbra, 1988.

\section{VERSOS DE DIOGO MENDES DE VASCONCELOS \\ EM LOUVOR DE LÚCIO ANDRÉ DE RESENDE}

1 Este poema é traduzido e exaustivamente comentado por J. Geraldes Freire, ob. cit., pp. 144-147 (poema XXVII) e 246-248 (comentário).

\section{EPIGRAMAS EM LOUVOR \\ DE DIOGO MENDES DE VASCONCELOS E DE RESENDE}

2 Tradução (e comentário) destes três poemas de J. G. Freire, ob. cit., pp. 75-78.

\section{CARTA DE LÚCIO ANDRÉ DE RESENDE \\ A BARTOLOMÉ FRIAS DE ALBORNOZ}

${ }^{1}$ Nicolau António, Bibl. Hisp. Nova, s.v., afirma que B. Frias de Albornoz foi o primeiro jurista a explicar os Instituta de Justiniano, sendo igualmente em $1551 \mathrm{um}$ dos fundadores da Universidade do México. Natural de Talavera, da qual de resto vinha, como se alude na carta, para visitar Évora e A. de Resende, era homem de engenho eminente e memória monstruosa. Cf. F. L. Ferreira, Vida, A. H. P., VIII (1910), p. 353.

2 A. R. tenta romanizar os cargos de administração pública portuguesa.

3 Rui (derivado do Lat. Rodericus) Fernandes de Castanheda (dos Castanhedas de Santarém) é referido por Cristóvão Alão de Morais, Pedatura Lusitana, tomo V (1667-1690), vol. I, p. 416.

${ }^{4}$ Corrector - Corregedor ou Desembargador como era designado por Jacinto Leitão Manso de Lima, Famílias do Reino de Portugal, vol. 7, pp. 194-195 e na BNL/RES/POMB., COD. 367 (Diogo de Macedo, Nobiliário, letra C (Castanhedas), fls. 291-291 v.

5 Ver Barbosa Machado, Bibl. Lus., e Nicolau António, Bibl. Hisp. Nova, s. vv., e Carolina Michaelis de Vasconcelos, A Infanta D. Maria de Portugal e as Suas Damas, Porto, 1902, pp. 107-117. Nasceu em Vila Viçosa em 1548 e morreu em Évora em 1595. 
${ }^{6}$ Esta carta, diz-nos Leitão Ferreira, Vida, A. H. P., VIII (1910), 353, teria sido escrita em 15 de Maio de 1556, data que parece errada, sendo preferível 1565, segundo D. Carolina Michaelis de Vasconcelos, ob. cit. (n. 5), pp. 111-113, o que é já referido por Anselmo Braamcamp Freire, no comentário a Leitão Ferreira, Vida, A. H. P. (1914), IX, p. 331.

\section{LIVRO PRIMEIRO}

${ }^{1}$ Plínio, H. N., III, 1, 8: "In uniuersam Hispaniam M. Varro peruenisse Hiberos et Persas et Phoenices Celtasque et Poenos tradit; lusum enim Liberi patris aut lyssam cum eo bacchantium nomen dedisse Lusitaniae, et Pana praefectum eius uniuersae.»; Marc. Capela, VI, 628 (p. 308 Dick): "cui [Lusitania] nomen fabula a lusu Liberi patris uel cum eo bacchantium sociauit."; S. Isidoro, Etim., XIV, 4, 29, não nos transmite qualquer etimologia. Quanto à possível origem do nome, tudo aponta para que seja céltica ou, pelo menos, língua indo-europeia ocidental: S. Lambrino, "Les Lusitaniens», Euphrosyne, I (1955), pp. 117-145; "Les Celtes dans la Péninsule Ibérique selon Aviénus", Bulletin des Études Portugaises, XIX (1956), pp. 7-33; J. Leite de Vasconcelos, As Religiões da Lusitânia, Lisboa, 1907-1913, 3 vols.; Mário Cardoso, Dicionário de História de Portugal, ed. Joel Serrão, s.v. Lusitanos; ver ainda Lusitânia em Antenor Nascentes, Dicionário Etimológico da Língua Portuguesa, tomo II (nomes próprios), Rio de Janeiro, 1952; J. P. Machado, Dic. Onom. Etim. Ling. Port., Lisboa, s. d. (1984), s.v. Lusitânia; R. M. Rosado Fernandes, "Méthodologie et Histoire dans De antiquitatibus Lusitaniae d'André de Resende", in Humanisme Portugais et l'Europe, Paris, 1984, pp. 496-497; K. H. Schmidt, "A Contribution to the Identification of Lusitanian", Actas del III Coloquio sobre lenguas paleobispánicas, Salamanca, 1985, pp. 319-341.

Quanto ao texto citado de Plínio, existe a variante Lysam em vez de lyssam, simplesmente esta última é a única aceite nas edições modernas, desde Detlefsen (ver n. 7). A tese aqui apresentada já fora concebida por Resende aquando das anotações ao seu poema Vicentius Leuita et martyr, Lisboa, 1545 (editado e estudado por J. V. Pina Martins em edição de Braga, 1981), sobretudo na n. 24 das pp. 38-39.

2 Trata-se evidentemente de uma possibilidade etimológica aceitável na perspectiva dos antigos devido à simples semelhança gráfica das palavras. Desde que o sentido conviesse, encarava-se a etimologia, como é o caso de ludus e lusio do verbo ludere, que pode significar "jogar», "brincar», pois relacionavam o seu valor semântico com os cortejos báquicos. Cf. J. P. Machado, Dic. Onom. Etim. Ling. Port., Lisboa, s. d. (1984), s. v. Luso.

3 H. N., III, 1,8 .

${ }^{4}$ Quanto a Pseudoberoso, ver Paul Schnabel, Berossos und die babylonisch-bellenistische Literatur, Leipzig, 1923 (Hildesheim, 1968); João Ânio de Viterbo publicou um passo falsamente atribuído a Beroso (sacerdote babilónico que teria vivido 340-370 a. C.) nos seus Comentários à obra de diversos autores que falaram sobre Antiguidade, cap. XX, Os Reis da Hispânia: "Este luso não era grego mas hispano, filho de Sileceu, e começou a reinar no ano décimo terceiro da Ascátide... Todos são de opinião que a Lusitânia foi assim chamada por causa de Luso.» Ver Encicl. Verbo, s. v. Beroso. As edições de J. Ânio de Viterbo são os Commentaria super opera diuersorum de Antiquitatibus loquentium, publicados em Roma, 1498, e dedicados aos Reis Católicos que de novo aparecem juntamente com a obra de Beroso: Berosi sacerdotis chaldaici, Antiquitatum libri quinque, cum commentariis Ioannis Annü Viterbensis sacrae Theologiae professoris, nunc primum in antiquitatum studiorum commoditatem, sub forma Enchiridü excusi et castigati... Antuérpia, 1545. Fls. 61v e 293. Ambas as obras são citadas por Braamcamp Freire, em Leitão Ferreira, Vida de André de Resende, A.H.P., VIII (1909), p. 179, n. 77 e IX (1914), p. 216, n. 215.

5 Liber é uma antiga divindade itálica, que cedo foi confundida com o Dioniso grego. Como o próprio nome faz supor, é "livre» o deus e, por isso, facilmente se confundiu com o deus grego que, por epíteto, também era conhecido como o deus que liberta $\Lambda$ vôsos. Daí que a sua mitologia fosse um reflexo da que os poetas atribuíram a Dioniso. Ver P. Grimal, Dictionnaire de la Mythologie Grecque et Romaine, Paris, 1969 (4. ${ }^{a}$ ed.), s. v. Liber; sob o mesmo nome, cf. também R. E., XIII, 68 segs. (Schur) e o Der Kleine Pauly, III, 620-621. Importante é 
o livro de A. Bruhl, Liber pater, Paris, 1953. De qualquer forma, a etimologia de Liber não tem que ver com «livre», mas sim com *leudh, "germinar, fecundar», mais consentâneo com a natureza de um deus ligado certamente aos cultos da fecundidade.

${ }^{6}$ Cic., Verr., II, 4, 57, 128: "Aristaeus qui [ut Graeci ferunt, Liberi filius] inuentor olei esse dicitur, una cum Libero patre apud illos eodem erat in templo consecratus.» A identificação de paternidade, que no texto se encontra entre parênteses rectos, corresponde à lição dos manuscritos repudiada por todos os editores modernos. No entanto, não acontecia assim com os editores contemporâneos de Resende, p. ex., em M. Tulii Ciceronis Orationes diligentius recognitae et aptiore serie repositae. Sunt autem cum actionibus in C. Verrem et philippicis in Mar. Antonium universae, LVII, etc., edição que tem no cólofon a indicação dos livreiros que em Paris a vendiam, e a data de impressão, 1522, sendo o lugar da impressão talvez Roma. Ver Os Lusíadas 1572-1972, Catálogo da Exposição Bibliográfica... Bibl. Nac. de Lisb., Lisboa, 1972, p. 213.

Cic., De nat. deorum., 3, 45, apresenta uma versão diferente da que acima se deduz: "Aristaeus qui oliuae dicitur inuentor, Apollinis filius...".

7 Resende perante as lições dos manuscritos, sobretudo dos AA. gregos, em que $\Lambda$ ovoı $\tau \alpha v i ́ \alpha$ aparece ao lado de $\Lambda v \sigma \imath \tau \alpha v i ́ \alpha$, decidiu-se pela introdução de aut, que é a lição corrente adoptada pelos editores modernos (ver n. 1). Quanto à etimologia ligada a $\lambda$ v́દıv "desligar, libertar», nada há a contrapor, pois a noção expressa pelo verbo estava intimamente ligada à acção psicológica do culto dionisíaco, conforme indica o epíteto $\Lambda$ v́ő e o nome dos sacerdotes $\Lambda$ v́oı ligados à ideia de libertação. O nome $\Lambda$ v́ $\sigma \alpha$ por seu lado, é nome corrente de bacante, como se pode ver em Eurípides, Herc. fur. 822, 834, etc.; Bacantes, 977.

${ }^{8}$ Claudi Ptolemaei Geographia, ed. C.F.A. Nobbe, Leipzig, 1843-5 (reimpr. Olms, Hildesheim,

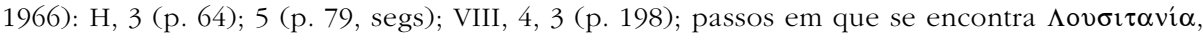

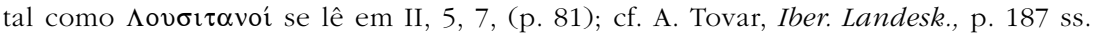

9 Estêvão de Bizâncio, Ethnica, ed. A. Meinecke, Berlim, 1849 (reimpr. Graz, 1958): s. vv.

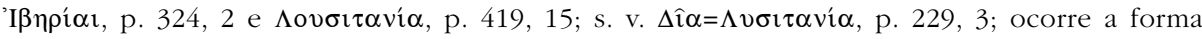

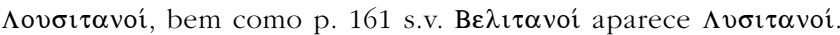

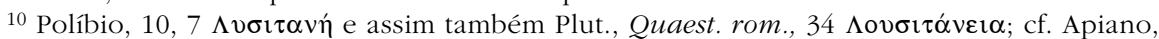
B. ciu., I, 110, 111; Díon Cássio, XXXVII, 52-53, 26; Estrabão, II, 120-3, 153; Ateneu, VII, 302 (que cita Políbio, que de facto é a grande fonte). Ver W. Pappe-G. Benseler, Woerterbuch der griech. Eigennamen, reimpr. da ed. de Brauschweig, 1911 (Graz, 1959), s. vv. Numa inscrição honorífica de Faro (Osónoba) editada por J. d'Encarnação, Inscr. Rom. Com. Pac., n. ${ }^{\circ} 7$, aparece-nos igualmente Lysitania.

11 Paulo, Digesta, XXXXX, Tit. XV, De censibus, VIII, p. 840 em Digestorum seu Pandectarum pars septima, De Stipulationibus et delictis, Lugduni, 1581; muito provavelmente a edição consultada por A. R. foi a de Justiniani digestorum libri L, Florentiae, 1553, em 3 vols.

12 C.I.L, II, 114. Trata-se da História da Antiguidade da Cidade de Évora, Évora, 1553, reeditada em 1576 na mesma cidade e em 1783 em Lisboa. A edição mais recente com útil introdução é a de J. Pereira Tavares, André de Resende, Obras Portuguesas, Lisboa, 1963. A inscrição da Flamínica é discutida e apresentada por Mestre André, no cap. VII desta obra e é considerada com grandes dúvidas por Huebner no C. I. L., II, 114; J. d'Encarnação, Inscr. Rom. Conv. Pac., p. 442, exclui-a do catálogo, depois de lhe dedicar análise cuidadosa; o A. refere igualmente esta inscrição em "Da Invenção de Inscrições Romanas pelo Humanista André de Resende», Biblos, LXVII (1991), p. 199 ss.

13 Estr., III, 3, 4 .

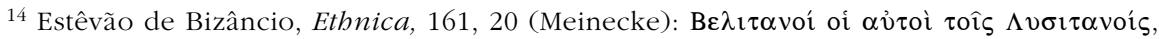

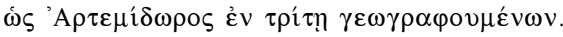

${ }^{15}$ H. N., III, 3, 24. Neste passo, Plínio refere-se aos Bilbilitani (ou seja os habitantes de Bilbilis, cidade da Tarraconense, hoje Calatayud, pátria de Marcial) e não os Belitani. Ver A. García y Bellido, La España del siglo primero de nuestra era, Buenos Aires, 1947, p. 104 (notas à tradução de Plínio).

16 Estr. III, 4, 13 (Ver Schulten, F. H. A., VI, p. 249).

17 Paus., VIII, 18, 7: no texto grego não se fala, contudo, das ruínas de Mepsas, topónimo que para mais não encontrámos. 
18 Estr. III, 3, 3. Resende tem uma noção correcta da diversidade da área da Lusitânia conforme as diversas épocas da administração romana. Para Estrabão a Lusitânia era compreendida entre o Atlântico do golfo de Biscaia e o Tejo. Para sul do Tejo não considerava o geógrafo grego que vivessem Lusitanos, e com razão. No entanto, sucessivas divisões administrativas farão integrar na Lusitânia o Sul do Tejo até ao Guadiana, compreendendo o actual Algarve. A. Tovar, Iber. Landesk., que, pp. 187-191, estuda a evolução da província, lembra-nos que Ptolomeu, citado seguidamente no texto de Resende, apresenta na Lusitânia 30 subdivisões lusitanas, 6 turdetanas, 9 célticas e 11 vetónicas, visto que os Cónios nem sequer são considerados. J. Alarcão, O Dom. Rom. Port., cap. II sobre as Divisões Administrativas p. 31, ss.

19 Ver p. 114.

${ }^{20}$ Estr., III, 3, 3. A controvérsia é analisada por A. Schulten, F. H. A., VI, pp. 201-206. Aqui também se estuda a descrição dos rios Minho e Lima e contesta-se que o Lima e o Minho venham da terra dos Vaceus e "mucho menos de los Celtiberos", visto procederem das serras asturianas.

21 Estr. III, 4, 20: os ordines que compunham o exército correspondem aos $\tau \alpha \gamma \mu \alpha \tau \alpha$ de que fala o geógrafo grego, ou seja, "companhias, legiões».

22 Ptol., Geogr. II, 5, 1-2.

23 Ver p. 114 ss.

24 Pompónio Mela, Cor., II, 6, 87.

${ }^{25}$ Id., Cor., III, 1, 8: abluens é lição que o editor Frick na ed. Teubner, 1880 (reimpr. 1967) não aceita, pois dá-nos adluens.

${ }^{26}$ H. N., III, 1, 6.

${ }^{27}$ H. N., IV, 21, 113.

${ }^{28}$ Hernán Nunez de Guzmán, o "Pinciano", era conhecido também como "O comendador grego", viveu de 1475? a 1553 e publicou as suas Observationes Ferdenandi Pintiani... in loca obscura, aut deprauata, bistoriae naturalis C. Plinii, Salamanca, 1544, com edições em Antuérpia, 1574, Francoforte, 1593 e Lião, 1593. Resende aponta para a existência, aliás real, dos dois códices fundamentais para o texto de Plínio: o Codex Toletanus, do séc. XIII e o Codex Salmanticensis Pintiani (historicamente ligado a Nunez de Guzmán. A sua datação não é bem conhecida, mas pensa-se que seja tardio). Ver A. García y Bellido, ob. cit. (n. 15), p. 105 segs.; José López Rueda, Helenistas Españoles del siglo XVI, Madrid, 1973, pp. 303, 304, 306.

29 Trata-se de pura fantasia, quanto à origem grega destes povos. Ver A. García y Bellido, ob. cit. (p. 15), p. 247, n. 140. De resto é conveniente seguir este comentário para compreender, ainda que com lacunas, o texto pliniano referente à Península Ibérica.

${ }^{30}$ Quanto ao texto pliniano aqui apresentado, em que a ordem dos manuscritos é alterada se a compararmos com os textos elaborados pela crítica moderna, alteração essa talvez devida a erro do copista, conforme alvitra Resende, ver R. M. Rosado Fernandes, art. cit., na n. 1, pp. 497-499. Aponta-se aqui para o "puzzle», em que a ordem foi alterada: Plínio, H.N., IV, 20, 111-112; IV, 21, 113; IV, 22, 114, aparecem em diferente combinação de forma a permitir que o "promontorium Celticum" seja descrito como se se tratasse do "promontorium Olisiponense". Ambos são, contudo, bem descritos geograficamente por Plínio. Quanto às medições podem traduzir-se millia por milhas, uma vez que a milha romana corresponde a "mil passos" (subentende-se passum), o que equivale a 1478,7 m.

31 Solino, Collectanea rerum memorabilium, 23, 5, p. 103, 17 (Mommsen). Neste texto não aparece o genitivo Hispaniae que no texto de Resende se sucede a Lusitania. O texto é simplesmente: "In Lusitania promunturium est...». O erro geográfico consiste em confundir o cabo Finisterra (Ártabro) com o cabo da Roca (Olisiponense), erro gritante e quase ridículo para os modernos, mas que acontecia nos geógrafos antigos, muitos dos quais não tinham visitado as regiões que descreviam, como parece ser o caso de Estrabão, fonte respeitada e citada sobretudo depois do séc. V d. C. Ver A. Schulten, F. H. A., VI, p. 2; F. Lasserre, s.v. Strabon, Der kleine Pauly, V, 378 ss.

32 Marciano Capela, De Nuptiis Mercurii et Philologiae, VI, 628-630 (p. 308 Dick): "Olisipone illic oppidum ab Ulixe conditum ferunt, ex cuius nomine promunturium, quod maria terrasque distinguit. Nam ab eius ambitu inchoat mare Gallicum et facies setentrionalis Oceani, Atlanticus 
uero et occiduus terminatur, qui tum Hispaniae limitatur excursibus.» De novo se repete o erro de que o promontório Olisiponense (cabo da Roca) é o ponto limite, que, depois de rondado, dá acesso ao mar Gálico, ou seja, ao mar Cantábrico no golfo da Gasconha.

33 Isidoro, Etim., XV, 1,70-71: "Olisipona ab Ulixe est condita et nuncupata; quo loco, sicut historiographi dicunt, caelum a terra et maria distinguuntur a terris.»

${ }^{4}$ H. N., IV, 22, 114: "Arrotebras enim, quos ante Celticum promunturium, hoc in loco posuere litteris permutatis." Este é o texto de Plínio à luz da ciência textual moderna. É importante ter a totalidade do período diante dos olhos, na medida em que ao finalizar com litteris permutatis Plínio alude à identificação que Resende discute um pouco mais adiante, ao citar repetidamente o mesmo passo.

35 Estr., III, 3, 5:

36 Resende não está consciente do que significa a afirmação de Plínio: é que o nome do povo era Arrotrebae e não, como diz aceitar, Arotebrae. Esta última forma do etnónimo era mais fácil de identificar com Ártabros. Plínio estava certo quanto ao nome do povo, embora se enganasse quanto à identificação do promontório.

37 Ver n. 34.

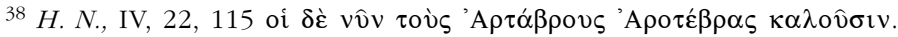

39 Joaquim Vadiano (Watt), cidadão suíço, publicou a edição Pomponi Melae de orbis situ libri tres accuratissime emendatis, una cum commentariis Ioachimi Vadiam Helvetii castigatioribus, Basileia, 1522, fl. 161, alínea $h$, em que acusa Plínio de "magnus error» porque «Olisiponensi promontorio oram Hispaniae occiduam finiri et septentrionalis lateris flexum incipi existimauit...». O erro que A. R. lhe aponta está na mesma fl. 161 em que faz o comentário à descrição da Lusitânia de Mela, "(Cuneum) caput hodie Sancti Vicentii nominant. Idipsum Ptolemaeus sacrum esse credit, ut facile in locis non adeo distantibus error commititur», e mais adiante na alínea $i$ "Sacrum. Quod Barbarium, nisi fallor, Ptol. uocat, Magnum aut, quod ipse Lunae montis promontorium dixit."

40 Nas notas ao poema Vicentius leuita et martyr, publicado em Lisboa, 1545 (ed. facsimilada, com introdução de J. V. Pina Martins, Braga, 1981), n. 41 ao livro II do poema, Resende explica pormenorizadamente o engano de Vadiano, porque interpretou mal a frase pliniana em questão (H. N., IV, 22, 116) por introduzir pontuação errónea. Assim, na versão de Vadiano, lia-se: "... cidades famosas na costa a partir do Tejo, Lisboa, célebre devido à fecundação das éguas pelo vento favónio, cognominada Alcácer do Sal (Salácia). Miróbriga, Cidade Imperatória." Vadiano, segundo Resende, "delirava», hallucinatus est, pois não entendeu a versão pliniana que muito simplesmente dizia: «... cidades famosas na costa a partir do Tejo, Lisboa, célebre devido à fecundação das éguas pelo vento favónio. Alcácer do Sal, cognominada Cidade Imperatória. Miróbriga, etc.». Vadiano na edição citada na nota anterior: fl. 162, alínea i: "Plinius ipsam etiam Vlyssiponem Olisiponem, quam hodie Lisbonam uocant, Salatiam cognominatam tradit.", o que é evidente incompreensão, por parte de Vadiano, do texto de Plínio.

41 Resende interfere violentamente no texto de Plínio e basta comparar com o texto que seguidamente e resignadamente acaba por aceitar para nos darmos conta das alterações. A verdade é que Plínio, autoridade incontestada no séc. XVI, se enganara, pois pela sua descrição mostra que estava convencido de que a costa entre o cabo da Roca e o cabo Finisterra (na Galiza) estava situada a norte de Espanha, ou seja que ocuparia o mesmo lugar da costa galega e asturiana. Ver Francisco Oliveira, "A Imagem da Hispânia em Plínio o Antigo", in II Congresso Peninsular de História Antiga, Fac. de Letras, Univ. de Coimbra, s.d. (1990), separata de 13 pp., que analisa a problemática levantada pelo texto pliniano.

${ }^{42}$ H. N. IV, 21, 113; 22, 114-118 (não é pois somente IV, 21, cap. 22, pois o parágrafo 118 também é considerado). O texto pliniano transmitido por Resende apresenta-se no essencial pouco diferente do texto de Plínio das mais recentes edições. Há, no entanto, leituras diferentes e sobretudo uma pontuação que não raro desvirtua o sentido, sem contudo o deturpar excessivamente. O leitor moderno terá de comparar este texto com o de uma edição actual, mas a verdade é que é este o texto em que Resende fundamentou as suas teorias, e, por isso, é reproduzido sem alteração. 
43 Stipendiariae, Stipendium, ver s. v. F. Lammert, R. E., m, 2536 ss, porque tinham de pagar o tributo em dinheiro, diferente de uectigal, que era pago em espécies. Ver s. v. E. Schwelm, R. E., VII, l ss. Quanto a Salácia Vrbs imperatoria, ver A. Tovar, Iber. Landesk., p. 214.

${ }^{44}$ M. Vipsanius Agrippa, amigo e apoiante de Augusto, militar e político, autor de um comentário geográfico, hoje perdido mas utilizado por Plínio e Estrabão, de onde foi tirado o mapa do Império Romano, construído no Porticus Vipsania depois da sua morte. Ver G. W. Richardson e T. J. Cadoux, Oxf. Class. Dict., s.v. e as referências que amiúde lhe faz A. Tovar, Iber. Landesk., vol.II, Lusitanien.

45 Encontra-se na edição de Coimbra das obras de Resende: Pro Sanctis Christi Martyribus Vincentio Olisiponensi patrono, Vincentio, Sabina et Christhetide, Eborensibus ciuibus et ad quaedam alia responsio, ad Bartholomaeum Kebedium, Sanctae Toletanae Ecclesiae sacerdotem, uirum doctissimum, p. 73: "De Lusitania quoque diuisa, paulo inferius", p. 98: «Expostulat hic locus, ut quod de diuisione Lusitaniae supra sum pollicitus, modo persoluam. In treis conuentus Lusitaniae diuisit Plinius: Emeritensem, Pacensem et Scalabitanum. Duos nos habemus et ultra Anam ex Baetica oppida aliqua neque ignobilia, etc.». Cf. ed. de V. Soares Pereira, André de Resende, Carta a Bartolomeu Quevedo, Coimbra, 1988, pp. 106-107; p. 134-135, n. 184 e 185.

46 Cf. n. anterior.

47 Geogr., n,5. Quanto à qualidade da obra de Ptolomeu e às suas medições, todas quantificadas e, portanto, "susceptíveis de erro", como por outros motivos afirma Resende, bem como quanto às cartas geográficas e tabelas estabelecidas, ver o artigo s. v. Ptolemy no Oxf. Class. Dict. (2a ed. - 1972). Também haverá interesse em consultar os artigos sobre o mesmo geógrafo e astrónomo grego na enciclopédia de Pauly-Wissowa, mesmo na sua versão abreviada, Der kleine Pauly. J. Barradas de Carvalho, O Renascimento Português (Em busca da sua Especificidade), Lisboa, 1980, cita Ptolomeu várias vezes, como fonte de roteiros e livros de viagem, p. ex., pp. 22, 24, 26, etc.; À la recherche de la spécificité de la Renaissance Portugaise, Paris, 1983, 2 vols. A. Tovar, Iber. Landesk., apresenta no fim do vol. II sobre a Lusitânia a carta da Ibéria segundo Ptolomeu.

48 Geogr., II, 5, 3 e 5; para outros geógrafos antigos, contudo, os Turdetanos não se encontram nesta zona, mas sim no Sul de Andaluzia. Resende considera-os o mesmo povo que os Túrdulos. Quanto à localização dos diversos povos, é elucidativa a carta de "distribuição dos povos pré-romanos de Portugal", em J. Alarcão, Portugal Romano, p. 19; o Dom. Rom. Port., p. 32 no importante cap. As Divisões Administrativas, p. 31 ss; A. Tovar, Iber. Landesk., p. 17 ss e passim, que os junta aos Tartéssios; quanto aos Túrdulos, pp. 23 (diferença entre Turdetani e Turduli) e 201ss.

${ }^{49}$ III, 1, 6: descreve a região entre os rios Tejo e Guadiana (a que chama de "entre-rios", ou seja, "mesopotâmia" e na qual diz habitarem Célticos e Lusitanos). Ver comentário de García $y$ Bellido à tradução que fez deste passo.

${ }^{50}$ Encontra-se na edição de Coimbra (1790) das obras de Resende: L. Andr. Resendii, pro colonia Pacensi ad Ioannem Vaseum uirum doctissimum, vol. II, pp. 7-33.

51 Plínio não esquece os Turdetanos, pois lhes chama Túrdulos, H. N., III, 8, 13, 14. Ver García y Bellido no comentário ao texto de Plínio. Este mais adiante diz (IV, 22, 116): «ab Ana ad Sacrum Lusitani». Resende, contudo, considera-os diferentes.

52 Para o leitor moderno a noção evocada no texto latino por ciuitates, que traduzimos por cidades, não corresponde ao seu valor semântico na antiguidade romana. A ideia abstracta de ciuitas reside essencialmente na sua ligação a ciuis romanus e, portanto, ao direito de cidadania, visto que as tribos, ao admitirem a sociedade romana e ao serem admitidas pelos representantes desta, agruparam-se em ciuitates que, mantendo os seus fundamentos autónomos, passavam no "entanto a organizar-se com formas de governo definidas desde o tempo da república romana. Nas zonas mais atrasadas, como na Hispânia e em África, eram elas a base da administração provincial. Ver s.vv. civitas e municipium em Oxf. Class. Dict., bem como as enciclopédias Pauly-Wissowa e Der Kleine Pauly.

53 É o actual cabo Finisterra. 
${ }^{54}$ III, 3, 5: o texto de Resende é fiel ao de Estrabão. Cf. M. Maia, "Celtici e Turduli nas fontes clássicas", in Actas del III Coloquio sobre lenguas y culturas Paleohispánicas, Salamanca, 1985, p. 165-177; A. Tovar, Iber. Landesk., 194-195.

55 H. N., III, 1, 13.

56 Ver n. 48.

${ }^{57}$ H. N., IV, 22, 116. Ver M. Maia, art. cit., n. 54. É evidente que Resende confunde Túrdulos e Turdetanos, esses sim perto de Córdova, com Túrdulos. Cf. n. 48 e A. Tovar, Iber. Landesk., pp. 23 e 201 ss.

58 Tito Ĺ́vio, XXIV, 16;17; 20;

59 III, 1, 6. O passo de Políbio, XXXIV, 8, é somente conhecido pela citação do geógrafo.

60 Deve tratar-se da seguinte edição: Polybii Lycortae historiaram libri $V$, opera Vincentii Obsopoei in lucem editi, graece. Iidem lat. Nic. Perotto interprete, Hagenoae, per Johan. Secerium, 1530 .

61 Geogr., IV, 10; 11 (Túrdulos, cuja capital diz ser Córdova); 12; 13; 14 (Turdetanos, cuja capital é indicada como Híspalis, ou seja, Sevilha). Quanto à Lusitânia, ver n. 48.

${ }^{62}$ H. N., IV, 21, 113; 22, 116. Cf. III, 1,8 .

${ }^{63}$ H. N., IV, 22, 116. Sobre os Vetões, ver J. M. Roldán Hervás, «Fuentes antiguas para el estudio de los Vetones», Zephyrus, XIX-XX (1968-1969), pp. 73-106; A. Tovar, Iber. Landesk., p. 202.

${ }^{64}$ III, 3, 2 e 3.

65 H. N., III, 1, 19.

${ }^{66}$ H. N., IV, 20, 112.

67 De bello ciu., I, 38.

68 Os dois passos de Plínio já citados em n. 63 e 66 são H. N., IV, 22, 116; IV, 20, 112.

69 Geogr., II, 5, 9.

70 Não é possível que Sêntica seja Zamora, visto que fica a sul de Salamanca, o que pode verificar-se pela consulta de qualquer Atlas antiquus, como o de A. van Kampen, publicado em Gotha, s.d., que é a reedição do velho Atlas de Julius Perthes (ver carta n. ${ }^{\circ} 17$ Hispania).

71 III, 3, 1.

72 Geogr., II, 5, 9.

$73 \mathrm{O}$ nome em grego transcreve-se como Ov̉é $\tau \tau \omega v \varepsilon \varsigma$, Estrabão, III, 3.2. Cf. Pape-Benseler, Woert. d. griech. Eigenn., s. v.

${ }^{7}$ Plínio só emprega Vettones, mas este etnónimo alternava em grafia com Vectones. Poderíamos pensar que se trate de uma hipercorrecção, em que a geminada $t t$ fosse corrigida para $c t$.

75 Ver n. 67.

76 Tito Lívio em XXXV, 7 e 22, fala em Vectones: "Vectonum magnus exercitus Toletanis subsidio uenit.» Ver A. Schulten, F.H.A. III, p. 196.

77 Luc., Fars., IV, 9: "Vettonesque leues».

78 Sílio Itálico, Pun., III, 378.

79 De Eborensis Ecclesiae Sanctis, dedicado a Bartolomeu Quevedo, no vol. II da ed. de Coimbra, p. 98 e pp. 99-100; cf. ed. V. Soares Pereira, nn. 185, 186.

${ }^{80}$ C. I. L., II, 18*: é uma inscrição forjada, segundo E. Huebner. Aparece numa inscrição de Beja o cognome Vettonianus, J. Encarnação, Insc. Rom. Conv. Pac, n. ${ }^{\circ}$ 248; "Da Invenção de Inscrições Romanas pelo Humanista André de Resende», Biblos, LXVII (1991), p. 208 ss.

81 C. I. L., II, 485.

82 C. I. L. II, 3884.

83 C. I. L. II, 823.

${ }^{84}$ C. I. L. II, 929.

85 Geogr. II, 5, 9: emprega Ov̉é $\tau \omega \nu \varepsilon \varsigma$ que não pode ser transcrito por Ovetones na medida em que o ditongo grego ov corresponde à semivogal latina $u$ : é pois Vettones. Tal como Resende aponta seguidamente, há em Grego uma alternância quantitativa na grafia do etnónimo 


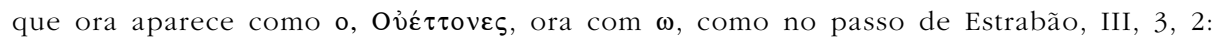

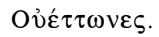

${ }^{86}$ IV, 8-10: há de facto manuscritos que nos transmitem a lição Vectones, mas refere-se em qualquer dos casos a um e ao mesmo povo, os Vettones. O o é de facto longo.

${ }^{87}$ Pun. XVI, 365-366: Vectonum é certamente a lição de alguns manuscritos, o que não impede que a lição mais comum seja a Vettonum, aceite nas edições modernas (vid. Pun., III, 378, indicado na n. 78) e ambas as formas com o longo. No texto da edição de 1593 de Resende a citação de Sílio Itálico é precedida erradamente em "itálico" pela identificação do passo, erro tipográfico emendado em edições posteriores.

${ }^{88}$ Peristephanon, hino 3 (in honorem passionis Eulaliae Beatissimae Martyris), vv. 186-190: "Nunc locus Emerita est túmulo,/ clara colonia Vettoniae,/ quam memorabilis amnis Ana/ praeterit et uiridante rapax/ gurgite moenia pulchra lauit./» (Agora já o seu túmulo tem Mérida para ficar, a célebre colónia da Vetónia, pela qual passa o rio Guadiana digno de ser lembrado e que em verdejante voragem lava rapidamente as suas lindas muralhas.) O metro, tetrâmetro dactílico cataléctico, mostra-nos efectivamente que o o de Vettoniae é breve, repetindo-se portanto em latim o que já o léxico grego nos mostrava (ver n. 85). Quanto à métrica, ver I. Rodrigues Herrera, Poeta christianus, Esencia y misión dei poeta cristiano en la obra de Prudencio, Salamanca, 1981 (Helmantica), p. 70 ss.

${ }^{89}$ H. N., I, 25, 46: trata-se da enumeração que Plínio faz no primeiro livro dos assuntos científicos que vai tratar. Ao referir-se ao livro XXV (Botânica), diz-nos que no parágrafo 46 será observado o "cestros siue psychotrophon, quae Vettonica siue serratula, etc». Infelizmente o livro XXV chegou até nós incompleto.

90 Quinto Sereno Samónico, uir saeculo suo doctus, nas palavras de Macróbio, III, 16, 6, vive no reinado de Septímio Severo (193-211) e era grande investigador de Plínio. Ver Funaioli, "Q. Serenus Sammonicus" na RE, s. v. O texto referido é de Sereni Sammonici, Liber medicinalis, P.L.M. (Baehrens), vol. III, p. 116 (XIII, Oculorum dolori mitigando), V, 202, (vv. 119-202):

Hyblaei mellis sucus cum felle caprino

Subueniunt oculis dirá caligine pressis.

Vettonicae mansus siccabit lamine sucus.

${ }^{91}$ Dioscórides, De med. mat., IV, 1 (De Betonica); Amato Lusitano, In Dioscoridis Anazarbei de medica materia libras quinque... enarrationes eruditissimae, Lugduni (Lião), apud Viduam Baettragaris Arnocetti, 1558, p. 579-80 confirma as observações de A. Resende.

92 Ver n. 67.

93 Geogr. II, 5, 9 com a indicação das latitudes.

94 Ver 74 .

95 A proposta de A. Resende é completamente fantasiosa, na medida em que as formas gregas estão perfeitamente definidas (nn. 73 e 85 ) e a grafia com $t$ geminado ou $c t$ não levanta problemas de maior na transcrição latina de um etnónimo hispânico. Enumeração diferente da que encontramos na p. 20 da ed. lat. (Ouettones, Vuettónes, Ouetiones). Neste passo Ouettones, Ouettônes (o longo, Ouetiones).

96 Ver n. 85

${ }^{97}$ H. N., IV, 20, 112. A correcção de A. R. refere-se a Castra Iullia (não identificável) perto de Metellinum, que se situava sobre o Guadiana. Ver J. Alarcão, Port. Rom., p. 40.

98 Sílaba ancípite, de anceps, ou seja, com duas cabeças. Daí o sentido de "duplo», ambíguo", de que se infere a noção métrica de sílaba com duas quantidades possíveis. Ver Ernout-Meillet, Dictionnaire Étymologique de la Langue Latine, Paris, 1959-1960, s. v. caput; Crusius-Rubenbauer, Römische Metrik, Munique, 1955, parágrafos 9 e 37.

99 Geogr. II, 5, 9.

${ }^{100}$ H. N., III, 1, 16.

101 Ver n. 73.

102 Ver n. 100.

103 Ver n. 99. 
104 Ver n. 88. Efectivamente Mérida aparece referida por perífrase antonomástica igualmente no Peristephanon, hino 4 (hino em honra dos dezoito mártires de Saragoça), v. 35 e segs: "Lusitanorum caput oppidorum/ urbs adoratae cineres puellae, etc.", quando da enumeração das cidades hispânicas célebres pelos seus mártires e santos.

105 De Eborensis Ecclesiae sanctis, ed. de Coimbra, II, pp. 98-100; cf. n. 79.

106 Florião do Campo, Los cinco libros primeros dela Cronica general de España, que recogila el maestro..., Medina del Campo, 1533, fól. 13 v. (promontorio Barbárico) remete para fól. 155 e ao falar dos Sários Lusitanos diz: ".. .nación cruel y de mal hospedaje para los estrangeros...", numa zona em que havia um promontório "a quien los Cosmógrafos deziam el Promontorio Barbárico, por estar en la provincia destos Bárbaros Sarios, y nosotros agora... lhes lhamamos Cabo Despichel." Mais notícias sobre a sua crueldade no fól. $95 \mathrm{v}$ ss.

107 Estr., III, 2, 9: no texto de Estrabão aparece simplesmente ßó $\rho \beta \alpha \rho o$, que significa os bárbaros que viviam nas regiões para além da Lusitânia e nas ilhas Cassitérides (em geral identificadas com a Grã-Bretanha). O termo bárbaros é por conseguinte genérico. Isso não impede que em III, 3, 1, Estrabão se refira ao promontório Barbário, que não é mais do que o cabo Espichel, depois do qual, segundo o geógrafo, aparecem as bocas do Tejo. Antes do promontório haveria um golfo, que é certamente o que era compeendido entre o cabo de S.

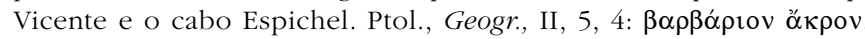

108 É o chamado "mármore da Arrábida", como refere O. Ribeiro, "Excursão à Arrábida", Finisterra, III, 6 (1968), p. 257-273.

${ }^{109}$ H. N., IX, 40, 141: "Coccum Galatiae rubens granum... aut circa Emeritam Lusitaniae in maxima laude est.» Descreve seguidamente as suas qualidades e classificação botânica. Ver o comentário de García y Bellido ao passo (n. 201, p. 264): trata-se sim de uma lagarta de que se extraía uma matéria para tingir (cf. Plínio, H. N., XVI, 8, 32).

${ }^{110}$ Blattea, blatteia, blattia, aparecem registados no Thes. Ling. Lat., s. v., bem como blatta (2) como os equivalentes a púrpura. Também coccineus, - $a$, -um nos aparece atestado com o sentido atribuído por Resende, no Thes. Ling. Lat., s. v. Referem-se-lhes autores tardios, como Venusiano, Carm., 2, 3, 19 (blattea); Sid. Apol., Carm., V, 48 (blatta); ou Marcial, XIV, 131 (coccineus). A primeira expressão só aparece tardiamente com o sentido de tecidos de púrpura.

111 Nero, 30: "Piscatus est rete aurato et purpura coccoque funibus nexis."

112 Breu., VII, 14.

113 Ep., IX, 13, 5, vv. 14-27. O texto apresentado por A. Resende, salvo nalguns particulares ortográficos, em pouco difere do texto modernamente estabelecido. Quanto ao trabalho crítico de Resende aqui referido, não foi ele encontrado quer impresso quer manuscrito, muito embora, com fundamento nesta informação, a ele se referiram tanto Barbosa Machado, Bibl. Lus., I, 169, como Nicolau António, Bibl. Hisp. N., I, 86, e outras fontes bibliográficas, citadas por BraamcampFreire, na biografia de Resende do A. H. P., IX (1914), p. 203, n. 184.

114 De rer. nat., II, 500-501: a lição tecla aceite por Resende é em geral substituída por infecta ("tingida"), ainda que certos códices (de Leiden, p. ex.) apresentem a lição "tincta", "tingidas». De realçar a erudição do humanista ao comparar os textos de Sidónio Apolinar e Lucrécio.

115 Gaio, 10, 66 (6) De excusationibus artificum, col. 108 in Volumen Legum, Parvum quod vocant in quo haec insunt tres posteriores libri codicis Justiniani, ..., Venetiis, 1583; anterior a esta temos a mesma informação no Parvus, ou seja, Brachylogos totius iuris ciuilis, Lugduni, 1553, (Brachylogos = Parvus).

${ }^{116}$ D. Andreae Alciati..., Paradoxorum ad Pratum libri sex. Dispunctionum, lib. IIII, De eo quod interest, liber unus, In tres libras Codicis, lib. III, Praetermissorum, lib. II, Declamatio una, De Stip. divisionibus, Commentariolus, Lugduni apud Sebastiaum Gryphium, MDXXXVII (In tres posteriores codicis Iustiniani libros annotatiunculae), p. 200: De excusationibus artificum. Depois de lecticarii, lactarii fala dos Barbaricarii. Cita os myrobrechariorum referidos por Flauto na Aulularia, 3, 5, 37 (ver murrobatharius, dub.), que corrige: "In praesentiarum tamen castigatius legendum hic putaverim barbaricarii, ut hi sint, qui barbaricas vestes intexunt, aliter dicti phrygiones. Horum artis est ex auro et coloratis filis in vestibus hominum animaliumque exprimere, ete." (cita Virgílio e Apuleio). 
117 Não pode tratar-se de Mariano Escoto, monge de Fulda, que escreveu no séc. XI uma Crónica da Igreja, só publicada no séc. XVI. Por sugestão do Prof. Nuno Espinoza Gomes da Silva, autor de Humanismo e Direito em Portugal no Século XVI, Lisboa, 1964, consultámos o repositório da bibliografia jurídica dos tempos quinhentistas, de A. Fontana, Amphitbeatrum legale ...seu Bibliotheca legalis amphissima ..., Parmae, 1688, onde encontrámos sob o nome Scotus, um Mariano Escoto autor de um De Romanis Pontificibus, impresso em Frankfurt, 1583, que poderá não ser necessariamente a primeira edição (Resende morre em 1573). No catálogo da Biblioteca Nacional de Paris encontra-se uma obra de Federicus Scotus, Ad rubricam Pandectarum de operis novi nuntiatione liber, Venetiis, J. Gryphius, 1547. Não nos foi possível consultar nenhum destes livros. Partindo, contudo, do princípio de que o texto tem sempre razão, só procedendo a uma busca mais apurada poderemos talvez identificar a obra utilizada por A. Resende.

118 Aulularia, vv. 508-521: linarius (508); caupones, patagiarii, indusiarii (509), flamarii, uiolari, carinarii (510): trata-se de uma enumeração caótica, com fins cómicos, proferida pela personagem Megadoro. Resende avança claramente com a hipótese, pouco provável aliás, de que Barbário seria a designação de um profissional de tinturaria.

119 Ver J. André, Lexique des Termes de Botanique en Latin, Paris, 1956, s. v.

${ }^{120}$ H. N. IV, 20, 113: Paesuri. A. Tovar, Iber. Landesk., p. 257.

121 C. I. L., II, 760; os Paesures são igualmente nomeados na inscr. dedicada a Adriano, como sendo os dedicantes. A inscrição é considerada forjada: C. I. L., II, 75*.

${ }^{122}$ H. N., IV, 21, 113. Quanto à situação dos Túrdulos na Costa Portuguesa, entre o Douro e o Tejo, ver R. Alarcão, Port. Rom., p. 18 (Fig. 1); O Dom. Rom. Port., p. 44 e Fig. 6 (p. 32).

123 Pómpónio Mela, Chorogr., III, 8.

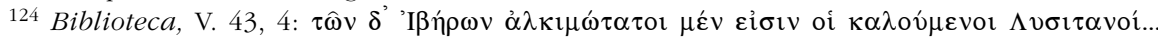

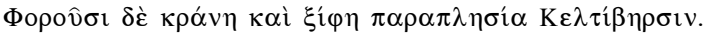

As dúvidas de A. Resende são levantadas pelo texto de Diodoro que ele utilizou, pois na versão corrente encontramos exactamente a lição que pretende o nosso humanista, ou seja, Iberos e não Celtiberos: "Dos Iberos os mais corajosos são os chamados Lusitanos... e usam os elmos e as espadas iguais às dos Celtiberos."

125 III, 3, 3: "Para norte do Tejo estende-se a Lusitânia, a maior das nações ibéricas e a que durante mais tempo foi combatida pelos Romanos." Cf. M. Cardoso, s. v. "Lusitanos»,Dic. Hist. Port.

126 Valério Máximo, Acções e Ditos Memoráveis, VI, 4. No capítulo De grauiter dictis aut factis ab externis ( $\mathrm{Da}$ autoridade nas palavras e nos actos dos estrangeiros). O passo trata da conquista da Lusitânia e da cidade de Cingínia, que faltava conquistar a Bruto, contra o qual resistia. Bruto propôs aos habitantes que pagassem um resgate, e a resposta foi que "os seus antepassados lhes tinham deixado ferro para que se defendessem, e não ouro para que comprassem a liberdade a um general ganancioso." Resende apresenta o topónimo de Cinania em vez de Cinginnia, o que é manifesto erro.

127 VII, 3, 6 (Da esperteza nas palavras e nos actos dos Romanos): é neste capítulo que o historiador romano faz uma referência, que Resende não transcreve, mas que critica, pois ela refere a ingovernabilidade da nação lusitana. É a conclusão à história de Sertório que, pela sua habilidade, tinha conseguido dos Lusitanos o que eles próprios não conseguiam uns dos outros: "Ita gens barbara, aspera et regi difficilis, in exitium suum ruens, quam utilitatem auribus respuerat, oculis peruidit.»; "Foi assim que um povo bárbaro, rude, difícil de governar e que se precipitava para a própria perda, viu pelos olhos a utilidade de um conselho que só pelos ouvidos tinha desprezado."

128 Tito Lívio, XXXV, 1 (são vencidos os Lusitanos por P. Cornélio Cipião e mortos 12.000); XXXVII, 46 (matam os Lusitanos a 6.000 Romanos); XXXVII, 57 (derrotados por L. Emílio Paulo, e mortos 18.000); XXXIX, 21 (O pretor Gaio Atínio mata 6.000); XXXIX, 42 (triunfo de Gaio Calpúrnio Pisão, pretor, sobre os Lusitanos); XLI, 3 e 11 (submissão: triunfo de L. Postúmio Albino).

129 Este aspecto propagandístico da historiografia romana é tratado por H. Peter, Wabrheit und Kunst, Geschichtschreibung und Plagiat im klassischen Altertum, Leipzig - Berlim, 1911, p. 277 ss. 
130 III, 4, 13: relata a troça feita pelo filósofo Posidónio a Políbio devido às trezentas cidades que este referia e que segundo Posidónio deveriam ter sido trezentas torres. Quanto à atitude de Posidónio a respeito do imperialismo romano, ver Oxf. Class. Dict., s. v.

131 XXVI, 49: trata-se da crítica liviana ao analista Valério Anciate, que costumava empolar os números a favor dos Romanos; cf. H. Peter, ob. cit. (n. 129).

132 XXXV, 1, 4 e segs.

133 XXXVII, 46, 7.

134 Paulo Orósio, Hist. adu. Paganos, IV, 20, 23; 21, 3 e 10.

135 IX, 6, 2.

136 XXII, 89-90; cf. Oratorum Romanorum fragmenta (Malcovati), M. Porcius Cato, frags. 196-198 (pp. 79-80) e Cíc., De or., I, 227.

137 XX, 66.

138 Pseudascónio, In div., p. 203: "Cato hic accusauit Ser. Galbam pro direptis Lusitanis".

139 Tito Lívio, Periochae, XLIX.

140 VIII, 1,2 .

141 XXXIX, 40, 12.

142 Hist. adu. Paganos, V, 4, 5 (a fonte é Q. Claudius Quadrigarius, Lib. VIII, frag. 69, H.R.R. (Peter). Cf. A. Schulten, R. E., s. v. Lusitani, vol. XIII (1869); R. M. Rosado Fernandes, "O Episódio dos Trezentos Lusitanos contra Mil Romanos e Sua Possível Explicação", in Rev. "Ocidente", LXXII (1967), pp. 278-283. Trata-se de um topos heróico inspirado na gesta espartana dos trezentos das Termópilas na guerra da Hélade contra os Persas.

143 Prodigiorum liber, 17 (ano 154 a.C.). Ver Periochae, XLVIII de Tito Lívio.

${ }^{144}$ Epitomae, I, 33, 13: «Sed tota certaminum moles cum Lusitanis fuit. Nec inmerito. Quippe solis gentium Hispaniae duces contigerunt".

145 Ibid. I, 33, 15: "Ceterum Lusitanos Viriatus erexit, uir calliditatis acerrimae. Qui ex uenatore latro, ex latrone subito dux atque imperator et, si fortuna cessisset, Hispaniae Romulus...".

146 Epit. hist. phil., XLIV, 2, 7.

147 Onomasticon, I, 173 (Bethe): o vocábulo aparece num longo capítulo sobre termos militares.

${ }^{148}$ De officiis, I, 30, 108

149 Díon Cássio, Hist. Rom., XXXVII, 52, 3.

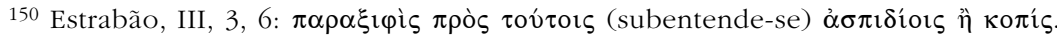

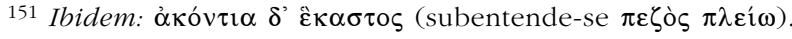

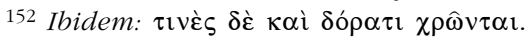

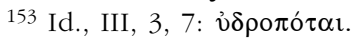

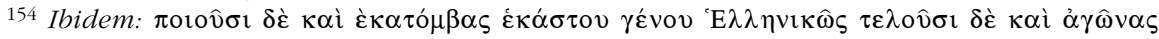
$\gamma \cup \mu \nu \imath \kappa о \hat{\varsigma} \varsigma, \kappa \tau \iota$.

Fala-se de "à moda grega" 'E $\lambda \lambda \eta \nu \imath \kappa \hat{\omega} \varsigma$ e não, pelo menos nas edições modernas, "à moda de Esparta".

155 De bello ciuili, I, 48.

156 César, B.C., 48; Tito Lívio, XXI, 27, 5; XXVIII, 5, 11; Sílio Itálico, Pun., III, 348; Luc., Fars. VII, 232, etc. A caetra era um pequeno escudo redondo. Cf. M. Cardoso, art. cit. (n. 126); Cabré Aguiló, "La Caetra y el Scutum en Hispania durante Ia Segunda Edad de Hierro", Bol. del Seminario de Estudio de Arte y Arqueología, Valladolid, VI, 1936-1940, p. 57 ss. Ver Escólios de Mendes de Vasconcelos, à p. 36, linha 10, e n. 1.

157 Chorogr. III, 10: "totam Celtici colunt, sed a Durio ad flexum Groui...».

${ }^{158}$ H. N., IV, 20, 112: "A Celenis conuentus Bracarum, Helleni, Groui, castellum Tyde, Gaecorum sobolis omnia;”. Como podemos avaliar pelas lições adoptadas posteriormente, O etnónimo é Groui e não Gronii ou Grauii como pretende Resende. Sabemos, no entanto, que Grauii ou Groui são uma e a mesma coisa. Cf. R. Grosse, F. H. A., VII, p. 226.

159 Sílio Itálico, Pun., I, 235-236 e III, 366-367; Grávios e Graios um mesmo nome para nobilitar com origem helénica, ainda que fantasiosa, um povo peninsular (ver n. 164).

160 Ver n. 158. 


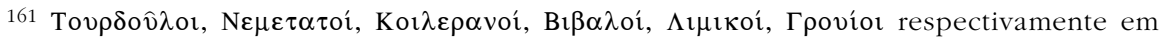
Geogr. II, 4, 6 e 10; II, 6, 41; 42; 43; 44 e 45.

${ }^{162}$ C. I. L, II, 2477 e 5616 (Aquae Flauiae). Há que ter em conta os comentários de Huebner; J. Alarcão, O Dom. Rom. Port., p. 35 ss.

163 Ver n. 157.

164 Hist. Phil. XLIV, 3, 4: "Gallaeciae autem portio Amphilochi dicuntur." Justino acrescenta, contudo, no parágrafo anterior (2) que os Galaicos se atribuem origem grega e que foi Teucro que, depois de ter passado por Chipre, a seguir à guerra de Tróia, e por ter sido impedido de regressar à sua terra natal, teria ido habitar no Sul da Espanha (a então Nova Cartago, hoje, Cartagena) e daí teria passado à Galécia. Sobre as origens míticas gregas da Ibéria, inventadas, segundo os historiadores, por Asclepíades de Mirleia, ver A. Schulten no comentário aos passos de Justino sobre a Hispânia, em F. H. A., VIII, pp. 334-354 e em especial p. 350.

165 Em III, 4, 3, transmite Estrabão a mesma lenda criada por Asclepíades. Ver o comentário ao passo referido feito por A. García y Bellido na sua tradução espanhola, bem como o de A. Scbulten, F. H. A., VI, p. 226.

166 Ver n. 158

167 Ver n. 164

168 Sílio Itálico, Pun., III, 367. Ver comentário ao passo em R. Grosse, F. H. A., VII, p. 226. Segando a lenda, teria sido Diomedes, rei da Etólia, que no seu regresso de Tróia teria fundado Tyde, em cujo nome recordaria a memória do seu pai Tydeus.

169 Ver n. 154

170 Ver pp. 92 e 186-187.

171 Quanto às influências gregas na Hispânia, ver J. Maluquer de Motes y Nicolau, "Gregos na Península",Dic. Hist. Port., que cita a principal bibliografia. Quanto às influências linguísticas não é de crer que se tenham exercido directamente, mas sim por intermédio do Latim.

172 Ver p. 126.

173 C. I. L., II, 258 (zona de Lisboa e Estremadura).

174 C. I. L., II, 259 (zona de Lisboa e Estremadura).

175 Intitula-se o livro referido, Inscriptiones sacrosanctae uetustatis non illae quidem Romanae, sed totius fere orbis summo studio ac maximis impensis Terra Marique conquisitae feliciter incipiunt. Magnifico Viro Domino Raymundo Fuggero invictissimorum. Caesaris Caroli Quinti ac Ferdinandi Romanorum regis a Consilis bonarum litterarum Mecaenati incomparabili Petrus Apianus Mathematicus Ingolstadiensis F. Bartholomeus Amantius Poeta DED. Ingolstatii in aedibus P. Apiani, anno M.D.XXXIIII.

176 C. I. L., II, 30* Inscript. Sacros., p. II no livro sobre Inscriptiones Hispaniae.

\author{
SIBILL. VATICINIVM OCCIDIIS DECRETVM \\ VOLVENTVR SAXA LITERIS ET ORDINE RECTIS \\ CVM VIDE AS OCCIDENS ORIENTIS OPES. \\ GANGES INDVS TAGVS ERIT MIRABILE VISV \\ MERCES COMMVTABIT SVAS VTERQ. SIBI. \\ SOLI AETERNO AC LVNAE DECRETVM
}

177 Foi o editor Valentim da Morávia (ver J. Barradas de Carvalho, s. v. Valentim Fernandes, Dic. Hist. Port.) que encontrou, nas circunstâncias adiante descritas, esta "duvidosa" inscrição e a dedica a Jeronimo Münzer (Monetário) de Nuremberga (Ob. cit., p. H): "Valentinus Moravus D. Hieronymo Monetário Nurenbergen. Anno a nativitate Dni 1505, nona uero die Augusti, regnante Emanuele Rege excellentissimi Portugalliae Regni autem sui anno 13. in ultimis suae ulterioris Hispaniae finibus, versus solis occasum in calce Lunar promontorii quod Rocham de Sinna vulgus appellat, secus Maris Occeani littus tres sub terra ex insperato compeste fuere ex saxo columnae quadrata forma priscis temporibus characteribus Romanis una tantum quadra incisis, quarum basis recta ordine immitato paululum in caput erigebatur, caput uero proprium in basim ex industria ut apparebat defixum conspeximus, euulsisque ferro et arte decoctis lapidibus, quibus praefatae mirandae colunnae subtus alligabantur tandem in earum una iam directe conuersa has figuras liquido annotauimus, nam aliarum literas in lucidum explicare 
non satis nobis fuit integrum, quia temporum uetustate ac maris imbribus et afflatu erant pare consumptae."

178 Varrão, De re rust., II, 1, 7. Ver R. M. Rosado Fernandes, "O Vento, as Éguas da Lusitânia e os Autores Gregos e Latinos», Euphrosyne, XII (1984), pp. 53-77, em que se estuda esta lenda na tradição antiga. Este trabalho é continuado em «O vento, as Éguas de Lisboa e os Humanistas do Ocidente Peninsular", Primera Reunión Gallega de Estudios Clásicos, Santiago de Compostela, 1981, pp. 369-388, em que se analisa a transmissão e interpretação do mesmo mito nos autores medievais, renascentistas e modernos.

179 H. N., VIII, 67, 166.

180 Hist. Phil. XLIV, 3, 1,: "In Lusitanis, iuxta fluuium Tagum...».

181 De re rust., VI, 27, 4-7.

182 Hist. Phil., XLIV, 3, 6: Justino fala de um "sacer mons", que não pode ser violado pelo ferro por motivos sagrados, isto é, não pode ser lavrado nem cultivado, certamente por estar consagrado a qualquer culto. O mesmo se deve ter dado nas imediações de Lisboa, pois já J. Leite de Vasconcelos apontava Monsanto, como possível lugar sagrado, Religiões da Lusitânia, II, Lisboa, p. 30. Cf. R. M. Rosado Fernandes, art. cit. (Euphrosyne), p. 55 e segs. e n. 3.

183 Leite de Vasconcelos, ob. cit., p. 103, propõe com razão que a lição de Varrão seja considerada como erro de copista. Tagro estaria por Sacro, visto que a toponímia o justificaria. Tagro é topónimo que não existe, segundo Leite de Vasconcelos.

184 Esta descrição lembra a dos cavalos do Sorraia de que fala Ruy de Andrade, "Les chevaux Sorraia”, in Comptes Rendues du XII Congrès International de Zoologie, Lisboa, 1935, pp. 23682370; publicado em sep., Lisboa, 1937.

185 Georg., III, 271-275, ver Ruy Mayer, As Geórgicas de Virgílio, Lisboa, 1948, p. 375. Resende admira-se de o caso das éguas lusitanas não ser referido por Virgílio, tanto mais que o poeta no passo indicado se refere em termos genéricos à grande intensidade do cio nas éguas, tema bem conhecido dos zoólogos e naturalistas antigos.

186 Sílio Itálico, Pun., III, 378-383; XVI, 362-365, não refere o caso olisiponense mas apresenta forte influência homérica e refere-se, sim, aos "campos dos Vetões», perto de Mérida e Salamanca, mas não de Lisboa.

187 Braamcamp Freire, na ed. da "Vida de André de Resende» de Leitão Ferreira, $A$. H. P., IX (1914), diz-nos a p. 215, n. 211, que não conseguiu encontrar nos repositórios bibliográficos as cartas a que se refere A. R., dirigidas a Manuel de Sousa, alcaide de Arronches, bem como a João Vaseu.

188 Meidubriga, Medobriga, Medobrega (ver n. 193) ou Medubriga, não é identificável na zona de Marvão, mas sim com Ranhados no concelho de Meda, na Beira Alta e, portanto, perto da serra da Estrela. Ver J. Alarcão, Portugal Romano, p. 46; O Dom. Rom. Port., p. 43; A. Tovar, Iber. Landesk., p. 254 ss.

189 No concelho de Marvão a citada Aramenha corresponde à antiga Ammaia e não a Herminia, criação fantasiosa. Ver J. Alarcão, ob. cit., p. 77 e sobretudo «Os Montes Hermínios e os Lusitanos" in Livro da Homenagem a Orlando Ribeiro, 2. ${ }^{\circ}$ vol., Lisboa, 1988, pp. 41-48; que em nada coincide com as hipóteses apresentadas nem com o passo de Díon Cássio; A. Tovar, Iber. Lméak., p. 220.

${ }^{190}$ H. N., IV, 22, 114: "Medubricenses qui Plumbari (cognominantur)...". Ver R. Grasse, $F$. H. A., VII, p. 199: “Medubriga, ciudad de Lusitania, llevava el nombre de Plumbaria, sin duda por el plomo que se obtenia alli». Como pode verificar-se, a informação não é abundante. Cf. ed. de Plínio de García y Bellido, p. 253, n. 156, com um comentário pouco conclusivo, em que se interroga se Medóbriga deve ser colocada na serra da Estrela. A resposta já foi dada na n. 190. Quanto ao passo de Plínio, ver J. Alarcão, ob. cit., p. 129; O Dom. Rom. Port., p. 43; A. Tovar, Iber. Landesk., 254 ss.

191 De bello Alexandrino, 48: o autor desconhecido desta pequena obra histórica refere-se ao ataque de Cássio Longino contra «in Lusitania Medobregam oppidum montemque Herminium... quo Medobregenses confugerant...", o que implica a proximidade de Medobrega ou -briga, do monte Hermínio, provavelmente serra da Estrela, apesar da identificação de Resende com a região de Portalegre. 
192 Antonino Pio, Itineraria, Itineraria Romana, vol. I, Itineraria Antonini Augusti..., ed. O. Cuntz, Leipzig, 1920, p. 64. A lição aceite transmite-nos o topónimo Montóbriga e não Medóbriga, além de que o texto se limita à enumeração dos nomes com as distâncias à frente. Montóbriga "está igualmente por localizar», diz J. Alarcão, ob. cit., p. 7; igual atitude assume J. M. Roldán Hervás, Itin. Hisp., s. v. Montobrica, p. 251 e também p. 66.

193 Budua é Bótoa já em território espanhol, J. Alarcão, ob. cit., p. 75; J. M. Roldán Hervás, Itin. Hisp., p. 65; A. Tovar, Iber. Landesk., p. 222.

194 Documentos publicados no Livro Santo de Santa Cruz - Cartulário do Séc. XII, ed. Leontina Ventura \& Ana Santiago Faria, Coimbra, INIC, 1990, indicação bibliográfica que ficamos a dever, assim como sugestões quanto à compreensão do texto de A. R., ao Prof. Aires do Nascimento.

195 Livro Santo (Torre do Tombo), fl. 64, doc. 70, publ. e Documentos Régios por Rui Pinto de Azevedo, doc. 10, e Livro Santo de Santa Cruz, doc. 70 (de 1106, 1 de Agosto). A. R. abrevia e altera o texto original: «Ego comes Henricus Portugalensium patrie princeps et uxor mea domna Tarasia magni regis Ildefonsi filia facimus cartam donationis et firmitudinis tibi Johanni Siiciz presbitero et socio tuo Fafila presbitero de illa hereditate nomine Sancto Romano que est sita juxta Senam sub Monte Hermeno».

196 A. Resende não falará mais do assunto, como promete, mas a Cabia Iuliani de que fala é a corruptela de Canea Juliani ou Cova Juliana (do Conde Julião, o traidor cristão causador da invasão árabe da península). É um dos étimos apresentados para Covilhã, como vemos em A. Nascentes, Dic. Etim. Ling. Port., II (nomes próprios), s. v.; J. P. Machado, Dic. Onom. Etim., s. v. contesta a "consistência científica" das hipóteses aduzidas por Nascentes, e não considera os potenciais étimos, apresentados, como este, pela imaginação dos eruditos, e que têm importância cultural e histórica.

197 Livro Santo, fl. 66, doc. 77; ed. doc. 77 (1140, Janeiro): «Idcirco ego Ansedus et uxor mea Gontila facimus cartam testamenti Deo... videlicet de medietate tocius nostre hereditatis quam habemus in villa Lagares territorio Sene sub Monte Hermeno».

198 Livro Santo, fl. 67 v. doc. 82; ed. doc. 82 (1139, Agosto): "de una nostra terra quam habemus in territorio Sene, subtus Monte Hermeno in loco qui dicitur Assamassa».

199 Livro Santo, fl. 68, doc. 84; ed. doc. 84 (1140, Janeiro). Confere o texto, só que à leitura Senae corresponde Sene do doc. medieval.

200 Livro Santo, fl. 68 v., doc. 87; ed. doc. 87 (1141, Maio). O texto de Resende reproduz fielmente o medieval.

201 C.R. (Corporações Religiosas, no A.N.T.T.), Santa Cruz de Coimbra, m. III, doc. 24; Livro Santo, fl. 72, ed. doc. 98 (1150, Janeiro): Senae = Sene.

202 C.R., Santa Cruz de Coimbra, m. III, doc. 25; Livro Santo, fl. 128, doc. 197 (1151, Março); "in villa quam vocitant Lagares..." com Senae por Sene.

203 Livro Santo, fl. 130, doc. 203; ed. doc. 203 (1142, Fevereiro): «in eadem villa Sancti Romani et in circuitu ejus sub monte Hermeno discurrente ilumine Alvia." A. R. cita trocando flumen por fluuius.

204 Ver A. Nascentes, Dic. Et. da Ling. Port., II, Nomes Próprios, s. v. Estrela, que cita a Leite de Vasconcelos, Tradições, 29, Etnografia, II, 26, o qual refere a lenda segundo a qual teria sido também um pastor que, guiado por uma estrela, ali teria chegado, depois de ter passado por muitas terras e que acabaria por ser rei. A história de Resende tem o aliciante de apresentar o enigma da rocha, que até agora parece não ter sido identificada. De resto, quanto à identificação do Mons Herminius com a serra da Estrela mostra-se Leite de Vasconcelos muito cauteloso e não assevera a identificação em Religiões da Lusitânia, II, p. 32.

205 Díon Cássio, XXXVII, 52: a tradução latina apresentada por Resende reproduz, com relativa fidelidade, o texto grego. O monte Hermínio, ou montes Hermínios como mais

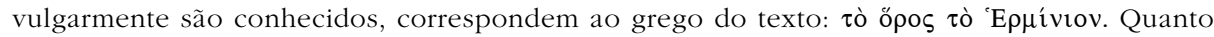
à ilha para onde, depois da perseguição movida por César, os Lusitanos se teriam refugiado, pensa A. Schulten, F. H. A., V, p. 13, que se trataria de Peniche, pois que a ilha na descrição de Díon tocava a costa durante a maré-baixa. É esta também a opinião de Resende.

206 De uita Caesarum, I, Diuus Iulius, 44. 


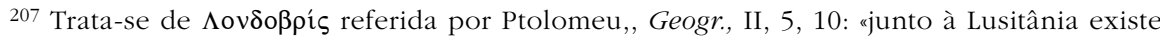
a ilha...", que Leite de Vasconcelos virá igualmente a identificar com as Berlengas, Religiões da Lusitânia, II, p. 26 e segs.

208 Ver n. 205.

209 Ver J. Veríssimo Serrão, s. v. "Ataíde, D. Luís de», no Dic. Hist. Port.

${ }^{210}$ A inscrição de D. Luís de Ataíde em Atouguia foi composta, segundo Braamcamp Freire, em Leitão Ferreira, Vida de André de Resende, A. H. P., IX (1914) 216, n. 212 "depois de 21 de Abril de 1555, data de carta de doação da vila de Atouguia a D. Luís de Ataíde, e antes de 2 de Março de 1568, quando ele foi nomeado vice-rei da Índia”. Ver também a citação de Leitão Ferreira na p. 257, n. ${ }^{\circ} 94$.

211 O Ad Ludouicum Ataidium Epigramma é publicado em Évora, 1593, e seguidamente na História da Índia de Frei Miguel da Cruz, Coimbra, 1616, p. XIV. Braamcamp Freire, Vida de André de Resende, A. H. P. IX, 197, n. 162, diz que o poema foi composto depois de 25 de Julho de 1572, quando da entrada triunfal de D. Luís de Atouguia em Lisboa.

212 Publicada como Vita S. Martini Saurensis nos Portugaliae Monumenta Historica, I, Scriptores, p. 59-62. Na p. 60, 0.2 o nome do Autor é Saluatus e não Saluianus.

213 P. M. H., Scriptores, I, 60, 2, 6-8: "Ab urbe uero Colimbrianorum XVIII', austrum uersus, distat miliario. Ad orientem sunt tapiei montis saxosa cacumina." Aires do Nascimento, Vita $S$. Martini Saurensis, Índices, concordância, análise linguística - dados estatísticos, Lisboa, 1977, s. vv. Colimbrianorum e Tapiei.

${ }^{214}$ Poema dedicado a Lopo Gentil na epístola que lhe dedica A. R. É referida na Vida de André de Resende, A.H.P., IX, 1914, p. 253, n. ${ }^{\circ} 46$, por Leitão Ferreira, e por Braamcamp Freire, p. 317, n. ${ }^{\text {os }} 90$ e 91, com as suas várias edições. Lupo Scintillae Iuris consulto L. Andrea Resendius S., Lisboa, 1561.

215 É certamente a evolução fonética popular a que não deve ser alheia a etimologia popular com fundamento em corvo/corva.

216 As Vidas de S. Rosendo, uma elaborada por Ordonho e outra por Estêvão, referem-se, tanto uma como outra, ao monte Córdova. Ver Vida e Milagres de São Rosendo, ed. de M. H. da Rocha Pereira, Porto, 1970, pp. 34 (in monte corduba) e 43 (baptismos de S. Rosendo in ecclesia sancti Saluatoris super montem Cordubae e referência logo a seguir à Igreja de S. Miguel). As duas Vidas foram igualmente publicadas nos Portugaliae Monumento Historica, Scriptores, pp. 34-46.

217 Sobre o Castelo de Arouca e as quatro ermidas que ali se erguem (de diferentes épocas), ver Guia de Portugal, vol. III (Beira Litoral, Beira Baixa, Beira Alta), s. d. (1944), p. 385 ss.

218 Deve tratar-se do opúsculo de Mestre António, de 1512, intitulado Tratado sobre a Província d'Antre Douro e Minho e suas avondanças publicado por Luciano Ribeiro, "Uma descrição de Entre Douro e Minho por Mestre António», Boletim Cultural da Câmara Municipal do Porto, vol. XXII (1959), pp. 441-460; também João de Barros (não o historiador) escreveu uma Geographia d'Antre Douro e Minho e Trás os Montes, publicada no Porto, Biblioteca Pública Municipal do Porto, 1919; estas obras e outras do seu tempo são analisadas por J. Romero Magalhães, "As descrições geográficas de Portugal: 1500-1650. "Esboço de Problemas", Rev. de Hist. Económica e Social, 1980, pp. 15-56.

219 II, 33, 49: Vindius e não Vinduus é o monte em que se refugiam os Cântabros. Ver A. Schulten, F.H.A., V, p. 193 e segs.

${ }^{220}$ Hist. adu. paganos, VI, 21, 5: aparece o orónimo como Vinnius, que é corruptela de Vindius, pois é Tito Lívio a sua fonte, ou seja, a mesma de Floro. Ver A. Schulten, F. H. A., V, pp. 196-198. De resto nalguns manuscritos de Orósio encontra-se Vindius. Quanto à identificação proposta por Resende, não parece ser de aceitar, na medida em que o Vindius mons se encontrava junto à costa cantábrica, ao Norte da Galécia e não em Trás-os-Montes.

221 Trata-se "das montanhas que na Tarraconense têm o nome genérico de Uníndio", em

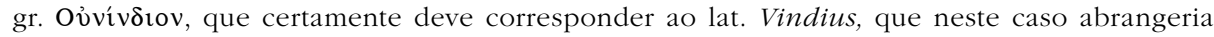
uma zona montanhosa mais dilatada, Ptol., Geogr., II, 6, 21, não sendo contudo evidente grande diferença geográfica no que respeita às duas fontes anteriormente citadas.

222 Não é fácil admitir esta interpretação do nosso humanista, na medida em que só na divisão administrativa de Augusto, entre 26 e 16 ou 13 a.C., é que a Lusitânia compreendeu 
as terras ao Norte do Douro e, por conseguinte, Chaves. De resto esta zona nortenha foi sempre considerada como pertencente à Galécia e parte naturalmente da Hispânia Citerior. Ver J. Alarcão, Portugal Romano, p. 20; O Dom. Rom. Port., p. 60.

\section{LIVRO SEGUNDO}

${ }^{1}$ III, 3, 4. Cf. A. Schulten, F. H. A., VI, pp. 203-205; ed. García y Bellido, p. 126 e notas.

2 Correspondendo o passus a 1479 m, 40.000 passus equivalem a 59.160 metros. Quanto às galerias subterrâneas, embora no texto nos pareçam aumentadas pela imaginação do humanista, não deixam elas de existir muito especialmente na zona do Pulo do Lobo, nas imediações de Serpa. A esse respeito já escreveu Mariano Feio, Os Terraços do Guadiana a Jusante do Ardila, Lisboa, 1947, especialmente no cap. IV, p. 34 ss. que o A. dedica ao estudo pormenorizado da geografia física do Pulo do Lobo.

3 Ver F. Sommer de Andrade, A Raça Bovina Transtagana, Sub-raça Alentejana, Lisboa, 1952, monografia que dá uma ideia histórica sobre a raça descrita por A. Resende. Quanto à precocidade e estatura do gado, há que atribuí-la em grande parte à imaginação do escritor.

${ }^{4}$ De pallio, V, 6, 68.

5 De pallio, V, 6, 68-70: "Inmergo aeque scalpellum acerbitati ei, qua Vedius Pollio seruos muraenis inuandendos obiectabat. Noua scilicet saeuitiae delectatio terrenae bestiae exedentulae et exungues et excomes; de piscibus placuit feras cogere, utique statim coquendis, ut in uisceribus earum aliquid de seruorum suorum corporibus et ipse gustaret». Tertuliano considerava pois esta forma de sádico assassínio, próxima do canibalismo, pois Vélio Folião ao mandar cozinhar as moreias depois de estas terem devorado os escravos, como que ia saborear a carne daqueles ainda existente nas vísceras desses peixes carnívoros.

Quanto aos nomes de peixes referidos por A. Resende, ver s. vv. comentário de E. SaintDenis, Le vocabulaire des animaux marins en latin classique, Paris, 1947.

${ }^{6}$ Asturjão, porque o esturjão, segundo Resende, deveria ser assim chamado por existir no rio Minho, que vem das Astúrias. De resto, o nome recente sturio (do germânico) estará em causa, pois segundo Resende não se pode identificar com o antigo acipenser. Emprega-se este nome latino na tradução, para permitir o entendimento do texto.

7 A zoologia era estudada sobretudo pelos médicos, tais como Jóvio ou Rondelet, cujas afirmações são discutidas por Resende.

${ }^{8}$ Pauli Iouii Comensiis medici, De romanis piscibus libellus, Basileia, 1531, no IV capítulo De sturione, pp. 18-48. Depois de refutar várias identificações já tentadas para o sturio, nome germânico recentemente (séc. IX) importado, decide-se Jóvio pela identificação, devido certamente ao porte e também à pele lisa, com o siluro, ainda que ao referir-se à possível identificação com o clássico acipenser recorda a descrição de Plínio, que o vê com as escamas voltadas para a cabeça, e considera essa uma das razões para o desaparecimento do acipenser (esturjão); ver cap. I, p. 7: "Acipenser quoque ille regum mensis usurpatus et conuersa in caput squamarum serie insignis, eadem ratione, quoad fartasse fuerit inquilinus, hac aetate procul dubio euanuit".

Discutimos estes aspectos no artigo "Solho, esturjão ou asturião do Guadiana», in Estudos de Homenagem a Mariano Feio, Lisboa, 1986, pp. 627-648, em que se publica um documento notarial de D. Dinis, celebrando a oferta de um esturjão em Valada do Ribatejo.

9 H. N. IX, 15, 45. Ver Com. de E. de Saint-Denis na edição Belles-Lettres, pp. 110-111, parágrafos 44-45. O Prof. S. Tavares de Pinho lembra, a este respeito, o texto do italiano Latino Latini (1513-93) intitulado "De siluro pisce", in Lucubrationes, II, Viterbo, 1667, p. 128 ss.

${ }^{10}$ IX, 37, 621 b. Cf. Eliano, De nat. animal, XII, 29.

${ }^{11}$ H. N., IX, 15, 44; 16, 58; e XXXII, 43, 125.

12 XVII, 2, 4 .

$13 \mathrm{XVH}, 2,5$.

${ }^{14} \mathrm{O}$ esturjão é um peixe anádromo, o que significa que vindo do mar sobe pelos estuários dos rios para vir desovar na água doce. Os Antigos pensavam que tal mudança era motivada pela necessidade de encontrarem esses peixes (é o caso do salmão e de outros) zonas mais 
ricas em comida e pensavam também que a tranquilidade dos rios os levaria a uma espécie de "engorda». Nunca relacionavam o facto com a procriação da espécie.

15 Trata-se de facto de um livro célebre, em que efectivamente a identificação de sturio com acipenser é proposta com toda a razão. Isso levará Lineu, no séc. XVIII, a considerar uma das espécies do esturjão como Acipenser sturio. Resende refere-se ao capítulo IX, De acipensere em Gulielmi Rondeletti Doctoris medici et medicinae in schola Monspeliensi Professoris regii, libri de piscibus marinis, in quibus uerae piscium effigies expressae sunt, Lião, 1554, nas pp. 410-417.

${ }^{16}$ Dórion é citado por Ateneu, III, 118 b-c, como sendo o autor de um tratado sobre peixes. A identificação com ővos (burro) e óvı $\sigma \kappa o s$ (burrinho) apoia-se na descrição do autor em VII, $312 \mathrm{~b}-\mathrm{c}$ e $315 \mathrm{e}$.

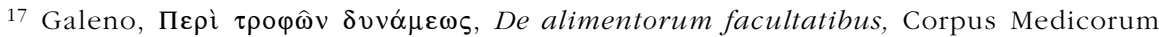

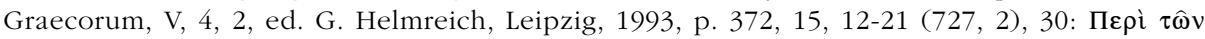

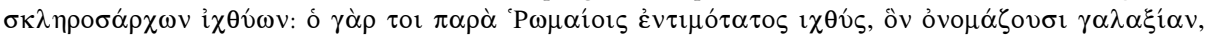

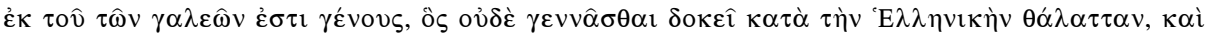

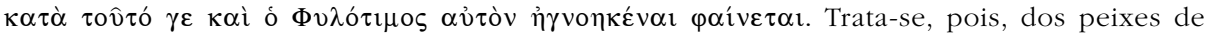
carne dura, entre os quais efectivamente se poderia incluir o esturjão, embora neste passo dele se não fale.

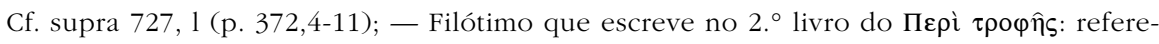

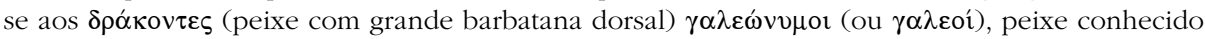
entre nós por cação, e a outros como os ảetoí em gr. águia, mas raia se aplicado ao mar. São peixes gordos, de carne dura, que produzem óleo.

${ }^{18}$ H. N., IX, 17, 60. E. Saint-Denis, ed. Belles-Lettres do livro IX de Plínio, $H$. N., aponta na p. 117 (parágrafo 60) para a sinonímia acipenser-elops. Considera, contudo, que o acipenser será o esturjão comum, Acipenser sturio, L., e o elops o pequeno «sterlet", Acipenser Ruthenus, $L$., que é frequente no Mediterrâneo Oriental. Quanto à extrema variedade de ictiónimos para caracterizar o esturjão, ver D. J. Georgacas, Icthyological Terms for the Sturgeon and Etimology of the International Terms Botargo, Caviar and Congeneres (A linguistic, philological and culture-historical Study), Atenas, 1978 (tomo 43 das Actas da Academia de Ciências de Atenas).

19 Plutarco, Moralia, Terrestriane an aquatilia animalia sint callidiora, 28, 979 c. No texto refere-se o elops, que o mesmo é dizer esturjão, e apresenta a ideia que também é transmitida por Plínio: a de que o elops terá as escamas voltadas para a cabeça, o que naturalmente o impede de nadar contra o vento e contra a corrente. Este pormenor é completamente fantasioso, na medida em que o esturjão não tem escamas, mas sim pele lisa com cinco fieiras de placas ganóides (isto é, placas de matéria parecida com a dos dentes humanos), que, conforme a perspectiva, podem até parecer voltadas para a cabeça. O texto latino, tradução do grego de Plutarco, não corresponde, porém, ao original grego que diz: «É isto, como já disse, comum a todos os peixes, com a excepção do elops. Diz-se que este nada a favor do vento e da corrente, por não temer que as suas escamas se levantem, na medida em que elas não estão inseridas na direcção da cauda». Por outro lado, o título do pequeno tratado (em diálogo) de Plutarco, que nos é dado como De industria animalium pelo humanista português, é mais conhecido como De sollertia animalium ou como se indica na citação. Cf. Eliano, De natura animalium, VIII, 28.

${ }^{20}$ Satumalia, III, 16, 3-4. Só fala da raridade do esturjão e cita Cícero, sem deixar de referir mais adiante também a peculiaridade das escamas. Quanto ao De fato de Cícero e à sua feição incompleta, ver Cicéron, Traité du Destin, ed. de A. Yon, Paris, 1950, introdução e frag. V., p. 28. O que importa salientar é a anedota contada por Cícero, segundo a qual teria dito a Cipião, durante um banquete que se preparava e para o qual este convidava toda a gente, que "O esturjão é peixe digno de pouca gente».

${ }^{21}$ Moralia, Terrestriane an aquatilia, etc., 32, 981 d-e: diz Plutarco que havia quem relacionasse o verso de Eratóstenes com o elops. Não fala de ântias e muito menos de acipenser. O verso de Eratóstenes é recolhido por Powell, Collectanea Alexandrina, p. 60, frag. 12, 3.

22 Marcial, Epigr., XIH, 91. 
${ }^{23}$ Halieutica, 132. A raridade do acipenser ou do elops como argumento contra a identificação com o esturjão (sturio), muito comum segundo Resende, é uma falácia, na medida em que o esturjão era um peixe igualmente raro. Daí a importância que lhe dão naturalistas do séc. XVI.

${ }^{24}$ G. Rondelet, De acipensere, fóls. 413-414: discute o problema das escamas e naturalmente defende que o esturjão ou acipenser não tinha escamas, como é a verdade, e que se trataria de um equívoco daqueles que confundiam o acipenser com o elops, que, este sim, teria escamas. Neste caso também Rondelet não tem razão, porque elops e acipenser eram, como já se disse, um e o mesmo peixe (ver n. 18).

25 Ver n. 19. Trata-se aqui, Sat., III, 16, 6-8, da carta escrita por Samónico Sereno a Septímio Severo, na qual refere a raridade do peixe e a pompa com que deveria ser servido. Na carta cita a autoridade de Plínio, bem como a do naturalista Nigídio Fígulo, que no tratado De animalibus também apontava para as escamas do acipenser: "cur alii pisces squama secunda, acipenser aduersa sit».

26 Ver n. 18.

27 Deipnosofistas, VII, 294 f: Arquéstrato, segundo Ateneu, é de opinião que o gáleo de Rodes, que era levado em grande pompa para os banquetes, era o esturjão (emprega o gr. $\dot{\kappa} \iota \pi \eta ́ \sigma ı s$ por acipenser), e descreve-o como diferente do gáleo (que é um seláceo da família do cação e do tubarão).

${ }^{28}$ De re rustica, VIII, 16, 9: "Non enim omni mari potest omnis esse, ut helops, qui Pamphilio profundo nec alio pascitur».

${ }^{29}$ Hist. animal., VIII, 28 (refere-se ao elops, a cuja identificação com o peixe sagrado de Homero, Il., XVI, 407 alude); noutros passos menciona também o antaceu (XIV, 26) e o oxirrinco, nomes gregos para o mesmo esturjão. Ver D. J. Georgacas, Ichthyological Terms for the Sturgeon, Atenas, 1978, pp. 110-212 (somente os nomes usados pelos escritores clássicos).

30 Noctes Atticae, VII, 16.

31 Plínio, H. N., IX, 60; Ateneu, VII, $294 \mathrm{f}$.

32 Teodoro de Gaza, na tradução latina das obras de zoologia de Aristóteles: In hoc volumine baec continentur, Aristotelis, De historia animalium libri IX; De partibus animalium et earum causis libri III; De generatione animalium libri V; Theodoro Gaza interprete, De communi animalium gressu liber I; De communi animalium motu liber I, Paris, Ex officini Simonis Colinaei, 1533, fól. 15 v, 35: "aliis quaternae (branchiae) utrimque simplices: ut acepenseri, dentici, murenae, anguillae». Igualmente traduz elops por acipenser, fól. 16 v, 1. 49. Tal facto também é mencionado por Hermolau Bárbaro no Corolário (ver n. 46), no cap. CCXCVII (297) fól. 41 v, intitulado Fel animalium: «... Dixi hellopa eundem qui accipenser dicatur. Item hellopa hoc est accipenserem et castum sacrumque piscem. Sunt qui callichtyn et anthiam quoque appelent».

33 Hist. Animal., II, 13, 505 a: enumera peixes de quatro guelras, quer as tenham simples de cada lado, ou uma simples e uma dupla de cada lado. Entre eles está o elops, de que fala também em II, 15, 49.

34 Halieutica, vv. 96 e 132 (verso já citado anteriormente na p. 114). E. de Saint-Denis na edição Belles Lettres, Paris, 1975, faz o comentário aos dois passos a propósito do v. 96 (p. 52) e diz: "Tandis que l'acipenser est l'esturgeon commun (Acipenser sturio L.), l'helops serait le petit esturgeon ou sterlet (Acipenser Ruthenus L.). En effet nostris incognitus undis ne convient pas à l'esturgeon commun qui se rencontre en Méditérranée occidentale et jusqu'à Sète; mais au sterlet qui appartient à la Méditérranée orientale et à la mer Noire». No entanto, o editor não explica a atribuição de um habitat também estrangeiro ao acipenser, que era conhecido, como vemos em Macróbio, Sat. III, 16, 5, já citado na n. 20. A verdade é que ambas as espécies eram raras e altamente apreciadas e passam grande parte da vida no mar alto, só subindo os rios para desovar.

${ }^{35}$ H. N., XXXII, 153: "helopem dicit (Ouidius) esse nostris incognitum undis, ex quo apparet falli eos qui eundem acipenserem existimauerint». Cf. com o passo pliniano da n. 31, bem como com a discussão de G. Rondelet que defende, ob. cit., f. ${ }^{\circ} 411$, que o elops e o acipenser não são o mesmo peixe. 
36 Carta II, na ed. Ermolao Barbaro, Epistolae, Orationes et Carmina, edizione a cura di Vittore Branca, vol. II, Florença 1943, p. 86 (carta não datada): «Hermolaus Barbarus Paulo Cortesio S. P. D.; Dicam igitur quod sentio. Sturionem Graeci modo appelant hyscam siue hyccam, id nomen porcum significat...». Faz esta afirmação depois de dizer que é mais perigoso do que difícil dar uma opinião sobre um assunto deste género.

37 Paulo Cortesi (1465-1510), humanista ligado à cúria papal. Distinguiu-se numa polémica com Policiano e publicou em 1489 De hominibus doctis. Dedicado a Lourenço-o-Magnífico. Ver Encicl. Ital., s. v.

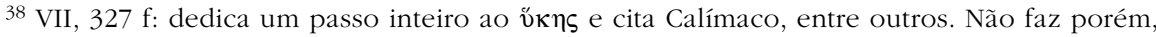
descrição do peixe de forma a termos alguma ideia taxonómica. Não há dúvida de que o ictiónimo está ligado a ưs (porco) e muito possivelmente corresponderia à toninha ou golfinho, com o qual o esturjão era não raro confundido, tanto mais que o golfinho também é conhecido como porco-marinho.

39 Em Omnia quotquot extant Divi Ambrosii Episcopi Mediolanensis Opera, per Des. Erasmum Roterodamum...emendata, Basileia, 1538, IV, fol. 52, C: "Patet quod diabolus non diligit filios suos, sed odit; quia non amat nisi ut perdat; sicut amat gluto porcellum ut comedat». A edição de Migne, P. L., XVI, 666, 432, Sermo XXX, De Sancta Quadragesima, XIV adopta a lição gluto. Ver o Thes. Ling. Lat., s. v. glutto.

${ }^{40}$ Id., Hexaemeron, V, 3, 6, $81 \mathrm{~F}$ : "Adde porcos maris etiam Iudaeis gratos; quia nihil est commune, quod non aqua abluat, et ideos communes eos sicut in terra editos aestimare non possunt".

${ }^{41}$ Paulo Jóvio, ob. cit., p. 29 e segs. (n. 8) analisa e critica as diferentes identificações dos peixes conhecidos pela antiguidade com o esturjão, entre as quais rejeita a de Hermolau Bárbaro (identificação com o bica citado por Ateneu).

${ }^{42}$ Etim., XII, 6, 12: É de suillum que Resende vai derivar erradamente solbo (que deriva sim de solea, "sola"). Ver R. M. Rosado Fernandes, "Solho, Esturjão ou *Asturião no Guadiana", p. 641, n. 24, e "A Etimologia e sua Finalidade em André de Resende, De antiquitatibus Lusitaniae", Homenagem a Joseph M. Piel, Tuebingen, 1988, p. 240 ss.

43 XVII, 2, 4. Este ictiónimo é de facto, como diz Georgacas, ob. cit., pp. 112-115, um dos correspondentes gregos para denominar o esturjão e preservou-se como tal na época bizantina.

${ }^{44} H$. N., IX, 14, 45: A lição da generalidade dos códices é a seguinte: "Silurus grassatur, ubicumque est, omne animal appetens, equos innatantes saepe demergens. Praecipue in Moeno Germaniae amne protelis boum et in Danubio mari extrahitur porco marino simillimus. Et in Borysthene memoratur praecipua magnitudo, nullis ossibus spinisue intersitis, carne praedulci".

É evidente que in Danubio mari extrabitur não é compreensível, na medida em que mar e rio Danúbio se encontram como se fossem um todo, quase levando a interpretar como mar Danúbio. Além disso o siluro de que se fala é um peixe de rio. Sentindo que não era possível aceitar o texto pliniano, houve a aceitação por parte de Gelénio, na edição de Basileia de 1543, da versão apresentada pelo códice recolhido por Dalecampius, em que se praticava uma nova pontuação e mari era intrepretado como mario, ou seja, como ictiónimo. Daí o marião, ou em esp. marión, que aparece na tradução de Jerónimo Huerta da História Natural de Plínio, 2 vols., Madrid, 1624 e 1629. A verdade é que marión ainda hoje é aceite nos dicionários espanhóis como significando esturjão, muito embora seja nome completamente inventado, porque traduzido de uma lição latina inexistente, mas também aceite por Resende. É ela: «Et in Danubio mario extrahitur, porculo marino simillimus, et in Borysthene. Memoratur praecipue magnitudo nullis ossibus, spinisue intersitis, carne autem praedulci». A versão aceite pelas edições modernas é, contudo, igual à versão da generalidade dos manuscritos, com a excepção de que mari é substituído por marris (arpões), emenda proposta pela edição de Hardouin, na edição de Paris de 1685. Temos assim: “...et in Danubio marris extrahitur». É este o texto adoptado por E. de Saint-Denis, Paris, 1955 (Belles-Lettres), na edição do livro IX da Hist. Nat. de Plínio, p. 52. A ed. de Detlefsen, Berlim, 1867, vol. II, p. 98, não apresenta sequer no aparato crítico a hipótese de Gelenius (mario). 
45 P. Jóvio, ob. cit, p. 142: «Laudant et Moronem, ignoti nobis praedura frusta, ualdeque rubentia, quae Maeotidis paludis accolae mercimonii causa transmittunt, ea prius exedi commode non possunt, nisi aquae calidae perfusione molliantur».

46 O Corolário está editado na edição de comentários a Dioscórides: Ioannis Baptistae Egnatii Veneti in Dioscoridem ab Hermolao Barbaro tralatum annotamenta. Quibis morborum et remediorum vocabulo obscuriora in usum etiam mediocriter eruditorum explicantur... Hermolai Barbari patricii Veneti et Patriarchae Aquileiensis Corollarium libris quinque absolutum. Accedit in Dioscoridem et Corollarium indexque copiosissimus, Veneza, 1516: Omotarichos CCXXXIII (233), fól. 34v-35: "Omotarichos e thynno salsa caro dicitur, Thunina uulgo. ...Invenio et hemitarichon et quoque ab hoc plane differt hemineron. Vtrumque salsamenti genus est...”

Antaceis nomen uidet ut amnis dedisse in Maeotim lacum asiatica parte influens. Magnitudine sunt delphinis pares et ipso Cimerii Bosphoro gelu fodiunt plerumque, nullis ossibus spinisque ut Herodoto placet in Borysthene copiosi carne praedulci ut ait Plinius... Aetate nostra Graeci piscem Hyscam de quo supra dixi tribus nominibus inveterant. Rhachin partem eius dorsuariam et spinalem uocantes. Quam nostrum uulgus schinalem corrupte appellat. Pleuram idest costas et latera. Hypococlion idest aluum eius atque pubem hunc piscem ut testati sumus Italia sturionem modo uocat".

Pelo texto (o adv. modo) vemos que o nome de esturjão é recente na Italia: No mesmo Corolário encontramos, além deste, outro passo ainda, em que praticamente se afirma identificação parecida, que, no entanto, se assemelha mais à hipótese de André de Resende, uma vez que byca e o porculus não serão de identificar com o esturjão. Fiber CCXXVI (226, fól. 33v-34: «Fiber quem Graeci Castora uocant... Athenaeus et Thurionem siue Thursionem dici obsonium hoc latina lingua solitum affirmat. Suauissimumque id ac lautissimum fuisse... unde coniectari liceat aut eum esse Thurionem, quem nos uulgo Sturionem appellamus... Sunt qui Graece hyscam siue hyccam hoc est porculum pro sturione capiant, etc.»

$47 \mathrm{O}$ passo a que se refere Resende é em Estrabão, VII, 3, 18 (e não livro XVII, que se

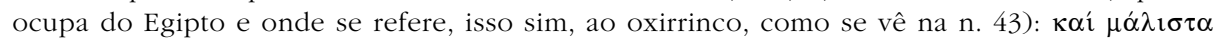

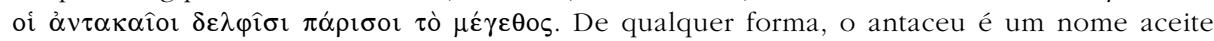
como designando o esturjão. Ver Georgacas, ob. cit., pp. 111-112. Estrabão trata neste passo do Dniepre e do mar Cáspio, do Don e do mar de Azov em que abunda o esturjão de grandes dimensões (mais de uma tonelada), o Huso buso L. Daí o parecer-se com o golfinho.

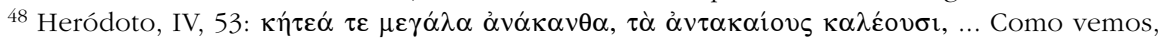
os antaceus (esturjões) são comparados, de novo, com cetáceos (baleia, golfinho), são situados no estuário do Borístenes (Dniepre), e são caracterizados como «sem espinhas" $\alpha$ vók $\alpha \nu \theta \alpha$. Ver Georgacas, ob. cit., p. 111.

${ }^{49}$ Cf. idêntica descrição em P. Jóvio, ob. cit., p. 42: "In Borysthene uero, qui hodie Neper est amnis, Phasique et in ipso Tanai apud Tanam emporium tanta eorum est copia (sturionum), ut cetariae ibi institutae sint officinae, in quibus ea salsamenta ex sturionum oueis salitis, quae cauiaria dicimus, itemque ipsa Schinalia ex sumo sturionis spinali dorso, sale, fumoque inueterata conficiantur». A descrição de Jóvio aponta para as regiões russas mais célebres pelo esturjão (Dniepre e Don) e não esquece de referir, além do caviar, o que ainda hoje se conhece como esturjão fumado, que é consumido em muitas partes do mundo, rivalizando com o salmão fumado.

50 Ver n. 46.

51 Ver n. 43.

52 Ver n. 44. Quanto ao "peixe sem nome», refere-se Resende ao passo acima discutido, na medida em que não está expresso o sujeito da segunda proposição. Na primeira frase do passo transcrito em n. 44 o sujeito é siluro, mas na oração começada Et in Borysthene memoratur tem de subentender-se o sujeito, que admitimos ser um peixe cujas características de excelência são seguidamente descritas e que não é o siluro. Esse peixe não tem o nome mencionado e é por isso que Resende nos apresenta a sua versão.

53 Ver n. 47.

54 Ver n. 48.

55 Ver n. 38.

56 Ver n. 42. 
57 Como é corrente nos textos da época, Etiópia é o equivalente de África, assim como Guiné significa, grosso modo, toda a costa ocidental africana, sobretudo a partir do Senegal.

58 Esta identificação completamente fantasiosa do esturjão com angulo amazi "porco das águas", assenta sobre informação desconhecida dos cronistas dos Descrobrimentos ou dos navegadores. A palavra indígena provém do Quicongo, língua falada junto ao rio Zaire e é ligeiramente diferente.: o ambize angulo de que fala Pigafetta (mbizi ngulu) em 1591, utilizando uma relação de Duarte Lopes, Relação do reino do Congo e das Terras Circunvizinhas, ed. e trad. de Rosa Capiaens, Lisboa, 1951, vol. I, p. 36, publicada em Roma, 1591, sob o título: Relatione dei reame di Congo et delle circonvicine confrade tratta dalli Scritti et ragionamenti di Odoardo Lopez Portoghese per Filipo Pigafetta, p. 36. O mbizi ngulu de Pigafetta é o chamado peixe-porco, o angulo amazi de Resende está foneticamente próximo do ngulu amazi, "porco das águas" do Quicongo. Ver R. M. Rosado Fernandes, "André de Resende e o seu asturjão africano (O angulo amazi do De ant. Lus.)", in Humanismo Português na Época dos Descobrimentos, Coimbra, 1993, pp. 355-368. Este falso peixe é afinal o mamífero manatim, conhecido também por peixe-porco, peixe-mulher (tem o úbere do mamífero), ou peixe-boi do Brasil (trichechus senegalensis ou manatus senegalensis) a que se referem Fr. Cristóvão de Lisboa na História dos Animais e Árvores do Maranhão, publicada por F. Frade em Garcia de Orta, 14 (1966), pp. 343-350, e Pêro de Magalhães de Gândavo, História da Província de Santa Cruz, Revista do Instituto Histórico e Geographico Brasileiro, 21 (1858), pp. 329-388, onde o manatim é apresentado como o Hipúpiàra, ou seja demónio d'água, morto em 1564, na capitania de S. Vicente. Já Anchieta, em carta de 1560, se lhe referira. Ver A. Geraldo da Cunha, Dic. Hist. das Palavras Port. de Origem Tupi, São Paulo, 1989, p. 157, s. v. ipupiara (informação do Prof. Tavares de Pinho). Toda esta confusão zoológica deriva de Resende ter identificado o esturjão, solho, com o "porco" das Etimologias de S. Isidoro.

${ }^{59}$ H. N., V, 10, 51 (cap. dedicado inteiramente ao Nilo).

60 O rio Senegal, também conhecido por Rio Negro, foi descoberto por Álvaro Fernandes em 1445 e já aparece citado na Crónica da Guiné de Azurara, cap. LX, e no Esmeralda de situ orbis de Duarte Pacheco Pereira (p. 95 da ed. Acad. Port. Hist.). O primeiro chama-lhe Çanaqua e Duarte Pacheco refere-o como "braço do Nilo». Ver L. de Albuquerque, Dic. Hist. Port., s. v. Senegal. Quanto à descrição topográfica e à toponímia, ver R. M. Rosado Fernandes, art. cit., na n. 58 .

61 O passo de Isidoro de Sevilha, já citado na n. 42, é precedido de uma alusão fantasiosa à existência de golfinhos no rio Nilo, que matam os crocodilos, Etim., XII, 6, 11: "Est et delphinum genus in Nilo dorso serrato, qui crocodillos tenera uentrium secantes interimunt". "Há no Nilo uma espécie de golfinhos com o dorso em forma de serra os quais matam os crocodilos por lhes cortarem a parte mole do ventre.» E depois segue-se a descrição já referida dos porci marini, chamados suilli, "porquinhos", de que Resende faz derivar soilho ou solbo. Tal etimologia é impossível. É-nos proposta a etimologia de solho (esp. sollo) como proveniente de sucutus, "porquinho", não só por J. Corominas e J. A. Pascual, Diccionario Crítico Etimológico Castellano y Hispánico, s. v. sollo, como por J. P. Machado, Dic. Etimol. da Língua Port., s. v. solbo; R. M. Rosado Fernandes, art. cit., na n. 42.

62 A proposta de Miguel da Silva, bispo de Viseu, ao Papa, aparece referida igualmente por P. Jóvio, ob. cit., p. 44, depois de ter descrito as navegações portuguesas e espanholas, e de se ter referido ao facto de que "Hispania autem omnis sturionem, sulium appellat", facto que lhe serve para defender a sua tese de que o esturjão é o mesmo que o siluro, pois sulius em pouco difere de siluro e por vezes até significa o mesmo. De qualquer modo, a forma asturjão que em esp. também surge como asturión, não é mais do que simples etimologia popular com origem em Astúrias, tal como aponta Corominas-Pascual, Dic. Cr. Etim. Cast. Hisp., s. v. asturión. O mesmo dicionário, s. v. marión, cf. n. 44, atribui-lhe existência duvidosa, mas embora refira e bem a tradução de Huerta a que já aludimos, não explica a razão da dúvida: a aceitação, por parte do tradutor espanhol, de uma lição não aceitável, e que, no entanto, se perpetua ainda no mesmo dicionário da Academia espanhola.

63 Esta confusão terminológica e taxonómica, ocupou muitos eruditos, humanistas e médicos do séc. XVI, como podemos ver pela profusa e actualizada bibliografia citada pelo nosso A. 
${ }^{64}$ Geogr., II, 5, 3: entre as cidades dos Turdetanos, como Balsa, Ossónoba, Salácia, menciona

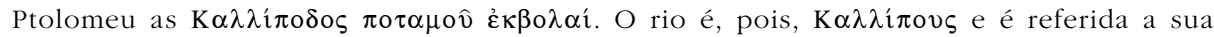
embocadura. Quanto ao nome Sado, ver J. Leite de Vasconcelos, Rei. Lus., II, p. 17. O nome Sadão foi usual até ao século XVIII; depois de Grândola, em direcção a Beja, passa-se por $S t^{\text {a }}$ Margarida do Sadão, agora, do Sado.

65 A descrição geográfica do Sado tem grande importância, pois deve ser Resende o primeiro que se lança na sua caracterização geográfica. Quanto aos afluentes, levanta problemas o Santa Detença, que ainda aparece no mapa de Fernão Vaz Seco, de 1561, e é identificado por Alves Ferreira, Custódio de Morais e Amorim Girão, "O mais Antigo Mapa de Portugal", Bol. Centro Est. Geogr., Coimbra, 12/13, 1956, pp. 1-65; João Bautista de Castro, Mappa de Portugal Antigo e Moderno, I, Parte I e II, 2. ${ }^{\mathrm{a}}$ ed., 1762, n. ${ }^{\circ} 224$, Sadão ou Sado.

Quanto a Salácia, deusa, não conhecemos fonte alguma que ateste o seu culto.

66 No que respeita ao Sado e seus peixes, consultar R. M. Albuquerque, "Peixes de Portugal e Ilhas adjacentes", Port. Acta Biol. (B), 5, 1954-56, 1-1164; A. X. L. Vieira, Catálogo dos Peixes de Portugal, Ann. Scient. Nac., 4 (1898), 1-87 (separata); A. Nobre, Fauna Marinha de Portugal, I - Vertebrados, 1935, Barcelos.

${ }^{67}$ III, 3, 1. Ver comentários de A. Schulten, F. H. A., VII, pp. 195, 203, 248 e de García y Bellido. Quanto às medidas há que lembrar que o estádio tem 625 pés romanos, o que perfaz cerca de $185 \mathrm{~m}$.

68 O passo é de facto corrupto e há várias emendas propostas. Quanto a Iponlacia trata-se de conclusão apressada, pois vem de uma sequência vocabular incompleta nos mss. $\varepsilon ı \pi o v \lambda \alpha \kappa \varepsilon \iota \alpha$, a qual tem sido emendada das mais variadas maneiras. Na edição de C. Mueller, por ex., a frase lacunar é entendida como c̉đì $\Sigma \alpha \lambda \alpha ́ \alpha \varepsilon \imath \alpha \nu$, "até Salácia», ou seja, Alcácer do Sal, no que se refere à navegabilidade do estuário do Tejo, o que é evidente erro geográfico de Estrabão, a ser correcta esta emenda. Quanto a $\pi$ ó $\gamma$ os que Resende traduz por turris trata-se simplesmente, como diz García y Bellido, do promontório Barbário, ou seja, o cabo Espichel.

${ }^{69}$ A largura de 20 estádios (estádio c. $185 \mathrm{~m}$ ) é portanto de $3.700 \mathrm{~m}$. O talento, peso grego variável, tem cerca de 50 libras. Corresponderá, arredondado, a cerca de $25 \mathrm{~kg}$, o que quer dizer que os barcos teriam uma tonelagem aproximada de duzentas e cinquenta toneladas, ou seja, o equivalente nos tempos modernos a um batelão.

70 Trata-se pois das lezírias, descritas com brevidade e elegância por Silva Teles, em Guia de Portugal, I, Lisboa e Arredores, p. 578-80.

71 Deve tratar-se de uma das lezírias que de facto pode ser por vezes circum-navegável. O dado concreto é o seu comprimento: 30 estádios $=5.550 \mathrm{~m}$.

72 Resende nega a existência da vide, mas nada prova que os Lusitanos não a tenham plantado ali, como o faziam noutras zonas. Não há dúvida, contudo, de que a tradição nos conta que ali se semeava cevada, trigo e outros cereais.

73 Quanto à fertilidade era já ela um locus amoenus para quem se referisse à Lusitânia. É pelo menos o que vemos em Ateneu, Deipnosofistas, VIII, 330 c, que, apoiando-se em Políbio, refere a fertilidade e o bom clima da Lusitânia. Naturalmente que a zona da lezíria aqui referida por Estrabão, e era essa que deviam normalmente conhecer os forasteiros romanos ou gregos que à Lusitânia viessem por mar, é ainda hoje uma zona que a todas excede em fertilidade e em extensão. Por isso, as terras de Santarém, as que se chamam do "campo", formadas de aluviões, são continuadamente celebradas, são mesmo um lugar-comum oratório, como vemos na oração de Cataldo Sículo, que deveria ter sido proferida diante de D. Manuel nos princípios de 1500, e em que o mestre siciliano diz, entre muitas coisas, depois de ter feito o elogio do Tejo: «Ó campo tão saudável! Ó campo preferível a todos os campos! Ó campo em nenhum preço avaliável, por nenhum bem, por grande que seja, comutável! Três vezes no ano floresce. Pouco cultivado produz três colheitas. Na primeira, trigo; na segunda, cevada; na terceira, milho». Ver Cataldo Parísio Sículo, Duas Orações, ed. M. Margarida Brandão G. da Silva e Américo da Costa Ramalho, Coimbra, 1974, p. 107 e p. 118, notas 23 e 24 (outro exemplo do mesmo lugar-comum). É evidente que a ceifa a 50 dias da sementeira é nítida hipérbole!

${ }^{74}$ O milbo meudo que não é o mesmo que o milho importado no século XVI da América. Ver a este respeito o artigo de O. Ribeiro, Agricultura, no Dic. Hist. Port.; E. Castro Caldas, A Agricultura Portuguesa Através dos Tempos, Lisboa, 1991, p. 196 ss. 
75 Pompónio Mela, III, 6, 47: «In Lusitania Erythia est quam Gerionae habitatam accepimus, aliaeque siue certis nominibus adeo agris fertiles, ut cum semel sata frumenta sint, subinde recidiuis seminibus segetem, septem minime, interdum plures etiam messes ferant».

76 Ainda hoje, de um modo global, se pode aceitar a afirmação de Estrabão, III, 3, 1: ஸ̋ $\sigma \varepsilon$

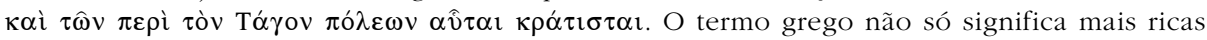
como mais poderosas, ou seja, com maior potencialidade.

77 A publicação sobre São Frei Gil de Santarém, espécie de Fausto português, é intitulada de Conversio Miranda D. Aegidii Lusitani, Doctoris Parisiensis, Ordinis Praedicatorum e está incluída no Thesaurus arcanus Lusitanis gemmis rejulgens in quo Aegidii Magi olim theurgici stupenda historia, variis exculta dialogis, atque aliorum S. Patrum Ord. Prae. ex ea Lusitania, gesta multaque alia scitu dignissima continentur, Paris, Thomas Perier, 1586, publicado por Fr. Estêvão de Sampaio. A alosa é discutida com a mesma profusão de citações eruditas que encontramos na disquisitio sobre o esturjão, na parte II do diálogo resendiano, fól. 57 ss. Cf. A. da Costa Ramalho, "A conversão Maravilhosa do Português D. Gil - Um Diálogo Latino quase ignorado - Da autoria de André de Resende», Revista da Universidade de Coimbra, XXVII (1979), pp. 239-262; Estudos Sobre o Século XVI, Lisboa (1983), pp. 341-366; quanto à lenda, é de extrema utilidade a leitura de Aires A. Nascimento, A Vida do Bem-Aventurado Gil de Santarém, por Fr. Baltazar de S. João, Lisboa, 1982, em que se estudam os aspectos mais ligados à formação da lenda do sábio que vendeu a alma ao diabo, tal como o Doutor Fausto. Quanto aos aspectos ictiológicos, consultar n. 66.

78 Ausónio, X. Mosella, 127 (Peiper). A forma correcta para sável é alausa.

79 Novamente alusão ao passo de Isidoro citado na n. 42 e aproveitado pelo nosso humanista no sentido de identificar o soilho (esturjão) com os suilli ou porcos-marinhos. Não conhece A. R. o documento notarial de D. Dinis, referente ao esturjão que lhe foi oferecido em Valada do Ribatejo, que publicamos no nosso artigo, citado na n. 8.

${ }^{80} \mathrm{O}$ Tejo das areias de ouro é um lugar-comum da literatura antiga que menciona a região. Ver Ov., Am., I, 15, 34: "et auriferi ripa benigni Tagi!», Lucano, Fars., VII, 755: "quidquid Tagus expuit auri..." e muitos outros. Cf. n. 82. Quanto ao ceptro dos reis de Portugal, ver Duarte Nunes de Leão, Descripção do Reino de Portugal, 2. ${ }^{\mathrm{a}}$ ed., Lisboa, 1785, p. 78: "Mas o ouro que em suas areias se tirava era tão puro, que querendo El-rei D. João III, deste reino, que lhe fizessem um ceptro, mandou que lhe buscassem o ouro nas areias do Tejo, do qual se fez um que muitas vezes vimos nas mãos dos Reis, nos tempos que faziam cortes ou os levantavam por Reis, o qual se guarda hoje entre o facto do tesouro em Lisboa com outras peças do Estado e que facilmente poderá ver quem for curioso».

81 Ver n. 4 do livro I.

${ }^{82}$ Isidoro, Etim., XIII, 21, 33. Quanto à discussão etimológica, ver A. Nascentes, Dic. Etim. Lingua Port., II, Nomes Próprios, s. v. Tejo. A semelhança entre Tagus e Cartago é naturalmente fortuita e não etimológica, além de que Cartago, a Cartago Nova do Sul de Espanha (Cartagena), está geográfica e etnicamente bem afastada.

83 Trata-se da região dos Ilergáones ou Ilergavonenses (ver A. Schulten, F. H. A., III, p.

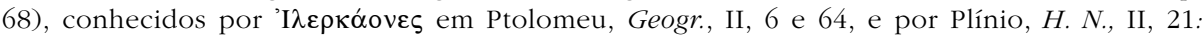
"regio Ilergaonum», situada na Hispânia Tarraconense. Ptolomeu considera de facto (II, 6, 64) erradamente Cartago-a-Velha nessa zona, uma vez que já antes (II, 6, 14) nomeara Cartago-aNova. Não havia na Hispânia duas Cartagos e a Cartago-a-Velha era no Norte de África, como é sabido. Ver Westermann, Grosser Atlas zur Weltgeschichte, Braunschweig, 1978, 10, 26-27, II, A, 2; 34-35, III, C, 1.

${ }^{84}$ Trata-se da edição Pomponii Melae Hispani, de orbis situ libri tres..., Basileia, 1522, fl. 140 .

85 A citação de Cícero feita por Vadiano difere da lição actual (cf. n. 86): "Post aut agros in Hispania apud Carthaginem nouam durum Scipionum eximia virtute possessos, tum ipsam veterem Carthaginem vendunt"; e comenta: "sita fuit haud procul Tarracone et a Teucris condita".

86 Cíc., De lege agraria, II, 19, 51: "et agros in Hispania propter Carthaginem nouam et in Africa ipsam ueterem Carthaginem vendit». Esta lição correcta é a apontada por A. R. 
87 Deve aludir genericamente aos trabalhos de M. Varrão sobre etimologias, cujos reflexos se encontram em parte significativa da sua obra, como nos tratados De lingua latina, libri $X X V$, ed. Schoell e Goetz, Leipzig, 1910, ou no Antiquitatum rerum bumanaram et divinarum libri XLI, de que restam fragmentos.

${ }^{8}$ Quanto a esta versão de Tago, companheiro de Ulisses, é eco de Ânio de Viterbo publicado em Berosi sacerdotis chaldaici, Antiquitatum libri quinque. Cum commentariis Ioannis Annii Viterbensis sacrae Theologiae professoris, nunc primum in antiquitatum studiorum commoditatem, sub forma Enchiridii excusi et castigati, Antuérpia, 1545, fls. 61 v. e 293, onde refere o rio Tejo e faz derivar o nome de Tago, rei de Espanha, no ano 552 do dilúvio e 309 da fundação de Espanha.

É importante observar a grafia Olysses e não Ulysses, a fim de aproximar o nome de Olisipo, dele derivado, segundo Resende.

89 Tito Lívio, XXVIII, 22: "superato Baete amni, quem incolae appelant Certim...".

90 Estrabão, III, 2, 11; Cf. A. Schulten, F. H. A., VI, p. 184 segs; García y Bellido, Estrabón, notas 135 (p. 101) e 137 (p. 101-102). O texto de Estesícoro corresponde ao frag. 184 (Page). Ver n. 5 do livro III.

91 Estêvão de Bizâncio, Ethnika, p. 156, 9.

92 En., IX, 418.

93 Sílio Itálico, Pun., I, 144-161: Resende acaba abruptamente a citação: o último verso, iniciado por cum rapidum... ageret... pressupõe um complemento que vem no verso seguinte (162), quadrupedem...

94 Pompónio Mela, Corografia, III, 1,8.

95 H. N., IV, 2, 115. 200.000 passos $(1,48 \mathrm{~m})=296 \mathrm{~km}$, próximo da distância real.

96 Calina não é referida por Duarte Nunes de Leão, Descrição do reino de Portugal, p. 68. Este A. refere algumas peripécias e experiências de personagens históricas em relação à fonte. O nome é, contudo, Cadima (cf. n. 98). Quanto aos peixes acima mencionados, consultar a bibliografia indicada na n. 66.

${ }^{97}$ H. N., II, 231: "In Carrinensi Hispaniae agro duo fontes iuxta fluunt, alter omnia respuens, alter absorbens». A identificação proposta por Resende é fantasiosa, na medida em que se trata de um topónimo Carrinum e não Catina, mesmo que lhe conviesse identificá-lo como Cadima. Ver R. Grosse, F. H. A., VIII, pp. 172-173, quanto a possíveis mas dificilmente verificáveis identificações. A fonte encontrava-se no actual território de Espanha, talvez na Cantábria, mas Resende reivindica-a, como é seu hábito, para território português, interpretando a seu favor o texto de Plínio.

98 Quanto a Fervença é atestada por Duarte Nunes de Leão no passo citado na n. 96.0 Guia de Portugal, vol. II, Beira Litoral, Beira Baixa, Beira Alta, p. 129, refere-se-lhe a respeito da freguesia de Cadima do conselho de Cantanhede, em que existem "os afamados 'olhos' da Fervença, grande manancial de águas em terrenos calcários”. A altura de um pé, a que se eleva a água em ebulição, corresponde a 0,29 m.

99 D. Afonso é o sexto filho de D. Manuel (1509-1540), por quem esta obra foi encomendada, conforme lemos na carta introdutória de Resende (p. 57). Era arcebispo de Lisboa e bispo de Évora.

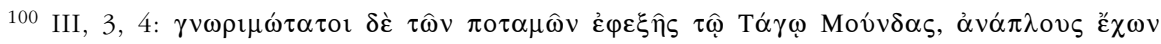

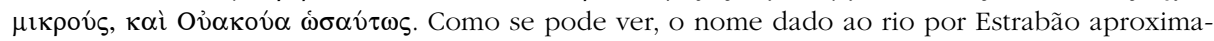
se literalmente do Munda romano, o que não impede que a forma Mov $\lambda \iota \alpha ́ \delta \alpha \varsigma$ apareça nos códices. Ver A. Schulten, F. H. A., VI, p. 203.

101 Ver n. anterior.

102 Geogr., II, 5, 3.: refere-se na Lusitânia, seguidamente ao Mondego, ao estuário do Vouga

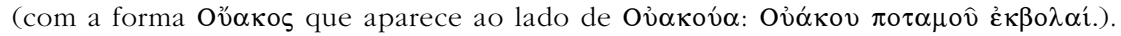

103 Etim., IX, 2, 107.

104 O provérbio indicado por Resende não o conseguimos localizar noutros A. A. Quanto aos peixes, ver bibliografia citada na n. 66.

105 Sobre Martinho de Figueiredo, ver A. Costa Ramalho, s. v. na Enciclopédia Verbo 19, 1293-1294; "Martim de Figueiredo e Erasmo», Humanitas XXIX-XXX 1977-78, p. 221-222; Latim 
Renascentista em Portugal, Coimbra, 1985, pp. 137-153, primeira edição acessível e comentada do A.

106 Trata-se de evidente alusão ao perigo castelhano. Simplesmente que, para encobrir a sua intenção acusatória, Resende lhes chama Vaceus, usando da antonomásia. A obra do "cachão da Valeira" acabou por ser feita nos fins do séc. XVIII, no tempo de D. Maria I. Ver R. M. Rosado Fernandes, "Méthodologie et Histoire dans De Antiquitatibus Lusitaniae d'André de Resende», in L'Humanisme Portugais et l'Europe, p. 505. Quanto a desaparecer o rio Douro, levado por galerias subterrâneas, trata-se da mesma fantasia que preside à descrição do percurso misterioso do Guadiana, quando o rio porventura corria pelos terraços (ver n. 2). 1.000 passos correspondem a $1470 \mathrm{~m}$.

107 Ś́lio Itálico, Pun., I, 234.

108 Ver p. 120.

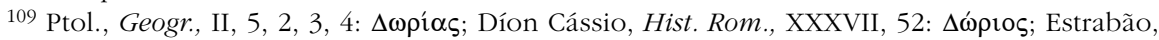
III, 3, 2: $\Delta$ ov́pıs, que é a forma usada em Estrabão, no entanto, encontramos $\Delta o ́ \rho ı$ é em Apiano, Iberica, VI, 15,91. Não encontramos Dúrias em Estrabão nas edições modernas, mas é possível que tal forma tenha aparecido, como parece inferir-se das afirmações de Hermolau Bárbaro a respeito de Plínio (n. 112).

110 Pompónio Mela, Corogr., II, 92: os nomes actuais são: Sorobi, Turia e Júcar.

${ }^{111}$ H. N., III, 3, 20: Plínio fala, sim, do flumen Turium, mas efectivamente localiza-o junto a Valência.

112 Em Hermolai Barbari castigationes in Plinium castigatissimae, Cremonae, 1495, c 3 c 5 v-6, comentário a Plínio, N. H., III, 3 (20): "Flumen Turium. Codices Romani Flumen Durias. Pomponius quoque proximum Valentiae amnem Duriam appellat. Cícero in oratione pro Cornelio Balbo Carthaginem inquit profectum esse acerrimisque proeliis Sucronensi Duriensique interfuisse Sallustius tamem Turiam... Idem quarto Historiarum Turia... Claudianus: «Floribus et roseis formosus Turia ripis». Grammatici formosum legerentque unum amnium Turia neutro genere proferri putent: Aurelius Augustinus auctor Priscianusque uti ne hunc quoque praeteream. Est et in Lusitania quoque Durius, quem Strabo Duriam, multi Doriam appellant. Silius Durium: "Hinc certant Pactole tibi Duriusque Tagusque».

113 Prisciano, Inst., G. L. II Keil, 5, 6; 6, 9 (=Sal., Hist., II, 47, 24, p. 136 Kurfess): «inter laeua moenium et dextrum flumen Turiam, quod Valentiam paruo interuallo praeterfluit".

114 Epistula Cn. Pompei ad Senatum, incluída nos Fragmentos das Historiae, II, 98, 4-8, publicados na edição das obras de Salústio de A. Kurfess, Leipzig, 1981, p. 156-158.

115 O texto da carta de Pompeio na sua versão actualizada não respeita a lição aceite por Resende e substitui apud flumen Turiam por apud flumen Durium [Ex historiis, frag., II, 98, 6, p. 157 (Kurfess)].

116 Plut., Vida de Sertório, 19: a tradução latina de Resende não corresponde inteiramente ao texto actual de Plutarco, onde se diz: "Devido ao facto de saber tirar partido das derrotas era mais admirado do que os generais vitoriosos seus opositores, como foi o caso na batalha de Sucro contra Pompeio, ou na de Turia, contra aquele e também Metelo». O que parece corresponder mais à zona referida, toda ela no Sul: Sucro, Valentia, etc. No entanto, a lição Turiam é mantida por J. C. Rolfe, na ed. Loeb.

117 Claudiano, Louvores à Rainha Serena, 70-73: nas edições modernas trata-se de Duria e não Turia. Não tem, portanto, razão de ser a observação de Resende. Claudiano fala efectivamente do Douro.

118 Claudiano, ibidem, v. 72.

119 Marcial, XII, 98, 2.

120 Resende relata o que na verdade aconteceu, simplesmente mantém um quiproquó inútil. Quanto a Estrabão, ver n. 109, não usa a forma indicada por Resende, mas sim Ptolomeu, numa declinação masculina de tema em -a.

121 De facto Durius, apresenta as três sílabas breves. Duria, ao contrário de Durius apresenta a primeira sílaba longa.

122 Sílio Itálico, V, 321-322. Julgamos que Resende deva citar de memória, na medida em que abstulerat Duri é início de hexâmetro, precedido de caeso quam uictor moenibus ille Sagunti. Quam refere-se a uma lança célebre. 
123 Sílio Itálico, XVI, 366.

${ }^{124}$ Pompónio Mela, Corogr., III, 1, 10: «totam Celtici colunt, sed a Durio ad flexum Groui, fluuntque per eos Auo, Celadus, Nebis, Minius et cui obliuionis cognomen est Limia».

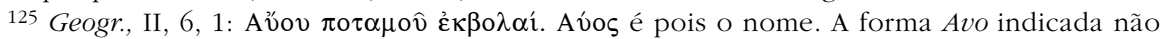
corresponde ao Grego.

126 Antonino, Itinerário, p. 66, 425, 2 (Cuntz); J. M. Roldán Hervás, Itin. Hisp., p. 76-78.

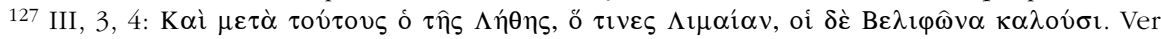
comentários de A. Schulten e de J. García y Bellido nas respectivas edições de Estrabão no referente a este passo.

${ }^{128}$ A coluna de Chaves (C. I. L., II, 2477) já é apresentada por A. R. em I, n. 121 e n. 162. Efectivamente, o nome de Límicos aparece, mas quanto à sua ciuitas limicorum, outras inscrições há mais elucidativas, como as do C. I. L., II, 2516, 2517. A zona chama-se Jinzo de Limia e pertencia à Tarraconensis.

129 Ver a resenha sobre o Lima feita por Duarte Nunes de Leão, Descrição do Reino de Portugal, cap. 19, Do Rio Lima, p. 85 e segs., em que o A. segue escrupulosamente a descrição de Resende.

130 Liv., Per., LV: «at cum flumen Obliuionem transire nollent milites, raptum signifero signum ipse transtulit et sic, ut transgrederentur, persuasit». Ver Floro, Epitome, I, 33, 12, que dá uma versão sem este pormenor, mas com o de Bruto ter olhado para o sol, quando este mergulhava no Oceano, já no caminho de volta, depois de ter atravessado o rio do Esquecimento.

131 Plut., Quaest. Rom., 34: tal como na versão de Floro (ver n. 130), refere-se unicamente que D. Júnio Bruto Galaico tinho sido o primeiro homem a visitar as remotas paragens da Lusitânia e a atravessar com um exército o rio Lete (Lima). Ver R. E., erste Reihe, 19 Halbband, s. v. Iunius (Brutus), n. ${ }^{\circ} 57$ Decimas Iunius Brutus Callaicus, cols. 1021-1025.

132 H. N., IV, 22, 115.

133 Justino, Epit. Hist. Phil., XLIV, 3, 4: "Regio (Gallaecia) cum aeris ac plumbi uberrima, tum et minio, quod etiam uicino flumini nomen dedit». O minio é o óxido vermelho de chumbo, vulgarmente chamado zarcão. Trata-se em Justino de mais uma tentativa de racionalizar a etimologia do nome por qualquer facto concreto. A verdade é que na zona não existia zarcão. É portanto etimologia popular. Tentativa idêntica fez o A. quando tratou das éguas da Lusitânia prenhas do vento (ver p. 94).

134 III, 3, 4. Ver comentários de A. Schulten e de García y Bellido a este passo, nas edições já referidas. A hipótese de emenda proposta pelo nosso A. não tem o mínimo fundamento. O

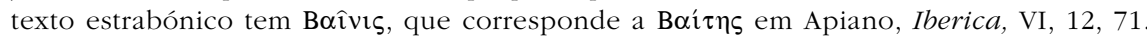

135 É efectivamente esta a etimologia aceite por Antenor Nascentes no Dicionário Etimológico e por J. P. Machado, Dic. Onom. Etim. Ling. Port., s.vv.

${ }^{136}$ A inscrição da ponte de Alcântara (C. I. L., II, 760) é discutida em I, n. 121. Na realidade, referente a Cuda $=$ Coa há o etnónimo transcudani.

137 Ver n. 128. De facto em C. I. L., II, 2477 são citados os Tamagani, a respeito dos quais E. Huebner (p. 346, 14-16) diz: "Tamagani aperte nomen ducunt a Tamaga fluuio, hodie Tâmega, cui pons ille superstructus est».

138 Também a esta santa se refere Duarte Nunes de Leão, Descripção do Reino de Portugal, cap. 45, p. 177-180, que para mais, quando descreve o rio Zêzere, cita Resende (p. 82). Quanto à história de St. ${ }^{a}$ Iria, ver Miguel de Oliveira, "Santa Iria e Santarém», R. P. H., VII (1957), pp. 439-470. Em apêndice apresenta o A. o Ofício do Breviário de S. Simão da Junqueira (1514), In natale Sancte Herene virginis et martyris, pp. 465-469 (do Breviarium secundum Ordinem Divi Augustini, fl. 444 e 446v, Bibl. Geral da Univ. de Coimbra, R-6-14) e as Lições do Breviário de Santa Cruz (1531), In Sancte Herene virginis et martyris, pp. 469-470. (Do Breviarium Sanctae Crucis, fl. 489 v a 490 v; Bibl. Geral da Univ. de Coimbra, R-3-16).

139 Trata-se, com Nabância, de uma hipotética cidade romana, cujo nome é obviamente derivado de Nabão, ver s. vv. Nabância e Nabão, J. P. Machado, Dic. Onom. Port.; M. de Oliveira, art. cit., p. 461, em que afirma que Nabância é topónimo "de fantasia erudita». Também A. R. não chegará a tratar desta cidade inventada. 
${ }^{140}$ O Zêzere, cuja etimologia é estudada por A. Nascentes, Dic. Etim., s. v., parece provir de nome árabe. A forma avançada por Resende também é considerada. Hipótese diferente é referida em J. P. Machado, Dic. Onom. Port., s. v., sem que defina etimologia definitiva. Surpreende-se o A. que J. Piel apresente Ozecarus como o topónimo lat. originário, quando A. R. já o refere aqui neste passo, aventando mesmo a etimologia fantasiosa de que Ozecarus derive de "ozaena, a gravi capitis odore», Plínio, H. N., IX, 30, 48.

${ }^{141}$ A informação de Resende sobre a cor e o nome do Zêzere é citada sem comentários por Duarte Nunes de Leão, Descr. do Rein. de Port., p. 82, o que leva a pensar que seja Resende o primeiro a testemunhar tal facto. Ver S. Daveau e O. Ribeiro, "Conhecimento Actual da História e Geografia em Portugal», in Hist. e Desc. da Ciência em Port., Coimbra, 1986, p. 1054 .

142 Cf. I, n. 214; Vita S. Martini Saurensis, P. M. H., I, parágrafo 60, 2: "Est ergo circa decursum anci cuiusdam aluei amene porrectum..." Quanto às hipóteses sobre a etimologia de Soure, ver A. Nascentes, Dic. Etim. Ling. Port., s. v. e J. P. Machado, Dic. Onom. Port., s. v.

143 Será o historiador João de Barros que redigiu uma Geografia, que, diz I. S. Révah, s. v. João de Barros, no Dic. da Lit. Port., se perdeu devido ao desleixo português, ou o outro João de Barros, alto funcionário, autor da Geografia de Entre Douro e Minho, referida na n. 218 do livro I.

144 Subur é naturalmente uma hipótese etimológica sedutora, só que não se encontra justificação geográfica nem atestação histórica. Ver J. P. Machado, Dic. Onom. Port., s. v. Soure, que aventa como possível étimo o lat. Saurium.

145 O sável é peixe comum em todo o vale do Tejo e do Sorraia e sobre ele faz Resende notável e erudita digressão na Maravilhosa Conversão de Frei Gil, citada na n. 77 deste livro II.

146 O mosteiro Urbanense não é mais, como confirma a sua proximidade de Ceira - ópido e rio - do que o mosteiro de Lorvão, situado no concelho de Penacova, a pouco mais de uma dezena de quilómetros de Coimbra, tal como nos sugeriu o Prof. Aires do Nascimento. Era monumento religioso e cultural importante na Idade Média (Apocalipse de Lorvão), fundado pela ordem de S. Bento. Adriano de Gusmão, s. v. "Lorvão, Mosteiro de»,Dic. Hist. Port.; Guia de Portugal, vol. III, p. 372 ss.

147 A Lusitânia foi tratada do ponto de vista da sua «riqueza e potencialidades por muitos autores da antiguidade (Estrabão, Ateneu, Plínio, Marcial, etc.), cujos testemunhos se encontram coligidos na totalidade nas Fontes Hispaniae Antiquae começados a editar por A. Schulten, e de que nos temos servido largamente nesta edição.

148 Ateneu, Deipnosofistas, VIII, 331, b-c.

149 Larênsio (de Larensius) é forma erradamente atribuída por Resende ao gr. $\Lambda \alpha \rho \eta ́ v \sigma ı s$, anfitrião do jantar de sábios relatado por Ateneu, Deipnosofistas, I. Em latim o nome é Larensis, que aparece atestado epigraficamente (C. I. L., VI 212). Cf. Oxf. Class. Dict. (2) s. v. Athenaeus (1).

O discurso de Larênsio é comentado por A. Resende como se fosse tendencioso, por contrastar, na fertilidade que descreve, com a real pobreza da Lusitânia.

\section{LIVRO TERCEIRO}

1 Tito Lívio, XXXIII, 21. O nome de Culca é Colcha na tradição textual.

2 Quanto à prática de Ânio de Viterbo de forjar antiguidades, ver C. Mitchell, "Archaeology and Romance in Renaissance Italy", in Italian Renaissance Studies, ed. E. F. Jacob, Londres (1960), pp. 445-483. Ioannes Annius Viterbensis (João Ânio de Viterbo) escreveu, no séc. XV, Antiquitatum variaram volumina XVII a venerando et sacrae theologiae et praedicatoris ordinis professore J. Annio hac serie declarata, venundantur ab Joanne Parvo et Jodoco Badio, obra depois editada com o título de Berosi sacerdotis chaldaici antiquitatum,..., datada de Paris, 1512 e 1515 no Catálogo da Biblioteca de Gand. O primeiro título encontra-se na Biblioteca Real de Bruxelas, INC B 581, mas sem data. 
Interessa sobretudo no Livro III, fól. XXXVI: Hispani priusquam Graeci nouerunt litteras plusquam mille annis; tese fantasiosa em que pretende provar o conhecimento do alfabeto pelos Hispanos, mil anos antes dos Gregos; Hispanorum origo, liv. XV, fól. CXXVI, v; De primis temporibus et quattuor et uiginti regibus Hispaniae et eius antiquitate, liv. XII, fól. LXXXVI, v. com os nomes de Lusus, fól. LXXXXIX, v e Romus, fól. XC.

Quanto a Beroso, consultar P. Schnabel, Berossos und die babylonisch-bellenistische Literatur, Leipzig, 1923 (reed. Hildesheim 1968).

No que respeita aos historiadores hispânicos "de épocas recuadas» recordemos Rodrigo de Toledo e outros. Ver Manuel Diaz y Diaz, Index Scriptorum Latinorum Medii Aevi Hispanorum, Madrid, 1959, nas rubricas que dedica ao cronista.

3 Gargoris "rex uetustissimus" dos Curetes é citado por Justino, Epit., XLIV, 4, 1, F. H. A., VIII, pp. 344 e 352, e o seu reino ficaria na zona de Gades (Cádis); Habis citado no mesmo passo de Justino, parágrafo 10 ss., parece poder identificar-se com o touro sagrado egípcio Hapi, F. H. A., VIII, p. 352-353. Argantónio é referido por Heródoto, I, 163 a 165, como rei de Tartessos que os Foceences teriam encontrado no séc. VI a.C. Reinou 80 anos e viveu 120. Este último número é aumentado por Apiano (61-63) para 150 (F. H. A., IV, 107-109). Esta versão já teria sido consagrada por Estrabão, III, 2, 14, e dada como proveniente de Anacreonte (F. H. A., VI, 191), lição também conservada por Plínio, H. N., VII, 48, 154. Quanto a Gérion, citado no parágrafo 14 do texto de Justino acima indicado, cf. n. 5.

${ }^{4}$ Arrian., An., II, 16, 5 (Eustácio, Comm. Dion. Per., p. 558), Hecateu, Geneal., frag. 30 (Nenci) ou F. G. Hist., I, 26 (Jacoby).

5 De facto a tradição antiga aponta para a identificação da terra de Gérion com a Hispânia, conforme nos transmite Estrabão, III, 2, 11, fazendo-se eco (como já Resende regista na p. 186, n. 90, do livro II) de Estesícoro, frag. 181 e segs (Page), muito especialmente o frag. 184, que refere o passo de Estrabão. Tinha Estesícoro de facto publicado um poema que

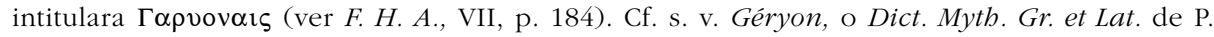
Grimal, que dá a lista dos autores antigos que trataram do tema desde o próprio Hesíodo, bem como W. Roscher, Woert. d. Gr. R. Myth., e R. E., ver comentário a Avieno de Schulten, F. H. A., I (2), p. 179 ss.

${ }^{6}$ Macróbio, Sat., I, 20, 12: "Theron rex Hispaniae citerioris...".

7 Tito Lívio, XXII, 21; XXVI, 49 e passim; Sílio Itálico, Pun. III, 376-377: "Mandonius populis domitorque equorum/ imperitat Caeso, et socio stant castra labore». Eram os chefes de povos oriundos da Tarraconense, de Saetabis (na zona de Valença) e das terras por onde passa o rio Sucro, ou Júcar, como agora se chama.

8 Sílio Itálico, Pun., XVI, 564-565.

9 Políbio, III, 76, 7, refere-se de facto a um general dos Iberos de nome Andobales, que corresponde a Indibilis em latim e que era o rei dos Ilergetas (Pol., IX, 18,7). Cf. F. W. Walbank, A Historical Commentary on Polybius, vol. I, p. 410.

${ }^{10}$ Não se conhece Vida de Plutarco com o título de Cipião. O único que é objecto de biografia é Aemilius Paulus e como tal é citado. Nessa vida nada se refere aos dois nomes mencionados por Resende. Eles aparecem, sim, em Tito Lívio, XXVIII, 21: "Neque obscuri generis homines sed clari inlustresque Corbis et Orsua, patrueles fratres, de principatu ciuitatis quam Idem uocabant ambigentes ferro se certaturos professi sunt.» A. Schulten, F. H. A., III, p. 148, diz-nos que os nomes de Corbis e Orsua, bem como da cidade de Ide, só aparecem neste passo, além de que a situação da cidade é completamente desconhecida. O texto de Resende, onde vemos, como em Lívio, patruelles, denuncia que deve ter havido erro de citação por parte do humanista.

11 Tito Lívio, XXXV, 7.

12 Id., XL, 49.

13 Id., XXI, 43; XXVII, 20.

14 Não há notícia de nenhuma Vida de Aníbal por Plutarco. A morte de Amílcar vem, contudo, descrita na história de Diodoro Sículo, XXV, 10, que afirma ter-se ela dado na guerra

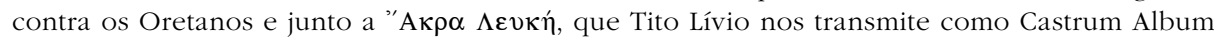
(e não Altum como nos diz Resende; ver n. seg.). Tão-pouco morreu na luta contra os Vetões, conforme lemos e que é versão transmitida por Cornélio Nepos, Amílcar, 4. Resende defende 
a versão que inclui erradamente os Vetões, porque estes vivem à volta de Mérida e, portanto, da Lusitânia e mais perto de Portugal, ao passo que os Oretanos se situam ao sul de Toledo, bem como Castrum Album que é identificado como Alicante. Ver A. Schulten, F. H. A., III, pp. 9-15.

15 Tito Lívio, XXIV, 41. Cf. comentário de A. Schulten, F. H. A., III, p. 84 e segs.

16 Políbio, II, 13, 1.

17 Pompónio Mela, Corogr., II, 6, 94.

18 Estrabão, III, 4, 6.

19 Sílio Itálico, Pun., III, 368.

20 Ver p. 184.

${ }^{21}$ Sílio Itálico, Pun., XV, 192-195. Sonho de Cipião em que lhe é descrita a cidade.

22 Tito Lívio, XXVI, 42 e segs. Descrição da cidade e da sua conquista por Cipião.

23 Justino, XLIV, 3, 3. Sobre esta versão, em que se apresenta um Troiano como ligado a uma cidade de origem cartaginesa, anacronismo evidente, ver R. Grosse, F. H. A., VIII, pp. 226-228.

${ }^{24}$ Aurélio Cassiodoro, Chronica, 55-57, M. G. H., Auctores antiquissimi, vol. XI, 2 (Mommsen), p. 122: "Latinus Silvius Hier. a. 94055 / Huius temporibus Hier. a. $94056 /$ Amazones Asiam vastaverunt. / Carthago condita est a Carcedone Tyrio, uti quidam dicunt.» Hier. a. 97457.

25 A data da conquista de Tróia parece-nos ser avaliada pela cronologia de S. Jerónimo que está subjacente à de Cassiodoro. Efectivamente, nos Chronica, p. 121, 47, lemos que no Hier. a. 835 e no $25 .^{\circ}$ ano do reinado de Latino "Troia capta est». Sendo a tomada de Tróia em 835 e a fundação de Cartago em 974 medeiam 139 anos, ou seja, "para cima de 135 anos", como diz Resende.

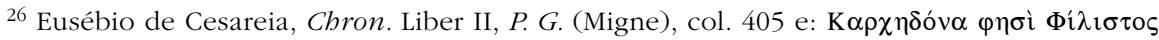

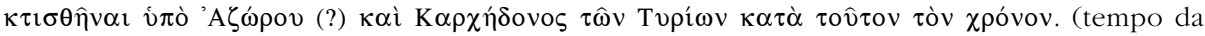

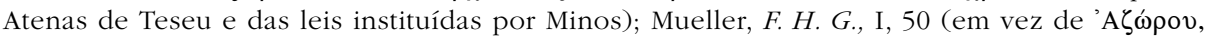

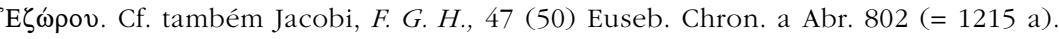

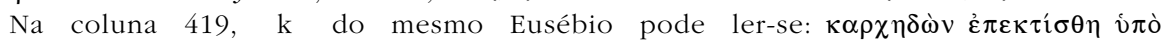

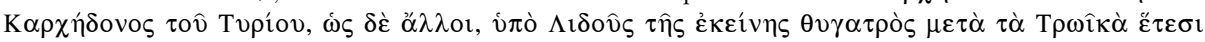
$\rho \mu \gamma^{\prime}$ (ano 143). Na col. 421 há o comentário e tradução de S. Jerónimo "Carthago secundum nonnullos condita a Didone. Alii suprascritpum tempus uindicant: quod Vergilius non esse uerum ostendit, qui Didonem se interfecisse ait.»

27 Timeu de Tauroménio, frag. 60, (Jacoby, F. G. H., dritter Teil, B, 566, p. 619, citação de

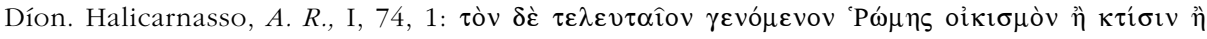

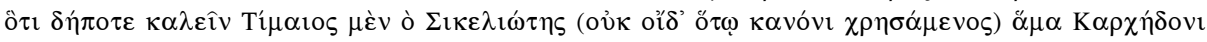

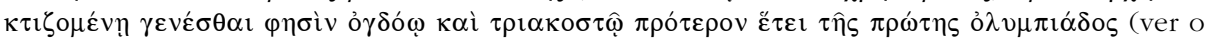
comentário e notas de Jacoby a este frag. nos vols. do dritter Teil b. Kommentar, Text, p. 564 ss. e Noten, p. 330 ss, n. 305 ss.).

Trata-se, como é evidente, de mostrar um certo alarde erudito, querido a Resende, que apresenta diversas fontes antigas que discutem o famoso problema de Tróia e sua queda, relativamente à fundação de Cartago e igualmente à fundação de Roma. Era um tipo de "arqueologia" favorito dos historiadores antigos, quando pretendiam descer às raízes das civilizações que estudavam.

28 Virg., em., I, 619.

29 Os livros XVIII a XXI das Hist. Filípicas de Justino ocupam-se da história de Cartago e naturalmente de Tiro na Ásia Menor. A história da pele de boi é contada no livro XVIII, 5, 8 segs. Quando Dido chegou a um golfo da costa de África começou por comprar aos nativos um pequeno pedaço de terra que se podia cobrir com uma pele de boi. Simplesmente, depois foi cortando a pele em tiras e com elas aumentando mais espaço, tanto mais que as tiras eram cortadas finíssimas. Assim começou a fundação de Cartago.

30 Hist. Filip., XVIII, 6, 9.

31 Hist. Rom., I, 6, 4.

32 Com. En., I, 12 (Thilo-Hagen): "et 'antiqua' autem et 'fuit' bene dixit, nam que et septuaginta annos urbis Romae condita erat, et eam deleuerat Scipio Aemilianus.» 
33 Solino, Coll. rerum memorab., 1, 28-29, p. 8 (Mommsen). Resende socorre-se de fontes tardias, como é Solino, para comprovar a tese de que Cartago não existia, quando Teucro abordou a Hispânia. Desta forma entra Resende na complicada discussão das datas de fundação das cidades, bem como da destruição de Tróia. Quanto à discutida Tróia homérica, sua tomada e possível destruição (não se sabe se por terramoto, no caso de Tróia VI, ou incêndio, Tróia VII b, pouco plausível por intervenção inimiga) pelas forças inimigas gregas, segundo a versão homérica, julga poder-se situar no séc. XII a. C. ou por volta de 1200, ainda que a Tróia histórica dificilmente se adapte à lenda homérica, o que contrasta com o séc. X a. C., data em que se pensa poder identificar as mais antigas construções do Palatino, Quirinal, Esquilino e Coles na zona que viria a ser Roma, a qual, segundo Varrão, teria sido fundada em 21 de Abril de 753, data que está longe de ser confirmada. Quanto a Cartago, parece que muito aponta para a sua fundação no séc. IX, muito embora as precisões dadas pelos diversos historiadores latinos e gregos, cujos ecos, de alguns pelo menos, Resende nos dá a conhecer, não tenham por vezes fundamento arqueológico e histórico. Ver s. vv. Karthago, Roma e Tróia os artigos do Der kleine Pauly. Quanto aos mesmos assuntos, consultar rapidamente as tábuas cronológicas de P. Leveque, A Aventura Grega, Lisboa, 1967, bem como R. Bloch e J. Cousin, Roma e o seu Destino, Lisboa, 1964, publicadas pela Cosmos.

34 II, 13, 1 (ver n. 16).

35 XXIV, 41 (ver n. 15)

36 Pompónio Mela, Corogr., III, 7: «in Sacro (promunturio) Laccobriga et Portus Hannibalis." A. Schulten admite que Porto Aníbal possa ser Portimão. Ver F. H. A., III, p. 44; A. Tovar, Iber. Landesk., 207.

37 Tito Lívio, XXI, 43

38 Id., XXI, 57.

39 Id., XXII, 20, 2.

${ }^{40} I d$., XXVII, 20 ss.

41 Id., XXVIII, 12, 11

42 Sílio Itálico, Pun., III, 354-356.

43 Id., Pun., V, 333-342. O verso final reflecte uma lição que não é aceite nas edições modernas, que alteram substancialmente o conteúdo do último verso: praebebat tellus, sparsis uix peruia telis, / iniecit pariter, pluresque in corpore nullum / inuenere locum perfossis ossibus hastae (vv. 341-343), "[e o que quer] que a terra juncada de dardos dispersos, que impediam o movimento, lhes oferecia. Até os ossos foram trespassados, e muitos dos dardos nem lugar tiveram naquele corpo".

${ }^{44}$ Id., Pun., X, 217-231.

45 A segunda guerra púnica, em que é inserido o $1 .^{\circ}$ Viriato, dura 4 anos, ou seja, de 218 a 222. A batalha de Canas, a que se refere o passo do canto X, dá-se em 216. O "bellum Viriaticum " dura de 154 a 133, data em que Viriato é assassinado. Conclui-se portanto que o lapso de 70 anos referido por Resende é correcto.

46 Vemos que se pretende ligar Viriatus a uis (força). Parece que o nome, no entanto, deve ser ligado, sim, a uiria do céltico, que significava "bracelete», tal como acontece com o nome bem latino de Torquatus que vem do célt. torques "colar". Ver M. Cardoso, s. v. Viriato, Dic. Hist. Port.; Der kleine Pauly, s. v. Viriatus; A. Nascentes, Dic. Et. L. Port, II, s. v. Viriato; J. P. Machado, Dic. Onom. Et., s. v. não se refere à etimologia proposta.

47 Lucílio, frag. 615-616 (Marx): Contra flagitium nescire bello uinci a barbaro / Viriato, Annibale...

${ }^{48}$ Plutarco, Marco Catão, X, 1: De facto Plutarco refere-se brevemente aos sucessos militares de Catão, a quem coubera, quando cônsul, a Hispânia Citerior. Devido a dificuldades criadas pelos povos indígenas, teria Catão feito um acordo com os Celtiberos, a quem pagou, e conquistou, com a sua ajuda e segundo Políbio, todas as cidades para aquém do Guadalquivir (Bétis) num só dia.

${ }^{49}$ C. I. L., II, 25*: diz Huebner no comentário que "tamen n. 25* potest genuinus esse, si modo correxeris Porcius." É de facto uma inscrição de Lisboa.

${ }^{50}$ C. I. L., II, 26* (inscrição de Sintra).

51 Tito Lívio, XXXV, 1. 
52 Ver p. 132.

53 Orósio, Hist. adu. pag., IV, 20, 23: neste passo fala-se unicamente de L. Aemelius, ao passo que mais adiante, IV, 20, 39, fala-se de L. Aemilius Paulus. Trata-se, contudo, do mesmo, como supõe Resende. Ver A. Tovar e J. M. Blásquez, Hist. Hisp. Rom., Madrid, 1975, p. 42.

54 Tito Lívio, XXXVII, 46. Também Lívio, tal como Orósio, lhe dá o título de procônsul, quando descreve a derrota em que seis mil romanos teriam morrido e os outros fugido. Não diz, porém, que tivesse morrido. Em XXXVII, 57, narra a futura vitória sobre os Lusitanos.

55 Plutarco, Emílio Paulo, IV, 1-2. Traduzimos secures, os machados com que os lictores ministravam justiça, porque consideramos tratar-se de uma metonímia, tal como no passo de Plutarco em que $\pi \varepsilon \lambda \varepsilon \kappa \kappa \varepsilon \varsigma$ equivale aos mesmos magistrados. Resende faz correctamente uma paráfrase que quase traduz literalmente o texto grego.

56 É o passo citado na n. 54.

57 Trata-se do Chronici rerum memorabilium Hispaniae tomus prior. Auctore Ioanne Vasaeo Burgensi humaniorum literarum in Salmanticensi Academia professore. Salmanticae..., MDLII. Também publicado no tomo I da Hispania Illustrata, pp. 572-726.

Tem Resende toda a razão em insistir na lição in Bastetanis, que é a correcta não só pela tradição textual de Lívio (que contrasta com o texto citado, que erroneamente apresenta Vascetani), como pelo texto de Apiano, VI, Iber., 11, 66, que nos refere B $\alpha \sigma \tau \imath \tau \alpha \nu \hat{\omega} \nu \chi \omega \dot{\omega} \rho \alpha \nu$. Os problemas de pronúncia referidos por Resende têm a sua razão de ser na medida em que os Espanhóis sempre pronunciaram o $v$ como $b$ e os Gregos (modernos) o $b$ como $v$. O nome de Vascetanos simplesmente não existe. Cf. A. Tovar, Iber. Landesk., pp. 26, 120, 182.

58 Plínio, N. H., III, 1, 10: "Vesci quod Fauentia", cidade que se situa entre o Bétis ou Guadalquivir e o mar Mediterrâneo.

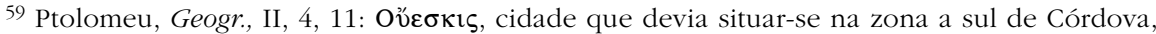
tal como A. Tovar a apresenta na carta que concebeu segundo a descrição do geógrafo grego, em Hist. Hisp. Rom., p. 353; Tovar, Iber. Landesk., pp. 14, 62.

60 XXXVII, 57 (cf. n. 54). É um passo que Resende refere já por três vezes.

61 Veleio Patérculo, Hist. Rom., I, 9, 3. O triunfo realizou-se efectivamente, mas, tal como defende Resende, para deslustrar o imperialismo romano na península, não foi para celebrar a vitória sobre os Lusitanos. Ver R. Bloch, Roma e o seu Destino, p. 67. A vitória que lhe conferiu o triunfo foi sobre o rei Perseu da Macedónia, em 168 a.C., realizando-se as cerimónias do triunfo em 167.

62 Tito Lívio, XXXVII, 58.

63 M. Vérrio Flaco é sobretudo conhecido como gramático. Refere-o Suetónio, De grammaticis, 17, como tendo uma estátua em Preneste perto de um hemiciclo «in quo fastos a se ordinatos et marmoreo parieti incisos publicaret». Albrecht Dihle aponta para a dificuldade de compatibilizar estes fastos com os publicados no séc. XVI por Onofre Panvínio (ver A. Dihle s. v. M. Verrius Flaccus na enciclopédia Pauly-Wissowa). É mais racional que ele tenha ordenado os Fasti Praenestini, cf. J. E. Sandys, Latin Epigraphy, reed. Groningen, 1969 (da ed. de Cambridge), p. 173 ss.

64 Onofre Panvínio (Veronense) é um humanista italiano que depois de Marliani (Roma, 1549) e outros, publica os Fasti Capitolini que intitula de Tabulas Capitolinae, às quais aparecia ligado o nome de M. Vérrio Flaco (n. 63), cf. J. E. Sandys, ob. cit., pp. 24-26. Também Panvínio foi célebre pelas suas peças forjadas, procedimento considerado elegante pelos antiquarii como o Cardeal António Agustín de Saragoça (1517-1586). Ver o art. de C. Mitchell, p. 458, cit. n. 2.

Há que consultar Onuphrii Panvinü Veronensis fratis eremitae augustiniani... Fastorum libri $V$ a Romulo rege usque ad Imp. Caesarem Carolum V Austrium Augustum. Eiusdem in fastorum libros commentarii... Onuphrii Panvinii... commentariorum in fastos consulares Appendix...In Verri Flacei triumphalium consulariumque tabularum fragmenta ...De antiquis Romanorum nominibus, ex officina Erasmiana Vicentij Valgrisij, Veneza, 1558 [Bibl. Nac. Paris, 1105 (1)].

Quanto a Lúcio Emílio, refere-se-lhe Panvínio na p. 25, mas o texto citado por A. R. provém do trabalho de Carolus Sigonius, In Fastos ac Triumphos Romanos commentarius, Basileia, 1569 (incorporado por vezes nas edições de Panvínio), p. 166 c. 
As inscrições foram editadas por Th. Mommsen, C. I. L., I, 1, pp. 1-54, e o enquadramento histórico dos Fasti Consulares e dos Acta triumphorum com as datas romanas e as cristãs. Estes últimos encontram-se respectivamente nas pp. 79-167 e 168-181.

65 Cf. R. E., s. v. L. Aemilius Paulus.

66 Tito Lívio, XXXVÜ, 57. Não se trata de C. Catinius, mas sim de C. Atinius. O nome Catinius deve ter surgido de uma má leitura dos manuscritos, em que o C. de Gaius foi ligado ao nomen. Trata-se de Tito Lívio, XXXIX, 21, 30-31.

67 Id., XXXIX, 30.

68 Id., XXXIX, 31.

69 Id., XXXIX, 32.

70 Id., XXXIX, 33.

${ }^{71}$ Estes acontecimentos são narrados no livro XXXIX de Lívio, seguidamente aos passos atrás citados. O passo transcrito está efectivamente no cap. 56.

${ }^{7}$ P. Mânlio é em 195 a. C. pretor e em 194 propretor da Hispânia Citerior e volta a ser pretor da Hispânia Ulterior de 181 a 180. As batalhas que Livio não descreve não são facilmente localizáveis, pois a bibliografia que se ocupa da Hispânia só cita Tito Lívio como sua fonte. Ver F. H. A., IV (guerras de 237-154 a.C.), pp. 177 ss. e 210-211.

73 Tito Lívio, XL, 50.

${ }^{74}$ Trata-se de Josse Bade (Badius), professor, impressor, erudito. Nasce em 1462, em Assche no Brabante, e morre em 1534 ou 35 em Paris. Erasmo compara-o a Budé. Ver Biographie Nationale publiée par l'Académie Royale, Bruxelles, 1866, tomo I, s. v. Badius, Josse, daí edição Badiana, intitulada T. Livii... Tres cum dimidia quae solae extant Decades ... Adjectae sunt praeterea doctorum quorundam virorum lucubrationes ... Lugduni, apud A. Vincentium, 1553.

75 Entre os eruditi viri, da edição citada na nota anterior, figura o nome de Henrichus Loritus Glareanus, polígrafo suíço, nascido em Glaris (daí Glareanus) em 1488 e morto em Friburgo de Brisgau (Alemanha) em 1563. Ver Nouvelle Biographie Générale, Firmin Didot Frères, Paris, 1857, tomo XX, s. v. Glareanus.

${ }^{76}$ João Vaseu, ver n. 57. De facto os Vaceus, na época a que se refere Lívio, seriam mais de incluir na Citerior do que na Ulterior. Ver Westermam Grosser Atlas zur Weltgeschichte, Braunschweig, 1978, p. 28. No entanto, o critério nunca seria suficiente para fundamentar a hipótese de Resende.

77 Neste epítome fala-se simplesmente da vitória sobre os Celtiberos, cuja rendição foi aceite por T. Semprónio Graco, e que os Vaceus e Lusitanos foram dominados por A. Postúmio Albino.

78 Lív. XL, 47.

79 Ver p. 96 ss.

80 Lív., XLI, 7.

81 Orósio, Hist. adv. Pag., IV, 32-33. Quanto aos códices e edições, ver as edições de C. Zangemeister do C.S.E.L., Viena, 1882, com reed. anastática da Olms, Hildesheim, 1967 e a das Belles Lettres, de Arnaut Lindet, vol. I, Paris, 1991.

82 J. Obsequente, Prod. Liber, 17. Os prenomes variavam conforme os mss.; mas efectivamente tratava-se, como se vê nas edições mais modernas, de Q. Opimius e L. Postumius.

83 Ver ed. de Veneza citada na n. 64, p. 44, C. I. L., I, 1, p. 25, coluna XVIIb dos Fasti Consulares, ano 600 da fundação de Roma, no tocante à guerra pérsica, ano 154 a. C., p. 147.

${ }^{84} \mathrm{~J}$. Obsequente, Prod. Liber, 18.

85 A citação provém, sim, do Per., XLVIII: "Lusitani uastati.»

86 São efectivamente M. Claudius Marcellus e L. Valerius Flacus, cônsules em 602 a.V.c. = 152 a. C. O primeiro foi depois enviado para a Hispânia. R. E., III, 2759 (s. v. Claudius - M. Claudius Marcellus 255) e VIII (zweite Reibe), 21 (s. v. Valerius Flaccus - L. Valerius Flaccus - 174).

87 Comentários às Tábuas Capitolinas. Cf. C. I. L., I, 1, p. 26, coluna XXII dos Fasti consulares, ano 608 da fundação de Roma referente à terceira guerra púnica, ou seja, 146 a. C., ver p. 149. 
88 Apiano, VI, Iber., X, 58. Cf. F. Muenzer, s. v. L. Mummius, R. E., XVI, 1, Nachtraege, 1195 SS.

89 Eutr., Breu., IV, 9.

90 Trata-se de facto de Mummius, ver A. Schulten, F. H. A., IV, 98. Nas edições de Eutrópio o nome de Memmius é confundido com o de Mummius, o que acontece também com Diodoro Sículo, 31, 42.

91 Cf. Políbio, XXXV, 4; Lív., per., 48; A. Tovar-Blásquez, Hist. Hisp. Rom., p. 55.

92 Lív., Per, XLVIII.

93 Orósio, Hist. adv. pag., IV, 31. Ver p. 136-138 do livro I.

94 Orósio, IV, 21, 3.

95 IV, 21, 10

96 Vai. Máx. Fact. dict. memor., IX, 6, 2. É difícil reproduzir na tradução a equivalência cladem - partem de que fala Resende. Fugindo à letra, podia substituir-se destruição por perda, palavra mais próxima de parte.

97 Cíc., Brutus, 80; Diuinatio in Caecilium, 66; Ps. Ascónio, p. 124 (Orelli); Lívio, Per., XLIX. Ainda há, porém, outras referências em autores antigos, ver A. Schulten, F. H. A. IV, pp. 103-106.

98 Lív. XXXIX, 40, o mesmo também é narrado no passo do Brutus da n. 97.

99 Catão, frags. 106-110 do livro VII das Origines em H. Peter, H. R. R., I, p. 89 ss.; E. Malcovati, Or. Rom. Frag., I, LI, p. 79.

100 Quint., Inst. or., II, 15, 8 refere especialmente a forma como Galba se apresentou no tribunal, rodeado de seus filhos menores e do sobrinho, a fim de impressionar a assistência e os juízes. Por isso e pela sua capacidade oratória, foi absolvido. Ver Frontão, Ad M. Caesarem, 3,20 .

101 Val. Máx., Fact. dict. memor., VIII, 1, 2; não se admite aqui que tenha sido a capacidade oratória de Galba, mas sim a comiseração que ele provocou, a causa da sua absolvição. O que parece ter sido a principal causa foi o interesse da ordem senatorial em não castigar muito duramente um dos seus. Isso não impediu, contudo, que se instituísse em 149 a. C. um tribunal permanente contra os abusos dos pretores; ver A. Schulten, F. H. A., IV, p. 105. Quanto a outras atrocidades, como a cometida por Galba, ver ibidem, p. 31.

102 Existem de facto as duas denominações, mas a de Sergius aparece em Orósio (Hist. adu. nat., IV, 21, 10), tal como diz Resende, enquanto o texto de Lívio sempre nos dá Seruius.

103 Em todos os passos de Lívio, como se disse anteriormente, é esta a forma usada.

104 O passo de Valério Máximo que citamos na n. 96 limita-se a apresentar o praenomen abreviado: «Ser. quoque Galba, etc.».

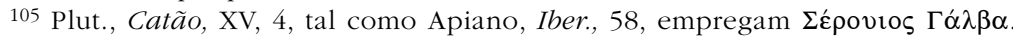

106 Suetónio, Galba, 3, limita-se a referir Seruius Galba.

107 O argumento de Resende, que da discordância entre os autores e personagens referidas pelos prenomes pretendia formar uma tese, não colhe, na medida em que, mesmo no texto de Eutrópio, VII, 16, aparece Seruius Galba.

108 Em Díon Cássio, Hist. Rom., LVII, 19, 4, aparece unicamente referência a Galba (o

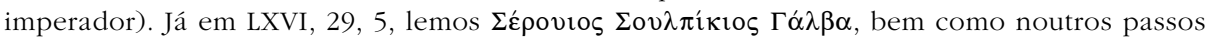
dos livros seguintes.

109 Qualquer dicionário nos indica que Seruius é um cognomen sobretudo ligado à gens Sulpicia, ao passo que Sergius é um nomen, característico portanto de uma gens, como é o caso de Lucius Sergius Catilina, sendo Catilina, como é sabido, um cognomen. Ver igualmente A. Schulten, F.H.A., IV, p. 103.

${ }^{110}$ C. I. L., II, 4268: P. Fábio P. f(ilio) Ser(gia) Lepido f(ilio); quae (i. e. statua) ex d(ecreto) d(ecurionum) Tarr(aconensium), quod factum post mortem eius, ... quam (i. e. impensam) mater eius Iuia Sex(ti) filia Reburrina de suo dedit. A leitura é de Huebner e trata-se não de um cipo mas de uma estátua.

111 Cf. n. 94.

112 Cf. n. 106. 
113 Floro, I, 33, 15. Traduz-se fasces por varas, muito embora fosse possível utilizar o latinismo fasces. A vara é, contudo, em português, o símbolo da autoridade.

114 Justino, Hist. Phil. XLIV, 2, 7.

115 Veleio Patérculo, Hist. Rom., u, 1, 3.

116 Eutrópio, Breu., IV, 16.

117 De uir. ill. ,71. Não se trata de obra de Plínio-o-Moço, nem tão-pouco de Sexto Aurélio Victor. É de autor anónimo e foi editada em 1911 por Fr. Pichlmayr nas ed. Teubner e de novo reeditada em 1970. O título é Incerti auctoris liber de Viris illustribus urbis Romae. Ver SchanzHosius, Geschichte der röm. Lit. Vierter Teil, Erster Band, Munique, 1914, pp. 70-72, p. 799.

118 Orósio, Hist. adu. pag., V, 4, 1-6. Orósio é uma das fontes preferidas, porque também uma das mais completas, acerca do bellum Viriathicum. Tinha além disso a vantagem de defender com forte patriotismo hispano a história dos seus antepassados. Daí o relevo que dá ao desenrolar da luta contra os Romanos, e a forma crítica como encara a acção militar dos invasores da Península. Quanto à ressonância dos 300 das Termópilas que se sente no episódio dos 300 Lusitanos, ver R. M. Rosado Fernandes, "O Episódio dos 'Trezentos Lusitanos Contra Mil Romanos' e a sua possível explicação», Ocidente, LXXII (1967), 278-283.

119 Id., V, 4, 8 e 12-14.

120 Frontino, Strat., II, 5, 7.

121 Por ex., II, 13, 4 ou III, 10, 6; 11, 6, etc.

122 Lív., Per, LII.

123 Lív., Per., LIV.

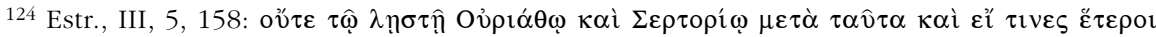

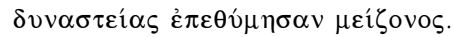

125 Cíc., De off., II, 11, 40. É de notar o aproveitamento dialéctico por parte de Resende, que comenta o passo ciceroniano dentro da técnica retórica, a fim de transmitir como que uma mensagem parenética para desmascarar o parcialismo romano. Dialéctica idêntica é utilizada no nosso tempo para ilibar da noção de crime de sangue o terrorismo ou guerrilha nacionalista de cariz político dos movimentos de libertação.

126 Id., Brut., XXI, 84: nota-se o eufemismo "recuar» por "ser vencido", que Resende aponta.

127 De uir. Ill., 71; ver n. 117. Como se vê, repete-se parte do passo pseudo-pliniano.

128 Resende procura habilmente passos em que possa fundamentar a refutatio da tese, defendida por historiadores antigos, em como Viriato era um ladrão. Refere por isso a figura de Masinissa, célebre pelo tipo de guerrilha que praticava. Lívio, XXIX, 31.

129 Eutr., Breu., IV, 16; ver n. 116.

130 Repete o passo indicado na n. 96 (IX, 6, 2).

131 Orósio, Hist. adu. pag., V, 4, 2; Lív., Per., 52.

132 Para o conhecimento deste período e da cronologia, ver A. Schulten, F. H. A., IV, pp. 96-140, em que se analisam todos os passos históricos, ou não, referentes às guerras lusitanas de 115 a 136 a. C. Também é útil o trabalho de A. Tovar, no já citado A. Tovar y J. M. Blazquez, Hist. Hisp. Rom., pp. 58-66 sobretudo. Naturalmente que, apesar dos anos, ainda continuam imprescindíveis os trabalhos de A. Schulten sobre Viriato, tanto na monografia Viriato, Porto, 1927, como no artigo Viriatus na R. E.

133 Lív. Per., LIV: "Q. Fabius procos. rebus in Hispania prospere gestis...".

${ }^{134}$ Floro, I, 33, 17. De facto trata-se de Quinto Fábio Máximo Serviliano, que será cônsul em 142 a. C., mas que em 141, quando se deu o acontecimento, era procônsul. Resende tem razão. Ver A. Schulten, F. H. A., IV, p. 118 segs.

135 Ver n. 116.

136 C. I. L. , II, 21* (Campos de Évora, São Bento de Pomares). Huebner apresenta as variantes introduzidas posteriormente pelos editores de colectâneas histórico-epigráficas. Sobre o heró́smo lusitano celebrado em inscrições forjadas, ver J. d'Encarnação, "Da Invenção de Insc. Rom. por A. R.», Biblos, LXVII (1991), p. 211 ss., e R. M. Rosado Fernandes, "Méthodologie et Histoire dans De ant. Lus. d'André de Resende», L'Humanisme Portugais et l'Europe, Paris, 1984, p. 501 ss. 
137 Honorato João Valentim, ou melhor, Valenciano, pois era natural de Valência, foi preceptor de D. Sebastião e viveu em Lisboa nos tempos de Resende. Foi mandado chamar pela rainha D. Catarina, irmã de Carlos V e mulher de D. João III. Dedicou-se certamente ao estudo das antiguidades romanas, uma vez que Huebner, C. I. L., II, p. XIV, n. 28, nos informa sobre um Codex Valentianus que conheceu num livreiro de Valença, intitulado Inscripciones de memorias Romanas y Españolas recogidas de varios autores, entre os quais Florião do Campo. Ver Luís de Matos, "O Ensino na Corte durante a Dinastia de Avis", in O Humanismo em Portugal, 1500-1600 - Simpósio Nacional, Lisboa, 1988, pp. 502-503 e sobretudo 574, n. 49.

138 Florião do Campo, continuado por Ambrósio Morales, Coronica General de España, Alcalá de Henares, 1574, vo. II, 7, ff. 112v-113. Apresenta o texto epigráfico de André de Resende e comenta: "Esta piedra de Lúcio Silo, tengo por la mas antiqua que de Romanos se habla agora en España.» Considera para mais Évora já em Espanha.

139 C. I. L., II, 20* (Évora).

${ }^{140}$ C. I. L., II, 51* (Viseu).

141 Trata-se de novo da obra anónima De uir. Ill., 71 (Cf. n. 117): «Viriatus ... bellum aduersus Romanos sumpsit eorumque Claudium Unimanum, dein C. Nigidium oppressit." Não se sabe de que Nigídio se trata, pois só neste passo é mencionado. Ver A. Schulten, F. H. A., IV, p. 113.

142 O Testamento de Galo Favónio Jocundo, transmitido por Bartolomeu Marliano, Topographia antiquae Romae, Lugduni, 1534, f. 209, que o recebeu de Giacomo Simonetta, que efectivamente foi bispo pisaurense de 1528 a 1535 e faleceu em 1539, é considerado como pseudoepigráfico por Huebner, C. I. L., II, 40*, XI Conimbriga, que apresenta impressionante recolha de testimonia que atestam a importância que lhe foi concedida no séc. XVI, ao mesmo tempo que consigna as variantes do texto mais próximo da leitura de Florião do Campo transmitida na de Honorato João.

143 A declaração de Honorato João a respeito da transcrição do mesmo testamento por Florião do Campo continuado por Ambrósio de Morales, La Coronica General de España, Alcalá de Henares, 1574, vol. II, 7, f. 116, apresenta o texto latino com tradução explicando a sua edição: "Carlo Sigonio tratando en sus fastos este ano (142 a.C.), y Aldo Manucio en su ortographia la pusieran: y yo movido por su authoridad, cuento lo que en ella avia, que yo ni la he visto, ni he oydo a nadie que la viesse." $O R$ que aparece em fim de inscrição é lido por Huebner como pertencendo a SER. do praenomen de Servius Galba.

144 Ver. ed. de Veneza, p. 259 (n. 64 deste Livro III) do livro I dos Fastos em que se diz: "hoc autem prope Coimbriani in agro repertum est."

145 Lív., Per., LV. Trata-se de D. Iunius Brutus Callaicus (cons. 138 a.C.). Há bastantes pormenores sobre a campanha de Bruto, dos quais ressalta a passagem pelo rio do Esquecimento, o Lima (ver p. 196). Ver A. Schulten, F. H. A., IV, p. 136-140. Quanto à identificação de Valentia, do Minho ou da Costa do Levante, ver p. 139. Valença do Minho é, apesar de tudo, a mais situada nas proximidades das zonas em que Bruto se movimentou.

146 Marcantonio Coccio Sabellico, Enneades seu rhapsodiae historiaram, Veneza, 1498-1504; foi traduzido em português como Coronica geral de Marcantonio... Des ho começo do mundo, até nosso tempo. Tresladada em lingoage Portugues por Dona Lianor filha do Marques de Vila Real D. Fernando, Coimbra, 1550. É considerada uma das fontes dos Lusíadas, Catálogo da Exposição Bibliográfica, etc., Lisboa, 1972, p. 285 (V. 562).

147 Ver A. Resende, Vicentius Levita et Martyr, ed. Pina Martins, Braga, 1981, Adnotationes, p. 8, n. 24, da ed. fac-similada de Lisboa, 1545 .

148 Cf. n. 2. Interessa sobretudo na edição de Ânio de Viterbo o livro II, fól. XC.

149 Florião do Campo, Los cinco libros primeros de la Coronica general de España, Alcalá de Henares, 1553, vol. I, 1, f. 55-55 v. (cap. 30), aceita efectivamente a tese de João de Viterbo e "Su Maneton" da origem de Valência ligada a Romo, cuja etimologia faz derivar do gr. $\rho \omega \mu \eta ́$ (força) e que teria começado a reinar em 1339 a. C. e fundado junto ao Mediterrâneo a cidade de Valência que fez derivar de Valere (ter força, ter valor), etimologia equivalente à de Romo. Compara-se depois às outras Valências: de Alcântara, de Campos, do Minho, mas considera Valência do Sul de Espanha a principal, ao contrário de A. Resende, que vai preferir a do Minho. 
150 Entre os recentes historiadores hispânicos pode contar-se Francisco Tarafa, Canonicus Barcinonensis, que no De origine a rebus gestis Regum Hispaniae tem um pequeno capítulo sobre Romo. A primeira edição da sua obra em Latim aparece em Antuérpia, 1553, seguida de uma edição espanhola de 1563. O referido capítulo pode consultar-se na edição da sua obra inclusa em Hispaniae Illustratae seu rerwn urbiumque Hispaniae, Lusitaniae, Aethiopiae et Indiae scriptores varii, Frankfurt, 1603, vol. I, p. 524, 35. Romo continuará a ser considerado posteriormente, p. ex., na obra de João Mariana, S. J. da mesma Hispania Illustrata: Ioannis Marianae ex Societate Iesu, Historiae de rebus Hispaniae, libri XX, cap. XI, De Siculo Hispaniae Rege, vol. II, p. 218, 31 em que diz: "Romus Valentiae fundator in Edetanis, etc.".

151 Val. Max., VI, 4, ext. 1. O nome da cidade é, porém, Cinginia, que é desconhecida. Ver F. H. A., p. 138.

152 Livro II, pp. 92 ss

153 Orósio, Hist. adu. nat., V, 5, 12.

${ }^{154}$ Estr., III, 3, 4. Refere-se o geógrafo ao rio Minho, em grego também chamado, $\Lambda \eta \dot{\theta} \eta$,

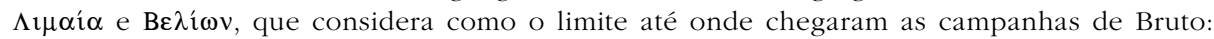

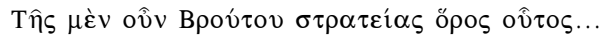

155 A tradução de Estrabão utilizada por A. de Resende é Strabonis Gnosii Amasini de situ orbis libri XVII e graeco traducti Gregorio Typlernale ac Guarino Veronense interpretibus, 1502, Venetiis, per Bartholomeum de Zanis de Porterio, fól. 32 v., e tem efectivamente a tradução latina que Resende refere, i. e., $\sigma \tau \rho \alpha \tau \varepsilon i ́ \alpha$ (ver n. 154) que é erradamente traduzida por praetura em vez de o ser por expeditio, como traduz o nosso humanista.

156 É certo, na medida em que tendo sido cônsul em 138 a. C., altura em que combatia na Lusitânia, passou para a Galécia em 137, já não sendo cônsul, mas sim procônsul. Quanto ao passo, ver p. 128.

157 A inscrição é diferente. No C. I. L. , I, 1, p. 26 dos Fasti consulares, coluna XXIV, lêemse em 616 e não 617 o nome reconstituído de Públio Cipião Nasica, e $d, i]$ VN $[i u s ~ m]$ F. M. N. BRUTV [s qui postea CAL [la] ICUS. APPEL [latus est. Cf. p. 149, 137 a.C.

${ }^{158}$ Júlio Obsequente, Ab anno urbis conditae DV prodigiorum liber, 42 , informa que no ano 549 a. C. sobre o nome dos cônsules P. Rutilius e Cn. Manlius, que "A Lusitanis exercitus Romanus caesus".

159 Cassiodori Senatoris Chronica, M. G. H., XI, 2, p. 132, 461 ab urbe condita 649: dá como nomes dos cônsules P. Rutilius Rufus et G. Manilius. Tem pois um Rufus não referido por Obsequente e em vez de Cnaeus.

160 Onofre Panvínio, Fastorum libri, p. 30 (n. 64). Se consultarmos o comentário de Cigonius (n. 64) veremos que o ano não é o de DCXLIX mas DCXLVIII, p. 242 D. Também se trata de C. Manilius e não Manlius.

161 Obsequente, quando refere o ano 101 a. C. (652 a. urb. cond.), cf. n. 158.

162 Rufio Festo, Breu., V, 1. No texto não figura o nome de Silanus, mas sim Sulla. Julga-se no entanto (ver A. Schulten, F. H. A., IV, p. 146) que deva entender-se de facto Silanus, conforme diz Resende, pois M. Júnio Silano, cônsul em 109, pode ter sido pretor da Ulterior e sucessor de Pisão. Quanto ao prenome de Silano, seria Marco e não Décio.

163 Vérrio Flaco (Cf. n. 64), Tábuas Capitolinas correspondem aos Acta Triumphalia, neste caso, com o texto transmitido em C. I. L., I, 1, 49, XXXIV, ano 656 da fundação de Roma: L. Cornelius P. f. L. n. Dolabell. procos. a. $D C L V$ ex Hispania ulterior. de Lusitan(is) V. K. Feb. É o dia 26 de Janeiro de 98 a. C. (ver p. 177).

164 Públio Licínio Crasso, cônsul em 97, triunfou em 93 pelas suas vitórias na Ulterior, diz-nos A. Schulten, F. H. A., IV, p. 152. Cf. R. E., XIII, 288. Cf. C. I. L., I, 1, p. 49 dos Acta Triumphalia, col. XXXIV, ano 661 da fundação de Roma, ou seja, ano 93 a. C. (p. 177 do $C$. I. L., I, 1).

165 Estr., II, 5, 11.

166 Floro, II, 10, 22.

167 Os principais trabalhos sobre Sertório são de A. Schulten, Sertorius, Leipzig, 1926, e Porto, 1928 (trad. port.), e os diversos artigos sobre a sua figura aparecidos na enciclopédia Pauly-Wissowa, R. E. no Oxford Classical Dictionary e no Dicionário de História de Portugal 
e outras fontes, que se baseiam muito na biografia de Sertório das Vidas Paralelas de Plutarco.

168 Trata-se ainda da principal fonte biográfica, sobre a qual se têm fundamentado as tentativas de compreender a actuação política e militar de Sertório. A vida de Sertório aparece a par da de Eumenes, nas Vidas Paralelas de Plutarco.

169 As guerras civis constituem, tal como as guerras na Ibéria (Iberica), uma das partes da História Romana de Apiano. A acção de Sertório é relatada portanto nos Bella Ciuilia, I, 8, 65, 67; 10, 85; 86 (partida para a Hispânia); 13, 107; 108-114 (guerra de Sertório).

170 Floro, II, 10 (bellum Sertorianum).

171 Orósio, Hist. adu. pag., V, 24, 18.

172 De uir. Ill., 77, 4 (cf. n. 177); Val. Máx., Fact. dict. memor., I, 2, 4; VII, 3, 6 passim. Frontino, I, 10 1-2; II, 5, 31, passim; Obsequente, 58, passim. Há muitas outras fontes, como Lívio, Diodoro Sículo, Salústio, que estão reunidas, com todos os outros já mencionados, por A. Schulten, F. H. A., IV, pp. 160-250, no capítulo que abrange as guerras de Sertório na Hispânia, de 82 a 72 a.C.

173 Não se trata de Manílio, mas sim de Lúcio Mânlio, como se pode verificar pelo passo de Orósio, Hist. adu. pag., V, 23, 3, ou mesmo por César, B. G., III, 20.

${ }^{174}$ Ver além de A. Schulten, ob. cit., na n. 172, A. Tovar e J. M. Blazquez, Hist. Hisp. Rom., p. 87 e segs.

175 O facto de Sertório chamar velha a Metelo aponta para a diferença entre o jovem e disciplinado Pompeio e o velho aristocrata decadente Metelo, conforme apontam Salústio, Hist., II, 17-19, bem como Plut., Pompeio, XIX. A frase de Sertório aparece nesta última obra no parágrafo 18 .

176 Há duas versões sobre a batalha denominada de Sagunto. A de Apiano, B. C., I, 110, e a de Plutarco, Sertório, 21. Embora diferentes, ambas apontam para o ataque a Metelo, que, segundo Plutarco, lutou com grande coragem e saiu ferido por uma lançada, ao passo que Apiano aponta para o facto de ter sido o próprio Pompeio a defender Metelo.

177 Obsequente, 58.

178 Julgamos que Resende se refere sobretudo à guarda celtibérica de que se fazia acompanhar Sertório, que assim dava azo a certa animosidade por parte dos seus seguidores romanos. É pelo menos o que se lê em Apiano, B.C., I, 112, onde são referidos Celtiberos, mas não Lusitanos. De resto, quanto à permanência de Sertório na Lusitânia e da defesa das cidades lusitanas contra os generais romanos, como Metelo, o mesmo Apiano, B.C., I, 108 segs., fornece também alguns pormenores.

179 Ver o livro IV dedicado efectivamente à descrição de cidades, entre as quais falta, contudo, a descrição de Évora. Esta foi consubstanciada no opúsculo em português, História da antiguidade da Cidade de Évora, publicada três vezes depois da edição de 1553 de Évora, que é a primeira, nomeadamente em 1576, em 1783 (Lisboa, Of. de Simão Thaddeo Ferreira), e finalmente por José Pereira Tavares, em André de Resende, Obras Portuguesas, Lisboa, s. d. (Sá da Costa; 1963). O opúsculo em vernáculo sobre Évora aparecerá traduzido para latim na edição de Coimbra, 1790, vol. I, pp. 295-392. O editor de Resende, Diogo Mendes de Vasconcelos, publicará também como livro V, da primeira edição do De antiquitatibus Lusitaniae, o De eborensi municipio traduzido para vernáculo por Bento José Farinha na Colleçam das Antiguidades de Évora, Lisboa, 1785, sob o título Livro V do Município Eborense, 37-111. Quanto ao monumento aos deuses Lares dedicado por Júnia Donace e pelos libertos de Sertório (C. I. L, II, 12*), trata-se evidentemente de um documento pseudo-epigráfico. Esta inscrição aparece referida na História da antiguidade da Cidade de Évora (1. ${ }^{\mathrm{a}}$ ed. 1576), 3. ${ }^{\mathrm{a}}$ ed. Lisboa, 1783, cap. III, fl. b ij v.; p. 17 da ed. Pereira Tavares; também Diogo Mendes de Vasconcelos a insere no livro V que acrescentou ao De antiquitatibus Lusitaniae, p. 15 (Évora, 1593).

180 Plutarco, Sertório, 23.

181 Vel. Pat., II, 30, 1.

182 Am. Marc., XXVI, 9, 9.

183 Orósio, Hist. adu. nat., V, 23, 14.

184 Val. Máx., Fact. dict. memor. VII, 6, ext. 3. 
185 C. I. L., I, l, Acta Triumphalia, p. 178, ano 683 da fundação de Roma, 29 de Dezembro. Não chegou até nós, contudo, a inscrição. O facto é relatado pelos historiadores.

186 Cíc., De leg. agr. contra P. Seru. Rullum, II, 30.

187 Ver p. 150.

188 Suet., César, 54.

189 Catulo, 26, 18-19.

190 César, B. C., I, 43-44

191 Val. Máx., Fact. dict. memor., IX, 2, rom. 4: trata-se efectivamente de Munatius Flaccus e dos Ateguenses, como pretende Resende quando um pouco à frente propõe a emenda ao códice de Valério.

192 Bell. Hisp., 19, 4 .

193 Díon Cássio, XLIII, 33; Plutarco, Cato, Minor, IX, 1; XXXVI, 3, etc. Chama-lhe somente

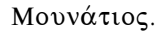

194 Plutarco, Cato Minor, XLVIII, 4 segs. Trata-se de Titus Munatius Plancus.

195 Plutarco, Pompeio, LV, 5: trata-se igualmente de Titus Munatius Plancus e não Flaccus. Cf. R. E., s. v. Munatius, ou mesmo o Kl. Pauly.

196 Hor., O., I, 7. É de facto dedicada ad Munatium Plancum.

197 Cf. a ed. de Veneza, 1558 (n. 64), nos Comentários aos Fastos, p. 283, repetindo-se o mesmo no De nominibus, p. 77. O mesmo se encontra no comentário de Cigonius (n. 64), pp. 324 B-C-D e 325-A.

198 C. I. L., X, 1, 6087: Resende transmite-nos uma leitura correcta da inscrição de Gaeta na Campânia, muito embora não reproduza com total fidelidade a disposição das palavras nas linhas que lhes competem. É pormenor contudo insignificante pois em nada altera o sentido do texto.

Os Septemuiri epulonum constituíam um colégio de sacerdotes encarregados de organizar festins dedicados a Júpiter e a outros deuses. Ver $R$. E., s. v. Septemuiri epulonum. Lugduno é Lião e a Ráurica situava-se nas imediações de Basileia.

199 No passo citado na n. 193 Díon Cássio não refere efectivamente o que lemos em Valério Máximo. Também o autor do Bell. Hisp. (n. 192) é omisso a esse respeito, referindo-se apenas à atitude de Munácio para com Pompeio.

200 César, B. C., I, 44.

201 Trata-se, segundo A. Schulten, F. H. A., V, p. 133, efectivamente de Cato, que é nome de origem céltica, como se pode averiguar pela existência de nomes como Cattos e de outros em que Catu aparece como parte de nome: Catuuolcus, p. ex. O passo em que disto se trata pertence ao Bell. Hisp., 17 segs.

202 Depois da batalha de Munda, em que Sexto Pompeio ficou ferido, acabou este por se refugiar em Carteia, mas os habitantes desta dividiram-se em duas facções, uma que o queria entregar a César e outra que o queria preservar. De qualquer forma foi Pompeio forçado a fugir em embarcações. Segundo Apiano, B. C., II, 15, 105, ao entrar para um pequeno barco prendeu o pé num cabo, e o homem que o tentou libertar, ao pretender cortar o cabo, cortou sim a palma do pé do fugitivo Pompeio. Diz Apiano que mesmo assim ele se fez ao mar e recebeu tratamento em determinado lugar. Do texto de Resende parece implicar-se que foi ele próprio que tentou libertar o pé com o gládio. Apiano, porém, diz-nos que foi alguém que o fez.

203 Bell. Hisp., 39, 1: "Pompeio ut supra demonstrauimus, saucius et intorto talo...".

${ }^{204}$ A exposição pormenorizada destes eventos pode seguir-se tanto em Apiano como no Bellum Hispaniense. O fim de Sexto Pompeio é contado por Apiano no passo citado na n. 202.

205 Bell. Hisp., 40, 1 segs. A opinião de Resende é correcta quanto ao estado do texto chegado até nós. Refere-se inclusivamente às hipóteses de autoria desta obra anónima. Quanto a miles Caesaris, possível autor deste comentário e à sua relação com o seu general, ver $\mathrm{H}$. Drexler, "Parerga Caesariana», Hermes, LXX (1935), 203-234.

206 Pela descrição de Resende é fácil entrever que o humanista toma o partido de Pompeio, na medida em que a Sexto Pompeio acabaram por ficar ligados muitos Lusitanos. Isso era já razão suficiente para a sua história quase parenética. Quanto ao nome de Carrinas, em Apiano, 


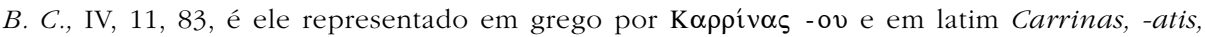
ver s. v. C. Carrinas, R. E., III, 1612, que em 45 chegou à Hispânia como legado de César contra Sexto Pompeio. Na tradução utilizamos o nome Carrinas e não Carrinate, como propõe F. Rebelo Gonçalves no seu Vocabulário da Língua Portuguesa, Coimbra, 1966, por ser mais próximo do nome latino e por semelhança com nomes da mesma declinação, como é o caso de Mecenas.

207 Apiano, B. C., IV, 88 segs., descreve as tropas de que dispunha Bruto na costa da Trácia,

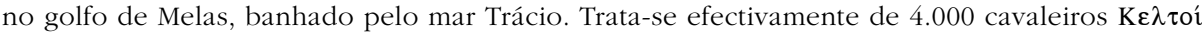
e lusitanos. Se este nome não levanta qualquer dúvida quanto à sua tradução, o mesmo não pode dizer-se com os Celtas que em Apiano significam Gauleses e não Celtiberos, como possivelmente Resende gostaria que fosse. De qualquer forma, é inegável a presença lusitana em regiões tão longínquas entre as tropas que se batiam, na parte republicana que ia perder, contra os Cesarianos.

208 A utilização do texto de Apiano por André de Resende é bastante criteriosa e foi feita, como o autor nos deu a entender, por uma tradução. Em Portugal, na B. N. L., existem dois incunábulos (incompletos) da ed. latina de Apiano, Historia Romana, de Petrus Candidus Decembrius, publicada em Veneza em 1472. Ver Biblioteca Nacional, Catálogo de Incunábulos, intr., org. e índices por Maria Valentina C. A. Sul Mendes, Lisboa, 1988, n. ${ }^{\text {os }} 121$, 122; a edição humanística do texto grego apareceu posteriormente em 1551 de autoria de C. Étienne e a tradução latina virá três anos depois, em 1554, e será de Sigism. Gelenius.

209 Efectivamente, Sexto Pompeio virá a morrer na Ásia em 35 a. C.

210 Orósio, Hist. adu. pag., VI, 16, 7 segs.

211 Foi efectivamente morto em Mitilene por ordem de Marco de Tício. Ver Apiano, Civ., $\mathrm{V}, 144$

212 Orósio, Hist. adu. pag., VI, 19 segs.

213 Asínio Folião, em Cíc., Ep. ad familiares, XXXIII, 3 (ed. L. C. Purser, Oxford)

214 Ver p. 183 ss.

215 Ver p. 73 ss. Como veremos nas n. 216 e 217 seg., a Bética não era dedicada à plebe mas ao senado. Resende não disse, porém, no cap. referido que a Bética fosse atribuída à plebe.

216 Díon Cássio, Hist. Rom., LIII, 12: é o comentário de Díon Cássio ao discurso proferido por Augusto diante do senado (3-11), em que o futuro imperador dá a entender com extrema hipocrisia que pretendia devolver o poder, embora este lhe pertencesse completamente e sem contestação, ao próprio senado. Por isso, só se atribui tudo o que pressupunha trabalho e risco, deixando o resto aos senadores. Diz o historiador: "Desta forma fazia ratificar a sua liderança pelo senado assim como pelo povo. Mas como além disso desejava ser considerado democrático... declarava que não governaria pessoalmente todas as províncias... e devolveu assim ao senado as províncias mais fracas, devido a serem pacíficas e não estarem em perigo de guerra, enquanto para si reservou as províncias mais poderosas, alegando que eram inseguras e em precária situação... Revelava, assim, a intenção de que o senado pudesse aproveitar dos aspectos mais agradáveis do império, enquanto ele ficava com os perigos e trabalhos, mas a finalidade real era a de que desta forma os senadores ficassem desarmados e incapazes de entrar em combate, enquanto seria ele o único a ter armas e soldados». Díon Cássio enumera então as províncias que passaram a pertencer a César Augusto, entre as quais «o que sobrava da Hispânia, ou seja a Tarraconense e a Lusitânia».

217 Ver p. 87 (Vetões). Sobre a divisão administrativa da Hispânia, ver a parte sobre a "romanização", inserta em A. Tovar e J. M. Blazquez, Hist. Hisp. Rom., p. 122 e segs., e correspondente bibliografia, como também os vols. V, VIII e IX das $F$. H. A., respectivamente da autoria de A. Schulten e de R. Grasse, e J. Alarcão, O Domínio Romano em Portugal, Lisboa, 1988, sobretudo o cap. II, As Divisões Administrativas, p. 31 ss, que refere Díon Cássio e a atribuição da Bética ao senado e não à plebe, como diz Resende. Efectivamente, tal como lemos, passou-se a falar no plural das Hispaniae no primeiro quartel do séc. V d. C., com as mencionadas divisões administrativas divididas em dois grupos: $10^{\circ}-$ as que eram governadas por um consularis, ou seja, por alguém que desempenhou no passado a função de cônsul; $2 .^{\circ}$ - as que estavam sob o mando de um praeses, ou seja, de um governador nomeado para 
o efeito. Ver R. Grosse, F. H. A., IX (Fuentes de la época visigoda y bizantina), 20 ss.; K. F. Stroheker, "Spanien im Spaetroemischen Reich (284-475)", Archivo Español de Archeología, 4547 (1972-74), 587 ss. Resende prepara-nos com a sua descrição para as informações que nos reserva sobre os Godos.

218 Sobre esta transferência das dignidades e cargos para que aponta Resende com uma evidente preocupação de continuidade histórica, ver Joel Serrão, s. vv. conde, duque e marquês no Dic. Hist. Port. A fonte mais autorizada sobre o assunto ainda é Gama Barros, Hist. da Administração Pública em Portugal nos sécs. XII a XV, ed. por T. de Sousa Soares, 11 vols., Lisboa, Liv. Sá da Costa, 1945-1954. Ver o passo das F. H. A. de R. Grosse citado na n. anterior.

219 Ver R. E., s. v. Langobardi.

220 Ver J. P. Machado, s. v. marca, Dic. Etim. Líng. Port.

221 Tác., An., XIII, 46, 3; trata-se de erro de A. Resende ou do seu editor quanto à citação do livro dos Anais. A outra referência a Otão e à Lusitânia encontra-se nas Hist., I, 13, 3, em que Tácito se refere à maneira eficiente como Otão geriu a Lusitânia. Quanto ao livro 17 não existe ele nas edições de que normalmente se dispõe. Os Anais são constituídos por 16 livros.

222 Suet., Otão, 3, 3-4.

223 Ibidem.

${ }^{224}$ Ver, p. ex., Plut., Galba, 22, 8. Cf. a recolha de passos referentes à história da Hispânia, por R. Grosse, F. H. A., VIII, p. 14 e segs.

225 Dá a impressão de que Resende leu depressa de mais o texto de Tác., Hist., I, 70, em que lemos "Caecina... dum sententiae Vitellii certior fieret... laetum ex Italia nuntium accipit, alam Silanam, circa Padum, agentem, sacramento Vitellii acessisse... [muito depois]... Et, quia praesidio alae unius latissima pars Italiae defendi nequibat, praemissis Gallorum Lusitanorum Britanorum cohortibus et Germanorum uexillis, cum ala Petrina, ipse paullulum cunctatus...». Não é pois claro que tenham prestado juramento.

226 In P. Cornelium Tacitum annotationes B. Rhenani, Alciati ac Beroaldi. Eiusdem B. Rhenani thesaurus constructionum, locutionum et uocum Tacito Solemnium, Lugduni apud Seb. Gryphium, 1542, p. 210, refere efectivamente Calpurnius Fabatus, sem que contudo Nouocomensis lhe seja aposto, como pretende A. Resende. A existência e a leitura da inscrição são aliás confirmadas e aceites por Th. Mommsen, C. I. L., V, 5267. Também se confirma o título de praef(ectus) cohortis VII Lusit(anorum). O praenomen é Gaius.

227 C. Calpurnius Fabatus é efectivamente natural de Como e prosocer (avô da mulher) de Plínio-o-Moço (Epist., 5, 11, 2); Kl. Pauly, s. v. Calpurnius, n. ${ }^{\circ} 7$.

228 Não se trata de Sorranal, mas, diz-nos Th. Mommsen, de Serravalle (lat. Libarna) perto da Dertona, entre Génova e Milão, C. I. L., V, 2, 7425. O texto da inscrição condiz com a leitura de Resende, que é correctíssima, só que a disposição das palavras da inscrição em causa não coincide: Q. Attio. T. F. / Maec. Prisco/Aed. Vir. Quinq. / Flam. Aug. Pontif/Praef. Fabr. Praef. Coh. I / Hispanorum. Et. Coh. I / Lusitanor., etc. Quanto à divisão das palavras, confessa o próprio Mommsen ter seguido a leitura de Resende.

229 L. Andr. Resendii, Pro Colonia Pacensi, Ad. Ioannem Vasaeum virum doctissimum, da ed. de Coimbra, 1790, vol. II, sobretudo depois da p. 18.

230 Juan Ginés de Sepúlveda (ver Nicolau António, Bibl. Hisp. N., s. v. Ioannes Genesius Sepulveda) deixou efectivamente nos seus escritos referências à identificação de Badajoz com Pax Augusta, que era confundida com a Pax Iulia que Resende, e bem, identificava com Beja: Ioannis Genesii Sepulvedae Cordubensis... Opera... omnia, Colónia, 1602; nos Epistolarum libri septem, pp. 168-170, está uma carta (XXXIV) de 1543 enviada a Filipe II de Espanha em que se refere Carcabosus (p. 168) a vinte e cinco léguas de Mérida, e mais adiante se diz claramente: "Hanc enim urbem, quae nunca Badajoz corrupto vocabulo nominatur, olim fuisse Pacem Augustam, consensus et eruditorum». "Esta cidade, que hoje em dia é denominada com a palavra deturpada de Badajoz, foi, na opinião consensual dos eruditos, a antiga Pax Augusta". Ver Angel Losada, J. G. de Sepúlveda através de su "Epistolario” y nuevos documentos, Madrid, 1949, cap. XVII, Sepúlveda, Arqueólogo, p. 298 ss.; E. Viejo Otero, Miscelânea, "CIL II 4658 en 
una cana inédita de Juan Ginés de Sepúlveda", Emérita X (1942), 345-348; V. Pereira Soares, "Uma carta de André de Resende reconstituída», Humanitas, XXXIX-XL (1987-88), p. 220 ss.

231 Ver p. 183 ss. A verdade é que não chegou a comentar, uma vez que as cidades incluídas no livro IV ficaram incompletas, como diz Mendes de Vasconcelos na Vida de Resende.

232 Não chega a tratar deste assunto com o pormenor que promete.

233 Plínio, H. N., IX, 9. R. M. Rosado Fernandes, "O Vento, as Éguas da Lusitânia e os Autores Gregos e Latinos", Euphrosyne, XII (1983-84), p. 56.

234 Eis mais uma promessa que Resende não virá a cumprir, pelo menos como nos dá a entender.

235 Quanto a estas divisões administrativas, ver L. García Iglesias, «El Guadiana y los limites comunes de Bélica y Lusitania”, H. Ant., II (1972), pp. 165-177; Albertini, Les divisions administratives de l'Espagne romaine, Paris, 1923, pp. 102-103, cf. n. 217.

236 S. Engrácia (Encratis) foi martirizada, em 304 da nossa era, na perseguição movida contra os Cristãos por Diocleciano. O seu martírio foi cantado por Prudêncio no Peristephanon, Hino 4, 110-140, que é a única fonte que nos resta sobre a santa, cujo pai não se conhece, apesar do que diz Resende.

237 Castinaldo era senhor de Nabância, cidade inventada pelos hagiólogos eruditos (ver n. 139 do Livro II). Foi contemporâneo de S. Iria e aparece citado no ofício do Breviário de $S$. Simão de Junqueira (1514) e no Breviário de Santa Cruz (1531), cujos textos latinos referentes a S. Iria nos são dados por M. de Oliveira no artigo "Santa Iria de Santarém», citado na n. 138 do livro II.

238 Vitichindus, ou melhor, Windichindus, como lemos em Sigberti de script. eccl., 129 (ed. Miraeus, p. 149): "Windichindus mon. Corbeiaei Saxonicae scripsit historiam Saxonum usque ad mortem primi Othonis imperatoris...» (apud M. Manitius, Gesch. d. lat. Literatur des Mittelalters, vol. I, Munique, 1911 (1974), p. 714 ss. Trata-se de Windekind von Korvei. A sua obra histórica intitula-se Windukindi monachi Corbeiensis Rerum gestarum Saxonicarum libri III, ed. P. Hirsch e Hans-Everhard Lohmann, M. G. H., Munique, 1935 (1977). Aparece também nos M. G. H., Scriptores, III, ed. G. Waitz, p. 408 ss. O passo citado por A. Resende encontra-se em I, 18 (p. 425), mas com a forma Gotha, ainda que também esteja registado no aparato critico Gothus. Windukind diz: "A proprio autem duce, nomine Gotha, Gothi appelati sunt". Quanto aos Godos, ver S. Teillet, Des Goths à la nation Gothique. Les origines de l'idée de nation en Occident du $V$ au VII siècle, Paris, 1984.

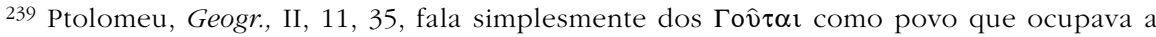
parte Sul da Escândia. A forma mantém-se em Ostrogothae e Vesegothae (ver n. 241).

240 Procópio, Hist. das Guerras, III, II (Guerra dos Vândalos), 2. Го $\tau \theta \imath \kappa \dot{\alpha} \varepsilon \dot{\varepsilon} v \eta \pi \mathrm{o} \lambda \lambda \dot{\alpha} \mu \dot{\varepsilon} v$

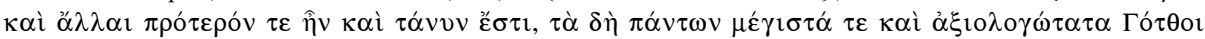

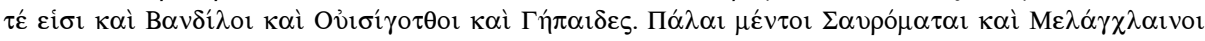

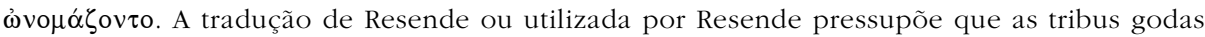
tenham sido mais diferentes outrora do que agora, o que não corresponde ao texto grego.

241 lordanes, Get., XIV, 82, p. 878, 7 (Mommsen): «id est orientales, dicti sunt Ostrogothae, residui uero Vesegothae, id est a parte occidua». Resende emprega Vesogothae.

242 De facto a forma do v.a.a. é Oster que linguistas tentaram relacionar com auster lat. "vento sul». Ver Ernout-Meillet, Dict. Etim. L. Lat., s. v. auster.

243 Einhardi Vita Karoli Magni, Post G. H. Pertz recensuit G. Waitz. Trata-se da obra de Einhard (Eginardo) publicada nos Monumenta Germaniae Histórica, Scriptores, II, pp. 426-463. É reproduzido o texto latino na edição bilingue de Evelyn Scherabon Firchow, Einhard, Vita Karoli Magni, Reclam, Estugarda, s. d. (1968), parágrafo 29 (p. 54): "Ventis vero hoc modo nomina inposuit, ut subsolanum vocaret ostroniuuint, eurum ostsundroni, euroaustrum sundostroni, austrum sundroni, austroafricum sunduuestroni, africum uuestsundroni, zefyrum uuestroni, chorum uuestnordroni, circium norduuestroni, septentrionem nordroni, aquilonem nordostroni, vulturnum ostnordroni” e depois publicado separadamente por Oswald HolderEgger, Hannover-Leipzig, 1911, reed. 1965.

${ }^{244}$ No Dicionário Etimológico da Língua Portuguesa, Lisboa, nos artigos Noroeste, Sudoeste, Sudeste, etc., J. P. Machado, embora dê o testemunho de livros de marinharia, não indica como 
origem dos nomes de ventos utilizados pelos marinheiros portugueses a nomenclatura lançada no tempo de Carlos Magno.

245 Iordanes, Get., V, 42, p. 64, 22 (Mommsen). A citação está correcta, só que as formas de etnónimos usadas por Iordanes são em -gothae e não -gothi, como pretende o nosso humanista.

246 É na obra de Iordanes que Resende se inspira, pois nela se estudam as genealogias diversas das estirpes godas. Baltha está certamente relacionado com o inglês bold "ousado" e o al. bald "em breve", que estão relacionados com o Germ. *balthaz e o Gót. Balthei "coragem".

${ }^{247}$ Iordanes, Get., XXXVI-XXXVII, p. 108-109 (Mommsen) relata esta batalha e chama ao chefe godo Theodoridus. Gregório de Tours, Hist. Francorum, III, 30, refere-se a Theudis que foi rei dos Godos na Hispânia.

248 Ver R. E., Erste Reine, Halbband 2, 1718-1719, s. v. Amali (da palavra alemã amal "incansável, esforçado»); zweite Reihe, Halband 10, 1746-1771, s. v. Theoderich $d$. Gr., Ostgotenkoenig, ca. 455 bis 526 n. Chr. zweite Reihe, Halbband 19, s. v. Zenon, Kaiser (474/475 e 476-491 d. C.), 149-213.

249 Procópio, Hist. das Guerras, III, III (Guerra dos Vândalos), 1:... 'A $\lambda \alpha$ vò̀ ऽ... Гo $\tau \theta$ «òv

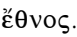

${ }^{250}$ Am. Marc., XXIII, 5, 16: «Namque ut Luculum transeam uel Pompeium, qui per Albanos et Massagetas, quos Alanos nunc apellamus, etc.». No entanto, os Massagetas e os Alanos são distintos, conforme lemos em Claud., in Ruf., I, 310 segs.

251 Honório Augusto e Vália são nomeados por Orósio, Hist. adu. pag., VII, 43, 10, 15 segs.

$252 \mathrm{O}$ "conde» Constâncio é assim denominado por Orósio, Hist. adu. pag., VII, 42, 1, segs. Aqui se narram os factos que Resende nos apresenta.

253 Ver M. G. H., Auctores Antiquissimi, Chronica Minora, I, 655; (Hyda Lemici) II, 30, 188; 35, 2463; rei Adoce e não Atace (como escreve Resende), in II, 19, 68 "Alani, qui Vandalis et Suevis potentabantur, adeo caesi sunt a Gothis, ut extincto Adace rege ipsorum pauci, qui superfuerant, ... se patrocinio subiugarent”; não há, contudo, qualquer referência a Lisboa, neste passo, mas sim em II, 30, 188, que refere a presença dos Suevos em Lisboa, como também em 35, 246; Isid., Hist. Goth., II, 276, 12 ss. (o mesmo assunto).

254 Orósio, Hist. adu. pag., VII, 43, 14.

255 A discussão dos vários nomes a dar às diversas nações é extremamente importante no texto de Orósio, Hist. adu. pag., VII, 43, 5 segs., na medida em que nele aparecem pela primeira vez nomes como Romania e Gotbia. Quanto à complicada geografia de Orósio, ver Y. Janvier, La Géographie d'Orose, Paris, 1982.

256 Sebastianus faz parte do "catalogus tyrannorum" apresentado por Orósio, Hist. adu. pag., VII, 42, 6.

257 Isid., Hist. Sueborum, M. G. H., Chronica Minora, XI, 2, 92, p. 303 (Mommsen).

258 A descrição dos territórios germânicos faz lembrar as palavras de Tácito, De Germania, 2: “informem terris, asperam coelo, tristem culto adspectuque...", muito embora mais adiante informe quanto à fertilidade (5): "satis ferax: frugiferarum arborum inpatiens: pecorum fecunda, sed plerumque inprocera...”.

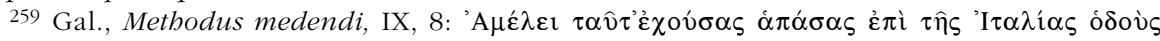

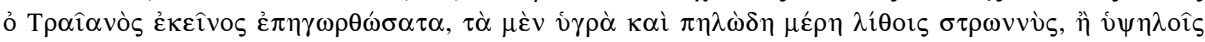

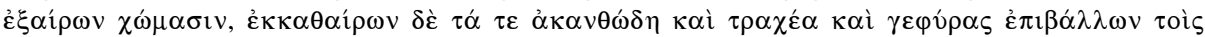
$\delta v \sigma \pi$ ópoıৎ $\tau \hat{\omega} v \pi$ o $\tau \alpha \mu \hat{\omega} v$. "Era assim que se apresentavam todas as estradas em Itália e foi Trajano que as reconstruiu, etc. ...».

260 Lucr., De rer. nat., I, 315-316.

261 Estradas reais, que eram as estradas principais e construídas por vezes sobre as antigas vias romanas. Quanto à feitura das vias romanas, ver R. Chevalier, Les voies romaines, Paris, 1972, entre outros, bem como, quanto às peculiaridades estereotipadas a que se refere Resende, cf. J. M. Roldán Hervás, Itineraria Hispana, Fuentes antiquas para el estudio de las vias romanas en la Península Ibérica, supl. de Historia Antiqua, Madrid, 1975, sobretudo as ilustrações XIVXXI, no fim. 
262 Sid. Apol., Carmina, XXIV, 5-7.

263 Virg., En., V, 273.

264 A. de Resende vai referir os três itinerários de Antonino Pio, mas o texto apresentado difere profundamente do texto na sua versão actualizada. Basta confrontar, neste primeiro caso, com o itinerário transmitido nos Itineraria Romana, vol. prius, Itineraria Antonini Augusti et Burdigalense, ed. O. Cuntz, Lípsia, 1929, 416, 4-5; 417, 1-5, p. 64, para vermos que muito difere, desde a distância total que são 161 mil passos e não 204 mil, bem como a sucessão das diferentes etapas e respectivas mansiones, cujos nomes não conferem. Temos assim no texto actual: Item ab Olisipone Emeritam m. p. CLXI, sic: Aquabona m. p. XII; Catobrica m. p. XII; Caeciliana m. p. VIII; Malateca m. p. XXVI; Salacia m. p. XII; Ebora m. p. XLIIII; Ad Atrum flumen m. p. VIII; Dipone m. p. XII; Euandriana m. p. XVII; Emerita m. p. VIII. Cf. J. M. Roldán Hervás, Itin. Hisp., 63-64. Ainda se podem consultar M. Sáa, As grandes vias da Lusitânia, O Itinerário de Antonino Pio, Lisboa, 1956-64; G. Árias, Portugal a la vista, Mil. Extr., 10, 1965, e Notas complementarias sobre las vias antoninianas de Portugal, Mil. Extr., 13, 1967. Segundo Roldán, a distância total de 161 milhas é excessivamente curta e as explicações até agora encontradas insatisfatórias. A verdade é que a distância apresentada por Resende está mais perto da verdade e até é possível que seja uma das habituais correcções que o humanista introduz nos textos antigos. Pode também provir do texto que utilizou. É de extrema utilidade o comentário de J. Alarcão, Portugal Romano, Lisboa, 1975, pp. 68-74, aos diversos lugares que figuram neste itinerário, visto que os analisa com excelente conhecimento arqueológico.

265 Não há a menor dúvida de que na Herdade do Pinheiro, perfeitamente localizada por A. de Resende, se encontram restos romanos importantes, conforme se lê em J. Alarcão, $o b$. cit., p. 70 e 135 .

266 C. I. L., II, 8* (Pinheria, segundo Huebner). Trata-se, por conseguinte, de uma inscrição possivelmente inventada, como é bastante usual em Resende.

267 C. I. L., II, 434* (Alcácer-Évora). Também parece inventada.

268 C. I. L., II, 433* (Évora-Tabuleiros). Na mesma situação que as anteriores.

269 Trata-se do opúsculo intitulado Pro sanctis Christi Martyribus Vincentio Olisiponensi patrono, Vincentio, Sabina, et Christhetide eborensibus ciuibus et ad quaedam alia responsio, ad Bartholomeum Kebedium, sanctae Toletanae ecclesiae sacerdotem, uirum doctissimum, publicado na ed. de Coimbra, 1790, vol. II, pp. 33-118. O passo referido encontra-se na p. 53 e segs. e foi publicado por V. Soares Pereira, A. Resende, Carta a Bartolomeu Quevedo, Coimbra, 1988 , p. 87 ss. e n. 54.

${ }^{270}$ C. I. L., II, 112 (Évora-Tourega), conforme diz Huebner, Cenáculo afirmava que se encontrava a "duas léguas a sudoeste de Évora». Esta inscrição, por várias vezes estudada devido à importância de que se reveste, no que respeita a informações regionais, é analisada pormenorizadamente por José d'Encarnação, Inscrições Romanas do Conventos Pacensis, Coimbra, 1984, n. ${ }^{\circ} 382$, pp. 456-458.

${ }^{271}$ C. I. L., II, 436*: Huebner afirma a respeito desta inscrição: "Quamquam genuini esse possunt... tamen propter Eborae, Resendii patriae, mentionem aliaque iam mihi suspecti sunt". José d'Encarnação, ob. cit., n. ${ }^{\circ}$ 661, p. 720, muito embora indique que o actual paradeiro é desconhecido, nem por isso a considera forjada.

${ }^{272}$ C. I. L., II, 435*. Huebner, só porque é recolhida por Resende e porque se refere a Évora, como lemos na frase citada na n. anterior, considera-a suspeita. Segundo José d'Encarnação, ob. cit., n. ${ }^{\circ} 663$, p. 722, não há razão para tanta suspeita, na medida em que os dados são correctos, excepto no que respeita à distância entre Évora e Barbacena, que é bastante mais do que os $32,56 \mathrm{~km}$ indicados, muito embora o miliário tenha eventualmente desaparecido.

273 C. I. L, II, 432*. O juízo de Huebner segue implacável: "Quamquam fortasse genuina, suspecta tamen utpote a tali auctore solo relata». O caso não é, contudo, estudado no livro de Encarnação.

${ }^{274}$ Itin. Anton. Pii, 425, 6, 426, 1-6, 427, 1-3, p. 66; Roldán Hervás, Itin. Hisp., p. 77-78: no texto actual Item de Esuri Pace Iulia. A ordem das mansiones corresponde ao texto de Resende, bem como as distâncias, só se exceptuando a distância global: em Resende CCLVII, muito embora a distância indicada de CCLXVII em nada resolva o problema da distância, que é muito maior, na medida em que o itinerário serpenteia pelo Sul de Portugal, pois não só passa por 
Alcácer do Sal como por Aroche, etc. Resende e os AA. modernos estão conscientes da falta de racionalidade do caminho traçado, o que leva a pensar que este itinerário até possa pressupor três vias. Ver Roldán Hervás, ob. cit., p. 79. Quanto ao topónimo Esuris, também aparece na forma Besuris (Baesuris), tal como o adopta J. Alarcão, Port. Rom., p. 80, possivelmente baseado na forma do Anónimo de Ravena, IV, 43, 9. A povoação de Fines, também segundo J. Alarcão, ob. cit., p. 83, talvez se possa identificar com as Cortes de Messangil, na freguesia de Vale de Vargo.

275 Itin. Anton. Pii., 431, 4-7, p. 66; Roldán Hervás, Itin. Hisp., p. 78-79. Segundo este A., a via não levanta problemas pois até a distância coincide, tal como também reconhece Resende. Há disparidade no primeiro número: em Resende LXVI, ao passo que na versão actual são LXXVI.

276 Itin. Anton. Pii., 418, 6, p. 64; Roldán Hervás, Itin. Hisp., p. 64-65, aponta com razão que o número de milhas conservado, ou seja de XVI, deve resultar do facto de se ter perdido o número C, o que perfaria a distância aproximada e aceitável de 116 milhas entre Alcácer e Faro, ou sejam, 116 x 1,480 kms = 171,680 kms.

277 Trata-se do opúsculo já citado na n. 269. O marco é discutido na p. 81 e segs. na ed. de Coimbra e p. 117 na ed. de V. Soares Pereira.

${ }^{278}$ C. I. L., II, $17^{*}$ (Oriola). José d'Encarnação, Ob. cit., p. 739, inclina-se, com Huebner, para considerar como "fortemente suspeito" um teminus inter Pacenses et Eborenses, definido curante P. Datiano v. p. praeside. Não anda longe, contudo, de admitir que o limite do terminus não estaria afastado de Oriola, na medida em que aí se situa o santuário de N. ${ }^{a}$ Sr. ${ }^{a}$ de Aires, considerado recentemente como a fronteira sul do território Eborense.

279 Itin. Anton. Pii., 418, 7-419, 6, p. 64; J. M. Roldán Hervás, Itin. Hisp., p. 61-66; J. Alarcão, Port. Rom., p. 74-75, que apresenta excelente comentário, pois toma em conta os vestígios arqueológicos. É evidente que a comparação do texto recolhido por Resende com o das edições mais modernas apresenta diferenças consideráveis na distância total, mas quanto a esta e a outras permanecem as dúvidas que o próprio humanista já levanta.

280 Via suburipontana, ou seja o caminho por Ponte de Sor, muito embora a mansio seja denominada Matusaro e a identificação possa levantar dúvidas. Ver Roldán Hervás, Itin. Hisp., p. 248. Quanto a Subur, étimo de Sor, não é ele considerado por J. P. Machado, Dic. Onom. Etim., s. v. Sor, que o faz derivar de Saurium; R. M. Rosado Fernandes, "A etimologia e sua finalidade em André de Resende, De ant. Lusit.», Homenagem J. Piel, Tuebingen, 1988, p. 248.

281 Itin. Anton. Pii., 419, 7-420, 7, p. 64; J. M. Roldán Hervás, Itin. Hisp., p. 66-67; J. Alcarcão, Port. Rom., p. 75-77, apresenta a discussão actualizada desta alternativa, sobre a qual subsistem dúvidas, ainda que não haja variação quanto à distância total entre Olisipo e Emerita, entre o texto humanista e o actual.

282 C. I. L, II, 439* (Alpiarça): como vemos, Huebner não o considera.

283 C. I. L., II, 4634.

${ }^{284}$ C. I. L., II, 4634: diz Huebner: "pro urbis sine dubio orbis corrigendum»; J. d'Encarnação, Inscr. Rom. Conv. Pac., p. 719, também afirma que "o texto não nos merece confiança", não só devido à identificação do imperador como também devido ao título em que figura restitutor, ao passo que o mais comum era pacator orbis.

285 C. I. L., II, 4636; J. d'Encarnação, Inscr. Rom. Conv. Pac., n. ${ }^{\circ}$ 666, compara com a inscr. cit. na nota seg., e aponta que a única discrepância reside na omissão do praenomen Marcus

${ }^{286}$ C. I. L., II, 4635; J. d'Encarnação, Inscr. Rom. Conv. Pac., n. ${ }^{\circ}$ 665. Pertence este miliário e o anterior à via Olisipo-Emerita por Scallabis e, segundo Encarnação, dataria dos finais de 275 d. C.

287 C. I. L., II, 4637; J. d'Encarnação, Inscr. Rom. Conv. Pac., n. 678: inscrição do termo de Almeirim. Segundo Encarnação, visto tratar-se de um miliário reconstituído, é possível que se refira a um imperador do séc. IV.

288 C. I. L., II, 441*; J. d'Encarnação, Inscr. Rom. Conv. Pac., n. ${ }^{\circ} 664$, p. 723, n. 1: J. d'Encarnação identifica com verosimilhança esta inscrição com o miliário encontrado na Herdade da Torre do Curvo, S. Aleixo, Monforte e hoje no Museu de Elvas, recusando assim 
a atitude de Huebner que não aceita a sua autenticidade, uma vez que a descoberta epigráfica se tinha ficado a dever exclusivamente a Resende.

\section{LIVRO QUARTO}

${ }^{1}$ Livro I, p. 106 ss.

${ }^{2}$ C. I. L., II, 1023 (Olivença): as inscrições da margem esquerda do Guadiana não são estudadas no livro de J. d'Encarnação visto estarem fora dos limites do conventus pacensis.

3 C. I. L., II, 963. Noua Ciuitas Aruccitana é de facto o nome romano de Moura. Ver J. Alarcão, Port. Rom., pp. 54, 83; Dom. Rom. Port., pp. 33, 40 fig. 8; A. Tovar, Iber. Landesk., p. 172.

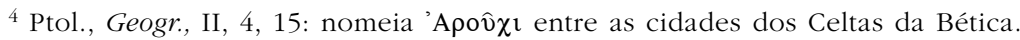

5 Moura é topónimo que provém de Maura, nome visigótico de homem, segundo J. M. Piel, "Os Nomes Germânicos na Toponímia Portuguesa", Bol. Fil. V (1938), pp. 51 e 53; ver Antenor Nascentes, Dic. Et. L. Port., II, s. v. Resende refere-se a óbvia etimologia popular.

${ }^{6}$ C. I. L., II, 101 *. Huebner considera esta descrição forjada. No entanto o praenomen Aurelia e o cognomen Galla encontram-se em inscrições do conventus pacensis. Ver J.

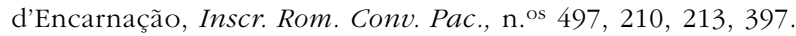

7 Refere-se Resende ao livro intitulado efectivamente Epigrammata antiquae urbis e editado por Iacobus Mazochius no ano de 1521 em Roma. É a terceira edição de uma colectânea epigráfica de Francesco de Albertinis, como lemos na introdução ao C. I. L., VI, l, p. XLVI, auctor $\mathrm{n} .^{\circ} \mathrm{XXI}$. A inscrição indicada por Resende e cuja leitura é bastante conforme ao original está na p. 148 e não 149 da ed. quinhentista e é reproduzida no C. I. L., VI, 24 720: D. M. S. / M. PONTIVS HIIDISTVS / DANAENI COIVGI BIINII / MIIRIINTI ГIICI VIXIT / ANNIS MIICVM / TRIBVS. De notar além do E=II apontado pelo humanista, o $\Gamma=\mathrm{F}$, bem como o nome da esposa que é Danaene e não Dene, e o COIVGI e não COIVNGI do lat. arc., que Resende já refere na carta ao Cardeal D. Afonso (p. 58). Devido às dúvidas levantadas por Huebner ( . $\circ$ 6), que nos parecem justificadas, deve tratar-se aqui de um arcaísmo inventado pelo humanista, uma vez que a inscrição de Moura não parece ser autêntica. Era uma forma de valorizar a antiguidade da Lusitânia.

Quanto à inscrição romana é de notar que a versão de Resende apresenta o dedicante a falar no texto na terceira pessoa fecit, apesar do mecum a seguir, ao passo que no texto real Hedisto fala na primeira pessoa: "Consagrado aos deuses Manes. (Eu) Marco Pôncio Hedisto erigi [este monumento] a Danene minha mulher tão digna, que comigo viveu três anos».

${ }^{8}$ C. I. L., II, 968; quanto a Myrtilis, ver A. Tovar, Iber. Landesk., pp. 170, 189, 210 ss., que dá muita informação sobre este município do Lácio.

9 C. I. L., II, 967.

${ }^{10}$ C. I. L., II, 971.

11 Pompónio Mela, Cor., III, 6 e 7.

12 Tito Lívio, XXI, 35, 8.

13 Estrabão, Geogr., III, 1, 6.

${ }^{14}$ Ptol., Geogr., II, 5, 3.

15 Pro colonia Pacensi, ad Ioannem Vasaeum uirum doctissimum, ed. de Coimbra, vol. II, p. 11 segs.

16 Pompónio Mela, Cor., III, 7; A. Tovar, Iber. Landesk., p. 194.

${ }^{17}$ Itin. Anton. Pii., 431, 4-7, p. 66; J. M. Roldán Hervás, Itin. Hisp., p. 78; J. Alarcão, Port. Rom., p. 81; Dom. Rom. Port., pp. 100-101, fig. 20, p. 93, com alguns pormenores importantes sobre Mértola. A distância de Mértola a Beja coincide efectivamente.

18 Plínio, H. N., IV, 22, 118.

19 Ptolomeu, Geogr., II, 5, 5:

20 Pompónio Mela, Cor., III, 7; ver A. Tovar, Iber. Landesk., p. 205 ss.

21 Plínio, H. N., IV, 22, 118.

22 Ptolomeu, Geogr., II, 5, 3. 
23 Antonino, Itinerário, Itin. Anton. Pii., 426, 1; J. M. Roldán Hervás, Itin. Hisp., p. 78; J. Alarcão, Port. Rom., p. 79 e passim; Dom. Rom. Port., pp. 53, 101.

24 Ver Concilios visigóticos y hispano-romanos, ed. José Vives, Consejo Superior de Investigaciones Científicas, Madrid-Barcelona, 1963. A presença de Bispos de Ossónoba está documentada nos seguintes concílios:

$\begin{array}{llllll}\text { Elvira } & - & \text { c. } 300 & - & \text { Vicente (p. 1) } \\ \text { Saragoça } & - & & 380 & - & \text { Itácio (p. 16) } \\ \text { Toledo III } & - & & 589 & - & \text { Pedro (p. 136) } \\ \text { Toledo VIII } & - & & 653 & - & \text { Saturnino, representado pelo diácono Sagarelo (p. 288) } \\ \text { Mérida } & - & & 666 & - & \text { Exarno (p. 343) } \\ \text { Toledo XIII } & - & & 683 & - & \text { Belito (p. 432) } \\ \text { Toledo XV } & - & & 685 & - & \text { Agrípio, representado pelo abade Gundila (p. 474) } \\ \text { Toledo XVI } & - & & 693 & - & \text { Agrípio, representado pelo presbítero Crisces (p. 521). }\end{array}$

25 É Resende uma das mais importantes fontes para o conhecimento da obra de Rasis. Ver Carolina Michaelis, "André de Resende e a Crónica do Mouro Rasis", Archeólogo Português, XXIV (1920), pp. 177-193. Resende utiliza Rasis também na sua Carta a Bartolomeu Quevedo (Ver V. Soares Pereira, pp. 51-52) bem como na carta a João Vaseu e no seu poema a S. Vicente, e nos caps. XI e XII da sua História da Antiguidade da Cidade de Évora, citações aproveitadas integralmente na edição actualizada que é a de Diego Catalan e Maria Soledad de Andrès, in Fuentes Cronísticas de la Historia de España, vol. III, Madrid, 1974: Crónica del moro Rasis versión del ajbár mulúk al-andalus de abmad ibn mubamed ibn músa al-rási, 889-955; romanizada para el rey don dionís de portugal hacia 1300 por mohamad, alarife y gil pérez, clérigo de don perianes porçel; Cf. J. Mattoso, Identificação de um País, Ensaio sobre as Origens de Portugal, II, Composição, Lisboa, 1985, p. 61; L. F. Lindley Cintra, A Crónica Geral de Espanha, 1344, vol. I, Lisboa, 1951, pp. CCCXXXI-CCCXXXII e CDLXVII-CDLXXII.

26 Trata-se das ruínas de Milreu e de importante villa ali encontrada. J. Alarcão, Port. Rom., p. 112 ss.; Dom. Rom. Port., pp. 53 e 101.

${ }^{27}$ C. I. L., II, 1; J. d'Encarnação, Inscr. Rom. Conv. Pac., n. ${ }^{\circ} 3$. Rui Barreto foi alcaide-mor de Faro, vedor da Fazenda do Algarve, capitão e governador de Azamor. Ver Damião de Gois, Crónica do Felicíssimo Rei Dom Manuel, parte III, cap. XLVIII e parte IV, cap. V; Baquero Moreno, "A Conspiração contra D. João II; O Julgamento do Duque de Bragança", in Arq. Centro Cult. Port., II (1970), pp. 80-87, informação devida ao Prof. S. Tavares de Pinho.

${ }^{28}$ C. I. L., II, 4; J. d'Encarnacão, Inscr. Rom. Conv. Pac., n. ${ }^{\circ} 18$; propõe, na esteira de uma hipótese de Huebner e de uma afirmação de Holder, a leitura do nome Caturisa como Caturica, frequente no Sul da Península.

29 C. I. L., II, 3; J. d'Encarnação, Inscr. Rom. Conv. Pac., n. ${ }^{\circ} 40$.

${ }^{30}$ C. I. L., II, 2 (corrigido em II, 5133); J. d'Encarnação, Inscr. Rom. Conv. Pac., n. ${ }^{\circ} 11$. O nome Eridimus da leitura de Resende deve ser lido Eridanus.

31 Estrabão, Geog., III, 1, 4.

32 Vicentius Leuita et Martyr, ed. Pina Martins, Lisboa, 1981, p. 8, n. ${ }^{\circ} 24$, p. 32, n. ${ }^{\circ}$ do comentário ao poema.

33 Pro sanctis Christi martyribus Vincentio Olisiponensi patrono, etc., ded. a Bartolomeu Quevedo, ed. de Coimbra, 1790, II, p. 41 segs.; ed. V. Soares Pereira, A. Resende, Carta a Bartolomeu Quevedo, Coimbra, 1988, p. 73 ss.

34 Pompónio Mela, Cor., III, 7.

35 Sobre o A., ver Sebastião Tavares de Pinho, "Baptista Mantuano na literatura do século XVI em Portugal», Humanitas, XLI-XLn (1990), pp. 3-29. Como o passo referido por A. R. não estivesse consignado na ed. utilizada por S. T. Pinho, indicou-nos este posteriormente a edição dos Opera Omnia em que o passo aparece referido. Ver BAPTISTAE MANTVANI CAR / MELTTANAE THEOLOGI / AGELARIORVM LIBRI SEX / AD CONSAIVVM [sic] FER / DINANDVM AGE / LARIVM DVCEM / INVICTIS / SIMVM., Fol. GG iij (vv. 16-30) in Vitima Pars ope/ris Baptistae Man/tuani Carmelitae./ Impressum. In Florentissima Lugdunesi Ciuitate,/ Solertia. Stephani de Basignana. Gorgoni Car/melitae. Doctoris. Theologi. In officina./ Bernardi Lescuyer./ 
Regnante Victo/riosissimo Francisco Francorum/ Rege. Christianu orbem./ Moderãte Leone deci/mo. Animarum tu/tissimo Me/dico./ Anno Domini Millesimo quingentesi/mo Decimo sexto. Die vero vigesima/ prima mensis Iulij./ 1516./ Cum gratia et priuilegio usque/ ad quattuor annos.

36 Livro III, p. 139 ss. Ver J. Alarcão, Port. Rom., 25, 79, 82; Dom. Rom. Port., p. 14; A. Tovar, Iber. Landesk., p. 267. Tudo indica que Portus Hannibalis estivesse nas proximidades de Portimão. Quanto à presença de Aníbal na Lusitânia, nada consta a esse respeito, pois a notícia que há é a de que o recrutamento dos habitantes da zona teria sido feito quando da estada do exército de Magão, que em 209 se encontrava no Algarve, bem como da presença do exército de Gisgão que por essa altura desembarcava na foz do Tejo. A. Shulten admite que tivesse sido construído por ordem de Aníbal, F. H. A., III, p. 44 e 127.

37 Tito Lívio, XXI, 21

38 Estrabão, III, 1, 4.

39 Plínio, H. N., IV, 22, 116. Quanto a Lisboa e Alcácer, ver pp. 76-79. Sobre Miróbriga na Lusitânia, ver A. Tovar, Iber. Landesk., 248, 269; a etimologia é contudo discutida na p. 96, a respeito de Miróbriga na Baeturia.

${ }^{40}$ C. I. L., II, 26; J. d'Encarnação, Inscr. Rom. Conv. Pac., n. ${ }^{\circ}$ 154: que completa os dizeres da inscrição, que analisa cuidadosamente. Propõem que o nomen lido por Resende como Cocilicus seja intrepretado como Cocilicius. Quanto a Vulcano, não encontrámos vestígios da estátua na bibliografia actual.

${ }^{41}$ C. I. L., II, 3*: inscrição atestada somente por Resende e considerada falsa por Huebner. Não é estudada por J. d'Encarnação.

42 O nome de Cacém deriva do antropónimo árabe, conforme indicação de Adel Sidarus, Kasim, com o $s$ surdo, que significa "que divide, repartidor" (ver J. P. Machado, Influência Arábica no Vocabulário Português, vol. 2, Lisboa, 1961, pp. 39-40; Dic. Onom, Etim, da L. Port., s. v.). A palavra árabe com acentuação aguda foi adoptada em português devido à influência de dialectos hispânicos que possibilitaram a deslocação do acento no adjectivo "relativo" Kasem, relacionando com o antropónimo em causa, segundo nos informa também Adel Sidarus.

Quanto a ser Cacém o derivado do nome do tirano mouro local, Cacim, é Resende a única fonte que o refere.

A imagem de S. Tiago de que temos conhecimento é a que figura num alto-relevo da Igreja Matriz, obra provavelmente do séc. XIV e que representa o apóstolo a combater os mouros, Guia de Portugal, II, Estremadura, Alentejo, Algarve, p. 10.

43 Consultar os dois importantes trabalhos saídos em Portugal sobre Bataça ou Vataça (esta forma mais fiel à leitura bizantina do grego): Maria Helena da Cruz Coelho e Leontina Ventura, "Vataça - Uma Dona na Vida e na Morte», separata das Actas das II Jornadas Luso-Espanbolas de História Medieval, vol. I, Porto (1987), pp. 159-194, e "Os Bens de Vataça, Visibilidade de Uma Existência", separata da Revista de História das Ideias, 9 (1987), Faculdade de Letras, Coimbra, pp. 33-77. No primeiro trabalho, fig. 3, p. 12, é apresentada a árvore genealógica de Vataça, pertencente à família dos Láscaris.

Havia efectivamente boas relações entre Miguel Paleólogo de Bizâncio e Pedro de Aragão. Daí a presença de D. Bataça junto a D. Isabel de Aragão, mulher de D. Dinis, a Rainha Santa, não sem que para tal tenhamos de seguir a complicada história bizantina relatada por Zurita, deformada ligeiramente por Resende, e que consta nos historiadores de Bizâncio, p. ex., George Acropolites, Opera, ed. A. Heisenberg, Leipzig, 1903, pp. 88-89; Nikeforos Gregoras, Byzantina Historia, ed. L. Schopen, I. Bekker, 3 vols., Bona, 1930-45, vol. I, pp. 92-93; Giorgios Pachymeres, De Michaelo et Andronico Paleologis, ed. I. Bekker, 2 vols., Bona, 1835, I, pp. 180-181.

${ }^{4}$ Jerónimo Zurita Valentim, de Saragoça, é o autor de Los cinco libros primeros de la primera parte de los Anales de la carona de Aragon, Saragoça, 1562, a que se seguem Los cinco libros pósteros de la primera parte, Saragoça, 1562, completada por uma segunda parte, dividida igualmente em dois grupos de cinco livros, publicada em Saragoça, em 1579 (ver n. 52).

45 Ioannis Baptistae Egnatii, De Caesaribus libri III, 1516. Cita-se edição impressa em Florença, 1519, livro II, fl. 33v-37v, sobretudo fl. 26v-37, Lascariorum stemma.

46 O imperador é Aléxio III Ângelo que reinou em Niceia de 1206 a 1259; Nicetes Coniates, Imperium Alexii Commeni Fratris Isacii Angeli, liv. III, c. 2: PG 139, col. 888: 'O $\delta \grave{\varepsilon}$ 


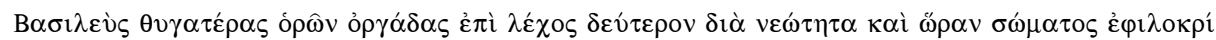

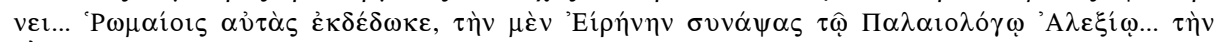

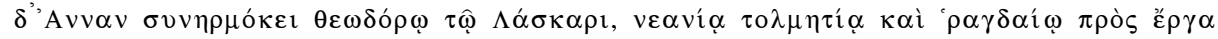
$\pi \mathrm{o} \lambda \dot{\varepsilon} \mu 1 \alpha$.

Quanto a Nicetas, ver. A. P. Kazhdan, The Oxf. Dict. Of Byz., s. v. Choniates, Nicetas.

É contudo no liv. II, c. 5, col. 876, que se diz que as filhas do imperador eram viúvas:

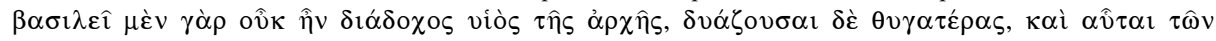

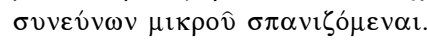

${ }^{47}$ I. Bapt. Egnatio, De Cães., fól. 37. «Imperator Alexius cognomento Angelus, ...Theodoro Lascari filiam despondit, dotis prenomine imperii titulos genero tribuit huic mascula proles ex uxore nulla, foemina tantum Irene filia fuit, quam Ioanni Batazio in matrimonium iunxit, imperiumque illi per manus tradidit». Batázio diz Egnácio e não Diplobatázio. O texto de Resende, quanto ao resto, segue pari passu o do humanista veneziano.

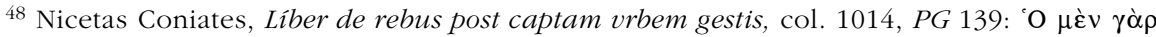

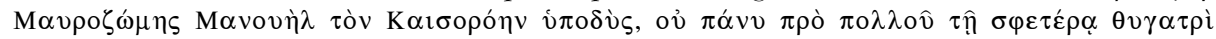

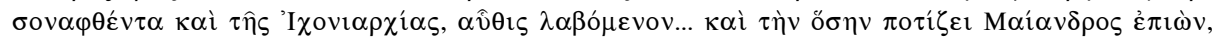

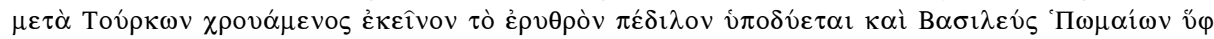

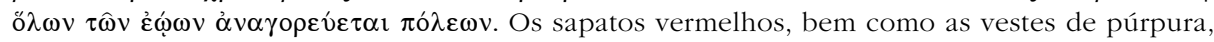
eram as insígnias imperiais.

49 Nicéforo Calisto, Enarratio de Episcopis Byzantii et de patriarchis omnibus Cpolitanis,

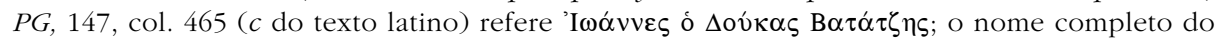
historiador é Xanthopoulos, Nikephoros Kallistus, ver art. de A. M. Talbot, em Oxf. Dict. of Byz., S. v.

50 Ioannes Zonaras, Epitome Historiaram, ed. L. Dindorf, Leipzig, 1871, vol. IV, XVII, 23 (=PG Migne, II, 253), pp. 166-167, refere efectivamente Vatazes por lhe terem arrancado os

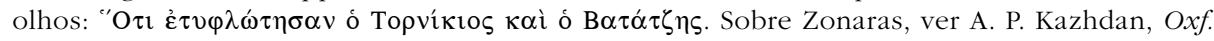
Dict. Of Byz., s. v. Zonaras, John.

51 Segundo Zurita, Miguel Paleólogo não matou João IV, mas «le hijo siendo moço innocente, sacar los ojos" (ver n. 52).

52 Zurita, no capítulo indicado, que está compreendido nas pp. 453-455 e se intitula "Delas hijas dela infanta de Corecia que casaron eneste reyno y dela donation que hijo la Emperatriz de Constantinopla al rey de Aragon", apresenta uma versão diferente da de Resende e mais próxima das fontes bizantinas.

53 Esta inscrição, hoje ilegível, é referida por Maria Helena da Cruz Coelho e Leontina Ventura no art. "Vataça - Uma Dona na Vida e na Morte», citado na n. 43, p. 38, n. 38, bem como o túmulo da Domina, fig. 7. No art. também citado na n. 43, das mesmas AA., "Os Bens de Vataça...", não aparece contudo o pormenor do Santo Lenho.

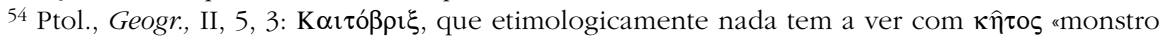
marinho", donde deriva o port. cetáceo: M. Isabel Rebelo Gonçalves, "Nota Morfológica sobre o lat. cetus", Euphrosyne, I (1967), pp. 187-190. Além disso o topónimo lat. é Caetobriga e não Cetobriga (cf. n. 58); A. Tovar, Iber. Landesk., p. 215 ss.

55 Hor., Sat., II, 5, 44.

56 C. I. L., II, 41=ILER 4667; J. d'Encarnação, Inscr. Rom. Conv. Pac., n. ${ }^{\circ} 211$, informa (p. 280) que "foi encontrado 'avulso' nos sedimentos de Tróia” e que o seu paradeiro é desconhecido. Refere igualmente a localização indicada por A. Resende. Quanto à estátua de Júpiter-Ámon (do deus Amana, depois Amun, de Tebas no Egipto, ver Der Kl. Pauly, s. v. Ammon) não conseguimos encontrar notícia, nem da estátua nem do culto na Lusitânia; J. Alarcão, Dom. Rom. Port., 167 ss (Júpiter).

57 Informações gerais sobre os Visigodos e o Rei Vamba são dadas por F. Almeida, s. v. Visigodos, Dic. Hist. Port.; textos e moedas a ele referentes encontram-se em R. Grosse, F. H. A., IX, Las fuentes de la época visigoda y byzantina, sobretudo pp. 323-342, onde faz a recolha de passos da Historia Wambae regis auctore Iuliano episcopo, ed. W. Levison, M. G. H., Script. Rer. Meroving., V, pp. 486-535 e de outras obras da história visigótica. L. Vazquez de Parga, La División de Wamba. Contribuición ai estudio de la Historia y Geografía eclesiásticas de la 
Edad Media española, Madrid, 1943; L. de Sousa Rebelo, "A Lenda do Rei Bamba: parábola do poder real", Arq. Centro Cult. Port., XXIII (1987), pp. 303-317. Vamba reinou de 627 a 680.

58 J. Alarcão, Port. Rom., pp. 68-69, afirma que "a palavra não deriva de Caetobriga, ainda que o aparente."; J. Leite de Vaconcelos, R. L., II, p. 21: "Caetobriga, que mal pode identificarse com as ruínas romanas de Tróia de Setúbal; Caetobriga devia ser, na origem, pelo menos como o nome -briga o indica, uma altura fortificada".

59 Florião do Campo, Los cinco libros primeros dela Crónica general de España, vol. I, Medina del Campo, 1553 (cf. n. 106 do livro I desta ed.), fls. 22, 95v, 96: Tubal "nuestro primero poblador" (fl. 95v) deu nome a Setúbal, topónimo que segundo Afonso de Castela tem a sua origem no seth caldeu. Quanto à sua etimologia não é ela diferente da que encontraremos algumas décadas depois em Fr. Bernardo de Brito e em Faria e Sousa. R. M. Rosado Fernandes, "Ulisses em Lisboa», Euphrosyne, XIII (1985), p. 150 ss. Não está, contudo, afastada a hipótese de o nome de Setúbal derivar de facto de Caetobriga (lido Cetobriga) por intermédio dos Árabes, conforme lemos em A. Nascentes, Dic. Et. L. Port., II, s. v.

Quanto ao comércio, ver entre outras obras a de V. Rau, A Exploração e o Comércio de Sal de Setúbal, vol. I, Lisboa, 1951.

60 Pro colonia Pacensi, ed. Coimbra, 1790, II, p. 7 ss. e especialmente 13-15. Ver A. Tovar, Iber. Landesk, p. 211 ss.

61 Trata-se de um autor e de um opúsculo não identificados, mas que são citados de bibliografia em bibliografia, como Barbosa Machado, Bibl. Lus., I, 170; Nicolau António, Bibl. Hisp. N., I, 85; Quétif, Script. Ord. Praedicatorum, II, 225, todos já considerados por Braamcamp Freire, na n. 223 de Leitão Ferreira, Vida de André de Resende, A. H. P., IX (1914), p. 219.

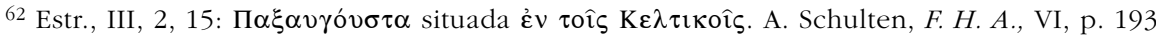
(ed. de Estrabão) diz-nos que só neste passo denomina Beja de Pax Augusta. De resto sempre Pax Iulia. Admite a hipótese de que Beja tenha sido projectada por J. César e terminada por Augusto.

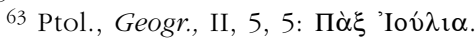

${ }^{64}$ De Apríngio, bispo de Beja, chegou até nós o fragmentário Tractatus in Apokalypsin, publicado por N. Férotin, Apringius de Beja - Son commentaire de l'Apocalypse, Paris, 1900, bem como A. C. Vega, Apringii Pacensis Episcopi Tractatus in Apocalypsin, Scriptores Ecclesiastici Hispano-Latini Veteris et Medii Aevii, Fasc. X-XI, Escorial, 1940. Cf. Diss. policopiada, apresentada à Fac. Letras de Lisboa, de J. Cunha Antunes, Leitura Crítica do Tractatus in Apokalypsin de Apríngio, Bispo da Igreja de Beja, Lisboa, 1973, que discute com pormenor as ideias e o texto de Apríngio e sua tradição manuscrita, cuja tradução apresenta.

65 Isidoro de Beja ou de Badajoz seria no séc. VIII o continuador da História de S. Isidoro de Sevilha. É citado por Vaseu no cap. 4 do Chronicon (ver n. 57 do livro III) e o seu estilo bárbaro é criticado pelo mesmo autor, fl. 4v. Segundo Mommsen, M. G. H., Chronica Minora, II, Berlim, 1894, p. 328, é da identificação aventada por Vaseu que depende o nosso humanista: "Ab hac coniectura pendent quae de Isidoro Pacensi horum chronicorum auctore scribunt Resendius... et Peresius...». Sobre este assunto ver a informação dada por V. Soares Pereira, $A$. R., Carta a Bartolomeu Quevedo, Coimbra, 1988, pp. 155 e 200, n. 244; M. Diaz y Diaz, Índex Scriptorum Latinorum Medii Aevi Hispanorum, Madrid, 1959, 397, onde se regista como Anónimo o A. da Chronica mozabarica, considerada por Mommsen, ob. cit., pp. 334-368, entre as Continuationes Isidorianae, Byzantiae, Arabicae et Hispanae. O texto também é publicado por Migne, P. L., 96, 1253-1280, como anteriormente por H. Florez, España Sagrada, 6 (2. ${ }^{\mathrm{a}}$ ed. 1773), pp. 430-441 (crónica de 741), 8 (2. ${ }^{\mathrm{a}}$ ed. 1769), pp. 282-325 (crónicas de 754).

66 Sisenando martirizado em Córdova em 16 de Julho 851. O seu martírio é referido no Memoriale Sanctorum, II, 5, de S. Eulógio, ed. de A. Morales, S. Eulogii Cordubensis Opera, Alcalá, 1574; publicado na P. L. de Migne, CXV, 772-773. Em II, cap. V, fala De Sisenando leuita martyre dizendo "Sisenandus ex pacensi oppido ortus", e no cap. VI, ao enumerar os santos moçárabes perseguidos por Abderramão II, refere "Tiberinus Pacensis presbyter", companheiro do diácono Paulo, mártir de Córdova. Cf. Dictionnaire d'Histoire et de Géographie Ecclésiastiques, ed. R. Aubert et E. van Caunenbergh, Paris, 1963, vol. XV, s. v. Euloge de Cordoue (850852). 
${ }^{67}$ C. I. L., II, 52. A. Resende não desenvolve suficientemente os dizeres da inscrição, como podemos ver pelas leituras de Huebner e J. d'Encarnação, Inscr. Rom. Conv. Pac., n. ${ }^{\circ} 233$ (p. 306), que lêem BIS PRAEF (ectus). FABRVM. Assim, no que ainda é reconstituível deve ler-se: "Gaio Júlio, filho de Gaio, duúnviro pela segunda vez, prefeito dos artífices». Terá sido um magistrado municipal.

${ }^{68}$ C. I. L., II, 56: a leitura de A. R. difere da apresentada por Huebner e por J. d'Encarnação, Inscr. Rom. Conv. Pac., n. ${ }^{\circ} 234$ (p. 307).

${ }^{69}$ C. I. L., II, 49: o texto coincide com as versões de Huebner e de J. d'Encarnação, Inscr. Rom. Conv. Pac., n. ${ }^{\circ} 236$ (p. 309). Subsistem, contudo, dúvidas quanto à sua autenticidade, pois não é sem razão que pode pensar-se ter sido a inscrição forjada por A. Resende, a fim de criar um cargo de currículo transparente.

${ }^{70}$ C. I. L., II, 66: confere o texto de Resende com o de Huebner e J. d'Encarnação, Inscr. Rom. Conv. Pac., n. ${ }^{\circ} 271$ (pp. 344-345), que data a inscrição do séc. I d. C.

${ }^{71}$ C. I. L., II, 55 e J. d'Encarnação, Inscr. Rom. Conv. Pac., n. ${ }^{\circ} 242$ (p. 316), que não admite o plural pontifices e flamines de A. Resende e os reduz para pontifex e flamen.

${ }^{72}$ C. I. L., II, 64 (=5188). J. d'Encarnação, Inscr. Rom. Conv. Pac., n. ${ }^{\circ} 260$ (p. 333). Ainda hoje se encontra no Museu Regional de Beja.

73 C. I. L., II, 61; J. d'Encarnação, Inscr. Rom. Conv. Pac., n. ${ }^{\circ} 265$ (p. 337): apresenta-nos o praenomen Iulius ligado a Sabinus, cuja reconstituição A. Resende tinha omitido.

${ }^{74}$ C. I. L., II, 48; J. d'Encarnação, Inscr. Rom. Conv. Pac., n. ${ }^{\circ} 232$ (p. 306), que a considera como o final de uma inscrição honorífica e a lê diferentemente, apresentando Quintus Petronius (acrescenta Maternus) em nominativo. Teria possivelmente sido a Colonia Pax Iulia a entidade dedicante.

75 C. I. L., II, 60; J. d'Encarnação, Inscr. Rom. Conv. Pac., n. ${ }^{\circ} 263$ (p. 336) que mantém a leitura de A. R. e aponta para a correcção do erro TERSPICORE interpretado correctamente por Resende em Terpsicore.

76 C. I. L., II, 47; J. d'Encarnação, Inscr. Rom. Conv. Pac., n. ${ }^{\circ}$ 291, p. 261-263: como não podia deixar de ser, merece esta inscrição, pela sua importância no respeitante ao culto imperial, um comentário alargado por parte dos eruditos portugueses, conforme demonstra a resenha de J. d'Encarnação. Há que introduzir acrescentamentos como, p. ex., Titus antes de Aelius, bem como o D. D. de Decreto Decurionum antes do dedicauit. De resto, a inscrição ainda existe em Beja, nos Paços do Conselho.

77 Inscriptiones Hispaniae Christianae, 3 (ver n. 116).

78 C. I. L, II, 102; J. d'Encarnação, Inscr. Rom. Conv. Pac., n. ${ }^{\circ} 313$ (p. 386): trata-se de uma inscrição ainda existente no Museu Regional de Évora, cuja proveniência coincide com a indicada por A. R. A leitura de A. R. é correcta e nada há a alterar.

79 Não é possível localizar qualquer baixo-relevo que corresponda a esta descrição, pelo menos por agora. Ver o levantamento geral da arte Romana em Portugal no Corpus Signorum Imperii Romani, Corpus der Skulpturem der roemischen Welt, Portugal, Coimbra, 1990.

${ }^{80}$ Esta carta a João de Barros é citada pelos bibliógrafos mais importantes, como nos indica Braamcamp Freire, Vida de André de Resende, A. H. P., IX, 1914, p. 199, n. 172; 311, n. $19 ; 317$. Consideram, no caso de Nicolau António, Bibl. Hisp. Nova, I, 1672, 67, que este não viu a carta. Quanto a Rodrigo de Toledo, é este considerado em Nicolau António, Bibl. Hisp. Vetus, II, 49 ss., como Rodricus Simonis, "vulgo Ximenez, Archiepiscopus Toletanus». Vid. M. Diaz y Diaz, Index Scriptorum Latinorum Medii Aevi Hispanorum, vol. II, Salamanca, 1959, n. ${ }^{\circ} 1241$, p. 266, Rodericus Ximenez de Rada, autor no séc. XIII dos Rerum in Hispania gestarum libri IX seu bistoria gothica.

É evidente que Resende, no que toca ao nascimento de Elvira e Teresa, toma a posição de defesa do bom nome português, apesar de ser geral a convicção de ilegitimidade quanto ao seu nascimento; ver Maria E. Cordeiro Ferreira, Dic. Hist. Port., s. v. Teresa, Condessa D.; J. Mat-toso, Identificação de um País, 2 vols., Lisboa, 1985, passim.

81 Ver L. F. Lindley Cintra, "Sobre a Formação e Evolução da Lenda de Ourique (até à Crónica de 1419)", in Miscelânia de Estudos em Honra do Prof. Hemâni Cidade, Lisboa, 1957, pp. 168-215; J. Mattoso, Identificação de Um País, Ensaio Sobre as Origens de Portugal, 10961325, Lisboa, 1985, I, p. 173; II, p. 189, 204, 209; Martim de Albuquerque, A Consciência 
Nacional Portuguesa, Ensaio de História das Ideias Políticas, I, Lisboa, 1974, p. 340 ss; M. T. Campos Rodrigues, Dic. Hist. Port., s. v. Ourique, Milagre de.

${ }^{82}$ Há de facto uma referência à batalha de Ourique no poema Vicentius Leuita et Martyr, Liber posterior, B, vi v. e vii r., a que correspondem as notas 25, p. 39, e sobretudo a 29, p. 41 das adnotationes. Não coincidem em nada com os versos do nosso texto, excepto nalgumas imagens "ubi castra, cruore tincta nigro" que corresponde ao "tellus tanto est imbuta cruore»; trata-se certamente de um outro poema que não identificámos.

83 Quanto à data de Ourique, que é efectivamente 1139, ver M. Teresa Campos Rodrigues, Ourique, Batalha de, no Dic. Hist. de Port.

${ }^{84}$ Parece que a inscrição nunca existiu, como vemos pelas palavras do Marquês de Abrantes na conferência pronunciada em 31 de Julho de 1721 na Academia Real de História, e citadas em Notícias da Vida de André de Resende, in A. H. P., IV, 1916, p. 128, n. 229: "Vi os sítios dos acampamentos dos Cristãos e dos Mouros, proporcionados para a nossa ordem e para a sua multidão... mas não vi o arco que André de Resende afirma mandara erigir Elrey D. Sebastião, não li a sua elegante inscrição que ele estampou no livro quarto das antiguidades, e o que mais é, não achei, nem na memória dos homens, vestígio algum de tal troféu, convertendo-se contra o mesmo Autor, que falsamente a divulgou, as próprias razões com que ele increpou a negligência dos que haviam descuidado de perpetuar tão digna memória». Braamcamp Freire não deixa de comentar discretamente: "É severo mas parece merecido». O mesmo não acontece com o biógrafo F. Leitão Ferreira que na p. 128 a este propósito afirma: «E porque nestes nossos tempos não está aquele Arco triunfal, nem as suas inscrições, nem há vestígios, memória ou tradição alguma, de que ali se houvesse erigido tal troféu, se duvidou na Academia Real desta verdade de Resende, como se ele fosse outro Cirilo Anconitano ou algum Ânio de Viterbo; porém, deixada a mui verosímil conjectura com que prudentemente se podia presumir, que por algum incidente não se chegaria a fabricar aquele arco... deixada, como digo, esta conjectura, ouvi dizer que o arco fora demolido pelos moradores e que se serviram da pedraria para outros usos, o que agora os seus descendentes ocultavam por se não castigar nos filhos e nos netos a desatenção ou ignorância rústica dos pais e dos avós. Eu não creio nem descreio isto, porém não me persuado que André de Resende quisesse enganar a posteridade com uma memória falsa e macular a sua fama com a nota infame de impostor, quando ele mesmo em seus escritos não só confessa à boca cheia que não crê antes lhe aborrecem as fábulas, mas censura também aos que lhes deram crédito». Naturalmente que estes comentários não tomam em conta a finalidade de propaganda política com que Resende inculcava por todos os meios nos concidadãos os fundamentos da consciência nacional. Ver R. M. Rosado Fernandes, "Méthodologie et Histoire dans De antiquitatibus Lusitaniae d'André de Resende», Actes du XXIe Colloque International d'Études Humanistes - Tours, 1978, Humanisme Portugais et l'Europe, Paris, 1984, p. 504 segs.

85 É possível que a etimologia proposta por A. R. esteja certa, na medida em que também para Colares se aventa etimologia idêntica. Ver A. Nascentes, Dic. Et. Líng. Port., II, s. v.

${ }^{86}$ C. I. L., 9*. Segundo julgamos, trata-se de uma excelente invenção de A. R., que com ela pretende criar a imagem do bonus Lusitanas, espécie de bom selvagem, a fim de nobilitar a origem dos Portugueses. Ver R. M. Rosado Fernandes, art. cit., p. 502 e segs; José d'Encarnação, "Da Invenção de Inscrições Romanas pelo Humanista André de Resende», Biblos, LXVII (1991), p. 193 ss

87 C. I. L., II, 489*

${ }^{88}$ C. I. L., II, 31; José d'Encarnação, Inscr. Rom. Conv. Pac., n. ${ }^{\circ} 181$ (p. 250). A única referência a este monumento provém de A. Resende e é aceite por Huebner bem como por Encarnação. Interessante notar os dativos femininos em -e por -ae do latim vulgar e medieval. De notar também o termo marita em vez de uxor, bem como o nome Thalassinus, que deve indicar tratar-se de um liberto. Encarnação afirma tratar-se de "texto não anterior ao séc. II".

${ }^{89}$ C. I. L., II, 4*. Parece tratar-se de outra inscrição forjada.

${ }^{90}$ C. I. L., II, 30; J. d'Encarnação, Inscr. Rom. Conv. Pac., n. ${ }^{\circ} 180$ (p. 249): não se trata de Marcellina mas sim de Marcella, demonstra Encarnação contra o C. I. L, na medida em que Marcella "é cognome bastante espalhado".

91 Livro I, p. 81. 


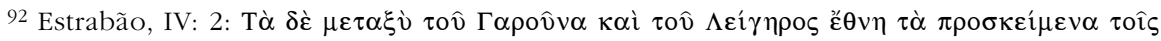

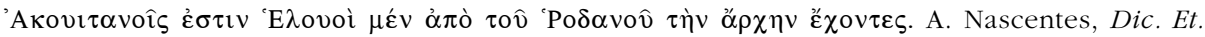
Líng. Port., II, s. v. Elvas atribui ao topónimo origem desconhecida. ELVIA aparece contudo em inscrições: C. I. L., II, 154; J. d'Encarnação, Inscr. Rom. Conv. Pac., n. ${ }^{\circ} 587$ (p. 651); C. I. L., II, 135 (n. 105); e Heluius, em C. I. L., II, 143 (n. 100); A. Tovar, Iber. Landesk., p. 218221.

93 Plínio, H. N., III, 4, 36 (Alba Helvorum); XIV, 43 («in Narbonensis provinciae Alba Helvia").

${ }^{94}$ C. I. L., II, 555; J. d'Encarnação, Inscr. Rom. Conv. Pac., n. ${ }^{\circ} 586$ (p. 650): a leitura difere quanto a CEPALONIS que hipoteticamente é lido $\mathrm{CEP}<\mathrm{H}>\mathrm{ALONIS}$.

95 C. I. L., II, $22^{*}$; foi esta inscrição, considerada falsa por Huebner, reabilitada pelos eruditos modernos, na medida em que as informações sobre o emigrante em si contidas podem ser justificadas pelas ligações com Itália, tal como lemos em J. d'Encarnacão, Inscr. Rom. Conv. Pac. , n. ${ }^{\circ} 576$ (p. 641). Aproximadamente a leitura de Resende está correcta, com excepção de Firmicae que deve ser FIR(mo) PICENO (actualmente Fermo).

96 C. I. L., II, 152; J. d 'Encarnação, Inscr. Rom. Conv. Pac., p. 631-632, põe as maiores reservas, e justificadas a nosso ver, quanto a esta inscrição, na medida em que aponta para diversos aspectos, como o do cognome Anthymius, que em nada se coadunam com a realidade epigráfica do território.

97 C. I. L., II, 153; J. d'Encarnação, Inscr. Rom. Conv. Pac., p. 632, também duvida da autenticidade desta inscrição aceite por Huebner sem demasiadas reservas. Quanto à lenda de Beltrão, refere-se esta a Bertrand du Guesclin [1315 (ou 1320) - 1380], Condestável de França e herói lendário.

98 Inscriptiones Hispaniae Christianae, 5*. Trata-se de mais um caso pseudo-epigráfico.

99 C. I. L., II, 144; J. d’Encarnação, Inscr. Rom. Conv. Pac., n. ${ }^{\circ} 571$ (p. 637). Quot está por quod, o que foneticamente é muito fácil de acontecer.

${ }^{100}$ C. I. L., II, 143; J. d'Encarnação, Inscr. Rom. Conv. Pac., n. ${ }^{\circ} 570$ (p. 636-637), prefere desenvolver 1.5 a abreviatura S. como suum e não como soluens. De Helvius, nome gentilício que aparece também numa inscrição de Mértola, procurou Huebner deduzir a etimologia de Elvas.

${ }^{101}$ C. I. L., II, 145; J. d'Encarnação, Inscr. Rom. Conv. Pac., n. ${ }^{\circ} 572$ (p. 638), propõe a mesma solução de suum e não soluens ou soluit. Quanto a nós e fundamentando-nos nos mesmos exemplos dos n. ${ }^{\text {os }} 570,571,572$, preferimos o uotum soluens, na medida em que não é frequente em latim o possessivo relacionado com o sujeito em casos como este. Assim uotum soluens é muito preferível ao uotum suum... posuit, sintacticamente e semanticamente pouco aconselhável, Votum... posuit já significaria realizou o seu voto, ou a sua promessa. O n. ${ }^{\circ} 571$ atesta até a construção bipartida com dois verbos: uotum quod fecit, animo libens posuit. Porque não uotum soluens, animo libens posuit, com perfeito e particípio presente? De facto, suum é redundante em latim, ainda que pode ser admissível num latim de província; no entanto, a construção solvens... posuit parece mais correcta e com o exemplo do n. ${ }^{\circ} 571$ até poderemos pensar em soluit... posuit, como fecit... posuit pagou a sua promessa e... colocou (subentendese monumentum).

${ }^{102}$ C. I. L., II, 148; J. d'Encarnação, Inscr. Rom. Conv. Pac., n. ${ }^{\circ} 466$ (p. 546-547), não discute o sentido a dar ao dat. matri, no contexto da inscrição. Em vez de Semnine deve ler-se Semnus.

103 C. I. L., II, 131; J. d’Encarnação, Inscr. Rom. Conv. Pac., n. ${ }^{\circ} 42$ (p. 572-573); D. Teodósio é o 5..$^{\circ}$ Duque de Bragança, falecido em 1563, ver F. Castelo-Branco, Dic. Hist. Port., s. v. Teodósio I, D.

104 C. I. L., II, 127; J. d'Encarnação, Inscr. Rom. Conv. Pac., n. ${ }^{\circ} 483$ (p. 564).

105 C. I. L., II, 135; J. d'Encarnação, Inscr. Rom. Conv. Pac., n. 510 (p. 587-588): gravado na lápida estava ENDOVOLLICO que deve analogicamente reproduzir a alternância existente em lat. de nel-/uol-.

106 C. I. L., II, 136; J. d'Encarnação, Inscr. Rom. Conv. Pac., n. ${ }^{\circ} 514$ (p. 591-592). Trata-se de uma promessa que acaba por ser cumprida pela mãe de quem a tinha feito. 
107 C. I. L., II, 129; J. d'Encarnação, Inscr. Rom. Conv. Pac., n. ${ }^{4} 488$ (p. 568-569), que nos apresenta a leitura corrigida, na medida em que o T(estamento) e o dat. numini são lidos como I(ussu) e, portanto, gen. numinis. Temos assim: Deo Endovellico sacrum. Ad relictitium (?) ex iussu numinis, Arrius Badiolus animo libens fecit. "Consagrado ao deus Endovélico, para a posteridade (?), por mandado da divindade, Árrio Badíolo fez de bom grado».

108 C. I. L., II, 139; J. d'Encarnação, Inscr. Rom. Conv. Pac., n. ${ }^{\circ} 526$ (p. 603-604).

109 C. I. L., II, 132; J. d'Encarnação, Inscr. Rom. Conv. Pac., n. ${ }^{\circ} 494$ (p. 574-575): a fórmula final é rejeitada tanto por este A. como por Huebner e S. Lambrino.

${ }^{110}$ C. I. L., II, 134; J. d'Encarnação, Inscr. Rom. Conv. Pac., n. ${ }^{\circ} 08$ (p. 586-587): parece, segundo hipótese de Escalígero, transmitida por Huebner, poder admitir-se que Manilia seja correspondente a mamma (ama). Teríamos assim uma correcção desta sucessão de dois gentilícios.

111 Não refere A. R. o carácter curandeiro de Endovélico, deus certamente de origem céltica e que desempenhava na Lusitânia o mesmo papel que Asclépio na Grécia e Esculápio no mundo romano. Sobre o culto e seus vestígios damos algumas indicações sobre a bibliografia mais importante. Ver J. Leite de Vasconcelos, Religiões da Lusitânia, II, 1905, p. 111-146; III, 1913, p. 195-196; S. Lambrino, Dic. Hist. Port., s. v. Endovélico; "Le dieu lusitanien Endovellicus", Bulletin des Études Portugaises, XV (1951), p. 93-146; J. Alarcão, Portugal Romano, p. 169, 171, 172, 187; o Dom. Rom. Port., p. 153 ss.; J. d'Encarnação, Inscr. Rom. Conv. Pac., Textos dedicados a Endovélico, p. 561-629, que reúne de forma sistemática as inscrições dedicadas ao deus, que comenta com critério e de forma exaustiva.

112 A. R. já dedicara a sua atenção a S. Mâncio (S. Manços), em trabalhos anteriores. Ver na História da Antiguidade de Évora e na Carta a Bartolomeu de Quevedo. Ver a este propósito as notas de Virgínia Soares Pereira, André de Resende, Carta a Bartolomeu Quevedo, pp. 30, n. 68, 76, 124, n. 40; igualmente C. da Silva Tarouca, "S. Manços, 1. ${ }^{\circ}$ Bispo de Évora?, Tradição Local Autêntica ou Falsificação Sistemática de Fontes?», Brotéria, 42 (1946), p. 5-13; Júlio César Baptista, "São Manços (Evolução Biográfica), in A Cidade de Évora, Boletim de Cultura da Câmara Municipal, 64-64 (1980-1981), pp. 5-86.

113 Trata-se da ligação do lendário 1. ${ }^{\circ}$ Arcebispo de Braga com S. Tiago. O seu culto entrou na liturgia bracarense em 1508. Teria sido um dos discípulos escolhidos por S. Tiago na Hispânia, e por ele ordenado bispo da igreja bracarense. Ver J. Ferreira, Origens do Cristianismo na Península Hispânica - A Vila de Rates, Sua Igreja e Seu Mosteiro, Póvoa de Varzim, 1912; Avelino de Jesus da Costa, "S. Pedro de Rates - Um Problema Histórico-Litúrgico» in Diário do Minho de 25 e 26 de Abril de 1948 e art. s. v. na Encicl. Verbo; S. da Silva Pinto, O problema de S. Pedro Mártir, 1. ${ }^{\circ}$ Bispo de Braga, Braga, 1958.

${ }^{114}$ C. I. L., II, 147; J. d'Encarnação, Inscr. Rom. Conv. Pac., n. ${ }^{\circ} 465$ (p. 545-546): a leitura proposta é Caustinus (?) e não Cautinnensis.

115 Trata-se de L. Andr. Rensendü Lusitani ad Epistolam D. Ambrosii Moralis uiri doctissimi - inclitae academiae complutensis rhetoris ac regii historiographi responsio, ed. de Coimbra, vol. II, 1790, pp. 127-161, cujo tema versa De Traiani pontis inscriptionibus aliisque, p. 157 e segs. É o eco das afirmações de Ildefonso, De uiris illustribus, in Hispaniae Illustratae... scriptores uarii, II, p. 8; ed. de Virgínia Soares Pereira, Carta a Bartolomeu Quevedo, pp. 97, 111 e 119 no texto de A. R. e tradução da autora.

116 Sobre esta inscrição, existente na capela de S. João Baptista dos Azinhais, cujos vestígios se encontram na Herdade de Vale de Arranas, concelho do Torrão, escreveu José Geraldes Freire um minucioso artigo, "Autenticidade da Inscrição do Torrão, datada de 682 d. C. Fidedignidade de André de Resende", Actas das III Jornadas de História Medieval do Algarve e Andaluzia, Loulé, 1989, pp. 197-216, em que discute os vários testemunhos de arqueólogos e estudiosos, bem como as dúvidas levantadas por Huebner, Inscriptiones Hispaniae Christianae, Berlim, 1871, p. 3, n. ${ }^{\circ}$, bem como de J. Vives, Inscriptiones cristianas de la España romana y visigótica, Barcelona, 1942, p. 105, n. ${ }^{\circ}$ 311. Contrariamente à opinião dos dois epigrafistas, decide-se Geraldes Freire com razões de peso pela autenticidade da inscrição. Estuda igualmente o papel histórico e religioso dos dois Santos, Justo e Pastor, naturais de Alcalá de Henares, "degolados em 304 à ordem do governador Daciano, sendo imperador Diocleciano» (p. 206). O texto da inscrição, texto que apresenta erros e falhas não só de correcção linguística (p. 
ex., concordância do acusativo masc. bunc com o neutro edificium, oc em vez de hoc, ceptum em vez de captum que poderia existir em compostos como inceptum, que aliás é a forma a considerar) como epigráfica. A possibilidade de se tratar de uma inscrição com pretensões métricas também não é descurada (pp. 212-214).

A inscrição, cuja tradução em português apresentada no texto é da autoria de Geraldes Freire, é vista como gotbica neste passo de Resende, que já a dera a conhecer "cum suis soloecismis" a Ambrósio Morales, numa carta de 19 de Março de 1570: L. Andr. Resendii Lusitani, ad epistolam D. Ambrosii Moralis viri doctissimi inclitae academiae complutensis rhetoris, ac regii historiagraphi responsio, publicada nas L. Andr. Resendii... Opera, Coimbra, 1790, vol. II, p. 158 ss.

Quanto à interpretação dada por Geraldes Freire a gotbica no sentido de bárbara, admitimos que assim seja pelo menos em parte. Os Godos eram considerados como pertencentes à Idade das Trevas, ou seja, à Idade Média, na conotação lançada a seu tempo por Petrarca. Este sentido é reforçado pela referência cum soloecismis feita por A. R. a Morales. Devido contudo à proximidade, do próprio De antiquitatibus, de um capítulo histórico sobre os Godos, julgamos que seria imprudente neste contexto traduzir gothica por bárbara, e assim nos limitámos a traduzir o adjectivo por "do tempo dos Godos», embora não esquecendo a "avalanche gótica ou bárbara» que Resende claramente refere na carta ao Cardeal D. Afonso (p. 58).

117 C. I. L., II, 32; J. d'Encarnação, Inscr. Rom. Conv. Pac., n. ${ }^{\circ} 183$ (p. 254-255), que faz extenso comentário a este rico monumento e a toda a sua simbologia, ligada ao culto de Júpiter, que foi encontrado, tal como diz Resende, na Capela de S. João dos Azinhais, Torrão, Alcácer do Sal, e que hoje se conserva no Museu Regional de Évora.

118 C. I. L., II, 5*: esta inscrição é considerada forjada, o que não é difícil de compreender se virmos o tipo de história breve contada pelo suposto lapidarius e pela dedicante; José d'Encarnação, "Da Invenção de Inscrições Romanas pelo Humanista André de Resende», Biblos, LXVII (1991), p. 204 ss.

119 C. I. L., II, 37; J. d'Encarnação, Inscr. Rom. Conv. Pac., n. ${ }^{\circ} 196$ (p. 269): da mesma proveniência que a referida na n. 117.

${ }^{120}$ C. I. L., II, 94; J. d'Encarnação, Inscr. Rom. Conv. Pac., n. ${ }^{\circ} 334$ (p. 410).

121 C. I. L., II, 6*: trata-se de mais uma inscrição forjada.

122 C. I. L., II, $7^{*}$ : igualmente forjada.

\section{ESCÓLIOS}

\section{DE DIOGO MENDES DE VASCONCELOS AOS QUATRO LIVROS DE RESENDE}

1 Ver p. 92 da trad.

2 Ver p. 92 da trad.

3 Ver p. 92 da trad.

4 Ver p. 92 da trad.

5 Ver p. 92 da trad.

6 Ver p. 92 da trad.

7 Ver p. 94-95 da trad.

8 Ver p. 96-97 da trad.

9 Ver p. 98-99 da trad.

10 Ver p. 100-101. Pelo Comentário de Mendes de Vasconcelos, vemos, a admitir que o texto tenha sido impresso correctamente, que há confusão entre Norte (de toda a Espanha) e costa ocidental (e não setentrional da Lusitânia).

11 Ver p. 100-101 da trad.

12 Ver p. 114-115 ss. da trad.

13 Bluquerium ou p. Bluqueria, indica o Prof. Aires do Nascimento, mais não é do que a latinização de Broquel, Bruquel ou Burquel, possivelmente proveniente do fr. bouclier, termo ligado à heráldica e referente a um pequeno escudo de madeira ou vime recoberto de couro 
e guarnecido de ferro, aço ou cortiça, no caso de ser utilizado para a esgrima. Veja-se que Resende refere a imagem simbólica da Hispânia que aparece na obra de Ambrósio Morales: La Coronica General de España, que continuava Ambrósio de Morales, natural de Córdova, Coronista del Rey Catbolico nuestro Señor don Philipe Segundo deste nombre, y catedrático de Rhetorica en la Universidad de Alcala de Henares (continuação dos 5 livros da Crónica de Florião do Campo), Alcalá de Henares, 1574, vol. I, fól. VI, v. da parte introdutória ao livro VI e segs., continuação, como se disse, dos 5 livros de Florião do Campo. A mesma efígie aparece no vol. II, livros XI e XII, Alcalá, 1577, fól. 18 da introdução, e está reproduzida no frontispício deste livro. Trata-se efectivamente, como nos indica A. Morales, da representação da Hispânia em moedas de Galba, muito raras. Cf. H. A. Seaby, Roman Silver Coins, vol. II, Londres, 1968, p. 18; o mesmo lemos em Sylloge Nummorum Romanorum - Italia, a cura di Rodolfo Martini, Milão, vol. II, 1991, pp. 42 e 43: "Hispania paludata, stante a s., regge com la mano d. protesa, spighe digrano e con la s., scudo rotondo e due lance verticali. Contorno perlinato."

14 Cf. J. M. Roldán Ervás, Itin. Hisp., p. 245.

15 Cacia? Ver J. Alarcão, Port. Rom., p. 98

16 Ver J. Alarcão, ob cit., p. 89, Coimbra.

17 Ver J. Alarcão, ob cit., p. 88-89: S. Sebastião do Freixo.

18 Perto do Tramagal. Ver J. Alarcão, ob cit., p. 80.

19 Todos estes nomes devem ser controlados com os trabalhos de Roldán Hervás e de J. Alarcão, porque muitas das indicações feitas por Mendes de Vasconcelos são discutíveis, além de que alguns topónimos nem sequer aparecem no texto de Resende.

20 Albert Krantz, Wandalia, I, 20. Trata-se de um humanista de Hamburgo dos sécs. XVXVI (1448-1517), que se ocupou da história dos povos do Norte da Europa e da Saxónia (ver Neue Biographie, Berlim, vol. XX, s. v.). A obra referida intitula-se A. Kranzii viri in Theologia et iure pontificio celeberrimi, historicique clarissimi; Wandalia, de Wandalorum vera origine, variis gentibus, crebris et patria migratonibus, regnis item, quorum vel autores vel eversores fuerunt, Francofurti, ex officina typographica Andreae de Wecheli, MDLXXV. Nesta edição também há um apêndice sobre a Polónia e a Prússia. De interesse, no livro I, o prefácio onde fala de Beroso, e os caps. 26-27 em que se ocupa brevemente da Hispânia e da Lusitânia e da unificação dos povos germânicos.

21 Ver p. 346-347 desta edição

22 Ver p. 354-355 desta edição

23 Ver p. 360-361 desta edição 
(Página deixada propositadamente em branco) 


\section{BIBLIOGRAFIA}


(Página deixada propositadamente em branco) 


\section{BIBLIOGRAFIA}

Evitaremos sobrecarregar a consulta desta bibliografia com a indicação das edições correntes dos textos clássicos, gregos, latinos e bizantinos citados. Provêm elas das mais conhecidas colecções de textos clássicos: Teubner, Belles Lettres, Oxford e, nalguns casos, Loeb. As edições mais especializadas, contudo, poderão ser encontradas nesta bibliografia. As grandes colecções de textos antigos históricos, bem como de enciclopédias, aparecerão citadas nas notas de forma abreviada, que será desenvolvida nas siglas.

\section{I - Siglas gerais}

A. H. P. - Arquivo Histórico Português.

Arq. Cent. Cult. Port. - Arquivo do Centro Cultural Português, Gulbenkian, Paris.

Dic. Hist. Port. - Dicionário da História de Portugal. Direcção de Joel Serrão, Porto, 1981.

Dic. Lit. Port. - Dicionário de Literatura - Literatura Portuguesa, Literatura Brasileira, Literatura Galega, Estilística Literária. Direcção de Jacinto do Prado Coelho, 3. ${ }^{a}$ ed. 1976.

C. I. L. - Corpus Inscriptionum Latinarum.

C. S. E. L. - Corpus Scriptorum Ecclesiasticorum Latinorum, Viena.

F. H. A. - Fontes Hispaniae Antiquae.

F. H. G. - Fragmenta Historicorum Graecorum, ed. Muller, C. e Th.

F. G. H. - Fragmente der griechischen Historiker, ed. Jacoby.

H. R. R. - Historicorum Romanorum reliquiae, ed. Hermann Peter, 1. ${ }^{a}$ ed. 1906, 2. ${ }^{\text {a }}$ ed. Estugarda, 1967.

Der kleine Pauly — Lexikon der Antike in fünf Bänden, Munique, 1979.

M. G. H. - Monumenta Germaniae Historica.

O. C. D. - The Oxford Classical Dictionary, 2. ${ }^{\text {a }}$ ed., Oxford, 1970.

P. G. - Patrologia Graeca de Migne.

P. L. - Patrologia Latina de Migne.

P. L. M. - Poetae Latini Minores, ed. E. Bachrens e F. Vollmer, Leipzig, 1879-1935.

P. M. H. - Portugaliae Monumento Histórica, ed. A. Herculano, Academia das Ciências, Lisboa, desde 1852.

R. E. - Realenzyklopädie der Alterturmswissenschaft, editada por Pauly-Wissowa, desde 1890.

R. P. H. - Revista Portuguesa de História.

\section{II - Siglas do aparato crítico desta edição}

$\mathrm{E}=$ Edição de Évora (1593)

$\mathrm{R}=$ Edição de Roma (1597)

$\mathrm{C}^{1}=$ Edicão de Colónia (1600)

$\mathrm{F}=$ Edição de Francoforte (1603)

$\mathrm{C}^{2}=$ Edição de Colónia (1613)

$\mathrm{U}=$ Edição da Universidade de Coimbra (1790)

\section{III - Edições do De antiquitatibus Lusitaniae}

Libri Quattuor De Antiquitatibus Lusitaniae a Lycio Andrea Resendio olim inchoati \& a Iacobo Menoetio Vasconcello recogniti atque absoluti. - Acessit liber quintus de antiquitate municipii 
Eborensis ab eodem Vasconcello conscriptus, quo etiam autore, secundus tomus quinque alios libros continens, cito, deo opt. max. fauente, in lucem prodibit. ...Excudebat Martinus Burgensis academiae typographus, Eborae anno 1593. É esta a edição princeps utilizada neste livro como texto latino em que se fundamenta a tradução portuguesa apresentada. É também pela sua paginação, indicada entre colchetes dentro do texto latino e português da presente edição, que a tradução se orienta.

De antiquitatibus Lusitaniae Libri Quattuor, a L. Andrea Resendio inchoati, a Iacobo Mendez de Vasconcellos obsoluti. Cum aliis opusculis, versibus et soluta oratione ab eodem conscriptus. ... Romae. Aupd Bernardum Basam. MDXCVII. Superiorum permissu. Esta edição de 1597 é organizada por Miguel de Cabedo e António de Cabedo, familiares de Mendes de Vasconcelos. O texto latino de Resende é precedido de uma parte introdutória, em que se dedica a obra ao Cardeal Aldobrandino, datada de 1596.

L. Andreae Resendii Eborensis antiquitatum Lusitaniae et de municipio Eborensi Lib. V, Orationes item, epistolae historicae et poemata omnia, quotquot reperiri potuerunt. In Hispania ab amico collecta, nunc primum summa dilligentia edita. ... Nicolaum et Simonem Rodericios fratres, Lusitanos. Colonia Agrippinae, in Officina Birckmannica, sumptibus Arnoldi Mylii. Anno salutis MDC. (1600), 2 vols. Nesta edição aparece já traduzida em latim, sob o título De Antiquitatibus Eborae, a obra em vernáculo de Resende, História da antiguidade da Cidade Évora, publicada em Évora, em 1553 e 1576, e em Lisboa em 1783 e 1963 (esta última por J. Pereira Tavares). A tradução para latim foi feita por Andreas Schottus de Antuérpia e será publicada nas edições subsequentes de Francoforte, 1603, Colónia, 1613 e Coimbra, 1790.

Deliciae Lusitano-Hispanicae: in quibus continentur De magnitude Hispanici imperii relatio: Noui orbis regionum a Lusitanis subactarum breuis descriptio. De Lusitania ceterae Hispaniae adiuncta Historia. Itemque Lusitaniae antiquitates ab Andrea Resendio collectae, tam bistoricis quam philologis cognitu tam iucundae quam utiles. Coloniae Agrippinae, apud Gerhardum Greuenbruch, MCXIII. Quanto ao valor desta edição, no que respeita às Antiguidades da Lusitânia, é imprescindível consultar as observações feitas a este respeito por Anselmo Braamcamp Freire, na sua edição da biografia de Resende por Leitão Ferreira, A. H. P., VIII, p. 161, n. 54, que apoda estas edições de "quase fraudes», pois que repetem a edição de Colónia, da oficina Birckmânica, impressa em 1600. É desta edição de Greuenbruch que Leitão Ferreira fará uso. Cf. também na mesma publicação de BraamcampFreire a p. 350, n. 104. A última palavra sobre este problema é de J. V. Pina Martins, "Uma Edição Fictícia nas Obras Latinas de Resende», Arquivo do Centro Cultural de Paris, II (1970), pp. 549-554.

Hispaniae Illustratae seu rerum orbiumque Hispaniae, Lusitaniae, Aethiopiae et Indiae scriptores varii. Partim editi nunc primum, partim aucti atque emendati. ... Tomis aliquanto divisi. Opera et studio doctorum hominum. Francoforti, Apud Claudium Marnium et Haeredes Iohannes Aubrii, MDCIII. Esta edição de 1603 contém o De antiquitatibus Lusitaniae, no seu tomo II, e é conhecida de forma abreviada por Hispania Illustrata.

L. Andr. Resendii Eborensis De antiquitatibus Lusitaniae, caeteraque historica, quae extant, Opera, Conimbricensis Academiae jussu edita, ..., Conimbricae, ex Typographia AcademicoRegia, Anno MDCCXC. Esta edição de 1790, em formato bastante manuseável certamente com a finalidade de maior divulgação, é em dois volumes. As Antiguidades de Resende encontram-se no vol. I. A edição foi, segundo pensam Braamcamp Freire e Pina Martins, estabelecida com fundamento na edição de Colónia de 1600.

Cardoso, Maria Tereza Araújo de Andrade, - Antiguidades da Lusitânia de André de Resende (tradução e notas) [diss. lic.], Faculdade de Letras, Lisboa, 1971. 


\section{IV - Outras Obras mais consultadas de Resende ou sobre Resende}

Historia da antiguidade de Cidade de Évora fecta per meestre Andree de Reesende, 3. ${ }^{\mathrm{a}}$ ed., copiada da 2. ${ }^{a}$ ed. de 1576, Lisboa, Of. Simão Thaddeo Ferreira, 1783.

L. André de Resende, História da Antiguidade da Cidade de Évora, em Obras Portuguesas, pref. e notas de José Pereira Tavares, Lisboa, 1963, pp. 1-69 e a ed. latina acima referida, L. Andr. Resendii de antiquitatibus Eborae, in L. Andr. Resendii Eborensis Opera Historica, Coimbra, 1790, vol. II, pp. 295-352.

L. Andr. Resendii Pro Sanctis martyribus Vincentio, Olisiponensi Patrono, Vincentio, Sabina et Christhetide, Eborensibus civibus et ad quaedam alia responsio (Epistola ad Kebedium), in Opera Historica, Coimbra, 1790, vol. II, pp. 33-117. Edição recente e de excelente qualidade histórica e filológica por Virgínia Soares Pereira, André de Resende, Carta a Bartolomeu de Quevedo, Coimbra, 1988.

L. Andreae Resendii, Vicentius Levita et Martyr, in Opera Historica, Coimbra, 1790, vol. II, pp. 162-283, importante não só devido ao poema, como aos escólios sobre este elaborados, que contêm inúmeras informações históricas e arqueológicas. Edição actualizada e extremamente erudita e informativa de J. V. de Pina Martins, André de Resende. Vicentius Levita et Martyr. Reproduction en fac-simile de l'édition de Luís Rodrigues, Lisbonne, 1545, Braga, 1981.

A Vida de André de Resende de Diogo Mendes de Vasconcelos, que traduzimos do latim, aparece traduzida em vernáculo por Bento José de Sousa Farinha, na obra por este publicada, Colleçam das Antiguidades de Évora, escriptas por André de Rezende, Diogo Mendes de Vasconcelos, Gaspar Estaco, Fr. Bernardo Brito e Manoel Severim de Faria, Lisboa, Off. de Filippe de Silva e Azevedo, 1785.

Quanto a referências fortuitas a outros opúsculos de Resende, são elas tiradas dos dois volumes da edição de Coimbra de 1790 dos Opera Historica, já citados.

\section{V - Obras e trabalhos consultados}

ACropolites, Georgios

- Opera, ed. A. Heisenberg, Leipzig, 1903.

Aguiló, Cabré

- "La caetra y el sartam en Hispania durante la segunda Edad de Hierro",Boletín del

Seminario de Estudio de Arte y Arqueología, Valladolid, VI (1936-1940), p. 57 ss.

ALARCÃO, Jorge de

- O Domínio Romano em Portugal, Lisboa, s. d. (1988).

- "Os Montes Hermínios e os Lusitanos", in Livro da Homenagem a Orlando Ribeiro, Vol.

II, Lisboa, 1988, pp. 41-48.

- Portugal Romano, 4. ${ }^{a}$ ed., Lisboa, s.d. (1974).

Albertini, E.

- Les divisions administratives de l'Espagne romaine, Paris, 1923.

Albuquerque, Martim de

- A Consciência Nacional Portuguesa - Ensaio da História das Ideias Políticas, Vol. I, Lisboa, 1974

Albuquerque, R. M.

— "Peixes de Portugal e Ilhas Adjacentes», Portugaliae Acta Biologica (B), 5 (1954-56), $1-1164$.

AlCiATO

- D. Andreae Alciati... Paradoxorwn ad Pratum libri sex, Disfunctionum, lib. III, De eo quod interest, liber unus in tres Codicis, lib. III, Praetermissorum lib. II, Declamatio una, De Stip. divisionibus, Commentariolus, Lugduni, apud Sebastianum Gryphium, MCXXXVII.

- In P. Cornelium Tacitum B. Rhenani, Alciati ac Beroaldi. Eiusdem B. Rhenani thesaurus constructionum, locutionum et uocum Tacito solemnium, Lugduni apud Seb. Gryphium, 1542 . 
Almeida, Fortunato de

- História da Igreja em Portugal, Porto, 1968.

Alves Ferreira, Custódio de Morais e Amorim Girão

- "O mais Antigo Mapa de Portugal", Boletim do Centro de Estudos Geográficos, Coimbra, 12/13 (1956), pp. 1-65.

Amato Lusitano

— In Dioscoridis Anazarbei de medica materia libros quinque ... enarrationes eruditissimae,

Lugduni [Lião] apud Viduam Baetragaris Arnocetti, 1558.

Ambrósıo, S.

- Omnia quotquot extant Divi Ambrosii Episcopi Mediolanensis. Opera, per Des. Erasmum Roterodamum ... emendata, Basileia, 1538.

— Amphiteatrum Legale... seu Bibliotbeca Legalis Amplissima... Quinque Partibus Divisa... Authore Augustino Fontana,... Parmae, MDCLXXXVIII.

ANDRADE, Fernando Sommer de

- A Raça Bovina Transtagana, Sub-raça Alentejana, Lisboa, 1952.

ANDRADE, Ruy de

— "Les chevaux du Sorraia", in Comptes Rendus du XIIe Congrès International de Zoologie,

Lisboa, 1935, pp. 2368-2370. Separata, 1937.

ANDRÉ, J.

- Lexique des Termes de Botanique en Latin, Paris, 1956.

ANTONINO PIO

- Itineraria, Itineraria Romana, Vol. I, Itineraria Antonini Augusti, ..., ed. O. Cuntz, Leipzig, 1920.

António, Mestre

- Tratado sobre a província d'Antre Douro e Minbo e suas avondanças, ed. Luciano Ribeiro,

"Uma Descrição do Entre Douro e Minho por Mestre António», Boletim Cultural da Câmara

Municipal do Porto, XXII (1959), pp. 441-460.

ANTÓNIO, Nicolau

- Bibliotheca Hispania Vetus, Madrid, 1788

- Bibliotheca Hispana Nova, Madrid, 1783.

ANTunEs, J. Cunha

- Leitura Crítica do Tractatus in Apokalypsis de Apringio, Bispo da Igreja de Beja (diss.

dact.), Faculdade de Letras de Lisboa, 1973.

APIANO

- Historia Romana, ed. Petrus Candidus Decembrius, Veneza, 1472.

Apríngio de Beja. Ver, Antunes, J. Cunha, B. Férotin e Vega, A. C.

ÁrIAS, G.

- Portugal a la vista, Mil. Extr., 10 (1965).

- Notas complementares sobre las vias antoninianas de Portugal, Mil. Extr. 13 (1967).

BÁdio (BADE), Josse

- T. Livii... Tres cum dimidia quae solae extant Decades ... Adjectae sunt praeterea doctorum quorundam virorum lucubrationes ..., Lugduni, apud A. Vincentium, 1553.

BAPTista, Júlio César

— "São Mancos (Evolução Biográfica)», Cidade de Évora, Boletim de Cultura da Câmara Municipal, 63-64 (1980-1981), pp. 5-86.

BAQUERO MORENO

- "A Conspiração contra D. João II: o julgamento do duque de Bragança", in Arquivos do Centro Cultural Português, II (1970), Paris.

BARREIROS, Gaspar

- Chorographia de alguns lugares que stam em hum caminho, que fez Gaspar Barreiros ó anno MDXXXXVI começãdo na cidade de Badajoz em Castella, te à de Milam em Itália, cõ alguas outras obras, cujo catalogo vai scripto com os nomes dos dictos lugares, na folha seguinte, Coimbra, por João Álvares impressor, 1561, reeditado em 1968 por ordem da Universidade. 
BARRos, João de

- Geographia d'Antre Douro e Minho e Trás os Montes, Porto, Biblioteca Pública Municipal do Porto, 1919.

Biographie Nationale publiée par l'Académie Royale, Tomo I, Bruxelas, 1866.

Bloch, R. e Cousin, J.

- Roma e o seu Destino, Lisboa, 1964.

BRUHL, A

- Liber Pater, Paris, 1953.

Calisto, Nicéforo - Enarratio de Episcopis Byzantii et de patriarchis omnibus Cpolitanis, $P$.

G. (Migne), Vol. 147.

Carvalho, J. Barradas de

- O Renascimento Português (Em busca da sua Especificidade), Lisboa, 1980.

- À la recherche de la spécificité de la Renaissance Portugaise, Paris, 1983.

Castro Caldas, Eugénio

- A Agricultura Portuguesa Através dos Tempos, Lisboa, 1991.

CASTro, João Bautista de

- Mappa de Portugal Antigo e Moderno, I, parte I e II, 2. ${ }^{\text {a }}$ ed., Lisboa, 1762.

CATAlan, Diego e Andrés, Maria Soledad de

- Crónica del moro Rasis versión dei ajbár mulúk al-andaluz de abmad ibn muhamad ibn musa al-rási, 889-955; romanizada para el rey don dionis de portugal hacia 1300 por mohamad, alarife y gil pérez, clérigo de don perianes porcel, in Fuentes Cronísticas de Ia Historia de Espana, Vol. III, Madrid, 1974.

Catálogo de Incunábulos, Biblioteca Nacional de Lisboa, org. e índices por Maria Valentina C.

A. Sul Mendes, Lisboa, 1988.

Chronica mozarabica

- M. G. H., Chronica Minora, ed. Mommsen, Vol. II, Berlim, 1894, sob o título Continuationes Isidorianae, Byzantia, Arabica et Hispana.

- P. L. (Migne), 96, 1253-1280.

CinTRA, L. F. Lindley

- A Crónica Geral de Espanha, 1344, Vol. I, Lisboa, 1951.

— "Sobre a Formação da Lenda de Ourique (até à Crónica de 1419)", in Miscelânea de Estudos em Honra do Prof. Hernâni Cidade, Lisboa, 1957, pp. 168-215.

Coelho, M. H. da Cruz e Ventura, L.

- "Os bens de Vataça, Visibilidade de Uma Existência", Revista da História das Ideias, 9 (1987), Faculdade de Letras, Coimbra, pp. 33-77.

— "Vataça - Uma Dona na Vida e na Morte», Actas das II Jornadas Luso-Espanholas de História Medieval, Vol. I, Porto (1987), pp. 159-194.

CONIATES, Nicetas

- Liber de rebus post captum urbem gestis, P. G. (Migne), Vol. 139.

- Imperium Alexei Commeni Fratis Isacei Angeli e P. G. (Migne), Vol. 139.

Corominas, J, e Pascual, J. A.

- Diccionario Crítico Etimológico Castellano y Hispánico.

Corpus Signorum Imperii Romani - Corpus der Skulpturen der roemischen Welt, Coimbra, 1990.

Costa, Avelino de Jesus da

— "S. Pedro de Rates - Um Problema Litúrgico", Diário do Minho de 25 e 26 de Abril de 1948.

CRISTÓvão DE LisBOA, Frei

- História dos Animais e Árvores do Maranhão, publicada por F. Frade, em Garcia de Orta, 14 (1966), pp. 343-350.

Crusius - Rubenbauer

- Roemische Metrik, Munique, 1959-60.

Cruz, Frei Miguel da

- História da Índia, Coimbra, 1616. 
Cunha, A. Geraldo da

- Dicionário Histórico das Palavras Portuguesas de Origem Tupi, São Paulo, 1989.

Daveau, S. e Ribeiro, O.

— "Conhecimento Actual da História da geografia em Portugal", in História e Desenvolvimento em Portugal, Lisboa, 1986, pp. 1041-1060.

DiaZ y DiaZ, Manuel

- Index scriptorum Latinorum Medii Aevi Hispanorum, 2 vols., Madrid-Salamanca, 1959.

- La vida de San Fructuoso de Braga, estudio y edición crítica, Braga, 1974.

Dicionário de literatura espanola, ed. G. Bleiberg - J. Mariás, 4. ${ }^{a}$ ed., Madrid, 1972.

Dictionnaire d'Histoire et de Géographie Ecclésiastiques, ed. R. Aubert et A. van Caunenbergh, Vol. XV, Paris, 1963.

Dioscórides. Ver Amato Lusitano e Egnácio, J. B.

DREZLER, H.

— "Parerga Caesariana», Hermes, LXX (1935), pp. 203-234.

DuARTE NunES DE LEÃO

- Descripção do reino de Portugal, 2. ${ }^{a}$ ed., Lisboa, 1785.

EGNÁCIO, João Baptista

- Ioannis Baptistae Egnatti Veneti in Dioscoridem ab Hermolao Barbaro tralatum annotamenta. Quibus morborum et remediorum vocabula obscuriora in usum etiam mediocriter eruditorum explicantur.. Hermolai Barbari patricii Veneti et Patriarchae Aquileiensis Corollarium libris quinque absolutum. Accedit in Dioscoridem et Corollarium indexque copiosissimus, Veneza, 1516.

- De Caesaribus libri III, Florença, 1519 (1. ${ }^{\mathrm{a}}$ ed. 1516)

EINHARD (EGINARDO)

- Einhardi Vita Karoli Magni, Post G. H. Pertz recensuit G. Waitz, M. G. H., Scriptores, II, pp. 426-463; ed. Oswald Holder-Egger, Hanover-Leipzig, 1911 (reed. 1965).

- Vita Karoli Magni, ed. bilingue de E. Scherabon Firchow, Reclam, Estugarda, s. d. (1968).

ENCARNAÇão, José de

— "Da Invenção de Inscrições Romanas pelo Humanista André de Resende», Biblos, LXVII (1991), pp. 193-221.

- Inscrições Romanas do Conventus Pacensis, Coimbra, 1984, 2 vols.

Enciclopédia Italiana.

Enciclopédia Verbo.

ERNOUT-MEILLET

- Dictionnaire Étymologique de la langue latine, Paris, 1959-1960.

ESTÊVÃO DE BIZÂNCIO

- Ethnica, ed. A. Meinecke, Berlim, 1849 (reimp. Graz, 1958).

ESTRABÃO

- Strabonis Gnosii Amasini de situ orbis libri XVII e graeco traducti Gregorio Typlernale ac Guarino Veronense interpretibus, Venetiis, 1502, per Bartholomeum de Zanis de Porterio. Eulógio, S.

- Memoriale Sanctorum, II, ed. A. Morales, S. Eulogii Cordubensis Opera, Alcalá, 1574.

P. L. (Migne), 115 .

FEIO, Mariano

- Os Terraços do Guadiana a Jusante do Ardila, Lisboa, 1947.

FERNANDES, R. M. Rosado

— "André de Resende e o Humanismo Europeu", in Humanismo Português, 1500-1600, II

Centenário da Academia de Ciências, Lisboa, 1988, pp. 593-616.

- "Etimologia e sua Finalidade em André de Resende, De antiquitatibus Lusitaniae», in Homenagem a Joseph M. Piel, Tuebingen, 1988, pp. 237-250.

— "Méthodologie et Histoire dans le De antiquitatibus Lusitaniae d'André de Resende", in Humanisme Portugais et l'Europe, Paris, 1984, pp. 59-76.

- "O Episódio dos 'Trezentos Lusitanos Contra os Romanos' e a sua possível explicação", in Ocidente, LXXII (1967), pp. 278-284. 
— "O Vento, as Éguas da Lusitânia e os Autores Gregos e Latinos",Euphrosyne, II (1983/84), pp. 53-77.

- "O Vento, as Éguas de Lisboa e os Humanistas do Ocidente Peninsular", in Primera Reunión Gallega de Estudios Clasicos, Santiago de Compostela, 1981, pp. 369-388.

— "Solho, Esturjão ou *Asturjão no Guadiana”, in Estudos de Homenagem a Mariano Feio, Lisboa, 1986, pp. 627-648.

— "Ulisses em Lisboa", Euphrosyne, XIII (1985), pp. 139-161.

FÉROTIN, N.

- Apringius de Béja - Son commentaire de l'Apocalypse, Paris, 1900

FERREIRA, J.

- Origens do Lusitanismo na Península Hispânica - A Vila de Rates, Sua Igreja e Seu Mosteiro, Póvoa de Varzim, 1912.

Ferreira, Leitão. Ver Freire, A. Braamcamp.

FLOREZ, H.

- España Sagrada, Tomos I a XLI, Madrid, 1754-1798.

FLORIÃO DO CAMPO

- Los cinco libros primeros dela Cronica general de España, que recogila el maéstro ..., Medina del Campo, 1533.

Fontes Hispaniae Antiquae (F. H. A.)

- Fasc. I, 2. ${ }^{a}$ ed., Avieno, Ora Marítima (Périplo Massaliota del siglo VI a. de J.C.), ed. Adolfo Schulten, Barcelona, 1955.

- Fasc. II - 500 a. de J.C. hasta César, ed. Adolfo Schulten Barcelona, 1925.

- Fasc. III - Las guerras de 237-154 a. de J. C., ed. A. Schulten, Barcelona, 1935.

- Fasc. IV - Las guerras de 154-72 a. de J. C., ed. A. Schulten, Barcelona, 1937.

- Fasc. V - Las guerras de 72-19 a. de J. C., ed. A. Schulten, Barcelona. 194.

- Fasc. VI - Estrabon, Geografia de Iberia, ed., trad. com. A. Schulten, Barcelona, 1952.

- Fasc. VII - Deveria tratar de Plínio-o-Velho e a sua descrição da Hispânia. A informação recebida é de que não foi publicado.

- Fasc. VIII - Las fuentes desde César hasta el siglo V d. de J. C., ed. Roberto Grosse, Barcelona, 1959.

- Fasc. IX - Las fuentes de la época visigoda y byzantinas, ed. R. Grosse, Barcelona, 1947.

Fragmenta poetarum latinorum, ed. E. Baehrens-W. Morei, 2. ${ }^{\text {a }}$ ed. Leipzig, 1927, reed. 1963.

FonTANA, Augustino. Ver Amphiteatrum Legale.

FREIRE, A. Braamcamp

- Vida de André de Resende de Leitão Ferreira, Arquivo Histórico Português, VII (1909), pp. 339-417; VIII (1910), pp. 62-69; 161-184; 338-366; IX (1914), pp. 177-334. Também separata de 1916. As notas de Braamcamp Freire actualizam o importante trabalho de Leitão Ferreira, sobretudo "A Bibliografia Resendiana" e a "Cronologia Resendiana",IX (1914), pp. 286-334.

FREIRE, José Geraldes

— «Autenticidade da Inscrição do Torrão datada de 682 d.C. - Fidedignidade de André de Resende", Actas das III Jornadas de História Medieval do Algarve e Andaluzia, Loulé, 1989, pp. 197-216.

- Obra Poética de Diogo Mendes de Vasconcelos, Coimbra, 1962.

Gaio. Ver Justiniano.

GAMA BARROS

- História da Administração Pública em Portugal nos séculos XII a XV, ed. por T. de Sousa Soares, 11 vols., Lisboa, Liv. Sá da Costa, 1945-1954.

GÂNDAVO, Pêro Magalhães de

- "História da Província de Santa Cruz", Revista do Instituto Histórico e Geográfico Brasileiro,

21 (1858), pp. 329-388.

Garcia y Bellido, António

- España y los Españoles hace dos mil años, según la Geografía de Strabón, Buenos Aires

- México, 1980. 
- La España del siglo primero de nuestra era (según P. Mela y C. Plinio), Buenos Aires México, 1947.

- Veinticinco estampas de la España antigua, Buenos Aires - México, 1967.

GARCIA IGLÉSIAS, L.

— "El Guadiana y los limites comunes de Bética y Lusitania», Historia Antigua, II (1972), pp. $165-177$.

GEORGACAS, D. J.

- Ichtyological Terms for the Sturgeon and Etimology of the International Terms Botargo, Caviar and Congeneres (A linguistic, philological and culture-bistorical Study), Atenas, 1978 (Actas da Academia de Ciências de Atenas).

Gil DE SANTARÉM, Frei

- Conversio Miranda D. Aegidii Lusitani, Doctoris Parisiensis, Ordinis Praedicatorum. Está incluída no Thesaurus arcanus Lusitanis gemmis refulgens in quo Aegidii Magi olim theurgici stupenda historia, varilis exculta dialogis, atque aliorum S. Patrum Ord. Praed. ex ea Lusitania, gesta multaque alia scitu dignissima continentur, Paris, Thomas Perier, 1586, publicado por Fr. Estêvão de Sampaio. Ver Nascimento, A. e Ramalho, A. da Costa.

Góis, Damião de

- Crónica do Felicíssimo Rei Dom Manuel, 1. ${ }^{\mathrm{a}}$ edição, Lisboa, 1566.

GONÇALVES, F. Rebelo

- Vocabulário da Língua Portuguesa, Coimbra, 1966.

GONÇALVES, M. I. Rebelo

— "Nota Morfológica sobre o Lat. Cetus", Euphrosyne, I (1967), pp. 187-190.

GREGORAS, Nikéforos

- Byzantina Historia, ed. L. Schopen, I. Bekker, 3 vols., Bona, 1930-45.

Guerra, Amílcar

- Plínio-o-Velbo e a Lusitânia, Lisboa, 1995: o mais recente comentário do texto pliniano.

Guia de Portugal, começado a publicar pela Biblioteca Nacional de Lisboa em 1924, sobre todas as províncias portuguesas, e reeditado recentemente pela Fundação Gulbenkian.

Grande Dicionário de Literatura Portuguesa e de Teoria Literária. Direcção de João José Cochofel, Vol. I e parte do II, s.d. (1977).

Grimal, Pierre

- Dictionnaire de la Mythologie Greque et Latine, $4 .^{\mathrm{a}}$ ed., Paris, 1969.

Herculano, Alexandre

- História da Inquisição, Lisboa, 1907, 2 vols.

HERMOLAU BÁRBARO

- Ermolao Barbaro, Epistolae, Orationes et Carmina, edizione a cura di Vittore Branca, Vol. II, Florença, 1943.

- Hermolai Barbari castigationes in Plinium castigatissimae, Cremonae, 1495.

HISLAMP

- Autores Latinos Peninsulares da Época dos Descobrimentos (1350-1560), M. C. Díaz y

Díaz, Aires A. Nascimento, J. M. Díaz de Bustamante, M. I. Rebelo Gonçalves, J. E. López

Pereira, A. Espírito Santo. Lisboa, Imprensa Nacional, s. d. (1993).

Hispania Illustrata. Ver a bibliografia de A. Resende.

HUEBNER, E.

- Corpus Inscriptionum Latinarum (C. I. L), Vol. II, Hispania, Berlim, 1869.

Inscriptiones Hispaniae Christianae, Berlim, 1871.

HuERTA, Jerónimo de

- Historia Natural de Plinio, 2 vols., Madrid, 1624 e 162

Inscriptiones sacrosanctae uetustatis non illae quidem Romanae, sed totius fere orbis summo studio ac maximis impensis Terra Manque conquisitae feliciter incipiunt. Magnifico Viro Domino Raymundo Fuggero invictissimorum. Caesaris Caroli Quinti ac Ferdinandi Romanorum regis a Consilüs bonarum litterarum Mecaenati incomparabili Petrus Apianus Mathematicus Ingolstadiensis F. Bartholomeus Amantius Poeta DED. Ingolstatii in aedibus P. Apiani, anno M.D.XXXIIII. 
IORDANES

- Iordanis Romana et Getica, M. G. H., Auctorum antiquissimorum tomi V pars prior, Berlim, 1882, reed. Weidmann, 1961.

ISIDORO DE BEJA

- M. G. H., Chronica Minora, ed. Mommsen, Vol. II, Berlim, 1894.

JACOBY, F.

- Die Fragmente der griechischen Historiker, Berlim e Leiden, desde 1923.

Jacob, E. F. Ver Mitchell, C.

JANVIER, Y.

- La Géographie d'Orose, Paris, 1982.

Jóvio, Paulo

— Pauli Iouii Comensis medici, De romanis piscibus libellus, Basileia, 1531.

Julĩ̃o, Bispo

- Historia Wambae regis auctore Iuliano episcopo, ed. W. Levison, M. G. H., Sriptorum Rerum Merovingicarum, V, pp. 486-535.

JUSTINIANO

- Brachylogos totius uiris civilis, Lugduni, 1553.

- Justiniani digestorum libri L, Florença, 1553, 3 vols.

- Volumen legum, Parvum quod vocant in quo baec insunt tres posteriores libri codicis Justiniani, ..., Venetiis, 1553.

Kampen, A. van Atlas antiquus, Gotha, s.d.

KRANTZ, Alberto

- A. Krantzii viri in theologia et iure pontificio celeberrimi, bistoricique clarissimi, Wandalia, De Wandalorum vera origine, variis gentibus, crebris e patria migrationibus, regnis item, quorum uel autores uel eversores fuerunt... Francofurti, ex officina typographica Andreae Wecheli, MDLXXV.

LAMBRINO, Scarlat

— "Le dieu lusitanien Endovellicus», Bulletin des Études Portugaises, XV (1951), pp. 93146.

— «Les Lusitaniens», Euphrosyne, I (1955), pp. 117-145.

— "Les Celtes dans Ia Péninsule Ibérique selon Aviénus", Bulletin des Études Portugaises, XIX (1956), pp. 7-33

LATINI, Latino

- Lucubrationes, Vol. II, Viterbo, 1667.

Leal, Augusto Pinho

- Portugal Antigo e Moderno, Lisboa, 1874.

LEVÊQUE, P.

- A Aventura Grega, Lisboa, 1967.

Lima, Jacinto Leitão Manso de

- Famílias do Reino de Portugal.

Livro Santo de Santa Cruz, ed. por Leontina Ventura e Ana Santiago Faria, Coimbra, 1990.

Losada, Angel

- J. G. de Sepúlveda a través de su "Epistolario"y nuevos documentos, Madrid, 1949.

Os Lusíadas 1572-1972, Catálogo da Exposição Bibliográfica ... Biblioteca Nacional de Lisboa, Lisboa, 1972

MACEDO, Diogo de

- Nobiliário, BNL/RES/POMB., COD. 367.

MaChado, Diogo Barbosa

- Biblioteca Lusitana, Coimbra, 1965 (reed. de Lisboa, 1741), 4 vols.

MaChado, José Pedro

- Dicionário Etimológico da Língua Portuguesa, 3. ${ }^{\text {a }}$ ed., Lisboa, 1977, 5 vols.

- Dicionário Onomástico Etimológico da Língua Portuguesa, Lisboa, s.d., 3 vols.

- Influência Arábica no Vocabulário Português, Vol. 2, Lisboa, 1961. 
MagalHÃEs, J. Romero de

— "As descrições geográficas de Portugal: 1500-1650. Esboço de Problemas", Revista da História Económica e Social, 1980, pp. 15-56.

MaIA, Manuel

— "Celtici e Turduli nas Fontes Clássicas", in Actas dei III Colóquio sobre Lenguas y Culturas Paleobispánicas, Salamanca, 1985.

MANITIVS, M.

- Geschichte der lateinischen Literatur des Mittelalters, Vol. I, Munique, 1911 (reed. 1974).

MANTVANO, Baptista

- BAPTISTAE MANTVANI CAR / MELITANAE THEOLOGI / AGELARIORVM LIBRI SEX. / AD CONSAIVVM [sic] FER / DINANDVM AGE / LARIVM DVCEM / INVICTIS / SIMVM., Foi. GG iiij (vv. 16-30) in Vltima Pars ope/ris Baptistae Man/tuani Carmelitae./ Impressum. In Florentissima Lugdunensi Ciuitate,/ Solertia. Stephani de Basignana. Gorgoni Car/melitae. Doctoris. Theologi. In officina./ Bernardi Lescuyer./ Anno Domini Millesimo quingentesi/ mo Decimo sexto. Die vero vigesima/ prima mensis Iulij./ 1516.

MARIANA S. J., João

- Historiae de rebus Hispaniae, libri XX, in Hispania Illustrata, Vol. II, Frankfurt, 1603.

MARLIANO, Bartolomeu

- Topographia antiquae Romae, Lugduni, 1534.

MARTINS, Isaltina das Dores Figueiredo

- Bibliografia do Humanismo em Portugal no Século XVI, Coimbra, 1986.

- O Poema "De Patientia Christiana" de Jorge Coelbo, Coimbra, 1974 (dissertação de licenciatura, dactilografada).

Matos, Luís de

- L'expansion portugaise dans la littérature latine de la Renaissance, Lisboa, 1991.

— "O Ensino na Corte durante a Dinastia de Avis", in O Humanismo Português, 1500-1600,

Primeiro Simpósio Nacional, Lisboa, 1988, pp. 499-592.

MatToso, J.

— Identificação de um País. Ensaio sobre as Origens de Portugal, II, Composição, Lisboa, 1985.

MAYER, Ruy

- As Geórgicas de Vergílio, Lisboa, 1948.

Mitchell, C.

- "Archeology and Romance in Renaissance Italy", in Italian Rennaissance Studies, ed. E.

F. Jacob, Londres, s.d. (1960), pp. 445-483.

MORAIS, Cristóvão Alão de

- Pedatura Lusitana-Hispânica em que se Contêm Várias Famílias Nobres e Ilustres, Porto, 1943-48, 12 vols.

Morales, Ambrósio de

- De la Coronica General de España, que continuava Ambrósio de Morales, natural de Cordova, coronista del Rey Catholico nuestro Señor don Philipe segundo deste nombre, y cathedratico de Rethorica en Ia Universidad de Alcalá de Henares... en Alcalá de Henares. En casa de Juan Iñiguez de Lequerica, 1574. Ver Eulógio, S.

Muller, C. e Th.

- Fragmenta Historicorum Graecorum, Paris, Firmin Didot, 1841-1870.

NASCimento, Aires do

- A Vida do Bem-Aventurado Gil de Santarém, por Fr. Baltazar de S. João, Lisboa, 1982.

- Vita S. Marini Saurensis, Índices, concordância, análise linguística-dados estatísticos, Lisboa, 1977.

NASCEnTES, Antenor

- Dicionário Etimológico da Língua Portuguesa, Tomo II (Nomes Próprios), Rio de Janeiro, 1952.

Neue Deutsche Biographie, Berlim, Vol. XII.

New Catholic Encyclopaedia. 
NoBre, A.

- Fauna Marinha de Portugal, I - Vertebrados, Barcelos, 1935.

Nouvelle Biographie Générale, Tomo XX, Firmin, Didot Frères, Paris, 1857.

Oliveira, Francisco

— "Imagem da Hispânia em Plínio o Antigo", in II Congresso Peninsular de História Antiga, Coimbra, s.d. (1990), separata.

Oliveira, Miguel de

— "Santa Iria e Santarém», Revista Portuguesa de História, VII (1957), pp. 439-470.

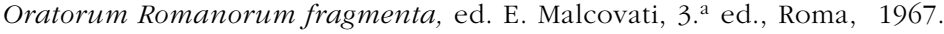

Orósio, Paulo

- Historiarum adversum paganos libri VII, ed. C. Zangemeister, C.S.E.L., V, Viena, 1882, reed. em Hildesheim, 1967.

The Oxford Dictionary of Byzantium, ed. Alexander P. Kazhdan et alii, Oxford, 1991, 3 vols. PACHYMERos, Georgios

- De Michaelo et Andronico Paleologis, ed. I. Bekker, 2 vols., Bona, 1835.

PANVÍNIO, Onofre

- Onuphrii Panvinii Veronensis fratis eremitae augustiniani... Fastorum libri V a Romulo rege usque ad Imp. Caesarem Carolum V Austrium Augustum. Eiusdem in fastorum libros commentarii... Onuphrii Panvinii... commentariorum in fastos consulares Appendix ...In Verri Flacci triumphalium consulariumque tabularum fragmenta ...De antiquis Romanorum nominibus ex officina Erasminiana Vicentij Valgrisij, Veneza, 1558 [Bibl. Nac. Paris, 1105 (1)]

PAPPE, W. - Benseler, G.

- Wörterbuch der griechischen Eigennamen, Braunschweig, 1911 (reimp. Graz, 1959).

PEREIRA, Cândido Aparício

- Subsídios para a História do Humanismo em Portugal - Pedro e Rodrigo Sanches, Coimbra, 1955 (tese de licenciatura, dactilografada).

PEREIRA, Duarte Pacheco

- Esmeraldo de situ orbis, Academia Portuguesa de História, ed. João Franco Machado e Damião Peres, Lisboa, 1954-1955.

- Esmeraldo de situ orbis, ed. Joaquim Barradas de Carvalho, Lisboa, 1991.

PEREIRA, Maria Helena da Rocha

- Vida e Milagres de São Rosendo, Porto, 1970.

PereIrA, V. Soares. Ver supra bibliografia de A. Resende, Carta a Bartolomeu de Quevedo.

— "Uma Carta de André de Resende Reconstituída», Humanitas, XXXIX-XL (1987-88), p. 211-232.

PETER, H. Ver Siglas, H. R. R.

- Warheit und Kunst, Geschichtschreibung und Plagiat im klassischen Altertum, LeipzigBerlim, 1911.

PFLUG, Julius

- Correspondance, 4 vols., Leiden, 1969-1979.

PIEL, J. M.

— "Os Nomes Germânicos na Toponímia Portuguesa", Boletim de Filologia, V (1939), pp. 51 e 53.

Pigafeta, Filipe

- Relação do reino do Congo e das Terras Circunvizinhas, ed. e trad. de Rosa Capiaens, Lisboa, 1951

- Relatione dei reame di Congo et delle circonvicine contrade tratta dalli scritti et ragionamenti di Odoardo Lopez, Portoghese per Filippo Pigafetta, Roma. 1591

PinHo, S. Tavares de

- "André de Resende e o Cardeal D. Afonso, em torno do sermão pregado no Sínodo de Évora de 1534", Eborensia, I (1988), pp. 39-70.

— "Baptista Mantuano na literatura do século XVI em Portugal», Humanitas, XLI-XLII (1990), pp. 3-29. 
PINTO, S. da Silva

- O Problema de S. Pedro Mártir, 1 Bispo de Braga, Braga, 1958.

POLÍBIO

- Polybii Lycortae historiaram libri V, opera Vincentii Obsopoei in lucem editi, graece, Idem

lat. Nic. Perotto interprete, Hagenoae, per Johan. Secerium, 1530.

Pompónio Mela. Ver Vadiano, G.

POWELL, J. V.

- Collectanea Alexandrina, Oxford, 1927.

Ptolomeu, Cláudio

- Geographia, ed. C. F. A. Nobbe, Leipzig, 1843-5 (reimp. Olms, Hildesheim, 1966).

QUÉTIF, J e ECHARD, F. J.

- Scriptorum Ordinis Praedicatorum, Vol. II, Paris, 1721.

Ramalho, A. da Costa

- "A conversão Maravilhosa do Português D. Gil - Um Diálogo Latino quase ignorado -

Da Autoria de André de Resende", Revista da Universidade de Coimbra, XXVII (1983), pp.

239-262.

- Estudos Sobre o século XVI, Lisboa, 1983.

- Latim Renascentista em Portugal, Coimbra, 1985.

— «Lucius Andreas Resendius. Porquê Lucius?», Humanitas, XXI-XXII (1969-70), pp. 353364.

— "Martim de Figueiredo e Erasmo",Humanitas, XXIX-XXX (1977-78), pp. 221-222.

- Para a História do Humanismo em Portugal, Vol. I, Coimbra, 1988, Vol. II, Lisboa, 1994.

RAU, Virgínia

- A Exploração e o Comércio de Sal de Setúbal, Vol I, Lisboa, 1951.

Rebelo, L. Sousa

- "A Lenda do Rei Bamba: Parábola do Poder Real",Arquivo do Centro Cultural Português,

XXIII (1987), pp. 303-317.

Ribeiro, Luciano. Ver Mestre ANTÓNIO.

RIBEIRO, O.

— "Excursão à Arrábida", Finisterra, III, 6 (1968), pp. 257-273. Ver Daveau, S.

RODRIGUES HERRERA, I.

- Poeta christianus. Esencia y misión del poeta cristiano en la obra de Prudencio, Salamanca,

1981 (col. Helmantica).

Roldán Hervás, José Manuel

-Itineraria Hispana. Fuentes antiguas para el estudio de las vias romanas en la Península

Ibérica, anejo de Hispania Antigua, Madrid, 1975.

RONDELET, Guilherme

- Gulielmi Rondeletti Doctoris mediei et medicinae in schola Monspeliensi Professoris regii,

Libri de piscibus marinis, in quibus uerae piscium effigies expressae sunt, Lugduni, 1554.

ROSCHER, W.

- Ausführliches Lexikon der griechischen und römischen Mythologie, Leipzig, 1884-1937.

Rosendo, R. Ver Pereira, M. H. Rocha.

RUEDA, J. Lopez

- Helenistas Españoles del Siglo XVI, Madrid, 1973.

SÁA, Mário

- As Grandes Vias da Lusitânia, O Itinerário de Antonino Pio, Lisboa, 1956-1964 (6 vols.).

SABÉLICO, Marcantonio Coccio

- Coronica geral de Marcantonio ... Des ho começo do mundo, até nosso tempo. Tresladada em lingoage Portugues por Dona Lianor filha do Marques de Vila Real D. Fernando, Coimbra, 1550.

- Enneades seu rhapsodiae historiarum, Venetiis, 1498-1504.

SAINT-DENIS, E.

- Le Vocabulaire des animaux marins en latin classique, Paris, 1947. 
SANDYS, J. E.

- Latin Epigraphy, 2. ${ }^{a}$ ed., Cambridge, 1927, reed. Groningen, 1969.

SANTARÉM, Visconde de

- Quadro Elementar das Relações Políticas e Diplomáticas de Portugal com as diversas

Potências do Mundo, Paris, 1843.

SAUVAGE, Odette

- L'Itinéraire Érasmien d'André de Resende, Paris, 1971.

SHANZ-HOSIUS

- Geschichte der römischen Literatur, Vol. IV, 1. Munique, 1914 (2. ${ }^{\text {a }}$ ed. 1959).

SCHMIDT, K. H.

- "A Contribution to the Identification of Lusitanian", in Actas del III Coloquio sobre lenguas paleohispánicas, Salamanca, 1985, pp. 319-341.

SCHNABEL, Paul

- Berossos und die babylonisch-bellenistiche Literatur, Leipzig, 1923 (Hildesheim, 1968).

Schulten, A.

- Sertorius, Leipzig, 1926.

- Viriatus. Trad. de A. Ataíde, Porto, 1940.

Sepúlveda, Juan Ginés de

- Ioannis Genesii Sepulvedae Cordubensis ... Opera ... omnia, Colónia, 1602.

SigONius, Carolus

- In Fastos ac Triumphos Romanos commentarius, Basileia, 1569 (incorporado frequentemente nas edições de O. Panvínio).

Silva, Nuno J. Espinosa Gomes da

- Humanismo e Direito em Portugal no Século XVI, Lisboa, 1964.

SOLINO

- Collectanea rerum memorabilium, ed. Th. Mommsen, 1. ${ }^{\mathrm{a}}$ ed., Berlim, 1895, 4. ${ }^{\mathrm{a}}$ ed., Weidmann, Berlim, 1979.

STROHEKER, K. F.

— «Spanien im spätrömischen Reich (284-475)", Archivo Español de Archeología, 45-47 (1972-1974), 587 ss

TARAFA, Francisco

- De origine a rebus gestis Regum Hispaniae, Antuérpia, 1553, publicado in Hispania Illustrata, Vol. I, p. 524 ss, Frankfurt, 1603.

TArouca, C. da Silva

— "S. Manços, $1 .^{\circ}$ Bispo de Évora? Tradição Local Autêntica ou Falsificação Sistemática de Fontes?», Brotéria, 42 (1946), pp. 5-13

TeIllet, S.

- Des Goths à la nation Gothique. Les origines de l'idée de nation en Occident du V au VI siècle, Paris, 1984.

TeOdoro de Gaza

- In hoc uolumine baec Continentur, Aristotelis, De historia animalium libri XI; De partibus animalium et earum causis libri III; De generatione animalium libri V; Theodoro Gaza interprete, De communi animalium gressu liber I; De communi animalium motu, liber I. Paris, Ex officina Simonis Colinaei,1533.

Terra, José da Silva

— "Espagnols au Portugal au temps de la Reine D. Catarina, I - D. Julião de Alva (c. 15001570), Arquivo do Centro Cultural Português, IX (1975), pp. 417-506.

- "O Humanista Português Jorge Coelho e a sua Correspondência com os Cardeais Bembo e Sadoleto", Mélanges André Jouda-Ruan, Univ. Provence, 1978, pp. 1133-1160.

Thesaurus Linguae Latinae, Munique, 1900 em diante.

TOVAR, A.

- Iberische Landeskunde, Band 1: Baetica; Band 2: Lusitanien, Baden-Baden, 1974-76; Segunda Parte, Las tribus y las ciudades de Ia antigua Hispania, Tomo 3, Tarraconensis, Baden-Baden, 1989. 
Tovar, A. e Blazquez, J. M.

- Historia de la Hispania Romana, Madrid, s.d. (1975).

VADIANO (WATT), Joaquim

- Pomponii Melae de orbis situ libri tres acuratissime emendatis, una cum commentariis Ioachimi Vadiani Helvetii castigatioribus, Basileia, 1522.

VAsConcelos, Carolina Michaëlis de

— "André de Resende e a Crónica do Mouro Rasis",Archeólogo Português, XXIV (1920), pp.

177-193.

- A Infanta D. Maria de Portugal e as Suas Damas, Porto, 1902.

VASCONCElos, José Leite de

- As Religiões da Lusitânia, Lisboa, 1907-1913, 3 vols. + 1 vol. de índices.

VASEU, João

- Chronici rerum memorabilium Hispaniae tomus prior. Auctore Ioanne Vasaeo Burgensi bumaniorum literarum in Salmanticensi Academia professore. Salmanticae, excudebat Ioannes Iunta, 1552. Publicado igualmente no Tomo I da Hispania Illustrata, pp. 572-726.

VAZQuez de PARga, L. La División de Wamba. Contribuición al estudio de la Historia y Geografía eclesiásticas de la Edad Media española, Madrid, 1943.

VEGA, A. C.

- Apringii Pacencis Episcopi Tractatus in Apocalypsis, Scriptores Ecclesiastici Hispano-Latini Veteris et Medü Aevii, Fascs. X-XI, Escorial, 1940.

Ventura, Leontina. Ver Coelho, M. H. da Cruz.

VIEJo OTERo, E.

— "C. I. L. II 4658 en una carta inédita de Juan Ginés de Sepúlveda", Emérita, X (1942), pp. 345-348.

Viterbo, João Ânio de

- Berosi sacerdotis chaldaici, Antiquitatum libri quinque, cum commentariis Ioannis Annii Viterbensis sacrae Theologiae professoris, nunc primum in antiquitatum studiorum commoditatem, sub forma Enchiridii excusi et castigati ..., Antuérpia, 1545.

- Commentaria super opera diversorum de Antiquitatibus loquentium, Roma, 1498.

Antiquitatum variarum volumina XVII a venerando et sacrae theologiae et praedicatoris ordinis professore J. Annio hac serie declarata, venundantur ab Joanne Parvo et Jodoco Badio, Biblioteca Real de Bruxelas INC B 581 s.d. depois publicado em Paris, 1512 e 1515 e Antuérpia, 1545.

Vieira, A. X. L.,

— "Catálogo dos Peixes de Portugal",Annales Scientiarum Naturalium, 4 (1898), pp. 1-87 (separata).

VIVES, J.

- Concilios visisigóticos y hispano-romanos, ed. José Vives, Madrid-Barcelona, 1963.

- Inscriptiones cristianas de la España romana y visigótica, Barcelona, 1942.

WALBANK, F. W.

- A Historical Commentary on Polybius, Oxford, 1957, etc.

WESTERMANN

- Grosser Atlas zur Weltgeschichte, Braunschweig, 1956, 10. ${ }^{\text {a }}$ ed., 1978.

WINDUKIND VON KORVEI

- Winderkindi monachi Corbeiensis Rerum gestarum Saxonicarum libri III, ed. P. Hirsch e Haus-Everhard Lohmann, M. G. H., Munique, 935 (reed. 1977). Também ed. G. Waitz, M. G. M. Scriptores, III, p. 408 ss.

ZONARAS, Ioannes

- Epitome Historiarum, ed. L. Dindorf, Leipzig, ou P. G. (Migne), II, 253.

Zurita VAlentim, Jerónimo

- Los cinco libros de la primera parte de los Anales de la Corona de Aragón, Saragoça,

1562, Los cinco libros posteros de la primera parte, Saragoça, 1562. 


\section{ÍNDICE \\ DOS PASSOS CITADOS DE AUTORES GRECO-LATINOS}

A enumeração dos loci citati faz-se pela simples indicação do número da nota em que aparecem, no seguimento de cada um dos quatro livros de Resende ou da abreviatura dos textos iniciais ou dos escólios finais. Pelo número da nota poderá o leitor facilmente localizar a página do De antiquitatibus, em que Resende cita e comenta a sua fonte greco-latina.

S. Ambrósio

Sermo XXX, De Sancta Quadragesima, XIV, II, n. 39

Hexaemeron, V, 3, 6, 81 F, II, n. 40.

Arniano Marcelino

XXIII, 5, 16: III, n. 150; XXVI, 9, 9: III, n. 182.

Apiano

Bella ciuilia, II, 8, 65, 67; 10, 85, 62; 13, 107, 108-114, I, n. 10; III, n. 169, 176, 178; II, 15, 105, III, n. 202; IV, 11, 83, 88, III, n. 206, 207.

Iberica, VI, 2,66;10,58; 12,71; 15,91; III, n. 57, 88, 105; II, n. 134, 109.

Aristóteles

Historia animalium, II, 13, 505 a, II, n. 33; IX, 15, 44, II, n. 10.

\section{Arriano}

Anabasis, II, 16, 5, III, n. 4.

Ateneu

Deipnosofistas, I, II, n. 149; III, 118 b-c, II, n. 16; VII, 294 f, II, n. 27, 31; 302, I, n. 10; 312 b-c, 315, e, II, n. 16; 327 f, II, n. 38; VIII, 330 c, II, n. 73; 331 b-c, II, n. 148.

Aulo Gélio

Noctes Atticae, IV, 15, 1, Carta Cardeal D. Afonso, n. 3. VII, 16, II, n. 30.
Ausónio

Camina, X, Mosella, 127, II, n. 78.

De bello Alexandrino, 48, I, n. 191.

Bellum Hispniense, 17, III, n. 201; 19, 4, III, n. 192; 39, 1, III, n. 203; 40, 1, III, n. 205 .

Cassiodoro, Aurélio

Chronica, 55-57, II, n. 264.

Catão

Frags., 106-1 10, Origines, VII (Peter), I, LI (Malcovati), III, n. 99; 196-198 (Malcovati), I, n. 36.

Catulo

Carmina, 14, 1-2, Vida A. R., n. 21; 26, 18-19, III, n. 189.

César

De bello ciuili, I, 38, I, n. 67; 43-44, III, n. 196, 200; 48, I, n. 155, 156

De bello Gallico, III, 20, III, n. 173

Cícero

Brutus, XXI, 80, III, n. 97; 84, III, n. 126; XXII, 89-90, I, n. 136.

De diuinatione, XX, 66, I, n. 137; III, n. 97. Epistulae ad familiares, XXXIII, 3, n. 213.

De fato, frag. V, II, n. 20.

De lege agraria, II, 19, 51, II, n. 86; 30, II, n. 186.

De natura deorum, 3, 45, I, n. 6. 
De oficiis, I, 30, 108, I, n. 148; II, 11, 40, III, n. 125 .

De oratore, I, 227, I, n. 136.

In Verrem, 11, 4, 57, 128, I, n. 6.

C. I. L.

I - 1, III, n. 164,$185 ; 1$, p. 26, III, n. 157.

II $-3^{*}$, IV, n. $41 ; 4^{*}$, IV, n. $89 ; 5^{*}$, II, n. 118; 6*, IV, n. 121; 7*, IV, n. 122; 8*, 111, n. 266; II, 9*, IV, n. 86; 17*, III, n. 278; $18^{*}$, I, n. 80; 20*, III, n. 139; 21*, III, n. 136; 22*, II, n. 95; 25*, III, n. 50; 30*, I, n. $176 ; 40^{*}, \mathrm{XI}, \mathrm{III}$, n. $142 ; 51^{*}$, III, n. 140 ; $75^{*}$, I, n. 121; 101*, IV, n. 6; 432*, III, n. 273; 433*, III, n. 268; 434*, III, n. 267; $435^{*}$, III, n. 277; 436*, III, n. 271; 439*, III, n. $282 ; 441^{*}$, III, n. 288; 489*, IV, n. 87; - p. XIV, n. 28, III, n. 137; 1, IV, n. 27; 2, IV, n. 30; 3, IV, n. 29; 4, IV, n. 28; 26, IV, n. $40 ; 30, I V$, n. $90 ; 31, I V$, n. $88 ; 32, I V$, n. $117 ; 37$, IV, n. $119 ; 41$, IV, n. 56; 47, IV, n. $76 ; 48, I V$, n. $74 ; 49, I V$, n. 68; 52, IV, n. $67 ; 55, \mathrm{IV}$, n. $71 ; 56, \mathrm{IV}$, n. $68 ; 60, \mathrm{IV}$, n. $75 ; 61, \mathrm{IV}$, n. $73 ; 64(=5188), \mathrm{IV}$, n. 72 ; 66, IV, n. 70; 94, IV, n. 120; 102, IV, n. 78; 112, III, n. 270; 114, I, n. 12; 127, IV, n. 104; 129, IV, n. 107; 131, IV, n. 103; 132, IV, n. $109 ; 134$, IV, n. 110; 135, IV, n. 92, 105; 136, IV, n. 106; 139, IV, n. 108; 143, IV, n. 92, 100; 144, IV, n. 99; 145, IV, n. 101; 147, IV, n. 114; 148, IV, n. 102; 152, IV, n. 96; 153, IV, n. 97; 154, IV, n. 92; 212, II, n. 149; 250, I, n. 173; 259, I, n. 174; 555, IV, n. 94; 760, I, n. 121; II, n. 136; 823, I, n. 83; 929, I, n. 84; 963, IV, n. 3; 967, IV, n. 9, 10; 968, IV, n. 8; 1023, IV, n. 2; 2477, II, n. 128, 137, 162; 2516, II, n. 128 ; 2517, II, n. 128; 3884, I, n. 82; 4268, III, n. 110; 5616, I, n. 162; 4634, III, n. 283,$284 ; 6435$, III, n. 286; 4636, III, n. 285; 6437, III, n. 287;

V - 5267, III, n. 226; 2, 7425, III, n. 228. VI - 1, p. XLVI, auctor n. ${ }^{\circ}$ XXI, IV, n. 7; 24720, IV , n. 7;

X - 1, 6087, III, n. 198.

Claudiano

Louvores à Rainha Serena, 70-73, II, $117 \mathrm{e}$ 118 ;

In Rufinum, I, 310 ss., III, n. 250.

Columela

De re rustica, VI, 27,4-7, I, n. 181 ; VII, 16, 9, II, n. 28.
Diodoro Sículo

Biblioteca, V, 43, 4, I, n. 124; XXV, 10, III, n. 14.

\section{Dion Cássio}

História Romana, VII, 15,91, II, n. 109; XXXVII, 52, I, n. 205; II, n. 109; 52, 3, I, n. 149; 52-53, 26, I, n. 149; XLIII, 33, III, n. 193; LIII, 12, 3-11, III, n. 216; LVII, 19, 4, III, n. 108; LXVI, 29,5, III, n. 108 .

Dioscórides

De medica materia, IV, 1, I, n. 91.

Donato

Vita Vergilii, 80, 81-82, Carta Cardeal D.

Henrique, n. 4.

Eliano

De natura animalium, VII, 28, II, n. 19, 29; XII, 29, II, n. 10; XIV, 26, II, n. 29.

Eratóstenes

Frag. 12, 3 (Powell), II, n. 21.

Estesícoro

Frags. 181 ss. (Page), III, n. 5; 184 (Page), II, n. 90 .

Estevão de Bizâncio

Ethnika (ed. Meinecke), p. 161; 229, 3; I 324, 2; 419, 15, I, n. 9; p. 161, 20, I, n. 14; 156, 9, 11, n. 91.

Estrabão

Geografia, II, 120-3, I, n. 10; II, 153, I, n. 10; III, 1, 4, IV, n. 31; III, 1, 6, I, n. 49, 59; IV, n. 13; III, 2, 9, I, n. 107; III, 2, 11, II, n. 90; III, 2, 14, III, n. 3; III, 2, 15, IV, n. 62; III, 2 e 3, I, n. 64, 73; III, 3, 1, II, n. 67; III, 3, 2, I, n. 85; II, n. 109; III, 3, 3, I, n. 18, 20, 125; III, 3, 4, I, n. 13; II, n. 1, 100, 127, 134; III, n. 154; III, 3, 5, I, n. 35, 54; III, 3, 6-7, I, n. 150, 152, 153, 154; III, 4, 3, I, n. 165; III, 4, 6, III, n. 18; III, 4, 13, I, n. 16, 130; III, 4, 20, I, n. 4; III, 5, 15, III, n. 165; III, 5, 158, III, n. 124; 111, 14, IV, n. 38; IV, 2, IV, n. 92; VII, 3, 18, II, n. 47; XVII, 2, 4, 5, II, n. 12, 13, 43.

\section{Eurípides}

Hercules furens, 822, 834, I, n. 7;

Bacantes, 977, I, n. 7. 
Eusébio de Cesareia

Chronicon, II, col. 405 e, 419 k, 421, III, n. 26.

Eustácio de Tessalonica

Commentarium in Dionysum Periegetem, p. 558, III, n. 4.

Eutrópio

Breuiarium, IV, 9, III, n. 89; 16, III, n. 116; VII, 14, I, n. 112; 16, III, n. 107.

Floro

Epitomae, I, 33, 12, TI, n. 130; 33, 13, I, n.144; 33, 15, I, n.115, III, n. 113; 33, 17, III, n. 134; II, 10, III, n. 170; 10, 22, III, n. 166; 33, 49, I, n. 219.

Frontão

Epistula ad M. Caesarem, 3, 20, II, n. 101.

Frontino

Stratagemata, I, 10, 1-2, III, n. 172; II, 5, 7, III, n. 120; II, 5, 31, III, n. 172.

Gaio

Instituta, 10, 66 (6), I, n. 115.

Galeno

De alimentorum facultatibus, 15, 12-21 e 4-11, II, n. 17.

Methodus medendi, IX, 8, III, n. 259.

Hecateu de Mileto

Genealogias, frag. 30 (Nenci) ou I, 26 (Jacoby), II, n. 4.

Heródoto

História, I, 163-165, III, n. 3; IV, 53, II, n. 48.

Homero

Iliada, XVI, 407, II, n. 29.

Horácio

Odes, I, 3, 8, Vida A. R., n. 21; I, 7, III, n. 196.

Sátiras, II, 5, 44, IV, n. 55.

Arte Poética, 387, Carta Cardeal D. Henrique, n. 3.

Inscrições Romanas do Conventus Pacensis N. ${ }^{\text {os }} 3$, IV, n. 27; 7, I, n. 10; 11, IV, n. 30; 18, IV, n. 28; 40, IV, n. 29; 154, IV, n. 40; 180, IV, n. 90; 181, IV, n. 88; 183, IV, n. 117; 196, IV, n. 119; 210, IV, n. 6; 213, IV, n. $6 ; 211$, IV, n. 56; 232, IV, n. 74; 233, IV, n. 67; 234, IV, n. 68; 236, IV, n. 69; 242, IV, n. 71; 248, I, n. 80; 263, IV, n. 75; 260, IV, n. 72; 265, IV, n. 73; 271, IV, n. 70; 291, IV, n. 76; 313, IV, n. 78; 334, IV, n. 120; 382, III, n. 270; 397, IV, n. 6; p. 442 , I, n. $12 ; 465$, IV, n. 114; 446, IV, n. 102; 483, IV, n. 104; 488, IV, n. 107; 492, IV, n. 103; 494, IV, n. 109; 497, IV, n. 6; 508, IV, n. $110 ; 510$, IV, n. $105 ; 514$, IV, n. 106; 526, IV, n. 108; 570, IV, n. 100; 571, IV, n. 99; 572, IV, n. 101; 576, IV, n. 95; 586, IV, n. 43; p. 631-632, IV, n. 96,97; 661, 111, n. $271 ; 663$, III, n. 272; 664, III, n. 288; 665, III, n. 286; 666, III, n. 285; 4637, III, n. 287 ; p. 718 , III, n. 284 ; p. 739 , III, n. 278 .

Inscriptiones Hispaniae Christianae N. ${ }^{\circ} 1, \mathrm{p}$. 3, IV, n.77, 116. N. ${ }^{\circ *}$ IV, n. 98.

\section{Iordanes}

Getica, V, 42, 22,III, n. 245; XIV, 82, III, n. 241; XXXVI-XXXVII, III, n. 247.

S. Isidoro de Sevilha

Etimologias, IX, 2, 107, II, n. 103; XII, 6, 12, II, n. 42, 61; XIII, 21,33, II, n. 82; XV, 1, 70-71, I, n. 33.

Historia Sueborum, M. G. H., XI, 2, 92 (Mommsen), III, n. 257.

Itineraria Antonini Augusti (O. Cuntz) p. 64: - I, n. 192; 416, 4-5, 417, III, n. 264; 418, 6, III, n. 276; 418, 7, 419, 6, III, n. 279; 419, 7-420, 7, III, n. 281; p. 66: - 425,2, II, n. 126 ; 425, 6, 426, 1-6, 427, 1-3, III, n. $274 ;$ IV, n. $23 ; 426,1, I V$, n. 23.

Justino

Epitome historiae philipicae, XVIII, 5, 8, III, n. 29; 6, 9, III, n. 30; XXI, III, n. 29; XLIV, 2, 7, I, n. 146, III, n. 114; 3, 1, I, n. 180; 3, 3, III, n. 33; 3, 4, II, n. 133; 3, 6, I, n. 182; 4, 1, III, n. 1; XLIX, 3, 4, I, n. 164.

Lívio, Tito

Décadas, XXI, 21, IV, n. 37; XXI, 27, 5, III, n. 156; XXI, 35,8, IV, n. 12; XXI, 43, III, n. 3; XXI, 57, III, n. 38; XXII, 20, 2, III, n. 39; XXII, 21, III, n. 7; XXIV, 16, 17, 20, I, n. 58; XXIV, 41, III, n. 15, 37; XXVI, 40, I, n. 131; XXVI, 42 ss., III, n. 22; XXVI, III, n. 7; XXVII, III, n. 13, 40; XXVIII, 5, 11, III, n. 156; XXVIII, 12, 11, III, n. 41; XXVIII, 21, III, n. 10; XXVIII, 22, II, n. 89; XXXV, 1, III, n. 51; XXXV, 7, III, n. 11; 
XXXIII, 21, III, n. 1; XXXV, 1, I, n. 128, 132; XXXV, 7 e 22, I, n. 76; XXXVII, 46 e 57, I, n. 128, 133; III, n. 54, 60, 62, 66; XXXIX, 21 e 42, I, n. 128; XXXIX, 30-32, III, n. 67, 70; XXXIX, 40, 12, I, n. 141; iII, n. 98; XXXIX, 56, III, n. 71; XL, 47, III, n. 78; XL, 49, III, n. 12; XL, 50, III, n. 73; XLI, 3 e 11, I, n. 128; XLI, 7, III, n.80.

Periochae, XLVIII, I, n. 143; III, n. 85, 92; XLIX, I, n. 139; III, n. 97; LII, III, n. 122, 131; LIV, III, n. 123, 133; LV, II, n. 130; III, n. 145 .

Lucano

Farsália, II, 716, Vida A. R., n. 21. IV, 9, I, n. 77; IV, 8-10, I, n. 86; VII, 232 ss., I, n. 156; VII, 755, II, n. 80 .

Lucílio

Frag. 615-616 (Marx), III, n. 47.

Lucrécio

De rerum natura, I, 315-316, III, n. 260; II, 500-501, I, n. 114.

Macróbio

Saturnalia, I, 20, 12, III, n. 6; III, 16, 3-4, 11, n. $20 ; 16,6$, I, n. $90 ; 16,6-8$, II, n. 25.

Marcial

Epigramas, VIII, 21, p. 209; XII, 98, 2, II, n. 119; XIII, 91, II, n. 22; XIV, 131, I, n. 110 .

Marciano Capela

De nuptiis Mercurii et Philologiae (Dick), VI, 628 , p. 308, I, n. 1; 628-630, p. 308, I, n. 32.

Mecenas

Fragmenta, 3 (Morel), Vida A. R., n. 21.

Nepos, Cornélio

Amílcar, 4, III, n. 14.

Obsequente, Júlio

Prodigiorum liber, 17, I, n. 143; III, n. 82; 18, III, n. $84 ; 42$, III, n. 158 ; 58, III, n. 172, 177 .

Orósio, Paulo

Historia aduersus paganos, IV, 20, 23, I, n. 134; III, n. 53; IV, 21, 3, III, n. 93; IV, 21, 3 e 10, I, n. 134; IV, 21, 10, III, n. 95, 102; IV, 32-33, III, n. 81; V, 4, 1-6, III, n. 118; V, 4, 2, III, n. 131; V, 4, 5, I, n. 142; V, 4,
8, III, n. 119; V, 12-14, III, n. 119; V, 23, 3, III, n. 173; V, 23, 14, III, n. 183; V, 24, 18, III, n. 171; VI, 19, III, n. 212; VI, 16, 7, III, n. 210; VI, 21, 5, I, n. 220; VII, 42, 1, III, n. 252; VII, 42, 6, III, n. 256; VII, 43, 5 ss, III, n. 255; VII, 43, 10, 15, III, n. 251; VII, 43, 14, III, n. 254.

Ovídio

Amores, I, 15, 37, II, n. 80.

Tristia, V, 10, 38; V, 12, 53-58, Carta Cardeal D. Henrique, n. 2

Pontica, IV, 13, 13, 22, Carta Cardeal D. Henrique, n. 2

Halieutica, 132, 11, n. 23.

Paulo

Digesta, XXXXX, Tit. XV, De censibus, VIII, I, n. 11 .

Pausânias

VIII, 18, 7, I, n. 15 .

Plauto

Aulularia, 508-521, I, n. 118.

Plínio-o-Velho

História Natural, I, 25, 46, I, n. 89; II, 6, 14, II, n. 83; II, 231, II, n. 97; III, 1, 6, I, n. 26; III, 1, 8, I, n. 1, 62; III,1, 10, III, n. 58; III, 1, 13, I, n. 55; III, 1, 16, I, n. 100; III, 1, 19, I, n. 65; III, 3, 24, I, n. 15; III, 4, 36, IV, n. 93; III, 3, 20, II, n. 111,112; III, 8,13, 14, I, n. 51; 111, 21, II, n. 83; III, 22, 116, I, n. 55, 63, 68; IV, 2, 115, II, n. 95; IV, 20, 111-112, I, n.30, 66, 68, 97,158; IV, 20, 113, I, n. 120; IV, 21, 13, I, n. 62; IV, 21, 113, I, n. 27, 30, 42, 122; IV, 22, 114, I, n. 30, 34, 42, 190; IV, 22, 115, I, n. 38, 42; II, n. 132; IV, 22, 116, I, n. 40, 42, 62; IV, n. 31; IV, 22, 118, IV, n. 18, 21, 42; VIII, 67, 166, I, n. 179; IX, 9, III, n. 223; IX, 14, 45, II, n. 44; IX, 15, 14, II, n. 11; IX, 15, 45, II, n. 9; IX, 16, 58, II, n. 11; IX, 17, 60, II, n. 18; IX, 30, 48, II, n. 140; IX, 40, 141, I, n. 109; IX, 60, II, n. 31; XIV, 43, IV, n. 93; XXXII, 43, 125, II, n. 11; XXXII, 153, II, n. 35; XXV, I, n. 89.

Plutarco

Vidas: Aníbal (?), III, n. 14.

Cipião (?) ou Paulo Emílio, III, n. 10, IV, 1-2, III, n. 55.

Catão o Censor, X, 1, III, n. 48; XV, 4, III, n. 105 . 
Catão de Útica, IX, 1, III, n. 193; XXXVI, 3, III, n. 193; XLVIII, 4, III, n. 194. Sertório, 19, II, n. 116; 21, III, n. 175; 23, III, n. 180.

Moralia: Quaestiones romanae, 34, I, n. 10; ii, n. 131.

Terrestriane an aquatilia animalia sint callidiora, 28, 979 c, II, n. 19; 32, 981 d-e, II, n. 21.

Políbio

História Romana, II, 13, 1, III, n. 16, 34; III, 76, 7, III, n. 8 ; IX, 18, 7, III, n. 8; X, 7, I, n. 10; XXXIV, 8, I, n. 59; XXXV, 4, III, n. 91 .

Pólux, Júlio

Onomasticon, I, 173 (Bethe), I, n. 147.

Pompónio Mela

Chorographia, II, 6, 87, I, n. 24; 6, 94, III, n. 17; 92, II, n. 110; III, 1, 8, I, n. 25, 123; II, n. 94; III, 4, Carta Cardeal D. Afonso, n. $8 ; 6,47$, II, n. 75; 6, 94, III, n. 17; III, 6 e 7, Carta Cardeal D. Afonso, n. 8; IV, n. 11, 16, 20; III, 7, IV, n. 34; 10, I, n. 157; 11, Carta Cardeal D. Afonso, n. 8.

Prisciano

Institutiones (Keil), 5, 6; 6, 9, II, n. 113.

Procópio

História das Guerras, III, II (Vândalos), 2, III, n. 240; III, III, 1, III, n. 249.

Prudêncio

Peristephanon, 3, 186-190, I, n. 88; 4, v. 35 ss., I, n. 104; 4, 110-140, III, n. 236.

Pseudascónio

In divinationem, p. 203, I, n. 138; p. 124 (Orelli), III, n. 97.

Ptolomeu, Cláudio

Geografia, II, 3, I, n. 8; II, 4, 6, 10, I, n. 161; II, 4, 11, III, n. 59; II, 4, 15, IV, n. 4; II, 5, 1-2, I, n. 22; II, 5, 2, 3, 4, II, n. 109; II, 5, 3, II, n. 64, 102; IV, n. 14, 22, 54; II, 5, 3, 5, I, n. 47, 48; 11, 5, 4, I, n. 107; II, 5, 5, IV, n. 19, 63; II, 5, 7, I, n. 8; II, 5, 9, I, n. 72, 85, 93, 99; I, 5, 10, I, n. 207; II, 6, II, n. 83; II, 6, 1, II, n. 125; II, 6, 21, I, n. 221; II, 6, 41, 42, 43, 44 e 45, I, n. 61; II, 10, 11, 12, 13, 14, I, n. 61; II, 11, 35, III, n. 239; II, 64, II, n. 83; VII, 4, 3, I, n. 8.
Quadrigário, Cláudio

VIII, frag. 69 (Peter), I, n. 142.

Quintiliano

Institutio Oratoria, I, 7, 1-35 Carta Cardeal D. Afonso, n. 2; II, 15, 8, III, n. 100.

Rúfio Festo, Sexto

Breuiarium, V, 1, III, n. 162.

Salústio

Historiae, II, 17-19, III, n. 175; II, 47, 24, II, n. 113 .

Epistula Cn. Pompei ad Senaturn = Hist., II, 98, 4-8, II, n. 114, 115.

Sarnónico, Quinto Sereno

Liber medicinalis, V, 202, 119-202, I, n. 90.

Sérvio

Comentário à Eneida, I, 12, III, n. 32.

Sidónio Apolinar

Carmina, V, 49, I, n. 110; XI, 96, Vida A. R., n. 21; XXIV, 5, 7, III, n. 262.

Epistulae, IX, 13, 5, 14-27, I, n. 113.

Sílio Itálico

Punica, I, 234, II, n. 107; I, 144-161, II, n. 93; I, 235-236, I, n. 159; III, 348, I, n. 156; III, 354-356, III, n. 42; III, 366-367, I, n. 159, 168; III, 368, III, n. 19; III, 376-377, III, n. 7; III, 378, I, n. 78, 87; III, 378-383, I, n. 186; V, 321-322, II, n. 122; V, 333-342, III, n. 43; X, 217-231, III, n. 44; XV, 192-195, III, n. 21; XVI, 362-365, I, n. 186; XVI, 365-366, I, n. 87; II, n. 123; XVI, 564-565, III, n. 8 .

Solino

Collectanea rerum memorabilium (Mommsen), 23,5 , p. 103,17 , I, n. 31 ; I, 28-29, p. 8 , III, n. 33 .

Suetónio

César, 54, III, n. 188; Galba, 3, III, n. 106; Nero, 30, I, n. 111; Otão, 3, 3-4, III, n. 222, 223.

De grammaticis, 17, III, n. 63.

Tácito

Anais, I, 70, III, n. 225; XIII, 46, 3, III, n. 221.

De Germania, 2, III, n. 258. 
Tertuliano

De pallio, V, 6, 68, II, n. 4; V, 6, 68-70, II, n. 5 .

Timeu

Frag. 60 (Jacoby), III, n. 27.

Valério Máximo

Factos e Ditos Memoráveis, I, 2, 4, III, n. 172; VI, 4, I, n. 126; ext. 1, III, n. 151; VII, 3, 6, I, n. 127; III, n. 172; 6, ext. 3, III, n. 184; VIII, 1, 2, I, n. 140; III, n. 101; IX, 2, rom. 4, III, n. $191 ; 6,2$, I, n. 135; III, n. 96, 130 .

\section{Varrão}

De re rustica, II, 1, 7, I, n. 178.

\section{Veleio Patérculo}

História Romana, I, 6, 4, III, n. 31; 9, 3, III, n. 61; II, 1, 3, III, n. 115 ; 30, 1, III, n. 181 .

\section{Venusiano}

Carmina, 2, 3, 19, I, n. 110.

\section{Virgílio}

Geórgicas, III, 271-275, I, n. 185.

Eneida, I, 619, III, n. 28; V, 273, III, n. 263.

De uiris illustribus 71, III, n. 117, 127, 141; 77, 4, III, n. 172; 78, III, n. 177. 


\section{ÍNDICE DE NOMES PRÓPRIOS E PALAVRAS}

\section{$\mathbf{A}$}

Abdarramão, 314

Abrantes, 292, 382, 383, 385, 453

Acaico, 228

Acipenser, 171, 175, 418, 419, 420

Ad Septem Aras, 157, 291, 293, 382, 383, 385, 386, 387

Adiabénico, 282

Abóbriga, 100

Adriano, 268, 282, 288, 332, 412, 429

Aeminium, 101, 107, 377, 379, 384, 385, 388, 389

Afonso IV, D., 378

Afonso, D., 17, 22, 58, 60, 426

Afonso, Cardeal D., 10, 12, 40, 58, 60, 66, 68, $70,402,447,456,471$

Afrânio, 114, 116, 254, 256, 258, 262

África, 36, 186, 200, 208, 212, 252, 276, 336, 408, $423,425,431$

Africano, Cipião,

Agger, 278, 279

Agostinho, S., 356

Agripa, 108

Agripina, Júlia, 302

Águeda, Rio, 100, 106, 190, 376, 378, 379, 385, 388

Agualva, 382, 383, 386, 387, 388, 389

Águas de Moura, 386, 388

Aierba, 320

Aires, Paio, 152

Aix-en-Provence, 5, 9

Alandroal, 360

Alanos, 276, 277, 444

Alarico, 274, 275

Alba, Rio, 154

Albardo, 148
Albino, Aulo Postúmio, 226, 230

Albino, Espúrio Postúmio, 222

Albino, Lúcio Postúmio, 226, 228, 366

Albornoz, Bartolomeu Frías, 12, 46, 86, 403

Alcácer do Sal (Cidade do Imperador), 104, 106, 110

Alcácer do Sal, Golfo de, 110, 180, 324, 326

Alcalá de Henares, 54, 362, 437, 455, 457, 470

Alcântara, ponte de, 23, 32, 198, 428

Alcântara, (forte de), 130

Alciato, André, 21, 270, 463

Alcides (Hércules), 84

Alcobaça, 100, 106, 384, 385

Alcobaça, Convento de, 30

Alcobacense, Historiografia, 14, 32, 34

Alegrete, 150, 152, 290, 292, 382, 383, 385, 386, 387

Alemães, 38

Alemanha, 21, 28, 64, 146, 401, 434

Alentejo, 32, 449

Alexandre Magno, 18

Alexandrino, Cardeal, 60, 415, 475

Algarve, 8, 17, 32, 110, 144, 308, 310, 342, 406, $448,449,455,467$

Aljezur, 144

Almeirim, 292, 446

Almourol, 384, 385

Alpalhão, 292, 382, 383, 384, 385

Ali (rei), 340

Alpiarça, 292, 446

Alter do Chão, 290, 382, 383, 386, 387

Alva, Julián de (Bispo de Miranda), 56, 400

Alvor, 316, 387

Amaea, 386, 387

Amaienses, 107, 108

Amalo, Teodorico, 274

Ambrácia, 206 
Ambrósio, S., 19

Amiano Marcelino, 19, 276

Amilcar, 209

Amon, 324

Ana, 79, 99, 107, 111, 113, 115, 117, 119, 195, 320, 379, 388, 408, 410, 416, 469

Ancus, 199, 388, 389

Anas Fluvius, 388, 389

Anão, 206

Andaluzia, 19, 408, 455, 467

Andóbal, 206

Anfílocos, 142, 206

Ângela, 54

Ângelo, Aléxio, 54, 320, 449

Angulo amazi, 180, 423

Aníbal (cartaginês),

Ânio de Viterbo, João, 9, 21, 31, 38, 206, 404, 426, 429, 437, 453

Ansedo, 152

Ansião, Serra de, 144, 160

Antaces (povos), 178

Antaceu, 176, 178, 420, 422

Antecatos, Região dos, 176

Ântias 170, 419

Antília, 270

Antiqua Epitaphia, 10

Antimo, 352

Antonino, César Élio Adriano, 332

Antonino, César Marco Aurélio, 146, 282, 286

António (mestre), 33, 417, 464

Aobrigenses, 142, 143

Aónias, Irmãs, 58

Apeles de Cós, 84

Apiano, 18, 25, 228, 252, 262, 264, 266, 398, 405 $427,428,430,433,435,439,440,441,464$, 475

Apião, 172

Apolinar, Sidónio, 278, 401, 411, 479

Apolinário, 130

Apríngio de Beja, 464

Aquae Flauiae, 384, 385, 414

Aqueus, 228

Aqui冈avienses, 108, 142, 388

Aquílio, 254

Arábico, 282

Arabricense, Rufino, 306

Arábriga, 324, 325

Aracne, 58

Aragão, 320, 449

Aragão, Rei de, 30, 320

Aramenha, 23, 292, 382, 383, 386, 387, 415,

Aranditanos, 108
Arani, 288, 289

Arautos, Roteiro dos, 33, 35

Arco de Triunfo, 30

Ardíbur, 314

Ardila, 108, 418, 466

Areva, 116

Arévacos, 100, 116

Argantónio, 206, 430 n. 3

Argote, J. Contador de, 32, 34

Arício, 292

Aristeu, 92

Aristóbulo, 168

Aristóteles, 168, 172, 420, 475

Arménios, 136

Arminius, 28

Arabrigenses, 107, 108

Aroce, 288

Aroche, Nova, 302, 304, 306, 446

Arótebras, 100, 102, 104, 106

Arouca, Templo da Virgem de, 160

Arouche 304, 305

Arquéstrato, 172, 420

Arrábida, 126, 144, 411, 472

Arrais, Frei Amador, 14, 34, 35, 397

Arriano, 18, 206, 475

Arronches, Ópidos de, 150

Arrotebras, 376, 407

Ártabro, 100, 102, 104, 106, 376, 406

Ártabros, 96, 100, 102, 104, 106, 112, 407

Artemidoro, 94

Arucitana, 304

Ascátide (rei da Babilónia), 92, 404

Ascónio Pediano, 19, 138, 230

Asclepíades de Mirleia, 414

Asdrúbal, 186, 188, 208, 212, 214

Ásia, 82, 206, 258, 400, 431, 441

Assumar, 382

Assamassa, 152, 153, 416

Asta, Região de, 222

Ástures, 96, 116, 124, 126, 162, 228

Astúrias, 23, 36, 418, 423

Asturio, 36

Asturjão, 166, 418, 467

Atace, Rei, 276, 444

Ataíde, D. Luís de, 158, 417, 473

Átega, 260

Atagor, mar, 340, 341

Atégua, 262

Ateneu, 15, 19, 31, 94, 174, 200, 405, 419, 420, $421,424,429,475$

Atequenses, 260

Átila, 274 
Atília, 270

Atinquenses, 260

Atlântico, Oceano, 98, 100, 102, 104, 106, 156, 212, 214, 248, 250, 308, 376, 386, 406

Atlântida, 34

Atlas, 84, 85

Atouguia, 31, 158, 417

Augusto, César, 8, 27, 72, 100, 120, 146, 264, 266, 268, 270, 408, 418, 441, 451

Augusto, Torre de, 72

Augustóbriga, 380

Augustobricenses, 108

Aurélio, Lúcio, 248

Aurélio, Marco, 290, 328

Aurélio, Quinto, 246

Áunios (ilha), 100

Ausónio, 184, 425, 475

Áustria, 54

Auxitânia, 276

Auus, 197, 388, 389

Axónio, Gaio, 350

Axónio, Quinto, 350

Ave, Rio, 166, 196, 388, 389

Aveiro, 378

Aveiro, Duque de, 280

Ávila, 116, 118

Avioli, 352

Avito, Gaio Júlio, 330

Avo, 196, 428

Azof, Mar de, 176, 178

\section{B}

Bacanais, 92, 374

Bacantes, 374, 405, 476

Bácia, Ópido de, 236

Baco, 6, 23, 92, 374

Badajoz, 72, 108, 272, 328, 380, 382, 442, 451, 464

Badiana, 227, 398, 434

Badíolo, Árrio, 358, 455

Baleares, 214

Balsa, 107, 289, 310, 384, 386, 387, 424

Balsenses, 107, 108

Baltha, 274, 275, 444

Balbo, 346

Baltos, 274

Barbacena, 284, 445

Barbaricários, 130

Barbário, Monte, 104, 126, 483

Barbário, Promontório, 388, 411, 424
Barbários (povo fantasioso), 26, 126, 130, 388

Bárbaros, 126, 411

Barbosa, Aires, 5, 54, 400

Barca, 208

Bardo, 206

Bárdolos, 108

Bárgulo, 238

Barreiros, Gaspar, 17, 32, 33, 34

Barreto, Rui, 312, 313, 448

Barros, Dr. João de, 33

Bastetanos, 220, 221

Bástulos, 114

Beatriz (da Grécia), 320

Bécula, 214

Beja, 17, 20, 21, 23, 29, 31, 33, 37, 94, 106, 110, 286, 288, 290, 310, 328, 330, 332, 366, 386, 387, 402, 403, 409, 424, 442, 447, 451, 452, 464,469

Bélion, 94, 196

Bélios, 94

Belitanos, 94, 95, 374

Bellum Hispaniense, 19, 440

Belon, 94, 95

Beltrão, 352, 454

Benavente, 35, 262, 290, 292, 382, 383, 386, 387

Bénis, 198

Beócia, 374

Berlenga, 156

Beroso, 207, 404, 430, 457

Berões, 378

Bética, 94, 98, 106, 108, 110, 112, 114, 132, 188, 220, 224, 254, 266, 268, 276, 302, 308, 336, $376,378,441,447,468$

Bétis, 112, 432, 433

Betónica, 122

Betove, Nossa Senhora de, 290

Betúria, 112, 224

Bíbalos, 142

Bilbilitani, 405

Biscaia, Golfo da, 24, 406

Bizâncio, 19, 20, 21, 30, 405, 426, 449, 466, 476

Bletise, 380

Bluquério (= Broquel, Bruquel, Burquel), 380

Bócoros, 108

Bonelli, Michele (= Alexandrino, Cardeal), 401

Borgonha, 336

Botarga, 15

Bracaraugustano, 108

Bracarense, 378, 398

Brácaros, 98, 100, 108, 114, 124, 140, 142, 162, 196, 226, 228, 248, 252, 388 
Braga, 7, 15, 100, 378, 384, 404, 407, 437, 455, $463,466,472$

Bragança, 48, 49, 192, 352, 388, 448, 454, 464

Brasil, 36, 423

Bretanha, 126, 411

Brigo, 186

Brito, Frei Bernardo de, 17, 35, 397

Brito, Luís Sílvio de, 48, 50

Broquel (Ver Bluquério), 456

Bruquel (Ver Bluquério), 456

Bruto Galaico, Décio Júnio, 196, 248

Bruto, Públio Júnio, 220, 222

Bruxelas, 5, 56, 400, 401, 429, 465, 474

Budua (Bótoa), 152, 153, 291, 384, 385, 416

Burgos, Martim de, 44

Burquel (vd. Bluquério) 456

\section{C}

Cacalo, 352, 353

Cação, 419 n. 17; 420 n. 27

Cacém (Kasim), 29, 30, 106, 318, 386, 387, 398, 449

Cáceres, 118

Cachão da Valeira, 15, 31, 34, 37

Cacia, 378, 457

Cacim (tirano árabe), 23, 318, 322, 449

Cadima 188, 426

Cádis, 106, 154, 156, 250, 262, 266, 322, 430

Caia, 108, 198, 199

Caiola (vd. Gaiola), 108, 109

Calahorra, 254, 256

Callipolin, 355, 390, 391

Calípole, 354

Callipolis (Vila Viçosa),

Calípode, 180, 366

Callipus, 388, 389

Calvo, Gaio Antéscio, 302

Campo Maior, 152

Canas, 216, 222, 432

Cania, 199

Cantábrico, Mar, 162, 407

Cântabros, 162, 417

Caparenses, 108

Caparra, 116, 118, 120, 124, 378

Capitólio, 222, 246

Cardo, 206

Carlos Magno, 20, 274, 444

Carlos Magno, Vida de (Cf. Einhard), 29

Carlos V, 5, 33, 56, 400, 437

Carpetânia, 224
Carpetanos, 96, 97, 114, 116, 117, 118, 119, 124, $125,126,127$

Carquédone, 210

Carrina, 264

Carrinas, Gaio Álbio, 264

Cartagineses, 15, 16, 26, 140, 186, 206, 208, 212, $214,218,374$

Cartago, 186, 208, 210, 212, 240, 425, 431, 432

Cartago-a-Nova, 186, 208, 414, 425

Cartago-a-Velha, 186, 425

Carteia, 262, 440

Cassiodoro, Aurélio, 19, 211, 431, 475

Cassitérides, Ilhas, 126, 252, 411

Castanheda, Rui Fernandes de, 403

Castela, 6, 16, 29, 30, 38, 322, 451

Castelhanos, 28, 37

Castra Iulia, 106, 107, 124, 125

Castro, Públia Hortênsia de, 86, 87

Castro Marim, 144, 145, 288

Castro Verde, 336

Catalunha, 274

Catão, Marco Pórcio, 138, 218, 260, 262, 432, 435

Catina, 189, 426

Catínio, Gaio, 222

Catulo, 258, 401, 440, 475

Caurienses, 107, 108

Cávado, 196, 198, 388, 389

Caviar, 419, 468

Ceciliana, 280, 281, 387, 388

Celandus, 197, 388, 389

Celere, 352

Celerinos, 142

Celtas, 78, 112, 122, 208, 209, 350, 351, 441, 447

Celtibéria, 212, 226, 238, 256, 258, 272

Celtiberos, 96, 114, 118, 132, 133, 134, 196, 212, 222, 224, 226, 228, 238, 406, 412, 432, 434, 439, 441

Célticos, 14, 26, 100, 106, 108, 110, 112, 114, 196 , 308, 328, 334, 386, 408

Célticos da Bética, 108

Ceice, 386, 387

Centil, Lopo, 160

Cepalão, 350

Cepião, 240

Cepião, Gneu Servílio, 234, 238, 240, 242

Cepião, Quinto, 234, 242, 250

Cepião-o-Velho, Quinto Servílio, 250

Cépio, Servílio, 216

Céporos, 100

César, 19, 114, 118, 124, 140, 146, 154, 156, 158, 258, 260, 262, 264, 266, 268, 282, 284, 286, 
288, 292, 294, 296, 298, 302, 312, 328, 332, 413, 416, 439, 440, 441, 451, 455, 464, 467, 475,479

Cesarobrigenses, 108

Cesónio, 266

Cetaria, 324, 325

Cetóbala, 326

Cetobra, 326, 327

Cetóbriga, 72, 180, 280, 324, 326, 388

Cetóbrix, 324

Cetra (= escudo lusitano), 41, 380

Cetus, 468

Cévio, Públio, 156

Chança, 108

Chaves, 72, 162, 384, 385, 398, 402, 418

Chaves, Coluna de, 42142, ,196, 198, 428

Chaves, Ponte de, 32

Cianeia, Rocha de, 64

Cibilitanos, 108

Cícero, Marco Túlio, 19, 70, 92, 140, 170, 174, 186, 232, 238, 242, 258, 266, 374, 398, 419, $425,427,475$

Cíclades, 390

Ceira (rio), 198, 200

Ceira (ópido), 429 n. 146

Cientino, Reburro, 352

Ciciliana, 382, 383, 386, 388, 389

Cilenos, 100

Cinânia, 132, 248

Cinanienses, 132

Cingínia, 412

Cipião, 134, 170, 206, 214, 218, 232, 419, 430, 431

Cipião, Gneu Cornélio, 206

Cipião, Lúcio Cornélio, 220

Cipião, Públio Comélio, 134, 218, 230, 412

Cipiões, Círculo dos, 18

Cipo, 33, 118, 122, 146, 218, 232, 280, 302, 306, $312,314,318,328,332,346,348,352,356$, $360,364,366,390,435$

Círtio, 186

Ciscudanos, 78

Cítia, 236

Cíticos, 278

Ciudad Rodrigo, 124, 378, 380

Ciuitates, 143

Civitatense, 380

Claro, Quinto Júlio, 284

Claudiano, 194, 427, 476

Cláudio, 138, 236

Cláudio, Ápio, 112, 224

Cláudio, Públio, 224
Clemente VII, 180

Clitórios, 94

Coa, 23, 389, 428

Coca (cidade), 116

Coelho, Jorge, 54, 400, 470, 473

Coellium, 386, 387

Coimbra, 39, 160, 188, 322, 336, 378, 402, 407, 408, 429, passim

Colarnos, 108

Colíbria, 378

Collipo, 107, 384, 385

Colímbrios, 160

Coloiane, 320

Columela, 19, 476

Comeno, João, 320

Comeno, Manuel, 320

Comitatus (condado), 268

Comites (condes), 93, 269

Como, 270

Cómodo, Lúcio Élio Adriano,

Cómodo, Lúcio Élio Aurélio, 280, 332

Concieiro, Monte, 152, 153

Concílios (Visigóticos), 310, 448

Concordienses, 107, 108

Congo, Reino do, 178, 423, 471

Coniates, Nicetas, 20, 449, 450, 465

Conímbriga, 100, 106, 323, 324, 325, 378, 379, 439 n. 142

Constança, 322, 336, 384

Constâncio, 276, 444

Constantino, 268

Constantinopla, 21, 322, 450

Contarelli, Mateu (Cardeal de Santo Estevão), 60

Contra-Reforma, 9

Córdova, 112, 328, 409, 433, 451, 457

Córdova, Monte, 23, 160, 417

Córdua, 160

Cória, 118

Coribantes, 380

Coríntios, 228

Cortesi, Paulo, 421

Corticata (ilha), 100, 101

Corunha, 156

Corva, Monte, 144

Cota, 252

Cotão, 262

Covilhã, 23, 152, 388, 416

Crasso, Públio Licínio, 252, 258, 438

Creus, Cabo, 100, 102, 106

Crisógono, Terêncio, 366

Críspia, Víbia, 306

Crispino, Lúcio Quíncio, 222, 224 
Cruz, Santa, 20, 29, 152, 160, 322, 416, 417, 423, 428, 443, 449, 450, 465, 467, 469, 474

Ctesifonte, Monte de, 128

Cuba, 366

Cuda, 23, 198, 199, 388, 389, 428

Culca, 206, 207, 429

Culucos, 292

Cúneo, 104

Cúneo, Campo, 308

Cúneo, Promontório,

Cunha, D. Luís da, 31

Cunha, D. Rodrigo da, 10, 34

\section{D}

Daciano, Públio, 290, 455

Dalmácia, 252

Dantisco, João, 401

Danúbio, 176, 421

Dardos, 3, 140, 214, 216, 242, 380, 392, 432

Daveau, Susanne, 35, 399, 429, 466, 472

Dene, 306, 447

Dídio, 254, 262

Dido, 210, 211, 431

Digício, Sexto, 218

Dilúvio (época do), 31

D. Dinis, 20, 30, 418, 425, 449

Diocleciano, Gaio Aurélio Valério Jóvio, 290, 443,455

Diodoro Sículo, 132, 430, 435, 439, 476

Diomedes, 142, 143, 414

Dion Cássio, 476

Dionisíada, 390

Dioniso, 92, 374, 404

Dioscórides, 410, 422, 466, 476

Diplobatásio, João, 320

Dipo, 280, 281

Direito do Lácio, 26, 106

Dirráquio, 258

Dniepre, 176, 178, 422

Dolabela, Lúcio Cornélio, 250, 252

Domício, Lúcio, 122, 252

Domingos, S., 5, 54, 324, 352, 401

Don (rio), 176

Donace, Júnia, 256, 364, 365, 439

Dórion, 419

Douro, 8, 15, 23, 31, 33, 34, 36, 37, 98, 100, 106, $108,110,112,114,116,118,124,132,142$, $154,156,162,188,190,192,194,196,268$, $336,376,378,384,385,388,389,412,417$, 418, 427, 429, 464, 465
Dracma, 202

Dórias, 192

Dório, 192

Dourada, 128, 170

Duques, 352

Dúria, 194

Dúrias, 427

Dúrio, 192, 194

\section{$\mathbf{E}$}

Eácida, 82

Eanes (Escrivão de D. Dinis), 20

Eburobritium, 107, 384, 385

Ebisocos, 142

Eborense, Município, 39, 44, 46

Eborenses, 10, 54, 55, 94, 290, 291, 360, 361, $386,387,397,439,446$

Ebro, 194, 212, 218, 234, 236, 238

Ebúcio, 346, 390

Écio, 274

Egídio, S. (ver Gil, S.), 336

Egipto, 178, 180, 422, 450

Egnácio, Baptista, 21, 320, 450, 466

Einhard (ou Eginhard). (Ver Carlos Magno, Vida de), 20, 443, 466

Eliana, Júnia, 358

Eliano, 418, 419, 476

Elisa, 210

Elteri, 382, 383, 386, 387

Elogio de Erasmo, 9

Elops (Helops), 168, 170, 172, 174, 419, 420

Elvas, 17, 23, 286, 350, 352, 386, 387, 446, 454

Elvira, 336, 448, 452

Emérita, 124, 443, 474

Emeritense, 106, 128, 272, 364, 380

Emiliano, Sérgio Terêncio, 230, 366, 368

Emílio, Paulo, 216, 433, 478

Emílio Paulo, Lúcio, 136, 220, 222, 226, 232, 244, 412, 433

Emínio, 100, 378

Encarnação, José d', 32, 397, 398, 399, 405, 409, 436, 445, 446, 447, 448, 449, 450, 452, 453, $454,455,456,466$

Endovélia, 360, 392

Endovélico, 17, 32, 356, 358, 360, 390, 455

Enea, Cidade de, 142

Eneias, 210

Engrácia, S., 443

Entemélio, Guilherme de, 320

Epigrafia, 32 
Equabona, 280, 281, 382

Equesílicos, 142

Eratóstenes, 419, 476

Eriano, Élio, 330

Eridimo, Marco Comélio, 314

Eriteia, 184

Escalabitano, Convento, 106, 272

Escândia, 274, 443

Escoto, Frederico, (Federicus Scottus) 412 n. 117

Escoto, Mariano, 130, 412

Esculápio, 17, 455

Esfina, 308

Esla, 108, 116

Espanha, 6, 8, 11, 12, 21, 30, 37, 52, 54, 220, $336,407,414,425,426,437,442,448,456$, 465

Esparta, 26, 413

Espichel, Cabo, 96, 182, 324, 326, 411, 424

Espúrio, 228

Esquecimento, Rio do, 106, 112, 196, 428, 437

Estaço, Aquiles, 402

Estesícoro 186, 426, 430, 476

Estevão de Bizâncio, 19, 94, 186, 374, 376, 405 n. 9,417 n. 216,426 n. 91,476

Estio, 166

Estói, 23, 30, 106, 110, 288, 308, 386

Estrabão, 14, 19, 22, 25, 26, 34, 78, 94, 96, 98 $102,110,112,114,118,124,126,132,134$, 140, 142, 166, 168, 176, 180, 182, 184, 190, 192, 196, 198, 228, 238, 248, 252, 350, 376, $405,406,408,409,410,411,413,414,422$, $424,425,426,427,428,429,430,431,438$, $447,448,449,451,454,466,476$

Estremoz, 284

Esturjão, 421, 467

Ethnika, 19, 426, 476

Etimologias, 174, 186, 423, 477

Etiópia, 423

Etíopes, 180

Etólios, 220

Eulália, S., 122

Eusébio de Cesareia, 18, 431, 477

Eutrópio, 19, 228, 232, 234, 240, 242, 435, 436 477

Evandriana, 280

Évora, 5, 6, 7, 9, 10, 11, 12, 13, 16, 17, 27, 28, 32 $35,39,44,46,48,52,54,60,66,68,72,80$, $94,100,106,118,242,256,280,282,286$ $288,290,310,326,350,382,383,384,385$ 386, 387, 397, 398, 399, 400, 401, 402, 403 $405,417,426,436,437,439,445,448,452$, $455,456,461,462,463,464,471,473$
Évora, Mosteiro de, 54,68

Eneida, 186, 278

Exúbana, 310

\section{$\mathbf{F}$}

Fábia, Quíncia, 244, 308

Fábio, 140, 232, 234, 236, 238, 242, 435, 436

Fábio, Quinto, 236, 238, 436

Facundo, S., 51, 322, 323

Fão, Vila de, 196, 198, 218, 388

Faro, 310, 312, 314, 384, 386, 405, 446, 448

Fausto, 154, 425

Favência, 220

Favónio, Galo, 244, 246, 248, 437

Favónio, Públio, 244

Favónio, Vento, 106, 407

Favónios, 102

Fenícios, 16, 208, 374

Fermosel, 378, 379, 380, 381

Fernando (Rei de Castela), 322

Ferreira, Leitão, 10, 366, 397, 400, 401, 402, 403, $404,415,417,424,439,451,452,453,455$. $462,463,464,467$

Ferreirinha, D. Antónia, 34

Fervença (Águas), 426

Festo, 392, 393, 438, 479

Fialho, P.e Manuel, 397

Ficalho, 304, 306

Fídio, 252

Figueiredo, Martim de, 21, 31, 192, 400, 402 , $426,470,472$

Fígulo, Nigídio, 172, 420

Filipe II de Espanha e de Portugal, 11, 12, 442

Filipo, Quinto Márcio, 222, 423

Filisto, 210

Fílon, 262

Fines, 288, 289, 446

Finisterra, Cabo, 24, 96, 100, 102, 104, 106, 162, 252, 376, 406, 407, 408, 411, 472

Firmano, Quinto Sévio, 360

Flaco, Marco Vérrio, 222, 250, 252, 433, 438

Flaco, Munácio, 260, 262

Flacos, 260

Flamínio, Gaio, 212

Flandres, 6, 21

Florião do Campo, 9, 21, 26, 31, 246, 378, 398, $411,437,451,457,467$

Floro, 19, 138, 162, 234, 242, 252, 417, 428, 436, 438,439

Floro, Rio, 100 
Flu, Júlio. (Ver P冈ug, Júlio), 401

Fonte Negra, 180

Fortunato, Domício, 122, 401, 402, 464

Forrester, Barão de, 34

França, 21, 28, 54, 64, 352, 454

Franco, António, 397, 471

Fraxinum, 109, 125, 293, 382, 383, 384, 385

Freire, Braamcamp, 10, 399, 400, 401, 403, 404, $415,417,451,452,453,455,456,462,467$

Freixo, 108, 124, 457

Frontino, 238, 252, 436, 439, 477

Fulvianila, Sentacínia, 318

Fúlvio, Marco, 118, 208, 222, 348

Fúlvio Nobílior, Marco, 208, 222

Fúrnio, 266

Fusco, Gaio Cocílico, 318, 319

Fusco, Gaio Numísio, 318

\section{G}

Gades, 214, 215, 251, 316, 430

Gadila, Fábia, 308

Gaeta, 260, 440

Gaio, 130, 232, 328, 346, 350, 411

Gaio, Lélio Nepos, 220, 238, 242

Gala, Aurélia, 94, 304

Galaicos, 96, 98, 100, 108, 114, 116, 124, 140, 196, 248, 250, 414

Galaicos Brácaros, 98, 108,0 124

Galáxia, 168, 174

Galba (Imperador), 240, 398, 435, 457

Galba, Sérvio Sulpício (ou Sérgio), 136, 138, 230, $231,232,233,248,435,437$

Galécia, 8, 100, 108, 110, 142, 148, 156, 194, 210 $248,252,258,268,414,417,418,438$

Galego, Aldeia de, 306

Galegos, 378

Galeno, 9, 169, 278, 419, 477

Gáleo Ródio, 172

Galéria, Tribo, 328, 330

Gália, 192, 254, 262, 276, 278, 284, 350

Galiza, 276, 336, 380, 407

Gallae, Aureliae, 95, 305

Gallaii, Auriiliaii, 304, 305

Garcia, João, 152, 423, 465, 467, 468

Garcilaso de la Vega, 401

Gargor, 206

Gasconha, Golfo da, 00, 102, 104, 106, 376, 407

Gauleses, 138, 140, 441

Gautinense, Públio Petrónio, 362
Gelénio, 21, 176, 374, 398, 421

Gélio, Gélio, 19, 70, 475

Génova, 6, 270, 320, 442

Gerês, 162

Gérion, 26, 206, 430

Germânia, 274

Germânico, César, 302

Germânico, Nerva Augusto, 272

Germanos, 140, 147

Getas, 80, 272, 273, 274, 403

Gético, 274

Gil, S. (Ver Egídio, S.), 7, 20, 22, 54, 184, 425, $429,468,470,472$

Gisgo, 214

Glabrião, Marco Ać́lio 220, 228

Glareano, Henrique, 226, 227

Goclénio, Conrado, 5, 60, 64, 372, 401

Goda, 272

Godos, 15, 16, 18, 23, 29, 80, 132, 270, 272, 274, $276,310,362,378,442,443,444,456$

Gonadramiro, 380

Góis, Leonor Vaz de (Mãe de André Vaz de Resende), 6, 468

Golfinho, 36, 168, 421, 422, 423

Gótica, Raça,

Gótico, 274, 278

Graco, Tibério Semprónio, 134, 226, 228, 434

Grávios, 100, 142, 196, 413

Grécia, 18, 206, 320, 322, 455

Gregório de Tours, 19, 29, 274, 444

Gregos, 16, 18, 26, 70, 82, 92, 96, 122, 172, 178 , 186, 196, 208, 220, 308, 414, 415, 430, 433, 443,467

Grónios, 142

Grosse, R., 27, 413, 414, 426, 431, 442, 450, 467

Gruios, 142, 143

Guadiana, 8, 15, 34, 46, 78, 96, 98, 106, 108, 110, $112,114,116,118,124,126,132,144,166$, 194, 196, 224, 280, 308, 326, 340, 374, 378, $382,383,386,387,388,406,408,410,418$, $421,427,443,447,466,467,468$

Guadalquivir, 118, 186, 194, 262, 402, 432, 433

Guerras Góticas, 18

Guto (Rei), 24

Gutos, 171274

Guzmán, Fernán Nufiez de (Pinciano), 21, 24, 406

\section{H}

Habis, 26, 430 
Hecateu, 206, 430, 477

Hedisto, Marco Pôncio, 306, 447

Hélade, 34, 413

Helenos, 100, 142, 143

Helops. (Ver Elops), 420

Heluii, 386, 387

Hélvio, Marco, 206, 354

Hélvios, 350, 386

Henriques, D. Afonso, 8, 17, 30, 152, 336, 340, 344, 398

Henrique, Cardeal D., 6, 11, 12, 400, 403

Henrique, Conde D., 152

Henrique, Rei D., 16, 52, 58

Hércules, 84, 114, 154, 266, 314, 316

Herénio, Gaio, 194

Hermann, 28, 38, 461

Hermerico, 276, 277

Hermínio (Monte), 28, 144, 150, 152, 154, 156, $158,258,415,416$

Hermínios, 29, 140, 156, 388, 415, 416, 463

Hermo, 188

Hermolau Bárbaro, 21, 174, 420, 421, 427, 468

Heródoto, 18, 176, 422, 430, 477

Hierabrica, 383

Hilermo, 208

Hipérion, 62, 401

Hírcio, 150, 264

Hirtuleio, 252, 254

Hispânia, 6, 24, 26, 29, 98, 100, 102, 104, 106, $108,112,114,116,118,122,124,126,130$, 132, 134, 136, 138, 144, 148, 166, 180, 186, 190, 200, 206, 208, 210, 212, 214, 218, 220, $222,224,226,228,230,232,234,236,238$, $248,250,252,254,256,258,264,266,268$, $276,326,328,336,374,376,380,404,407$, 408, 414, 418, 425, 430, 432, 434, 439, 441, $442,444,455,457,467,471$

Hispalense, Convento, 112

Hispânia Citerior, 114, 116, 118, 124, 126, 190, 200, 218, 226, 276, 418, 432, 434

Hispânia Ulterior, 98, 112, 130, 134, 206, 220, 222, 224, 226, 228, 250, 252, 258, 264, 336, 376,434

Hispanos, 6, 97, 140, 206, 208, 224, 228, 250, $251,258,272,276,324,430$

Homero, 25, 170, 420, 477

Honorino, Sexto Coceio Cratero, 356

Honório, Augusto, 276, 444

Horácio, 76, 260, 324, 401, 477

Hórtulo, 66

Huebner, Emil, 10, 18, 32, 38, 397, 398, 402 , $405,409,414,428,432,435,436,437$,
$445,446,447,448,449,452,453,454$, 455,468

Hycca-Hysca. (Ver Iça),

\section{I}

Ibas, Hélvia, 358

Ibéria, 16, 18, 19, 25, 26, 92, 98, 200, 206, 228, $258,408,414,439$

Iberos, 16, 132, 133, 206, 208, 209, 216, 374, 375, 412, 430

Ica-Isca, (gr. hykes),

Idade Média, 11, 27, 29, 429, 456

Idade das Trevas, 11, 456

Idanha-a-Velha, 386

Ierabrica, 384

Igaedita, 386, 387

Ilerda, 254

Ilhas Secas, 100

Imperatória, Urbe, 318, 407

Índia, 6, 400, 417, 465

Indíbil, 206

Indigetes, 192, 193

Interâmnicos, 142

Interamnenses, 389

Interausenses, 108, 109

Iordanes (ou Jordanes), 17, 19, 25, 275, 444, 469, 477

Irene, 320, 321, 450

Iria, S., 20, 30, 198, 428, 443, 471

Isabel, D., 20, 320, 322, 449, 450

Isidoro de Beja, S., 20, 31, 451, 469

Isidoro de Sevilha, S., 17, 19, 20, 423, 451, 477

Ismar, 336, 338, 340, 344

Itália, 21, 31, 64, 136, 170, 176, 178, 214, 252, 262, 266, 268, 270, 274, 278, 444, 454, 464

Itinerários de Antonino Pio, 445

\section{J}

Januária, Álbia, 356

Jerónimo, S., 21, 144, 320, 400, 421, 431, 449, 468, 474

João III, D., 6, 21, 56, 60, 66, 158, 314, 400, 402, 425, 437

João da Pesqueira, S., 190

Jocundo, Galo Favónio, 244, 246, 437

Jordanes (ou Iordanes), 274

Jóvio, Paulo, 9, 21, 36, 290, 397, 418, 421, 422, 423, 469 
Jubato, Gaio Minúcio, 346

Júcar, 192, 194, 254, 427, 430

Júlia (de Júlio César), 302

Júlia Augusta, 146

Juliano, Gaio Júlio, 332

Junónio, 376

Júpiter, 17, 134, 246, 324, 362, 364, 440, 450, 456

Justino, 19, 27, 138, 140, 148, 198, 210, 234, 240, 398, 414, 415, 428, 430, 431, 436, 477

Justo, S., (Mártir), 29, 362, 364, 455

\section{K}

Kammerherr (Camerarius), 35

Késtron, 122

Krantz, Alberto, 390, 391, 457, 469

\section{L}

Lacetânia, 192

Lacóbriga, 314, 324

Lagares, 152, 154, 155, 416

Lagos, 314, 315, 386, 387, 390

Lama, 384, 385

Larneca, 384

Lamecense, 378

Lamego, 160, 384, 385

Lança, 138, 186, 236, 254, 427

Lancienses, 108, 109, 244, 245

Langobardos, 268

Larênsio, 429

Láscara, 320, 322

Láscaris, João, 320

Láscaris, Teodoro, 320

Lasso, Graciano. (Ver Garcilaso), 401

Laudice, 362, 363

Lauro, 254

Lauronenses, 254

Leão, Duarte Nunes de, 33, 34, 35, 425, 426, 428, 429, 466

Leão, Reino de,

Leça, 196

Leiria, 100, 106, 385

Lélio, Gaio, 220, 238, 242

Lelo, Dídio, 254

Lemónia, 346

Lenas, Popílio, 240

Lêntulo, Gneu Cornélio, 234

Leovegildo, 276
Lépido, Marco, 258, 260

Lépido, Públio Fábio Sérgio, 232

Leunos, 100, 142, 143

Líber, 92, 144, 374, 450

Liberi, 93, 145, 374, 375, 404, 405

Líbia, 208

Líbios, 62

Lico, Ópido de, 220

Lícon, 136

Lídia, 188

Ligúria, 320

Lima, Rio (Ver Esquecimento, Rio do), 94, 100, 104, 106, 112, 142, 166, 196, 198, 248, 376, 384, 385, 388, 389, 402, 403, 406, 428, 437, 438,469

Límia, 196

Límicos, 142, 196, 428

Lisboa, 6, 7, 9, 10, 16, 24, 35, 36, 40, 54, 102, $104,106,148,150,182,186,218,244,276$, 280, 290, 292, 316, 378, 380, 382, 384, 385, 397, 398, 399, 400, 401, 403, 404, 405, 407, $408,412,414,415,417,418,423,424,425$, 426, 432, 437, 439, 441, 442, 443, 444, 445, 448, 449, 451, 452, 453, 461, 462, 463, 464, 465, 466, 467, 468, 469, 470, 471, 472, 473, 474

Lísia, 84

Lívio, Tito, 19, 25, 27, 112, 114, 118, 124, 132, 134, 136, 138, 140, 206, 208, 210, 212, 214, $218,220,222,224,226,228,230,232,238$, 240, 302, 308, 316, 398, 409, 412, 413, 417, 426, 429, 430, 431, 432, 433, 434, 435, 436, $439,447,449,477$

Livro Negro, 17, 28 20, 29

Livro de testamentos e vendas de Santa Cruz de Coimbra, 20

Londobre, 156

Longino, Cássio, 150, 258, 259, 415

Longino, Quinto, 244

Longo, Públio Semprónio, 226

Lorena, 336

Lovaina, 5, 9, 56, 60, 401, 402

Lua, Monte da, 144, 146, 401, 404

Luangos, 142, 143

Lubenos, 142

Lucano, 122, 124, 401, 425, 478

Lúcifer, 372

Lucílio, Emílio Paulo, 218, 432, 478

Lucrécio, 128, 130, 278, 411, 478

Luculo, Lúcio Licínio, 230

Lugduno, 262, 440

Luscínio, 206 
Lusíadas, 6, 8, 42, 82, 405, 437, 469

Luso, 6, 23, 92, 93, 374, 404, 449, 465

Lusões, 94

Lutácio, Quinto, 250

Luteranismo, 9

Lysa, 92, 93, 374, 375

Lyssa, 92, 374

Lysios, 92, 374

\section{M}

Macedónia, Rei da, 82, 114, 206, 220, 232, 252, 433

Macróbio, 170, 172, 206, 410, 420, 430, 478

Magalhães, Romero de, 35, 417, 423, 467, 470

Mago, 214, 215

Malceca, 280, 281, 382, 383, 387, 388, 389

Malteca, 386

Mamede, São, 306

Mamerco, 214

Mâncio, 360, 455

Manços, S., 30, 455, 473

Mandónio, 206

Manes, 246, 284, 302, 304, 306, 308, 312, 330 $332,334,346,348,350,356,362,366,368$, 447

Manília, Vivénia Venusta, 360

Manílio (Mânlio, Lúcio), 254, 439

Mânlio, Gneu, 222, 250

Mânlio, Públio, 112, 226

Mantuano, Baptista, 21, 314, 390, 448, 471

Manuel, D., 10, 46, 70, 400, 402, 424, 426

Marão, 108, 144, 162

Marateca, 382, 383, 386, 387, 388, 389

Marcela, Úlpia, 306

Marcelina, Júlia, 350

Marcelo, Marco, 228

Marcelo, Nónio, 218

Marciano Capela, 406

Marchiones, (Marqueses), 268, 269

Marcial, 170, 194, 372, 405, 411, 419, 427, 429, 478

Marco, 118, 120, 146, 186, 206, 208, 218, 219, 220, 222, 224, 228, 230, 238, 240, 244, 248, $250,252,256,258,260,282,286,287,290$, 291, 296, 297, 304, 306, 314, 328, 331, 358, 374, 432, 438, 441, 447

Margarida, Santa, 66, 401, 424

Maria, Cabo de Santa 2, 106, 152, 153, 308, 318, 400, 403, 427, 441, 448, 449, 450, 452, 462, $465,471,474$
Marianos, (Montes), 144, 224

Mário, Gaio, 250

Mario/marião, 170, 176, 178, 421

Marliano, 44, 398, 437, 470

Marselha, 5, 126, 264

Martim, Vasco, 21, 31, 44, 54, 190, 192, 426, 452 , 463,472

Martinho de Soure, S., 20, 22, 30, 200

Marvão, 150, 415

Masanissa, 214, 215

Mascarenhas, D. Luís de, 33

Mascarenhas, D. Pedro, 5, 56, 400

Massagetas, 276, 444

Masséssilos, 180

Materno, Quinto Petrónio, 332, 333

Matosinhos, 196

Matusaro, 291, 382, 383, 446

Maurozomes, Manuel, 320

Máxima, Critónia, 360

Maximiano, César Gaio Júlio Vero, 282, 283, 298

Maximiano, Marco Aurélio Valério Hercúleo, 290, 291

Máximo, Q. Fábio, 19, 138, 140, 230, 232, 234 , 236, 240, 242, 248, 252, 260, 282, 284, 286, 298, 364, 412, 435, 436, 440

Medellín, 106

Medimno, 202

Mediterrâneo, 202, 322, 419, 433, 437

Medóbriga, 72, 258, 415, 416

Medobrigences,

Megadoro, 130, 412

Megalópolis, 200

Meidúbriga, 150, 152, 156

Meidubrigenses, 108, 109, 150, 151

Melanclénios, 274

Melas, Golfo de, 264, 441

Melibeia, Água, 128

Mémio, Lúcio, 228

Ménades, 92

Mentesanos, 114

Meónia, 188

Mepsas, 94, 405

Mercador, 334

Mérida, 8, 28, 94, 96, 98, 106, 118, 120, 126, 150, 152, 276, 280, 290, 292, 364, 382, 383, 410, $411,415,431,442,448$

Meróbriga, 316, 318

Mértola, 17, 106, 110, 166, 288, 308, 310, 386, 387, 447, 454

Mértola, Portas de, 330

Mesquita, Santa Maria de, 
Messejana, 344

Mestas, 296, 297

Metelo, 194, 236, 254, 258, 364, 427, 439

Metreta, 202, 203

Mexia, Pedro, 120

Miguel, S., 7, 21, 38, 160, 180, 304, 320, 417, 423, $428,449,450,462,465,471$

Mileto, 266, 477

Milho-miúdo, 184, 424

Minerva, 58

Minho, 23, 33, 36, 96, 98, 100, 104, 106, 108, 162, 166, 180, 190, 194, 196, 198, 248, 336, 376, 388, 389, 398, 406, 417, 418, 429, 437, 438, 455, 464, 465

Minho, Rio,

Minício, Gaio, 390

Minius, 101, 197, 199, 388, 389, 428

Minúcio, Quinto, 112, 346

Mirabilia, Geografia dos, 19, 35, 36

Miranda, 108, 116, 384, 385, 388, 400, 425, 468

Miranda do Douro, 384

Miróbriga, 380, 407, 449

Mirobrigenses, 108, 109

Mírtilis, 308

Mitridates, 256

Mondego, Rio, 98, 100, 106, 132, 160, 162, 166, 188, 190, 200, 378, 388, 389, 426

Modestina, 368, 369

Modestina, Flávia, 366, 367

Monchique, Monte de, 144

Monsanto, 415

Montejunto, Monte de, 144

Montemuro, Monte de, 144, 160

Montanos, 272

Monterrei, 196

Montóbriga, 416

Montpellier, Universidade de, 21

Morales, Ambrósio de, 6, 9, 12, 21, 26, 31, 380, 398, 437, 451, 456, 457, 466, 470

Morávia, Valentim da, 414

Morone, 176

Mortigão, 302

Mosela, 184

Moura, 17, 23, 108, 302, 304, 328, 330, 386, 387, 388, 389, 447

Moura, Portas de, 328, 330

Mourão, 108, 302

Mouros, 30, 308, 310, 328, 453

Mugem, 168

Mulíadas, 190

Múmio, Lúcio, 228, 234

Munácio, 260, 262, 440
Munda, 99, 101, 107, 133, 189, 191, 201, 226, 262, 266, 267, 379, 388, 389, 426, 440

Múnio, Ximena, 336

Murtária, Rio, 286

Murtigão, Castelo de, 108

$\mathbf{N}$

Naban, 199, 388, 389

Nabância, Aginaldo de, 30, 428, 443

Nabão, Rio, 30, 198, 200, 388, 428

Naebis, 197, 199, 384, 385, 388, 389

Narbasos 142, 143

Narbonense, Gália, 254, 276, 278, 284

Nascimento, Aires, 33, 416, 417, 425, 429, 456, 468, 470

Nasica, Públio Cornélio, 248, 249, 438

Naxos, 390

Nebrissa, António de, 54

Neiva, 196, 198, 384, 385, 388, 389

Neiva, Ponte de, 196, 198, 384, 385, 388, 389

Nela (cidadela), 100, 350, 352, 402

Nelo, Rio, 100, 101

Nemetatos, 142, 143

Némio, 254

Neocetóbriga, 326

Nepociano, Quinto Júlio, 284

Nepos, Lúcio Múmio, 234

Nepos, Quinto Opímio, (filho de Lúcio Quinto Postúmio), 228, 229

Neptuno, 266

Nério (Cabo), 110, 112, 376

Nérios, 100

Nero, Ápio Cláudio, 112, 128, 232, 270, 411, 479

Névis, 198

Nicéforo Calisto Xantópulo 20

Nifate, Monte de, 128

Níger, Cecílio, 262, 263

Nigídio, Gaio, 172, 174, 234, 240, 244, 420, 437

Nílides, Lago, 180

Nilo, 168, 169, 176, 177, 178, 179, 180, 181, 423

Noudar, Castelo de, 108, 109

Nova Civitas Aruccitana, 303, 305, 386, 387, 447

Novato, Gaio Júlio, 360

Novocomense, Calpúrnio Fabado, 270

Numácio, 260

Numância, 100, 114, 116, 234

Numantinos, 138, 236

Númidas, 240

Nunes, Francisco (de Beja), 2, 21, 33, 34, 35, 80, 398, 403, 425, 426, 428, 429, 466 


\section{$\mathbf{O}$}

Obsequente, Júlio, 19, 138, 250, 251, 252, 366, 434, 438, 439, 478

Óbulos Alexandrinos, 202

Ocelenses, 108

Octávio, 264, 266

Odivelas (rio), 180, 286

Olisipo Felicitas Iulia, 384

Olisiponense, 100, 101, 102, 103, 104, 105, 106, $107,126,144,145,376,377,406,407$

Olissiponense (da Roca, ou Magno) Cabo, 24

Olissiponense, Estuário,

Oliva, Aldeia de, 120

Olivença, 108, 302, 447

Ómega, 334

Ópio, 150, 264

Ordem de Cristo, 54

Ordem Dominicana, 68

Ordem da Espada da Terra Santa, 322

Ordines, 99, 369, 406

Ordonho, 378, 417

Orense, 196

Oretanos, 96, 114, 430, 431

Oriola, 290, 446

Orósio, Paulo, 19, 28, 136, 138, 220, 228, 230 , $232,236,240,248,252,266,276,398,413$ $417,433,434,435,436,438,439,441,444$ 471,478

Orsua, 206, 430

Ortografia, 40

Osma (cidade), 116, 256

Ossónoba, 30, 310, 316, 424, 448

Oster, 275, 443

Ostrenwindt, 274, 275

Ostrogodos, 274

Otão, 270, 442, 479

Otobesano, Tito

Ouguela, 108

Ovídio, 170, 172, 174, 403, 478

Ourique, 17, 30, 31, 33, 110, 334, 336, 340, 342, 344, 386, 387, 390, 398, 452, 453, 465

Ourique, Milagre de, 30

Oxirrinco, 176, 178, 180, 420, 422

Ozécaro, 200

Ozecarus, 23, 199, 201, 388, 389, 429

\section{$\mathbf{P}$}

Pã, 374

Pacense, 106, 272, 328
Paços (lugar), 152, 452

Pactolo, 192

Pais, Mem, 154

Palatino, 170, 432

Palência, 254

Paleólogo, Alésio, 320

Paleólogo, Miguel, 320, 449, 450

Pamplona, 162

Panfília, 170, 252

Pânfilo, Gneu Bébio, 226

Panónias, 276

Panóplia, 140

Pansa, 266, 267

Panvínio, Onofre (de Verona), 9, 21, 248, 250, 260, 398, 433, 438, 471, 473

Papíria, Tribo, 122, 350, 360

Partenopeio, Gaio Júlio, 354

Pastor (Mártir), 29, 235, 362, 364, 455

Pastos, Cocilícia, 318, 319

Paterna, Júlia, 332

Paulo, (jurisconsulto), 20, 94

Paulo, Lúcio Emílio, 136, 220, 222, 226, 230, 232. 412

Paulo, Lúcio Vocónio,

Pausânias, 18, 22, 34, 94, 374, 478

Pax Augusta (Badajoz), 442, 451

Pax Iulia, 331, 333, 386, 387, 442, 451, 452

Pedro, D., (Rei de Aragão), 5, 56, 120, 320, 360, $400,401,448,449,455,465,469,471,472$

Pelendónios, 100, 114, 116

Peloro, (cavalo), 122, 123

Penalva Del Castro, 116

Peniche, 28, 31, 156, 416

Peno, Marco Júnio, 248

Perce, 186

Peregrina, Sérgia, 120, 129

Perene, Céstio Acídio, 146

Periannes, D., de Portel, 30

Pericot, L., 27

Perotto, Nicolau, 18, 115, 409, 472

perpena, Marco, 256

Persas, 208, 209, 374, 375, 404, 413

Perseu (rei), 222, 232, 433

Pesures (ou Pesuros), 26, 78, 130, 132, 387, 388

Pesuros 78, 100, 106, 110, 130, 388

Petrarca, 11, 456

Petreio, Marco, 114, 116, 258, 260, 262

Petrónio, Quinto, 330, 332, 362

P冈ug, Júlio. (Ver Flu, Júlio), 401, 471

Piceno, 350, 351

Piel, J., 23, 421, 429, 446, 447, 466, 471

Píncia, 116 
Pinciano. (Ver Guzmán, F. Núnez de), 24, 31, 102 , 104, 376, 406

Pirenéus, 5, 21, 100, 104, 106, 108, 162, 190, 192, 254

Pisão, Gaio Calpúrnio, 222, 224, 226, 412, 438

Pisuerga, 116, 378

Placência, 124

Placídia, 276

Plagiária, 152, 290, 292

Plâncio, Gaio, 236

Planco, Lúcio Munácio, 260, 261, 262

Platão, 34

Plaucino, Gaio, 242

Pláucio, Gaio, 238, 240

Plautila, Eunóide, 354

Plauto, 478

Plínio-o-Moço, 252, 436, 442

Plínio-o-Velho, 19, 34, 467, 468, 478

Plumbários, 108, 150

Plutarco, 19, 168, 170, 172, 174, 194, 196, 206 208, 222, 232, 252, 260, 419, 427, 430, 432, 433, 439, 440, 478

Pó, Rio, 168, 170, 174

Polião, Gaio Asínio, 264, 266

Polião, Védio, 116

Políbio, 18, 25, 114, 134, 200, 206, 212, 218, 374 $405,409,413,424,430,431,432,435,472$, 479

Policiano de Florença, 190

Pólux, Júlio, 479

Pombal, 160

Pompeio, Gneu, 14, 154, 155, 192, 194, 236, 242, $254,255,256,257,258,259,260,261,262$, 264, 265, 266, 364, 427, 439, 440, 441

Pompónio Mela, 19, 21, 25, 34, 376, 390, 406, $425,426,427,428,431,432,447,448,472$, 479

Pontífices da Cúria, 330

Popeia, 270

Popílio, Aulo, 234, 240

Porceleto, 174

Pórcio, Lúcio, 218, 224

Porco-marinho, 174, 176, 178, 421

Pórculo, 178

Portalegre, 150, 386, 387, 400, 415

Portimão, 314, 316, 386, 387, 432, 449

Porto, 160, 180, 212, 316, 384, 385, 401, 403, 417, 432, 436, 438, 449, 461, 464, 465, 470, 471, 473, 474

Porto de Rei, 180

Portus Annibalis, 315, 386, 387

Posidónio, 413
Postúmio, Lúcio Quinto, 222, 226, 228, 230, 366, 368, 412, 434

Presamarcos, 100

Pretório, 292

Prima, Caturisa, 281, 312, 325

Prisciano, 19, 192, 427, 479

Prisco, Quinto Átio Mecenal, 272, 273, 308, 442

Próculo, Gaio Antéscio, 302

Próculo, Marco Júlio, 358

Priscino, Lúcio Rúbio, 366

Procópio, 17, 18, 29, 274, 276, 443, 444, 479

Prosérpina, 354

Prudêncio, 19, 122, 124, 126, 443, 479

Pseudoberoso, 21, 186, 206, 374, 404

Pseudomanéton, 248

Pucci, António, 401

Pudente, 244, 246

Pulo do Lobo, 418

Pultário, 356

Punhal, 140

Punhete, 384, 385

Púnica, 208

Púnicos, 208

Puzzi, António, 64

\section{Q}

Quarquernos, 142, 143

Quersoneso Címbrico, 274

Quevedo, Bartolomeu (Toledano), 6, 7, 9, 10, 12, 21, 31, 35, 80, 284, 290, 314, 398, 402, 403, 408, 409, 445, 448, 451, 455, 463, 471

Quinciano, Fúlvio, 348

Quinto, 12, 112, 146, 222, 228, 229, 234, 236, $238,240,242,244,246,250,252,253,272$, $273,284,285,318,330,331,332,333,348$, $350,351,354,360,364,365,401,410,436$, 479

Quirina, Tribo, 120, 121

R

Rabaçal, 160

Raia, 200

Raimundo, D., 336, 337

Ranhados, 415

Rarapia, 288, 289

Rasis (Mouro), 20, 22, 30, 310, 311, 448, 465, 474 
Rates, S. Pedro de, 360, 455, 465, 467

Ráurica, 262, 440

Recepto, Gaio Júnio, 314

Récios, 262

Régulo, Marco, 244

Renascimento, 7, 9, 27, 408, 465

Resende, Vasco Martim de, 54

Ribeiro, Orlando, 5, 411, 415, 417, 424, 429, 463, $464,466,472$

Roca, Cabo da, 24, 100, 102, 104, 308, 406, 407

Roderico, 87, 279, 313

Rodes, 172, 420

Rodrigo, 124, 278, 336, 378, 380

Rodrigo de Toledo, 336, 430, 452

Roldán Hervás, 409, 416, 428, 444, 445, 446, 447, $448,457,472$

Roma, 16, 19, 21, 26, 27, 32, 37, 39, 82, 120, 130, $154,202,210,211,212,216,218,220,222$, $224,226,228,232,233,234,242,245,246$, $247,248,250,252,254,258,264,270,274$, 294, 304, 402, 404, 405, 423, 431, 432, 433, $434,438,440,447,461,465,471,474$

Romanos, 15, 17, 18, 22, 27, 36, 37, 54, 76, 78, $82,96,98,122,132,134,135,136,137,138$, 139, 140, 141, 154, 155, 156, 172, 173, 178, 192, 196, 200, 206, 207, 208, 212, 214, 215, 216, 217, 218, 222, 224, 228, 229, 230, 234, $235,236,237,238,239,240,241,251,252$, 253, 256, 260, 272, 274, 276, 278, 302, 398, 412, 413, 433, 436, 437, 466, 473

Romão, São, 152, 154

Romis, 248

Romo, 248, 249, 437, 438

Rómulo, Gaio Ânio, 312

Rómulo da Hispânia (Viriato), 138, 234

Rondelet, Guilherme, 9, 21, 36, 168, 170, 172, $174,397,418,420,472$

Rosendo, S., 20, 29, 30, 417, 471, 472

Ruão, 176

Rufina, Flávia, 364, 365

Rufo, Quinto Petício, 330

Rufo, Quinto Pompeio, 242

Rufo, Públio Rutílio, 250, 251

Rufo, Sexto, 250

Rulo, 258

Rutela, 326

\section{$\mathbf{S}$}

Sabélico, Marcantónio, 21, 248, 472

Sabina, Calpúrnia, 284, 285, 408, 445, 463
Sabino, Lúcio Silão, 242, 330

Sabor, Rio, 108

Sacro, Cabo, 104, 308

Sacro, Monte, 148

Sadão, 180, 182, 366, 424

Sado, Rio, 33, 34, 110, 316, 366, 424

Sagrado (= Sacro), Promontório, 308, 314

Sagres, 308, 314

Sagunto, 120, 194, 212, 254, 439

Salácia, 72, 107, 111, 181, 182, 183, 281, 289, 311, $317,319,382,383,385,387,399,407,424$, 445

Salaciense, 182, 364, 366

Salamanca, 5, 21, 24, 54, 98, 100, 102, 116, 118, $124,380,400,404,406,409,410,415,452$, $466,470,472,473$

Salústio, 70, 192, 427, 439, 479

Salvador, Basílica do, 160, 332, 338, 342, 362

Salvaterra, 108, 292

Salviano, 158

Samónico Sereno, 122, 172, 420

Sanches, Pedro, 400, 471

Santa Cruz de Coimbra, (Mosteiro), 20, 152, 160, 416

Santa Detença (rio), 180, 424

Santa Maria, Cabo de, 106, 152

Santarém, 292, 382, 383, 384, 385, 424

Santarém, S. Frei Gil de, 7, 20, 22,184, 425, 468

Santiago, 318, 354

Santiago do Cacém, 29, 30, 106, 318, 386, 387, 398

São Brás, 318

Sárabris, 116

Saragoça, 94, 272, 411, 433, 448, 449, 474

Sármatas, 272, 274

Sarmático, 282, 298

Sarracenos, 336

Sarte, Rio, 72, 73

Saturnais, 170

Saturno, 262

Saurium, 161, 386, 387, 429, 446

Sável, 168, 184, 425, 429

Saxónicos, 24, 274

Scallabis, 107, 293, 384, 385, 446

Schottus , Andreas, 9, 462

Schulten, A., 19, 27, 398, 405, 406, 409, 413, 414, 416, 417, 418, 424, 425, 426, 428, 429, 430, $431,432,435,436,437,438,439,440,441$, $451,467,473$

Sebastião, D., 2, 3, 6, 16, 17, 30, 31, 42, 60, 276, 314, 342, 344, 350, 398, 401, 437, 448, 453, 457 
Seco, Fernão Vaz, 34, 424

Seda, 198

Segundo, Galo Favónio, 96, 118, 160, 178, 228, $248,440,445,446,450,451,453,457$

Seia, 152, 154

Seilia, 201, 384, 385, 388, 389

Seire, 384, 385, 388, 389

Semne, 356, 357

Semnine, 356, 357, 454

Semprónio, Marco, 224

Semprónio, Públio, 226

Semprónio, Tibério, 226, 228, 434

Senegal, Rio, 36, 180, 423

Sêntica, 116, 409

Sepúlveda, Genésio de, 272, 442, 443, 469, 473, 474

Serápio, 248

Serena, 194

Serena, Villa Nueva de La, 379, 380

Sérgia, (Tribo), 120, 232

Sergila, Rúbria, 348

Sérgio, 120, 136, 138, 230, 232, 366, 368

Serpa, 108, 288, 289, 306, 307, 386, 387, 418

Serpa, Fábia Prisca de, 308

Serpenses, 386, 387

Serra do Buçaco 160, 190

Serra da Estrela, 28, 29, 152, 156, 388, 415, 416

Serra do Gerês, 162

Serra do Marão, 162

Serra de Montemuro, 162

Serra de Segura, 116

Serra do Soajo, 162

Sertorianos, 254, 255

Sertório, Quinto, 16, 18, 27, 28, 37, 132, 138, 192 $194,252,254,256,258,364,412,427,438$, 439, 479

Serviliano, Quinto Fábio Máximo, 236, 436

Servílio, 216, 232, 234

Servílio, Gneu, 212, 216, 242

Sérvio, 210, 230, 232, 248, 479

Sesimbra, 324, 326

Séstio, Altares de, 100

Sete Altares, 152

Setentrião, 376

Setúbal, 26, 180, 324, 382, 383, 386, 387, 451, 472

Seurbos, 100, 142, 143

Severo, (presbítero), 172, 334

Severo, Felix, 350

Severo, Gaio Septímio, 410, 420

Sevilha, 17, 19, 20, 86, 254, 262, 409, 423, 451, 477
Sevirato, 314

Sicília, 18, 208, 264, 266, 284, 390

Sídon, 210

Sigeu, 82

Sila, 154

Silano, Décio Júnio, 250, 438

Sílio Itálico, 208, 380, 409, 410, 413, 414, 415, 426, 427, 428, 430, 431, 432, 479

Siluro, 166, 168, 169, 174, 175, 418, 421, 422, 423

Silva, D. Miguel da (Bispo de Viseu), 21, 398, $400,412,423,424,455,463,472,473$

Silvano, 246, 354

Silves, 310, 316

Silvino, Gaio Vétio, 354

Sílvio, 48, 50, 210

Simoente, 82

Simonetta, Giacomo, 244, 437

Sines, 322, 348

Sintra (Monte), 144, 218, 432

Sirte, 316

Sisenando, 328, 451

Sofistas, Jantar dos, 200

Solho-Soilho, (doc. de D. Diniz)

Solimão (Rei dos Turcos) 400

Solino, 102, 103, 104, 210, 406, 432, 473, 479

Soor, 200, 201

Sor, 23, 198, 200, 290, 382, 383, 386, 387, 388, 389, 446

Sorobi, 192, 427

Sorraia, 200, 429

Sorraia, Cavalos do, 415, 464

Sorranal (Serravalle), 270, 442

Soure, Ópido de, 160

Soure, Rio, 160, 198, 388, 389

Sousa, Manuel de,

Sousa, Manuel Coelho de, 48, 49, 150

Soutelo, 108

S. Sebastião do Freixo, 457

Stipendiariae, 408

Sturio, 36, 418, 419, 420

Subsolano, 274

Subur, 199, 200, 201, 388, 429, 446

Suculus (= solho),

Suetónio, 19, 232, 270, 433, 435, 479

Suevos, 272, 276, 444

Suíça, 21

Suillum (= Suilho), 79

Sula, 252

Sulpício, Gaio, 230, 232

Surso, 346 


\section{$\mathbf{T}$}

Tábuas Triunfais, 250

Tácito (e o Direito Romano), 21

Tácito, César Cláudio, 296

Tácito, César Marco Cláudio, 296

Tago, 97, 107, 113, 117, 148, 149, 151, 167, 185, 186, 187, 188, 191, 193, 195, 293, 317, 426

Tagro, Monte, 148, 149, 415

Tagus, 63, 83, 97, 101, 103, 107, 183, 185, 187, 189, 191, 201, 259, 375, 379, 388, 389, 425

Talábriga (Ópido de), 100, 378

Talassino, Cláudio, 348

Talavera, 5, 86, 403

Talaveruela, 382, 383

Tamaca, 199, 389

Tamacanos, 78, 109, 142, 198

Tamarcos, 100

Tâmega, 23, 198, 388, 402, 428

Tameganos, 108

Tanaide, Região da, 62

Tancos, 184, 185

Táparos, 108

Tarafa, Francisco, 438, 473

Tapieu, Monte, 158, 160

Tarraconense, Província, 98, 108, 112, 190, 268, $405,417,425,430,441$

Tarragona, 232

Tártaro, 244

Tartesso, 186

Tavira, 106, 110, 288, 308, 310, 312, 384, 386

Tebas, 374, 450

Tejo, Região do, 8, 15, 23, 35, 62, 82, 94, 96, 98, $100,102,106,108,112,114,116,118,122$, $130,132,136,148,150,166,182,184,186$, 188, 190, 192, 194, 200, 212, 224, 230, 234, 236, 258, 292, 316, 374, 378, 386, 387, 388, 389, 401, 406, 407, 408, 411, 412, 424, 425, 426, 429, 449

Tejo, Rio, 96, 102, 148, 212, 224, 230, 426

Télamon, 142

Telo, 214

Teodoreto, 274

Teodorico, 274

Teodoro, Lúcio Calpúrnio, 312

Teodoro de Gaza, 21, 172, 420, 473

Teodósio, Duque, 356, 454

Teodósio-o-Moço, 276

Teotónio, S., 2 (vida), 8, 29

Teotónio D., de Bragança, (Arcebispo de Évora), 48

Tera, 198
Terena, 17, 32, 356

Teresa, D. 152, 336, 452, 453

Terges, 336, 340, 341, 344

Téron, 206

Terpsícore, Júlia, 332

Tertula, Cornélia, 302

Tertuliano (Septímio), 19, 166, 418

Tessália, 128

Teucro, 142, 208, 209, 210, 211, 212, 414, 432

Teudão, 274

Tiago, (Rei), 320

Tiago (Apóstolo), 318, 338, 362

Tiamo, Lúcio Publício, 122

Tiberino, 328

Tibério, 36, 134, 226, 228, 272, 328,

Tibre, Rio, 170, 174

Tício, 266, 324, 330, 441

Tigranes, 136

Timeu da Sicília, 210

Timócrates, 200

Tingitânia, 268

Tírios, 208, 210

Tiro, 210, 431

Toledo, 5, 21, 24, 100, 102, 118, 208, 224, 336, $430,431,448,452$

Tolosa, 276, 336

Tomar, 30, 160, 386, 387, 388

Torânio, 254

Tormes, 116, 124

Toro, 124, 192

Torrão, 2, 17, 29, 33, 362, 455, 456, 467

Tortona, 270

Toureja, 284

Trácios, 272, 374

Trajano, 278, 282, 288, 294, 444

Tramagal, 457

Transcudani, 23, 199, 247, 389

Transcudanos, 78, 108, 198, 388

Transmontanos, 388

Transtaganos, 140, 214

Trás-os-Montes, Região de, 162, 388, 417

Trasímeno, 214

Tritão de Lisboa, 36

Triunvirato, 258

Tróia, 82, 110, 210, 212, 280, 316, 324, 326, 414, $431,432,450,451$

Tróia (Setúbal), 110, 280, 316, 324, 326, 450 n. 56

Túbal, 26, 31, 326

Tubucci, 293, 382, 383, 384, 385

Tubucos, 292

Tui, Castelo de, 100, 142 
Turdetânia, 112, 114

Turdetanos, 26, 78, 110, 111, 112, 113, 114, 115, $132,133,214,215,272,308,309,328,334$, 386, 408, 409, 424

Túrdulos, 14, 26, 78, 96, 112, 114, 122, 124, 126, 132, 142, 388, 408, 409, 412

Túrdulos, Béticos, 112

Túrdulos, Velhos, 98, 100, 106, 110, 130, 196

Túrdula, Guerra, 112

Túria, 192, 194, 196, 254

Turro, 208

Tyde, 101, 143, 413, 414

\section{U}

Ulisses, 16, 102, 186, 399, 426, 451, 467

Unímano, Cláudio, 234, 236, 240, 346, 390

Urbanense, Mosteiro de, 429

Urbe, 252, 318

Urraca, 336

Universidade de Lovaina,

Universidade de Paris, 54

\section{V}

Vaca, 190

Vaceus, 37, 96, 100, 114, 116, 118, 124, 126, 190, 192, 196, 226, 228, 406, 427, 434

Vaco, 190

Vacua, 90, 388, 389

Vadiano, Joaquim, 186, 398, 407, 425, 472, 474

Valência, 192, 194, 248, 314, 320, 427, 437

Valente, Lúcio Júlio, 324

Valentim (ou Valenciano), Honorato João, 244, 437

Valentim da Morávia, 146, 414

Valentiniano, 276, 390

Valeriano, César Públio Licínio, 312, 313

Valério, Lúcio, 228

Valério Anciate, 413

Valério Máximo, 19, 138, 230, 232, 240, 248, 252, $260,412,435,440,480$

Vália, 274, 276, 444

Valladolid, Concílio de, 9, 413, 463

Vamba, Rei, 326, 450, 451

Vandália, 276

Vandalícia, 276

Vândalos, 274, 276, 390, 443, 444, 479

Vargo, Vale de, 304, 446

Varrão, 19, 35, 92, 100, 106, 116, 148, 150, 172,
$186,258,374,415,426,432,480$

Vascetanos, 220, 221, 433

Vasconcelos, Diogo Mendes, 10, 11, 12, 14, 17, $29,39,44,46,48,50,52,54,74,82,84,372$, 397, 399, 401, 403, 413, 439, 443, 456, 457, 462, 463, 467

Vasconcelos, Manuel Cabedo de, 11, 84

Vaseu, João, 5, 6, 9, 12, 21, 31, 110, 112, 220, 272, 378, 380, 398, 402, 415, 434, 448, 451, 474

Vataça, D., 17, 20, 30, 320, 322, 449, 450, 465

Vatatzes, João, 320

Vaz, André, 54

Vaz, Ângela Leonor, 54

Vaz, Egídio (Gil), 54

Vaz, Martim, 54

Vectões. (Ver Vetões), 26, 114, 116, 118, 122, 124, 126

Veleio Patérculo, 19, 210, 222, 256, 433, 436, 480

Velha dos Ilercáones (Cartago), 186

Ventimiglia, 320

Vénus, 84

Vercingetorix, 28, 38

Vermudes, Sanches, 152

Vero, César Gaio Júlio, 292, 298

Verres, 374

Vesco (Ópido de), 220

Vespasiano, 334

Vetão, Cecílio, 122

Vetão, Lúcio Domício, 122

Vetão, Marco Sérgio, 120

Vetílio, Gaio, 236, 240

Vetílio, Marco, 238, 240

Vetões. (Ver Vectões), 8, 14, 26, 78, 96, 98, 100, 106, 108, 110, 112, 114, 116, 118, 122, 124, $126,208,258,378,409,415,430,431,441$

Vetónia, 120, 122, 126, 130, 268, 280, 410

Viana de Caminha, 385

Vicente, São, 12, 108, 248, 314, 423, 448

Vicente, Cabo de S., 102, 104, 106, 110, 212, 308, 314, 316, 318, 322, 411

Vida de S. Martinho de Soure, 20

Viena, 6, 56, 400, 434, 461, 471

Vila Franca, 182, 292

Vila Nova, 316

Vila Nova da Coelheira, 118

Vila Nova de Portimão,

Vila Viçosa, 314, 316, 386, 387, 432, 449

Viminal, 17, 246, 352, 390, 403

Vínduo (ou Víndio), Monte, 162

Violante, 320 
Virgílio, 5, 70, 76, 186, 210, 278, 401, 411, 415, 480

Viriato, 6, 8, 14, 16, 18, 23, 27, 28, 34, 37, 138, $214,216,217,218,232,234,235,236,237$, 238, 239, 240, 241, 242, 243, 244, 245, 246, 248, 249, 390, 398, 432, 436

Viseu, 21, 160, 244, 402, 423, 437

Visigótia, 276

Visigodos; 20, 274, 276, 450

Vital, Públio Élio, 120

Vitélio, 270

Vitichindo, 29, 274

Vitória, 162, 342

Vouga, Rio, 100, 106, 162, 190, 388, 389, 426

Vulcano, 318, 449

Vulso, Gneu Mânlio, 222

\section{W}

Watt, Joachim (Vadianus), 21, 407, 474

West, 274, 275

Westgothen 274

Westren, 274, 275

Widukind Von Corvey. (Ver Vitichindo), 20
$\mathbf{X}$

Xarrama, 180, 286, 362

Xanto, 82

Xigonza, 116

Ximena, 336

Xisto, 6

\section{$\mathbf{Y}$}

Yepes, 224

\section{$\mathbf{Z}$}

Zamora (= Sêntica), 108, 116, 117, 192, 409

Zaire, Rio, 36, 423

Zaro, 210, 211

Zéfiro, 35

Zenão, Augusto, 274

Zêzere, 23, 36, 198, 200, 388, 389, 428, 429

Zonaras, 20, 320, 450, 474

Zurita, Jerónimo, 21

Zurita Valentim, Jerónimo 320, 449, 474 
(Página deixada propositadamente em branco) 


\section{ÍNDICE GERAL}

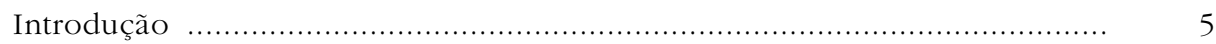

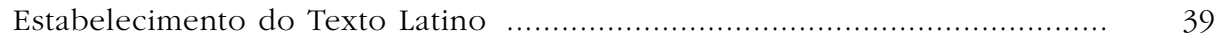

\section{TEXTO E TRADUÇÃO}

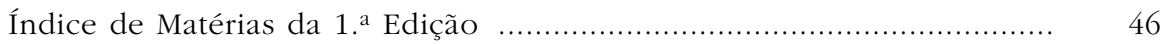

Parecer e licença .............................................................. 48

Epigrama de Luís Sílvio de Brito .............................................. 50

Carta de Mendes de Vasconcelos a Filipe II de Espanha .................... 52

Vida de André de Resende por Diogo Mendes de Vasconcelos ............. 54

Carta de André de Resende ao Cardeal D. Afonso ........................... 70

Carta de Mendes de Vasconcelos ao Cardeal D. Henrique ................... 74

Versos de Mendes de Vasconcelos em Louvor de Resende .................. 82

Três Epigramas de Manuel Cabedo de Vasconcelos em Louvor

de Mendes de Vasconcelos e de Resende ................................... 84

Carta de André de Resende a Bartolomeu Frías de Albornoz ............... 86

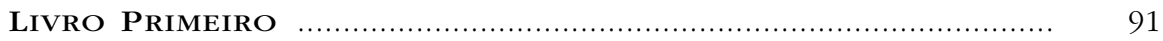

LIVRO SEgUNDO

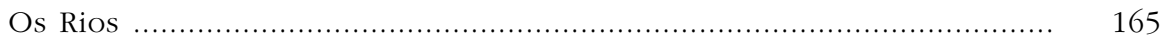

\section{Livro Terceiro}

Que Povos Dominaram Outrora a Lusitânia

\section{LIVRO QUARTO}

Escólios de Diogo Mendes de Vasconcelos 


\section{NOTAS E COMENTÁRIOS}

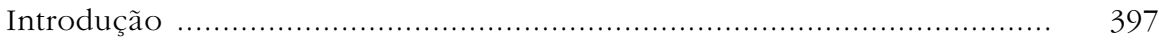

Título da Obra e Índice ........................................................ 399

Epigrama a Mendes de Vasconcelos ............................................. 399

Vida de Lúcio André de Resende ................................................ 399

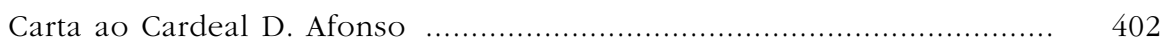

Carta ao Cardeal D. Henrique .......................................................... 403

Versos de Diogo Mendes de Vasconcelos .................................... 403

Epigramas de Manuel Cabedo de Vasconcelos ................................... 403

Carta a Bartolomé Frías Albornoz ................................................... 403

Livro Primeiro ............................................................................. 404

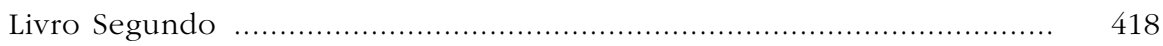

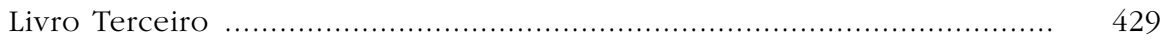

Livro Quarto .................................................................... 447

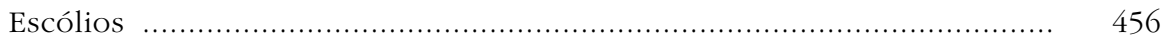

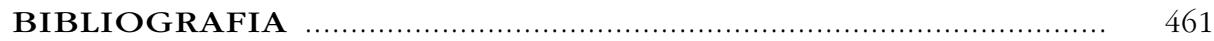

Índice dos Passos Citados de Autores Greco-Latinos .............................. 475

Índice de Nomes Próprios e Palavras f................................................. 481 
(Página deixada propositadamente em branco) 
(19 